\title{
MINERAL COMMODITY SUMMARIES 2020
}

\begin{tabular}{llll} 
Abrasives & Fluorspar & Mercury & Sillicon \\
Aluminum & Gallium & Mica & Silver \\
Antimony & Garnet & Molybdenum & Soda Ash \\
Arsenic & Gemstones & Nickel & Stone \\
\hline Asbestos & Germanium & Nitrogen & Strontium \\
Barite & Gold & Sulfur \\
Bauxite & Graphite & Palladium & Talc \\
Beryllium & Gypsum & Peat & Tantalum \\
Bismuth & Hafnium & Perlite & Tellurium \\
Boron & Helium & Phosphate Rock & Thallium \\
Bromine & Indium & Platinum & Thorium \\
\hline Cadmium & lodine & Potash & Tin \\
Cement & Iron and Steel & Pumice & Titanium \\
Cesium & Iron Ore & Quartz Crystal & Tungsten \\
Chromium & Iron Oxide Pigments & Rare Earths & Vanadium \\
\hline Clays & Kyanite & Rhenium & Vermiculite \\
Cobalt & Lead & Rubidium & Wollastonite \\
Copper & Lime & Salt & Yttrium \\
Diamond & Lithium & Sand and Gravel & Zeolites \\
Diatomite & Magnesium & Scandium & Zinc \\
Feldspar & Manganese & Selenium & Zirconium \\
\hline
\end{tabular}


Cover: Minerals play an integral part in all aspects of our lives. In this rural setting, minerals provide nutrients, such as nitrogen, phosphorus, potassium, and a host of micronutrients essential to maximize crop yields to ensure reliable food supplies. Various metals and other mineral materials are required to build the harvesters shown, in addition to the equipment needed to prepare the fields for and to plant these crops. Open spaces are ideal for wind farms, comprising myriad wind turbines that require numerous mineral materials for the actual structures as well as the infrastructure to transmit the electrical power produced to consumers across the nation. (Image provided as a courtesy of John Deere.) 


\section{MINERAL COMMODITY SUMMARIES 2020}

$\begin{array}{llll}\text { Abrasives } & \text { Fluorspar } & \text { Mercury } & \text { Silicon } \\ \text { Aluminum } & \text { Gallium } & \text { Mica } & \text { Silver } \\ \text { Antimony } & \text { Garnet } & \text { Molybdenum } & \text { Soda Ash } \\ \text { Arsenic } & \text { Gemstones } & \text { Nickel } & \text { Stone } \\ \text { Asbestos } & \text { Germanium } & \text { Niobium } & \text { Strontium } \\ \text { Barite } & \text { Gold } & \text { Nitrogen } & \text { Sulfur } \\ \text { Bauxite } & \text { Graphite } & \text { Palladium } & \text { Talc } \\ \text { Beryllium } & \text { Gypsum } & \text { Peat } & \text { Tantalum } \\ \text { Bismuth } & \text { Hafnium } & \text { Perlite } & \text { Tellurium } \\ \text { Boron } & \text { Helium } & \text { Phosphate Rock } & \text { Thallium } \\ \text { Bromine } & \text { Indium } & \text { Platinum } & \text { Thorium } \\ \text { Cadmium } & \text { lodine } & \text { Potash } & \text { Tin } \\ \text { Cement } & \text { Iron and Steel } & \text { Pumice } & \text { Titanium } \\ \text { Cesium } & \text { Iron Ore } & \text { Quartz Crystal } & \text { Tungsten } \\ \text { Chromium } & \text { Iron Oxide Pigments } & \text { Rare Earths } & \text { Vanadium } \\ \text { Clays } & \text { Kyanite } & \text { Rhenium } & \text { Vermiculite } \\ \text { Cobalt } & \text { Lead } & \text { Rubidium } & \text { Wollastonite } \\ \text { Copper } & \text { Lime } & \text { Salt } & \text { Yttrium } \\ \text { Diamond } & \text { Lithium } & \text { Sand and Gravel } & \text { Zeolites } \\ \text { Diatomite } & \text { Magnesium } & \text { Scandium } & \text { Zinc } \\ \text { Feldspar } & \text { Manganese } & \text { Selenium } & \text { Zirconium }\end{array}$




\title{
U.S. Department of the Interior \\ DAVID BERNHARDT, Secretary
}

\author{
U.S. Geological Survey \\ James F. Reilly II, Director
}

\section{U.S. Geological Survey, Reston, Virginia: 2020}

Manuscript approved for publication January 31, 2020.

For more information on the USGS - the Federal source for science about the Earth, its natural and living resources, natural hazards, and the environmentvisit https://www.usgs.gov or call 1-888-ASK-USGS.

For an overview of USGS information products, including maps, imagery, and publications, visit https://store.usgs.gov/.

For sale by the Superintendent of Documents, U.S. Government Publishing Office

Mail: Stop IDCC; Washington, DC 20402-0001

Phone: (866) 512-1800 (toll-free); (202) 512-1800 (Washington, DC area)

Fax: (202) 512-2104

Internet: https://bookstore.gpo.gov

Email: ContactCenter@gpo.gov

Any use of trade, product, or firm names is for descriptive purposes only and does not imply endorsement by the U.S. Government.

Although this report is in the public domain, permission must be secured from the individual copyright owners to reproduce any copyrighted material contained within this report.

\section{Suggested citation:}

U.S. Geological Survey, 2020, Mineral commodity summaries 2020: U.S. Geological Survey, 200 p., https://doi.org/10.3133/ mcs2020.

ISBN 978-1-4113-4362-7 
CONTENTS

General:

$\underline{\text { Page }}$

Introduction 3

The Role of Nonfuel Minerals in the U.S. Economy ...... 4

Significant Events, Trends, and Issues.......................... 5 2019 U.S. Net Import Reliance .................................... 7

Major Import Sources of Nonfuel Mineral

Commodities in 2019.

Table 1-U.S. Mineral Industry Trends

Table 2-U.S. Mineral-Related Economic Trends......... 9

\section{Mineral Commodities:}

Abrasives (Manufactured) ............................................ 18

Aluminum ....................................................... 20

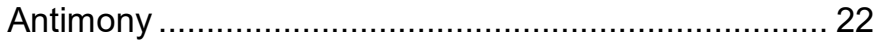

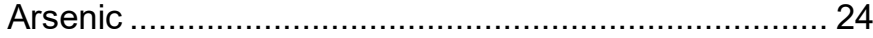

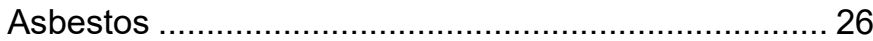

Barite ................................................................... 28

Bauxite and Alumina ............................................... 30

Beryllium ......................................................... 32

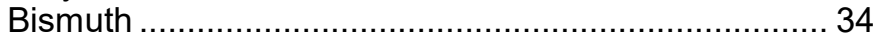

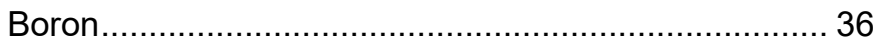

Bromine ............................................................. 38

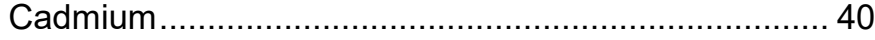

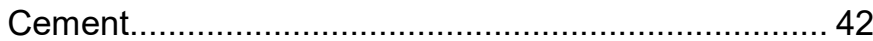

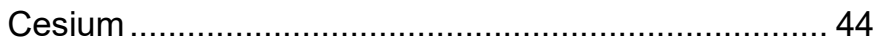

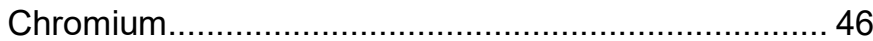

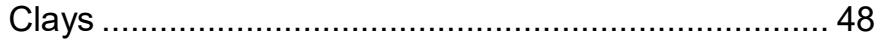

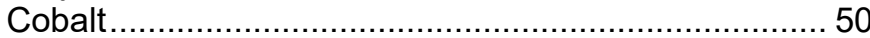

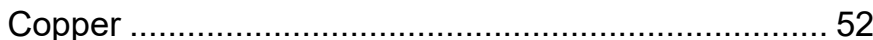

Diamond (Industrial)............................................ 54

Diatomite ........................................................ 56

Feldspar and Nepheline Syenite............................... 58

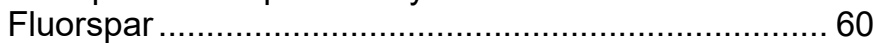

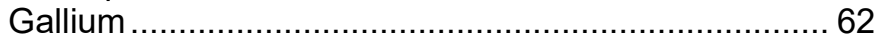

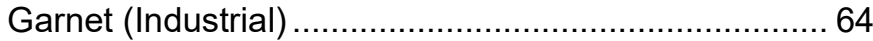

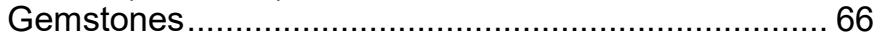

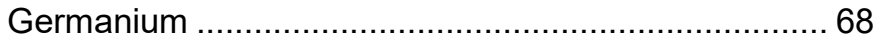

Gold............................................................ 70

Graphite (Natural) …......................................... 72

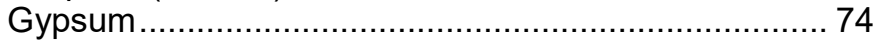

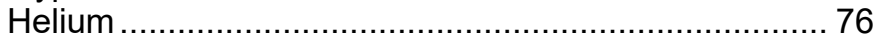

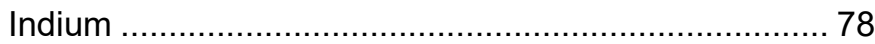

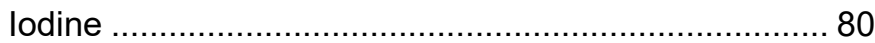

Iron and Steel.................................................... 82

Iron and Steel Scrap .............................................. 84

Iron and Steel Slag .............................................. 86

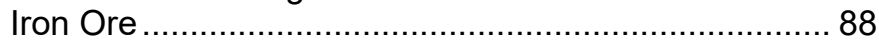

Iron Oxide Pigments .............................................. 90

Kyanite and Related Minerals .................................... 92

Lead ................................................................... 94

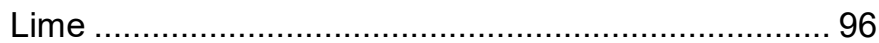

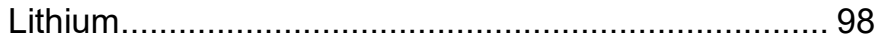

Magnesium Compounds ......................................... 100

Magnesium Metal..................................................... 102

Manganese ....................................................... 104
Table 3-Value of Nonfuel Mineral Production in

the United States in 2019 ........................................ 10

Appendix A-Abbreviations and Units of Measure .... 194

Appendix B-Definitions of Selected Terms Used

In This Report...................................................... 194

Appendix C-Reserves and Resources..................... 195

Appendix D—Country Specialists Directory............... 199

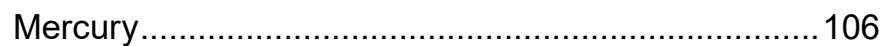

Mica (Natural) ............................................... 108

Molybdenum …….......................................... 110

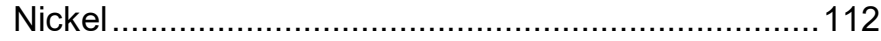

Niobium (Columbium)........................................ 114

Nitrogen (Fixed)—Ammonia ....................................116

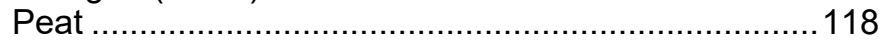

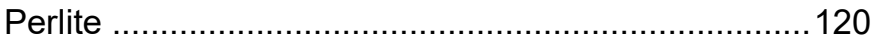

Phosphate Rock ..................................................122

Platinum-Group Metals...........................................124

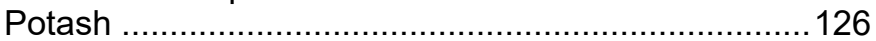

Pumice and Pumicite...............................................128

Quartz Crystal (Industrial) ....................................... 130

Rare Earths ........................................................ 132

Rhenium .......................................................... 134

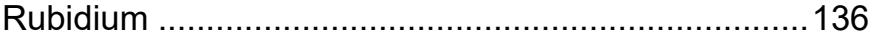

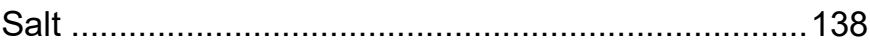

Sand and Gravel (Construction)................................. 140

Sand and Gravel (Industrial) ................................... 142

Scandium ......................................................... 144

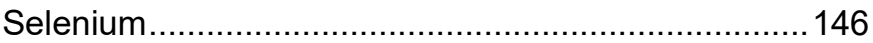

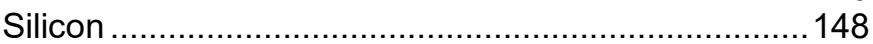

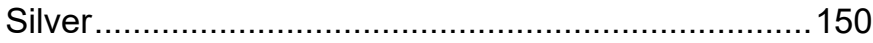

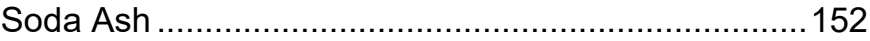

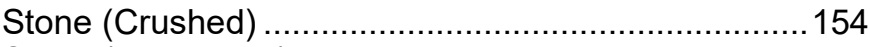

Stone (Dimension) .................................................. 156

Strontium ................................................... 158

Sulfur ........................................................... 160

Talc and Pyrophyllite ............................................. 162

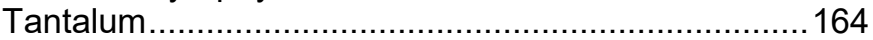

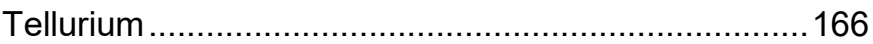

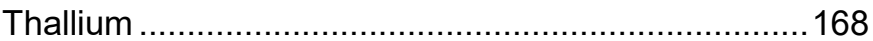

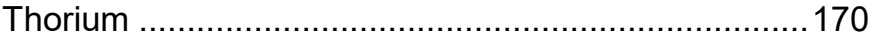

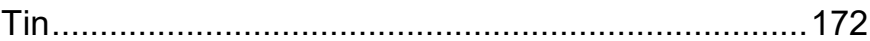

Titanium and Titanium Dioxide ................................. 174

Titanium Mineral Concentrates ................................. 176

Tungsten ......................................................... 178

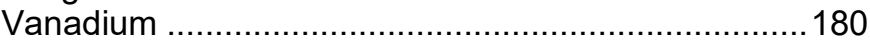

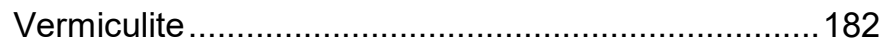

Wollastonite ............................................................ 184

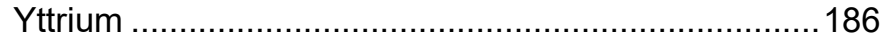

Zeolites (Natural) …........................................... 188

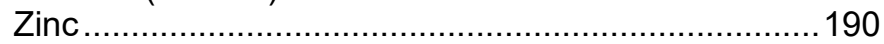

Zirconium and Hafnium ....................................... 192 


\section{INSTANT INFORMATION}

Information about the U.S. Geological Survey, its programs, staff, and products is available from the internet at https://www.usgs.gov or by calling (888) ASK-USGS [(888) 275-8747].

This publication has been prepared by the National Minerals Information Center. Information about the Center and its products is available from the internet at https://www.usgs.gov/centers/nmic or by writing to Director, National Minerals Information Center, 988 National Center, Reston, VA 20192.

\section{KEY PUBLICATIONS}

Minerals Yearbook-These annual publications review the mineral industries of the United States and of more than 180 other countries. They contain statistical data on minerals and materials and include information on economic and technical trends and developments and are available at https://www.usgs.gov/centers/nmic/publications. The three volumes that make up the Minerals Yearbook are Volume I, Metals and Minerals; Volume II, Area Reports, Domestic; and Volume III, Area Reports, International.

Mineral Commodity Summaries-Published on an annual basis, this report is the earliest Government publication to furnish estimates covering nonfuel mineral industry data and is available at

https://www.usgs.gov/centers/nmic/mineral-commodity-summaries. Data sheets contain information on the domestic industry structure, Government programs, tariffs, and 5-year salient statistics for more than 90 individual minerals and materials.

Mineral Industry Surveys-These periodic statistical and economic reports are designed to provide timely statistical data on production, shipments, stocks, and consumption of significant mineral commodities and are available at https://www.usgs.gov/centers/nmic/mineral-industry-surveys. The surveys are issued monthly, quarterly, or at other regular intervals.

Materials Flow Studies-These publications describe the flow of minerals and materials from extraction to ultimate disposition to help better understand the economy, manage the use of natural resources, and protect the environment and are available at https://www.usgs.gov/centers/nmic/materials-flow.

Recycling Reports-These studies illustrate the recycling of metal commodities and identify recycling trends and are available at https://www.usgs.gov/centers/nmic/recycling-statistics-and-information.

Historical Statistics for Mineral and Material Commodities in the United States (Data Series 140)_This report provides a compilation of statistics on production, trade, and use of approximately 90 mineral commodities since as far back as 1900 and is available at https://www.usgs.gov/centers/nmic/historical-statistics-mineral-and-materialcommodities-united-states.

\section{WHERE TO OBTAIN PUBLICATIONS}

- Mineral Commodity Summaries and the Minerals Yearbook are sold by the U.S. Government Publishing Office. Orders are accepted over the internet at https://bookstore.gpo.gov, by email at ContactCenter@gpo.gov, by telephone toll free (866) 512-1800; Washington, DC area (202) 512-1800, by fax (202) 512-2104, or through the mail (P.O. Box 979050, St. Louis, MO 63197-9000).

- All current and many past publications are available in PDF format (and some are available in XLS format) through https://www.usgs.gov/centers/nmic. 


\section{INTRODUCTION}

Each chapter of the 2020 edition of the U.S. Geological Survey (USGS) Mineral Commodity Summaries (MCS) includes information on events, trends, and issues for each mineral commodity as well as discussions and tabular presentations on domestic industry structure, Government programs, tariffs, 5-year salient statistics, and world production and resources. The MCS is the earliest comprehensive source of 2019 mineral production data for the world. More than 90 individual minerals and materials are covered by two-page synopses.

For mineral commodities for which there is a Government stockpile, detailed information concerning the stockpile status is included in the two-page synopsis.

Abbreviations and units of measure and definitions of selected terms used in the report are in Appendix $A$ and Appendix B, respectively. "Appendix C-Reserves and Resources" includes "Part A-Resource/Reserve Classification for Minerals" and "Part B-Sources of Reserves Data." A directory of USGS minerals information country specialists and their responsibilities is Appendix D.

The USGS continually strives to improve the value of its publications to users. Constructive comments and suggestions by readers of the MCS 2020 are welcomed. 


NET EXPORTS OF MINERAL
RAW MATERIALS
GOLD, SODA ASH, ZINC
CONCENTRATES, ETC.
Exports: $\$ 9.3$ billion
Imports: $\$ 5.6$ billion
Net exports: $\$ 3.7$ billion

\section{DOMESTIC MINERAL RAW} MATERIALS FROM MINING

COPPER ORES, IRON ORE, SAND AND GRAVEL

STONE, ETC

Value: $\$ 86.3$ billion

\section{METALS AND MINERAL PRODUCTS RECYCLED DOMESTICALLY \\ ALUMINUM, GLASS, STEEL, ETC. \\ Value of old scrap: $\$ 36.1$ billion}

\section{NET EXPORTS OF OLD}

SCRAP

GOLD, STEEL, ETC.

Exports: $\$ 15.8$ billion

Imports: $\$ 6.1$ billion

Net exports: $\$ 9.7$ billion

\section{THE ROLE OF NONFUEL MINERALS IN THE U.S. ECONOMY \\ (ESTIMATED VALUES IN 2019)}

\footnotetext{
Sources: U.S. Geological Survey and the U.S. Department of Commerce.
}

${ }^{1}$ Major consuming industries of processed mineral materials are construction, durable goods manufacturers, and some nondurable goods manufacturers. The value of shipments for processed mineral materials cannot be directly related to gross domestic product.

VALUE ADDED TO

PRODUCT BY MAJOR INDUSTRIES THAT CONSUME PROCESSED MINERAL MATERIALS ${ }^{1}$

Value: $\$ 3,130$ billion

NET IMPORTS OF

PROCESSED MINERAL

MATERIALS

METALS, CHEMICALS, ETC.

Imports: \$139 billion

Exports: $\$ 86$ billion

Net imports: $\$ 53$ billion

\section{U.S. ECONOMY}

Gross Domestic Product: $\$ 21,429$ billion 


\section{SIGNIFICANT EVENTS, TRENDS, AND ISSUES}

In 2019, the estimated total value of nonfuel mineral production in the United States was $\$ 86.3$ billion, an increase of 3\% from the revised total of $\$ 84$ billion in 2018. The estimated value of metals production increased slightly to $\$ 28.1$ billion. Lower production of some metals was offset by increased values. Byproduct vanadium was produced in Utah for the first time since 2013. The total value of industrial minerals production was $\$ 58.2$ billion, a 3\% increase from that of 2018 . Of this total, $\$ 27.7$ billion was construction aggregates production (construction sand and gravel and crushed stone). Crushed stone was the leading nonfuel mineral commodity in 2019 accounting for $22 \%$ of the total value of U.S. nonfuel mineral production. Increased construction activity resulted in increased prices and production of some industrial minerals.

In 2018, as a result of U.S. Department of Commerce findings of harm to national security under Section 232 of the Trade Expansion Act of 1962, as amended (19 U.S.C. 1862), additional import duties for aluminum articles and steel articles were put into place. Several Presidential Proclamations were issued in 2019 modifying either the tariff rates or the countries affected. After the United States, Canada, and Mexico reached an agreement on trade terms in May, the ad valorem duties for aluminum and steel imports were removed for Canada and Mexico. As of December 2019, aluminum imports from all countries except Argentina, Australia, Canada, and Mexico remained subject to a $10 \%$ ad valorem tariff, and steel imports from all countries except Argentina, Australia, Brazil, Canada, the Republic of Korea, and Mexico remained subject to a $25 \%$ ad valorem tariff.

Under Section 301 (b) of the Trade Act of 1974, as amended, the Office of the United States Trade Representative (USTR) determined that acts, policies and practices of China related to technology transfer, intellectual property, and innovation were discriminatory or unreasonable and those actions burdened or restricted United States commerce (83 FR 14906) in 2018. Several lists of tariff lines (Lists 1, 2, 3) were compiled, and imports of those materials became subject to an additional import duty for products from China. Lists 1 and 2 had duty rates of 25\% implemented in July 2018 and August 2018, respectively. List 3, which included nonfuel mineral commodities, had a duty rate of $10 \%$ imposed in late September 2018. The rate was scheduled to increase to $25 \%$ on January 1, 2019; however, that action was delayed. From January through May 2019, trade discussions between the United States and China were ongoing. In May 2019, because a trade agreement was not reached, the United States

increased tariffs for List 3 items to 25\% (84 FR 20459). China likewise imposed additional import duties for certain items originating in the United States. In December, a phase one trade agreement was reached between the United States and China, which reduced some tariff rates and resulted in additional tariffs not being implemented. At yearend 2019, the United States had a $25 \%$ tariff on approximately $\$ 250$ billion of imports from China, including nonfuel mineral commodities, and a $7.5 \%$ tariff on approximately $\$ 120$ billion of imports from China. China had additional tariffs ranging from $5 \%$ to $30 \%$ on approximately $\$ 110$ billion of imports from the United States.

Also under Section 301 (b) of the Trade Act of 1974, as amended, the USTR published a request for comments in December (84 FR 67992) on proposed additional ad valorem duty rates of up to $100 \%$ for items from specified European countries, including several ferroalloys and other nonfuel mineral commodities. The critical minerals niobium, palladium, rhenium, and vanadium were on the list of proposed items.

Executive Order 13817, A Federal Strategy to Ensure Secure and Reliable Supplies of Critical Minerals (EO), was issued on December 20, 2017. Several actions were required of Federal agencies to address critical minerals. Pursuant to the EO, the Secretary of the Interior, in coordination with the Secretary of Defense, and in consultation with the heads of other relevant executive departments and agencies, was tasked with developing and submitting a list of minerals defined as critical minerals to the Federal Register. The final list of critical minerals was published in the Federal Register on May 18, 2018 (83 FR 23295), which included 35 minerals or mineral material groups. These were aluminum (bauxite), antimony, arsenic, barite, beryllium, bismuth, cesium, chromium, cobalt, fluorspar, gallium, germanium, graphite (natural), hafnium, helium, indium, lithium, magnesium, manganese, niobium, platinumgroup metals, potash, the rare-earth-elements group, rhenium, rubidium, scandium, strontium, tantalum, tellurium, tin, titanium, tungsten, uranium, vanadium, and zirconium.

The EO also directed the Secretary of Commerce, in coordination with heads of selected executive branch agencies and offices, to submit a report to the President that includes: "a strategy to reduce the Nation's reliance on critical minerals; an assessment of progress toward developing critical minerals recycling and reprocessing technologies, and technological alternatives to critical minerals; options for accessing and developing critical minerals through investment and trade with our allies and partners; a plan to improve the topographic, geologic, and geophysical mapping of the United States and make the resulting data and metadata electronically accessible, to the extent permitted by law and subject to appropriate limitations for purposes of privacy and security, to support private sector mineral exploration of critical minerals; and recommendations to streamline permitting and review processes related to developing leases; enhancing access to critical mineral resources; and increasing discovery, production, and domestic refining of critical minerals." In June 2019, the U.S. Department of Commerce issued the report, 
which presented 6 Calls to Action, 24 goals, and 61 recommendations that describe specific steps that the Federal Government will take to achieve the objectives outlined in the EO.

As shown in the figure on page 4, minerals remained fundamental to the U.S. economy, contributing to the real gross domestic product at several levels, including mining, processing, and manufacturing finished products. The estimated value of nonfuel minerals produced at mines in the United States in 2019 was $\$ 86.3$ billion. The value of net exports of mineral raw materials increased to $\$ 3.7$ billion from $\$ 2.9$ billion in 2018. Domestic raw materials and domestically recycled materials were used to produce mineral materials worth $\$ 770$ billion. Of the $\$ 36.1$ billion of domestically recycled products, iron and steel scrap contributed $\$ 17.6$ billion. These mineral materials as well as imports of processed mineral materials, which decreased by $8 \%$ in 2019 , were, in turn, consumed by downstream industries with an estimated value of $\$ 3.13$ trillion in 2019 , a $2.5 \%$ increase from the revised figure of $\$ 3.05$ trillion in 2018 .

The figure on page 7 illustrates the reliance of the United States on foreign sources for raw and processed mineral materials. In 2019, imports made up more than one-half of the U.S. apparent consumption for 46 nonfuel mineral commodities, and the United States was 100\% net import reliant for 17 of those. Critical minerals comprised 14 of the 17 mineral commodities with $100 \%$ net import reliance and comprised 17 of the 29 remaining mineral commodities with imports greater than $50 \%$ of annual consumption.

The figure on page 8 shows the countries from which the majority of these mineral commodities were imported and the number of mineral commodities for which each highlighted country was a leading supplier. China, followed by Canada, supplied the largest number of nonfuel mineral commodities. The United States was import reliant for an additional 30 commodities and was a net exporter of 17 nonfuel mineral commodities.

The estimated value of U.S. metal mine production in 2019 was $\$ 28.1$ billion, slightly more than that of 2018 (table 1). Principal contributors to the total value of metal mine production in 2019 were gold (32\%), copper (28\%), iron ore (19\%), and zinc (7\%). The estimated value of U.S. industrial minerals production in 2019, including construction aggregates, was $\$ 58.2$ billion, about 3\% more than the revised value of 2018 (table 1). The value of industrial minerals production in 2019 was dominated by crushed stone (32\%), cement (masonry and portland) (19\%), construction sand and gravel (16\%) and industrial sand and gravel (10\%).

In 2019, U.S. production of 13 mineral commodities was valued at more than $\$ 1$ billion each. These commodities were, in decreasing order of value, crushed stone, cement, construction sand and gravel, gold, copper, industrial sand and gravel, iron ore, lime, salt, zinc, soda ash, phosphate rock, and molybdenum concentrates.

In 2019, 13 States each produced more than $\$ 2$ billion worth of nonfuel mineral commodities. These States were, in descending order of production value, Nevada, Arizona, Texas, Minnesota, California, Florida, Utah, Alaska, Missouri, Michigan, Wyoming, Georgia, and Pennsylvania (table 3 and figure on page 12).

The Defense Logistics Agency (DLA) Strategic Materials is responsible for providing safe, secure, and environmentally sound stewardship for strategic and critical materials in the U.S. National Defense Stockpile (NDS). DLA Strategic Materials stores 48 commodities at 12 locations in the United States. In fiscal year 2019, DLA Strategic Materials acquired approximately $\$ 14.5$ million of new stock and sold $\$ 37.14$ million of excess materials from the NDS. At the end of fiscal year 2019, materials valued at $\$ 1.03$ billion remained in the NDS. Of the remaining material, portions were held in reserve, offered for sale, or sales were suspended. Additional detailed information can be found in the "Government Stockpile" sections in the mineral commodity chapters that follow. Under the authority of the Defense Production Act of 1950, the U.S. Geological Survey advises the DLA on acquisitions and disposals of NDS mineral materials. 


\section{U.S. NET IMPORT RELIANCE ${ }^{1}$}

Commodity

ARSENIC (all forms)

ASBESTOS

CESIUM

FLUORSPAR

GALLIUM

GRAPHITE (natural)

INDIUM

MANGANESE

MICA, sheet (natural)

NEPHELINE SYENITE

NIOBIUM (columbium)

RARE EARTHS ${ }^{3}$ (compounds and metal)

RUBIDIUM

SCANDIUM

STRONTIUM

TANTALUM

YTTRIUM

GEMSTONES

BISMUTH

TELLURIUM

VANADIUM

TITANIUM MINERAL CONCENTRATES

POTASH

DIAMOND (industrial stones)

BARITE

ZINC (refined)

TITANIUM (sponge)

ANTIMONY (metal and oxide)

RHENIUM

STONE (dimension)

COBALT

TIN (refined)

ABRASIVES, fused Al oxide (crude)

BAUXITE

CHROMIUM

PEAT

SILVER

GARNET (industrial)

PLATINUM

ALUMINA

MAGNESIUM COMPOUNDS

ABRASIVES, silicon carbide (crude)

GERMANIUM

IODINE

IRON OXIDE PIGMENTS (natural and synthetic)

TUNGSTEN

DIAMOND (industrial dust, grit, and powder)

CADMIUM

MAGNESIUM METAL

NICKEL

SILICON (metal and ferrosilicon)

MICA, scrap and flake (natural)

COPPER (refined)

PALLADIUM

LEAD (refined)

SALT

PERLITE

LITHIUM

BROMINE

SELENIUM

ALUMINUM

IRON and STEEL
Percent

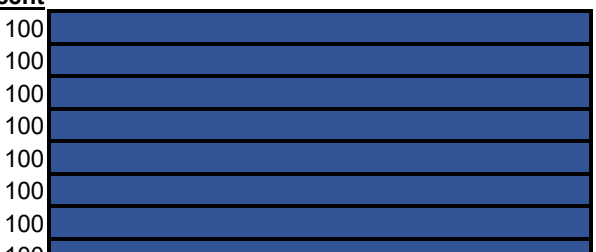

100

100

100

100

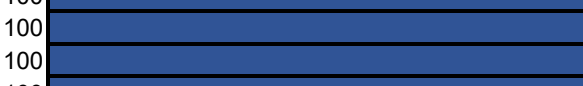

100

100

9

96
$>95$

94

9

91
88
87

$$
\begin{aligned}
& 87 \\
& 87
\end{aligned}
$$

$$
\begin{aligned}
& 87 \\
& 86 \\
& 84 \\
& 82
\end{aligned}
$$

$$
\begin{aligned}
& 8 \\
& 8 \\
& 78
\end{aligned}
$$$$
\begin{aligned}
& 78 \\
& 77
\end{aligned}
$$$$
\begin{array}{r}
77 \\
>75 \\
>75 \\
72
\end{array}
$$$$
\begin{aligned}
& 72 \\
& 70 \\
& 68
\end{aligned}
$$$$
68
$$
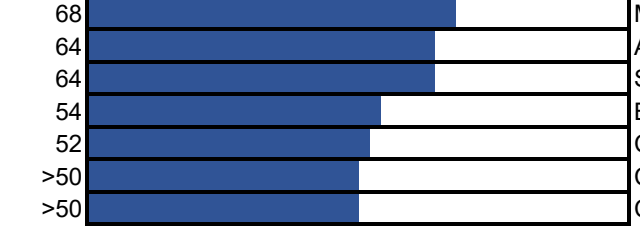

$>>50$

$>50$
$>50$
$>50$

50
$<50$
$<50$
47

$<5$
47

47
41
37
35
32

32

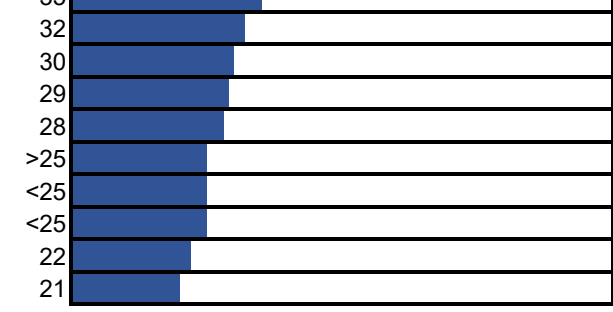

Major import sources (2015-18)

China, Morocco, Belgium

Brazil, Russia

Canada

Mexico, Vietnam, South Africa, China

China, United Kingdom, Germany, Ukraine

China, Mexico, Canada, India

China, Canada, Republic of Korea, Taiwan

South Africa, Gabon, Australia, Georgia

China, Brazil, Belgium, Austria

Canada

Brazil, Canada, Russia, Germany

China, Estonia, Japan, Malaysia

Canada

Europe, China, Japan, Russia

Mexico, Germany, China

Rwanda, Brazil, Australia, Congo (Kinshasa)

China, Estonia, Republic of Korea, Japan

India, Israel, Belgium, South Africa

China, Belgium, Mexico, Republic of Korea

Canada, China, Germany

Austria, Canada, Russia, Republic of Korea

South Africa, Australia, Canada, Mozambique

Canada, Russia, Belarus, Israel

India, South Africa, Botswana, Australia

China, India, Morocco, Mexico

Canada, Mexico, Australia, Peru

Japan, Kazakhstan, Ukraine, China, Russia

China, Thailand, Belgium, India

Chile, Germany, Kazakhstan, Canada

China, Brazil, Italy, Turkey

Norway, Japan, China, Canada

Indonesia, Malaysia, Peru, Bolivia

China, Hong Kong, France, Canada

Jamaica, Brazil, Guinea, Guyana

South Africa, Kazakhstan, Russia

Canada

Mexico, Canada, Peru, Poland

Australia, India, South Africa, China

South Africa, Germany, Italy, Russia

Brazil, Australia, Jamaica, Canada

China, Canada, Australia, Hong Kong

China, South Africa, Netherlands, Hong Kong

China, Belgium, Germany, Russia

Chile, Japan

China, Germany, Brazil, Canada

China, Bolivia, Germany, Spain

China, Ireland, Republic of Korea, Russia

China, Australia, Canada, Peru

Israel, Canada, Mexico, United Kingdom

Canada, Norway, Australia, Finland

Russia, Brazil, Canada

Canada, China, India, Finland

Chile, Canada, Mexico

South Africa, Russia, Germany, Italy

Canada, Mexico, Republic of Korea, India

Chile, Canada, Mexico, Egypt

Greece, China, Mexico

Argentina, Chile, China

Israel, Jordan, China

China, Philippines, Mexico, Germany

Canada, Russia, United Arab Emirates, China

Canada, Brazil, Republic of Korea

${ }^{1}$ Not all mineral commodities covered in this publication are listed here. Those not shown include mineral commodities for which the United States is a net exporter (abrasives, metallic; boron; clays; diatomite; gold; helium; iron and steel scrap; iron ore; kyanite; molybdenum concentrates; sand and gravel, industrial; soda ash; titanium dioxide pigment; wollastonite; zeolites; and zirconium mineral concentrates) or less than $21 \%$ import reliant (beryllium; cement; feldspar; gypsum; iron and steel slag; lime; nitrogen (fixed)-ammonia; phosphate rock; pumice; sand and gravel, construction; stone, crushed; sulfur; talc and pyrophyllite; and vermiculite.). For some mineral commodities (hafnium; mercury; quartz crystal, industrial; thallium; and thorium), not enough information is available to calculate the exact percentage of import reliance.

${ }^{2}$ In descending order of import share.

${ }^{3}$ Data include lanthanides. 


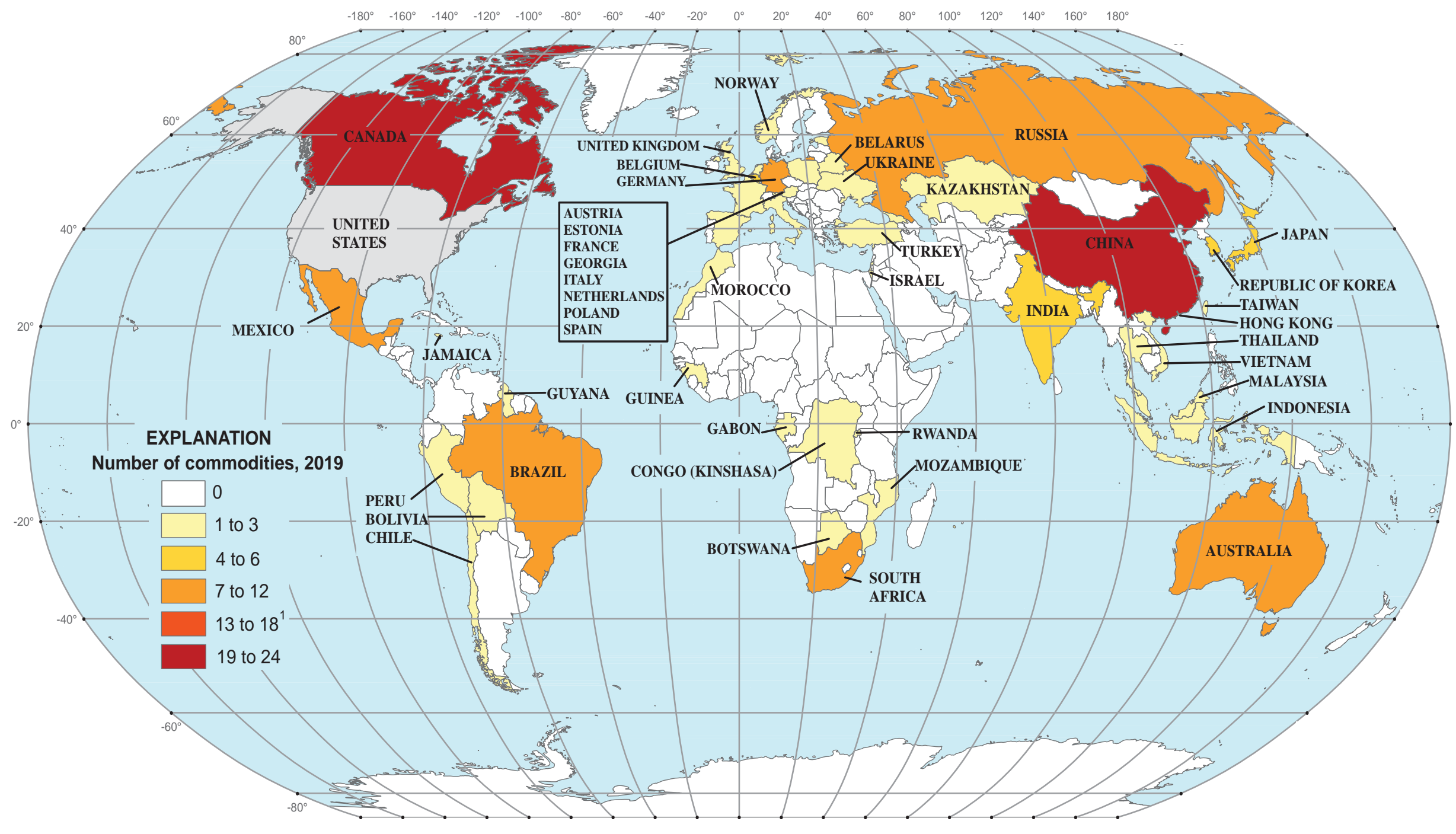

${ }^{1}$ In 2019, no countries qualified for the "13 to 18 commodities" category.

Source: U.S. Geological Survey 
TABLE 1.-U.S. MINERAL INDUSTRY TRENDS

\begin{tabular}{|c|c|c|c|c|c|}
\hline & $\underline{2015}$ & $\underline{2016}$ & $\underline{2017}$ & $\underline{2018}$ & $\underline{2019^{\mathrm{e}}}$ \\
\hline \multicolumn{6}{|l|}{ Total mine production (million dollars): } \\
\hline Metals & 24,400 & 23,800 & 26,500 & 27,700 & 28,100 \\
\hline Industrial minerals & 48,600 & 47,700 & 52,700 & 56,300 & 58,200 \\
\hline Coal & 28,500 & 22,300 & 26,100 & 27,200 & 25,100 \\
\hline \multicolumn{6}{|c|}{ Employment (thousands of production workers): } \\
\hline Coal mining & 54 & 42 & 43 & 44 & 45 \\
\hline Nonfuel mineral mining & 99 & 95 & 97 & 101 & 101 \\
\hline Chemicals and allied products & 507 & 516 & 525 & 548 & 563 \\
\hline Stone, clay, and glass products & 296 & 306 & 305 & 310 & 311 \\
\hline Primary metal industries & 307 & 293 & 292 & 294 & 296 \\
\hline \multicolumn{6}{|c|}{ Average weekly earnings of production workers (dollars): } \\
\hline Coal mining & 1,383 & 1,336 & 1,432 & 1,437 & 1,520 \\
\hline Chemicals and allied products & 927 & 920 & 1,011 & 1,072 & 1,069 \\
\hline Stone, clay, and glass products & 843 & 850 & 873 & 945 & 967 \\
\hline Primary metal industries & 987 & 1,002 & 995 & 1,035 & 1,025 \\
\hline
\end{tabular}

eEstimated.

Sources: U.S. Geological Survey, U.S. Department of Energy, and U.S. Department of Labor.

TABLE 2.-U.S. MINERAL-RELATED ECONOMIC TRENDS

\begin{tabular}{crrrrr}
\hline Gross domestic product (billion dollars) & $\underline{\mathbf{2 0 1 5}}$ & $\underline{\mathbf{2 0 1 6}}$ & $\underline{\mathbf{2 0 1 7}}$ & $\underline{\mathbf{2 0 1 8}}$ & $\underline{\mathbf{2 0 1 9}}$ \\
Industrial production (2012=100): & 18,225 & 18,715 & 19,519 & 20,580 & 21,429 \\
Total index: & & & & & \\
Manufacturing: & 104 & 102 & 104 & 109 & 109 \\
Nonmetallic mineral products & 102 & 101 & 103 & 106 & 106 \\
Primary metals: & 110 & 111 & 115 & 120 & 120 \\
$\quad$ Iron and steel & 97 & 93 & 94 & 98 & 98 \\
$\quad$ Aluminum & 92 & 87 & 92 & 97 & 98 \\
$\quad$ Nonferrous metals (except aluminum) & 107 & 106 & 103 & 107 & 109 \\
Chemicals & 98 & 95 & 91 & 91 & 88 \\
Coal & 95 & 95 & 97 & 100 & 101 \\
Oil and gas extraction & 114 & 103 & 110 & 124 & 132 \\
Metals & 87 & 70 & 75 & 74 & 70 \\
Nonmetallic minerals & 134 & 129 & 135 & 156 & 171 \\
Mining: & 100 & 100 & 98 & 93 & 94 \\
Capacity utilization (percent): & 116 & 114 & 118 & 119 & 125 \\
Total industry: & & & & & \\
Mining: & 77 & 75 & 76 & 79 & 78 \\
Metals & 84 & 78 & 84 & 90 & 91 \\
Nonmetallic minerals & 75 & 75 & 71 & 69 & 69 \\
Light vehicle sales (thousands) & 90 & 87 & 88 & 88 & 91 \\
Highway construction, value, put in place (billion dollars) & 1,107 & 1,178 & 1,209 & 1,250 & 1,260 \\
\hline
\end{tabular}

eEstimated.

Sources: U.S. Department of Commerce, Federal Reserve Board, and U.S. Department of Transportation. 


\section{TABLE 3.-VALUE OF NONFUEL MINERAL PRODUCTION IN THE UNITED STATES AND PRINCIPAL NONFUEL MINERALS PRODUCED IN 2019e, 1}

\begin{tabular}{|c|c|c|c|c|}
\hline State & $\begin{array}{c}\text { Value } \\
\text { (millions) }\end{array}$ & Rank $^{2}$ & $\begin{array}{l}\text { Percent } \\
\text { of U.S. } \\
\text { total }\end{array}$ & Principal commodities $^{3}$ \\
\hline$\overline{\text { Alabama }}$ & $\$ 1,690$ & 19 & 1.96 & $\begin{array}{l}\text { Cement (portland), lime, sand and gravel (construction), sand and } \\
\text { gravel (industrial), stone (crushed). }\end{array}$ \\
\hline Alaska & 3,130 & 8 & 3.63 & Gold, lead, sand and gravel (construction), silver, zinc. \\
\hline Arizona & 6,970 & 2 & 8.08 & $\begin{array}{l}\text { Cement (portland), copper, molybdenum concentrates, sand and } \\
\text { gravel (construction), stone (crushed). }\end{array}$ \\
\hline Arkansas & 901 & 31 & 1.04 & $\begin{array}{l}\text { Bromine, cement (portland), sand and gravel (construction), sand } \\
\text { and gravel (industrial), stone (crushed). }\end{array}$ \\
\hline California & 4,490 & 5 & 5.20 & $\begin{array}{l}\text { Boron minerals, cement (portland), gold, sand and gravel } \\
\text { (construction), stone (crushed). }\end{array}$ \\
\hline Colorado & 1,790 & 17 & 2.07 & $\begin{array}{l}\text { Cement (portland), gold, molybdenum concentrates, sand and } \\
\text { gravel (construction), stone (crushed). }\end{array}$ \\
\hline Connecticut 4 & 191 & 43 & 0.22 & $\begin{array}{l}\text { Clay (common clay), sand and gravel (construction), stone } \\
\text { (crushed), stone (dimension). }\end{array}$ \\
\hline Delaware 4 & 30 & 50 & 0.03 & $\begin{array}{l}\text { Magnesium compounds, sand and gravel (construction), stone } \\
\text { (crushed). }\end{array}$ \\
\hline Florida & 3,370 & 6 & 3.91 & $\begin{array}{l}\text { Cement (portland), phosphate rock, sand and gravel } \\
\text { (construction), stone (crushed), zirconium mineral concentrates. }\end{array}$ \\
\hline Georgia & 2,170 & 12 & 2.52 & $\begin{array}{l}\text { Cement (portland), clay (kaolin and montmorillonite), sand and } \\
\text { gravel (construction), stone (crushed). }\end{array}$ \\
\hline Hawaii & 134 & 46 & 0.16 & Sand and gravel (construction), stone (crushed). \\
\hline Idaho 4 & 185 & 35 & 0.21 & $\begin{array}{l}\text { Lead, phosphate rock, sand and gravel (construction), silver, } \\
\text { stone (crushed). }\end{array}$ \\
\hline Illinois 4 & 1,470 & 20 & 1.17 & $\begin{array}{l}\text { Cement (portland), sand and gravel (construction), sand and } \\
\text { gravel (industrial), silica (tripoli), stone (crushed). }\end{array}$ \\
\hline Indiana & 695 & 26 & 0.81 & $\begin{array}{l}\text { Cement (portland), lime, sand and gravel (construction), stone } \\
\text { (crushed), stone (dimension). }\end{array}$ \\
\hline lowa4 & 836 & 27 & 0.97 & $\begin{array}{l}\text { Cement (portland), lime, sand and gravel (construction), sand and } \\
\text { gravel (industrial), stone (crushed). }\end{array}$ \\
\hline Kansas 4 & 1,070 & 24 & 1.24 & $\begin{array}{l}\text { Cement (portland), helium (Grade-A), salt, sand and gravel } \\
\text { (construction), stone (crushed). }\end{array}$ \\
\hline Kentucky4 & 591 & 30 & 0.68 & $\begin{array}{l}\text { Cement (portland), clay (common clay), lime, sand and gravel } \\
\text { (construction), stone (crushed). }\end{array}$ \\
\hline Louisiana ${ }^{4}$ & 614 & 34 & 0.71 & $\begin{array}{l}\text { Clay (common clay), salt, sand and gravel (construction), sand } \\
\text { and gravel (industrial), stone (crushed). }\end{array}$ \\
\hline Maine 4 & 102 & 45 & 0.12 & $\begin{array}{l}\text { Cement (portland), peat, sand and gravel (construction), stone } \\
\text { (crushed), stone (dimension). }\end{array}$ \\
\hline Maryland 4 & 575 & 32 & 0.67 & $\begin{array}{l}\text { Cement (masonry and portland), sand and gravel (construction), } \\
\text { stone (crushed), stone (dimension). }\end{array}$ \\
\hline Massachusetts 4 & 289 & 42 & 0.34 & $\begin{array}{l}\text { Clay (common clay), lime, sand and gravel (construction), stone } \\
\text { (crushed), stone (dimension). }\end{array}$ \\
\hline Michigan & 2,750 & 10 & 3.18 & $\begin{array}{l}\text { Cement (portland), iron ore, salt, sand and gravel (construction), } \\
\text { stone (crushed). }\end{array}$ \\
\hline Minnesota 4 & 5,300 & 4 & 6.14 & $\begin{array}{l}\text { Iron ore, lime, sand and gravel (construction), sand and gravel } \\
\text { (industrial), stone (crushed). }\end{array}$ \\
\hline Mississippi & 504 & 37 & 0.58 & $\begin{array}{l}\text { Clay (ball clay and montmorillonite), sand and gravel } \\
\text { (construction), sand and gravel (industrial), stone (crushed). }\end{array}$ \\
\hline Missouri & 3,050 & 9 & 3.53 & $\begin{array}{l}\text { Cement (portland), lead, lime, sand and gravel (industrial), stone } \\
\text { (crushed). }\end{array}$ \\
\hline Montana & 1,280 & 23 & 1.49 & $\begin{array}{l}\text { Copper, molybdenum concentrates, palladium, platinum, sand } \\
\text { and gravel (construction). }\end{array}$ \\
\hline
\end{tabular}

See footnotes at end of table. 


\section{TABLE 3.-VALUE OF NONFUEL MINERAL PRODUCTION IN THE UNITED STATES AND PRINCIPAL NONFUEL MINERALS PRODUCED IN 2019e, 1_Continued}

\begin{tabular}{|c|c|c|c|c|}
\hline State & $\begin{array}{c}\text { Value } \\
\text { (millions) }\end{array}$ & Rank $^{2}$ & $\begin{array}{l}\text { Percent } \\
\text { of U.S. } \\
\text { total }\end{array}$ & Principal commodities $^{3}$ \\
\hline Nebraska $^{4}$ & $\$ 214$ & 39 & 0.25 & $\begin{array}{l}\text { Cement (portland), lime, sand and gravel (construction), sand and } \\
\text { gravel (industrial), stone (crushed). }\end{array}$ \\
\hline Nevada & 8,190 & 1 & 9.49 & Copper, diatomite, gold, lime, sand and gravel (construction). \\
\hline New Hampshire & 156 & 44 & 0.18 & $\begin{array}{l}\text { Sand and gravel (construction), stone (crushed), stone } \\
\text { (dimension). }\end{array}$ \\
\hline New Jersey & 377 & 40 & 0.44 & $\begin{array}{l}\text { Peat, sand and gravel (construction), sand and gravel (industrial), } \\
\text { stone (crushed). }\end{array}$ \\
\hline New Mexico & 1,090 & 28 & 1.26 & $\begin{array}{l}\text { Cement (portland), copper, potash, sand and gravel } \\
\text { (construction), stone (crushed). }\end{array}$ \\
\hline New York & 1,870 & 16 & 2.16 & $\begin{array}{l}\text { Cement (portland), salt, sand and gravel (construction), stone } \\
\text { (crushed), zinc. }\end{array}$ \\
\hline North Carolina 4 & 1,420 & 18 & 1.64 & $\begin{array}{l}\text { Clay (common clay), phosphate rock, sand and gravel } \\
\text { (construction), sand and gravel (industrial), stone (crushed). }\end{array}$ \\
\hline North Dakota 4 & 58 & 48 & 0.07 & $\begin{array}{l}\text { Clay (common clay), lime, sand and gravel (construction), sand } \\
\text { and gravel (industrial), stone (crushed). }\end{array}$ \\
\hline Ohio 4 & 1,400 & 15 & 1.62 & $\begin{array}{l}\text { Cement (portland), lime, salt, sand and gravel (construction), } \\
\text { stone (crushed). }\end{array}$ \\
\hline Oklahoma & 1,070 & 29 & 1.24 & $\begin{array}{l}\text { Cement (portland), iodine, sand and gravel (construction), sand } \\
\text { and gravel (industrial), stone (crushed). }\end{array}$ \\
\hline Oregon & 499 & 38 & 0.58 & $\begin{array}{l}\text { Cement (portland), diatomite, perlite (crude), sand and gravel } \\
\text { (construction), stone (crushed). }\end{array}$ \\
\hline Pennsylvania 4 & 2,100 & 13 & 2.44 & $\begin{array}{l}\text { Cement (portland), lime, sand and gravel (construction), sand and } \\
\text { gravel (industrial), stone (crushed). }\end{array}$ \\
\hline Rhode Island 4 & 54 & 49 & 0.06 & $\begin{array}{l}\text { Sand and gravel (construction), sand and gravel (industrial), stone } \\
\text { (crushed). }\end{array}$ \\
\hline South Carolina 4 & 1,140 & 25 & 1.32 & $\begin{array}{l}\text { Cement (masonry and portland), gold, sand and gravel } \\
\text { (construction), stone (crushed). }\end{array}$ \\
\hline South Dakota & 312 & 41 & 0.36 & $\begin{array}{l}\text { Cement (portland), gold, lime, sand and gravel (construction), } \\
\text { stone (crushed). }\end{array}$ \\
\hline Tennessee & 1,420 & 22 & 1.64 & $\begin{array}{l}\text { Cement (portland), sand and gravel (construction), sand and } \\
\text { gravel (industrial), stone (crushed), zinc. }\end{array}$ \\
\hline Texas & 6,470 & 3 & 7.49 & $\begin{array}{l}\text { Cement (portland), salt, sand and gravel (construction), sand and } \\
\text { gravel (industrial), stone (crushed). }\end{array}$ \\
\hline Utah & 3,320 & 7 & 3.85 & $\begin{array}{l}\text { Copper, gold, molybdenum concentrates, salt, sand and gravel } \\
\text { (construction). }\end{array}$ \\
\hline Vermont 4 & 95 & 47 & 0.11 & $\begin{array}{l}\text { Sand and gravel (construction), stone (crushed), stone } \\
\text { (dimension), talc (crude). }\end{array}$ \\
\hline Virginia & 1,520 & 21 & 1.76 & $\begin{array}{l}\text { Cement (portland), kyanite, lime, sand and gravel (construction), } \\
\text { stone (crushed). }\end{array}$ \\
\hline Washington & 869 & 33 & 1.01 & $\begin{array}{l}\text { Cement (portland), diatomite, sand and gravel (construction), } \\
\text { stone (crushed), zinc. }\end{array}$ \\
\hline West Virginia 4 & 332 & 36 & 0.38 & $\begin{array}{l}\text { Cement (masonry and portland), lime, sand and gravel } \\
\text { (industrial), stone (crushed). }\end{array}$ \\
\hline Wisconsin 4 & 1,950 & 14 & 2.26 & $\begin{array}{l}\text { Lime, sand and gravel (construction), sand and gravel (industrial), } \\
\text { stone (crushed), stone (dimension). }\end{array}$ \\
\hline Wyoming & 2,630 & 11 & 3.05 & $\begin{array}{l}\text { Cement (portland), clay (bentonite), helium (Grade-A), sand and } \\
\text { gravel (construction), soda ash. }\end{array}$ \\
\hline Undistributed & 3,580 & $X X$ & 4.15 & \\
\hline Total & 86,300 & $X X$ & 100.00 & \\
\hline
\end{tabular}




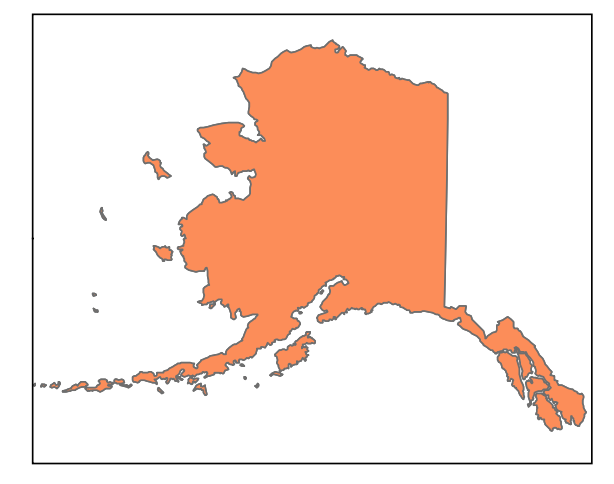

VALUE OF NONFUEL MINERALS PRODUCED IN 2019, BY STATE

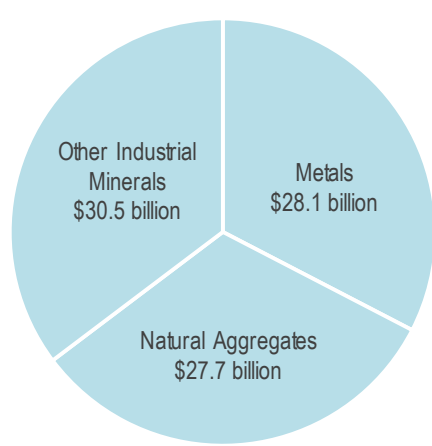

U.S. total: $\$ 86.3$ billion
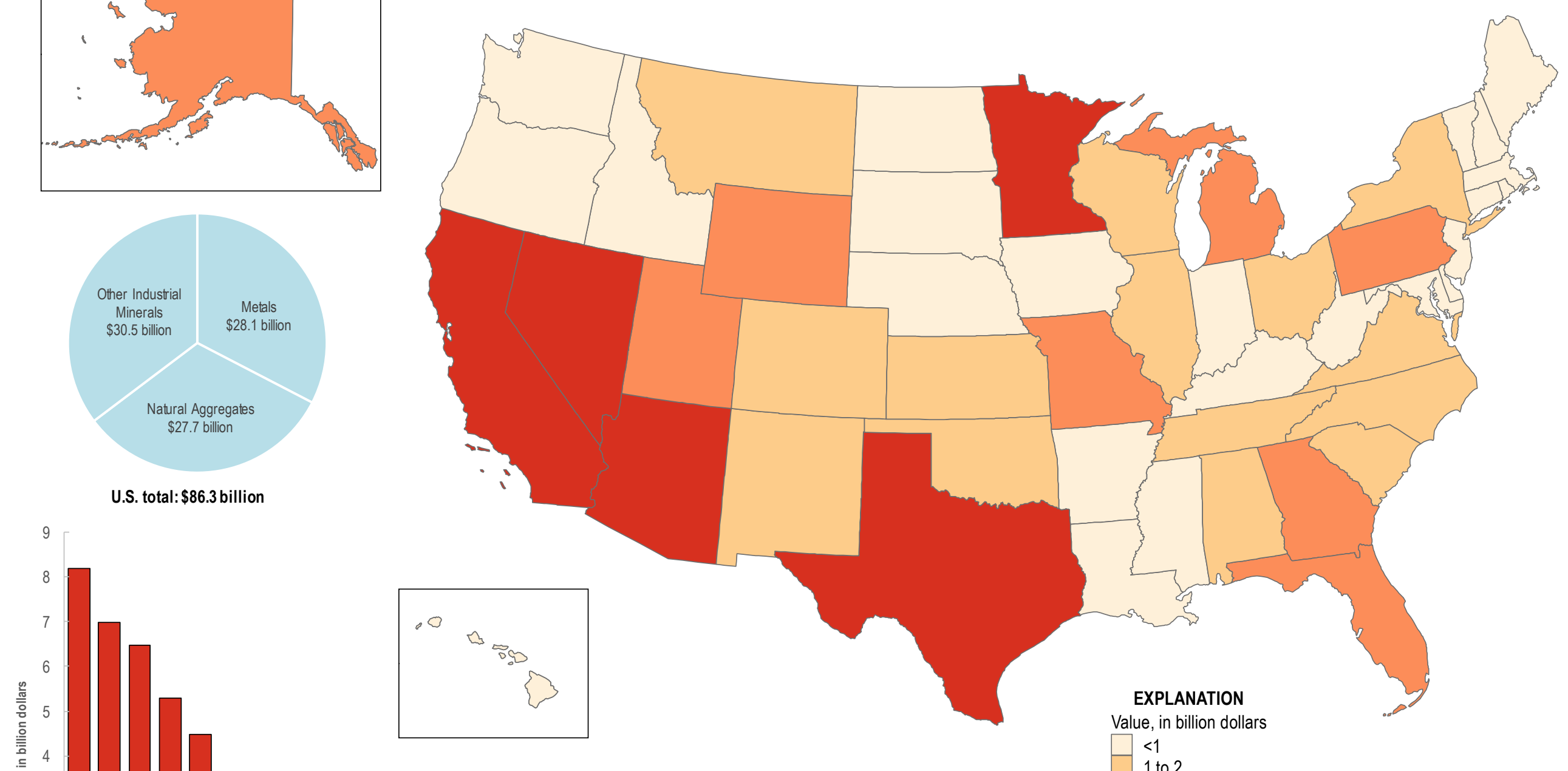

Value, in billion dollars

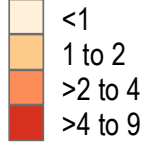




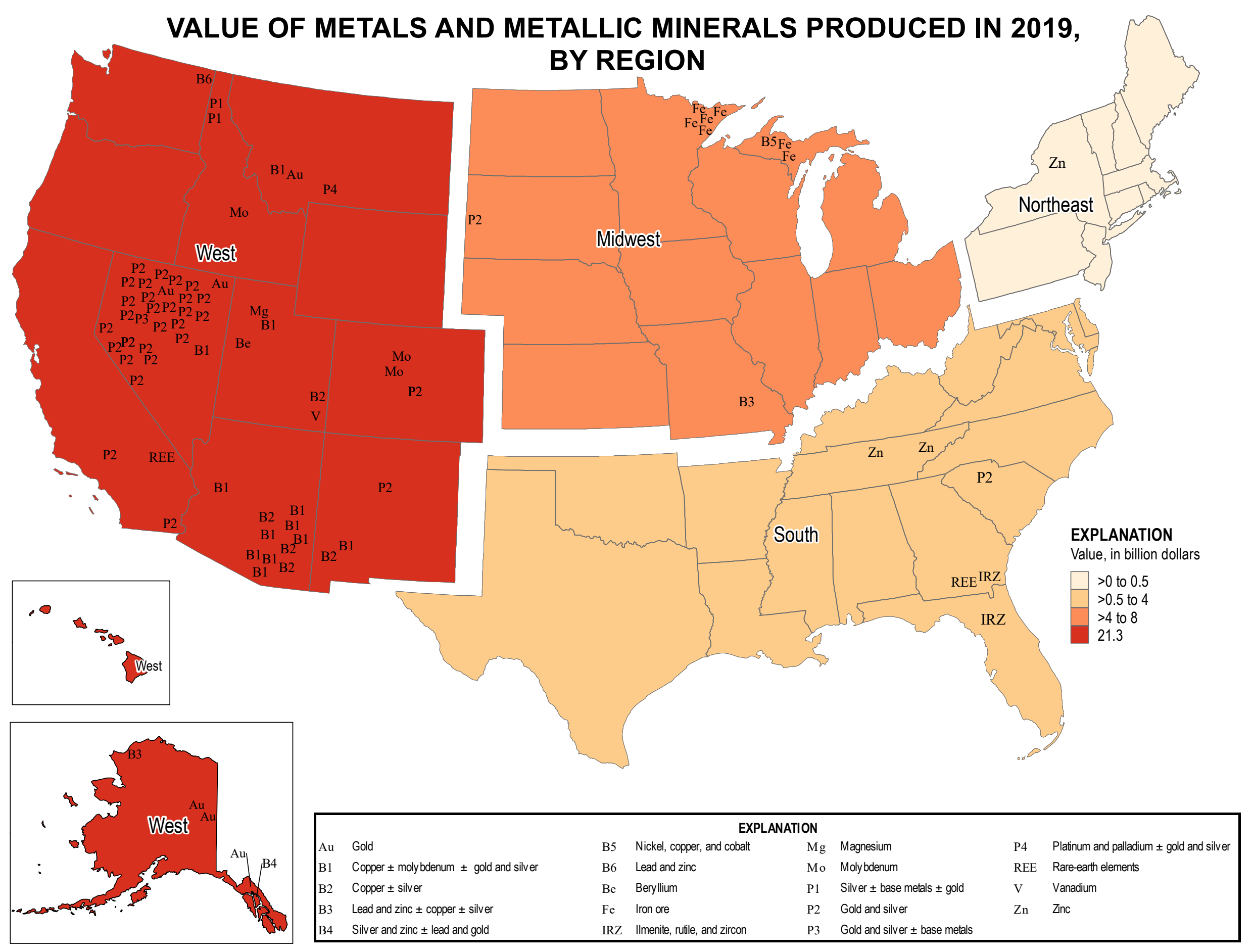




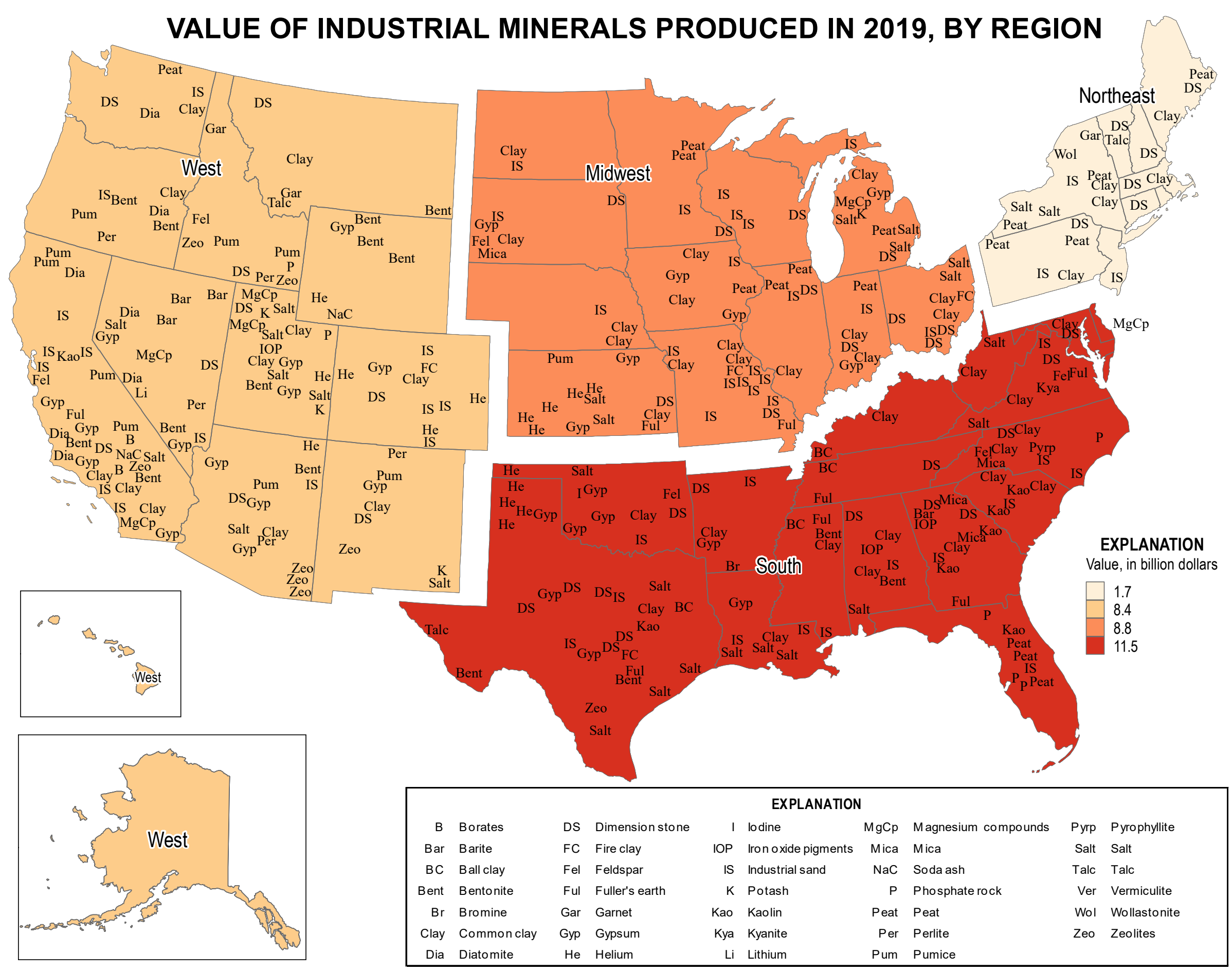



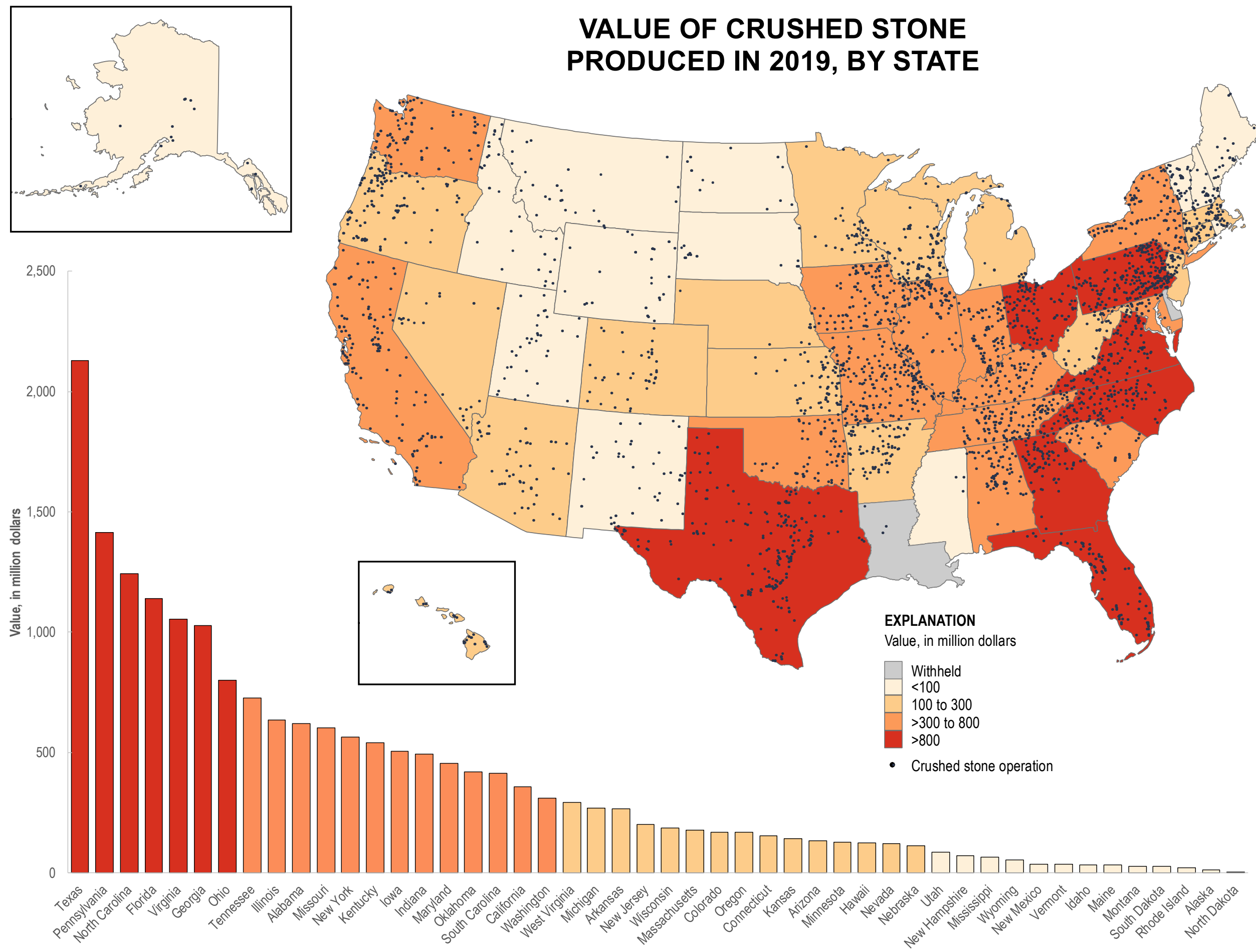


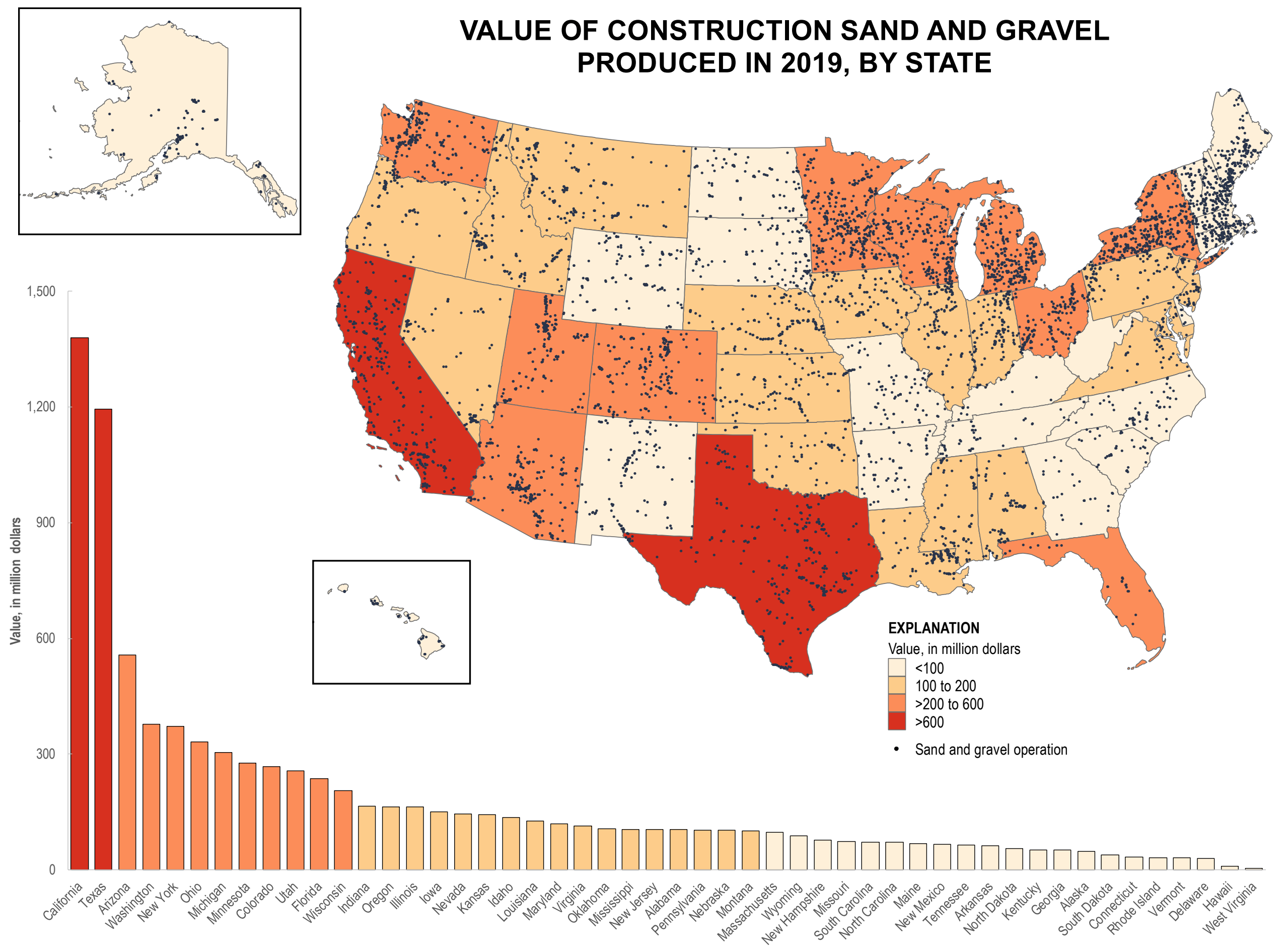


(THIS PAGE INTENTIONALLY LEFT BLANK) 


\section{ABRASIVES (MANUFACTURED)}

(Fused aluminum oxide, silicon carbide, and metallic abrasives)

(Data in metric tons unless otherwise noted)

Domestic Production and Use: Fused aluminum oxide was produced by two companies at three plants in the United States and Canada. Production of crude fused aluminum oxide had an estimated value of $\$ 7$ million. Silicon carbide was produced by two companies at two plants in the United States. Production of crude silicon carbide had an estimated value of about \$26 million. Metallic abrasives were produced by 11 companies in 8 States. Production of metallic abrasives had an estimated value of about $\$ 190$ million. Bonded and coated abrasive products accounted for most abrasive uses of fused aluminum oxide and silicon carbide. Metallic abrasives are used primarily for steel shot and grit and cut wire shot, which are used for sandblasting, peening, and stonecutting applications.

\begin{tabular}{|c|c|c|c|c|c|}
\hline $\begin{array}{l}\text { Salient Statistics_-United States: } \\
\text { Production: }\end{array}$ & $\underline{2015}$ & $\underline{2016}$ & $\underline{2017}$ & $\underline{2018}$ & $\underline{2019^{e}}$ \\
\hline Fused aluminum oxide, crude 1,2 & 10,000 & 10,000 & 10,000 & 10,000 & 10,000 \\
\hline Silicon carbide 2 & 35,000 & 35,000 & 35,000 & 35,000 & 35,000 \\
\hline Metallic abrasives & 206,000 & 188,000 & 179,000 & 180,000 & 180,000 \\
\hline Shipments, metallic abrasives & 224,000 & 204,000 & 197,000 & 196,000 & 190,000 \\
\hline \multicolumn{6}{|l|}{ Imports for consumption: } \\
\hline Fused aluminum oxide & 164,000 & 155,000 & 206,000 & 193,000 & 170,000 \\
\hline Silicon carbide & 139,000 & 116,000 & 137,000 & 146,000 & 110,000 \\
\hline Metallic abrasives & 52,800 & 54,100 & 29,600 & 29,900 & 30,000 \\
\hline \multicolumn{6}{|l|}{ Exports: } \\
\hline Fused aluminum oxide & 15,000 & 14,300 & 15,500 & 19,300 & 22,000 \\
\hline Silicon carbide & 19,700 & 6,820 & 6,100 & 10,100 & 12,000 \\
\hline Metallic abrasives & 35,900 & 28,600 & 31,000 & 33,600 & 32,000 \\
\hline \multicolumn{6}{|l|}{ Consumption, apparent: } \\
\hline Fused aluminum oxide ${ }^{3}$ & 159,000 & 151,000 & 201,000 & 184,000 & 160,000 \\
\hline Silicon carbide ${ }^{4}$ & 154,000 & 144,000 & 166,000 & 171,000 & 130,000 \\
\hline Metallic abrasives 5 & 241,000 & 230,000 & 196,000 & 192,000 & 190,000 \\
\hline \multicolumn{6}{|c|}{ Price, average unit value of imports, dollars per ton: } \\
\hline Fused aluminum oxide, regular & 579 & 418 & 489 & 692 & 730 \\
\hline Fused aluminum oxide, high-purity & 1,290 & 1,360 & 1,220 & 1,280 & 1,300 \\
\hline Silicon carbide, crude & 552 & 452 & 479 & 670 & 800 \\
\hline Metallic abrasives & 584 & 543 & 1,020 & 1,180 & 1,300 \\
\hline \multicolumn{6}{|l|}{$\begin{array}{l}\text { Net import reliance } 6 \text { as a percentage } \\
\text { of apparent consumption: }\end{array}$} \\
\hline Fused aluminum oxide & $>75$ & $>75$ & $>75$ & $>75$ & $>75$ \\
\hline Silicon carbide & $>75$ & $>75$ & $>75$ & $>75$ & $>50$ \\
\hline Metallic abrasives & 7 & 11 & E & $E$ & $E$ \\
\hline
\end{tabular}

Recycling: Up to $30 \%$ of fused aluminum oxide may be recycled, and about $5 \%$ of silicon carbide is recycled.

Import Sources (2015-18): Fused aluminum oxide, crude: China, 69\%; Hong Kong, 14\%; France, 8\%; Canada, 4\%; and other, 5\%. Fused aluminum oxide, grain: Austria, 19\%; Brazil, 17\%; Canada, 16\%; Germany, 14\%; and other, 34\%. Silicon carbide, crude: China, 80\%; South Africa, 7\%; Netherlands, 5\%; Hong Kong, 4\%; and other, 4\%. Silicon carbide, grain: China, 52\%; Brazil, 19\%; Russia, 10\%; Norway, 5\%; and other, 14\%. Metallic abrasives: Sweden, 32\%; Canada, 24\%; China, 13\%; Germany, 9\%; and other, 22\%.

Tariff: Item

Artificial corundum, crude

White, pink, ruby artificial corundum, greater than $97.5 \%$

aluminum oxide, grain

Artificial corundum, not elsewhere

specified or included, fused

aluminum oxide, grain

Silicon carbide, crude

Silicon carbide, grain

Iron, pig iron, or steel granules
Number

2818.10.1000

2818.10.2010

2818.10.2090

2849.20.1000

2849.20.2000

7205.10 .0000
Normal Trade Relations 12-31-19

Free.

$1.3 \%$ ad val.

$1.3 \%$ ad val.

Free.

$0.5 \%$ ad val.

Free. 


\section{ABRASIVES (MANUFACTURED)}

Depletion Allowance: None.

\section{Government Stockpile: None.}

Events, Trends, and Issues: In 2019, China was the world's leading producer of abrasive fused aluminum oxide and abrasive silicon carbide. Imports, especially from China where operating costs were lower, continued to challenge abrasives producers in the United States and Canada. In recent years, imports of abrasives from Hong Kong have also increased. Foreign competition is expected to persist and continue to limit production in North America. The average unit value of imports has increased every year since 2016 for regular fused aluminum oxide and crude silicon carbide. The average unit values of imports of regular fused aluminum oxide and crude silicon carbide during the first 6 months of 2019 were 5\% and 20\% higher, respectively, than those in 2018 and $49 \%$ and $60 \%$ higher, respectively, than those in 2017.

Abrasives consumption in the United States is greatly influenced by activity in the manufacturing sectors, in particular the aerospace, automotive, furniture, housing, and steel industries. Steel grit can be reclaimed and used multiple times. The use of reclaimed metallic abrasives increased potentially owing to rising surcharges on scrap and waste disposal and increasing prices for new material.

One of the leading abrasives producers in the world divested its silicon carbide business to a private equity firm during 2019.

\section{World Production Capacity:}

\begin{tabular}{|c|c|c|c|c|}
\hline \multirow[b]{3}{*}{ United States } & \multicolumn{2}{|c|}{ Fused aluminum oxide } & \multicolumn{2}{|c|}{ Silicon carbide ${ }^{\mathrm{e}}$} \\
\hline & 2018 & 2019 & 2018 & 2019 \\
\hline & 60,000 & 60,000 & 40,000 & 40,000 \\
\hline Argentina & - & - & 5,000 & 5,000 \\
\hline Australia & 50,000 & 50,000 & - & - \\
\hline Austria & 60,000 & 60,000 & - & - \\
\hline Brazil & 50,000 & 50,000 & 40,000 & 40,000 \\
\hline China & 800,000 & 800,000 & 450,000 & 450,000 \\
\hline France & 40,000 & 40,000 & 20,000 & 20,000 \\
\hline Germany & 80,000 & 80,000 & 35,000 & 35,000 \\
\hline India & 40,000 & 40,000 & 5,000 & 5,000 \\
\hline Japan & 15,000 & 15,000 & 60,000 & 60,000 \\
\hline Mexico & + & 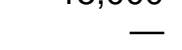 & 45,000 & 45,000 \\
\hline Norway & - & - & 80,000 & 80,000 \\
\hline Venezuela & - & - & 30,000 & 30,000 \\
\hline Other countries & 80,000 & 80,000 & 190,000 & 190,000 \\
\hline World total (rounded) & $1,300,000$ & $1,300,000$ & $1,000,000$ & $1,000,000$ \\
\hline
\end{tabular}

World Resources: Although domestic resources of raw materials for the production of fused aluminum oxide are rather limited, adequate resources are available in the Western Hemisphere. Domestic resources are more than adequate for the production of silicon carbide.

Substitutes: Natural and manufactured abrasives, such as garnet, emery, or metallic abrasives, can be substituted for fused aluminum oxide and silicon carbide in various applications.

\footnotetext{
eEstimated. E Net exporter. - Zero.

${ }^{1}$ Production data for aluminum oxide are combined production data from the United States and Canada to avoid disclosing company proprietary data.

${ }^{2}$ Rounded to the nearest 5,000 tons to avoid disclosing company proprietary data.

${ }^{3}$ Defined as imports - exports because production includes data from Canada; actual consumption is higher than that shown.

${ }^{4}$ Defined as production + imports - exports.

${ }^{5}$ Defined as shipments + imports - exports.

${ }^{6}$ Defined as imports - exports.
} 


\section{ALUMINUM $^{1}$}

(Data in thousand metric tons unless otherwise noted)

Domestic Production and Use: In 2019, three companies operated seven primary aluminum smelters in six States. Two smelters operated at full capacity and five smelters operated at reduced capacity throughout the year. One other smelter remained on standby throughout the year. Domestic smelters were operating at about $60 \%$ of capacity of 1.79 million tons per year in 2019. Production increased for the second year in a row after declining each year since 2012 and was $22 \%$ more than that in 2018. Based on published prices, the value of primary aluminum production was about $\$ 2.4$ billion, $7 \%$ more than the value in 2018. The average annual U.S. market price declined by about $13 \%$ from that in 2018, partially offsetting the value of the increased production. Transportation applications accounted for $39 \%$ of domestic consumption; in descending order of consumption, the remainder was used in packaging, 19\%; building, 14\%; electrical, 9\%; consumer durables, 8\%; machinery, 8\%; and other, 3\%.

\begin{tabular}{|c|c|c|c|c|c|}
\hline $\begin{array}{l}\text { Salient Statistics-United States: } \\
\text { Production: }\end{array}$ & $\underline{2015}$ & $\underline{2016}$ & $\underline{2017}$ & $\underline{2018}$ & $\underline{2019^{e}}$ \\
\hline Primary & 1,587 & 818 & 741 & 891 & 1,100 \\
\hline Secondary (from old scrap) & 1,470 & 1,570 & 1,590 & 1,570 & 1,500 \\
\hline Secondary (from new scrap) & 1,910 & 2,010 & 2,050 & 2,140 & 1,900 \\
\hline \multicolumn{6}{|l|}{ Imports for consumption: } \\
\hline Crude and semimanufactures & 4,560 & 5,410 & 6,220 & 5,540 & 3,700 \\
\hline Scrap & 521 & 609 & 700 & 695 & 600 \\
\hline \multicolumn{6}{|l|}{ Exports: } \\
\hline Crude and semimanufactures & 1,460 & 1,470 & 1,330 & 1,340 & 1,100 \\
\hline Scrap & 1,550 & 1,350 & 1,570 & 1,760 & 1,900 \\
\hline Consumption, apparent ${ }^{2}$ & 5,220 & 5,090 & 5,680 & 4,860 & 3,400 \\
\hline Supply, apparent ${ }^{3}$ & 7,120 & 7,100 & 7,730 & 7,000 & 5,300 \\
\hline $\begin{array}{l}\text { Price, ingot, average U.S. market (spot), } \\
\text { cents per pound }\end{array}$ & 88.2 & 80.4 & 98.3 & 114.7 & 100 \\
\hline \multicolumn{6}{|l|}{ Stocks, yearend: } \\
\hline Aluminum industry & 1,350 & 1,400 & 1,470 & 1,570 & 1,600 \\
\hline London Metal Exchange (LME), U.S. warehouses 4 & 507 & 362 & 254 & 186 & 65 \\
\hline Employment, number ${ }^{5}$ & 31,000 & 31,900 & 31,700 & 31,600 & 31,600 \\
\hline $\begin{array}{l}\text { Net import reliance } 6 \text { as a percentage of } \\
\text { apparent consumption }\end{array}$ & 41 & 53 & 59 & 49 & 22 \\
\hline
\end{tabular}

Recycling: In 2019, aluminum recovered from purchased scrap in the United States was about 3.4 million tons, of which about 56\% came from new (manufacturing) scrap and $44 \%$ from old scrap (discarded aluminum products). Aluminum recovered from old scrap was equivalent to about $45 \%$ of apparent consumption.

Import Sources (2015-18): Canada, 48\%; Russia 9\%; United Arab Emirates, 9\%; China, 6\%; and other, 28\%.

\section{Tariff: Item}

Aluminum, not alloyed:

Unwrought (in coils)

Unwrought (other than aluminum alloys)

Aluminum alloys:

Unwrought (billet)

Aluminum waste and scrap:

Used beverage container scrap

Other

\section{Number}

7601.10.3000

7601.10 .6000

7601.20 .9045

7602.00 .0030

7602.00 .0090

\section{Normal Trade Relations} 12-31-19

$2.6 \%$ ad val.

Free.

Free.

Free.

Free.

Depletion Allowance: Not applicable. ${ }^{1}$

Government Stockpile: None.

Events, Trends, and Issues: A 252,000-ton-per-year smelter in Hawesville, KY, shut down one potline with 50,000 tons per year of capacity in June for scheduled maintenance work. Another 50,000-ton-per-year potline at the Hawesville smelter was shut down for maintenance work in October ahead of a scheduled shutdown. Both potlines were scheduled to be restarted in 2020 . 


\section{ALUMINUM}

In January, a 2-year power supply agreement took effect between a primary aluminum smelter in Mt. Holly, SC, and its power provider. In March, a 7-year power supply agreement between the owner of the 130,000-metric-ton-per-year Massena, NY, smelter and its power provider was signed. In September, workers represented by the United Steelworkers union ratified a 4-year contract covering about 1,700 employees, most of whom were located at a 269,000-metric-ton-per-year smelter in Evansville, IN, the smelter in Massena, NY, and a rolling mill in Gum Springs, AR. The new contract was retroactive to May 15 when the prior contract expired, and production was not disrupted during the negotiations.

In January, the U.S. Department of the Treasury lifted sanctions that were imposed against a Russian producer of aluminum, alumina, and bauxite in April 2018 in response to activities of the Government of Russia. Prior to the sanctions being lifted, a winddown period was granted to companies with contracts with the sanctioned company. The winddown period was extended several times until the sanctions were lifted and deliveries to consumers in the United States were not disrupted.

After the United States, Canada, and Mexico reached an agreement on trade terms, Presidential Proclamation 9893, issued in May 2019, removed the $10 \%$ ad valorem tariff on imports of aluminum from Canada and Mexico. The tariff on aluminum imports for Canada and Mexico was imposed under the authority of Section 232 of the Trade Expansion Act of 1962 in 2018. Canada and Mexico agreed to remove retaliatory measures that were imposed on United States products. Under the agreement, a quota on aluminum imports was not imposed, but if imports increased dramatically compared with historical volumes, the United States reserved the right to reimpose the tariff and Canada and Mexico reserved the right to reimpose retaliatory measures. Aluminum imports from all countries except Argentina, Australia, Canada, and Mexico remained subject to the $10 \%$ ad valorem tariff as of early December.

On October 22, the U.S. Department of Commerce announced its final determination in an antidumping investigation of imports of aluminum wire from China, which affirmed the preliminary finding announced May 30 . The finding determined that aluminum cable and wire from China was sold below fair market value and antidumping rates of duty ranging from $58.51 \%$ to $63.47 \%$ were assigned.

World Smelter Production and Capacity: Capacity data for China in 2018 was revised based on Government data.

\begin{tabular}{lrrrr} 
& \multicolumn{2}{c}{ Production } & \multicolumn{2}{c}{ Yearend capacity } \\
United States & $\mathbf{2 0 1 8}$ & $\underline{\mathbf{2 0 1 9}}$ & $\underline{\mathbf{2 0 1 8}}$ & $\frac{\mathbf{2 0 1 9}}{1,790}$ \\
Australia & 891 & 1,100 & 1,790 & 1,720 \\
Bahrain & 1,580 & 1,600 & 1,720 & 1,540 \\
Canada & 1,010 & 1,400 & 1,050 & 3,270 \\
China & 2,920 & 2,900 & 3,270 & 890 \\
Iceland & 35,800 & 36,000 & 44,000 & 4,060 \\
India & 885 & 850 & 890 & 1,430 \\
Norway & 3,680 & 3,700 & 4,060 & 3,900 \\
Russia & 1,300 & 1,300 & 1,430 & 2,700 \\
United Arab Emirates & 3,630 & 3,600 & 3,900 & 12,200 \\
Other countries & 2,640 & 2,700 & 2,700 & 77,900
\end{tabular}

World Resources: Global resources of bauxite are estimated to be between 55 billion to 75 billion tons and are sufficient to meet world demand for metal well into the future. ${ }^{1}$

Substitutes: Composites can substitute for aluminum in aircraft fuselages and wings. Glass, paper, plastics, and steel can substitute for aluminum in packaging. Composites, magnesium, steel, and titanium can substitute for aluminum in ground transportation uses. Composites, steel, vinyl, and wood can substitute for aluminum in construction. Copper can replace aluminum in electrical and heat-exchange applications.

\footnotetext{
eEstimated.

${ }^{1}$ See also Bauxite and Alumina.

${ }^{2}$ Defined as domestic primary metal production + recovery from old aluminum scrap + net import reliance; excludes imported scrap.

${ }^{3}$ Defined as domestic primary metal production + recovery from all aluminum scrap + net import reliance; excludes imported scrap.

${ }^{4}$ Includes aluminum alloy.

${ }^{5}$ Alumina and aluminum production workers (North American Industry Classification System-3313). Source: U.S. Department of Labor, Bureau of Labor Statistics.

${ }^{6}$ Defined as imports - exports + adjustments for industry stock changes.
} 


\section{ANTIMONY}

(Data in metric tons of antimony content unless otherwise noted)

Domestic Production and Use: In 2019, no marketable antimony was mined in the United States. A mine in Nevada that had extracted about 800 tons of stibnite ore from 2013 through 2014 was placed on care-and-maintenance status in 2015 and had no reported production in 2019. Primary antimony metal and oxide were produced by one company in Montana using imported feedstock. Secondary antimony production was derived mostly from antimonial lead recovered from spent lead-acid batteries. The estimated value of secondary antimony produced in 2019 , based on the average New York dealer price for antimony, was about \$34 million. Recycling supplied about 14\% of estimated domestic consumption, and the remainder came mostly from imports. The value of antimony consumption in 2019, based on the average New York dealer price, was about $\$ 234$ million. The estimated distribution of domestic primary antimony consumption was as follows: nonmetal products, including ceramics and glass and rubber products, 22\%; flame retardants, 40\%; and metal products, including antimonial lead and ammunition, 39\%.

\begin{tabular}{|c|c|c|c|c|c|}
\hline $\begin{array}{l}\text { Salient Statistics-United States: } \\
\text { Production: }\end{array}$ & $\underline{2015}$ & $\underline{2016}$ & $\underline{2017}$ & $\underline{2018}$ & $\underline{2019^{e}}$ \\
\hline $\begin{array}{l}\text { Production: } \\
\text { Mine (recoverable antimony) }\end{array}$ & \multicolumn{5}{|c|}{ Production: } \\
\hline \multicolumn{6}{|l|}{ Smelter: } \\
\hline Primary & 645 & 664 & 621 & 331 & 370 \\
\hline Secondary & 3,740 & 3,810 & e 3,800 & e 4,000 & 4,000 \\
\hline \multicolumn{6}{|l|}{ Imports for consumption: } \\
\hline Ore and concentrates & 308 & 119 & 61 & 96 & 140 \\
\hline Oxide & 16,700 & 16,100 & 17,900 & 19,200 & 17,000 \\
\hline Unwrought, powder, waste and scrap 1 & 5,790 & 7,150 & 6,830 & 6,500 & 7,200 \\
\hline \multicolumn{6}{|l|}{ Exports: } \\
\hline Ore and concentrates ${ }^{1}$ & 31 & 12 & 46 & 38 & 10 \\
\hline Oxide & 1,760 & 1,330 & 1,600 & 1,750 & 1,500 \\
\hline Unwrought, powder, waste and scrap 1 & 1,440 & 623 & 653 & 506 & 280 \\
\hline Consumption, apparent ${ }^{2}$ & 23,500 & 28,500 & 28,700 & 28,400 & 27,000 \\
\hline Price, metal, average, dollars per pound ${ }^{3}$ & 3.27 & 3.35 & 3.98 & 3.88 & 3.90 \\
\hline Stocks, yearend & 11,100 & 8,360 & 6,540 & 6,080 & 6,000 \\
\hline Employment, plant, number (yearend) ${ }^{\mathrm{e}}$ & 27 & 27 & 27 & 27 & 27 \\
\hline $\begin{array}{l}\text { Net import reliance } 4 \text { as a percentage of } \\
\text { apparent consumption }\end{array}$ & 81 & 84 & 85 & 84 & 84 \\
\hline
\end{tabular}

Recycling: The bulk of secondary antimony is recovered at secondary lead smelters as antimonial lead, most of which was generated by, and then consumed by, the lead-acid battery industry.

Import Sources (2015-18): Metal: China, 52\%; India, 20\%; Vietnam, 8\%; United Kingdom, 6\%; and other, 14\%. Ore and concentrate: Italy, 76\%; China, 17\%; Mexico, 4\%; Bosnia and Herzegovina, 1\%; and other, 2\%. Oxide: China, 64\%; Belgium, 10\%; Thailand, 10\%; Bolivia, 7\%; and other, 9\%.

\section{Tariff: Item}

Ore and concentrates

Antimony oxide

Antimony and articles thereof:

Unwrought antimony; powder

Waste and scrap

Other
Number

2617.10.0000

2825.80.0000

8110.10 .0000

8110.20 .0000

8110.90 .0000
Normal Trade Relations 12-31-19

Free.

Free.

Free.

Free.

Free.

Depletion Allowance: 22\% (Domestic), 14\% (Foreign).

Government Stockpile: ${ }^{5}$ Antimony was added to the National Defense Stockpile in December 2018.

Material

Antimony
Inventory

As of 9-30-19

73.5
FY 2019

Potential Potential

Acquisitions Disposals

1,100
FY 2020

Potential Potential Acquisitions Disposals 1,100 


\section{ANTIMONY}

Events, Trends, and Issues: One company operated a smelter in Montana that produced antimony metal and oxides from imported intermediate products (antimony oxide and sodium antimonate) primarily from a smelter in Mexico that processed concentrates from mines in Australia and Mexico.

China continued to be the leading global antimony producer in 2019 and accounted for more than $60 \%$ of global mine production. Beginning in 2018, many large-scale producers reduced production, and many small-scale producers were put on care-and-maintenance status in response to stricter environmental standards from Provincial and National Governments. In 2019, producers in Guizhou, Hunan, and Yunnan Provinces maintained a steady production rate after their smelters completed upgrades to meet the environmental standards. However, it was reported some mines had begun stockpiling concentrates, which lead to the suspension of operations at several smelters in Lengshuijiang area, Hunan Province, in August 2019. In September 2019, one of China's largest mining and metal-producing state-owned companies was the only bidder on the inventory of 18,600 tons of antimony and rare earths from the defunct Fanya Metal Exchange.

World Mine Production and Reserves: Reserves for Pakistan were revised based on Government reports.

\begin{tabular}{lrrr} 
& \multicolumn{2}{c}{ Mine production } & Reserves $^{\mathbf{6}}$ \\
United States & $\mathbf{2 0 1 8}$ & $\underline{\mathbf{2 0 1 9}}$ & 760,000 \\
Australia & 2,170 & 2,000 & 8140,000 \\
Bolivia & 3,110 & 3,000 & 310,000 \\
Burma & 2,640 & 3,000 & $\mathrm{NA}$ \\
China & 89,600 & 100,000 & 480,000 \\
Ecuador & 50 & 50 & $\mathrm{NA}$ \\
Guatemala & 25 & 25 & $\mathrm{NA}$ \\
Honduras & 12 & 10 & $\mathrm{NA}$ \\
Iran & 600 & 600 & $\mathrm{NA}$ \\
Kazakhstan & 300 & 300 & $\mathrm{NA}$ \\
Kyrgyzstan & 370 & 400 & $\mathrm{NA}$ \\
Laos & 300 & 300 & 18,000 \\
Mexico & 260 & 300 & 26,000 \\
Pakistan & 28 & 30 & 350,000 \\
Russia (recoverable) & 30,000 & 30,000 & 50,000 \\
Tajikistan & 15,200 & 16,000 & 100,000 \\
Turkey & 2,400 & 3,000 & $\mathrm{NA}$ \\
Vietnam & 240 & 240 & $1,500,000$
\end{tabular}

World Resources: U.S. resources of antimony are mainly in Alaska, Idaho, Montana, and Nevada. Principal identified world resources are in Australia, Bolivia, China, Mexico, Russia, South Africa, and Tajikistan. Additional antimony resources may occur in Mississippi Valley-type lead deposits in the Eastern United States.

Substitutes: Selected organic compounds and hydrated aluminum oxide are substitutes as flame retardants. Chromium, tin, titanium, zinc, and zirconium compounds substitute for antimony chemicals in enamels, paint, and pigments. Combinations of calcium, copper, selenium, sulfur, and tin are substitutes for alloys in lead-acid batteries.

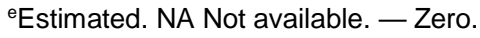

${ }^{1}$ Gross weight.

${ }^{2}$ Defined as primary production + secondary production from old scrap + net import reliance.

${ }^{3} \mathrm{New}$ York dealer price for $99.65 \%$ metal, cost, insurance, freight U.S. ports. Source: Platts Metal Week.

${ }^{4}$ Defined as imports of antimony in oxide, unwrought metal, powder, waste and scrap - exports of antimony in oxide, unwrought metal, powder, waste and scrap + adjustments for industry stock changes.

${ }^{5}$ See Appendix $B$ for definitions.

${ }^{6}$ See Appendix $C$ for resource and reserve definitions and information concerning data sources.

${ }^{7}$ Company-reported probable reserves for the Stibnite Gold Project in Idaho.

${ }^{8}$ For Australia, Joint Ore Reserves Committee-compliant reserves were 64,300 tons.
} 


\section{ARSENIC}

(Data in metric tons of arsenic content ${ }^{1}$ unless otherwise noted)

Domestic Production and Use: Arsenic trioxide and primary arsenic metal have not been produced in the United States since 1985. The principal use for arsenic trioxide was for the production of arsenic acid used in the formulation of chromated copper arsenide (CCA) preservatives for the pressure treating of lumber used primarily in nonresidential applications. Three companies produced CCA preservatives in the United States in 2019. The grids in lead-acid storage batteries were strengthened by the addition of arsenic metal. Arsenic metal was also used as an antifriction additive for bearings, to harden lead shot, and in clip-on wheel weights. Arsenic compounds were used in herbicides and insecticides. High-purity arsenic (99.9999\%) was used to produce gallium-arsenide (GaAs) semiconductors for solar cells, space research, and telecommunications. Arsenic also was used for germanium-arsenide-selenide specialty optical materials. Indium-gallium-arsenide (InGaAs) was used for short-wave infrared technology. The value of arsenic compounds and metal imported domestically in 2019 was estimated to be about $\$ 7.2$ million. Given that arsenic metal has not been produced domestically since 1985, it is likely that only a small portion of the material reported by the U.S. Census Bureau as arsenic exports was pure arsenic metal, and most of the material that has been reported under this category reflects the gross weight of alloys, compounds, residues, scrap, and waste containing arsenic. Therefore, the estimated consumption reported under salient U.S. statistics reflects only imports of arsenic products.

\begin{tabular}{|c|c|c|c|c|c|}
\hline Salient Statistics-United States: & $\underline{2015}$ & $\underline{2016}$ & $\underline{2017}$ & $\underline{2018}$ & $\underline{2019}^{\mathrm{e}}$ \\
\hline \multicolumn{6}{|l|}{ Imports for consumption: } \\
\hline Arsenic metal & 514 & 793 & 942 & 929 & 400 \\
\hline Compounds & 5,920 & 5,320 & 5,980 & 5,540 & 7,000 \\
\hline Exports, all forms of arsenic (gross weight) ${ }^{2}$ & 1,670 & 1,760 & 698 & 107 & 20 \\
\hline Estimated consumption, all forms of arsenic ${ }^{3}$ & 6,430 & 6,120 & 6,920 & 6,470 & 7,400 \\
\hline \multicolumn{6}{|l|}{ Value, dollars per kilogram, average ${ }^{4}$} \\
\hline Arsenic metal (China) & 1.85 & 1.89 & 1.56 & 1.43 & 2.10 \\
\hline Trioxide (China) & 0.45 & 0.46 & 0.45 & 0.44 & 0.44 \\
\hline Trioxide (Morocco) & 0.64 & 0.68 & 0.68 & 0.75 & 0.77 \\
\hline $\begin{array}{l}\text { Net import reliance }{ }^{5} \text { as a percentage of. } \\
\text { estimated consumption, all forms of arsenic }\end{array}$ & 100 & 100 & 100 & 100 & 100 \\
\hline
\end{tabular}

Recycling: Arsenic metal was contained in new scrap recycled during GaAs semiconductor manufacturing. Arseniccontaining process water was internally recycled at wood treatment plants where CCA was used. Although scrap electronic circuit boards, relays, and switches may contain arsenic, no arsenic was known to have been recovered during the recycling process to recover other contained metals. No arsenic was recovered domestically from arseniccontaining residues and dusts generated at nonferrous smelters in the United States.

Import Sources (2015-18): Arsenic metal: China, 93\%; Japan, 4\%; Hong Kong, 3\%, and other, <1\%. Arsenic trioxide: China, 50\%; Morocco, 47\%; Belgium, 2\%; and other, 1\%. All forms of arsenic: China, 55\%; Morocco, 42\%; Belgium, 2\%; other, $1 \%$.

Tariff: Item

Arsenic metal

Arsenic acid

Arsenic trioxide

Arsenic sulfide
Number

2804.80.0000

2811.19.1000

2811.29.1000

2813.90.1000
Normal Trade Relations

12-31-19

Free.

$2.3 \%$ ad val.

Free.

Free.

Depletion Allowance: 14\% (Domestic and foreign).

Government Stockpile: None. 


\section{ARSENIC}

Events, Trends, and Issues: China and Morocco continued to be the leading global producers of arsenic trioxide, accounting for about $90 \%$ of estimated world production and supplied almost all of United States imports of arsenic trioxide in 2019. China was the leading world producer of arsenic metal and supplied about $90 \%$ of United States arsenic metal imports in 2019.

High-purity (99.9999\%) arsenic metal was used to produce GaAs, indium-arsenide, and InGaAs semiconductors that were used in biomedical, communications, computer, electronics, and photovoltaic applications. Almost one-half of global GaAs wafer production took place in China. See the Gallium chapter for additional details.

\section{World Production and Reserves (gross weight):}

\begin{tabular}{lrr} 
& \multicolumn{2}{c}{$\begin{array}{c}\text { Production } \\
\text { Pr, } \mathbf{~}\end{array}$} \\
United States & $\underline{\mathbf{2 0 1 8}}$ & $\underline{\mathbf{2 0 1 9}}$ \\
Belgium & 1,000 & 1,000 \\
Bolivia & 40 & 40 \\
China & 24,000 & 24,000 \\
Iran & 110 & 110 \\
Japan & 45 & 40 \\
Morocco & 6,000 & 6,000 \\
Namibia & 700 & 700 \\
Russia & 1,500 & 1,500 \\
$\quad$ World total (rounded) & 33,400 & 33,000
\end{tabular}

\section{Reserves $^{7}$}

2019

000

40

110

40

700

1,500

World Resources: Arsenic may be obtained from copper, gold, and lead smelter flue dust, as well as from roasting arsenopyrite, the most abundant ore mineral of arsenic. Arsenic has been recovered from orpiment and realgar in China, Peru, and the Philippines; has been recovered from copper-gold ores in Chile; and was associated with gold occurrences in Canada. Orpiment and realgar from gold mines in Sichuan Province, China, were stockpiled for later recovery of arsenic. Arsenic also may be recovered from enargite, a copper mineral. Arsenic trioxide was produced at the hydrometallurgical complex of Guemassa, near Marrakech, Morocco, from cobalt arsenide ore from the BouAzzer Mine.

Substitutes: Substitutes for CCA in wood treatment include alkaline copper quaternary, ammoniacal copper quaternary, ammoniacal copper zinc arsenate, alkaline copper quaternary boron-based preservatives, copper azole, copper citrate, and copper naphthenate. Treated wood substitutes include concrete, plastic composite material, plasticized wood scrap, or steel. Silicon-based complementary metal-oxide semiconductor power amplifiers compete with GaAs power amplifiers in midtier third generation cellular handsets. Indium phosphide components can be substituted for GaAs-based infrared laser diodes in some specific-wavelength applications, and helium-neon lasers compete with GaAs in visible laser diode applications. Silicon is the principal competitor with GaAs in solar-cell applications. GaAs-based integrated circuits are used in many defense-related applications because of their unique properties, and no effective substitutes exist for GaAs in these applications. GaAs in heterojunction bipolar transistors is being replaced in some applications by silicon-germanium.

\footnotetext{
eEstimated. - Zero.

${ }^{1}$ Arsenic content of arsenic metal is $100 \%$; arsenic content of arsenic compounds is calculated at $77.7 \%$ for arsenic acids, $60.7 \%$ for arsenic sulfides, and $75.71 \%$ for arsenic trioxide.

${ }^{2}$ Most of the materials reported to the U.S. Census Bureau as arsenic exports are thought to be arsenic-containing compounds (such as arsenic acids, sulfides, and trioxides) or residues, waste, and scrap and was reported as gross weight.

${ }^{3}$ Estimated to be the same as imports.

${ }^{4}$ Calculated from U.S. Census Bureau import data.

${ }^{5}$ Defined as imports - exports.

${ }^{6}$ Includes calculated arsenic trioxide equivalent of output of elemental arsenic compounds other than arsenic trioxide; inclusion of such materials would not duplicate reported arsenic trioxide production. Chile, Mexico, and Peru were thought to be significant producers of commercial-grade arsenic trioxide but have reported no production in recent years.

${ }^{7}$ See Appendix $\mathrm{C}$ for resource and reserve definitions and information concerning data sources.
} 


\section{ASBESTOS}

(Data in metric tons unless otherwise noted)

Domestic Production and Use: The last U.S. producer of asbestos ceased operations in 2002 as a result of the decline in domestic and international asbestos markets associated with health and liability issues. The United States has since been wholly dependent on imports to meet manufacturing needs. In 2019 , all of the asbestos minerals imported into and used within the United States consisted of chrysotile and were shipped from Russia. Domestic consumption of chrysotile in 2019 was estimated to be 100 tons, based on import data available through August. Actual consumption may have been higher owing to companies drawing from stockpiles, but information regarding industry stocks was unavailable. The chloralkali industry, which uses asbestos to manufacture semipermeable diaphragms that prevent chlorine generated at the anode of an electrolytic cell from reacting with sodium hydroxide generated at the cathode, accounted for $100 \%$ of asbestos consumption in 2019 , based on bill of lading information from a commercial trade database. In addition to asbestos minerals, a small, but unknown, quantity of asbestos was imported within manufactured products, including brake blocks for use in the oil industry, rubber sheets for gaskets used to create a chemical containment seal in the production of titanium dioxide, certain other types of preformed gaskets, and some vehicle friction products.

\section{Salient Statistics-United States:}

Imports for consumption ${ }^{1}$

Exports $^{3}$

Price, average U.S. Customs value, dollars per ton

Net import reliance 5 as a percentage of

estimated consumption
Consumption, estimated 4

$\begin{array}{rrrrr}\frac{\mathbf{2 0 1 5}}{325} & \frac{\mathbf{2 0 1 6}}{747} & \frac{\mathbf{2 0 1 7}}{332} & \frac{\mathbf{2 0 1 8}}{681} & \frac{\mathbf{2 0 1 9}}{2100} \\ - & - & - & - & - \\ 325 & 747 & 332 & 681 & 100 \\ 1,880 & 1,910 & 1,870 & 1,670 & 1,500 \\ 100 & 100 & 100 & 100 & 100\end{array}$

Recycling: None.

Import Sources (2015-18): Brazil, 96\%; and Russia, 4\%.

\section{Tariff: Item}

Crocidolite

Amosite

Chrysotile:

Crudes

Milled fibers, group 3 grades

Milled fibers, group 4 and 5 grades

Other

Other, asbestos

\section{Number}

2524.10.0000

2524.90.0010

2524.90.0030

2524.90 .0040

2524.90 .0045

2524.90.0055

2524.90 .0060

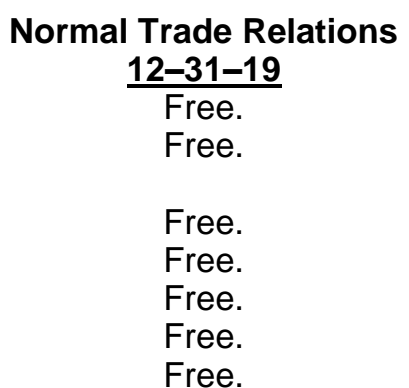

Depletion Allowance: 22\% (Domestic), 10\% (Foreign).

\section{Government Stockpile: None.}

Events, Trends, and Issues: Consumption of asbestos in the United States (excluding asbestos contained within imported manufactured products) has decreased during the past several decades, falling from a record high of 803,000 tons in 1973 to less than 775 tons in each year since 2013. From 2013 through 2018, consumption fluctuated between 325 tons and roughly 775 tons, likely owing to stockpiling by companies in certain years, and averaged about $550 \mathrm{t}$, less than $0.1 \%$ of peak consumption in the $1970 \mathrm{~s}$. This decline has taken place as a result of health and liability issues associated with asbestos use, leading to the displacement of asbestos from traditional domestic markets by substitutes, alternative materials, and new technology. The chloralkali industry is the only remaining domestic consumer of asbestos in mineral form. Asbestos diaphragms are used in 11 chloralkali plants in the United States and account for about one-third of domestic chlorine production.

Estimated worldwide consumption of asbestos minerals decreased from approximately 2 million tons in 2010 to approximately 1 million tons in 2019. Asbestos-cement products, such as corrugated roofing tiles, pipes, and wall panels, are expected to continue to be the leading global market for asbestos. 


\section{ASBESTOS}

The U.S. Environmental Protection Agency (EPA) issued a significant new use rule (SNUR) under Section 5 of the Toxic Substances Control Act of 1976. The regulation, which went into effect on June 24, prohibits discontinued uses of asbestos from restarting without the EPA having an opportunity to evaluate each intended use for potential risks to health and the environment and take any necessary regulatory action, which may include a ban. The SNUR requires manufacturers to request approval before importing, manufacturing, or processing asbestos for adhesives, arc chutes, beater-add gaskets, building materials (insulation, plastics, textured paints, etc.), cement products, coatings, extruded sealant tape and other tape, filler for acetylene cylinders, friction materials (except brake blocks used in oil drilling equipment and vehicle brakes and linings), high-grade electrical paper, millboard, missile liner, packings, pipeline wrap, reinforced plastics, roofing felt, sealants, separators in fuel cells and batteries, vinyl-asbestos floor tile, woven products, and any other applications that are not currently in use in the United States.

The only asbestos producer in Brazil suspended mining activities on February 11. A comprehensive national ban on asbestos was enacted in November 2017, but the company had previously been allowed to continue operating owing to a judicial injunction. As of the end of September, the company was awaiting a decision from the Supreme Federal Court on a petition to restart mining for export purposes only.

At the former Mashaba Mine in Zimbabwe, which closed in 2007, a company began producing asbestos from tailings and was working to dewater the mining shafts and procure equipment to restart underground production. At full capacity, the mine was expected to produce 75,000 tons of asbestos per year. Asbestos was last produced in Zimbabwe in 2013.

World Mine Production and Reserves:

\begin{tabular}{lcrr} 
& \multicolumn{2}{c}{ Mine production } & Reserves $^{\mathbf{6}}$ \\
United States & $\underline{\mathbf{2 0 1 8}}$ & $\underline{\mathbf{2 0 1 9}}$ & Small \\
Brazil & $\mathrm{e} 110,000$ & 15,000 & $12,000,000$ \\
China & $\mathrm{e} 125,000$ & 125,000 & $96,000,000$ \\
Kazakhstan & 203,000 & 200,000 & Large \\
Russia & $\mathrm{e} 710,000$ & 750,000 & $110,000,000$ \\
Zimbabwe & - & $\frac{2,500}{\text { Large }}$ \\
$\quad$ World total (rounded) & $1,150,000$ & $1,100,000$ & Large
\end{tabular}

World Resources: Reliable evaluations of global asbestos resources have not been published recently, and the available information is insufficient to make accurate estimates for many countries. However, world resources are large and more than adequate to meet anticipated demand in the foreseeable future. Resources in the United States are composed mostly of short-fiber asbestos for which use in asbestos-based products is more limited than long-fiber asbestos.

Substitutes: Numerous materials substitute for asbestos. Substitutes include calcium silicate, carbon fiber, cellulose fiber, ceramic fiber, glass fiber, steel fiber, wollastonite, and several organic fibers, such as aramid, polyethylene, polypropylene, and polytetrafluoroethylene. Several nonfibrous minerals or rocks, such as perlite, serpentine, silica, and talc, are also considered to be possible asbestos substitutes for products in which the reinforcement properties of fibers are not required. Membrane cells and mercury cells are alternatives to asbestos diaphragms used in the chloralkali industry.

\footnotetext{
EEstimated. — Zero.

${ }^{1}$ Additional imports were reported by the U.S. Census Bureau in some years, but bill of lading information from a commercial trade database suggests that some shipments were misclassified.

${ }^{2}$ According to the U.S. Census Bureau, imports of asbestos minerals (chrysotile) totaled 100 tons through November 2019. Final 2019 imports may differ significantly from the provided estimate because imports of chrysotile typically do not follow a predictable pattern throughout the year. ${ }^{3}$ Exports of asbestos reported by the U.S. Census Bureau were 517 tons in 2015, 587 tons in 2016, 143 tons in 2017, 235 tons in 2018, and an estimated 200 tons in 2019. These shipments likely consisted of materials misclassified as asbestos, reexports, and (or) waste products because the United States no longer mines asbestos.

${ }^{4}$ Assumed to equal imports. Actual consumption in each year may have been higher or lower owing to stockpiling by companies, but information regarding industry stocks was unavailable.

${ }^{5}$ Defined as imports - exports.

${ }^{6}$ See Appendix C for resource and reserve definitions and information concerning data sources.
} 


\section{BARITE}

(Data in thousand metric tons unless otherwise noted)

Domestic Production and Use: In 2019, domestic mine production increased by approximately $6 \%$, to an estimated 390,000 tons valued at an estimated $\$ 44$ million. Most of the production came from Nevada and a single mine in Georgia. An estimated 2.5 million tons of barite (from domestic production and imports) was sold by crushers and grinders operating in seven States. The United States is the world's leading barite consumer, with more than $90 \%$ of the barite sold in the United States used as a weighting agent in fluids used in the drilling of oil and natural gas wells. The majority of Nevada crude barite was ground in Nevada and then sold to companies drilling in the Central and Western United States. Offshore drilling operations in the Gulf of Mexico and onshore drilling operations in other regions primarily used imported barite.

Barite also is used as a filler, extender, or weighting agent in products such as paints, plastics, and rubber. Some specific applications include use in automobile brake and clutch pads, automobile paint primer for metal protection and gloss, use as a weighting agent in rubber, and in the cement jacket around underwater petroleum pipelines. In the metal-casting industry, barite is part of the mold-release compounds. Because barite significantly blocks x-ray and gamma-ray emissions, it is used as aggregate in high-density concrete for radiation shielding around x-ray units in hospitals, nuclear powerplants, and university nuclear research facilities. Ultrapure barite is used as a contrast medium in x-ray and computed tomography examinations of the gastrointestinal tract.

\begin{tabular}{|c|c|c|c|c|c|}
\hline Salient Statistics-United States: & $\underline{2015}$ & $\underline{2016}$ & $\underline{2017}$ & $\underline{2018}$ & $2019^{\mathrm{e}}$ \\
\hline \multicolumn{6}{|l|}{ Production: } \\
\hline Sold or used, mine & 433 & 232 & 334 & 366 & 390 \\
\hline Ground and crushed ${ }^{1}$ & 2,010 & 1,420 & 2,030 & 2,420 & 2,500 \\
\hline Imports for consumption ${ }^{2}$ & 1,660 & 1,260 & 2,470 & 2,460 & 2,600 \\
\hline Exports $^{3}$ & 147 & 78 & 116 & 67 & 34 \\
\hline Consumption, apparent (crude and ground) ${ }^{4}$ & 1,950 & 1,410 & 2,680 & 2,760 & 3,000 \\
\hline Estimated price, ground, average value, & & & & & \\
\hline dollars per ton, ex-works & 194 & 187 & 179 & 176 & 180 \\
\hline Employment, mine and mill, number & 458 & 300 & 350 & 440 & 440 \\
\hline $\begin{array}{l}\text { Net import reliance } 5 \text { as a percentage of } \\
\text { apparent consumption }\end{array}$ & 78 & 84 & 88 & 87 & 87 \\
\hline
\end{tabular}

Recycling: None.

Import Sources (2015-18): China, 58\%; India, 17\%; Morocco, 12\%; Mexico, 11\%; and other, 2\%.

\section{Tariff: Item}

Ground barite

Crude barite

Barium compounds:

Barium oxide, hydroxide, and peroxide

Barium chloride

Barium sulfate, precipitated

Barium carbonate, precipitated
Number

2511.10.1000

2511.10.5000

2816.40 .2000

2827.39.4500

2833.27.0000

2836.60 .0000
Normal Trade Relations

12-31-19

Free.

$\$ 1.25$ per metric ton.

$2 \%$ ad val.

$4.2 \%$ ad val.

$0.6 \%$ ad val.

$2.3 \%$ ad val.

Depletion Allowance: 14\% (Domestic and foreign).

Government Stockpile: None. 


\section{BARITE}

Events, Trends, and Issues: Although the U.S. monthly average count of active rigs dropped throughout 2019, sales of ground barite were estimated to have increased slightly. Nearly one-half of sales were from plants in Texas, reflecting increased domestic drilling activity, which has been concentrated in the Permian Basin in recent years.

Beginning in the 1980s, China emerged as the world's leading producer of barite and the United States has been its leading customer. Although that remains true, in recent years, owing partially to industry consolidation and increased barite consumption in China, domestic consumers have diversified import sources. A higher percentage of United States imports has been supplied by other leading exporting countries such as India and Morocco. This trend has also apparently stimulated increased production and exports in other countries, particularly Laos and Mexico.

Beginning in 2018, the U.S. Census Bureau reported increased quantities of barite imports from Vietnam. However, imports from Vietnam were more likely mined in Laos, where a new mine reportedly exported ore through the Port of Cua Lo in Vietnam. Domestic grinding plants reported importing more than 100,000 tons of barite from Laos in 2018 and, in 2019 , this quantity was estimated to have increased to approximately 300,000 tons.

Production increases in Mexico in recent years corresponded with increased truck and rail shipments to key drilling areas in the Permian Basin. Most barite imports have been crude barite, which was processed at domestic grinding plants but, in 2019, an increasing proportion of barite from Mexico was reportedly ground barite shipped to warehouses or to onshore drilling sites.

World Mine Production and Reserves: In response to concerns about dwindling global reserves of 4.2-specificgravity barite used by the oil and gas drilling industry, the American Petroleum Institute issued an alternate specification for 4.1-specific-gravity barite in 2010. This has likely stimulated exploration and expansion of global barite resources. Estimated reserves data are included only if developed since the adoption of the 4.1-specific-gravity standard. Reserves data for Pakistan were revised based on Government information.

\begin{tabular}{lrrr} 
& \multicolumn{2}{c}{ Mine production } & Reserves $^{\mathbf{6}}$ \\
United States & $\underline{\mathbf{2 0 1 8}}$ & $\underline{\mathbf{2 0 1 9}}$ & NA \\
China & 366 & 390 & 36,000 \\
India & 2,900 & 2,900 & 51,000 \\
Iran & 2,390 & 2,200 & 24,000 \\
Kazakhstan & 490 & 490 & $\mathbf{8 5}, 000$ \\
Laos & 620 & 620 & $\mathrm{NA}$ \\
Mexico & 90 & 420 & $\mathrm{NA}$ \\
Morocco & 380 & 400 & 26,000 \\
Pakistan & 940 & 1,100 & 12,000 \\
Russia & 110 & 110 & 35,000 \\
Turkey & 163 & 160 & 30,000 \\
Other countries & 245 & 250 & 300,000
\end{tabular}

World Resources: In the United States, identified resources of barite are estimated to be 150 million tons, and undiscovered resources contribute an additional 150 million tons. The world's barite resources in all categories are about 2 billion tons, but only about 740 million tons are identified resources. However, no known systematic assessment of either U.S. or global barite resources has been conducted since the 1980s.

Substitutes: In the drilling mud market, alternatives to barite include celestite, ilmenite, iron ore, and synthetic hematite that is manufactured in Germany. None of these substitutes, however, has had a major impact on the barite drilling mud industry.

\footnotetext{
eEstimated. NA Not available.

${ }^{1}$ Imported and domestic barite, crushed and ground, sold or used by domestic grinding establishments.

${ }^{2}$ Imports calculated from Harmonized Tariff Schedule of the United States codes 2511.10.1000, 2511.10.5000, and 2833.27.0000.

${ }^{3}$ Exports calculated from Schedule B numbers 2511.10.1000 and 2833.27.0000.

${ }^{4}$ Defined as sold or used by domestic mines + imports - exports.

${ }^{5}$ Defined as imports - exports.

${ }^{6}$ See Appendix C for resource and reserve definitions and information concerning data sources.
} 


\section{BAUXITE AND ALUMINA ${ }^{1}$}

(Data in thousand metric dry tons unless otherwise noted)

Domestic Production and Use: In 2019, the quantity of bauxite consumed was estimated to be 5.1 million tons, $30 \%$ more than that reported in 2018, with an estimated value of about $\$ 162$ million. About $73 \%$ of the bauxite was refined by the Bayer process for alumina or aluminum hydroxide, and the remainder went to products such as abrasives, cement, chemicals, proppants, refractories, and as a slag adjuster in steel mills. Two domestic Bayer-process refineries with a combined alumina production capacity of 1.7 million tons per year produced an estimated 1.6 million tons in 2019, slightly more than that in 2018. One other refinery with 2.3 million tons per year of capacity that had been on care-and-maintenance status since 2016 was permanently shut down in December. About $66 \%$ of the alumina produced went to primary aluminum smelters, and the remainder went to nonmetallurgical products, such as abrasives, ceramics, chemicals, and refractories.

\begin{tabular}{|c|c|c|c|c|c|}
\hline$\frac{\text { Salient Statistics_-United States: }}{\text { Bauxite }}$ & $\underline{2015}$ & $\underline{2016}$ & $\underline{2017}$ & $\underline{2018}$ & $\underline{2019^{\mathrm{e}}}$ \\
\hline \multicolumn{6}{|l|}{ Bauxite: } \\
\hline Production, mine & W & W & W & W & \\
\hline Imports for consumption ${ }^{2}$ & 11,500 & 6,050 & 4,360 & 4,200 & 5,100 \\
\hline Exports $^{2}$ & 21 & 40 & 29 & 17 & 20 \\
\hline Stocks, industry, yearend ${ }^{2}$ & 1,500 & 880 & 880 & 600 & 300 \\
\hline \multicolumn{6}{|l|}{ Consumption: } \\
\hline Apparent $^{3}$ & W & W & W & W & \\
\hline Reported & 9,660 & 5,360 & 3,510 & 3,890 & 5,100 \\
\hline $\begin{array}{l}\text { Price, average value, U.S. imports (f.a.s.), } \\
\text { dollars per ton }\end{array}$ & 28 & 28 & 31 & 31 & 32 \\
\hline $\begin{array}{l}\text { Net import reliance } 4 \text { as a percentage of } \\
\text { apparent consumption }\end{array}$ & $>75$ & $>75$ & $>75$ & $>75$ & $>75$ \\
\hline \multicolumn{6}{|l|}{ Alumina: } \\
\hline Production, refinery ${ }^{5}$ & 4,550 & 2,360 & 1,430 & 1,570 & 1,600 \\
\hline Imports for consumption ${ }^{5}$ & 1,570 & 1,140 & 1,330 & 1,530 & 2,100 \\
\hline Exports $^{5}$ & 2,210 & 1,330 & 481 & 288 & 200 \\
\hline Stocks, industry, yearend 5 & 274 & 320 & 264 & 275 & 300 \\
\hline Consumption, apparent ${ }^{3}$ & 3,920 & 2,130 & 2,340 & 2,800 & 3,500 \\
\hline $\begin{array}{l}\text { Price, average value, U.S. imports (f.a.s.), } \\
\text { dollars per ton }\end{array}$ & 400 & 362 & 486 & 592 & 500 \\
\hline $\begin{array}{l}\text { Net import reliance } 4 \text { as a percentage of } \\
\text { apparent consumption }\end{array}$ & $\mathrm{E}$ & $\mathrm{E}$ & 38 & 44 & 54 \\
\hline
\end{tabular}

Recycling: None.

Import Sources (2015-18): Bauxite:2 Jamaica, 51\%; Brazil, 23\%; Guinea, 10\%; Guyana, 7\%; and other, $9 \%$. Alumina:5 Brazil, 39\%; Australia, 31\%; Jamaica, 9\%; Canada, 5\%; and other, 16\%.

\section{Tariff: Item}

Bauxite, calcined (refractory grade)

Bauxite, calcined (other)

Bauxite, crude dry (metallurgical grade)

Aluminum oxide (alumina)

Aluminum hydroxide

Number
2606.00 .0030
2606.00 .0060
2606.00 .0090
2818.20 .0000
2818.30 .0000

Normal Trade Relations 12-31-19

Free.

Free.

Free.

Free.

Free.

Depletion Allowance: 22\% (Domestic), 14\% (Foreign).

Government Stockpile: None

Events, Trends, and Issues: In 2019, two domestic alumina refineries produced alumina from imported bauxite. A 500,000-ton-per-year alumina refinery in Burnside, LA, produced specialty-grade alumina. A 1.2-million-ton-per-year alumina refinery in Gramercy, LA, produced alumina principally for aluminum smelting. A project at the Gramercy refinery was adding another production line for specialty-grade alumina but the amount of additional capacity and a projected completion date were not announced. A 2.3-million-ton-per-year alumina refinery in Point Comfort, TX, was permanently shut down in December. The average prices free alongside ship (f.a.s.) for U.S. imports for consumption of crude-dry bauxite and metallurgical-grade alumina during the first 8 months of 2019 were $\$ 32$ per ton, slightly more than that of the same period in 2018, and \$497 per ton, 12\% lower than that in the same period of 2018, respectively. 


\section{BAUXITE AND ALUMINA}

In April, the Government of Malaysia ended its ban on bauxite mining that was imposed in January 2016 because of concerns about pollution from mines and uncovered stockpiles at ports. During the mining ban, exports of stockpiled bauxite were allowed and media sources reported that some mines continued illegal mining. In May, a court in Brazil lifted restrictions on production at a 6.3-million-ton-per-year alumina refinery. In February 2018, the Government of Brazil ordered the alumina refinery and a nearby 10-million-ton-per-year bauxite mine to shut down one-half of their capacities, citing concerns that leaks from disposal areas may have taken place after heavy rainfall in the area. The mine and refinery were ramped up to their full capacities by yearend. In March, a new 22.8-million-ton-per-year bauxite mine was commissioned in Queensland, Australia. In April, a new 2-million-ton-per-year alumina refinery in the United Arab Emirates was commissioned. In August, a new 12-million-ton-per-year bauxite mine in Guinea was commissioned and started exporting bauxite to the alumina refinery in the United Arab Emirates for which it would be the principal bauxite source. In October, a 1.65-million-ton-per-year alumina refinery in Jamaica shut down for a modernization project that would take about 2 years to complete.

In January, the U.S. Department of the Treasury lifted sanctions that were imposed in April 2018 against several Russian individuals and businesses in response to activities of the Government of Russia. Among the designated companies was a producer of bauxite, alumina, and aluminum. Prior to the sanctions being lifted, a winddown period was granted to companies with contracts with the sanctioned company. The winddown period was extended several times until the sanctions were lifted and deliveries to consumers in the United States were not disrupted.

\section{World Alumina Refinery and Bauxite Mine Production and Bauxite Reserves:}

\begin{tabular}{lrrrrr} 
& \multicolumn{2}{c}{ Alumina $^{\mathbf{5}}$} & \multicolumn{2}{c}{ Bauxite } & Reserves $^{\mathbf{6}}$ \\
United States & $\mathbf{2 0 1 8}$ & $\underline{\mathbf{2 0 1 9}}$ & $\underline{\mathbf{2 0 1 8}}$ & $\underline{\mathbf{2 0 1 9}}$ & \\
Australia & 1,570 & 1,600 & 20,000 \\
Brazil & 20,400 & 20,000 & 86,400 & 100,000 & $76,000,000$ \\
Canada & 8,100 & 8,900 & 29,000 & 29,000 & $2,600,000$ \\
China & 1,570 & 1,500 & - & - & - \\
Guinea & 72,500 & 73,000 & 79,000 & 75,000 & $1,000,000$ \\
India & 180 & 300 & 57,000 & 82,000 & $7,400,000$ \\
Indonesia & 6,430 & 6,700 & 23,000 & 26,000 & 660,000 \\
Jamaica & 1,000 & 1,000 & 11,000 & 16,000 & $1,200,000$ \\
Malaysia & 2,480 & 2,100 & 10,100 & 8,900 & $2,000,000$ \\
Russia & - & - & 500 & 900 & 110,000 \\
Saudi Arabia & 2,760 & 2,700 & 5,650 & 5,400 & 500,000 \\
Vietnam & 1,770 & 1,800 & 3,890 & 4,100 & 200,000 \\
Other countries & 1,310 & 1,300 & 4,100 & 4,500 & $3,700,000$ \\
$\quad$ World total (rounded) & 11,400 & 12,000 & 17,000 & 15,000 & $5,000,000$ \\
\hline
\end{tabular}

World Resources: Bauxite resources are estimated to be 55 billion to 75 billion tons, in Africa (32\%), Oceania (23\%), South America and the Caribbean (21\%), Asia (18\%), and elsewhere (6\%). Domestic resources of bauxite are inadequate to meet long-term U.S. demand, but the United States and most other major aluminum-producing countries have essentially inexhaustible subeconomic resources of aluminum in materials other than bauxite.

Substitutes: Bauxite is the only raw material used in the production of alumina on a commercial scale in the United States. Although currently not economically competitive with bauxite, vast resources of clay are technically feasible sources of alumina. Other raw materials, such as alunite, anorthosite, coal wastes, and oil shales, offer additional potential alumina sources. Synthetic mullite, produced from kaolin, bauxitic kaolin, kyanite, and sillimanite, substitutes for bauxite-based refractories. Silicon carbide and alumina-zirconia can substitute for abrasives but cost more.

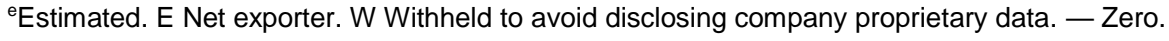

${ }^{1}$ See also Aluminum. As a general rule, 4 tons of dried bauxite is required to produce 2 tons of alumina, which, in turn, produces 1 ton of aluminum. ${ }^{2}$ Includes all forms of bauxite, expressed as dry equivalent weights.

${ }^{3}$ Defined as production + imports - exports + adjustments for industry stock changes.

${ }^{4}$ Defined as imports - exports + adjustments for industry stock changes.

${ }^{5}$ Calcined equivalent weights.

${ }^{6}$ See Appendix $C$ for resource and reserve definitions and information concerning data sources.

${ }^{7}$ For Australia, Joint Ore Reserves Committee-compliant reserves were 2.2 billion tons.

${ }^{8}$ Excludes U.S. production.
} 


\section{BERYLLIUM}

(Data in metric tons of beryllium content unless otherwise noted)

Domestic Production and Use: One company in Utah mined bertrandite ore and converted it, along with imported beryl, into beryllium hydroxide. Some of the beryllium hydroxide was shipped to the company's plant in Ohio, where it was converted into metal, oxide, and downstream beryllium-copper master alloy, and some was sold. Based on the estimated unit value for beryllium in imported beryllium-copper master alloy, beryllium apparent consumption of 180 tons was valued at about $\$ 113$ million. Based on sales revenues, approximately $21 \%$ of beryllium products were used in industrial components; $20 \%$ in aerospace and defense applications; $14 \%$ each in automotive electronics, consumer electronics, and telecommunications infrastructure; $9 \%$ in energy applications; $1 \%$ in semiconductor applications; and $7 \%$ in other applications. Beryllium alloy strip and bulk products, the most common forms of processed beryllium, were used in all application areas. The majority of unalloyed beryllium metal and beryllium composite products were used in defense and scientific applications.

\section{Salient Statistics-United States:}

Production, mine shipments

Imports for consumption ${ }^{1}$

Exports $^{2}$

Shipments from Government stockpile ${ }^{3}$

Consumption:

\section{Apparent $^{4}$}

Reported, ore

Unit value, annual average, beryllium-copper master

alloy, dollars per kilogram contained beryllium ${ }^{5}$

Stocks, ore, consumer, yearend

Net import reliance ${ }^{6}$ as a percentage

of apparent consumption

$\begin{array}{rrrrr}\frac{\mathbf{2 0 1 5}}{205} & \frac{\mathbf{2 0 1 6}}{155} & \frac{\mathbf{2 0 1 7}}{150} & \frac{\mathbf{2 0 1 8}}{165} & \frac{\mathbf{2 0 1 9}}{170} \\ 66 & 68 & 60 & 67 & 45 \\ 29 & 34 & 38 & 30 & 40 \\ 1 & 3 & 2 & - & - \\ 233 & 182 & 179 & 202 & 180 \\ 220 & 160 & 160 & 170 & 170 \\ 490 & 510 & 640 & 590 & 660 \\ 25 & 35 & 30 & 30 & 30 \\ 12 & 15 & 16 & 18 & 3\end{array}$

3

Recycling: Beryllium was recovered from new scrap generated during the manufacture of beryllium products and from old scrap. Detailed data on the quantities of beryllium recycled are not available but may account for as much as $20 \%$ to $25 \%$ of total beryllium consumption. The leading U.S. beryllium producer established a comprehensive recycling program for all of its beryllium products, recovering approximately $40 \%$ of the beryllium content of the new and old beryllium alloy scrap.

Import Sources (2015-18): ${ }^{1}$ Kazakhstan, 39\%; Japan, 15\%; Brazil, 13\%; United Kingdom, 5\%; and other, $28 \%$.

Tariff: Item

Beryllium ores and concentrates

Beryllium oxide and hydroxide

Beryllium-copper master alloy

Beryllium-copper plates, sheets, and strip:

Thickness of 5 millimeters $(\mathrm{mm})$ or more

Thickness of less than $5 \mathrm{~mm}$ :

Width of $500 \mathrm{~mm}$ or more

Width of less than $500 \mathrm{~mm}$

Beryllium:

Unwrought, including powders

Waste and scrap

Other
Number

2617.90.0030

2825.90.1000

7405.00 .6030

7409.90 .1030

7409.90 .5030

7409.90 .9030

8112.12 .0000

8112.13 .0000

8112.19 .0000
Normal Trade Relations $\underline{\text { 12-31-19 }}$

Free.

$3.7 \%$ ad val.

Free.

$3.0 \%$ ad val.

$1.7 \%$ ad val.

$3.0 \%$ ad val.

$8.5 \%$ ad val.

Free.

$5.5 \%$ ad val.

Depletion Allowance: 22\% (Domestic), 14\% (Foreign).

Government Stockpile: ${ }^{7}$ The Defense Logistics Agency Strategic Materials had a goal of retaining 47 tons of beryllium metal in the National Defense Stockpile.

\begin{tabular}{lccc} 
& Inventory & \multicolumn{2}{c}{ FY 2019 } \\
Material & $\begin{array}{c}\text { Potential } \\
\text { As of 9-30-19 }\end{array}$ & $\begin{array}{c}\text { Potential } \\
\text { Acquisitions }\end{array}$ & $\begin{array}{c}\text { Disposals } \\
\text { Beryl ore (gross weight) }\end{array}$ \\
Metal & 67 & - & - \\
Structured powder & 7 & - & 5 \\
& 7 & - & -
\end{tabular}

\begin{tabular}{cc}
\multicolumn{2}{c}{ FY 2020} \\
Potential & Potential \\
Acquisitions & Disposals \\
- & - \\
- & 7 \\
- & -
\end{tabular}

Prepared by Brian W. Jaskula [(703) 648-4908, bjaskula@usgs.gov] 


\section{BERYLLIUM}

Events, Trends, and Issues: Apparent consumption of beryllium-based products was estimated to have decreased by about 11\% in 2019 from that of 2018 owing primarily to a 33\% decrease in beryllium imports and a 33\% increase in beryllium exports. Imported beryl concentrate has decreased substantially since 2015. Domestic beryllium production and consumption in 2019 were estimated to be close to that of 2018. During the first 6 months of 2019, the leading U.S. beryllium producer reported that net sales of its beryllium alloy strip and bulk products and beryllium metal and composite products were $6 \%$ higher than those during the first 6 months of 2018. Value-added sales of beryllium products increased primarily in the aerospace and defense, consumer electronics, energy, and telecommunications markets.

Because of the toxic nature of beryllium, various international, national, and State guidelines and regulations have been established regarding beryllium in air, water, and other media. Industry is required to carefully control the quantity of beryllium dust, fumes, and mists in the workplace.

World Mine Production and Reserves: Reserves for the United States were revised based on updated company information.

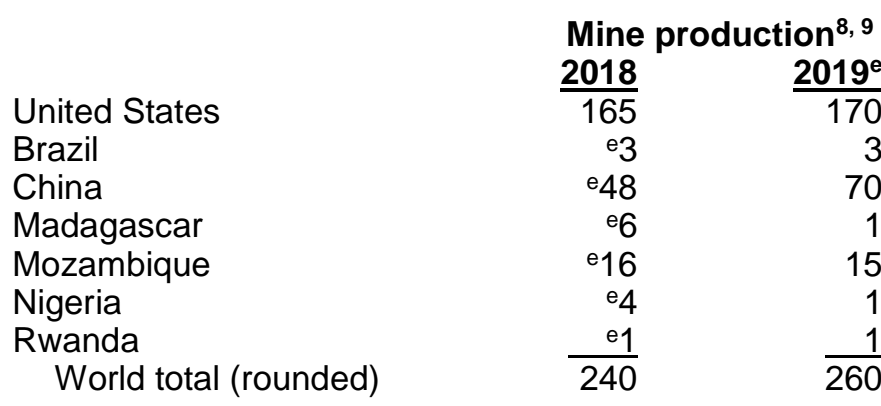

\section{Reserves $^{10}$}

The United States has very little beryl that can be economically hand sorted from pegmatite deposits. The Spor Mountain area in Utah, an epithermal deposit, contains a large bertrandite resource, which is being mined. Proven and probable bertrandite reserves in Utah total about 20,000 tons of contained beryllium. World beryllium reserves are not available.

World Resources: The world's identified resources of beryllium have been estimated to be more than 100,000 tons. About $60 \%$ of these resources are in the United States; by size, the Spor Mountain area in Utah, the McCullough Butte area in Nevada, the Black Hills area in South Dakota, the Sierra Blanca area in Texas, the Seward Peninsula in Alaska, and the Gold Hill area in Utah account for most of the total.

Substitutes: Because the cost of beryllium is high compared with that of other materials, it is used in applications in which its properties are crucial. In some applications, certain metal matrix or organic composites, high-strength grades of aluminum, pyrolytic graphite, silicon carbide, steel, or titanium may be substituted for beryllium metal or beryllium composites. Copper alloys containing nickel and silicon, tin, titanium, or other alloying elements or phosphor bronze alloys (copper-tin-phosphorus) may be substituted for beryllium-copper alloys, but these substitutions can result in substantially reduced performance. Aluminum nitride or boron nitride may be substituted for beryllium oxide.

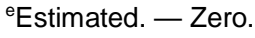

${ }^{1}$ Includes estimated beryllium content of imported ores and concentrates, oxide and hydroxide, unwrought metal (including powders), beryllium articles, waste and scrap, beryllium-copper master alloy, and beryllium-copper plates, sheets, and strip.

${ }^{2}$ Includes estimated beryllium content of exported unwrought metal (including powders), beryllium articles, and waste and scrap.

${ }^{3}$ Change in total inventory level from prior yearend inventory.

${ }^{4}$ Defined as production + net import reliance.

${ }^{5}$ Calculated from gross weight and customs value of imports; beryllium content estimated to be $4 \%$. Rounded to two significant figures.

${ }^{6}$ Defined as imports - exports + adjustments for Government and industry stock changes.

${ }^{7}$ See Appendix $B$ for definitions.

${ }^{8}$ In addition to the countries listed, Kazakhstan, Portugal, and Uganda may have produced beryl ore, but available information was inadequate to make reliable estimates of output. Other nations that produced gemstone beryl ore may also have produced some industrial beryl ore.

${ }^{9}$ Based on a beryllium content of $4 \%$ from bertrandite and beryl sources.

${ }^{10}$ See Appendix $\mathrm{C}$ for resource and reserve definitions and information concerning data sources.
} 


\section{BISMUTH}

(Data in metric tons gross weight unless otherwise noted)

Domestic Production and Use: The United States ceased production of primary refined bismuth in 1997 and is highly import dependent for its supply. Bismuth is contained in some lead ores mined domestically. However, the last domestic primary lead smelter closed at yearend 2013; since then all lead concentrates have been exported for smelting.

About two-thirds of domestic bismuth consumption was for chemicals used in cosmetic, industrial, laboratory, and pharmaceutical applications. Bismuth use in pharmaceuticals included bismuth salicylate (the active ingredient in over-the-counter stomach remedies) and other compounds used to treat burns, intestinal disorders, and stomach ulcers. Bismuth is also used in the manufacture of ceramic glazes, crystalware, and pearlescent pigments.

Bismuth has a wide variety of metallurgical applications, including use as an additive to enhance metallurgical quality in the foundry industry and as a nontoxic replacement for lead in brass, free-machining steels, and solders. The use of bismuth in brass for pipe fittings, fixtures, and water meters increased after 2014 when the definition of "lead-free" under the Safe Drinking Water Act was modified to reduce the maximum lead content of "lead free" pipes and plumbing fixtures to $0.25 \%$ from $8 \%$. The melting point of bismuth is relatively low at $271{ }^{\circ} \mathrm{C}$, and it is an important component of various fusible alloys, some of which have melting points below that of boiling water. These bismuthcontaining alloys can be used in holding devices for grinding optical lenses, as a temporary filler to prevent damage to tubes in bending operations, as a triggering mechanism for fire sprinklers, and in other applications in which a low melting point is ideal. Bismuth-tellurium-oxide alloy film paste is used in the manufacture of semiconductor devices.

\begin{tabular}{|c|c|c|c|c|c|}
\hline Salient Statistics_-United States: & $\underline{2015}$ & 2016 & 2017 & 2018 & $\underline{2019^{\mathrm{e}}}$ \\
\hline \multicolumn{6}{|l|}{ Production: } \\
\hline Refinery & - & - & - & - & \\
\hline Secondary (scrap)e & 80 & 80 & 80 & 80 & 80 \\
\hline Imports for consumption, metal, alloys, and scrap & 1,950 & 2,190 & 2,820 & 2,510 & 2,400 \\
\hline Exports, metal, alloys, and scrap & 519 & 431 & 392 & 653 & 580 \\
\hline \multicolumn{6}{|l|}{ Consumption: } \\
\hline Apparent ${ }^{1}$ & 1,490 & 1,780 & 2,520 & 1,900 & 1,900 \\
\hline Reported & 621 & 710 & 756 & 566 & 600 \\
\hline Price, average, dollars per pound ${ }^{2}$ & 6.43 & 4.53 & 4.93 & 4.64 & 3.40 \\
\hline Stocks, yearend, consumer & 456 & 512 & 494 & 533 & 500 \\
\hline $\begin{array}{l}\text { Net import reliance }{ }^{3} \text { as a percentage of } \\
\text { apparent consumption }\end{array}$ & 95 & 96 & 97 & 96 & 96 \\
\hline
\end{tabular}

Recycling: Bismuth-containing alloy scrap was recycled and thought to compose less than $5 \%$ of U.S. bismuth apparent consumption.

Import Sources (2015-18): China, 76\%; Belgium, 6\%; Mexico, 6\%; Republic of Korea, 5\%; and other, 7\%.

Tariff: Item

Bismuth and articles thereof, including waste and scrap
Number

8106.00 .0000
Normal Trade Relations 12-31-19

Free.

Depletion Allowance: 22\% (Domestic), 14\% (Foreign).

Government Stockpile: None. 


\section{BISMUTH}

Events, Trends, and Issues: Bismuth prices continued a significant downward trend that began in 2014, when the annual average domestic dealer price was $\$ 11.14$ per pound. Bismuth was one of the metals held in significant quantities by the defunct Fanya Nonferrous Metals Exchange in China, which closed in 2015. In 2019, sales of the exchange's assets began, and though bismuth was not among the limited initial offerings the potential sale was a factor on the price of bismuth throughout the year.

In 2019, a stable bismuth-based perovskite oxide semiconductor was discovered that could potentially be used in thin-film solar technology. The discovery was the product of a National Science Foundation grant for development of high-performance semiconductors that could replace lead-halide perovskites in applications such as perovskite solar cells, the commercial production of which was not feasible because of stability issues as well as the toxicity of the lead-based perovskite material. Additional research to improve the photovoltaic efficiency of the bismuth-based perovskites is needed before their use would be feasible.

World Refinery Production and Reserves: Available information was inadequate to make reliable estimates for mine production and reserves data.

\begin{tabular}{lrr} 
& \multicolumn{2}{c}{ Refinery } \\
& $\underline{\mathbf{2 0 1 8}}$ & $\underline{\mathbf{2 0 1 9}}$ \\
United States & - & - \\
Bulgaria & 25 & 50 \\
Canada & 14,000 & 25 \\
China & 571 & 14,000 \\
Japan & 290 & 540 \\
Kazakhstan & 900 & 270 \\
Korea, Republic of & 3,010 & 900 \\
Laos & 333 & 3,000 \\
Mexico & 19,200 & 400 \\
$\quad$ World total (rounded) & & 19,000
\end{tabular}

\section{Reserves $^{4}$}

Quantitative estimates of reserves are not available.

World Resources: Bismuth ranks 65th in elemental abundance in the Earth's continental crust, at an estimated 85 parts per billion by weight, constituting much less than $0.001 \%$. World reserves of bismuth are usually estimated based on the bismuth content of lead resources because bismuth production is most often a byproduct of processing lead ores. In China and Vietnam, bismuth production is a byproduct or coproduct of tungsten and other metal ore processing. Bismuth minerals rarely occur in sufficient quantities to be mined as principal products; the Tasna Mine in Bolivia and a mine in China are the only mines where bismuth has been the primary product. The Tasna Mine in Bolivia has been inactive since 1996.

Substitutes: Bismuth compounds can be replaced in pharmaceutical applications by alumina, antibiotics, calcium carbonate, and magnesia. Titanium dioxide-coated mica flakes and fish-scale extracts are substitutes in pigment uses. Cadmium, indium, lead, and tin can partially replace bismuth in low-temperature solders. Resins can replace bismuth alloys for holding metal shapes during machining, and glycerine-filled glass bulbs can replace bismuth alloys in triggering devices for fire sprinklers. Free-machining alloys can contain lead, selenium, or tellurium as a replacement for bismuth. Bismuth is an environmentally friendly substitute for lead in plumbing and many other applications, including fishing weights, hunting ammunition, lubricating greases, and soldering alloys.

\footnotetext{
eEstimated. — Zero.

${ }^{1}$ Defined as secondary production + imports - exports + adjustments for industry stock changes.

${ }^{2}$ Price in 2015 is based on New York dealer price for 99.99\%-purity metal in minimum lots of 1 ton; source: Platts Metals Week. Prices in 2016-19 are based on 99.99\%-purity metal at warehouse (Rotterdam) in minimum lots of 1 ton; source: American Metal Market (Fastmarkets AMM).

${ }^{3}$ Defined as imports - exports + adjustments for industry stock changes.

${ }^{4}$ See Appendix $\mathrm{C}$ for resource and reserve definitions and information concerning data sources.
} 


\section{BORON}

(Data in thousand metric tons unless otherwise noted)

Domestic Production and Use: Two companies in southern California produced borates in 2019, and most of the boron products consumed in the United States were manufactured domestically. U.S. boron production and consumption data were withheld to avoid disclosing company proprietary data. The leading boron producer mined borate ores, which contain the minerals kernite, tincal, and ulexite, by open pit methods and operated associated compound plants. Kernite was used to produce boric acid, tincal was used to produce sodium borate, and ulexite was used as a primary ingredient in the manufacture of a variety of specialty glasses and ceramics. A second company produced borates from brines extracted through solution-mining techniques. Boron minerals and chemicals were principally consumed in the North Central United States and the Eastern United States. In 2019, the glass and ceramics industries remained the leading domestic users of boron products, accounting for an estimated $80 \%$ of total borates consumption. Boron also was used as a component in abrasives, cleaning products, insecticides, and insulation and in the production of semiconductors.

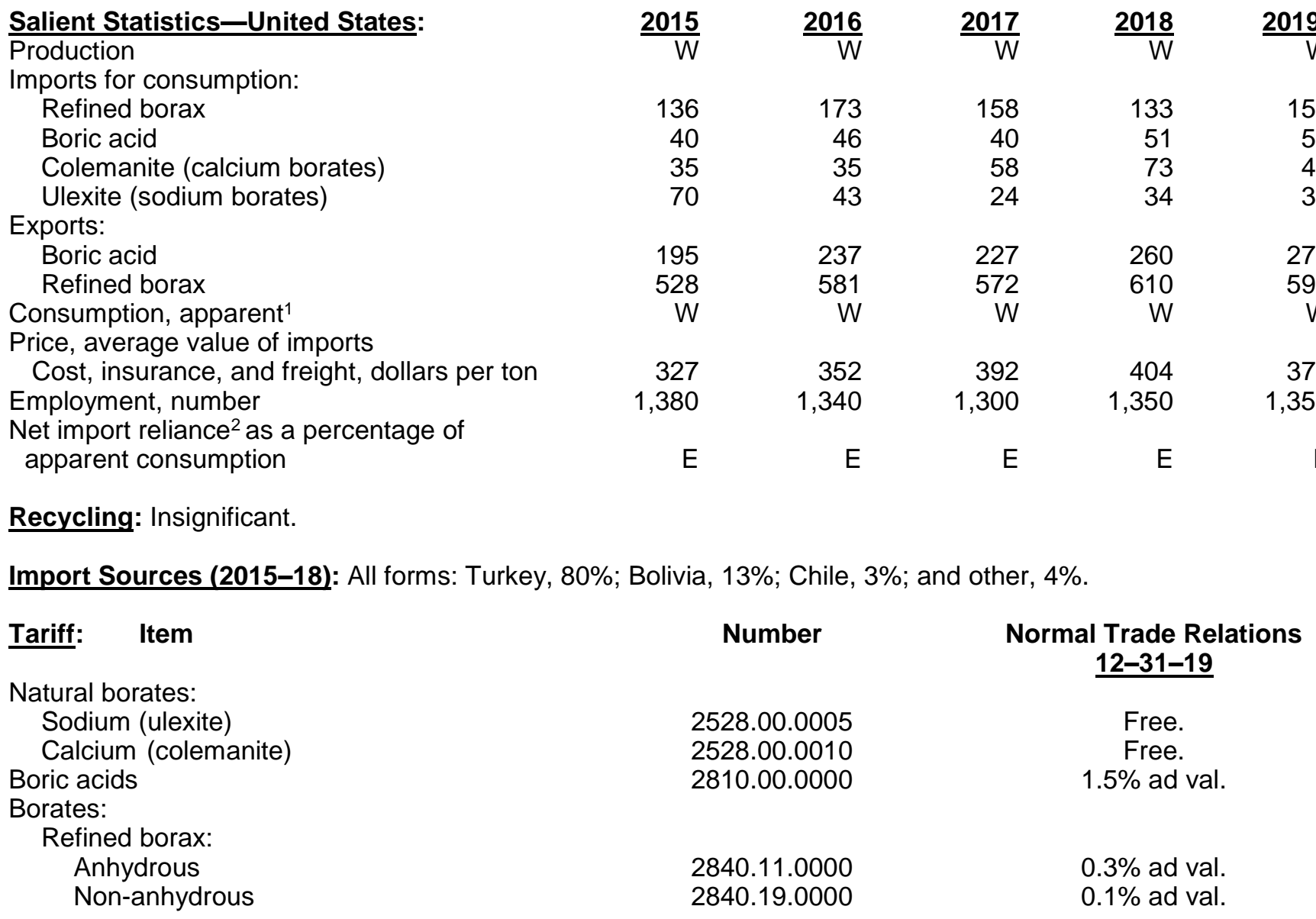

Depletion Allowance: Borax, 14\% (Domestic and foreign).

Government Stockpile: None. 


\section{BORON}

Events, Trends, and Issues: Elemental boron is a metalloid with limited commercial applications. Although the term "boron" is commonly referenced, it does not occur in nature in an elemental state. Boron combines with oxygen and other elements to form boric acid, or inorganic salts called borates. Boron compounds, chiefly borates, are commercially important; therefore, boron products are priced and sold based on their boric oxide $\left(\mathrm{B}_{2} \mathrm{O}_{3}\right)$ content, varying by ore and compound and by the absence or presence of calcium and sodium. The four borate mineralscolemanite, kernite, tincal, and ulexite-account for $90 \%$ of the borate minerals used by industry worldwide. Although borates were used in more than 300 applications, more than three-quarters of world consumption was used in ceramics, detergents, fertilizers, and glass.

China, India, Indonesia, Malaysia, and the Netherlands are the countries that imported the largest quantities of refined borates from the United States in 2019. Because China has low-grade boron reserves and demand for boron is anticipated to rise in that country, imports to China from Chile, Russia, Turkey, and the United States were expected to remain steady during the next several years.

Continued investment in new borate refineries and the continued rise in demand were expected to fuel growth in world production for the next few years. Two Australia-based mine developers confirmed that production of highquality boron products is possible from their projects in California and Nevada. These companies have the potential to become substantial boron producers when they are fully developed. Both companies expect production to begin in 2021, with construction beginning at one site by late 2019 .

World Production and Reserves: Reserves for Turkey were updated based on company information.

United States

Argentina, crude ore

Bolivia, ulexite

Chile, ulexite

China, boric oxide equivalent

Germany, compounds

Kazakhstan, unspecified

Peru, crude borates

Russia, datolite ore

Turkey, refined borates

World total ${ }^{4}$

\begin{tabular}{cr}
$\begin{array}{c}\text { Production-All forms } \\
\text { 2018 }\end{array}$ & $\frac{\mathbf{2 0 1 9}}{W}$ \\
\hline$W$ & 100 \\
200 & 210 \\
150 & 400 \\
600 & 250 \\
75 & 140 \\
143 & - \\
500 & 100 \\
101 & 80 \\
80 & $\frac{2,500}{X X}$ \\
$\frac{2,000}{X X}$ &
\end{tabular}

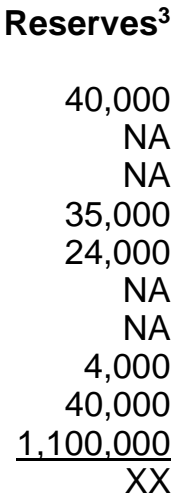

World Resources: Deposits of borates are associated with volcanic activity and arid climates, with the largest economically viable deposits in the Mojave Desert of the United States, the Alpide belt in southern Asia, and the Andean belt of South America. U.S. deposits consist primarily of tincal, kernite, and borates contained in brines, and to a lesser extent, ulexite and colemanite. About $70 \%$ of all deposits in Turkey are colemanite, primarily used in the production of heat-resistant glass. At current levels of consumption, world resources are adequate for the foreseeable future.

Substitutes: The substitution of other materials for boron is possible in detergents, enamels, insulation, and soaps. Sodium percarbonate can replace borates in detergents and requires lower temperatures to undergo hydrolysis, which is an environmental consideration. Some enamels can use other glass-producing substances, such as phosphates. Insulation substitutes include cellulose, foams, and mineral wools. In soaps, sodium and potassium salts of fatty acids can act as cleaning and emulsifying agents.

\footnotetext{
eEstimated. E Net exporter. NA Not available. W Withheld to avoid disclosing company proprietary data. XX Not applicable. — Zero.

${ }^{1}$ Defined as production + imports - exports.

${ }^{2}$ Defined as imports - exports.

${ }^{3}$ See Appendix $\mathrm{C}$ for resource and reserve definitions and information concerning data sources.

${ }^{4}$ World totals cannot be calculated because production and reserves are not reported in a consistent manner by all countries.
} 


\section{BROMINE}

(Data in metric tons of bromine content unless otherwise noted)

Domestic Production and Use: Bromine was recovered from underground brines by two companies in Arkansas. Bromine is one of the leading mineral commodities, in terms of value, produced in Arkansas. The two bromine companies in the United States account for a large percentage of world production capacity.

The leading global applications of bromine are for the production of brominated flame retardants, and intermediates and industrial uses. Bromine compounds are also used in a variety of other applications, including drilling fluids and industrial water treatment. U.S. apparent consumption of bromine in 2019 was estimated to be greater than that in 2018.

\begin{tabular}{|c|c|c|c|c|c|}
\hline Salient Statistics_United States: & $\underline{2015}$ & $\underline{2016}$ & $\underline{2017}$ & $\underline{2018}$ & $\frac{2019^{\mathrm{e}}}{W}$ \\
\hline$\overline{\text { Production }}$ & $\mathrm{W}$ & $\mathrm{W}$ & $\mathrm{W}$ & $\mathrm{W}$ & $\mathrm{W}$ \\
\hline \multicolumn{6}{|l|}{ Imports for consumption, elemental } \\
\hline bromine and compounds ${ }^{1}$ & 61,200 & 58,400 & 52,700 & 56,200 & 66,000 \\
\hline Exports, elemental bromine and compounds ${ }^{2}$ & 29,600 & 28,300 & 43,400 & 40,500 & 44,000 \\
\hline Consumption, apparent ${ }^{3}$ & W & W & W & W & W \\
\hline \multicolumn{6}{|l|}{ Price, average value of imports, } \\
\hline Cost, insurance, and freight, dollars per kilogram & 2.27 & 2.19 & 2.30 & 2.21 & 2.19 \\
\hline Employment, numbere & 1,100 & 1,100 & 1,100 & 1,100 & 1,100 \\
\hline $\begin{array}{l}\text { Net import reliance } 4 \text { as a percentage } \\
\text { of apparent consumption }\end{array}$ & $<25$ & $<25$ & $<25$ & $<25$ & $<25$ \\
\hline
\end{tabular}

Recycling: Some bromide solutions were recycled to obtain elemental bromine and to prevent the solutions from being disposed of as hazardous waste. For example, hydrogen bromide is emitted as a byproduct in many organic reactions. This byproduct waste can be recycled with virgin bromine brines and used as a source of bromine production. Bromine contained in plastics can be incinerated as solid organic waste, and the bromine can be recovered.

Import Sources (2015-18): ${ }^{5}$ Israel, 79\%; Jordan, 11\%; China, 7\%; and other, 3\%.

\section{Tariff: Item}

Bromine

Hydrobromic acid

Potassium or sodium bromide

Ammonium, calcium, or zinc bromide

Potassium bromate

Sodium bromate

Ethylene dibromide

Methyl bromide

Dibromoneopentyl glycol

Tetrabromobisphenol A

Decabromodiphenyl and

octabromodiphenyl oxide

\section{Number}

2801.30.2000

2811.19.3000

2827.51 .0000

2827.59.2500

2829.90.0500

2829.90.2500

2903.31.0000

2903.39.1520

2905.59.3000

2908.19.2500

2909.30.0700
Normal Trade Relations

12-31-19

$5.5 \%$ ad val.

Free.

Free.

Free.

Free.

Free.

$5.4 \%$ ad val.

Free.

Free.

$5.5 \%$ ad val.

$5.5 \%$ ad val.

Depletion Allowance: Brine wells, 5\% (Domestic and foreign).

Government Stockpile: None. 


\section{BROMINE}

Events, Trends, and Issues: The United States maintained its position as one of the leading bromine producers in the world. China, Israel, and Jordan also are major producers of elemental bromine. In 2019, U.S. net imports of bromine and bromine compounds increased compared with those in 2018. The average import value of elemental bromine increased by about $20 \%$ in 2019 compared with that in 2018 . The leading source of imports of bromine and bromide compound (gross weight) was Israel. The leading imported bromine products in terms of both gross weight and bromine content were bromides and bromide oxides of ammonium, calcium, or zinc (79\%) and bromides of potassium or sodium (17\%). The leading exported bromine product was methyl bromide (45\%).

Global consumption of elemental bromine and brominated flame retardants was strong in 2019. The price of bromine compounds also increased in 2019. The amount of clear brine fluids consumed in the oil-well and gas-well drilling industries continued to mirror global changes in oil prices and the number of active drilling rigs. In 2019, the monthly average number of active drilling rigs was about the same as in 2018.

Many bromine facilities in Shandong Province, China, remained closed in the first half of 2019 while rectifications and improvements were completed to meet new environmental regulations initiated by the Government of China in late 2017. Some plants restarted operations in the spring of 2019 following approval by the local government while others, especially small-scale unofficial plants, remained closed until they could meet the new guidelines.

In order to meet growing demand, a company in Jordan began an expansion project in 2018 to increase production capacity. The increased capacity was expected to have increased the country's 2019 bromine production.

\section{World Production and Reserves:}

\begin{tabular}{|c|c|c|c|}
\hline & & ction & Reserves $^{6}$ \\
\hline & 2018 & $\underline{2019^{e}}$ & \\
\hline United States & $\mathrm{W}$ & $\mathrm{W}$ & $11,000,000$ \\
\hline Azerbaijan & - & - & 300,000 \\
\hline China & 60,000 & 60,000 & NA \\
\hline India & 2,300 & 2,300 & NA \\
\hline Israel & 175,000 & 180,000 & Large \\
\hline Japan & 20,000 & 20,000 & NA \\
\hline Jordan & 100,000 & 150,000 & Large \\
\hline Ukraine & 4,500 & 4,500 & $\mathrm{NA}$ \\
\hline World total (rounded) & 7362,000 & 7420,000 & Large \\
\hline
\end{tabular}

World Resources: Bromine is found principally in seawater, evaporitic (salt) lakes, and underground brines associated with petroleum deposits. The Dead Sea, in the Middle East, is estimated to contain 1 billion tons of bromine. Seawater contains about 65 parts per million of bromine, or an estimated 100 trillion tons. Bromine is also recovered from seawater as a coproduct during evaporation to produce salt.

Substitutes: Chlorine and iodine may be substituted for bromine in a few chemical reactions and for sanitation purposes. There are no comparable substitutes for bromine in various oil-well and gas-well completion and packer applications. Because plastics have a low ignition temperature, aluminum hydroxide, magnesium hydroxide, organic chlorine compounds, and phosphorus compounds can be substituted for bromine as fire retardants in some uses.

\footnotetext{
eEstimated. NA Not available. W Withheld to avoid disclosing company proprietary data. — Zero.

${ }^{1}$ Imports calculated from items shown in Tariff section.

${ }^{2}$ Exports calculated from Schedule B numbers 2801.30.2000, 2827.51.0000, 2827.59.0000, 2903.31.0000, and 2903.39.1520.

${ }^{3}$ Defined as production (sold or used) + imports - exports.

${ }^{4}$ Defined as imports - exports.

${ }^{5}$ Calculated using the gross weight of imports.

${ }^{6}$ See Appendix $\mathrm{C}$ for resource and reserve definitions and information concerning data sources.

${ }^{7}$ Excludes U.S. production.
} 


\section{CADMIUM}

(Data in metric tons of cadmium content unless otherwise noted)

Domestic Production and Use: Two companies in the United States produced refined cadmium in 2019. One company, operating in Tennessee, recovered primary refined cadmium as a byproduct of zinc leaching from roasted sulfide concentrates. The other company, operating in Ohio, recovered secondary cadmium metal from spent nickelcadmium (NiCd) batteries. Domestic production and consumption of cadmium were withheld to avoid disclosing company proprietary data. Cadmium metal and compounds are mainly consumed for alloys, coatings, NiCd batteries, pigments, and plastic stabilizers. For the past 4 years, the United States has been a net importer of unwrought cadmium metal and cadmium metal powders and a net exporter of wrought cadmium products and cadmium pigments.

\begin{tabular}{|c|c|c|c|c|c|}
\hline Salient Statistics-United States: & $\underline{2015}$ & $\underline{2016}$ & $\underline{2017}$ & $\underline{2018}$ & $\underline{2019^{\mathrm{e}}}$ \\
\hline$\overline{\text { Production, refined }{ }^{1}}$ & W & $\bar{W}$ & W & $\mathrm{W}$ & W \\
\hline \multicolumn{6}{|l|}{ Imports for consumption: } \\
\hline Unwrought cadmium and powders & 237 & 240 & 274 & 273 & 350 \\
\hline Wrought cadmium and other articles (gross weight) & 18 & $\left({ }^{2}\right)$ & 2 & 1 & \\
\hline Cadmium waste and scrap (gross weight) & 71 & 52 & 20 & 20 & \\
\hline \multicolumn{6}{|l|}{ Exports: } \\
\hline Unwrought cadmium and powders & 350 & 157 & 223 & 41 & \\
\hline Wrought cadmium and other articles (gross weight) & 246 & 371 & 205 & 99 & \\
\hline Cadmium waste and scrap (gross weight) & $\left({ }^{2}\right)$ & 12 & $\left({ }^{2}\right)$ & $\left({ }^{2}\right)$ & \\
\hline Consumption, reported, refined & W & W & W & W & \\
\hline Price, metal, annual average, dollars per kilogram ${ }^{3}$ & 1.47 & 1.34 & 1.75 & 2.89 & \\
\hline Stocks, yearend, producer and distributor & W & W & W & W & \\
\hline $\begin{array}{l}\text { Net import reliance } 4 \text { as a percentage of } \\
\text { apparent consumption }\end{array}$ & $\mathrm{E}$ & $<25$ & $<25$ & $<50$ & \\
\hline
\end{tabular}

Recycling: Secondary cadmium is mainly recovered from spent consumer and industrial NiCd batteries. Other waste and scrap from which cadmium can be recycled includes copper-cadmium alloy scrap, some complex nonferrous alloy scrap, cadmium-containing dust from electric arc furnaces, and cadmium telluride (CdTe) solar panels.

Import Sources (2015-18): ${ }^{5}$ China, 25\%; Australia, 22\%; Canada, 21\%; Peru, 10\%; and other, 22\%.

\section{Tariff: Item}

Cadmium oxide

Cadmium sulfide

Pigments and preparations based

on cadmium compounds

Unwrought cadmium and powders

Cadmium waste and scrap

Wrought cadmium and other articles
Number

2825.90.7500

2830.90.2000

3206.49 .6010

8107.20 .0000

8107.30 .0000

8107.90 .0000
Normal Trade Relations

12-31-19

Free.

$3.1 \%$ ad val.

$3.1 \%$ ad val.

Free.

Free.

$4.4 \%$ ad val.

Depletion Allowance: 22\% (Domestic), 14\% (Foreign).

Government Stockpile: None. 


\section{CADMIUM}

Events, Trends, and Issues: Most of the world's primary cadmium metal was produced in Asia, and leading global producers, in descending order of production, were China, the Republic of Korea, and Japan. A smaller amount of secondary cadmium metal was recovered from recycling NiCd batteries. Although detailed data on the global consumption of primary cadmium were not available, NiCd battery production was thought to have continued to account for most global cadmium consumption. Other end uses for cadmium and cadmium compounds included alloys, anticorrosive coatings, pigments, polyvinyl chloride (PVC) stabilizers, and semiconductors for solar cells.

The average monthly cadmium price began 2019 averaging $\$ 2.80$ per kilogram in January and trended upward to about $\$ 3.06$ per kilogram in March. Prices began decreasing in May, falling to an average of about $\$ 2.40$ per kilogram in August.

In 2019, a U.S.-based CdTe thin-film solar-cell producer continued constructing a second manufacturing plant in Ohio. The facility was expected to be completed in 2019 and reach its full production rate in 2020 . The plant would triple the company's U.S. CdTe solar cell manufacturing capacity to 1.8 gigawatts per year.

\section{World Refinery Production and Reserves:}

\begin{tabular}{|c|c|c|}
\hline & Refin & oductior \\
\hline & $\underline{2018}$ & $\underline{2019^{e}}$ \\
\hline United States ${ }^{1}$ & $\mathrm{~W}$ & $\mathrm{~W}$ \\
\hline Canada & 1,680 & 1,600 \\
\hline China & 8,200 & 8,200 \\
\hline Japan & 1,980 & 1,900 \\
\hline Kazakhstan & 1,500 & 1,400 \\
\hline Korea, Republic of & 5,000 & 5,000 \\
\hline Mexico & 1,360 & 1,400 \\
\hline Netherlands & 1,100 & 1,100 \\
\hline Peru & 765 & 770 \\
\hline Russia & 1,200 & 1,000 \\
\hline Other countries & 2,310 & 2,300 \\
\hline World total (rounded) & 725,100 & 725,000 \\
\hline
\end{tabular}

\section{Reserves $^{6}$}

Quantitative estimates of reserves are not available. The cadmium content of typical zinc ores averages about $0.03 \%$. See the Zinc chapter for zinc reserves.

World Resources: Cadmium is generally recovered from zinc ores and concentrates. Sphalerite, the most economically significant zinc ore mineral, commonly contains minor amounts of cadmium, which shares certain similar chemical properties with zinc and often substitutes for zinc in the sphalerite crystal lattice. The cadmium mineral greenockite is frequently associated with weathered sphalerite and wurtzite.

Substitutes: Lithium-ion and nickel-metal hydride batteries can replace NiCd batteries in many applications. Except where the surface characteristics of a coating are critical (for example, fasteners for aircraft), coatings of zinc, zincnickel, aluminum, or tin can be substituted for cadmium in many plating applications. Cerium sulfide is used as a replacement for cadmium pigments, mostly in plastics. Barium-zinc or calcium-zinc stabilizers can replace bariumcadmium stabilizers in flexible PVC applications. Amorphous silicon and copper-indium-gallium-selenide photovoltaic cells compete with cadmium telluride in the thin-film solar-cell market. Research efforts continued to advance new thin-film technology based on perovskite material as a potential substitute.

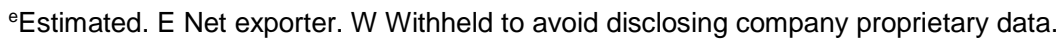

${ }^{1}$ Cadmium metal produced as a byproduct of zinc refining plus metal from recycling.

${ }^{2}$ Less than $1 / 2$ unit.

${ }^{3}$ Average New York dealer price for $99.95 \%$ purity in 5-short-ton lots (2015). Source: Platts Metals Week. Average free market price for $99.95 \%$ purity in 10-ton lots; cost, insurance, and freight; global ports (2016-18). Source: Metal Bulletin.

${ }^{4}$ Defined as imports of unwrought metal and metal powders - exports of unwrought metal and metal powders + adjustments for industry stock changes.

${ }^{5}$ Imports for consumption of unwrought metal and metal powders (Harmonized Tariff Schedule of the United States code 8107.20.0000).

${ }^{6}$ See Appendix C for resource and reserve definitions and information concerning data sources.

${ }^{7}$ Excludes U.S. production.
} 


\section{CEMENT}

(Data in thousand metric tons unless otherwise noted)

Domestic Production and Use: In 2019, U.S. portland cement production increased by $2.5 \%$ to 86 million tons, and masonry cement production continued to remain steady at 2.4 million tons. Cement was produced at 96 plants in 34 States, and at 2 plants in Puerto Rico. U.S. cement production continued to be limited by closed or idle plants, underutilized capacity at others, production disruptions from plant upgrades, and relatively inexpensive imports. In 2019 , sales of cement increased slightly and were valued at $\$ 12.5$ billion. Most cement sales were to make concrete, worth at least $\$ 65$ billion. In 2019 , it was estimated that $70 \%$ to $75 \%$ of sales were to ready-mixed concrete producers, $10 \%$ to concrete product manufactures, $8 \%$ to $10 \%$ to contractors, and $5 \%$ to $12 \%$ to other customer types. Texas, California, Missouri, Florida, Alabama, Michigan, and Pennsylvania were, in descending order of production, the seven leading cement-producing States and accounted for nearly $60 \%$ of U.S. production.

\begin{tabular}{|c|c|c|c|c|c|}
\hline \multirow{2}{*}{\multicolumn{6}{|c|}{$\frac{\text { Salient Statistics-United States: }}{\text { Production: }^{1}}$}} \\
\hline & & & & & \\
\hline Portland and masonry cement ${ }^{2}$ & 84,405 & 84,695 & 86,356 & 86,368 & 88,500 \\
\hline Clinker & 76,043 & 75,633 & 76,678 & 77,112 & 78,000 \\
\hline Shipments to final customers, includes exports & 93,543 & 95,397 & 97,935 & 99,406 & 100,000 \\
\hline Imports of hydraulic cement for consumption & 10,376 & 11,742 & 12,288 & 13,764 & 15,000 \\
\hline Imports of clinker for consumption & 879 & 1,496 & 1,209 & 967 & 1,100 \\
\hline Exports of hydraulic cement and clinker & 1,543 & 1,097 & 1,035 & 940 & 1,000 \\
\hline Consumption, apparent ${ }^{3}$ & 92,150 & 95,150 & 97,160 & 98,480 & 102,000 \\
\hline Price, average mill value, dollars per ton & 106.50 & 111.00 & 117.00 & 121.00 & 123.50 \\
\hline Stocks, cement, yearend & 7,230 & 7,420 & 7,870 & 8,580 & 8,850 \\
\hline Employment, mine and mill, numbere & 12,300 & 12,700 & 12,500 & 12,300 & 12,500 \\
\hline $\begin{array}{l}\text { Net import reliance } 4 \text { as a percentage of } \\
\text { apparent consumption }\end{array}$ & 11 & 13 & 13 & 14 & 15 \\
\hline
\end{tabular}

Recycling: Cement is not recycled, but significant quantities of concrete are recycled for use as a construction aggregate. Cement kilns can use waste fuels, recycled cement kiln dust, and recycled raw materials such as slags and fly ash. Various secondary materials can be incorporated as supplementary cementitious materials (SCMs) in blended cements and in the cement paste in concrete.

Import Sources (2015-18): ${ }^{5}$ Canada, 35\%; Greece, 16\%; China, 14\%; Turkey, 11\%; and other, 24\%.

Tariff: Item

Cement clinker

White portland cement

Other portland cement

Aluminous cement

Other hydraulic cement
Number

2523.10.0000

2523.21.0000

2523.29.0000

2523.30.0000

2523.90.0000
Normal Trade Relations 12-31-19

Free.

Free.

Free.

Free.

Free.

Depletion Allowance: Not applicable. Certain raw materials for cement production have depletion allowances.

Government Stockpile: None. 


\section{CEMENT}

Events, Trends, and Issues: Construction spending decreased in 2019, owing to a decline in private residential and nonresidential spending. Cement shipments into North Carolina and South Carolina increased owing to reconstruction following a hurricane in 2018. The leading cement-consuming States were Texas, California, and Florida, in descending order by tonnage.

No new company mergers were reported in 2019, but one European cement company entered into an agreement to purchase a Mexican cement company's plant in Pennsylvania, pending regulatory approval.

No major cement plant upgrades were completed during the year, but several minor upgrades were ongoing at a few domestic plants. One cement company began work on an upgrade to one of its plants in Indiana, with completion expected in 2022. Another company continued to work on securing permits for a new white cement plant in Texas, which would be the third white cement plant in the country. Many plants have installed emissions-reduction equipment to comply with the 2010 National Emissions Standards for Hazardous Air Pollutants (NESHAP). It remains possible that some kilns could be shut, idled, or used in a reduced capacity to comply with NESHAP, which would constrain U.S. clinker capacity.

\section{World Production and Capacity:}

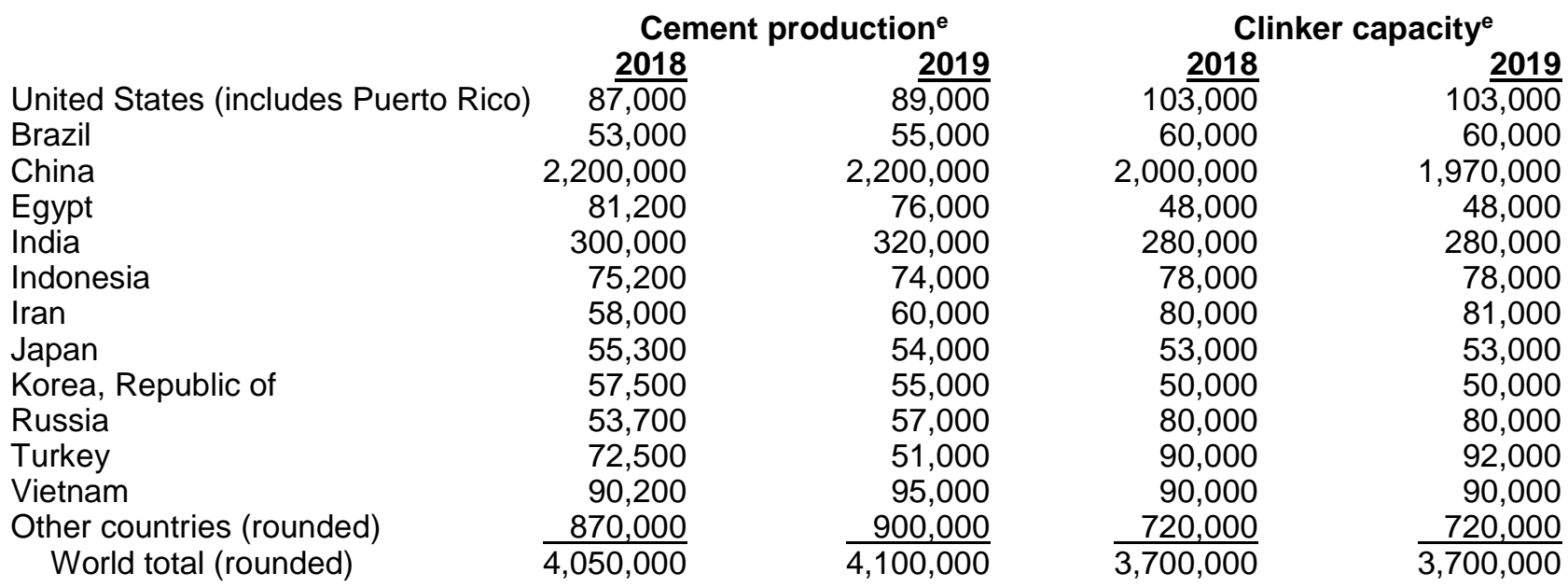

World Resources: Although reserves at individual plants are subject to exhaustion, limestone and other cement raw materials are geologically widespread and abundant, and overall shortages are unlikely in the future.

Substitutes: Most portland cement is used to make concrete, mortars, or stuccos, and competes in the construction sector with concrete substitutes, such as aluminum, asphalt, clay brick, fiberglass, glass, gypsum (plaster), steel, stone, and wood. Certain materials, especially fly ash and ground granulated blast furnace slag, develop good hydraulic cementitious properties by reacting with lime, such as that released by the hydration of portland cement. Where readily available (including as imports), these SCMs are increasingly being used as partial substitutes for portland cement in many concrete applications and are components of finished blended cements.

\footnotetext{
${ }^{\text {eEstimated. }}$

${ }^{1}$ Portland plus masonry cement unless otherwise noted; excludes Puerto Rico unless otherwise noted.

${ }^{2}$ Includes cement made from imported clinker.

${ }^{3}$ Defined as production of cement (including from imported clinker) + imports (excluding clinker) - exports + adjustments for stock changes.

${ }^{4}$ Defined as imports (cement and clinker) - exports.

${ }^{5}$ Hydraulic cement and clinker; includes imports into Puerto Rico.
} 


\section{CESIUM}

(Data in metric tons of cesium oxide unless otherwise noted)

Domestic Production and Use: In 2019, no cesium was mined domestically, and the United States was $100 \%$ import reliant for cesium minerals. Pollucite, mainly found in association with lithium-rich, lepidolite-bearing or petalitebearing zoned granite pegmatites, is the principal cesium ore mineral. Cesium minerals are used as feedstocks to produce a variety of cesium compounds and cesium metal. The primary application for cesium, by gross weight, is in cesium formate brines used for high-pressure, high-temperature well drilling for oil and gas production and exploration.

Cesium metal is used in the production of cesium compounds and potentially in photoelectric cells. Cesium bromide is used in infrared detectors, optics, photoelectric cells, scintillation counters, and spectrophotometers. Cesium carbonate is used in the alkylation of organic compounds and in energy conversion devices, such as fuel cells, magneto-hydrodynamic generators, and polymer solar cells. Cesium chloride is used in analytical chemistry applications as a reagent, in high-temperature solders, as an intermediate in cesium metal production, in isopycnic centrifugation, as a radioisotope in nuclear medicine, as an insect repellent in agricultural applications, and in specialty glasses. Cesium hydroxide is used as an electrolyte in alkaline storage batteries. Cesium iodide is used in fluoroscopy equipment-Fourier-transform infrared spectrometers-as the input phosphor of $x$-ray image intensifier tubes, and in scintillators. Cesium nitrate is used as a colorant and oxidizer in the pyrotechnic industry, in petroleum cracking, in scintillation counters, and in x-ray phosphors. Cesium sulfates are soluble in water and are thought to be used primarily in water treatment, fuel cells, and to improve optical quality for scientific instruments.

Cesium isotopes, which are obtained as a byproduct in nuclear fission or formed from other isotopes, such as barium131, are used in electronic, medical, metallurgical, and research applications. Cesium isotopes are used as an atomic resonance frequency standard in atomic clocks, which plays a vital role in aircraft guidance systems, global positioning satellites, and internet and cellular telephone transmissions. Cesium clocks monitor the cycles of microwave radiation emitted by cesium's electrons and use these cycles as a time reference. Owing to the high accuracy of the cesium atomic clock, the international definition of 1 second is based on the cesium atom. The U.S. civilian time and frequency standard is based on a cesium fountain clock at the National Institute of Standards and Technology in Boulder, CO. The U.S. military frequency standard, the United States Naval Observatory Time Scale, is based on 48 weighted atomic clocks, including 25 cesium fountain clocks.

A company in Richland, WA, produced a range of cesium-131 medical products for treatment of various cancers. Cesium-137 may be used in industrial gauges, in mining and geophysical instruments, and for sterilization of food, sewage, and surgical equipment. Because of the danger posed by the radiological properties of cesium-137, efforts to find substitutes in its applications continued.

Salient Statistics-United States: Consumption, import, and export data for cesium have not been available since the late 1980s. Because cesium metal is not traded in commercial quantities, a market price is unavailable. Only a few thousand kilograms of cesium chemicals are thought to be consumed in the United States every year. The United States was $100 \%$ import reliant for its cesium needs.

In 2019, one company offered 1-gram ampoules of $99.8 \%$ (metal basis) cesium for $\$ 63.00$, a slight increase from $\$ 61.80$ in 2018, and 99.98\% (metal basis) cesium for \$81.10, a 3\% increase from \$78.70 in 2018 .

In 2019, the prices for 50 grams of $99.9 \%$ (metal basis) cesium acetate, cesium bromide, cesium carbonate, cesium chloride, and cesium iodide were $\$ 118.20, \$ 71.90, \$ 101.80, \$ 103.60$, and $\$ 117.00$ respectively, a $3 \%$ increase from prices in 2018. The price for a cesium-plasma standard solution (10,000 micrograms per milliliter) was $\$ 81.90$ for 50 milliliters and $\$ 125.00$ for 100 milliliters, and the price for 25 grams of cesium formate, $98 \%$ basis, was $\$ 39.90$.

Recycling: Cesium formate brines are typically rented by oil and gas exploration clients. After completion of the well, the used cesium formate brine is returned and reprocessed for subsequent drilling operations. The formate brines are recycled with an estimated recovery rate of $85 \%$, which can be reprocessed for further use.

Import Sources (2015-18): No reliable data have been available to determine the source of cesium ore imported by the United States since 1988. Previously, Canada was thought to be the primary supplier of cesium ore. 


\section{CESIUM}

Tariff: Item

Alkali metals, other

Chlorides, other

Bromides, other

Iodides, other

Sulfates, other

Nitrates, other

Carbonates, other

Cesium-137, other
Number

2805.19.9000

2827.39.9000

2827.59.5100

2827.60 .5100

2833.29.5100

2834.29.5100

2836.99.5000

2844.40.0021
Normal Trade Relations

12-31-19

$5.5 \%$ ad val.

$3.7 \%$ ad val.

$3.6 \%$ ad val.

$4.2 \%$ ad val.

$3.7 \%$ ad val.

$3.5 \%$ ad val.

$3.7 \%$ ad val.

Free

Depletion Allowance: 14\% (Domestic and foreign).

Government Stockpile: None.

Events, Trends, and Issues: Domestic cesium occurrences will likely remain uneconomic unless market conditions change. No known human health issues are associated with naturally occurring cesium, and its use has minimal environmental impact. Radioactive isotopes of cesium have been known to cause adverse health effects. Certain cesium compounds may be toxic if consumed. Food that has been irradiated using the radioisotope Cesium-137 has been found to be safe by the U.S. Food and Drug Administration.

During 2019, projects that were primarily aimed at developing lithium resources with cesium content were at various stages of development. One United States-based company sold its cesium mine in Manitoba, Canada, and its specialty fluids division, including cesium formate, in Norway, Scotland, and Singapore to a company in China. Operations commenced at a pollucite mine in Western Australia in December 2018, with cesium being exported to the United States as contracted with a cesium chemical producer. The company reported that the first stage of mining produced 19,000 tons of pollucite with an average grade of $9.1 \%$ cesium oxide. The U.S. Food and Drug

Administration issued a notice of significant health and safety risks associated with compounded cesium chloride, which had been used as an alternative cancer treatment. In May 2019, a blood irradiator that used cesium-137 spilled while being moved from a medical research center to a secure disposal site. The National Nuclear Security Administration managed the cleanup efforts and an investigation. Congressional budget proposals recommended increased funding for the National Nuclear Security Administration's Cesium Irradiator Replacement Project to assist in replacing cesium-137 blood irradiators.

World Mine Production and Reserves: There were no official sources for cesium production data. In addition to production of pollucite in Australia, Namibia and Zimbabwe were thought to have produced cesium in small quantities as a byproduct of lithium mining operations. Cesium reserves are, therefore, estimated based on the occurrence of pollucite, which is mined as a byproduct of the lithium mineral lepidolite. Most pollucite contains $5 \%$ to $32 \%$ cesium oxide. Reserves data for Australia and Canada were added based on industry information.

\begin{tabular}{lr} 
Australia & Reserves $^{\mathbf{1}}$ \\
Canada & 7,100 \\
Namibia & 120,000 \\
Zimbabwe & 30,000 \\
$\quad$ World total (rounded) & 60,000 \\
\hline 220,000
\end{tabular}

World Resources: Cesium is associated with lithium-bearing pegmatites worldwide, and cesium resources have been identified in Australia, Canada, Namibia, the United States, and Zimbabwe. In the United States, pollucite occurs in pegmatites in Alaska, Maine, and South Dakota. Lower concentrations occur in brines in Chile and China and in geothermal systems in Germany, India, and Tibet. China was thought to have cesium-rich deposits of geyserite, lepidolite, and pollucite, with concentrations highest in Yichun, Jiangxi Province, although no resource, reserves, or production estimates were available.

Substitutes: Cesium and rubidium can be used interchangeably in many applications because they have similar physical properties and atomic radii. Cesium, however, is more electropositive than rubidium, making it a preferred material for some applications. However, rubidium is mined from similar deposits, in relatively smaller quantities, as a byproduct of cesium production in pegmatites and as a byproduct of lithium production from lepidolite (hard-rock) mining and processing, making it no more readily available than cesium.

\footnotetext{
${ }^{1}$ See Appendix $\mathrm{C}$ for resource and reserve definitions and information concerning data sources.
} 


\section{CHROMIUM}

(Data in thousand metric tons of chromium content unless otherwise noted)

Domestic Production and Use: In 2019, the United States was expected to consume 4\% of world chromite ore production in various forms of imported materials, such as chromite ore, chromium chemicals, chromium ferroalloys, chromium metal, and stainless steel. Imported chromite ore was consumed by one chemical firm to produce chromium chemicals. Stainless-steel and heat-resisting-steel producers were the leading consumers of ferrochromium. Stainless steels and superalloys require the addition of chromium via ferrochromium or chromiumcontaining scrap. The value of chromium material consumption in 2018 was $\$ 1.2$ billion as measured by the value of net imports, excluding stainless steel, and was expected to be about \$810 million in 2019.

\begin{tabular}{|c|c|c|c|c|c|}
\hline Salient Statistics-United States: & $\underline{2015}$ & $\underline{2016}$ & $\underline{2017}$ & $\underline{2018}$ & $\underline{2019^{e}}$ \\
\hline \multicolumn{6}{|l|}{ Production: } \\
\hline Mine & - & - & - & - & - \\
\hline Recycling $^{1}$ & 159 & 156 & 156 & 143 & 140 \\
\hline Imports for consumption & 511 & 528 & 615 & 621 & 520 \\
\hline Exports & 238 & 253 & 256 & 230 & 150 \\
\hline Shipments from Government stockpile & 9 & 5 & 8 & 4 & 3 \\
\hline \multicolumn{6}{|l|}{ Consumption: } \\
\hline Reported (includes recycling) & 486 & 475 & 483 & 464 & 460 \\
\hline Apparent (includes recycling) ${ }^{2}$ & 441 & 436 & 523 & 538 & 510 \\
\hline \multicolumn{6}{|c|}{ Unit value, average annual import (dollars per ton): } \\
\hline Chromite ore (gross weight) & 216 & 198 & 259 & 279 & 270 \\
\hline Ferrochromium (chromium content) ${ }^{3}$ & 2,606 & 2,227 & 3,212 & 2,933 & 2,200 \\
\hline Chromium metal (gross weight) & 11,386 & 9,827 & 9,682 & 11,344 & 11,000 \\
\hline Stocks, yearend, held by U.S. consumers & 8 & 8 & 8 & 8 & - \\
\hline $\begin{array}{l}\text { Net import reliance } 4 \text { as a percentage of } \\
\text { apnarent consumption }\end{array}$ & 64 & 64 & 70 & 73 & 72 \\
\hline
\end{tabular}

Recycling: In 2019, recycled chromium (contained in reported stainless steel scrap receipts) accounted for $28 \%$ of apparent consumption.

Import Sources (2015-18): Chromite (mineral): South Africa, 99\%; and Canada, 1\%. Chromium-containing scrap: ${ }^{5}$ Canada, 49\%; Mexico, 43\%; and other, 8\%. Chromium (primary metal): ${ }^{6}$ South Africa, 34\%; Kazakhstan, 9\%; Russia, 8\%; and other, 49\%. Total imports: South Africa, 38\%; Kazakhstan, 7\%; Russia, 6\%; and other, 49\%.

Tariff: $^{7}$ Item

Number

Chromium ores and concentrates:

$\mathrm{Cr}_{2} \mathrm{O}_{3}$ not more than $40 \%$

$\mathrm{Cr}_{2} \mathrm{O}_{3}$ more than $40 \%$ and less than $46 \%$

$\mathrm{Cr}_{2} \mathrm{O}_{3}$ more than or equal to $46 \%$

Chromium oxides and hydroxides:

Chromium trioxide

Other

Sodium dichromate

Potassium dichromate

Other chromates and dichromates

Carbides of chromium

Ferrochromium:

Carbon more than $4 \%$

Carbon more than 3\%

Carbon more than $0.5 \%$

Other

Ferrosilicon chromium

Chromium metal:

Unwrought, powder

Waste and scrap

Other

Number

2610.00 .0020
2610.00 .0040
2610.00 .0060

2819.10 .0000
2819.90 .0000
2841.30 .0000
2841.50 .1000
2841.50 .9100
2849.90 .2000
7202.41 .0000
7202.49 .1000
7202.49 .5010
7202.49 .5090
7202.50 .0000

8112.21 .0000
8112.22 .0000
8112.29 .0000

Depletion Allowance: 22\% (Domestic), 14\% (Foreign).

\section{Normal Trade Relations} 12-31-19

Free.

Free.

Free.

$3.7 \%$ ad val.

$3.7 \%$ ad val.

$2.4 \%$ ad val.

$1.5 \%$ ad val.

$3.1 \%$ ad val.

$4.2 \%$ ad val.

$1.9 \%$ ad val.

$1.9 \%$ ad val.

$3.1 \%$ ad val.

$3.1 \%$ ad val.

$10 \%$ ad val.

$3 \%$ ad val.

Free.

$3 \%$ ad val. 


\section{CHROMIUM}

\section{Government Stockpile: ${ }^{8}$}

\begin{tabular}{lccccc} 
& Inventory & \multicolumn{2}{c}{ FY 2019 } & \multicolumn{2}{c}{ FY 2020 } \\
Material & Potential & Potential & Potential & Potential \\
Ferrochromium: $^{\text {High-carbon }}$ & As of 9-30-19 & Acquisitions & Disposals & Acquisitions & Disposals \\
Low-carbon & 39.6 & - & ${ }^{10} 21.3$ & - & 1021.3 \\
Chromium metal & 27.4 & - & - & - & -181
\end{tabular}

Events, Trends, and Issues: Chromium is consumed in the form of ferrochromium to produce stainless steel. South Africa was the leading chromite ore producer. Increased labor costs, increased costs for electricity, an unreliable supply of electricity, and challenges related to deep level mining, together with the decreasing cost of chromite ore, could affect production in South Africa.

China was the leading chromium-consuming country. China was also the leading stainless-steel- and ferrochromiumproducing country. South Africa was the second-leading country in ferrochromium production. Ferrochromium production is electrical-energy intensive, so constrained electrical power supply and rising costs for electricity in South Africa could also impact ferrochromium production.

From September 2018 to September 2019, high-carbon ferrochromium prices decreased by 43\%. Prices in September 2019 were below the prior low in October 2016.

\section{World Mine Production and Reserves:}

\begin{tabular}{lccc} 
& \multicolumn{2}{c}{$\begin{array}{c}\text { Mine production } \\
\text { U1 }\end{array}$} & $\begin{array}{c}\text { Reserves } \\
\text { (shipping grade) }^{\mathbf{1 3}}\end{array}$ \\
United States & $\underline{\mathbf{2 0 1 8}}$ & $\underline{\mathbf{2 0 1 9}}$ & 620 \\
Finland & 2,210 & 2,200 & 13,000 \\
India & 4,300 & 4,100 & 100,000 \\
Kazakhstan & 6,690 & 6,700 & 230,000 \\
South Africa & 17,600 & 17,000 & 200,000 \\
Turkey & 8,000 & 10,000 & 26,000 \\
Other countries & 4,250 & $\underline{-}, 000$ & $\mathrm{NA}$ \\
$\quad$ World total (rounded) & 43,100 & $\underline{44,000}$ & $\overline{570,000}$
\end{tabular}

World Resources: World resources are greater than 12 billion tons of shipping-grade chromite, sufficient to meet conceivable demand for centuries. The world's chromium resources are heavily geographically concentrated (95\%) in Kazakhstan and southern Africa; United States chromium resources are mostly in the Stillwater Complex in Montana.

Substitutes: Chromium has no substitute in stainless steel, the leading end use, or in superalloys, the major strategic end use. Chromium-containing scrap can substitute for ferrochromium in some metallurgical uses.

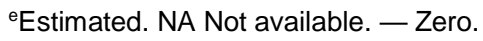

${ }^{1}$ Recycling production is based on reported receipts of all types of stainless steel scrap.

${ }^{2}$ Defined as production (from mines and recycling) + imports - exports + adjustments for Government and industry stock changes.

${ }^{3}$ Excludes ferrochromium silicon.

${ }^{4}$ Defined as imports - exports + adjustments for Government and industry stock changes.

${ }^{5}$ Includes chromium metal scrap and stainless steel scrap.

${ }^{6}$ Includes chromium metal, ferrochromium, and stainless steel.

${ }^{7}$ In addition to the tariff items listed, certain imported chromium materials (see 26 U.S.C. sec. 4661, 4662, and 4672) are subject to excise tax.

${ }^{8}$ See Appendix $B$ for definitions.

${ }^{9}$ Units are thousand tons of material by gross weight.

${ }^{10} \mathrm{High}$-carbon and low-carbon ferrochromium, combined.

${ }^{11}$ Mine production units are thousand tons, gross weight, of marketable chromite ore.

${ }^{12}$ See Appendix $\mathrm{C}$ for resource and reserve definitions and information concerning data sources.

${ }^{13}$ Reserves units are thousand tons of shipping-grade chromite ore, which is deposit quantity and grade normalized to $45 \% \mathrm{Cr}_{2} \mathrm{O}_{3}$, except for the United States where grade is normalized to $7 \% \mathrm{Cr}_{2} \mathrm{O}_{3}$ and Finland where grade is normalized to $26 \% \mathrm{Cr}_{2} \mathrm{O}_{3}$.
} 


\section{CLAYS}

(Data in thousand metric tons unless otherwise noted)

Domestic Production and Use: Production of clays (sold or used) in the United States was estimated to be 26 million tons valued at $\$ 1.8$ billion in 2019 , with about 145 companies operating clay and shale mines in 40 States. The leading 20 firms produced approximately $50 \%$ of the U.S. tonnage and $85 \%$ of the value for all types of clay. Principal uses for specific clays were estimated to be as follows: ball clay- $50 \%$ floor and wall tile and $15 \%$ sanitaryware; bentonite- $52 \%$ pet waste absorbents and 31\% drilling mud; common clay-34\% brick, 29\% lightweight aggregate, and $24 \%$ cement; fire clay- $70 \%$ heavy clay products (for example, brick and cement) and $30 \%$ refractory products and miscellaneous uses; fuller's earth-98\% pet waste absorbents; and kaolin-60\% paper coating and filling, 12\% paint, and 9\% catalysts. Lightweight ceramic proppants for use in hydraulic fracturing are also a significant market for kaolin, but data were insufficient to estimate market size.

Exports of clay and shale were estimated to have increased by $4 \%$ in 2019 after remaining essentially unchanged in 2018. In 2019, the United States exported 820,000 tons of bentonite mainly for pet waste absorbent, drilling mud, foundry sand bond, and iron ore pelletizing applications, with Canada, Japan, and Mexico being the leading destinations. About 2.5 million tons of kaolin were exported mainly as a paper coating and filler; a component in ceramic bodies; and fillers and extenders in paint, plastic, and rubber products, with China, Japan, and Mexico being the leading destinations. Lesser quantities of ball clay, fire clay, and fuller's earth were exported for ceramic, refractory, and absorbent uses, respectively.

\begin{tabular}{|c|c|c|c|c|c|}
\hline $\begin{array}{l}\text { Salient Statistics-United States: } \\
\text { Production (sold or used): }\end{array}$ & $\underline{2015}$ & $\underline{2016}$ & $\underline{2017}$ & $\underline{2018}$ & $\underline{2019^{e}}$ \\
\hline Ball clay & 1,220 & 1,270 & 1,270 & 1,120 & 1,100 \\
\hline Bentonite & 4,080 & 4,000 & 4,430 & 4,670 & 4,700 \\
\hline Common clay & 12,000 & 13,000 & 13,300 & 12,700 & 12,000 \\
\hline Fire clay & 398 & 534 & 575 & 567 & 560 \\
\hline Fuller's earth ${ }^{1}$ & 1,960 & 1,860 & 1,840 & 1,880 & 2,000 \\
\hline Kaolin & 5,810 & 5,290 & 5,560 & 5,530 & 5,500 \\
\hline Total 1,2 & $\overline{25,500}$ & $\overline{26,000}$ & $\overline{27,000}$ & $\overline{26,400}$ & $\overline{26,000}$ \\
\hline \multicolumn{6}{|l|}{ Imports for consumption: } \\
\hline Artificially activated clays and earths & 24 & 26 & 28 & 23 & 16 \\
\hline Kaolin & 426 & 389 & 316 & 330 & 260 \\
\hline Other & 71 & 57 & 86 & 68 & 58 \\
\hline Total $^{2}$ & $\overline{520}$ & $\overline{473}$ & 430 & $\overline{421}$ & $\overline{330}$ \\
\hline \multicolumn{6}{|l|}{ Exports: } \\
\hline Artificially activated clays and earths & 173 & 143 & 147 & 149 & 160 \\
\hline Ball clay & 48 & 41 & 83 & 90 & 93 \\
\hline Bentonite & 938 & 801 & 961 & 845 & 820 \\
\hline Clays, not elsewhere classified & 268 & 256 & 244 & 244 & 290 \\
\hline Fire clay 3 & 217 & 184 & 225 & 250 & 300 \\
\hline Fuller's earth & 77 & 86 & 78 & 70 & 67 \\
\hline Kaolin & $\underline{2,420}$ & $\underline{2,290}$ & $\underline{2,310}$ & $\underline{2,390}$ & $\underline{2,500}$ \\
\hline Total $^{2}$ & $\overline{4,140}$ & $\overline{3,800}$ & $\overline{4,040}$ & $\overline{4,030}$ & $\overline{4,200}$ \\
\hline Consumption, apparent ${ }^{4}$ & 21,800 & 22,600 & 23,400 & 22,800 & 22,000 \\
\hline \multicolumn{6}{|l|}{ Price, ex-works, average, dollars per ton: } \\
\hline Ball clay & 50 & 39 & 49 & 54 & 55 \\
\hline Bentonite & 98 & 99 & 99 & 99 & 100 \\
\hline Common clay & 14 & 14 & 15 & 16 & 17 \\
\hline Fire clay & 13 & 13 & 13 & 12 & 11 \\
\hline Fuller's earth ${ }^{1}$ & 86 & 89 & 93 & 88 & 89 \\
\hline Kaolin & 151 & 157 & 156 & 156 & 158 \\
\hline \multicolumn{6}{|l|}{ Employment (excludes office workers): } \\
\hline Mine (may not include contract workers) & 1,130 & 1,120 & 1,220 & 1,110 & 1,110 \\
\hline Mill & 4,730 & 4,440 & 4,370 & 4,360 & 4,360 \\
\hline $\begin{array}{l}\text { Net import reliance } 5 \text { as a percentage of } \\
\text { apparent consumption }\end{array}$ & $\mathrm{E}$ & $\mathrm{E}$ & $\mathrm{E}$ & $\mathrm{E}$ & $\mathrm{E}$ \\
\hline
\end{tabular}

Recycling: Insignificant.

Import Sources (2015-18): All clay types combined: Brazil, 75\%; China, 7\%; Mexico, 6\%; and other, 12\%. 


\section{CLAYS}

Tariff: Item

Kaolin and other kaolinic clays, whether or not calcined

Bentonite

Fire clay

Common blue clay and other ball clays

Decolorizing earths and fuller's earth

Other clays

Chamotte or dinas earth

Activated clays and activated earths

Expanded clays and other mixtures
Number

2507.00.0000

2508.10.0000

2508.30.0000

2508.40 .0110

2508.40 .0120

2508.40 .0150

2508.70.0000

3802.90 .2000

6806.20 .0000
Normal Trade Relations

12-31-19

Free.

Free.

Free.

Free.

Free.

Free.

Free.

$2.5 \%$ ad val.

Free.

Depletion Allowance: Ball clay, bentonite, fire clay, fuller's earth, and kaolin, 14\% (Domestic and foreign); clay used in the manufacture of common brick, lightweight aggregate, and sewer pipe, $7.5 \%$ (Domestic and foreign); clay used in the manufacture of drain and roofing tile, flower pots, and kindred products, $5 \%$ (Domestic and foreign); clay from which alumina and aluminum compounds are extracted, 22\% (Domestic).

Government Stockpile: None.

Events, Trends, and Issues: Total U.S. sales of clays decreased slightly in 2018 and again in 2019 compared with those of the previous year. Over the past 2 years, other industrial minerals associated with construction activity have been estimated to have increased. Ball clay and common clay experienced decreases during this period and sales of bentonite increased in 2018 and were essentially unchanged in 2019.

World Mine Production and Reserves: ${ }^{6}$ Global reserves are large, but country-specific data are not available.

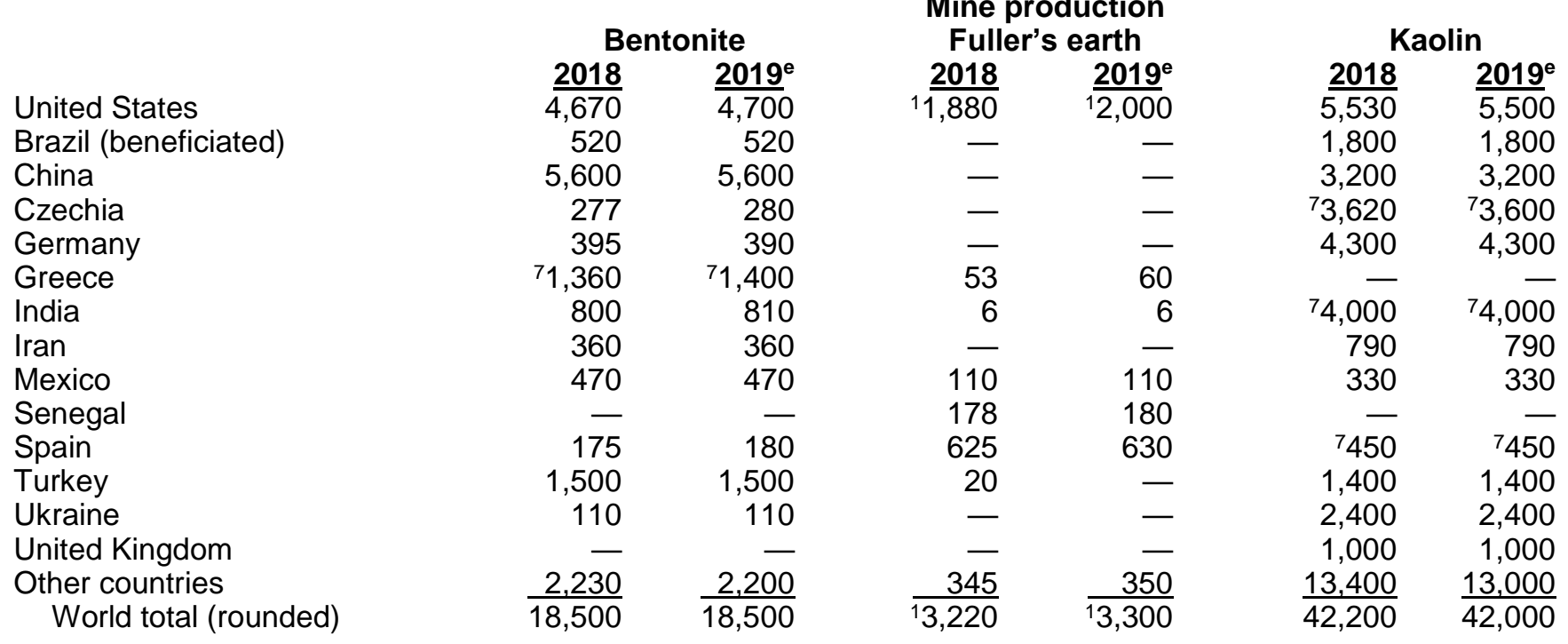

World Resources: Resources of all clays are extremely large.

Substitutes: Clays compete with calcium carbonate in filler and extender applications; diatomite, organic pet litters, polymers, silica gel, and zeolites as absorbents; and various siding and roofing types in building construction.

\footnotetext{
eEstimated. E Net exporter. - Zero.

${ }^{1}$ Does not include U.S. production of attapulgite.

${ }^{2}$ Data may not add to totals shown because of independent rounding

${ }^{3}$ Includes refractory-grade kaolin.

${ }^{4}$ Defined as production (sold or used) + imports - exports.

${ }^{5}$ Defined as imports - exports.

${ }^{6}$ See Appendix $\mathrm{C}$ for resource and reserve definitions and information concerning data sources.

${ }^{7}$ Includes production of crude ore.
} 


\section{COBALT}

(Data in metric tons of cobalt content unless otherwise noted)

Domestic Production and Use: In 2019, the nickel-copper Eagle Mine in Michigan produced cobalt-bearing nickel concentrate. In Missouri, a company built a flotation plant and produced nickel-copper-cobalt concentrate from historic mine tailings. Most U.S. cobalt supply comprised imports and secondary (scrap) materials. Approximately six companies in the United States produced cobalt chemicals. About $46 \%$ of the cobalt consumed in the United States was used in superalloys, mainly in aircraft gas turbine engines; $9 \%$ in cemented carbides for cutting and wearresistant applications; $14 \%$ in various other metallic applications; and 31\% in a variety of chemical applications. The total estimated value of cobalt consumed in 2019 was $\$ 400$ million.

\begin{tabular}{|c|c|c|c|c|c|}
\hline Salient Statistics-United States: & $\underline{2015}$ & 2016 & $\underline{2017}$ & $\underline{2018}$ & $\underline{2019^{\mathrm{e}}}$ \\
\hline \multicolumn{6}{|l|}{ Production: } \\
\hline Mine ${ }^{\mathrm{e}}$ & 760 & 690 & 640 & 490 & 500 \\
\hline Secondary & 2,750 & 2,750 & 2,750 & 2,740 & 2,700 \\
\hline Imports for consumption & 11,400 & 12,800 & 11,900 & 11,800 & 13,600 \\
\hline Exports & 3,830 & 4,160 & 5,710 & 6,960 & 4,000 \\
\hline \multicolumn{6}{|l|}{ Consumption: } \\
\hline Reported (includes secondary) & 8,830 & 9,010 & 9,240 & 9,270 & 9,300 \\
\hline Apparent (includes secondary) ${ }^{1}$ & 10,300 & 11,500 & 8,920 & 7,580 & 12,400 \\
\hline \multicolumn{6}{|l|}{ Price, average, dollars per pound: } \\
\hline U.S. spot, cathode ${ }^{2}$ & 13.44 & 12.01 & 26.97 & 37.43 & 17.00 \\
\hline London Metal Exchange (LME), cash & 12.90 & 11.57 & 25.28 & 32.94 & 15.00 \\
\hline \multicolumn{6}{|l|}{ Stocks, yearend: } \\
\hline Industry ${ }^{3}$ & 1,070 & 969 & 1,020 & 1,040 & 1,000 \\
\hline LME, U.S. warehouse & 165 & 195 & 160 & 130 & 110 \\
\hline $\begin{array}{l}\text { Net import reliance }{ }^{4} \text { as a percentage of } \\
\text { apparent consumption }\end{array}$ & 73 & 76 & 69 & 64 & 78 \\
\hline
\end{tabular}

Recycling: In 2019, cobalt contained in purchased scrap represented an estimated $29 \%$ of cobalt reported consumption.

Import Sources (2015-18): Cobalt contained in metal, oxide, and salts: Norway, 17\%; Japan, 13\%; China, 11\%; Canada, 11\%; and other, $48 \%$.

\section{Tariff: Item}

Cobalt ores and concentrates

Chemical compounds:

Cobalt oxides and hydroxides

Cobalt chlorides

Cobalt sulfates

Cobalt carbonates

Cobalt acetates

Unwrought cobalt, alloys

Unwrought cobalt, other

Cobalt mattes and other intermediate

products; cobalt powders

Cobalt waste and scrap

Wrought cobalt and cobalt articles

\section{Number}

2605.00 .0000

2822.00.0000

2827.39.6000

2833.29.1000

2836.99.1000

2915.29.3000

8105.20 .3000

8105.20 .6000

8105.20 .9000

8105.30 .0000

8105.90 .0000

\section{Normal Trade Relations} 12-31-19

Free.

$0.1 \%$ ad val.

$4.2 \%$ ad val.

$1.4 \%$ ad val.

$4.2 \%$ ad val.

$4.2 \%$ ad val.

$4.4 \%$ ad val.

Free.

Free.

Free.

$3.7 \%$ ad val.

Depletion Allowance: 22\% (Domestic), 14\% (Foreign).

Government Stockpile: ${ }^{5}$ See the Lithium chapter for statistics on lithium-cobalt oxide and lithium-nickel-cobaltaluminum oxide.

Material
Cobalt
Cobalt alloys, gross weight

Inventory

As of 9-30-19

302

3
FY 2019

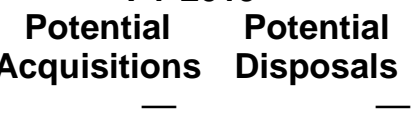

FY 2020

Potential Potential Acquisitions Disposals

Prepared by Kim B. Shedd [(703) 648-4974, kshedd@usgs.gov] 


\section{COBALT}

Events, Trends, and Issues: Congo (Kinshasa) continued to be the world's leading source of mined cobalt, supplying approximately $70 \%$ of world cobalt mine production. With the exception of production in Morocco and artisanally mined cobalt in Congo (Kinshasa), most cobalt is mined as a byproduct of copper or nickel. China was the world's leading producer of refined cobalt, most of which it produced from partially refined cobalt imported from Congo (Kinshasa). China was the world's leading consumer of cobalt, with more than $80 \%$ of its consumption being used by the rechargeable battery industry.

During the first 7 months of 2019, cobalt prices generally trended downward, which analysts attributed to oversupply and consumer destocking and deferral of purchases. In early August, a Switzerland-based producer and marketer of commodities announced that, owing to low cobalt prices, it planned to place its world-leading cobalt mine on careand-maintenance status by yearend 2019. Following the announcement, cobalt prices increased, then stabilized.

World Mine Production and Reserves: Reserves for multiple countries were revised based on industry reports.

\begin{tabular}{lrrr} 
& \multicolumn{2}{c}{ Mine production } & Reserves $^{\mathbf{6}}$ \\
United States & $\mathbf{2 0 1 8}$ & $\underline{\mathbf{2 0 1 9}}$ & \\
Australia & 490 & 500 & 55,000 \\
Canada & 3,520 & 5,100 & $71,200,000$ \\
China & 2,000 & 3,000 & 230,000 \\
Congo (Kinshasa) & 104,000 & 100,000 & 80,000 \\
Cuba & 3,500 & 3,500 & $3,600,000$ \\
Madagascar & 3,300 & 3,300 & 500,000 \\
Morocco & 2,100 & 2,100 & 120,000 \\
New Caledonia & 2,100 & 1,600 & 18,000 \\
Papua New Guinea & 3,280 & 3,100 & 56,000 \\
Philippines & 4,600 & 4,600 & 260,000 \\
Russia & 6,100 & 6,100 & 250,000 \\
South Africa & 2,300 & 2,400 & 50,000 \\
Other countries & 5,540 & 5,700 & 570,000 \\
$\quad$ World total (rounded) & 148,000 & 140,000 & $7,000,000$
\end{tabular}

World Resources: Identified cobalt resources of the United States are estimated to be about 1 million tons. Most of these resources are in Minnesota, but other important occurrences are in Alaska, California, Idaho, Michigan, Missouri, Montana, Oregon, and Pennsylvania. With the exception of resources in Idaho and Missouri, any future cobalt production from these deposits would be as a byproduct of another metal. Identified world terrestrial cobalt resources are about 25 million tons. The vast majority of these resources are in sediment-hosted stratiform copper deposits in Congo (Kinshasa) and Zambia; nickel-bearing laterite deposits in Australia and nearby island countries and Cuba; and magmatic nickel-copper sulfide deposits hosted in mafic and ultramafic rocks in Australia, Canada, Russia, and the United States. More than 120 million tons of cobalt resources have been identified in manganese nodules and crusts on the floor of the Atlantic, Indian, and Pacific Oceans.

Substitutes: Depending on the application, substitution for cobalt could result in a loss in product performance or an increase in cost. The cobalt contents of lithium-ion batteries, the leading global use for cobalt, are expected to be reduced rather than eliminated; nickel contents of lithium-ion batteries will increase as cobalt contents decrease. Potential substitutes in other applications include barium or strontium ferrites, neodymium-iron-boron, or nickel-iron alloys in magnets; cerium, iron, lead, manganese, or vanadium in paints; cobalt-iron-copper or iron-copper in diamond tools; copper-iron-manganese for curing unsaturated polyester resins; iron, iron-cobalt-nickel, nickel, cermets, or ceramics in cutting and wear-resistant materials; nickel-based alloys or ceramics in jet engines; nickel in petroleum catalysts; rhodium in hydroformylation catalysts; and titanium-based alloys in prosthetics.

\footnotetext{
${ }^{e}$ Estimated. - Zero.

${ }^{1}$ Defined as net import reliance + secondary production, as estimated from consumption of purchased scrap.

${ }^{2}$ As reported by Platts Metals Week. Cobalt cathode is refined cobalt metal produced by an electrolytic process.

${ }^{3}$ Stocks held by consumers and processors; excludes stocks held by trading companies and held for investment purposes.

${ }^{4}$ Defined as imports - exports + adjustments for Government and industry stock changes for refined cobalt.

${ }^{5}$ See Appendix B for definitions.

${ }^{6}$ See Appendix $C$ for resource and reserve definitions and information concerning data sources.

${ }^{7}$ For Australia, Joint Ore Reserves Committee-compliant reserves were 310,000 tons.

${ }^{8}$ Overseas territory of France. Although nickel-cobalt mining and processing continued, the leading producer reported zero reserves based on recent nickel prices.
} 


\section{COPPER}

(Data in thousand metric tons of copper content unless otherwise noted)

Domestic Production and Use: In 2019, U.S. mine production of recoverable copper increased by $6 \%$ to an estimated 1.3 million tons and was valued at an estimated $\$ 7.9$ billion, slightly less than $\$ 8.05$ billion in 2018 . Arizona was the leading copper-producing State and accounted for an estimated $68 \%$ of domestic output, followed by, in descending order, Utah, New Mexico, Nevada, Montana, Michigan, and Missouri. Twenty-four mines recovered copper, 15 of which accounted for $99 \%$ of production. Three smelters, 3 electrolytic refineries, 4 fire refineries, and 14 electrowinning facilities operated during 2019. Refined copper and scrap were used at about 30 brass mills, 15 rod mills, and 500 foundries and miscellaneous consumers. Copper and copper alloy products were used in building construction, 43\%; electrical and electronic products, 20\%; transportation equipment, $20 \%$; consumer and general products, $10 \%$; and industrial machinery and equipment, $7 \%{ }^{1}$

\begin{tabular}{|c|c|c|c|c|c|}
\hline $\begin{array}{l}\text { Salient Statistics_-United States: } \\
\text { Production: }\end{array}$ & \multicolumn{4}{|c|}{ Production: } & $\underline{2019}^{\mathrm{e}}$ \\
\hline Mine, recoverable & 1,380 & 1,430 & 1,260 & 1,220 & 1,300 \\
\hline \multicolumn{6}{|l|}{ Refinery: } \\
\hline Primary (from ore) & 1,090 & 1,180 & 1,040 & 1,070 & 1,000 \\
\hline Secondary (from scrap) & 49 & 46 & 40 & 41 & 45 \\
\hline Copper recovered from old (post-consumer) scrap² & 166 & 149 & 146 & 149 & 160 \\
\hline \multicolumn{6}{|l|}{ Imports for consumption: } \\
\hline Ores and concentrates & $\left({ }^{3}\right)$ & $\left({ }^{3}\right)$ & 14 & 32 & \\
\hline Refined & 687 & 708 & 813 & 778 & 650 \\
\hline \multicolumn{6}{|l|}{ Exports: } \\
\hline Ores and concentrates & 392 & 331 & 237 & 253 & \\
\hline Refined & 86 & 134 & 94 & 190 & 140 \\
\hline \multicolumn{6}{|l|}{ Consumption: } \\
\hline Reported, refined metal & 1,810 & 1,800 & 1,800 & 1,820 & 1,850 \\
\hline Apparent (primary refined and old scrap) $)^{2,4}$ & 1,840 & 1,880 & 1,860 & 1,830 & 1,800 \\
\hline \multicolumn{6}{|l|}{ Price, annual average, cents per pound: } \\
\hline U.S. producer, cathode (COMEX + premium) & 256.2 & 224.9 & 285.4 & 298.7 & 280.0 \\
\hline COMEX, high-grade, first position & 250.8 & 219.7 & 280.4 & 292.6 & 270.0 \\
\hline London Metal Exchange, high-grade & 249.5 & 220.6 & 279.5 & 296.0 & 270.0 \\
\hline \multicolumn{6}{|l|}{ Stocks, yearend, refined, held by U.S. } \\
\hline producers, consumers, and metal exchanges & 209 & 223 & 265 & 244 & 130 \\
\hline Employment, mine and plant, thousands & 11.2 & 10.1 & 10.5 & 11.7 & 12.0 \\
\hline $\begin{array}{l}\text { Net import reliance } 5 \text { as a percentage of } \\
\text { apparent consumption }\end{array}$ & 32 & 30 & 36 & 33 & 35 \\
\hline
\end{tabular}

Recycling: Old (post-consumer) scrap, converted to refined metal and alloys, provided an estimated 160,000 tons of copper, equivalent to $9 \%$ of apparent consumption. Purchased new (manufacturing) scrap, derived from fabricating operations, yielded an estimated 710,000 tons of copper. Of the total copper recovered from scrap (including aluminum- and nickel-base scrap), brass and wire-rod mills recovered approximately 80\%; copper smelters, refiners, and ingot makers, 15\%; and miscellaneous chemical plants, foundries, and manufacturers, 5\%. Copper in all scrap contributed about $35 \%$ of the U.S. copper supply. ${ }^{6}$

Import Sources (2015-18): Copper content of blister and anodes: South Africa, 61\%; Finland, 29\%; Malaysia, 8\%; and other, 2\%. Copper content of ores and concentrates: Mexico, 99\%; and other, 1\%. Copper content of scrap: Canada, 55\%; Mexico, 33\%; and other, 12\%. Refined copper: Chile, 56\%; Canada, 26\%; Mexico, 11\%; and other, $7 \%$. Refined copper accounted for $85 \%$ of all unwrought copper imports.

\section{Tariff: Item}

Copper ores and concentrates, copper content Unrefined copper anodes

Refined copper and alloys, unwrought

Copper wire rod
Number

2603.00.0010

7402.00 .0000

7403.00 .0000

7408.11 .0000
Normal Trade Relations 12-31-19

$1.7 \$ / \mathrm{kg}$ on lead content. Free.

$1.0 \%$ ad val.

$1.0 \%$ or $3.0 \%$ ad val.

Depletion Allowance: 15\% (Domestic), 14\% (Foreign).

Government Stockpile: None. 


\section{COPPER}

Events, Trends, and Issues: In 2019, U.S. mine production of copper increased by an estimated 6\% owing to higher ore grades and (or) higher mining and milling rates at several operations. Output from the Mission Mine rose from that in 2018, when production was significantly affected by a landslide early in the year. On October 11 , about $75 \%$ of unionized workers at a company with mines and plants in Arizona and Texas voted to go on strike. The company announced that it would temporarily close its smelter and refinery but did not address the status of its Arizona mines. Non-striking workers may have continued to extract ore at some sites, based on media reports. Production of refined copper in the United States fell by an estimated $7 \%$ as a result of the strike, which had not been resolved as of early December, and maintenance shutdowns at two other smelters. Two projects (Gunnison in Arizona and Pumpkin Hollow in Nevada) planned to begin production by yearend but had not started up as of the end of November.

Estimated global mine production of copper decreased slightly to 20 million tons in 2019 from 20.4 million tons in 2018, owing primarily to reduced output from the Batu Hijau and Grasberg Mines in Indonesia, where mining was shifting to new ore zones. Production also declined in Chile as a result of lower ore grades, strikes, and weatherrelated disruptions. These decreases were partially offset by increased output from multiple other countries. Global refined production increased slightly to an estimated 25 million tons in 2019 from 24.4 million tons in 2018. Higher refinery capacity in China was mostly offset by smelter shutdowns for maintenance and upgrades in other countries. In Zambia, mined and refined copper output were affected by a new import duty on copper concentrates, which lowered smelter production and constrained the supply of sulfuric acid needed to produce electrowon copper.

Through November 2019, the monthly average COMEX spot copper price varied between $\$ 2.56$ per pound (October) and $\$ 2.92$ per pound (April). It was projected to average about $\$ 2.70$ per pound for the full year, a decrease of $8 \%$ from \$2.93 per pound in 2018.

World Mine Production and Reserves: Reserves for multiple countries were revised based on reported company data and (or) information from the Governments of those countries.

\begin{tabular}{|c|c|c|c|}
\hline & Mir & ction & Reserves $^{7}$ \\
\hline & $\underline{2018}$ & $\underline{2019^{\mathrm{e}}}$ & \\
\hline United States & $\overline{1,220}$ & $\overline{1,300}$ & 51,000 \\
\hline Australia & 920 & 960 & 887,000 \\
\hline Chile & 5,830 & 5,600 & 200,000 \\
\hline China & 1,590 & 1,600 & 26,000 \\
\hline Congo (Kinshasa) & 1,230 & 1,300 & 19,000 \\
\hline Indonesia & 651 & 340 & 28,000 \\
\hline Kazakhstan & 603 & 700 & 20,000 \\
\hline Mexico & 751 & 770 & 53,000 \\
\hline Peru & 2,440 & 2,400 & 87,000 \\
\hline Russia & 751 & 750 & 61,000 \\
\hline Zambia & 854 & 790 & 19,000 \\
\hline Other countries & 3,540 & 3,800 & 220,000 \\
\hline World total (rounded) & $\overline{20,400}$ & $\overline{20,000}$ & $\overline{870,000}$ \\
\hline
\end{tabular}

World Resources: A 2014 U.S. Geological Survey assessment of copper deposits indicated that identified resources contained about 2.1 billion tons of copper, and undiscovered resources contained an estimated 3.5 billion tons. ${ }^{9}$

Substitutes: Aluminum substitutes for copper in automobile radiators, cooling and refrigeration tube, electrical equipment, and power cable. Titanium and steel are used in heat exchangers. Optical fiber substitutes for copper in telecommunications applications, and plastics substitute for copper in drain pipe, plumbing fixtures, and water pipe.

\footnotetext{
eEstimated.

${ }^{1}$ Distribution reported by the Copper Development Association. Some electrical components are included in each end use.

${ }^{2}$ Includes copper converted to refined metal and alloys by brass and wire-rod mills, foundries, refineries, and other manufacturers.

${ }^{3}$ Less than $1 / 2$ unit.

${ }^{4}$ Primary refined production + copper in old scrap converted to refined metal and alloys + refined imports - refined exports \pm refined stock changes.

${ }^{5}$ Defined as refined imports - refined exports \pm adjustments for refined copper stock changes.

${ }^{6}$ Primary refined production + copper recovered from old and new scrap + refined imports - refined exports \pm refined stock changes.

${ }^{7}$ See Appendix $\mathrm{C}$ for resource and reserve definitions and information concerning data sources.

${ }^{8}$ For Australia, Joint Ore Reserves Committee-compliant reserves were 23 million tons.

9 Johnson, K.M., Hammarstrom, J.M., Zientek, M.L., and Dicken, C.L., 2014, Estimate of undiscovered copper resources of the world, 2013 : U.S. Geological Survey Fact Sheet 2014-3004, 3 p., https://doi.org/10.3133/fs20143004.
} 


\section{DIAMOND (INDUSTRIAL) ${ }^{1}$}

\section{(Data in million carats unless otherwise noted)}

Domestic Production and Use: In 2019, total domestic primary production of manufactured industrial diamond bort, grit, and dust and powder was estimated to be 190 million carats with a value of $\$ 86$ million. There was no domestic production of stone. One firm in Ohio and one firm in Pennsylvania accounted for all of the production. At least nine firms produced polycrystalline diamond from diamond powder. At least two companies recovered used industrial diamond as one of their principal operations. The major consuming sectors of industrial diamond are computer chip production; construction; drilling for minerals, natural gas, and oil; machinery manufacturing; stone cutting and polishing; and transportation (infrastructure and vehicles). Highway building, milling, and repair and stone cutting consumed most of the industrial diamond stone. About $99 \%$ of U.S. industrial diamond apparent consumption was synthetic industrial diamond because its quality can be controlled and its properties can be customized.

Salient Statistics-United States:

Bort, grit, and dust and powder; natural and synthetic:

Production:

Manufactured diamonde

Secondary

Imports for consumption

Exports

Consumption, apparent ${ }^{2}$

Price, value of imports, dollars per carat

Net import reliance ${ }^{3}$ as a percentage of apparent consumption

Stones, natural and synthetic:

Production:

Manufactured diamonde

Secondary

Imports for consumption

Exports

Sales from Government stockpile excesses

Consumption, apparent ${ }^{2}$

Price, value of imports, dollars per carat

Net import reliance ${ }^{3}$ as a percentage of

apparent consumption

\begin{tabular}{|c|c|c|c|c|}
\hline 2015 & 2016 & 2017 & $\underline{2018}$ & $2019^{\mathrm{e}}$ \\
\hline 40 & 42 & 41 & 184 & 190 \\
\hline 63 & 66 & 11 & 33 & 38 \\
\hline 275 & 216 & 362 & 548 & 350 \\
\hline 140 & 134 & 161 & 159 & 120 \\
\hline 238 & 190 & 253 & 606 & 460 \\
\hline 0.20 & 0.23 & 0.16 & 0.12 & 0.13 \\
\hline 57 & 43 & 79 & 64 & 50 \\
\hline 79 & 83 & 87 & - & - \\
\hline 0.19 & 0.36 & 0.39 & 0.13 & 0.12 \\
\hline 1.31 & 1.37 & 1.23 & 0.95 & 0.84 \\
\hline - & - & - & - & - \\
\hline - & - & - & - & - \\
\hline 80.7 & 84.9 & 89.0 & 1.1 & 1.0 \\
\hline 17.50 & 13.60 & 12.90 & 7.60 & 7.20 \\
\hline 2 & 2 & 1 & 88 & 88 \\
\hline
\end{tabular}

Recycling: In 2019, the amount of diamond bort, grit, and dust and powder recycled was estimated to be 38 million carats with an estimated value of $\$ 790,000$. It was estimated that 120,000 carats of diamond stone was recycled with an estimated value of $\$ 190,000$.

Import Sources (2015-18): Bort, grit, and dust and powder; natural and synthetic: China, 77\%; Ireland, 8\%; Republic of Korea, 5\%; Russia, 4\%; and other, 6\%. Stones, primarily natural: India, 32\%; South Africa, 31\%; Botswana, 17\%; Australia, 9\%; and other, $11 \%$.

\section{Tariff: Item}

Industrial Miners' diamonds, carbonados

Industrial Miners' diamonds, other

Industrial diamonds, simply sawn, cleaved, or bruted

Industrial diamonds, not worked

Grit or dust and powder of natural diamonds,

80 mesh or finer

Grit or dust and powder of natural diamonds, over 80 mesh

Grit or dust and powder of synthetic diamonds, coated with metal

Grit or dust and powder of synthetic diamonds,

not coated with metal, 80 mesh or finer

Grit or dust and powder of synthetic diamonds,

not coated with metal, over 80 mesh
Number

7102.21 .1010

7102.21 .1020

7102.21 .3000

7102.21 .4000

7105.10 .0011

7105.10.0015

7105.10.0020

7105.10.0030

7105.10 .0050
Normal Trade Relations 12-31-19

Free.

Free.

Free.

Free.

Free.

Free.

Free.

Free.

Free. 


\section{DIAMOND (INDUSTRIAL)}

Depletion Allowance: 14\% (Domestic and foreign).

Government Stockpile: None.

Events, Trends, and Issues: In 2019, China was the world's leading producer of synthetic industrial diamond, with annual production exceeding 14.6 billion carats. The United States is likely to continue to be one of the world's leading markets for industrial diamond into the next decade and is expected to remain a significant producer and exporter of synthetic industrial diamond as well. U.S. demand for industrial diamond is likely to be strong in the construction sector as the United States continues building, milling, and repairing the Nation's highway system. Industrial diamond coats the cutting edge of saws used to cut concrete in highway construction and repair work.

In 2018 and 2019, U.S. synthetic-industrial-diamond producers did not manufacture any diamond stone. This resulted in the large decrease in apparent consumption and the large increase in industrial diamond stone import reliance seen in the salient statistics table. Domestic and global demand for synthetic diamond grit and powder is expected to remain greater than that for natural diamond material.

Synthetic diamond production far exceeds natural industrial diamond output. Worldwide production of manufactured industrial diamond totaled at least 14.6 billion carats in 2019; the leading producers included China, France, Ireland, Japan, Russia, South Africa, Sweden, and the United States.

Global rough diamond production decreased by $14 \%$ during the first two quarters of 2019 driven by reductions in Botswana and South Africa. Globally, most natural industrial diamond is produced as a byproduct of mining gemquality diamond.

World Natural Industrial Diamond Mine Production and Reserves: ${ }^{4}$ Reserves for Australia and South Africa were revised based on Government and company information.

\begin{tabular}{lrrr} 
& \multicolumn{2}{c}{ Mine production } & Reserves $^{\mathbf{5}}$ \\
United States & $\mathbf{2 0 1 8}$ & $\mathbf{2 0 1 9}$ & NA \\
Australia & - & - & 640 \\
Botswana & 14 & 13 & 90 \\
Congo (Kinshasa) & 7 & 6 & 150 \\
Russia & 12 & 12 & 650 \\
South Africa & 19 & 19 & 54 \\
Zimbabwe & 2 & 2 & NA \\
Other countries & 3 & 3 & 120 \\
$\quad$ World total (rounded) & 1 & $\underline{1}$ & 1,100
\end{tabular}

World Resources: Natural diamond deposits have been discovered in more than 35 countries. Natural diamond accounts for about $1 \%$ of all industrial diamond used; synthetic diamond accounts for the remainder. At least 15 countries have the technology to produce synthetic diamond.

Substitutes: Materials that can compete with industrial diamond in some applications include manufactured abrasives, such as cubic boron nitride, fused aluminum oxide, and silicon carbide. Globally, synthetic diamond, rather than natural diamond, is used for about $99 \%$ of industrial applications.

\footnotetext{
eEstimated. NA Not available. - Zero.

${ }^{1}$ See Gemstones for information on gem-quality diamond.

${ }^{2}$ Defined as manufactured diamond production + secondary diamond production + imports - exports.

${ }^{3}$ Defined as imports - exports.

${ }^{4}$ Natural industrial diamond only.

${ }^{5}$ See Appendix $C$ for resource and reserve definitions and information concerning data sources.

${ }^{6}$ For Australia, Joint Ore Reserves Committee-compliant reserves were 39 million carats.
} 


\section{DIATOMITE}

(Data in thousand metric tons unless otherwise noted)

Domestic Production and Use: In 2019, production of diatomite was estimated to be 980,000 tons with an estimated processed value of $\$ 330$ million, f.o.b. plant. Six companies produced diatomite at 12 mining areas and 9 processing facilities in California, Nevada, Oregon, and Washington. Approximately $60 \%$ of diatomite is used in filtration products. The remaining $40 \%$ is used in absorbents, fillers, lightweight aggregates, and other applications. A small amount, less than $1 \%$, is used for specialized pharmaceutical and biomedical purposes. The unit value of diatomite varied widely in 2019, from approximately $\$ 10$ per ton when used as a lightweight aggregate in portland cement concrete to more than $\$ 1,000$ per ton for limited specialty markets, including art supplies, cosmetics, and DNA extraction.

\section{Salient Statistics_-United States:}

Production $^{1}$

Imports for consumption

Exports

Consumption, apparent ${ }^{2}$

Price, average value, dollars per ton, f.o.b. plant

Employment, mine and plant, number ${ }^{\mathrm{e}}$

Net import reliance ${ }^{3}$ as a percentage

of apparent consumption

$\begin{array}{rr}\mathbf{2 0 1 5} & \underline{\mathbf{2 0 1 6}} \\ 832 & 686 \\ 7 & 8 \\ 74 & 66 \\ 765 & 628 \\ 290 & 280 \\ 345 & 350\end{array}$

E

2017
768
9
87
690
360
360

E

\begin{tabular}{rr}
$\mathbf{2 0 1 8}$ & $\underline{\mathbf{2 0 1 9}}$ \\
\hline 957 & 980 \\
9 & 10 \\
68 & 72 \\
898 & 920 \\
330 & 340 \\
370 & 370
\end{tabular}

E

Recycling: None.

Import Sources (2015-18): Canada, 75\%; Mexico, 11\%; Germany, 9\%; Japan, 2\%; and other, 3\%.

Tariff: Item

Siliceous fossil meals, including diatomite

Depletion Allowance: 14\% (Domestic and foreign).
Number

2512.00.0000
Normal Trade Relations $\underline{12-31-19}$

Government Stockpile: None.

Events, Trends, and Issues: The amount of domestically produced diatomite sold or used by producers in 2019 increased slightly compared with that of 2018. Apparent domestic consumption increased slightly in 2019 to an estimated 920,000 tons; exports increased by an estimated 6\%. The United States remained the leading global producer and consumer of diatomite. Filtration (including the purification of beer, liquors, and wine and the cleansing of greases and oils) continued to be the leading end use for diatomite, also known as diatomaceous earth. An important application for diatomite is the removal of microbial contaminants, such as bacteria, protozoa, and viruses in public water systems. Other applications for diatomite include filtration of human blood plasma, pharmaceutical processing, and use as a nontoxic insecticide. Domestically, diatomite used in the production of cement was the second-ranked use. 


\section{DIATOMITE}

In 2019, the United States was the leading producer of diatomite, accounting for an estimated $34 \%$ of total world production, followed by Denmark and China with $15 \%$ each, Turkey with $6 \%$, the Republic of Korea with 5\%, Peru with $4 \%$, and Mexico with 3\%. Smaller quantities of diatomite were mined in 23 additional countries.

\section{World Mine Production and Reserves:}

\begin{tabular}{|c|c|c|c|}
\hline \multirow[b]{3}{*}{ United States ${ }^{1}$} & \multicolumn{2}{|c|}{ Mine production } & \multirow{2}{*}{ Reserves $^{4}$} \\
\hline & 2018 & $2019^{e}$ & \\
\hline & 957 & 980 & 250,000 \\
\hline Argentina & 70 & 70 & NA \\
\hline China & 420 & 420 & 110,000 \\
\hline Denmark $^{5}$ (processed) & 440 & 440 & NA \\
\hline France & 75 & 80 & NA \\
\hline Germany & 52 & 50 & NA \\
\hline Japan & 40 & 40 & NA \\
\hline Korea, Republic of & 134 & 130 & NA \\
\hline Mexico & 96 & 100 & NA \\
\hline New Zealand & 40 & 40 & NA \\
\hline Peru & 110 & 110 & NA \\
\hline Russia & 47 & 50 & NA \\
\hline Spain & 50 & 50 & NA \\
\hline Turkey & 170 & 170 & 44,000 \\
\hline Other countries & 143 & 170 & NA \\
\hline World total (rounded) & $\overline{2,840}$ & $\overline{2,900}$ & Large \\
\hline
\end{tabular}

World Resources: Diatomite deposits form from an accumulation of amorphous hydrous silica cell walls of dead diatoms in oceanic and fresh waters. Diatomite is also known as kieselguhr (Germany), tripolite (after an occurrence near Tripoli, Libya), and moler (an impure Danish form). Because U.S. diatomite occurrences are at or near Earth's surface, recovery from most deposits is achieved through low-cost, open pit mining. Outside the United States, however, underground mining is fairly common owing to deposit location and topographic constraints. World resources of crude diatomite are adequate for the foreseeable future.

Substitutes: Many materials can be substituted for diatomite. However, the unique properties of diatomite assure its continued use in many applications. Expanded perlite and silica sand compete for filtration. Filters made from manufactured materials, notably ceramic, polymeric, or carbon membrane filters and filters made with cellulose fibers, are becoming competitive as filter media. Alternate filler materials include clay, ground limestone, ground mica, ground silica sand, perlite, talc, and vermiculite. For thermal insulation, materials such as various clays, exfoliated vermiculite, expanded perlite, mineral wool, and special brick can be used. Transportation costs will continue to determine the maximum economic distance that most forms of diatomite may be shipped and still remain competitive with alternative materials.

\footnotetext{
eEstimated. E Net exporter. NA Not available.

${ }^{1}$ Processed ore sold or used by producers.

${ }^{2}$ Defined as production + imports - exports.

${ }^{3}$ Defined as imports - exports.

${ }^{4}$ See Appendix $\mathrm{C}$ for resource and reserve definitions and information concerning data sources.

${ }^{5}$ Includes sales of moler production.
} 


\section{FELDSPAR AND NEPHELINE SYENITE}

(Data in thousand metric tons unless otherwise noted)

Domestic Production and Use: U.S. feldspar production in 2019 had an estimated value of $\$ 46$ million. The three leading companies mined and processed about $80 \%$ of production; four other companies supplied the remainder. Producing States were North Carolina, California, Oklahoma, Virginia, and Idaho, in descending order of estimated tonnage. Feldspar processors reported joint product recovery of mica and silica sand. Nepheline syenite produced in the United States was not included in production figures because the material was not considered to be marketable as a flux and was mostly used in construction applications.

Feldspar is ground to about 20 mesh for glassmaking and to 200 mesh or finer for most ceramic and filler applications. It was estimated that domestically produced feldspar was transported by ship, rail, or truck to at least 30 States and to foreign destinations, including Canada and Mexico. In pottery and glass, feldspar and nepheline syenite function as a flux. The estimated 2019 end-use distribution of domestic feldspar and nepheline syenite was glass, about $65 \%$, and ceramic tile, pottery, and other uses, $35 \%$.

\begin{tabular}{|c|c|c|c|c|c|}
\hline Salient Statistics-United States: & $\underline{2015}$ & $\underline{2016}$ & $\underline{2017}$ & $\underline{2018}$ & $\frac{2019^{\mathrm{e}}}{470}$ \\
\hline$\overline{\text { Production, marketable }^{1}}$ & $\overline{520}$ & $\overline{470}$ & $\overline{440}$ & $\overline{550}$ & \\
\hline \multicolumn{6}{|l|}{ Imports for consumption: } \\
\hline Feldspar & 120 & 37 & 290 & 181 & \\
\hline Nepheline syenite & 449 & 572 & 1,460 & 1,070 & 50 \\
\hline Exports, feldspar & 15 & 6 & 5 & 4 & \\
\hline \multicolumn{6}{|l|}{ Consumption, apparent ${ }^{1,2}$} \\
\hline Feldspar only & 630 & 510 & 730 & 720 & \\
\hline Feldspar and nepheline syenite & 1,100 & 1,100 & 2,200 & 1,800 & 1,00 \\
\hline \multicolumn{6}{|l|}{ Price, average value, dollars per ton: } \\
\hline Feldspar only, marketable production & 71 & 69 & 64 & 97 & \\
\hline Nepheline syenite, import value & 150 & 128 & 61 & 76 & \\
\hline $\begin{array}{l}\text { Employment, mine, preparation plant, } \\
\text { and office, numbere }\end{array}$ & 270 & 250 & 240 & 240 & \\
\hline \multicolumn{6}{|l|}{$\begin{array}{l}\text { Net import reliance } 3 \text { as a percentage } \\
\text { of apparent consumption: }\end{array}$} \\
\hline Feldspar & 17 & 6 & 39 & 24 & \\
\hline Nepheline syenite & 100 & 100 & 100 & 100 & \\
\hline
\end{tabular}

Recycling: Feldspar and nepheline syenite are not recycled by producers; however, glass container producers use cullet (recycled container glass), thereby reducing feldspar and nepheline syenite consumption.

Import Sources (2015-18): Feldspar: Turkey, 98\%; and other, 2\%. Nepheline syenite: Canada, 100\%.

Tariff: Item

Number

Feldspar

Nepheline syenite
2529.10.0000

2529.30.0010

\author{
Normal Trade Relations \\ 12-31-19 \\ Free. \\ Free.
}

Depletion Allowance: 14\% (Domestic and foreign).

Government Stockpile: None.

Events, Trends, and Issues: In 2019, domestic production and sales of feldspar decreased by almost $15 \%$ and the average unit value of sales was virtually unchanged from that of 2018. Imports of feldspar and nepheline syenite decreased substantially in 2019 and appear to have returned to the levels of imports prior to the unusually high level of 2017. A company based in Canada continued development of a feldspar-quartz-kaolin project in Idaho that contained high-grade potassium feldspar. In March 2019, the company amended project development plans to open a smaller than initially planned operation, with production expected to be about 30,000 tons per year of potassium feldspar during a 25-year mine life. For several years, the operation has produced a low-iron and trace-element feldspathic sand product from old mine tailings, which was sold to ceramic tile producers. 


\section{FELDSPAR AND NEPHELINE SYENITE}

Domestic feldspar consumption has been gradually shifting toward glass from ceramics. A growing segment in the glass industry was solar glass, used in the production of solar panels. Glass, including beverage containers (more than one-half of the feldspar consumed by the glass industry), plate glass, and fiberglass insulation for housing and building construction, continued to be the leading end use of feldspar in the United States.

In the United States, residential construction, in which feldspar is a raw material commonly used in the manufacture of plate glass, ceramic tiles and sanitaryware, and insulation, slowed down during the first 9 months of 2019 compared with the same period in 2018.

A company based in Canada continued development of its White Mountain high-purity calcium feldspar (anorthosite) deposit in southwestern Greenland; the construction of all necessary facilities was finished in 2018. Upon completion of the electrical components and the road to the port facility, the company began shipping products to customers in August 2019. Owing to the feldspar's purity and tests, which indicate an alumina recovery of greater than $90 \%$, the company is targeting its product as a replacement for bauxite as a primary source of alumina. In addition, this highpurity calcium feldspar is targeted to compete with kaolin in the production of electrical-grade glass (E-glass) fiberglass and kaolin and premium nepheline syenite in the filler market for paint and clear-coating formulations and polymers.

World Mine Production and Reserves: ${ }^{4}$ Reserves data for Thailand were revised based on Government information.

\begin{tabular}{lrrr} 
& \multicolumn{2}{c}{ Mine production } & Reserves $^{\mathbf{5}}$ \\
United States & $\mathbf{2 0 1 8}$ & $\mathbf{2 0 1 9}$ & NA \\
Brazil (beneficiated marketable) & 550 & 470 & 150,000 \\
China & 400 & 400 & NA \\
Czechia & 2,000 & 2,000 & 23,000 \\
Egypt & 449 & 460 & $1,000,000$ \\
India & 400 & 400 & 320,000 \\
Iran & 4,000 & 4,000 & 630,000 \\
Italy & 750 & 750 & NA \\
Korea, Republic of & 4,000 & 4,000 & 240,000 \\
Malaysia & 617 & 650 & NA \\
Spain (includes pegmatites) & 420 & 420 & NA \\
Thailand & 600 & 600 & 235,000 \\
Turkey & 1,500 & 1,600 & 240,000 \\
Other countries & 7,500 & 7,500 & NA \\
$\quad$ World total (rounded) & 2,380 & 2,400 & Large
\end{tabular}

World Resources: Identified and undiscovered resources of feldspar are more than adequate to meet anticipated world demand. Quantitative data on resources of feldspar existing in feldspathic sands, granites, and pegmatites generally have not been compiled. Ample geologic evidence indicates that resources are large, although not always conveniently accessible to the principal centers of consumption.

Substitutes: Imported nepheline syenite was the major alternative material for feldspar. Feldspar can be replaced in some of its end uses by clays, electric furnace slag, feldspar-silica mixtures, pyrophyllite, spodumene, or talc.

\footnotetext{
eEstimated. NA Not available.

${ }^{1}$ Rounded to two significant digits to avoid disclosing company proprietary data.

${ }^{2}$ Defined as production + imports - exports.

${ }^{3}$ Defined as imports - exports.

${ }^{4}$ Feldspar only.

${ }^{5}$ See Appendix $\mathrm{C}$ for resource and reserve definitions and information concerning data sources.
} 


\section{FLUORSPAR}

(Data in thousand metric tons unless otherwise noted)

Domestic Production and Use: In 2019, minimal fluorspar (calcium fluoride, $\mathrm{CaF}_{2}$ ) was produced in the United States. One company sold fluorspar from stockpiles produced as a byproduct of its limestone quarrying operation in Cave-in-Rock, IL. Synthetic fluorspar may have been recovered as a byproduct of petroleum alkylation, stainless steel pickling, or uranium processing, but no data were collected from any of these operations. An estimated 17,000 tons of fluorosilicic acid (FSA), equivalent to about 27,000 tons of fluorspar grading $100 \%$, was recovered from four phosphoric acid plants processing phosphate rock. Fluorosilicic acid was used primarily in water fluoridation.

U.S. fluorspar consumption was satisfied by imports and small quantities of byproduct synthetic fluorspar. Domestically, production of hydrofluoric acid (HF) in Louisiana and Texas was by far the leading use for acid-grade fluorspar. Hydrofluoric acid is the primary feedstock for the manufacture of virtually all fluorine-bearing chemicals, particularly refrigerants and fluoropolymers, and is also a key ingredient in the processing of aluminum and uranium. Fluorspar was also used in cement production, in enamels, as a flux in steelmaking, in glass manufacture, in iron and steel casting, and in welding rod coatings.

\begin{tabular}{|c|c|c|c|c|c|}
\hline $\begin{array}{l}\text { Salient Statistics_-United States: } \\
\text { Production: }\end{array}$ & $\underline{2015}$ & $\underline{2016}$ & $\underline{2017}$ & $\underline{2018}$ & $\underline{2019^{\mathrm{e}}}$ \\
\hline Finished, metalluraical arade & NA & NA & NA & NA & NA \\
\hline Fluorspar equivalent from phosphate rock & 105 & 72 & 64 & 27 & 27 \\
\hline \multicolumn{6}{|l|}{ Imports for consumption: } \\
\hline Acid grade & 328 & 328 & 331 & 381 & 370 \\
\hline Metallurgical grade & 48 & 55 & 70 & 78 & 70 \\
\hline Total fluorspar imports & 376 & 383 & 401 & 459 & 440 \\
\hline Hydrofluoric acid & 120 & 126 & 123 & 122 & 130 \\
\hline Aluminum fluoride & 32 & 20 & 21 & 26 & 9 \\
\hline Cryolite & 19 & 16 & 10 & 17 & 22 \\
\hline Exports, all grades & 14 & 12 & 11 & 9 & \\
\hline \multicolumn{6}{|l|}{ Consumption } \\
\hline Apparent 1 & 362 & 371 & 390 & 450 & 430 \\
\hline Reported & W & W & W & W & W \\
\hline \multicolumn{6}{|l|}{ Price, average value of imports } \\
\hline Cost, insurance, and freight, dollars per ton & & & & & \\
\hline Acid grade & 289 & 273 & 267 & 276 & 30 \\
\hline Metallurgical grade & 249 & 233 & 237 & 258 & 270 \\
\hline Stocks, yearend, consumer and dealer ${ }^{2}$ & e150 & e150 & NA & NA & \\
\hline Employment, mine, numbere & 5 & 4 & 4 & 3 & \\
\hline $\begin{array}{l}\text { Net import reliance }{ }^{3} \text { as a percentage of } \\
\text { apparent consumption }\end{array}$ & 100 & 100 & 100 & 100 & 100 \\
\hline
\end{tabular}

Recycling: Synthetic fluorspar may be produced from neutralization of waste in the enrichment of uranium, petroleum alkylation, and stainless steel pickling; however, undesirable impurities constrain use. Primary aluminum producers recycle HF and fluorides from smelting operations.

Import Sources (2015-18): Mexico, 66\%; Vietnam, 13\%; South Africa, 8\%; China, 6\%; and other, 7\%.

Tariff: Item

Metallurgical grade (less than $97 \% \mathrm{CaF}_{2}$ )

Acid grade (97\% or more $\mathrm{CaF}_{2}$ )

Natural cryolite

Hydrogen fluoride (hydrofluoric acid)

Aluminum fluoride

Synthetic cryolite
Number

2529.21.0000

2529.22.0000

2530.90.1000

2811.11.0000

2826.12.0000

2826.30.0000
Normal Trade Relations

12-31-19

Free.

Free.

Free.

Free.

Free.

Free.

Depletion Allowance: 22\% (Domestic), 14\% (Foreign).

Government Stockpile: None. 


\section{FLUORSPAR}

Events, Trends, and Issues: In recent years, several of the world's leading mines have been operating at or near full capacity. Further, there have been increasing concerns about the possibility of China becoming a net fluorspar importer owing to increased environmental regulation of its mining industry. Although there is little reliable information on China's fluorspar production, China's reported imports of fluorspar increased by approximately 350,000 tons from 2017 to 2018, and by an estimated 100,000 tons in 2019; imports were primarily from Mongolia and new production in Burma. New producers in Canada, Morocco, and South Africa were also ramping up production in 2019.

A hydrofluoroolefin (HFO) plant in Corpus Christi, TX, went into operation in February. HFO manufacturers continued to introduce HFOs and blends as low global-warming-potential alternatives to hydrofluorocarbon-based foam-blowing agents, propellants, and refrigerants, which are subject to increased restrictions under the Montreal Protocol.

Because refrigerant gases are a leading downstream use of HF, the HFO plant, along with a similar plant in Baton Rouge, LA, that went into operation in 2017, were expected to support strong demand for fluorspar in the United States.

World Mine Production and Reserves: Reserves for Brazil and Spain were revised based on updated data from Government sources, and reserves for Morocco were revised based on company-reported information.

\begin{tabular}{lrrr} 
& \multicolumn{2}{c}{ Mine production } & Reserves $^{\mathbf{4}, \mathbf{5}}$ \\
& $\underline{\mathbf{2 0 1 8}}$ & $\underline{\mathbf{2 0 1 9}}$ & \\
United States & $\mathrm{NA}$ & 14 & 4,000 \\
Argentina & 14 & 14 & $\mathrm{NA}$ \\
Brazil & 26 & 18 & $\mathrm{~N}$ \\
Burma & 70 & 44 & $\mathrm{NA}$ \\
Canada & 20 & 110 & $\mathrm{NA}$ \\
China & 4,000 & 4,000 & $\mathrm{NA}$ \\
Germany & 45 & 45 & 3,400 \\
Iran & 70 & 55 & 68,000 \\
Mexico & 1,080 & 1,200 & 22,000 \\
Mongolia & 605 & 670 & 320 \\
Morocco & 65 & 100 & 41,000 \\
South Africa & 242 & 240 & 10,000 \\
Spain & 145 & 140 & 3,600 \\
Thailand & 48 & 50 & 4,000 \\
United Kingdom & 11 & 21 & 5,000 \\
Vietnam & 239 & 240 & 110,000 \\
Other countries & 40 & 41 & 310,000
\end{tabular}

World Resources: Enormous quantities of fluorine are present in phosphate rock. Current U.S. reserves of phosphate rock are estimated to be 1 billion tons, containing about 72 million tons of $100 \%$ fluorspar equivalent assuming an average fluorine content of $3.5 \%$ in the phosphate rock. World reserves of phosphate rock are estimated to be 70 billion tons, equivalent to about 5 billion tons of $100 \%$ fluorspar equivalent.

Substitutes: Fluorosilicic acid is used to produce aluminum fluoride $\left(\mathrm{AlF}_{3}\right)$, but because of differing physical properties, $\mathrm{AlF}_{3}$ produced from FSA is not readily substituted for $\mathrm{AlF}_{3}$ produced from fluorspar. Fluorosilicic acid has been used to produce HF, but this practice has not been widely adopted. Synthetic fluorspar could potentially be recovered by the Department of Energy's two depleted uranium hexafluoride conversion plants in Paducah, KY, and Portsmouth, $\mathrm{OH}$. However, the preferred product is currently aqueous HF rather than fluorspar. Aluminum smelting dross, borax, calcium chloride, iron oxides, manganese ore, silica sand, and titanium dioxide have been used as substitutes for fluorspar fluxes.

\footnotetext{
eEstimated. NA Not available. W Withheld to avoid disclosing company proprietary data.

${ }^{1}$ Defined as total fluorspar imports - exports.

${ }^{2}$ Industry stocks for leading consumers and fluorspar distributors.

${ }^{3}$ Defined as imports - exports.

${ }^{4}$ See Appendix $\mathrm{C}$ for resource and reserve definitions and information concerning data sources.

${ }^{5}$ Measured as $100 \%$ calcium fluoride.
} 


\section{GALLIUM}

(Data in kilograms of gallium content unless otherwise noted)

Domestic Production and Use: No domestic primary (low-grade, unrefined) gallium has been recovered since 1987. Globally, primary gallium is recovered as a byproduct of processing bauxite and zinc ores. One company in Utah recovered and refined high-purity gallium from imported low-grade primary gallium metal and new scrap. Imports of gallium metal and gallium arsenide (GaAs) wafers were valued at about $\$ 700,000$ and $\$ 170$ million, respectively. GaAs was used to manufacture integrated circuits (ICs) and optoelectronic devices, which include laser diodes, lightemitting diodes (LEDs), photodetectors, and solar cells. Gallium nitride (GaN) principally was used to manufacture optoelectronic devices. ICs accounted for $73 \%$ of domestic gallium consumption, optoelectronic devices accounted for $25 \%$, and research and development accounted for $2 \%$. About $81 \%$ of the gallium consumed in the United States was contained in GaAs, GaN, and gallium phosphide (GaP) wafers. Gallium metal, triethyl gallium, and trimethyl gallium, used in the epitaxial layering process to fabricate epiwafers for the production of LEDs and ICs, accounted for most of the remainder. Optoelectronic devices were used in aerospace applications, consumer goods, industrial equipment, medical equipment, and telecommunications equipment. Uses of ICs included defense applications, highperformance computers, and telecommunications equipment.

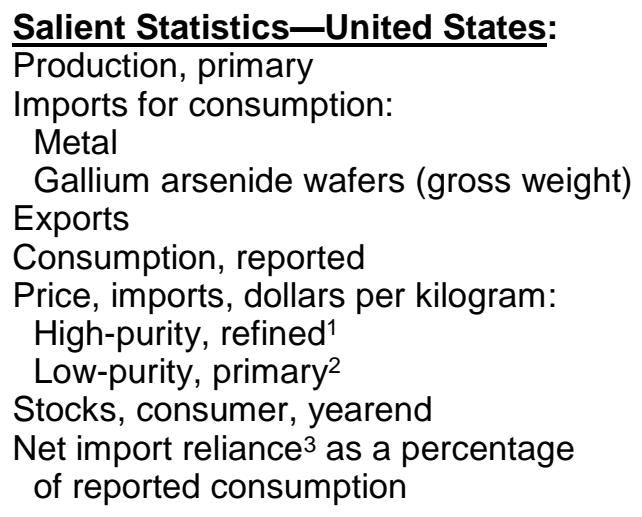

$\begin{array}{rrrrr}\frac{\mathbf{2 0 1 5}}{-} & \underline{\mathbf{2 0 1 6}} & \underline{\mathbf{2 0 1 7}} & \underline{\mathbf{2 0 1 8}} & \frac{\mathbf{2 0 1 9}}{-} \\ 28,600 & 10,500 & 20,200 & 32,000 & 3,000 \\ 2,690,000 & 1,290,000 & 804,000 & 446,000 & 340,000 \\ \text { NA } & \text { NA } & \text { NA } & \text { NA } & \text { NA } \\ 29,700 & 18,100 & 17,900 & 15,000 & 15,000 \\ & & & & \\ 317 & 690 & 477 & 508 & 570 \\ 188 & 125 & 124 & 185 & 150 \\ 3,280 & 2,720 & 2,840 & 2,920 & 1,920 \\ 100 & 100 & 100 & 100 & 100\end{array}$

Recycling: Old scrap, none. Substantial quantities of new scrap generated in the manufacture of GaAs-based devices were reprocessed to recover high-purity gallium at one facility in Utah.

Import Sources (2015-18): Metal: China 4 , 50\%; United Kingdom, 18\%; Germany, 10\%; Ukraine, 9\%; and other, $13 \%$.

\section{Tariff: Item}

Gallium arsenide wafers, doped

Gallium metal

\section{Number}

3818.00.0010

8112.92.1000

\author{
Normal Trade Relations \\ 12-31-19 \\ Free. \\ $3.0 \%$ ad val.
}

Depletion Allowance: 14\% (Domestic and foreign).

Government Stockpile: None.

Events, Trends, and Issues: Imports of gallium metal and GaAs wafers continued to account for all U.S. consumption of gallium. In 2019, gallium metal imports decreased by about $90 \%$ from those of 2018 , most likely owing to the introduction of higher import tariffs on gallium from China and the $300 \%$ increase of gallium imports from China in 2018 before the tariffs were introduced. Gallium stockpiling in 2018 may have been prompted by the discussion of China's potential tariffs.

Primary low-grade (99.99\%-pure) gallium prices in China decreased by about $7 \%$ in 2019. Low-grade gallium prices worldwide continued to decline as China's primary low-grade gallium production continued to exceed worldwide consumption despite reduced production. The average monthly price for low-grade gallium in China decreased to $\$ 145$ per kilogram throughout 2019 from approximately $\$ 155$ per kilogram at yearend 2018. China's primary lowgrade gallium production capacity has expanded to approximately 600 tons per year since 2016 from 140 tons per year in 2010 . China accounted for more than $80 \%$ of worldwide low-grade gallium capacity. 


\section{GALLIUM}

Low-grade primary gallium producers outside of China most likely restricted output owing to a large surplus of primary gallium. These producers included Japan, the Republic of Korea, Russia, and Ukraine. Germany and Kazakhstan ceased primary production in 2016 and 2013, respectively.

Primary high-purity refined gallium production in 2019 was estimated to be about 205 tons. China, Japan, Slovakia, and the United States were the known principal producers of high-purity refined gallium. The United Kingdom ceased high-purity gallium production in 2018. Gallium was recovered from new scrap in Canada, China, Germany, Japan, Slovakia, and the United States. World primary low-grade gallium production capacity in 2019 was estimated to be 720 tons per year; high-purity refinery capacity, 330 tons per year; and secondary capacity, 270 tons per year.

In 2018, the value of worldwide radio frequency (RF) GaAs device consumption increased slightly to $\$ 8.9$ billion owing to a growing wireless telecommunications infrastructure in Asia; growth of third- and fourth-generation (3G and 4G) "smartphones," which employ up to 10 times the amount of GaAs in standard cellular handsets; and robust use in military radar and communications applications. Global GaAs wafer consumption by volume increased by $17 \%$ in 2019, with an estimated $50 \%$ and $40 \%$ of wafers used in LED and RF applications, respectively. Countries within the Asia and the Pacific region dominated the GaAs wafer market. Owing to their large power-handling capabilities, highswitching frequencies, and higher voltage capabilities, GaN-based products, which historically have been used in defense applications, continued to be used in cable television transmission, commercial wireless infrastructure, power electronics, and satellite markets. The GaN RF device market was estimated to be $\$ 750$ million in 2019 , an increase of $15 \%$ from the revised $\$ 650$ million in 2018.

The global high-power LED market was estimated to be $\$ 13.3$ billion in 2019, an increase of 5.3\% from that in 2018. LED manufacturing capacity in Asia increased significantly in 2018 and 2019 owing to China's Government-instituted incentives to increase LED production. China's increased LED production outpaced worldwide consumption and LED prices declined.

\section{World Production and Reserves:}

United States

China

Japan

Korea, Republic of

Russia

Ukraine

World total (rounded)

\begin{tabular}{cr}
\multicolumn{2}{c}{ Primary production } \\
$\frac{\mathbf{2 0 1 8}}{-}$ & $\underline{\mathbf{2 0 1 9}}$ \\
397,000 & 310,000 \\
3,000 & 3,000 \\
3,000 & 3,000 \\
6,000 & 4,000 \\
4,000 & 4,000 \\
\hline 413,000 & 320,000
\end{tabular}

\begin{abstract}
Reserves $^{5}$
Quantitative estimates of reserves are not available.
\end{abstract}

World Resources: Gallium occurs in very small concentrations in ores of other metals. Most gallium is produced as a byproduct of processing bauxite and the remainder is produced from zinc-processing residues. The average gallium content of bauxite is 50 parts per million. U.S. bauxite deposits consist mainly of subeconomic resources that are not generally suitable for alumina production owing to their high silica content. Some domestic zinc ores contain up to 50 parts per million gallium and could be a significant resource, although no gallium is currently recovered from domestic ores. Gallium contained in world resources of bauxite is estimated to exceed 1 million tons, and a considerable quantity could be contained in world zinc resources. However, less than $10 \%$ of the gallium in bauxite and zinc resources is potentially recoverable.

Substitutes: Liquid crystals made from organic compounds are used in visual displays as substitutes for LEDs. Silicon-based complementary metal-oxide semiconductor power amplifiers compete with GaAs power amplifiers in midtier 3G cellular handsets. Indium phosphide components can be substituted for GaAs-based infrared laser diodes in some specific-wavelength applications, and helium-neon lasers compete with GaAs in visible laser diode applications. Silicon is the principal competitor with GaAs in solar-cell applications. GaAs-based ICs are used in many defense-related applications because of their unique properties, and no effective substitutes exist for GaAs in these applications. GaAs in heterojunction bipolar transistors is being replaced in some applications by silicon-germanium.

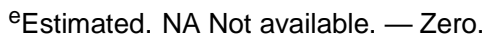

${ }^{1}$ Estimated based on the average values of U.S. imports for $99.9999 \%$ - and $99.99999 \%$-pure gallium.

${ }^{2}$ Estimated based on the average values of U.S. imports for $99.99 \%$-pure gallium.

${ }^{3}$ Defined as imports - exports. Excludes gallium arsenide wafers.

${ }^{4}$ Includes Hong Kong.

${ }^{5}$ See Appendix $\mathrm{C}$ for resource and reserve definitions and information concerning data sources.
} 


\section{GARNET (INDUSTRIAL) ${ }^{1}$}

(Data in metric tons of garnet unless otherwise noted)

Domestic Production and Use: In 2019, garnet for industrial use was mined by four firms-one in Idaho, one in Montana, and two in New York. One processing facility operated in Pennsylvania and another opened in Oregon in June. The estimated value of crude garnet production was about \$21 million, and refined material sold or used had an estimated value of $\$ 62$ million. The major end uses of garnet were, in descending percentage of consumption, for abrasive blasting, water-filtration media, water-jet-assisted cutting, and other end uses, such as in abrasive powders, nonslip coatings, and sandpaper. Domestic industries that consume garnet include aircraft and motor vehicle manufacturers, ceramics and glass producers, electronic component manufacturers, filtration plants, glass polishing, the petroleum industry, shipbuilders, textile stonewashing, and wood-furniture-finishing operations.

\begin{tabular}{|c|c|c|c|c|c|}
\hline Salient Statistics-United States: & $\underline{2015}$ & 2016 & 2017 & $\underline{2018}$ & $\frac{2019^{e}}{93.000}$ \\
\hline$\overline{\text { Production (crude) }}$ & $7 \overline{7,200}$ & $8 \overline{1,300}$ & $9 \overline{2,900}$ & $10 \overline{1,000}$ & $9 \overline{3,000}$ \\
\hline Production (refined, sold or used) & 47,200 & 46,600 & 84,100 & 166,000 & 140,000 \\
\hline Imports for consumption ${ }^{e, 2}$ & 212,000 & 156,000 & 54,200 & 254,000 & 180,000 \\
\hline Exports $^{e}$ & 11,000 & 10,100 & 17,700 & 14,200 & 12,000 \\
\hline Consumption, apparent $\mathrm{e}^{\mathrm{e}, 3}$ & 278,000 & 227,000 & 129,000 & 341,000 & 260,000 \\
\hline Price, average value, dollars per ton, import & 230 & 200 & 300 & 210 & 250 \\
\hline Stocks, yearend & NA & NA & NA & NA & NA \\
\hline Employment, mine and mill, numbere & 110 & 110 & 140 & 170 & 160 \\
\hline $\begin{array}{l}\text { Net import reliance } 4 \text { as a percentage } \\
\text { of apparent consumption }\end{array}$ & 72 & 64 & 28 & 70 & \\
\hline
\end{tabular}

Recycling: Garnet was recycled in Pennsylvania at a plant with a recycling capacity of 25,000 tons per year and at a new plant in Oregon, with a recycling capacity of 16,000 tons per year, that opened in June 2019. Garnet can be recycled multiple times without degradation of its quality. Most recycled garnet is from blast cleaning and water-jetassisted cutting operations.

Import Sources (2015-18): ${ }^{\text {e }}$ Australia, 30\%; India, 30\%; South Africa, 26\%; China, 10\%; and other, 4\%.

Tariff: Item

Emery, natural corundum, natural garnet,

and other natural abrasives, crude

Emery, natural corundum, natural

garnet, and other natural abrasives,

other than crude
Number

2513.20.1000

2513.20.9000

\section{Normal Trade Relations 12-31-19}

Free.

Free.

Depletion Allowance: 14\% (Domestic and foreign).

Government Stockpile: None.

Events, Trends, and Issues: During 2019, estimated domestic production of crude garnet concentrates decreased by $8 \%$ compared with production in 2018 . U.S. garnet production was estimated to be about $8 \%$ of total global garnet production. The 2019 estimated domestic sales or use of refined garnet decreased by $12 \%$ compared with sales in 2018. This decrease was thought to have taken place because of high quantities of industry stocks of garnet and decreased crude garnet production and imports into the United States. 


\section{GARNET (INDUSTRIAL)}

Garnet imports in 2019 were estimated to have decreased by $29 \%$ compared with those in 2018 . Most of the decrease was attributed to a lack of imports of garnet from South Africa, owing to the Pennsylvania processing facility reaching its storage capacity. Imports from India remained steady and continued to recover from previous export restrictions. Imports from China increased and somewhat offset the decrease from South Africa. In 2019, the average unit value of garnet imports was $\$ 250$ per ton, an increase of $19 \%$ compared with the average unit value in 2018 . In the United States, most domestically produced crude garnet concentrate was priced at about \$230 per ton. U.S. exports in 2019 were estimated to have decreased by $15 \%$.

The United States consumed about $22 \%$ of global garnet production and world production of garnet decreased by $4 \%$ in 2019. Garnet production increased in Australia and China; garnet production decreased in India and South Africa.

The garnet market is very competitive. To increase profitability and remain competitive with imported material, production may be restricted to only high-grade garnet ores or as a byproduct of other salable mineral products that occur with garnet, such as kyanite, marble, metallic ores, mica minerals, sillimanite, staurolite, or wollastonite.

World Mine Production and Reserves: Data for China were revised based on a new data source, which nearly tripled estimated production compared with previously published data.

\begin{tabular}{lrrr} 
& \multicolumn{2}{c}{ Mine production } & Reserves $^{\mathbf{5}}$ \\
United States & $\mathbf{2 0 1 8}$ & $\underline{\mathbf{2 0 1 9}}$ & \\
Australia & 101,000 & 93,000 & $5,000,000$ \\
China & 360,000 & 400,000 & Moderate to Large \\
India & 290,000 & 310,000 & Moderate to Large \\
South Africa & 162,000 & 150,000 & $13,000,000$ \\
Other countries & 278,000 & 190,000 & NA \\
$\quad$ World total (rounded) & 60,000 & 60,000 & $6,500,000$ \\
\cline { 2 - 3 }
\end{tabular}

World Resources: World resources of garnet are large and occur in a wide variety of rocks, particularly gneisses and schists. Garnet also occurs in contact-metamorphic deposits in crystalline limestones, pegmatites, serpentinites, and vein deposits. In addition, alluvial garnet is present in many heavy-mineral sand and gravel deposits throughout the world. Large domestic resources of garnet also are concentrated in coarsely crystalline gneiss near North Creek, NY; other significant domestic resources of garnet occur in Idaho, Maine, Montana, New Hampshire, North Carolina, and Oregon. In addition to those in the United States, major garnet deposits exist in Australia, Canada, China, India, and South Africa, where they are mined for foreign and domestic markets; deposits in Russia and Turkey also have been mined in recent years, primarily for internal markets. Additional garnet resources are in Chile, Czechia, Pakistan, Spain, Thailand, and Ukraine; small mining operations have been reported in most of these countries.

Substitutes: Other natural and manufactured abrasives can substitute to some extent for all major end uses of garnet. In many cases, however, using the substitutes would entail sacrifices in quality or cost. Fused aluminum oxide and staurolite compete with garnet as a sandblasting material. Ilmenite, magnetite, and plastics compete as filtration media. Corundum, diamond, and fused aluminum oxide compete for lens grinding and for many lapping operations. Emery is a substitute in nonskid surfaces. Fused aluminum oxide, quartz sand, and silicon carbide compete for the finishing of plastics, wood furniture, and other products.

\footnotetext{
${ }^{e}$ Estimated. NA Not available.

${ }^{1}$ Excludes gem and synthetic garnet.

${ }^{2}$ Source: U.S. Census Bureau and Trade Mining, LLC; adjusted by U.S. Geological Survey.

${ }^{3}$ Defined as crude production + imports - exports.

${ }^{4}$ Defined as imports - exports.

${ }^{5}$ See Appendix $\mathrm{C}$ for resource and reserve definitions and information concerning data sources.
} 


\section{GEMSTONES $^{1}$}

(Data in million dollars unless otherwise noted)

Domestic Production and Use: The combined value of U.S. natural and synthetic gemstone output in 2019 was an estimated $\$ 65$ million, a 9\% increase compared with that of 2018. Domestic gemstone production included agate, beryl, coral, diamond, garnet, jade, jasper, opal, pearl, quartz, sapphire, shell, topaz, tourmaline, turquoise, and many other gem materials. In decreasing order of production value, Arizona, Oregon, Nevada, California, Montana, Maine, Arkansas, Colorado, Utah, Idaho, North Carolina, Tennessee, and New York produced $96 \%$ of U.S. natural gemstones. Synthetic gemstones were manufactured by four firms in North Carolina, California, Maryland, and Arizona, in decreasing order of production value. Major gemstone uses were carvings, gem and mineral collections, and jewelry.

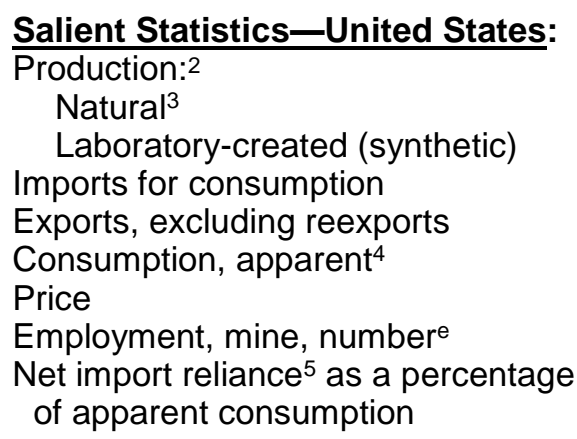

\begin{tabular}{rrrrr}
$\underline{\mathbf{2 0 1 5}}$ & $\underline{\mathbf{2 0 1 6}}$ & $\underline{\mathbf{2 0 1 7}}$ & $\underline{\mathbf{2 0 1 8}}$ & $\underline{\mathbf{2 0 1 9}}$ \\
8.5 & 11.7 & 9.2 & 9.5 & 10 \\
55.1 & 54.9 & 55.1 & 50.0 & 55 \\
25,100 & 25,200 & 24,900 & 27,700 & 26,000 \\
3,030 & 2,940 & 2,440 & 1,850 & 1,200 \\
22,100 & 22,300 & 22,500 & 25,900 & 25,000 \\
\multicolumn{5}{c}{ Variable, depending on size, type, and quality } \\
1,100 & 1,120 & 1,120 & 1,120 & 1,120 \\
99 & 99 & 99 & 99 & 99
\end{tabular}

Recycling: Gemstones are often recycled by being resold as estate jewelry, reset, or recut, but this report does not account for those stones.

Import Sources (2015-18 by value): Diamond: India, 37\%; Israel, 33\%; Belgium, 14\%; South Africa, 4\%; and other, $12 \%$. Typically, diamond imports account for $90 \%$ to $95 \%$ of the total value of gem imports.

Tariff: Item

Coral and similar materials, unworked Imitation gemstones

Pearls, imitation, pearl beads, not strung Imitation gemstones, glass beads

Pearls, natural, graded and temporarily strung

Pearls, natural, other

Pearls, cultured

Diamonds, unworked or sawn

Diamonds, $1 / 2$ carat or less

Diamonds, cut, more than $1 / 2$ carat

Other nondiamond gemstones, unworked

Other nondiamond gemstones, uncut

Rubies, cut

Sapphires, cut

Emeralds, cut

Other nondiamond gemstones, cut

Other nondiamond gemstones, worked

Synthetic gemstones, cut but not set

Synthetic gemstones, other
Number

0508.00.0000

3926.90 .4000

7018.10.1000

7018.10 .2000

7101.10 .3000

7101.10 .6000

7101.21 .0000

7102.31 .0000

7102.39 .0010

7102.39 .0050

7103.10 .2000

7103.10 .4000

7103.91 .0010

7103.91 .0020

7103.91 .0030

7103.99 .1000

7103.99 .5000

7104.90 .1000

7104.90 .5000

Normal Trade Relations
12-31-19
Free.
2.8\% ad val.
4.0\% ad val.
Free.
Free.
Free.
Free.
Free.
Free.
Free.
Free.
10.5\% ad val.
Free.
Free.
Free.
Free.
10.5\% ad val.
Free.
6.4\% ad val.

Depletion Allowance: 14\% (Domestic and foreign).

Government Stockpile: None.

Events, Trends, and Issues: In 2019, U.S. imports for consumption of gem-quality diamonds were estimated to be about $\$ 23$ billion, which was an 8\% decrease compared with $\$ 25.1$ billion in 2018. U.S. imports for consumption of natural, nondiamond gemstones were estimated to be about $\$ 3.0$ billion, which was a $14 \%$ increase compared with $\$ 2.64$ billion in 2018 . U.S. synthetic gemstone production increased by $10 \%$ compared with that in 2018 . The increase 


\section{GEMSTONES}

in synthetic production was because of the combination of a $5 \%$ increase in the value of U.S. synthetic diamond production and a $16 \%$ increase in the value of U.S. synthetic moissanite production compared with those of 2018 . No synthetic diamond production was reported in South Carolina during 2019.

The United States accounted for more than $35 \%$ of the world's diamond consumption and was once again the leading global market in terms of consumer demand. The United States is expected to continue to dominate global gemstone demand. Consumption also increased in Asia. During the first three quarters of 2019, globally, the leading gemstone sales by value were diamond, emerald, ruby, sapphire, and tanzanite. Worldwide rough gem-grade diamond sales decreased by $39 \%$ during the first three quarters compared with the same period of 2018.

Total world diamond production during 2019 increased slightly from 2018 levels. Production is expected to continue to remain steady in the near term and then decline slightly, until 2025, when several large mines are expected to reach the end of their mine life, and only a few new projects are being developed.

\section{World Gem Diamond Mine Production and Reserves:}

\begin{tabular}{|c|c|c|}
\hline & Mine & ction $^{6}$ \\
\hline & $\underline{2018}$ & $\underline{2019^{e}}$ \\
\hline United States & $(8)$ & $(8)$ \\
\hline Angola & 7,570 & 7,500 \\
\hline Australia & 281 & 280 \\
\hline Botswana & 17,100 & 18,000 \\
\hline Brazil & 251 & 250 \\
\hline Canada & 23,200 & 23,000 \\
\hline China & 99 & 100 \\
\hline Congo (Kinshasa) & 3,030 & 3,000 \\
\hline Guinea & 234 & 240 \\
\hline Lesotho & 1,290 & 1,300 \\
\hline Namibia & 2,400 & 2,500 \\
\hline Russia & 24,200 & 25,000 \\
\hline Sierra Leone & 590 & 600 \\
\hline South Africa & 7,930 & 8,000 \\
\hline Tanzania & 328 & 400 \\
\hline Zimbabwe & 326 & 400 \\
\hline Other countries & 242 & 400 \\
\hline World total (rounded) & 89,000 & $\overline{91,000}$ \\
\hline
\end{tabular}

World Resources: Most diamond-bearing ore bodies have a diamond content that ranges from less than 1 carat per ton to about 6 carats per ton of ore. The major diamond reserves are in southern Africa, Australia, Canada, and Russia.

Substitutes: Glass, plastics, and other materials are substituted for natural gemstones. Synthetic gemstones (manufactured materials that have the same chemical and physical properties as natural gemstones) are common substitutes. Simulants (materials that appear to be gems but differ in chemical and physical characteristics) also are frequently substituted for natural gemstones.

\footnotetext{
eEstimated.

${ }^{1}$ Excludes industrial diamond and industrial garnet. See Diamond (Industrial) and Garnet (Industrial).

${ }^{2}$ Estimated minimum production.

${ }^{3}$ Includes production of freshwater shell.

${ }^{4}$ Defined as production (natural and synthetic) + imports - exports (excluding reexports).

${ }^{5}$ Defined as imports - exports (excluding reexports).

${ }^{6}$ Data in thousands of carats of gem diamond.

${ }^{7}$ See Appendix $\mathrm{C}$ for resource and reserve definitions and information concerning data sources.

${ }^{8}$ Less than $1 / 2$ unit.
} 


\section{GERMANIUM}

(Data in kilograms of germanium content unless otherwise noted)

Domestic Production and Use: In 2019, zinc concentrates containing germanium were produced at mines in Alaska, Tennessee, and Washington. Germanium-containing concentrates in Alaska and Washington were exported to a refinery in Canada for processing and germanium recovery. A zinc smelter in Clarksville, TN, produced and exported germanium leach concentrates recovered from processing zinc concentrates from the Middle Tennessee Mines. Germanium in the form of compounds and metal was imported into the United States for further processing by industry. A company in Utah produced germanium wafers for solar cells used in satellites from imported and recycled germanium. A refinery in Oklahoma recovered germanium from industry-generated scrap and produced germanium tetrachloride for the production of fiber optics. Although the consumption quantity was estimated to have remained level in 2019 compared with that in 2018, the estimated value of germanium consumed in 2019, based on the annual average germanium metal price, was \$37 million, about 20\% less than that in 2018.

\begin{tabular}{|c|c|c|c|c|c|}
\hline \multicolumn{5}{|l|}{ Production: } & $\underline{2019^{e}}$ \\
\hline Primary refinery & - & - & - & - & - \\
\hline Secondary refinery & W & W & W & W & W \\
\hline \multicolumn{6}{|l|}{ Imports for consumption: } \\
\hline Germanium metal & 20,100 & 11,000 & 11,100 & 11,800 & 14,000 \\
\hline Germanium dioxide $^{1}$ & 14,300 & 15,200 & 12,000 & 12,400 & 13,000 \\
\hline Total exports ${ }^{2}$ & 5,000 & 4,780 & 3,670 & 4,880 & 3,300 \\
\hline Shipments from Government stockpile & - & - & - & - & - \\
\hline Consumption, estimated ${ }^{3}$ & 34,000 & 30,000 & 30,000 & 30,000 & 30,000 \\
\hline \multicolumn{6}{|c|}{ Price, annual average, dollars per kilogram: 4} \\
\hline Germanium metal & 1,792 & 1,087 & 1,082 & 1,543 & 1,240 \\
\hline Germanium dioxide & 1,211 & 830 & 731 & 1,084 & 920 \\
\hline $\begin{array}{l}\text { Net import reliance } 5 \text { as a percentage of } \\
\text { estimated consumption }\end{array}$ & $>75 \%$ & $>50 \%$ & $>50 \%$ & $>50 \%$ & $>50 \%$ \\
\hline
\end{tabular}

Recycling: Worldwide, about $30 \%$ of the total germanium consumed is produced from recycled materials. During the manufacture of most optical devices, more than $60 \%$ of the germanium metal used is routinely recycled as new scrap. Germanium scrap is also recovered from the windows in decommissioned tanks and other military vehicles. The United States has the capability to recycle new and old scrap.

Import Sources (2015-18): ${ }^{6}$ Germanium metal: China, 59\%; Belgium, 22\%; Germany, 9\%; Russia, 7\%; and other, $3 \%$.

Tariff: Item

Germanium oxides and zirconium dioxide

Metal, unwrought

Metal, powder

Metal, wrought
Number

2825.60 .0000

8112.92 .6000

8112.92 .6500

8112.99 .1000
Normal Trade Relations

12-31-19

$3.7 \%$ ad val.

$2.6 \%$ ad val.

$4.4 \%$ ad val.

$4.4 \%$ ad val.

Depletion Allowance: 14\% (Domestic and foreign).

\section{Government Stockpile: ${ }^{7}$}

\section{Material}

Germanium metal

Germanium scrap (gross weight)

Germanium wafers (each)

Inventory
As of 9-30

14,004
3,794
68,671

FY 2019 $\begin{array}{cc}\text { Potential } & \text { Potential } \\ \text { Acquisitions } & \text { Disposals }\end{array}$
$5, \overline{0} \overline{-}$
FY 2020

Potential Potential Acquisitions Disposals

$\begin{array}{lr}- & \overline{-} \\ - & -000\end{array}$

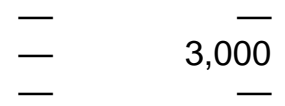

Events, Trends, and Issues: The major global end uses for germanium were electronics and solar applications, fiber-optic systems, infrared optics, polymerization catalysts, and other uses (such as chemotherapy, metallurgy, and phosphors). Germanium-containing infrared optics were primarily for military use, but the commercial applications for thermal-imaging devices that use germanium lenses have increased during the past few years. 


\section{GERMANIUM}

The 2019 estimated average annual prices of germanium dioxide and germanium metal decreased by $15 \%$ and $20 \%$, respectively, from prices in 2018; however, the 2019 average annual prices remained higher than those in 2016 and 2017. Global demand for fiber-optic cable was thought to have decreased in 2019 compared with that in 2018 owing to a slowdown in the rollout of fifth-generation cellular network technology and reduced spending on cable installation by major telecommunication companies. Fiber-optic cable manufacturing accounted for about one-third of global germanium consumption.

A Canada-based mining company lifted a partial force majeure on its germanium sales in February. The company imposed the partial force majeure in January 2018 after an explosion damaged a slag fuming furnace at its lead-zinc refinery in Canada. During the 13 -month period, the company was able to fulfill about $60 \%$ of its contract sales for germanium.

According to China news sources, several germanium producers temporarily stopped production during the year either for maintenance or in response to low germanium prices. Most notably, a leading germanium producer in Yunnan Province reportedly shut down a 10,000-kilogram-per-year germanium metal production line in June. At full production, the company produced between 40,000 and 50,000 kilograms per year of germanium metal. The shutdown was expected to last 6 months. This company received nine Government subsidies totaling 3.6 million yuan between January 1, 2019, and June 27, 2019.

In October, the Government of Yunnan Province, China, auctioned 92,300 kilograms of germanium metal, which was previously held by the now-defunct Fanya Metal Exchange. Kunming Rongke New Material Co. Ltd. was awarded the full quantity.

\section{World Refinery Production and Reserves: ${ }^{8}$}

United States
China
Russia
Other countries ${ }^{10}$
$\quad$ World total (rounded) ${ }^{11}$

United States

Other countries ${ }^{10}$
$\quad$ World total (rounded) $)^{11}$

World Resources: The available resources of germanium are associated with certain zinc and lead-zinc-copper sulfide ores. Substantial U.S. reserves of recoverable germanium are contained in zinc deposits in Alaska, Tennessee, and Washington. Based on an analysis of zinc concentrates, U.S. reserves of zinc may contain as much as 2,500 tons of germanium. Because zinc concentrates are shipped globally and blended at smelters, however, the recoverable germanium in zinc reserves cannot be determined. On a global scale, as little as 3\% of the germanium contained in zinc concentrates is recovered. Significant amounts of germanium are contained in ash and flue dust generated in the combustion of certain coals for power generation.

Substitutes: Silicon can be a less-expensive substitute for germanium in certain electronic applications. Some metallic compounds can be substituted in high-frequency electronics applications and in some light-emitting-diode applications. Zinc selenide and germanium glass substitute for germanium metal in infrared applications systems, but often at the expense of performance. Antimony and titanium are substitutes for use as polymerization catalysts.

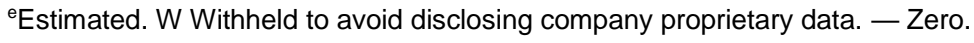

${ }^{1}$ Data has been adjusted to exclude low-value shipments, then multiplied by $69 \%$ to account for germanium content.

${ }^{2}$ Includes Schedule B numbers: 8112.92.6100, 8112.99.1000, and 2825.60.0000. Data have been adjusted to exclude low-value shipments. Oxide data have been multiplied by $69 \%$ to account for germanium content.

${ }^{3}$ Estimated consumption of germanium contained in metal and germanium dioxide.

${ }^{4}$ Average European price for minimum 99.999\% purity. Source: Argus Media group-Argus Metals International.

${ }^{5}$ Defined as imports - exports + adjustments for Government stock changes.

${ }^{6}$ Import sources are based on gross weight of wrought and unwrought germanium metal and germanium metal powders.

${ }^{7}$ See Appendix B for definitions.

${ }^{8}$ Includes primary and secondary production.

${ }^{9}$ See Appendix $\mathrm{C}$ for resource and reserve definitions and information concerning data sources.

${ }^{10}$ Includes Belgium, Canada, Germany, Japan, and Ukraine.

${ }^{11}$ Excludes U.S. production.
} 


\section{GOLD}

(Data in metric tons ${ }^{1}$ of gold content unless otherwise noted)

Domestic Production and Use: In 2019, domestic gold mine production was estimated to be about 200 tons, $11 \%$ less than that in 2018 , and the value was estimated to be about $\$ 9.0$ billion. Gold was produced in 12 States at more than 40 lode mines, at several large placer mines in Alaska, and numerous smaller placer mines (mostly in Alaska and in the Western States). About $7 \%$ of domestic gold was recovered as a byproduct of processing domestic basemetal ores, chiefly copper ores. The top 27 operations yielded more than $99 \%$ of the mined gold produced in the United States. Commercial-grade gold was produced at about 15 refineries. A few dozen companies, out of several thousand companies and artisans, dominated the fabrication of gold into commercial products. U.S. jewelry manufacturing was heavily concentrated in the New York, NY, and Providence, RI, areas, with lesser concentrations in California, Florida, and Texas. Estimated domestic uses (excluding gold bullion bar) were jewelry, 50\%; electrical and electronics, 37\%; official coins, $8 \%$; and other, $5 \%$.

\begin{tabular}{|c|c|c|c|c|c|}
\hline Salient Statistics-United States: & $\underline{2015}$ & $\underline{2016}$ & 2017 & $\underline{2018}$ & $\underline{2019^{e}}$ \\
\hline \multicolumn{6}{|l|}{ Production: } \\
\hline Mine & 214 & 232 & 237 & 226 & 200 \\
\hline \multicolumn{6}{|l|}{ Refinery: } \\
\hline Primary & 244 & 242 & 207 & 205 & 200 \\
\hline Secondary (new and old scrap) & 238 & 220 & 119 & 117 & 130 \\
\hline Imports for consumption ${ }^{2}$ & 265 & 374 & 255 & 213 & 170 \\
\hline Exports $^{2}$ & 478 & 393 & 461 & 474 & 350 \\
\hline Consumption, reported & 165 & 169 & 150 & 160 & 150 \\
\hline Stocks, yearend, Treasury ${ }^{3}$ & 8,140 & 8,140 & 8,140 & 8,140 & 8,140 \\
\hline Price, dollars per troy ounce 4 & 1,163 & 1,252 & 1,261 & 1,272 & 1,400 \\
\hline Employment, mine and mill, number 5 & 11,500 & 11,600 & 11,900 & 12,200 & 12,000 \\
\hline $\begin{array}{l}\text { Net import reliance } 6 \text { as a percentage of } \\
\text { apparent consumption }\end{array}$ & $\mathrm{E}$ & $\mathrm{E}$ & $\mathrm{E}$ & $\mathrm{E}$ & $E$ \\
\hline
\end{tabular}

Recycling: In 2019, an estimated 130 tons of new and old scrap was recycled, equivalent to about $87 \%$ of reported consumption. The domestic supply of gold from recycling increased by $11 \%$ compared with that in 2018 .

Import Sources (2015-18): ${ }^{2}$ Mexico, 26\%; Canada, 22\%; Peru, 13\%; Colombia, 9\%; and other, 30\%.

\section{Tariff: Item}

Precious metal ore and concentrates:

Gold content of silver ores

Gold content of other ores

Gold bullion

Gold dore

Gold scrap
Number

2616.10.0080

2616.90.0040

7108.12.1013

7108.12.1020

7112.91 .0000
Normal Trade Relations 12-31-19

$0.8 \$ / \mathrm{kg}$ on lead content

$1.7 \$ / \mathrm{kg}$ on lead content.

Free.

Free.

Free.

Depletion Allowance: 15\% (Domestic), 14\% (Foreign).

Government Stockpile: The U.S. Department of the Treasury maintains stocks of gold (see salient statistics above), and the U.S. Department of Defense administers a Governmentwide secondary precious-metals recovery program.

Events, Trends, and Issues: The estimated gold price in 2019 was 10\% higher than the price in 2018 but was 16\% lower than the record-high annual price in 2012. The Engelhard daily price of gold in 2019 fluctuated through several cycles. Early in the year the gold price was about \$1,300 per troy ounce and started increasing at the end of May, reaching a projected annual high of $\$ 1,547$ per troy ounce in September. During this time, several factors were reported to have spurred the increase in price: demand from central banks and investors increased; the U.S. Federal Reserve Board cut interest rates; and trade negotiations halted between the United States and China. The price started a downward trend in October and November. 


\section{GOLD}

The11\% decrease in domestic mine production in 2019 was attributed to decreases in production from the Bald Mountain, Carlin, and Cortez Mines in Nevada and the Fort Knox and Pogo Mines in Alaska. In 2019, worldwide gold mine production was estimated to be unchanged from that in 2018. Increased mine production in Australia, China, and Indonesia offset decreased gold mine production in Peru, South Africa, the United States, and Zimbabwe.

In the first 9 months of 2019, domestic consumption of gold used in the production of coins and bars decreased by more than 19\%; however, gold consumption for jewelry increased slightly. Globally, gold consumption by the jewelry industry decreased by $5 \%$ and gold used for the production of coins and bars decreased by $22 \%$ compared with that in the first 9 months of 2018. Investments in gold-based exchange-traded funds were significantly higher in the United States and globally during the same period. Also, gold holdings in central banks increased during the year.

World Mine Production and Reserves: Reserves for Australia, Canada, Indonesia, Papua New Guinea, Peru, and South Africa were revised based on Government and (or) industry reports.

United States
Argentina
Australia
Brazil
Canada
China
Ghana
Indonesia
Kazakhstan
Mexico
Papua New Guinea
Peru
Russia
South Africa
Uzbekistan
Other countries
$\quad$ World total (rounded)

\begin{tabular}{rrr}
\multicolumn{2}{c}{$\begin{array}{c}\text { Mine production } \\
\mathbf{2 0 1 8}\end{array}$} & Reserves $^{\mathbf{2 0 1 9}}$ \\
\hline 226 & $\frac{\mathbf{2 0 1 9}}{200}$ & 3,000 \\
72 & 72 & 1,600 \\
315 & 330 & 810,000 \\
85 & 85 & 2,400 \\
183 & 180 & 1,900 \\
401 & 420 & 2,000 \\
127 & 130 & 1,000 \\
135 & 160 & 2,600 \\
100 & 100 & 1,000 \\
117 & 110 & 1,400 \\
67 & 70 & 1,000 \\
143 & 130 & 2,100 \\
311 & 310 & 5,300 \\
117 & 90 & 3,200 \\
104 & 100 & 1,800 \\
797 & 800 & 10,000 \\
\hline 3,300 & 3,300 & 50,000
\end{tabular}

World Resources: An assessment of U.S. gold resources indicated 33,000 tons of gold in identified (15,000 tons) and undiscovered (18,000 tons) resources. ${ }^{9}$ Nearly one-quarter of the gold in undiscovered resources was estimated to be contained in porphyry copper deposits. The gold resources in the United States, however, are only a small portion of global gold resources.

Substitutes: Base metals clad with gold alloys are widely used in electrical and electronic products, and in jewelry to economize on gold; many of these products are continually redesigned to maintain high-utility standards with lower gold content. Generally, palladium, platinum, and silver may substitute for gold.

\footnotetext{
${ }^{\text {e}}$ Estimated. E Net exporter.

${ }^{1}$ One metric ton $(1,000$ kilograms $)=32,150.7$ troy ounces.

${ }^{2}$ Refined bullion, dore, ores, concentrates, and precipitates. Excludes: Waste and scrap, official monetary gold, gold in fabricated items, gold in coins, and net bullion flow (in tons) to market from foreign stocks at the New York Federal Reserve Bank.

${ }^{3}$ Includes gold in Exchange Stabilization Fund. Stocks were valued at the official price of $\$ 42.22$ per troy ounce.

${ }^{4}$ Engelhard's average gold price quotation for the year. In 2019, the price was estimated by the U.S. Geological Survey based on data from January through November.

${ }^{5}$ Data from the Mine Safety and Health Administration.

${ }^{6}$ Defined as imports - exports.

${ }^{7}$ See Appendix $\mathrm{C}$ for resource and reserve definitions and information concerning data sources.

${ }^{8}$ For Australia, Joint Ore Reserves Committee-compliant reserves were 3,900 tons.

${ }^{9}$ U.S. Geological Survey National Mineral Resource Assessment Team, 2000, 1998 assessment of undiscovered deposits of gold, silver, copper, lead, and zinc in the United States: U.S. Geological Survey Circular 1178, 21 p.
} 


\section{GRAPHITE (NATURAL)}

(Data in metric tons unless otherwise noted)

Domestic Production and Use: In 2019, natural graphite was not produced in the United States; however, approximately 95 U.S. firms, primarily in the Great Lakes and Northeastern regions and Alabama and Tennessee, consumed 52,000 tons valued at an estimated $\$ 44$ million. The major uses of natural graphite were brake linings, lubricants, powdered metals, refractory applications, and steelmaking. During 2019, U.S. natural graphite imports were an estimated 58,000 tons, which were about $65 \%$ flake and high-purity, $34 \%$ amorphous, and $1 \%$ lump and chip graphite.

\begin{tabular}{|c|c|c|c|c|c|}
\hline Salient Statistics-United States: & 2015 & 2016 & 2017 & 2018 & $2019^{e}$ \\
\hline Production, mine & - & - & - & - & - \\
\hline Imports for consumption & 46,700 & 38,900 & 51,900 & 70,700 & 58,000 \\
\hline Exports & 11,600 & 14,300 & 13,900 & 10,400 & 6,600 \\
\hline Consumption, apparent ${ }^{1}$ & 35,100 & 24,700 & 38,000 & 60,300 & 52,000 \\
\hline \multicolumn{6}{|c|}{ Price, imports (average dollars per ton at foreign ports): } \\
\hline Flake & 1,710 & 1,920 & 1,390 & 1,520 & 1,300 \\
\hline Lump and chip (Sri Lankan) & 1,800 & 1,880 & 1,900 & 1,890 & 2,370 \\
\hline Amorphous & 454 & 571 & 451 & 310 & 438 \\
\hline $\begin{array}{l}\text { Net import reliance }{ }^{1} \text { as a percentag } \\
\text { of apparent consumption }\end{array}$ & 100 & 100 & 100 & 100 & 100 \\
\hline
\end{tabular}

Recycling: Refractory brick and linings, alumina-graphite refractories for continuous metal castings, magnesiagraphite refractory brick for basic oxygen and electric arc furnaces, and insulation brick led the way in the recycling of graphite products. The market for recycled refractory graphite material is expanding, with material being recycled into products such as brake linings and thermal insulation. Recovering high-quality flake graphite from steelmaking kish is technically feasible, but currently not practiced. The abundance of graphite in the world market inhibits increased recycling efforts. Information on the quantity and value of recycled graphite is not available.

Import Sources (2015-18): China, 33\%; Mexico, 24\%; Canada, 16\%; India, 9\%; and other, 18\%.

Tariff: Item

Crystalline flake (not including flake dust)

Powder

Other
Number

2504.10.1000

2504.10.5000

2504.90.0000
Normal Trade Relations 12-31-19

Free.

Free.

Free.

Depletion Allowance: 22\% (Domestic lump and amorphous), 14\% (Domestic flake), and 14\% (Foreign).

Government Stockpile: None.

Events, Trends, and Issues: Worldwide consumption of graphite has steadily increased since 2013 and into 2019. U.S. consumption has fluctuated over this time period. During 2015 and 2016, U.S. consumption decreased by 39\% and by $30 \%$, respectively. In 2017 and 2018, consumption increased by $54 \%$ and by $59 \%$, respectively, to its highest point during the past 5 years. However, during 2019, consumption declined again by $14 \%$.

In 2019, principal United States import sources of natural graphite were, in descending order of tonnage, China, Mexico, Canada, Madagascar, Brazil, Mozambique, the United Kingdom, Japan, Sri Lanka, and Austria, which combined accounted for $99 \%$ of the tonnage and $97 \%$ of the value of total United States imports. Mexico and China provided most of the amorphous graphite, and Sri Lanka provided all the lump and chip dust variety.

During 2019, China produced more than $60 \%$ of the world's graphite. Approximately $40 \%$ of production in China was amorphous graphite and about $60 \%$ was flake. China does produce some large flake graphite, but the majority of its flake graphite production is very small, in the +200 -mesh range. North America produced only $4 \%$ of the world's graphite supply with production in Canada and Mexico. No production of natural graphite was reported in the United States, but two companies were developing graphite projects-one in Alabama and one in Alaska.

Large graphite deposits were being developed in Madagascar, northern Mozambique, Namibia, and south-central Tanzania. Some mines in Madagascar began ramping up production in 2018, and a mine in Tanzania started sampling production beginning in 2017. A graphite mine project in Mozambique commenced operations at the start of 2018 and was ramping up production during 2018 and 2019 at a high-grade graphite deposit, which was reportedly 


\section{GRAPHITE (NATURAL)}

the largest natural graphite mine globally. The mine cut back production during 2019 in an effort to stabilize graphite prices. The mine is expected to operate for 50 years.

During the first half of 2019, crystalline flake graphite prices declined to levels similar to those of midyear 2017. The price decline was the result of oversupply, and some graphite mining companies cut back production in an effort to stabilize and increase graphite prices.

A U.S. automaker continued to build a large plant to manufacture lithium-ion electric vehicle batteries. The plant's completion was projected for 2020. A portion of the plant was operational and battery packs were being assembled in 2018 and 2019. When the plant is complete, it was expected to require 35,200 tons per year of spherical graphite for use as anode material for lithium-ion batteries.

New thermal technology and acid-leaching techniques have enabled the production of higher purity graphite powders that are likely to lead to development of new applications for graphite in high-technology fields. Innovative refining techniques have made the use of graphite possible in carbon-graphite composites, electronics, foils, friction materials, and specialty lubricant applications. Flexible graphite product lines are likely to be the fastest growing market. Largescale fuel-cell applications are being developed that could consume as much graphite as all other uses combined.

World Mine Production and Reserves: Reserves for Mozambique and Tanzania were revised based on information reported by graphite-producing companies and the Governments of those countries.

\begin{tabular}{lrrr} 
& \multicolumn{2}{c}{ Mine production } & Reserves $^{\mathbf{2}}$ \\
United States & $\underline{\mathbf{2 0 1 8}}$ & $\underline{\mathbf{2 0 1 9}}$ & $(3)$ \\
Austria & 1,000 & 1,000 & $(3)$ \\
Brazil & 95,000 & 96,000 & $72,000,000$ \\
Canada & 40,000 & 40,000 & $(3)$ \\
China & 693,000 & 700,000 & $73,000,000$ \\
Germany & 800 & 800 & $(3)$ \\
India & 35,000 & 35,000 & $8,000,000$ \\
Korea, North & 6,000 & 6,000 & $2,000,000$ \\
Madagascar & 46,900 & 47,000 & $1,600,000$ \\
Mexico & 9,000 & 9,000 & $3,100,000$ \\
Mozambique & 104,000 & 100,000 & $25,000,000$ \\
Namibia & 3,460 & 3,500 & $(3)$ \\
Norway & 16,000 & 16,000 & 600,000 \\
Pakistan & 14,000 & 14,000 & $(3)$ \\
Russia & 25,200 & 25,000 & $(3)$ \\
Sri Lanka & 4,000 & 4,000 & $18,000,000$ \\
Tanzania & 150 & 150 & $90,000,000$ \\
Turkey & 2,000 & 2,000 & $(3)$ \\
Ukraine & 20,000 & 20,000 & $(3)$ \\
Vietnam & 5,000 & 5,000 & $(3)$ \\
Zimbabwe & 2,000 & 2,000 & $7,600,000$ \\
Other & 200 & 200 & $300,000,000$
\end{tabular}

World Resources: Domestic resources of graphite are relatively small, but the rest of the world's inferred resources exceed 800 million tons of recoverable graphite.

Substitutes: Synthetic graphite powder, scrap from discarded machined shapes, and calcined petroleum coke compete for use in iron and steel production. Synthetic graphite powder and secondary synthetic graphite from machining graphite shapes compete for use in battery applications. Finely ground coke with olivine is a potential competitor in foundry-facing applications. Molybdenum disulfide competes as a dry lubricant but is more sensitive to oxidizing conditions.

\footnotetext{
EEstimated. - Zero.

${ }^{1}$ Defined as imports - exports.

${ }^{2}$ See Appendix $C$ for resource and reserve definitions and information concerning data sources.

${ }^{3}$ Included with "World total."
} 


\section{GYPSUM}

(Data in thousand metric tons unless otherwise noted)

Domestic Production and Use: In 2019, domestic production of crude gypsum was estimated to be 20 million tons with a value of about $\$ 160$ million. The leading crude gypsum-producing States, in alphabetical order, were estimated to be lowa, Kansas, Nevada, Oklahoma, and Texas, which together accounted for an estimated $64 \%$ of total output. Overall, 47 companies produced or processed gypsum in the United States at 52 mines in 16 States. The majority of domestic consumption, which totaled approximately 42 million tons, was used by agriculture, cement production, and manufacturers of wallboard and plaster products. Small quantities of high-purity gypsum, used in a wide range of industrial processes, accounted for the remaining tonnage. At the beginning of 2019, the production capacity of 63 operating gypsum panel manufacturing plants in the United States was about 34.1 billion square feet ${ }^{1}$ per year. Total wallboard sales were estimated to be 24.0 billion square feet.

\begin{tabular}{|c|c|c|c|c|c|}
\hline Salient Statistics-United States: & $\underline{2015}$ & $\underline{2016}$ & $\underline{2017}$ & $\underline{2018}$ & $\underline{2019^{e}}$ \\
\hline \multicolumn{6}{|l|}{ Production: } \\
\hline Crude & 18,800 & 19,800 & 20,700 & 21,100 & 20,000 \\
\hline Synthetic $^{2}$ & 15,500 & 16,700 & 20,700 & 16,600 & 16,000 \\
\hline Calcined $^{3}$ & 16,500 & 17,900 & 17,800 & 16,900 & 17,000 \\
\hline Wallboard products sold (million square feet ${ }^{1}$ ) & 22,100 & 24,400 & 25,000 & 23,700 & 24,000 \\
\hline Imports, crude, including anhydrite & 4,030 & 4,340 & 4,800 & 5,190 & 6,100 \\
\hline Exports, crude, not ground or calcined & 63 & 43 & 36 & 36 & 38 \\
\hline Consumption, apparent ${ }^{4}$ & 38,300 & 40,800 & 46,200 & 42,900 & 42,000 \\
\hline \multicolumn{6}{|l|}{ Price: } \\
\hline $\begin{array}{l}\text { Average crude, free on board (f.o.b.) mine, } \\
\text { dollars per metric ton }\end{array}$ & 7.80 & 8.00 & 7.50 & 8.30 & 8.00 \\
\hline Average calcined, f.o.b. plant, dollars per metric tor & 28.00 & 30.00 & 30.00 & 32.00 & 32.00 \\
\hline Employment, mine and calcining plant, numbere & 4,500 & 4,500 & 4,500 & 4,500 & 4,500 \\
\hline \multicolumn{6}{|l|}{ Net import reliance ${ }^{5}$ as a percentage } \\
\hline of apparent consumption & 10 & 11 & 10 & 12 & 14 \\
\hline
\end{tabular}

Import Sources (2015-18): Mexico, 41\%; Spain, 29\%; Canada, 28\%; and other, 2\%.

Tariff: Item

Gypsum; anhydrite
Number

2520.10 .0000
Normal Trade Relations $\underline{12-31-19}$

Depletion Allowance: 14\% (Domestic and foreign).

Government Stockpile: None.

Events, Trends, and Issues: U.S. gypsum production decreased by $5 \%$ compared with that of 2018. Apparent consumption decreased slightly compared with that of 2018. U.S. gypsum imports increased by $17 \%$ compared with those of 2018. Exports, although very low compared with imports and often subject to wide fluctuations, increased by $6 \%$. 


\section{GYPSUM}

Demand for gypsum depends principally on construction industry activity, particularly in the United States, where the majority of gypsum consumed is used for building plasters, the manufacture of portland cement, and wallboard products. The construction of wallboard manufacturing plants designed to use synthetic gypsum from coal flue gas desulfurization (FGD) units as feedstock has resulted in less mining of natural gypsum. The availability of inexpensive natural gas, however, has limited the additional construction of FGD units and, therefore, the use of synthetic gypsum in wallboard.

The United States, the world's leading crude gypsum producer, produced an estimated 20 million tons. China and Iran were the second-leading producers each producing an estimated 16 million tons. Increased use of wallboard in Asia, coupled with new gypsum product plants, spurred increased production in that region. As wallboard becomes more widely used in other regions, worldwide production of gypsum is expected to increase.

World Mine Production and Reserves: Reserves for India, Iran, Oman, Pakistan, and Thailand were revised based on Government and other public data.

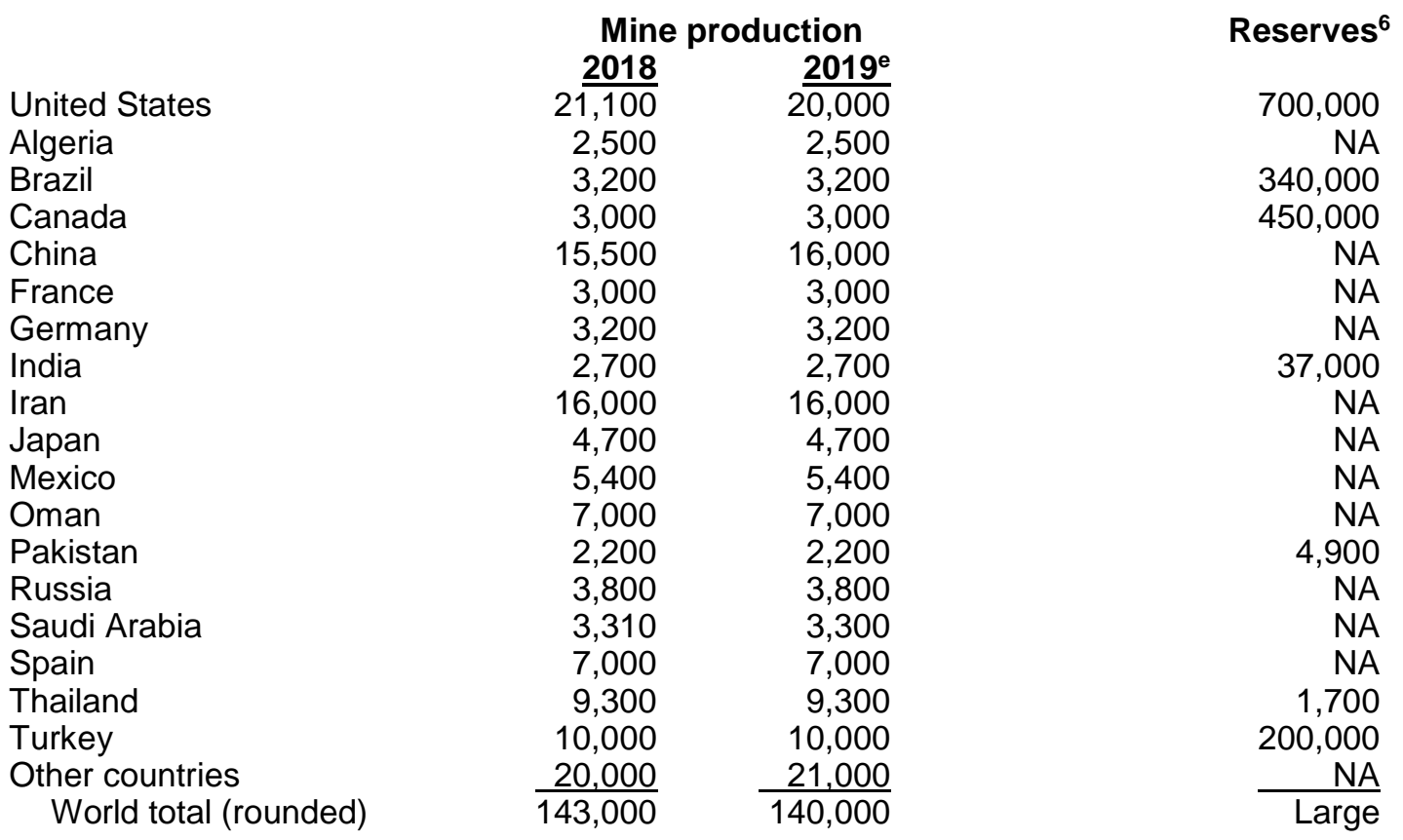

World Resources: Reserves are large in major producing countries, but data for most are not available. Domestic gypsum resources are adequate but unevenly distributed. Large imports from Canada augment domestic supplies for wallboard manufacturing in the United States, particularly in the eastern and southern coastal regions. Imports from Mexico supplement domestic supplies for wallboard manufacturing along portions of the U.S. western seaboard. Large gypsum deposits occur in the Great Lakes region, the midcontinent region, and several Western States. Foreign resources are large and widely distributed; 80 countries were thought to produce gypsum in 2019.

Substitutes: In such applications as stucco and plaster, cement and lime may be substituted for gypsum; brick, glass, metallic or plastic panels, and wood may be substituted for wallboard. Gypsum has no practical substitute in the manufacturing of portland cement. Synthetic gypsum generated by various industrial processes, including FGD of smokestack emissions, is very important as a substitute for mined gypsum in wallboard manufacturing, cement production, and agricultural applications (in descending order by tonnage). In 2019, synthetic gypsum was estimated to account for about $45 \%$ of the total domestic gypsum supply.

\footnotetext{
eEstimated. NA Not available.

${ }^{1}$ The standard unit used in the U.S. wallboard industry is square feet; multiply square feet by $9.29 \times 10^{-2}$ to convert to square meters. Source: The Gypsum Association.

${ }^{2}$ Synthetic gypsum used; the majority of these data were obtained from the American Coal Ash Association.

${ }^{3}$ From domestic crude and synthetic gypsum.

${ }^{4}$ Defined as domestic crude production + synthetic used + imports - exports.

${ }^{5}$ Defined as imports - exports.

${ }^{6}$ See Appendix C for resource and reserve definitions and information concerning data sources.
} 


\section{HELIUM}

(Data in million cubic meters of contained helium gas ${ }^{1}$ unless otherwise noted)

Domestic Production and Use: The estimated value of Grade-A helium (99.997\% or greater) extracted during 2019 by private industry was about $\$ 717$ million. Fourteen plants (one in Arizona, two in Colorado, five in Kansas, one in Oklahoma, four in Texas, and one in Utah) extracted helium from natural gas and produced crude helium that ranged from $50 \%$ to $99 \%$ helium. One plant in Colorado and another in Wyoming extracted helium from natural gas and produced Grade-A helium. Three plants in Kansas and one in Oklahoma accepted crude helium from other producers and the Bureau of Land Management (BLM) pipeline and purified it to Grade-A helium. In 2019, estimated domestic consumption of Grade-A helium was 40 million cubic meters (1.4 billion cubic feet), and it was used for magnetic resonance imaging, 30\%; lifting gas, 17\%; analytical and laboratory applications, 14\%; welding, 9\%; engineering and scientific applications, 6\%; leak detection and semiconductor manufacturing, 5\% each; and various other minor applications, $14 \%$.

\begin{tabular}{|c|c|c|c|c|c|}
\hline Salient Statistics-United States: & $\underline{2015}$ & $\underline{2016}$ & $\underline{2017}$ & $\underline{2018^{e}}$ & $\underline{2019^{e}}$ \\
\hline$\overline{\text { Helium extracted from natural gas }{ }^{2}}$ & 71 & 66 & 63 & 64 & 68 \\
\hline Withdrawn from storage ${ }^{3}$ & 20 & 23 & 28 & 26 & 2 \\
\hline Grade-A helium sales & 91 & 89 & 91 & 90 & 9 \\
\hline Imports for consumption & 16 & 23 & 19 & 8 & \\
\hline Exports & 64 & 62 & 74 & 84 & 83 \\
\hline Consumption, apparent ${ }^{4}$ & 43 & 50 & 36 & 40 & 40 \\
\hline $\begin{array}{l}\text { Net import reliance }{ }^{5} \text { as a percentage } \\
\text { of apparent consumption }\end{array}$ & $\mathrm{E}$ & $E$ & $E$ & $\mathrm{E}$ & \\
\hline
\end{tabular}

In fiscal year (FY) 2019, the price for crude helium to Government users was $\$ 3.10$ per cubic meter ( $\$ 86.00$ per thousand cubic feet) and to nongovernment users was $\$ 4.29$ per cubic meter ( $\$ 119.00$ per thousand cubic feet). The price for the Government-owned helium is mandated by the Helium Stewardship Act of 2013 (Public Law 113-40) and determined through public auctions and industry surveys. The last year helium prices were posted by the Federal Government was in 2018. The estimated price for private industry's Grade-A helium was about \$7.57 per cubic meter (\$210 per thousand cubic feet), with some producers posting surcharges to this price.

Recycling: In the United States, helium used in large-volume applications is seldom recycled. Some low-volume or liquid boil-off recovery systems are used. In the rest of the world, helium recycling is practiced more often.

Import Sources (2015-18): Qatar, 79\%; Canada, 8\%; Algeria, 5\%; Portugal, 4\%; and other, 4\%.

Tariff: Item

Helium
Number

2804.29.0010
Normal Trade Relations 12-31-19

$3.7 \%$ ad val.

Depletion Allowance: Allowances are applicable to natural gas from which helium is extracted, but no allowance is granted directly to helium.

Government Stockpile: Under the Helium Stewardship Act of 2013, the BLM manages the Federal Helium Program, which includes all operations of the Cliffside Field helium storage reservoir, in Potter County, TX, and the Government's crude helium pipeline system. Private firms that sell Grade-A helium to Federal agencies are required to purchase a like amount of (in-kind) crude helium from the BLM. The law mandates that the BLM sell at auction Federal Conservation helium stored in Bush Dome at the Cliffside Field. The last auction was completed in the summer of 2018. Because the remaining conservation helium is less than 83.2 million cubic meters (3 billion cubic feet), the law requires that the BLM begin disposal of all helium assets including all operations of the Cliffside Field helium storage reservoir and pipeline system and complete the sale by yearend 2021. In the meantime, the BLM will continue to make in-kind helium available to Federal customers. In FY 2019, privately owned companies purchased about 4.8 million cubic meters (176 million cubic feet) of in-kind crude helium. During FY 2019, the BLM's Amarillo Field Office, Helium Operations, accepted about 3.0 million cubic meters (107 million cubic feet) of private helium for storage and redelivered nearly 24.2 million cubic meters ( 0.875 billion cubic feet). As of September 30, 2019, about 67.4 million cubic meters ( 2.43 billion cubic feet) of privately owned helium remained in storage at Cliffside Field.

Stockpile Status-9-30-196

$\begin{array}{lcc}\text { Material } & \text { Inventory } & \begin{array}{c}\text { Authorized } \\ \text { for disposal }\end{array} \\ \text { Helium } & 68.0 & 51.4\end{array}$
Disposal plan FY 2019 4.8

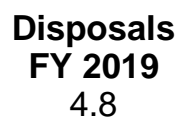

Prepared by Joseph B. Peterson7 [(806) 356-1030, jbpeters@blm.gov] 


\section{HELIUM}

Events, Trends, and Issues: In 2019, the BLM continued implementation of the Helium Stewardship Act of 2013 by supplying helium to Federal agencies through the in-kind helium program from Federal helium storage at the Cliffside Field near Amarillo. The Bush Dome at the Cliffside Field is the only geologic structure in the United States that is used to store of helium. The Federal Government has stored helium in the Bush Dome since 1962. By about 2025, international helium extraction facilities are likely to become the main sources of supply for world helium users.

\section{World Production and Reserves: ${ }^{8}$}

\begin{tabular}{lrrr} 
& \multicolumn{2}{c}{ Production } & Reserves $^{\mathbf{9}}$ \\
United States (extracted from natural gas) & $\frac{\mathbf{2 0 1 8}}{64}$ & $\frac{\mathbf{2 0 1 9}}{68}$ & 3,900 \\
United States (from Cliffside Field) & 26 & 21 & $(10)$ \\
Algeria & 14 & 14 & 1,800 \\
Australia & 4 & 4 & NA \\
Canada & $<1$ & $<1$ & NA \\
China & $\mathrm{NA}$ & $\mathrm{NA}$ & $\mathrm{NA}$ \\
Poland & 2 & 2 & 25 \\
Qatar & 45 & 51 & NA \\
Russia & 3 & $\underline{2}$ & $\underline{1,700}$ \\
$\quad$ World total (rounded) & 158 & 160 & NA
\end{tabular}

World Resources: Section 16 of Public Law 113-40 requires the U.S. Geological Survey (USGS) to complete a national helium gas assessment. The USGS and the BLM coordinated efforts to complete this assessment. The USGS expects results to be published in 2020. The BLM plans to publish an update to its report of the Helium Resources of the United States by midyear 2020. Until then, the following estimates are still the best available.

As of December 31, 2006, the total helium reserves and resources of the United States were estimated to be 20.6 billion cubic meters ( 744 billion cubic feet). This includes 4.25 billion cubic meters (153 billion cubic feet) of measured reserves, 5.33 billion cubic meters (192 billion cubic feet) of probable resources, 5.93 billion cubic meters (214 billion cubic feet) of possible resources, and 5.11 billion cubic meters (184 billion cubic feet) of speculative resources. Included in the measured reserves are 670 million cubic meters (24.2 billion cubic feet) of helium stored in the Cliffside Field Government Reserve, and 65 million cubic meters (2.3 billion cubic feet) of helium contained in Cliffside Field native gas. The Hugoton (Kansas, Oklahoma, and Texas), Panhandle West, Panoma, Riley Ridge in Wyoming, and Cliffside Fields are the depleting fields from which most U.S.-produced helium is extracted. These fields contained an estimated 3.9 billion cubic meters (140 billion cubic feet) of helium.

Helium resources of the world, exclusive of the United States, were estimated to be about 31.3 billion cubic meters (1.13 trillion cubic feet). The locations and volumes of the major deposits, in billion cubic meters, are Qatar, 10.1; Algeria, 8.2; Russia, 6.8; Canada, 2.0; and China, 1.1. As of December 31, 2018, the BLM had analyzed about 22,300 gas samples from 26 countries and the United States, in a program to identify world helium resources.

Substitutes: There is no substitute for helium in cryogenic applications if temperatures below $-429^{\circ} \mathrm{F}$ are required. Argon can be substituted for helium in welding, and hydrogen can be substituted for helium in some lighter-than-air applications in which the flammable nature of hydrogen is not objectionable. Hydrogen is also being investigated as a substitute for helium in deep-sea diving applications below 1,000 feet.

\footnotetext{
${ }^{\text {e}}$ Estimated. E Net exporter. NA Not available.

${ }^{1}$ Measured at 101.325 kilopascals absolute (14.696 psia) and $15^{\circ} \mathrm{C} ; 27.737$ cubic meters of helium $=1,000$ cubic feet of helium at $70{ }^{\circ} \mathrm{F}$ and 14.7 psia.

${ }^{2}$ Both Grade-A and crude helium.

${ }^{3}$ Extracted from natural gas in prior years.

${ }^{4}$ Grade-A helium. Defined as Grade-A helium sales + imports - exports. However, substantial increases in exports reported in 2018 and 2019 suggest that domestic consumption declined, although no significant decline in U.S. helium consumption is thought to have taken place. For that reason, apparent consumption for 2018 and 2019 was estimated to have remained at about 40 million cubic meters.

${ }^{5}$ Defined as imports - exports.

${ }^{6}$ See Appendix B for definitions.

${ }^{7}$ Supervisory General Engineer, Helium Resources Division, Bureau of Land Management, Amarillo Field Office, Helium Operations, Amarillo, TX. ${ }^{8}$ Production and reserves outside of the United States are estimated.

${ }^{9}$ See Appendix $\mathrm{C}$ for resource and reserve definitions and information concerning data sources.

${ }^{10}$ Included in United States (extracted from natural gas) reserves.
} 


\section{INDIUM}

(Data in metric tons unless otherwise noted)

Domestic Production and Use: Indium was not recovered from ores in the United States in 2019. Several companies produced indium products—including alloys, compounds, high-purity metal, and solders-from imported indium metal. Production of indium tin oxide (ITO) continued to account for most of global indium consumption. ITO thin-film coatings were primarily used for electrical conductive purposes in a variety of flat-panel displays-most commonly liquid crystal displays (LCDs). Other indium end uses included alloys and solders, compounds, electrical components and semiconductors, and research. Based on an average of recent annual import levels, estimated domestic consumption of refined indium was 110 tons in 2019. The estimated value of refined indium consumed domestically in 2019 , based on the average New York dealer price, was about $\$ 43$ million.

\begin{tabular}{|c|c|c|c|c|c|}
\hline Salient Statistics_-United States: & $\underline{2015}$ & $\underline{2016}$ & $\underline{2017}$ & $\underline{2018}$ & $\underline{2019^{\mathrm{e}}}$ \\
\hline$\overline{\text { Production, refinery }}$ & 二 & 二 & 二 & 二 & \\
\hline Imports for consumption & 140 & 160 & 127 & 125 & 110 \\
\hline Exports & NA & NA & NA & NA & \\
\hline Consumption, estimated ${ }^{1}$ & 140 & 160 & 127 & 125 & 110 \\
\hline \multicolumn{6}{|l|}{ Price, annual average, dollars per kilogram: } \\
\hline New York dealer ${ }^{2}$ & 520 & 345 & 363 & 375 & \\
\hline Duties unpaid in warehouse, Rotterdam ${ }^{3}$ & 410 & 240 & 225 & 291 & \\
\hline $\begin{array}{l}\text { Net import reliance } 4 \text { as a percentage of } \\
\text { estimated consumption }\end{array}$ & 100 & 100 & 100 & 100 & 100 \\
\hline
\end{tabular}

Recycling: Indium is most commonly recovered from ITO scrap in Japan and the Republic of Korea. A significant quantity of scrap was recycled domestically; however, data on the quantity of secondary indium recovered from scrap were not available.

Import Sources (2015-18): China, 36\%; Canada, 22\%; Republic of Korea, 11\%; Taiwan, 7\%; and other, $24 \%$.

\section{Tariff: Item}

Unwrought indium, including powders, waste, and scrap
Number

8112.92.3000
Normal Trade Relations

$\underline{12-31-19}$

Free.

Depletion Allowance: 14\% (Domestic and foreign).

Government Stockpile: None.

Events, Trends, and Issues: The 2019 estimated average New York dealer price of indium was \$390 per kilogram, $4 \%$ more than that of 2018 . The average monthly price in January was $\$ 390$ per kilogram where it remained through September. The 2019 estimated average free market price of indium was \$210 per kilogram, 28\% less than in 2018. The average monthly free market price began the year at $\$ 232$ per kilogram and decreased throughout the year to an average of $\$ 160$ per kilogram in September. 


\section{INDIUM}

In January, the Fanya Metal Exchange attempted to auction two lots of indium, totaling 37.41 tons, with a starting price of \$170 per kilogram, but no bids were received. A second auction for 34.64 tons of indium was held in April, and the total lot sold for about $\$ 5.5$ million (\$161 per kilogram) to the State-owned China National Corporation for Overseas Economic Cooperation (CCOEC). The Fanya Metal Exchange reportedly held 3,600 tons of indium, which is equivalent to 4 years of global primary indium production, before it closed in 2015.

New telecommunication networks have created a new demand for indium, which is used for indium phosphide (InP) lasers and receivers. InP lasers are used in telecommunications for fiber-optic networks that have connections between third-, fourth-, and fifth-generation (3G, 4G, and 5G) wireless antennas; have data transmission speeds of greater than 10 terabits per second; and have total transmission distances of more than 5,000 kilometers.

\section{World Refinery Production and Reserves:}

\begin{tabular}{|c|c|c|c|}
\hline & \multicolumn{2}{|c|}{ Refinery production } & \multirow[t]{2}{*}{ Reserves $^{5}$} \\
\hline & 2018 & $2019^{e}$ & \\
\hline United States & 二 & - & Quantitative estimates of reserves are not \\
\hline Belgium & 22 & 20 & available. \\
\hline Canada & 58 & 60 & \\
\hline China & 300 & 300 & \\
\hline France & 40 & 50 & \\
\hline Japan & 70 & 75 & \\
\hline Korea, Republic of & 235 & 240 & \\
\hline Peru & 11 & 10 & \\
\hline Russia & 5 & 5 & \\
\hline World total (rounded) & $\overline{741}$ & $\overline{760}$ & \\
\hline
\end{tabular}

World Resources: Indium is most commonly recovered from the zinc-sulfide ore mineral sphalerite. The indium content of zinc deposits from which it is recovered ranges from less than 1 part per million to 100 parts per million. Although the geochemical properties of indium are such that it occurs in trace amounts in other base-metal sulfidesparticularly chalcopyrite and stannite-most deposits of these minerals are subeconomic for indium.

Substitutes: Antimony tin oxide coatings have been developed as an alternative to ITO coatings in LCDs and have been successfully annealed to LCD glass; carbon nanotube coatings have been developed as an alternative to ITO coatings in flexible displays, solar cells, and touch screens; PEDOT [poly(3,4-ethylene dioxythiophene)] has also been developed as a substitute for ITO in flexible displays and organic light-emitting diodes; and copper or silver nanowires have been explored as a substitute for ITO in touch screens. Graphene has been developed to replace ITO electrodes in solar cells and also has been explored as a replacement for ITO in flexible touch screens. Researchers have developed a more adhesive zinc oxide nanopowder to replace ITO in LCDs. Hafnium can replace indium in nuclear reactor control rod alloys.

${ }^{5}$ See Appendix $\mathrm{C}$ for resource and reserve definitions and information concerning data sources.
} 


\section{IODINE}

(Data in metric tons of elemental iodine unless otherwise noted)

Domestic Production and Use: Iodine was produced from brines in 2019 by three companies operating in Oklahoma. U.S. iodine production in 2019 was withheld to avoid disclosing company proprietary data. The average annual cost, insurance, and freight value of iodine imports in 2019 was estimated to be \$26 per kilogram, a 16\% increase from that of 2018.

Because domestic and imported iodine was used by downstream manufacturers to produce many intermediate iodine compounds, it was difficult to establish an accurate end-use pattern. Crude iodine and inorganic iodine compounds were thought to account for more than $50 \%$ of domestic iodine consumption in 2019 . Worldwide, the leading uses of iodine and its compounds were $\mathrm{x}$-ray contrast media, pharmaceuticals, liquid-crystal-displays (LCDs), and iodophors, in descending order of quantity consumed.

\begin{tabular}{|c|c|c|c|c|c|}
\hline Salient Statistics-United States: & $\underline{2015}$ & $\underline{2016}$ & $\underline{2017}$ & $\underline{2018}$ & $\underline{2019^{e}}$ \\
\hline$\overline{\text { Production }}$ & $\mathrm{W}$ & $\mathrm{W}$ & $\bar{W}$ & $\mathrm{~W}$ & $\mathrm{~W}$ \\
\hline Imports for consumption & 5,630 & 4,320 & 4,170 & 4,930 & 4,600 \\
\hline Exports & 1,210 & 1,050 & 1,230 & 1,190 & 1,200 \\
\hline \multicolumn{6}{|l|}{ Consumption: } \\
\hline Apparent ${ }^{1}$ & W & W & W & W & W \\
\hline Reported & 3,800 & 4,610 & 4,500 & 4,620 & 4,800 \\
\hline \multicolumn{6}{|l|}{ Price, crude, average value of imports, } \\
\hline cost, insurance, and freight, dollars per kilogram & 27.74 & 22.71 & 19.55 & 22.46 & 26 \\
\hline Employment, numbere & 60 & 60 & 60 & 60 & 60 \\
\hline $\begin{array}{l}\text { Net import reliance }{ }^{2} \text { as a percentage } \\
\text { of reported consumption }\end{array}$ & $>50$ & $>50$ & $>50$ & $>50$ & $>50$ \\
\hline
\end{tabular}

Recycling: Small amounts of iodine were recycled.

Import Sources (2015-18): Chile, 88\%; Japan, 11\%; and other, 1\%.

Tariff: Item

Number

lodine, crude

2801.20 .0000

\section{Normal Trade Relations $\underline{12-31-19}$ \\ Free.}

Depletion Allowance: $14 \%$ (Domestic and foreign).

Government Stockpile: None. 


\section{IODINE}

Events, Trends, and Issues: According to trade publications, spot prices for iodine crystal averaged about \$28 per kilogram during the first half of 2019. Although this was an increase from the 2018 annual average of about $\$ 25$ per kilogram, prices were still considerably less than the historically high levels of \$65 to \$85 per kilogram in late 2012 and early 2013. The increase in the average spot price was attributed to an undersupply in the market. The estimated average annual value of crude iodine imported in the United States increased by about $16 \%$ in 2019 compared with that in 2018.

As in recent years, Chile was the world's leading producer of iodine, followed by Japan and the United States. Excluding production in the United States, Chile accounted for about $65 \%$ of world production in 2019. In Turkmenistan, a new iodine producer started operations and was thought to have contributed to an increase in the country's total iodine production in 2019. Most of the world's iodine supply comes from three areas: the Chilean desert nitrate mines, the oilfields and gasfields in Japan, and the iodine-rich brine wells in northwestern Oklahoma.

World Mine Production and Reserves: China and Iran also produce crude iodine, but output is not officially reported.

\begin{tabular}{lrrr} 
& \multicolumn{2}{c}{ Mine production } & Reserves $^{\mathbf{3}}$ \\
United States & $\frac{\mathbf{2 0 1 8}}{W}$ & $\frac{\mathbf{2 0 1 9}}{W}$ & 250,000 \\
Azerbaijan & 200 & 200 & 170,000 \\
Chile & 18,000 & 18,000 & 610,000 \\
Indonesia & 38 & 40 & 100,000 \\
Japan & 8,800 & 9,000 & $5,000,000$ \\
Russia & 8 & 10 & 120,000 \\
Turkmenistan $\quad 540$ & 600 & 70,000 \\
$\quad$ World total (rounded) & $\frac{600}{427,600}$ & $\frac{4}{428,000}$ & $6,300,000$
\end{tabular}

World Resources: Seawater contains 0.06 part per million iodine, and the oceans are estimated to contain approximately 90 billion tons of iodine. Seaweeds of the Laminaria family are able to extract and accumulate up to $0.45 \%$ iodine on a dry basis. Although not as economical as the production of iodine as a byproduct of gas, nitrates, and oil, the seaweed industry represented a major source of iodine prior to 1959 and remains a large resource.

Substitutes: No comparable substitutes exist for iodine in many of its principal applications, such as in animal feed, catalytic, nutritional, pharmaceutical, and photographic uses. Bromine and chlorine could be substituted for iodine in biocide, colorant, and ink, although they are usually considered less desirable than iodine. Antibiotics can be used as a substitute for iodine biocides.

\footnotetext{
eEstimated. W Withheld to avoid disclosing company proprietary data.

${ }^{1}$ Defined as production + imports - exports.

${ }^{2}$ Defined as imports - exports.

${ }^{3}$ See Appendix $\mathrm{C}$ for resource and reserve definitions and information concerning data sources.

${ }^{4}$ Excludes U.S. production.
} 


\section{IRON AND STEEL ${ }^{1}$}

(Data in million metric tons of metal unless otherwise noted)

Domestic Production and Use: The U.S. iron and steel industry produced raw steel in 2019 with an estimated value of about $\$ 92$ billion, an 11\% decrease from $\$ 103$ billion in 2018 and a 9\% increase from $\$ 84$ billion in 2017. Pig iron and raw steel was produced by three companies operating integrated steel mills in nine locations. Fifty companies produced raw steel at 98 minimills. Combined production capacity was about 111 million tons. Indiana accounted for an estimated $26 \%$ of total raw steel production, followed by Ohio, 12\%; Michigan, 5\%; and Pennsylvania, 5\%, with no other State having more than $5 \%$ of total domestic raw steel production. Construction accounted for an estimated $44 \%$ of total domestic shipments by market classification, followed by transportation (predominantly automotive), 28\%; machinery and equipment, 9\%; energy, 6\%; appliances, 5\%; and other applications, $8 \%$.

\begin{tabular}{|c|c|c|c|c|c|}
\hline Salient Statistics-United States: & $\underline{2015}$ & $\underline{2016}$ & $\underline{2017}$ & $\underline{2018}$ & $\frac{2019^{\circ}}{23}$ \\
\hline$\overline{\text { Pig iron production }{ }^{2}}$ & $\overline{25.4}$ & $\overline{22.3}$ & $\overline{22.4}$ & $\overline{24.1}$ & 23 \\
\hline Raw steel production & 78.8 & 78.5 & 81.6 & 86.6 & 87 \\
\hline Basic oxygen furnaces, percent & 37.3 & 33.0 & 31.6 & 32.0 & \\
\hline Electric arc furnaces, percent & 62.7 & 67.0 & 68.4 & 68.0 & 70 \\
\hline Continuously cast steel, percent & 99.0 & 99.4 & 99.6 & 98.2 & 99 \\
\hline Shipments, steel mill products & 78.5 & 78.5 & 82.5 & 86.4 & 87 \\
\hline \multicolumn{6}{|l|}{ Imports: } \\
\hline Finished steel mill products & 28.6 & 23.9 & 26.8 & 23.3 & \\
\hline Semifinished steel mill products & 6.6 & 6.1 & 7.8 & 7.3 & 7.0 \\
\hline Total steel mill products & 35.2 & 30.0 & 34.6 & 30.6 & 27. \\
\hline \multicolumn{6}{|l|}{ Exports: } \\
\hline Finished steel mill products & 8.9 & 8.3 & 9.5 & 7.9 & 6.7 \\
\hline Semifinished products & $\left({ }^{3}\right)$ & $\left({ }^{3}\right)$ & $\left({ }^{3}\right)$ & $(3)$ & \\
\hline Total steel mill products & 9.0 & 8.4 & 9.6 & 8.0 & \\
\hline Stocks, service centers, yearend 4 & 7.5 & 6.6 & 7.0 & 7.3 & \\
\hline Consumption, apparent (steel) 5 & 110 & 105 & 111 & 101 & 100 \\
\hline \multicolumn{6}{|l|}{ Producer price index for steel mill products } \\
\hline$(1982=100)^{6}$ & 177.1 & 167.8 & 187.4 & 211.1 & 20 \\
\hline \multicolumn{6}{|l|}{ Total employment, average, number 6} \\
\hline Blast furnaces and steel mills & 87,000 & 83,900 & 80,600 & 82,100 & 83,000 \\
\hline Iron and steel foundries & 64,900 & 65,000 & 65,000 & 65,200 & 63,000 \\
\hline $\begin{array}{l}\text { Net import reliance } 7 \text { as a percentage of } \\
\text { apparent consumption }\end{array}$ & 29 & 25 & 26 & 22 & \\
\hline
\end{tabular}

Recycling: See Iron and Steel Scrap and Iron and Steel Slag.

Import Sources (2015-18): Canada, 17\%; Brazil, 13\%; Republic of Korea, 11\%; and other, 59\%.

\section{Tariff: Item}

Carbon steel:

Semifinished

Flat, hot-rolled

Flat, cold-rolled

Galvanized

Bars and rods, hot-rolled

Structural shapes

Stainless steel:

Semifinished

Flat-rolled sheets

Bars and rods
Number

7207.00 .0000

7208.00 .0000

7209.00 .0000

7210.00 .0000

7213.00 .0000

7216.00 .0000

7218.00 .0000

7219.00 .0000

7222.00 .0000
Normal Trade Relations 12-31-19

Free.

Free.

Free.

Free.

Free.

Free.

Free.

Free.

Free.

Depletion Allowance: Not applicable.

Government Stockpile: None. 


\section{IRON AND STEEL}

Events, Trends, and Issues: After several Presidential proclamations were issued in 2018 imposing 25\% ad valorem tariffs on steel imports from most countries of origin under the authority of Section 232 of the Trade Expansion Act of 1962 (83 FR 11625), the President of the United States modified proclamation 9705 and issued two additional proclamations in 2019. Presidential Proclamation 9886, issued in May 2019, reduced the ad valorem tariff on steel imports from Turkey to 25\% from 50\%. Also, in May 2019, Proclamation 9894 removed the Section 232 tariffs for steel imports from Canada and Mexico. Steel imports from all countries except Argentina, Australia, Brazil, Canada, Mexico, and the Republic of Korea still required a 25\% ad valorem tariff. In September 2018, March 2019, and June 2019, the U.S. Department of Commerce issued additional guidance in the Federal Register for companies to request product exemptions from the Section 232 tariffs.

The World Steel Association ${ }^{8}$ forecast global finished steel demand to increase by $3.9 \%$ in 2019 and $1.7 \%$ in 2020 , as a result of real estate investment in China and $4.1 \%$ growth in emerging and developing economies in 2020. Steel consumption in developed economies, except for China, was expected to remain the same or decrease slightly in 2019 despite growth in consumer and construction applications as potential and enacted trade policies affected investments and exports among the manufacturing sector. Growth of the construction sectors in 2019 and 2020 was expected to decrease slightly in the United States, as well as in the European Union, Latin America, Japan, and the Republic of Korea. In other countries in Asia, including India, Government stimulus was expected to increase demand in the construction sector. Automotive production rates were expected to decrease in 2019 in China, Germany, the Republic of Korea, and Turkey.

\section{World Production:}

\begin{tabular}{lrrrr} 
& \multicolumn{2}{c}{ Pig iron } & \multicolumn{2}{c}{ Raw steel } \\
United States & $\underline{\mathbf{2 0 1 8}}$ & $\underline{\mathbf{2 0 1 9}}$ & $\underline{\mathbf{2 0 1 8}}$ & $\underline{\mathbf{2 0 1 9}}$ \\
Brazil & 24 & 23 & 37 & 32 \\
China & 29 & 26 & 928 & 1,000 \\
Germany & 771 & 820 & 42 & 41 \\
India & 27 & 26 & 106 & 110 \\
Iran & 71 & 75 & 25 & 27 \\
Italy & 2 & 3 & 25 & 24 \\
Japan & 5 & 5 & 104 & 100 \\
Korea, Republic of & 77 & 75 & 72 & 72 \\
Mexico & 47 & 48 & 20 & 19 \\
Russia & 4 & 4 & 23 & 71 \\
Taiwan & 52 & 50 & 37 & 23 \\
Turkey & 15 & 16 & 21 & 34 \\
Ukraine & 11 & 10 & 18 & 22 \\
Vietnam & 21 & 21 & 198 & 194 \\
Other countries & 6 & 10 & 1,810 & 1,900
\end{tabular}

World Resources: Not applicable. See Iron Ore and Iron and Steel Scrap for steelmaking raw-material resources.

Substitutes: Iron is the least expensive and most widely used metal. In most applications, iron and steel compete either with less expensive nonmetallic materials or with more expensive materials that have a performance advantage. Iron and steel compete with lighter materials, such as aluminum and plastics, in the motor vehicle industry; aluminum, concrete, and wood in construction; and aluminum, glass, paper, and plastics in containers.

\footnotetext{
eEstimated.

${ }^{1}$ Production and shipments data source is the American Iron and Steel Institute; see also Iron and Steel Scrap and Iron Ore.

${ }^{2}$ More than $95 \%$ of iron made is transported in molten form to steelmaking furnaces located at the same site.

${ }^{3}$ Less than $1 / 2$ unit.

${ }^{4}$ Steel mill products. Source: Metals Service Center Institute.

${ }^{5}$ Defined as steel shipments + imports of finished steel mill products - total exports of steel mill products + adjustments for industry stock changes.

${ }^{6}$ Source: U.S. Department of Labor, Bureau of Labor Statistics, North American Industry Classification System Code 331100.

${ }^{7}$ Defined as total imports - total exports + adjustments for industry stock changes.

${ }^{8}$ World Steel Association, 2019, Short range outlook October 2019: Brussels, Belgium, World Steel Association press release, October 14, 6 p.
} 


\section{IRON AND STEEL SCRAP ${ }^{1}$}

(Data in million metric tons of metal unless otherwise noted)

Domestic Production and Use: In 2019, the total value of domestic purchases of iron and steel scrap (receipts of ferrous scrap by all domestic consumers from brokers, dealers, and other outside sources) and exports was estimated to be $\$ 17.6$ billion, approximately $17 \%$ less than the $\$ 21.1$ billion in 2018 and $4 \%$ more than the $\$ 16.8$ billion in 2017. U.S. apparent steel consumption, an indicator of economic growth, was estimated to have decreased slightly to 100 million tons in 2019 from 101 million tons in 2018. Manufacturers of pig iron, raw steel, and steel castings accounted for about $92 \%$ of scrap consumption by the domestic steel industry, using scrap together with pig iron and direct-reduced iron to produce steel products for the appliance, construction, container, machinery, oil and gas, transportation, and various other consumer industries. The ferrous castings industry consumed most of the remaining scrap to produce cast iron and steel products. Relatively small quantities of steel scrap were used for producing ferroalloys, for the precipitation of copper, and by the chemical industry; these uses collectively totaled less than 1 million tons.

During 2019, raw steel production was an estimated 87 million tons, up slightly from 86.6 million tons in 2018 . Net shipments of steel mill products were an estimated 87 million tons, up slightly from 86.4 million tons in 2018.

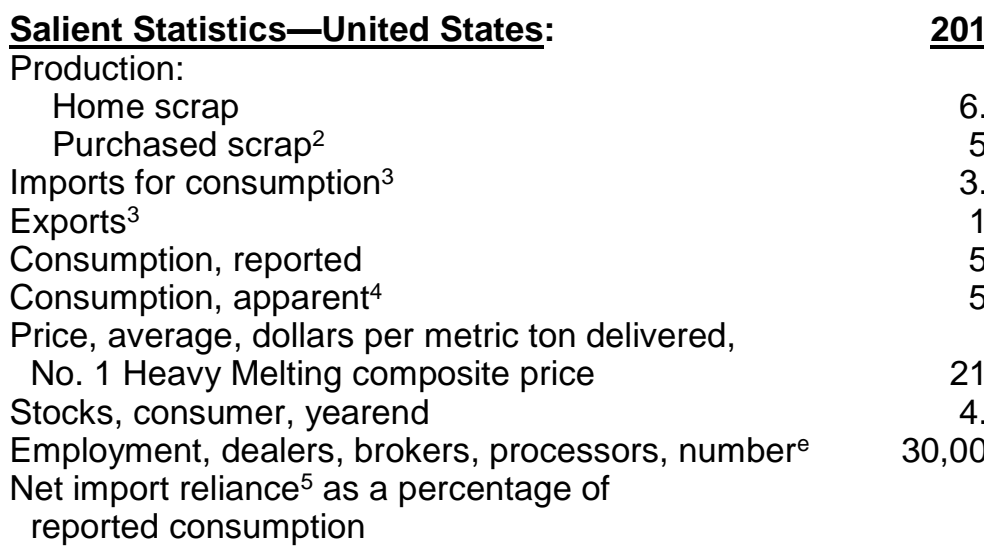

$\begin{array}{rrrrr}\underline{\mathbf{2 0 1 5}} & \underline{\mathbf{2 0 1 6}} & \underline{\mathbf{2 0 1 7}} & \underline{\mathbf{2 0 1 8}} & \underline{\mathbf{2 0 1 9}} \\ 6.3 & 5.9 & 5.6 & 5.8 & 5.8 \\ 54 & 53 & 55 & 59 & 59 \\ 3.5 & 3.9 & 4.6 & 5.0 & 4.5 \\ 13 & 13 & 15 & 17 & 18 \\ 51 & 50 & 50 & 52 & 53 \\ 51 & 50 & 51 & 52 & 52 \\ & & & & \\ 213 & 196 & 266 & 323 & 266 \\ 4.2 & 4.3 & 4.5 & 5.1 & 5.2 \\ 30,000 & 27,000 & 27,000 & 27,000 & 28,000 \\ & & E & E & E\end{array}$

Recycling: Recycled iron and steel scrap is a vital raw material for the production of new steel and cast iron products. The steel and foundry industries in the United States have been structured to recycle scrap, and, as a result, are highly dependent upon scrap. One ton of steel that is recycled conserves 1.1 tons of iron ore, 0.6 ton of coking coal, and 0.05 ton of limestone.

Overall, the scrap recycling rate in the United States has averaged between $80 \%$ and $90 \%$ during the past decade, with automobiles making up the primary source of old steel scrap. Recycling of automobiles is nearly $100 \%$ each year, with rates fluctuating slightly owing to the rate of new vehicle production and general economic trends. More than 15 million tons of steel is recycled from automobiles annually, the equivalent of approximately 12 million cars, from more than 7,000 vehicle dismantlers and 350 car shredders in North America. The recycling of steel from automobiles is estimated to save the equivalent energy necessary to power 18 million homes every year.

Recycling rates, which fluctuate annually, were estimated to be $98 \%$ for structural steel from construction, $88 \%$ for appliances, $71 \%$ for rebar and reinforcement steel, and $70 \%$ for steel packaging. The recycling rates for appliance, can, and construction steel are expected to increase in the United States and in emerging industrial countries at an even greater rate. Public interest in recycling continues, and recycling is becoming more profitable and convenient as environmental regulations for primary production increase.

Recycling of scrap plays an important role in the conservation of energy because the remelting of scrap requires much less energy than the production of iron or steel products from iron ore. Also, consumption of iron and steel scrap by remelting reduces the burden on landfill disposal facilities and prevents the accumulation of abandoned steel products in the environment. Recycled scrap consists of approximately $58 \%$ post-consumer (old, obsolete) scrap, $24 \%$ prompt scrap (produced in steel-product manufacturing plants), and $18 \%$ home scrap (recirculating scrap from current operations). 


\section{IRON AND STEEL SCRAP}

Import Sources (2015-18): Canada, 72\%; Mexico, 9\%; United Kingdom, 8\%; Sweden, 5\%; and other, 6\%.

\section{Tariff: Item}

Ferrous waste and scrap:

Stainless steel

Turnings, shavings, chips, milling waste, sawdust,

filings, trimmings, and stampings:

No. 1 bundles

No. 2 bundles

Borings, shovelings, and turnings

Other: Other

No. 1 heavy melting

No. 2 heavy melting

Cut plate and structural

Shredded

Remelting scrap ingots

Powders, of pig iron, spielgeleisen, iron, or steel:

Alloy steel

Other

\section{Number}

7204.21 .0000

7204.41 .0020

7204.41 .0040

7204.41 .0060

7204.41 .0080

7204.49 .0020

7204.49 .0040

7204.49 .0060

7204.49 .0070

7204.50 .0000

7205.21 .0000

7205.29 .0000
Normal Trade Relations 12-31-19

Free.

Free.

Free.

Free.

Free.

Free.

Free.

Free.

Free.

Free.

Free.

Free.

Depletion Allowance: Not applicable.

Government Stockpile: None.

Events, Trends, and Issues: In 2019, steel mill production capacity utilization peaked to the highest rates since April 2012, reaching $82.4 \%$ in February 2019 , with rates remaining over $80 \%$ between January and June. Composite prices published for No. 1 Heavy Melting steel scrap delivered averaged about \$271 per ton during the first 8 months of 2019 , a decrease from $\$ 323$ per ton in 2018 . The average monthly prices during this time fluctuated between a high of \$309.87 per ton in March and a low of \$225.91 per ton in July. In the first 8 months of 2019, Turkey was the primary destination for exports of ferrous scrap, by tonnage, accounting for $20 \%$ of total exports, followed by Canada $(11 \%)$, Taiwan (10\%), Vietnam (9\%), and Mexico (7\%). The value of exported scrap decreased to an estimated $\$ 5.3$ billion in 2019 from $\$ 5.9$ billion in 2018.

The World Steel Association ${ }^{6}$ forecast global finished steel demand to increase by $3.9 \%$ in 2019 and $1.7 \%$ in 2020 , as a result of real estate investment in China and $4.1 \%$ growth in emerging and developing economies in 2020. Steel demand among developed economies, except for China, was expected to remain the same or decrease slightly in 2019 despite growth in consumer and construction applications as potential and enacted trade policies affected investments and exports within the manufacturing sector. Growth of the construction sectors in 2019 and 2020 was expected to decrease slightly in the United States, as well as the European Union, Japan, Latin America, and the Republic of Korea. In other countries in Asia, including India, Government stimulus was expected to increase demand in the construction sector. Automotive production growth was also expected to decrease in 2019 in China, Germany, the Republic of Korea, and Turkey.

World Mine Production and Reserves: Not applicable.

World Resources: Not applicable.

Substitutes: An estimated 2.8 million tons of direct-reduced iron was used in the United States in 2019 as a substitute for iron and steel scrap, up from 2.4 million tons in 2018.

\footnotetext{
eEstimated. E Net exporter.

${ }^{1}$ See also Iron and Steel and Iron Ore.

${ }^{2}$ Defined as net receipts + exports - imports.

${ }^{3}$ Excludes used rails for rerolling and other uses, and ships, boats, and other vessels for scrapping.

${ }^{4}$ Defined as home scrap + purchased scrap + imports - exports + adjustments for industry stock changes.

${ }^{5}$ Defined as imports - exports + adjustments for industry stock changes.

${ }^{6}$ World Steel Association, 2019, Short range outlook October 2019: Brussels, Belgium, World Steel Association press release, October 14, 6 p.
} 


\section{IRON AND STEEL SLAG}

(Data in million metric tons unless otherwise noted)

Domestic Production and Use: Iron and steel (ferrous) slags are formed by the combination of slagging agents and impurities during the production of crude (or pig) iron and crude steel. The slags are tapped separately from the metals, cooled and processed, and are primarily used in the construction industry. Data are unavailable on actual U.S. ferrous slag production, but domestic slag sales ${ }^{1}$ in 2019 were estimated to be 17 million tons valued at about $\$ 470$ million. Blast furnace slag was about $50 \%$ of the tonnage sold and accounted for $88 \%$ of the total value of slag, most of which was granulated. Steel slag produced from basic oxygen and electric arc furnaces accounted for the remainder of sales. Slag was processed by 28 companies servicing active iron and steel facilities or reprocessing old slag piles at about 129 processing plants (including some iron and steel plants with more than one slag-processing facility) in 33 States, including facilities that import and grind unground slag to sell as ground granulated blast furnace slag (GGBFS).

Air-cooled iron slag and steel slag are used primarily as aggregates in concrete (air-cooled iron slag only); asphaltic paving, fill, and road bases; both slag types also can be used as a feed for cement kilns. Almost all GGBFS is used as a partial substitute for portland cement in concrete mixes or in blended cements. Pelletized slag is generally used for lightweight aggregate but can be ground into material similar to GGBFS. Actual prices per ton ranged in 2019 from a few cents for some steel slags at a few locations to about \$120 or more for some GGBFS. Owing to low unit values, most slag types can be shipped only short distances by truck, but rail and waterborne transportation allow for greater travel distances. Because much higher unit values make it economic to ship GGBFS longer distances, much of the GGBFS consumed in the United States is imported.

\begin{tabular}{|c|c|c|c|c|c|}
\hline Salient Statistics_-United States: & 2015 & 2016 & 2017 & 2018 & $2019^{\mathrm{e}}$ \\
\hline Production (sales) 1,2 & 17.7 & 15.7 & 16.2 & 16.8 & $\overline{17.0}$ \\
\hline Imports for consumption ${ }^{3}$ & 1.5 & 2.0 & 2.1 & 2.2 & 2.3 \\
\hline Exports & $(4)$ & (4) & $(4)$ & $(4)$ & (4) \\
\hline Consumption, apparent ${ }^{5}$ & 17.7 & 15.7 & 16.2 & 16.8 & 17.0 \\
\hline Price, average value, dollars per ton, f.o.b. plant 6 & 19.50 & 22.00 & 24.50 & 26.50 & 27.50 \\
\hline Employment, numbere & 1,700 & 1,600 & 1,500 & 1,500 & 1,600 \\
\hline $\begin{array}{l}\text { Net import reliance }{ }^{7} \text { as a percentage of } \\
\text { apparent consumption }\end{array}$ & 8 & 13 & 13 & 13 & 14 \\
\hline
\end{tabular}

Recycling: Following removal of entrained metal, slag can be returned to the blast and steel furnaces as ferrous and flux feed, but data on these returns are incomplete. Entrained metal, particularly in steel slag, is routinely recovered during slag processing for return to the furnaces and is an important revenue source for slag processors; data on metal returns are unavailable.

Import Sources (2015-18): Japan, 24\%; Canada, 20\%; Brazil, 12\%; Italy, 12\%; and other, 32\%.

Tariff: Item

Number

Granulated slag

Slag, dross, scale, from

manufacture of iron and steel
2618.00.0000

2619.00 .0000
Normal Trade Relations 12-31-19

Free.

Free. 


\section{IRON AND STEEL SLAG}

Depletion Allowance: Not applicable.

Government Stockpile: None.

Events, Trends, and Issues: In 2019, two blast furnaces were idled in the United States after two different blast furnaces were restarted in 2018. This continued the trend of U.S. blast furnaces being closed or idled in recent years (including four in 2015) and contributed to the reduction in the domestic supply of new blast furnace slag. However, many sites have large slag stockpiles, which can allow for processing to continue for several years after the furnaces are closed or idled. The majority of U.S steel slag production is from electric arc furnaces.

At yearend 2019, domestic GGBFS remained in limited supply because granulation cooling was available at only two active U.S. blast furnaces. It remained unclear if new granulation cooling installations at additional blast furnace sites would be economic. Another plant produced a limited supply of pelletized slag, but it was uncertain if additional pelletizing capacity would be added. Grinding of granulated blast furnace slag was only done domestically by cement companies. Supply constraints appear to have limited domestic consumption of GGBFS in recent years. Although prices have increased, sales of GGBFS have not correlated with the increases in the quantity of cement sold since 2010.

The domestic supply of fly ash, which is used as an additive in concrete production, has decreased, owing to new restrictions of mercury and carbon dioxide $\left(\mathrm{CO}_{2}\right)$ emissions at coal-fired powerplants, powerplant closures, and conversion of powerplants to natural gas. Mercury emission restrictions on cement plants, enacted in 2015, may reduce the demand for fly ash as a raw material in clinker manufacture, and air-cooled and steel slags could be used as substitute raw materials. Demand for GGBFS is likely to increase because its use in cement yields a superior product in many applications and reduces the unit $\mathrm{CO}_{2}$ emissions in the production of the cement.

World Mine Production and Reserves: Because slag is not mined, the concept of reserves does not apply. World production data for slag were unavailable, but may be estimated as $25 \%$ to $30 \%$ of crude (pig) iron production and steel furnace slag as $10 \%$ to $15 \%$ of crude steel production. In 2019 , world iron slag production was estimated to be between 320 million to 384 million tons, with steel slag production estimated to be between 190 million to 280 million tons.

World Resources: Not applicable.

Substitutes: In the construction sector, ferrous slags compete with natural aggregates (crushed stone and sand and gravel) but are far less widely available than the natural materials. As a cementitious additive in blended cements and concrete, GGBFS mainly competes with fly ash, metakaolin, and volcanic ash pozzolans. In this respect, GGBFS reduces the amount of portland cement per ton of concrete, thus allowing more concrete to be made per ton of portland cement. Slags (especially steel slag) can be used as a partial substitute for limestone and some other natural raw materials for clinker (cement) manufacture and compete in this use with fly ash and bottom ash. Some other metallurgical slags, such as copper slag, can compete with ferrous slags in some specialty markets, such as a ferrous feed in clinker manufacture, but are generally in much more restricted supply than ferrous slags.

\footnotetext{
${ }^{e}$ Estimated.

${ }^{1}$ Processed slag sold during the year, excluding entrained metal.

${ }^{2}$ Data include sales of imported granulated blast furnace slag and exclude sales of pelletized slag.

${ }^{3}$ U.S. Census Bureau data adjusted by the U.S. Geological Survey to remove nonslag materials (such as cenospheres, fly ash, and silica fume) and slags or other residues of other metallurgical industries (especially copper slag), whose unit values are outside the range expected for granulated slag. In some years, tonnages may be underreported.

${ }^{4}$ Less than 0.05 million tons.

${ }^{5}$ Defined as total sales of slag - exports.

${ }^{6}$ Rounded to the nearest $\$ 0.50$ per ton.

${ }^{7}$ Defined as imports - exports.
} 


\section{IRON ORE ${ }^{1}$}

(Data in thousand metric tons, usable ore, unless otherwise noted)

Domestic Production and Use: In 2019, mines in Michigan and Minnesota shipped 98\% of the usable iron ore products consumed in the steel industry in the United States with an estimated value of $\$ 5.4$ billion, an increase from $\$ 4.6$ billion in 2018. The remaining $2 \%$ of domestic iron ore was produced for nonsteel end uses. Seven open-pit iron ore mines (each with associated concentration and pelletizing plants), and three iron metallic plants-one directreduced iron (DRI) plant in Louisiana and two hot-briquetted iron ( $\mathrm{HBI}$ ) plants in Indiana and Texas-operated during the year to supply steelmaking raw materials. The United States was estimated to have produced $1.9 \%$ and consumed $2.0 \%$ of the world's iron ore output.

\begin{tabular}{|c|c|c|c|c|c|}
\hline \multicolumn{6}{|l|}{$\begin{array}{l}\text { Salient Statistics-United States: } \\
\text { Production: }\end{array}$} \\
\hline Iron ore & 46,100 & 41,800 & 47,900 & 49,500 & 48,000 \\
\hline Iron metallics & 1,450 & 2,070 & 3,250 & 3,560 & 3,700 \\
\hline Shipments & 43,500 & 46,600 & 46,900 & 50,400 & 50,000 \\
\hline Imports for consumption & 4,550 & 3,010 & 3,710 & 3,810 & 5,100 \\
\hline Exports & 7,500 & 8,710 & 10,600 & 13,000 & 13,000 \\
\hline \multicolumn{6}{|l|}{ Consumption: } \\
\hline Reported & 38,500 & 34,500 & 34,400 & 36,600 & 37,000 \\
\hline Apparent ${ }^{3}$ & 42,100 & 37,900 & 40,100 & 41,200 & 41,000 \\
\hline Value, U.S. dollars per metric ton & 81.19 & 73.11 & 78.54 & 93.00 & 112.15 \\
\hline $\begin{array}{l}\text { Stocks, mine, dock, and consuming } \\
\text { plant, yearend, excluding byproduct ore }\end{array}$ & 4,760 & 2,990 & 3,930 & 3,100 & 2,700 \\
\hline $\begin{array}{l}\text { Employment, mine, concentrating and } \\
\text { pelletizing plant, number }\end{array}$ & 4,800 & 4,660 & 4,630 & 4,860 & 4,800 \\
\hline $\begin{array}{l}\text { Net import reliance } 4 \text { as a percentage of } \\
\text { apparent consumption (iron content of ore) }\end{array}$ & $E$ & $E$ & $E$ & $\mathrm{E}$ & $\mathrm{E}$ \\
\hline
\end{tabular}

Recycling: None. See Iron and Steel Scrap.

Import Sources (2015-18): Brazil, 55\%; Canada, 28\%; Sweden, 6\%, Chile, 4\%; and other, 7\%.

\section{Tariff: Item}

Iron ores and concentrates:

Concentrates

Coarse ores

Other ores

Pellets

Briquettes

Sinter

Roasted iron pyrites
Number

2601.11.0030

2601.11.0060

2601.11.0090

2601.12.0030

2601.12.0060

2601.12.0090

2601.20.0000
Normal Trade Relations 12-31-19

Free.

Free.

Free.

Free.

Free.

Free.

Free.

Depletion Allowance: 15\% (Domestic), 14\% (Foreign).

Government Stockpile: None.

Events, Trends, and Issues: U.S. iron ore production was estimated to have decreased slightly in 2019 owing to a decrease in domestic pig iron production and raw steel production from basic oxygen furnaces. Total raw steel production was estimated to have increased to 87 million tons in 2019 from 86.6 million tons in 2018. The share of steel produced by basic oxygen furnaces, the process that uses iron ore, continued to decline from $37.3 \%$ in 2015 to an estimated 30\% in 2019 owing to increased use of electric arc furnaces because of their energy efficiency, reduced environmental impacts, and the ready supply of scrap.

Overall, global prices trended upwards in 2019 and the annual average value of $\$ 112.15$ per ton was a $21 \%$ increase from $\$ 93.00$ per ton in 2018 . Based on reported prices for iron ore fines (62\% iron content) imported into China (cost and freight into Tianjin port), the highest monthly average price during the first 10 months of 2019 was $\$ 120.24$ per ton in July compared with the high of $\$ 77.46$ per ton in February 2018. The lowest monthly average price during the same period in 2019 was $\$ 76.16$ per ton in January compared with the low of $\$ 64.56$ per ton in July 2018 . The prices trended upwards owing to an estimated $4 \%$ increase in raw steel production and a reduced supply of higher grade iron ore products, spurred partially by closures of pelletizing plants in Brazil. 


\section{IRON ORE}

In August, one company completed a project at an iron-ore-processing facility in Minnesota enabling the plant to produce 3.5 million tons per year of direct-reduced-iron-grade pellets that will feed into a hot-briquetted plant under construction in Ohio, which was expected to open in mid-2020. Globally, iron ore production in 2019 was expected to increase by $5 \%$ from that of 2018, primarily owing to increased production in Australia, Brazil, China, and India.

Global finished steel demand was forecast by the World Steel Association ${ }^{5}$ to increase by $3.9 \%$ in 2019 and $1.7 \%$ in 2020, as a result of real estate investment in China and 4.1\% growth in emerging and developing economies in 2020. Steel demand among developed economies, except for China, was expected to remain the same or decrease slightly in 2019 despite growth in consumer and construction applications as potential and enacted trade policies impacted investments and exports among the manufacturing sector. Increased pressure on steel producers around the world to increase efficiency, reduce energy consumption, and meet environmental benchmarks continued the slow decline in use of low-grade iron ore and spurred investment in the production of iron metallics and high-grade iron ore products, such as pellets.

World Mine Production and Reserves: Reserves for Australia, Brazil, India, South Africa, and the United States were revised based on Government and industry sources.

\begin{tabular}{|c|c|c|c|c|c|c|}
\hline \multicolumn{7}{|c|}{ Mine production } \\
\hline & \multicolumn{2}{|c|}{ Usable ore } & \multicolumn{2}{|c|}{ Iron content } & \multicolumn{2}{|c|}{ Reserves $^{6,7}$} \\
\hline & 2018 & $\underline{2019^{e}}$ & $\underline{2018}$ & $\underline{2019^{e}}$ & Crude ore & Iron content \\
\hline United States & $4 \overline{9,500}$ & $4 \overline{8,000}$ & $3 \overline{1,300}$ & $3 \overline{1,000}$ & 3,000 & 1,000 \\
\hline Australia & 900,000 & 930,000 & 557,000 & 580,000 & 848,000 & ${ }^{8} 23,000$ \\
\hline Brazil & 460,000 & 480,000 & 250,000 & 260,000 & 29,000 & 15,000 \\
\hline Canada & 52,400 & 54,000 & 31,500 & 33,000 & 6,000 & 2,300 \\
\hline Chile & 14,000 & 14,000 & 8,940 & 9,000 & NA & NA \\
\hline China & 335,000 & 350,000 & 209,000 & 220,000 & 20,000 & 6,900 \\
\hline India & 205,000 & 210,000 & 126,000 & 130,000 & 5,500 & 3,400 \\
\hline Iran & 36,400 & 38,000 & 23,900 & 25,000 & 2,700 & 1,500 \\
\hline Kazakhstan & 41,900 & 43,000 & 11,700 & 12,000 & 2,500 & 900 \\
\hline Mexico & 22,300 & 23,000 & 14,000 & 14,000 & NA & NA \\
\hline Peru & 14,200 & 15,000 & 9,530 & 10,000 & NA & NA \\
\hline Russia & 96,100 & 99,000 & 56,700 & 59,000 & 25,000 & 14,000 \\
\hline South Africa & 74,300 & 77,000 & 47,200 & 49,000 & 1,100 & 690 \\
\hline Sweden & 35,800 & 37,000 & 22,200 & 23,000 & 1,300 & 600 \\
\hline Ukraine & 60,300 & 62,000 & 37,700 & 39,000 & 96,500 & 92,300 \\
\hline Other countries & 62,500 & 62,000 & 35,800 & 35,000 & 18,000 & 9,500 \\
\hline World total (rounded) & $\overline{2,460,000}$ & $\overline{2,500,000}$ & $\overline{1,470,000}$ & $\overline{1,500,000}$ & $\frac{170,000}{170}$ & $\overline{81,000}$ \\
\hline
\end{tabular}

World Resources: U.S. resources are estimated to be 110 billion tons of iron ore containing about 27 billion tons of iron. U.S. resources are mainly low-grade taconite-type ores from the Lake Superior district that require beneficiation and agglomeration prior to commercial use. World resources are estimated to be greater than 800 billion tons of crude ore containing more than 230 billion tons of iron.

Substitutes: The only source of primary iron is iron ore, used directly as direct-shipping ore or converted to briquettes, concentrates, DRI, iron nuggets, pellets, or sinter. DRI, iron nuggets, and scrap are extensively used for steelmaking in electric arc furnaces and in iron and steel foundries. Technological advancements have been made, which allow hematite to be recovered from tailings basins and pelletized.

\footnotetext{
eEstimated. E Net exporter. NA Not available.

${ }^{1}$ Data are for iron ore used as a raw material in steelmaking unless otherwise noted. See also Iron and Steel and Iron and Steel Scrap.

${ }^{2}$ Except where noted, salient statistics are for all forms of iron ore used in steelmaking, and do not include iron metallics, which include DRI, hotbriquetted iron, and iron nuggets.

${ }^{3}$ Defined as production + imports - exports + adjustments for industry stock changes.

${ }^{4}$ Defined as imports - exports + adjustments for industry stock changes.

${ }^{5}$ World Steel Association, 2019, Short range outlook October 2019: Brussels, Belgium, World Steel Association press release, October 14, 6 p.

${ }^{6}$ See Appendix $\mathrm{C}$ for resource and reserve definitions and information concerning data sources.

${ }^{7}$ Million metric tons.

${ }^{8}$ For Australia, Joint Ore Reserves Committee-compliant reserves were 24 billion tons for crude ore and 11 billion tons for iron content.

${ }^{9}$ For Ukraine, reserves consist of the A+B categories of the Soviet reserves classification system.
} 


\section{IRON OXIDE PIGMENTS}

(Data in metric tons unless otherwise noted)

Domestic Production and Use: Iron oxide pigments (IOPS) were mined domestically by two companies in two States. Mine production, which was withheld to avoid disclosing company proprietary data, decreased in 2019 from that of 2018. Five companies, including the two producers of natural IOPs, processed and sold about 38,000 tons of finished natural and synthetic IOPs with an estimated value of \$52 million, significantly below the most recent sales peak of 88,100 tons in 2007 . About $59 \%$ of natural and synthetic finished IOPs were used in concrete and other construction materials; $11 \%$ in plastics; $7 \%$ in coatings and paints; $5 \%$ in foundry sands and other foundry uses; $3 \%$ each in animal food, industrial chemicals, and glass and ceramics; and 9\% in other uses.

\section{Salient Statistics-United States:}

Mine production, crude

Sold or used, finished natural and synthetic IOP Imports for consumption

Exports, pigment grade

Consumption, apparent ${ }^{1}$

Price, average value, dollars per kilogram ${ }^{2}$

Employment, mine and mill

Net import reliance ${ }^{3}$ as a percentage of:

Apparent consumption

Reported consumption

$\begin{array}{rrrrr}\frac{\mathbf{2 0 1 5}}{W} & \frac{\mathbf{2 0 1 6}}{W} & \underline{\mathbf{2 0 1 7}} & \frac{\mathbf{2 0 1 8}}{W} & \frac{\mathbf{2 0 1 9}}{W} \\ 53,500 & 48,500 & 47,300 & 48,200 & 38,000 \\ 176,000 & 179,000 & 179,000 & 179,000 & 160,000 \\ 8,930 & 15,800 & 13,500 & 11,100 & 9,900 \\ 221,000 & 212,000 & 213,000 & 216,000 & 190,000 \\ 1.46 & 1.46 & 1.46 & 1.58 & 1.40 \\ 55 & 60 & 60 & 60 & 55 \\ W & W & W & W & W \\ >50 & >50 & >50 & >50 & >50\end{array}$

Recycling: None.

Import Sources (2015-18): Natural: Spain, 43\%; Cyprus, 36\%; Austria, 10\%; France, 9\%; and other, 2\%.

Synthetic: China, 50\%; Germany, 28\%; Brazil, 6\%, Canada, 4\%, and other, 12\%. Total: China, 48\%; Germany, 28\%; Brazil, 6\%; Canada, 4\%; and other, 14\%.

\section{Tariff: Item}

Natural:

Micaceous iron oxides

Earth colors

Iron oxides and hydroxides containing

$70 \%$ or more by weight $\mathrm{Fe}_{2} \mathrm{O}_{3}$ :

Synthetic:

Black

Red

Yellow

Other

Earth colors

\section{Number}

2530.90.2000

2530.90.8015

2821.10.0010

2821.10.0020

2821.10.0030

2821.10.0040

2821.20.0000
Normal Trade Relations 12-31-19

$2.9 \%$ ad val.

Free.

$3.7 \%$ ad val.

$3.7 \%$ ad val.

$3.7 \%$ ad val.

$3.7 \%$ ad val.

$5.5 \%$ ad val.

Depletion Allowance: 14\% (Domestic and foreign).

Government Stockpile: None. 


\section{IRON OXIDE PIGMENTS}

Events, Trends, and Issues: In 2019, domestic mine production of crude ntural IOPs decreased owing to a major producer reducing mine output to draw down stocks after excess crude production in 2016 and 2017. Production and sales of finished natural and synthetic IOPs decreased by about 21\%. Production and sales of synthetic IOPs also decreased in 2019, owing in part to a decrease in natural-disaster-related construction and refurbishment projects. In the United States, residential construction, in which IOPs are commonly used to color concrete block and brick, ready-mixed concrete, and roofing tiles, remained about the same during the first 9 months of 2019 compared with that of the same period in 2018. Housing starts decreased slightly.

Exports of pigment-grade IOPs decreased by about 11\% during the first 9 months of 2019 compared with that during the same period in 2018, mostly owing to a significant decrease in exports to Malaysia, the Netherlands, and Thailand. More than $87 \%$ of pigment-grade IOPs went to Mexico, China, Belgium, Chile, Brazil, Thailand, the United Kingdom, and Germany, in descending order of quantity. Exports of other grades of iron oxides and hydroxides, nearly double those of pigment grade, increased by about $47 \%$ during the first 9 months of 2019 compared with those of the same period in 2018. About $98 \%$ of exports of other grades of iron oxides and hydroxides went to Spain, Canada, China, Mexico, Israel, Argentina, and Australia in descending order of quantity. Total imports of natural and synthetic IOPs decreased slightly in 2019 compared with those in 2018.

World Mine Production and Reserves: Reserves for Pakistan were revised based on Government information.

United States
Austria (micaceous IOP)
Cyprus (umber)
France
Germany
India (ocher)
Italy
Pakistan (ocher)
Spain (ocher and red iron oxide)
$\quad$ World total

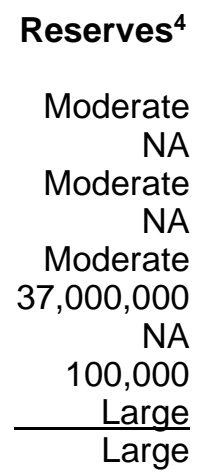

World Resources: Domestic and world resources for production of IOPs are adequate. Adequate resources are available worldwide for the manufacture of synthetic IOPs.

Substitutes: Milled IOPs are thought to be the most commonly used natural minerals for pigments. Because IOPs are color stable, low cost, and nontoxic, they can be economically used for imparting black, brown, red, and yellow coloring in large and relatively low-value applications. Other minerals may be used as colorants, but they generally cannot compete with IOPs because of their higher costs and more limited availability. Synthetic IOPs are widely used as colorants and compete with natural IOPs in many color applications. Organic colorants are used for some colorant applications, but many of the organic compounds fade over time from exposure to sunlight.

\footnotetext{
eEstimated. NA Not available. W Withheld to avoid disclosing company proprietary data.

${ }^{1}$ Defined as sold or used finished natural and synthetic IOPs + imports - exports.

${ }^{2}$ Average unit value for finished iron oxide pigments sold or used by U.S. producers.

${ }^{3}$ Defined as imports - exports.

${ }^{4}$ See Appendix $\mathrm{C}$ for resource and reserve definitions and information concerning data sources.

${ }^{5}$ Includes natural and synthetic IOP.

${ }^{6}$ A significant number of other countries, including Azerbaijan, Brazil, China, Honduras, Iran, Kazakhstan, Lithuania, Paraguay, Russia, South Africa, Turkey, Ukraine, and the United Kingdom, are thought to produce IOPs, but output was not reported and no basis was available to make reliable estimates of production.
} 


\section{KYANITE AND RELATED MINERALS}

(Data in metric tons unless otherwise noted)

Domestic Production and Use: In Virginia, one firm with integrated mining and processing operations produced an estimated 90,000 tons of kyanite worth $\$ 33$ million from two hard-rock open pit mines and synthetic mullite by calcining kyanite. Two other companies, one in Alabama and another in Georgia, produced synthetic mullite from materials mined from four sites; each company sourced materials from one site in Alabama and one site in Georgia. Synthetic mullite production data are withheld to avoid disclosing company proprietary data. Commercially produced synthetic mullite is made by sintering or fusing such feedstock materials as kyanite, kaolin, bauxite, or bauxitic kaolin. Natural mullite occurrences typically are rare and uneconomic to mine. Of the kyanite-mullite output, $90 \%$ was estimated to have been used in refractories and $10 \%$ in other uses, including abrasive products, such as motor vehicle brake shoes and pads and grinding and cutting wheels; ceramic products, such as electrical insulating porcelains, sanitaryware, and whiteware; foundry products and precision casting molds; and other products. An estimated $60 \%$ to $65 \%$ of the refractory use was by the iron and steel industries, and the remainder was by industries that manufacture chemicals, glass, nonferrous metals, and other materials. Andalusite was commercially mined from an andalusite-pyrophyllite-sericite deposit in North Carolina and processed as a blend of primarily andalusite for use by producers of refractories in making firebrick.

\begin{tabular}{|c|c|c|c|c|c|}
\hline$\frac{\text { Salient Statistics_-United States: }}{\text { Production: }}$ & $\underline{2015}$ & $\underline{2016}$ & $\underline{2017}$ & $\underline{2018}$ & $\underline{2019^{e}}$ \\
\hline Mine & ${ }^{1} 109,000$ & 179,700 & 191,300 & 189,200 & 90,000 \\
\hline Synthetic mullite & W & W & W & W & W \\
\hline Imports for consumption (andalusite) & 11,500 & 2,510 & 7,420 & 8,590 & 9,000 \\
\hline Exports (kyanite) & 39,900 & 37,100 & 42,400 & 43,000 & 40,000 \\
\hline Consumption, apparent ${ }^{2}$ & W & W & W & W & W \\
\hline Price, average, dollars per metric ton: ${ }^{3}$ & & & & & \\
\hline U.S. kyanite, raw concentrate & 270 & 270 & 270 & NA & NA \\
\hline U.S. kyanite, calcined & 410 & 420 & 420 & NA & NA \\
\hline Employment, kyanite mine, office, and plant, numbere & 155 & 150 & 140 & 150 & 150 \\
\hline Employment, mullite plant, office, and plant, numbere & 220 & 210 & 200 & 200 & 200 \\
\hline $\begin{array}{l}\text { Net import reliance } 4 \text { as a percentage of } \\
\text { apparent consumption }\end{array}$ & $E$ & $E$ & $\mathrm{E}$ & $\mathrm{E}$ & $\mathrm{E}$ \\
\hline
\end{tabular}

Recycling: Insignificant.

Import Sources (2015-18): South Africa, 75\%; Peru, 19\%; France, 4\%; and other, 2\%.

\section{Tariff: Item}

Andalusite, kyanite, and sillimanite Mullite
Number

2508.50.0000

2508.60.0000
Normal Trade Relations

$\underline{12-31-19}$

Free.

Free. 


\section{KYANITE AND RELATED MINERALS}

Depletion Allowance: 22\% (Domestic), 14\% (Foreign).

Government Stockpile: None.

Events, Trends, and Issues: Crude steel production in the United States, which ranked fourth in the world, increased by about $4 \%$ in the first 8 months of 2019 compared with that of the same period in 2018, indicating a similar change in consumption of kyanite-mullite refractories. Total world steel production similarly increased by about $4 \%$ during the first 8 months of 2019 compared with that of the same period in 2018. The increase in world steel production during the first 8 months of 2019 was the result of sustained growth in China with a 9\% increase in steel production. The steel industry continued to be the largest market for refractories.

In June 2019, a company in South Africa suspended production for more than 1 month after entering business rescue proceedings resulting from financial setbacks. The company accounted for almost one-third of global andalusite output. The complications were the result of low prices and weakening demand for refractories globally. Bauxite and mullite could receive increased consideration as alternatives to refractory andalusite, if andalusite producers are unable to meet demand in 2020.

\section{World Mine Production and Reserves:}

\begin{tabular}{lrrr} 
& \multicolumn{2}{c}{ Mine production } & Reserves $^{5}$ \\
United States (kyanite) & $\underline{\mathbf{2 0 1 8}}$ & $\underline{\mathbf{2 0 1 9}}$ & Large \\
India (kyanite and sillimanite) & 189,200 & 90,000 & $7,190,000$ \\
Peru (andalusite) & 101,000 & 110,000 & NA \\
South Africa (andalusite) & 40,000 & 40,000 & NA \\
$\quad$ World total (rounded) & $\frac{200,000}{6 \mathrm{NA}}$ & $\frac{190,000}{6 \mathrm{NA}}$ & $\mathrm{NA}$
\end{tabular}

World Resources: Large resources of kyanite and related minerals are known to exist in the United States. The chief resources are in deposits of micaceous schist and gneiss, mostly in the Appalachian Mountains and in Idaho. Other resources are in aluminous gneiss in southern California. These resources are not economic to mine at present. The characteristics of kyanite resources in the rest of the world are thought to be similar to those in the United States. Significant resources of andalusite are known to exist in China, France, Peru, and South Africa; kyanite resources have been identified in Brazil, India, and Russia; and sillimanite has been identified in India.

Substitutes: Two types of synthetic mullite (fused and sintered), superduty fire clays, and high-alumina materials are substitutes for kyanite in refractories. Principal raw materials for synthetic mullite are bauxite, kaolin and other clays, and silica sand.

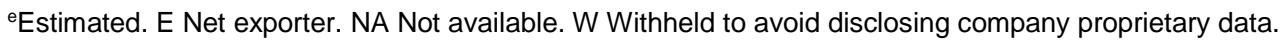

${ }^{1}$ Source: Virginia Department of Mines, Minerals and Energy.

${ }^{2}$ Defined as production + imports - exports.

${ }^{3}$ Source: Average of prices reported in Industrial Minerals.

${ }^{4}$ Defined as imports - exports.

${ }^{5}$ See Appendix $\mathrm{C}$ for resource and reserve definitions and information concerning data sources.

${ }^{6}$ In addition to the countries listed, France continued production of andalusite and Cameroon and China produced kyanite and related minerals.

Output was not reported quantitatively, and no reliable basis was available for estimation of output levels.
} 


\section{LEAD}

(Data in thousand metric tons of lead content unless otherwise noted)

Domestic Production and Use: Six lead mines in Missouri, plus five mines in Alaska, Idaho, and Washington that produced lead as a principal product or byproduct, accounted for all domestic lead mine production. The value of the lead in concentrates mined in 2019, based on the average North American Market price for refined lead, was about $\$ 630$ million. Nearly all lead mine production has been exported since the last primary refinery closed in 2013 . The 12 secondary refineries in 10 States accounted for more than $95 \%$ of the secondary lead produced in 2019 . It was estimated that the lead-acid battery industry accounted for about 93\% of reported U.S. lead consumption during 2019. Lead-acid batteries were primarily used as starting-lighting-ignition (SLI) batteries for automobiles, as industrial-type batteries for standby power for computer and telecommunications networks, and for motive power. During the first 9 months of 2019, 97 million lead-acid automotive batteries were shipped by North American producers, a 3\% decrease from those shipped in the same period of 2018.

\begin{tabular}{|c|c|c|c|c|c|}
\hline$\frac{\text { Salient Statistics-United States: }}{\text { Production: }}$ & $\underline{2015}$ & $\underline{2016}$ & $\underline{2017}$ & $\underline{2018}$ & $\underline{2019^{e}}$ \\
\hline \multicolumn{6}{|l|}{ Production: } \\
\hline Mine, lead in concentrates & 370 & 346 & 310 & 280 & 280 \\
\hline Primary refinery & - & - & - & - & - \\
\hline Secondary refinery, old scrap & 1,050 & 1,110 & 1,140 & 1,140 & 1,200 \\
\hline \multicolumn{6}{|l|}{ Imports for consumption: } \\
\hline Lead in concentrates & - & - & $(1)$ & - & $\left({ }^{1}\right)$ \\
\hline Refined metal, unwrought (gross weight) & 521 & 533 & 658 & 563 & 520 \\
\hline \multicolumn{6}{|l|}{ Exports: } \\
\hline Lead in concentrates & 350 & 341 & 269 & 251 & 260 \\
\hline Refined metal, unwrought (gross weight) & 56 & 43 & 24 & 67 & 28 \\
\hline Consumption, apparent ${ }^{2}$ & 1,510 & 1,600 & 1,770 & 1,630 & 1,650 \\
\hline \multicolumn{6}{|l|}{ Price, average, cents per pound: ${ }^{3}$} \\
\hline North American market & 91.2 & 94.4 & 114.5 & 110.9 & 100.0 \\
\hline London Metal Exchange (LME), cash & 81.0 & 84.8 & 105.1 & 101.8 & 91.0 \\
\hline \multicolumn{6}{|l|}{ Employment, number: } \\
\hline Mine and mill (average) ${ }^{4}$ & 1,970 & 1,970 & 1,890 & 1,870 & 1,790 \\
\hline $\begin{array}{l}\text { Net import reliance } 5 \text { as a percentage of } \\
\text { apparent consumption, refined metal }\end{array}$ & 31 & 31 & 36 & 30 & 30 \\
\hline
\end{tabular}

Recycling: In 2019, about 1.2 million tons of secondary lead was produced, an amount equivalent to $73 \%$ of apparent domestic consumption. Nearly all secondary lead was recovered from old scrap, mostly lead-acid batteries.

Import Sources (2015-18): Refined metal: Canada, 44\%; Mexico, 18\%; Republic of Korea, 17\%; India, 5\%; and other, $16 \%$.

\section{Tariff: Item}

Lead ores and concentrates,

lead content

Refined lead

Antimonial lead

Alloys of lead

Other unwrought lead
Number

2607.00.0020

7801.10 .0000

7801.91 .0000

7801.99 .9030

7801.99 .9050

\section{Normal Trade Relations 12-31-19}

$1.1 \$ / \mathrm{kg}$ on lead content. $2.5 \%$ on the value of the lead content. $2.5 \%$ on the value of the lead content. $2.5 \%$ on the value of the lead content. $2.5 \%$ on the value of the lead content.

Depletion Allowance: 22\% (Domestic), 14\% (Foreign).

Government Stockpile: None. 


\section{LEAD}

Events, Trends, and Issues: During the first 11 months of 2019, the average LME cash price for lead was 91 cents per pound, $11 \%$ less than the average price in 2018. Global stocks of lead in LME-approved warehouses were 67,275 tons in mid-December 2019, which was 37\% less than those at yearend 2018.

In 2019 , domestic mine production was estimated to be essentially unchanged from that in the previous year in all four lead-producing States. Production at one mine in Idaho continued to be relatively low owing to an employee strike, which began in March 2017. The United States has become more reliant on imported refined lead in recent years owing to the closure of the last primary lead smelter in 2013. In the first 10 months of 2019, 22.9 million spent SLI lead-acid batteries were exported, essentially unchanged compared with that in the same time period in 2018.

According to the International Lead and Zinc Study Group, ${ }^{6}$ global refined lead production in 2019 decreased by $0.3 \%$ to 11.76 million tons, and metal consumption decreased by $0.5 \%$ to 11.81 million tons, resulting in a production-toconsumption deficit of about 50,000 tons of refined lead owing to the decline in automobile production and increased uses of lithium-ion batteries.

World Mine Production and Reserves: Reserves estimates for Australia, Peru, and Turkey were revised based on new information from company or Government reports.

\begin{tabular}{lrrr} 
& \multicolumn{2}{c}{ Mine production } & Reserves $^{\mathbf{7}}$ \\
United States & $\mathbf{2 0 1 8}$ & $\underline{\mathbf{2 0 1 9}}$ & \\
Australia & 280 & 480 & 5,000 \\
Bolivia & 432 & 430 & 836,000 \\
China & 112 & 100 & 1,600 \\
India & 2,100 & 2,100 & 18,000 \\
Kazakhstan & 192 & 190 & 2,500 \\
Mexico & 86 & 90 & 2,000 \\
Peru & 240 & 240 & 5,600 \\
Russia & 289 & 290 & 6,300 \\
Sweden & 220 & 220 & 6,400 \\
Turkey & 65 & 60 & 1,100 \\
Other countries $\quad 76$ & 70 & 860 \\
$\quad$ World total (rounded) & 468 & 430 & 5,000 \\
\hline
\end{tabular}

World Resources: Identified world lead resources total more than 2 billion tons. In recent years, significant lead resources have been identified in association with zinc and (or) silver or copper deposits in Australia, China, Ireland, Mexico, Peru, Portugal, Russia, and the United States (Alaska).

Substitutes: Substitution by plastics has reduced the use of lead in cable covering and cans. Tin has replaced lead in solder for potable water systems. The electronics industry has moved toward lead-free solders and flat-panel displays that do not require lead shielding. Steel and zinc are common substitutes for lead in wheel weights.

\footnotetext{
eEstimated. — Zero.

${ }^{1}$ Less than $1 / 2$ unit.

${ }^{2}$ Defined as primary refined production + secondary refined production (old scrap) + refined imports - refined exports.

${ }^{3}$ Source: Platts Metal Week.

${ }^{4}$ Includes lead and zinc-lead mines for which lead was either a principal product or significant byproduct.

${ }^{5}$ Defined as imports - exports.

${ }^{6}$ International Lead and Zinc Study Group, 2019, ILZSG session/forecasts: Lisbon, Portugal, International Lead and Zinc Study Group news release, October $28,7 \mathrm{p}$.

${ }^{7}$ See Appendix $C$ for resource and reserve definitions and information concerning data sources.

${ }^{8}$ For Australia, Joint Ore Reserves Committee-compliant reserves were 12 million tons.
} 


\section{LIME $^{1}$}

(Data in thousand metric tons unless otherwise noted)

Domestic Production and Use: In 2019, an estimated 18 million tons of quicklime and hydrate was produced (excluding independent commercial hydrators ${ }^{2}$ ), valued at about $\$ 2.4$ billion. At yearend, 28 companies were producing lime, which included 18 companies with commercial sales and 10 companies that produced lime strictly for internal use (for example, sugar companies). These companies had 74 primary lime plants (plants operating quicklime kilns) in 28 States and Puerto Rico. Six of these 28 companies operated only hydrating plants in 11 States. In 2019, the five leading U.S. lime companies produced quicklime or hydrate in 21 States and accounted for about $80 \%$ of U.S. lime production. Principal producing States were, in alphabetical order, Alabama, Kentucky, Missouri, Ohio, and Texas. Major markets for lime were, in descending order of consumption, steelmaking, chemical and industrial applications (such as the manufacture of fertilizer, glass, paper and pulp, and precipitated calcium carbonate, and in sugar refining), flue gas treatment, construction, water treatment, and nonferrous mining.

\begin{tabular}{|c|c|c|c|c|c|}
\hline Salient Statistics-United States: & $\underline{2015}$ & $\underline{2016}$ & 2017 & 2018 & $2019^{\mathrm{e}}$ \\
\hline$\overline{\text { Production } 3}$ & $18 \overline{300}$ & 17,300 & $1 \overline{17,600}$ & $18 \overline{100}$ & $1 \overline{8,000}$ \\
\hline Imports for consumption & 391 & 376 & 367 & 370 & 360 \\
\hline Exports & 346 & 329 & 391 & 422 & 350 \\
\hline Consumption, apparent ${ }^{4}$ & 18,300 & 17,300 & 17,600 & 18,000 & 18,000 \\
\hline Quicklime average value, dollars per ton at plant & 121.50 & 121.00 & 122.10 & 124.60 & 124.00 \\
\hline Hydrate average value, dollars per ton at plant & 146.40 & 145.50 & 147.10 & 151.50 & 151.00 \\
\hline Employment, mine and plant, number & NA & NA & NA & NA & NA \\
\hline $\begin{array}{l}\text { Net import reliance } 5 \text { as a percentage of } \\
\text { apparent consumption }\end{array}$ & $<1$ & $<1$ & $E$ & E & $<1$ \\
\hline
\end{tabular}

Recycling: Large quantities of lime are regenerated by paper mills. Some municipal water-treatment plants regenerate lime from softening sludge. Quicklime is regenerated from waste hydrated lime in the carbide industry. Data for these sources were not included as production in order to avoid duplication.

Import Sources (2015-18): Canada, 93\%; Mexico, 6\%; and other, 1\%.

Tariff: Item

Calcined dolomite

Quicklime

Slaked lime

Hydraulic lime
Number

2518.20 .0000
2522.10 .0000
2522.20 .0000
2522.30 .0000

Normal Trade Relations
$\begin{gathered}\text { 12-31-19 } \\ \text { 3\% ad val. } \\ \text { Free. } \\ \text { Free. } \\ \text { Free. }\end{gathered}$

Depletion Allowance: Limestone produced and used for lime production, 14\% (Domestic and foreign).

Government Stockpile: None.

Events, Trends, and Issues: In 2019, domestic lime production was estimated to have remained essentially unchanged from that of 2018. In 2018, one sugar cooperative finalized its decision to close the sugar beet facility in Torrington, WY, in 2019, thereby removing one quicklime kiln from production. Another company sold its quicklime and hydrate production plant in Calera, AL, which reduced the number of companies producing lime. As a result, the total number of operating quicklime plants remained at 74 in 2019. Hydrated lime is a dry calcium hydroxide powder made from reacting quicklime with a controlled amount of water in a hydrator. It is used in chemical and industrial, construction, and environmental applications. In 2019, the leading uses of hydrated lime were chemical and industrial, and construction applications; flue gas desulfurization; and water treatment. 
World Lime Production and Limestone Reserves:

\begin{tabular}{lrr} 
& \multicolumn{2}{c}{ Production $^{\mathrm{e}, \mathbf{6}}$} \\
United States & $\mathbf{2 0 1 8}$ & $\underline{\mathbf{2 0 1 9}}$ \\
Australia & 18,100 & 18,000 \\
Belgium $^{8}$ & 2,000 & 2,100 \\
Brazil & 1,330 & 1,300 \\
Bulgaria & 8,300 & 8,400 \\
Canada (shipments) & 1,500 & 1,500 \\
China & 1,810 & 1,800 \\
Czechia & 300,000 & 300,000 \\
France & 1,040 & 1,100 \\
Germany & 2,600 & 2,600 \\
India & 7,000 & 7,100 \\
Iran & 16,000 & 16,000 \\
Italy & 3,300 & 3,300 \\
Japan (quicklime only) & 3,600 & 3,600 \\
Kazakhstan & 7,580 & 7,600 \\
Korea, Republic of & 1,050 & 1,100 \\
Malaysia & 5,200 & 5,200 \\
Poland (hydrated and quicklime) & 1,600 & 1,600 \\
Romania & 2,680 & 2,700 \\
Russia (industrial and construction) & 2,210 & 2,200 \\
Slovenia & 11,100 & 11,000 \\
South Africa & 1,060 & 1,200 \\
Spain & 1,200 & 1,200 \\
Turkey & 1,820 & 1,800 \\
Ukraine & 4,700 & 4,700 \\
United Kingdom & 2,100 & 2,100 \\
Other countries & 1,400 & 1,400 \\
World total (rounded) & 13,400 & 14,000 \\
& 424,000 & 430,000
\end{tabular}

\section{Reserves $^{7}$}

Adequate for all countries listed.

World Resources: Domestic and world resources of limestone and dolomite suitable for lime manufacture are very large.

Substitutes: Limestone is a substitute for lime in many applications, such as agriculture, fluxing, and sulfur removal. Limestone, which contains less reactive material, is slower to react and may have other disadvantages compared with lime, depending on the application; however, limestone is considerably less expensive than lime. Calcined gypsum is an alternative material in industrial plasters and mortars. Cement, cement kiln dust, fly ash, and lime kiln dust are potential substitutes for some construction uses of lime. Magnesium hydroxide is a substitute for lime in $\mathrm{pH}$ control, and magnesium oxide is a substitute for dolomitic lime as a flux in steelmaking.

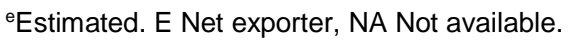

${ }^{1}$ Data are for quicklime, hydrated lime, and refractory dead-burned dolomite. Includes Puerto Rico.

${ }^{2}$ To avoid double counting quicklime production, excludes independent commercial hydrators that purchase quicklime for hydration.

${ }^{3}$ Sold or used by producers.

${ }^{4}$ Defined as production + imports - exports. Includes some double counting based on nominal, undifferentiated reporting of company export sales as U.S. production.

${ }^{5}$ Defined as imports - exports.

${ }^{6}$ Only countries that produced 1 million tons of lime or more are listed separately.

${ }^{7}$ See Appendix $\mathrm{C}$ for resource and reserve definitions and information concerning data sources.

${ }^{8}$ Includes hydraulic lime.
} 


\section{LITHIUM}

(Data in metric tons of lithium content unless otherwise noted)

Domestic Production and Use: The only lithium production in the United States was from a brine operation in Nevada. Two companies produced a wide range of downstream lithium compounds in the United States from domestic or imported lithium carbonate, lithium chloride, and lithium hydroxide. Domestic production data were withheld to avoid disclosing company proprietary data.

Although lithium markets vary by location, global end-use markets are estimated as follows: batteries, $65 \%$; ceramics and glass, 18\%; lubricating greases, 5\%; polymer production, 3\%; continuous casting mold flux powders, 3\%; air treatment, 1\%; and other uses, 5\%. Lithium consumption for batteries has increased significantly in recent years because rechargeable lithium batteries are used extensively in the growing market for portable electronic devices and increasingly are used in electric tools, electric vehicles, and grid storage applications. Lithium minerals were used directly as ore concentrates in ceramics and glass applications.

\begin{tabular}{|c|c|c|c|c|c|}
\hline Salient Statistics-United States: & $\underline{2015}$ & 2016 & 2017 & $\underline{2018}$ & $\underline{2019^{e}}$ \\
\hline$\overline{\text { Production }}$ & $\mathrm{W}$ & $\mathrm{W}$ & $\mathrm{W}$ & $\mathrm{W}$ & W \\
\hline Imports for consumption & 2,750 & 3,140 & 3,330 & 3,420 & 2,500 \\
\hline Exports & 1,790 & 1,520 & 1,960 & 1,660 & 1,700 \\
\hline Consumption, estimated ${ }^{1}$ & 2,000 & 3,000 & 3,000 & 3,000 & 2,000 \\
\hline $\begin{array}{l}\text { Price, annual average, battery-grade lithium } \\
\text { carbonate, dollars per metric ton }{ }^{2}\end{array}$ & 6,500 & 8,650 & 15,000 & 17,000 & 13,000 \\
\hline Employment, mine and mill, number & 70 & 70 & 70 & 70 & 70 \\
\hline $\begin{array}{l}\text { Net import reliance }{ }^{3} \text { as a percentage of } \\
\text { estimated consumption }\end{array}$ & $>25$ & $>50$ & $>50$ & $>50$ & $>25$ \\
\hline
\end{tabular}

Recycling: One domestic company has recycled lithium metal and lithium-ion batteries since 1992 at its facility in British Columbia, Canada. In 2015, the company began operating the first U.S. recycling facility for lithium-ion vehicle batteries in Lancaster, $\mathrm{OH}$.

Import Sources (2015-18): Argentina, 53\%; Chile, 40\%; China, 3\%; and other, 4\%.

Tariff: Item

Other alkali metals

Lithium oxide and hydroxide

Lithium carbonate:

U.S. pharmaceutical grade

Other
Number

2805.19.9000

2825.20.0000

2836.91.0010

2836.91.0050
Normal Trade Relations 12-31-19

$5.5 \%$ ad val.

$3.7 \%$ ad val.

$3.7 \%$ ad val.

$3.7 \%$ ad val.

Depletion Allowance: 22\% (Domestic), 14\% (Foreign).

\section{Government Stockpile: ${ }^{4}$}

\section{Material}

Lithium cobalt oxide

(kilograms, gross weight)

Lithium nickel cobalt aluminum

oxide (kilograms, gross weight)

Lithium-ion precursors

(kilograms, gross weight)
FY 2019

Inventory Potential Potential

As of 9-30-19 Acquisitions Disposals

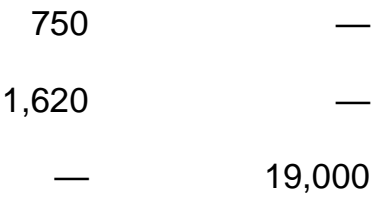

FY 2020

Potential Potential Acquisitions Disposals

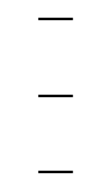

Events, Trends, and Issues: Excluding U.S. production, worldwide lithium production in 2019 decreased by $19 \%$ to 77,000 tons of lithium content from 95,000 tons of lithium content in 2018 in response to lithium production exceeding consumption and decreasing lithium prices. Global consumption of lithium in 2019 was estimated to be about 57,700 tons of lithium content, an increase of $18 \%$ from 49,100 tons of lithium content in 2018 . However, consumption was lower than anticipated by the lithium industry owing to China scaling back subsidies on electric vehicles, consumers reducing lithium inventories, and lower electric vehicle sales volumes. 


\section{LITHIUM}

Spot lithium carbonate prices in China decreased from approximately $\$ 11,600$ per ton at the beginning of the year to about \$7,300 per ton in December. For large fixed contracts, the annual average U.S. lithium carbonate price was $\$ 13,000$ per metric ton in 2019 , a $24 \%$ decrease from that of 2018. Spot lithium hydroxide prices in China decreased from approximately $\$ 15,500$ per ton at the beginning of the year to about $\$ 8,000$ per ton in December. Spot lithium metal $(99.9 \% \mathrm{Li})$ prices in China decreased from approximately $\$ 120,000$ per ton at the beginning of the year to about $\$ 82,000$ per ton in December.

Six mineral operations in Australia, two brine operations each in Argentina and Chile, and one brine and one mineral operation in China accounted for the majority of world lithium production. Owing to overproduction and decreased prices, several established lithium operations postponed capacity expansion plans. Junior mining operations in Australia, Canada, and Namibia ceased production altogether.

Lithium supply security has become a top priority for technology companies in the United States and Asia. Strategic alliances and joint ventures among technology companies and exploration companies continued to be established to ensure a reliable, diversified supply of lithium for battery suppliers and vehicle manufacturers. Brine-based lithium sources were in various stages of development in Argentina, Bolivia, Chile, China, and the United States; mineralbased lithium sources were in various stages of development in Australia, Austria, Brazil, Canada, China, Congo (Kinshasa), Czechia, Finland, Germany, Mali, Namibia, Portugal, Serbia, Spain, and Zimbabwe; and lithium-clay sources were in various stages of development in Mexico and the United States.

World Mine Production and Reserves: Reserves for Argentina, Australia, Brazil, Chile, the United States, and Zimbabwe were revised based on new information from Government and industry sources.

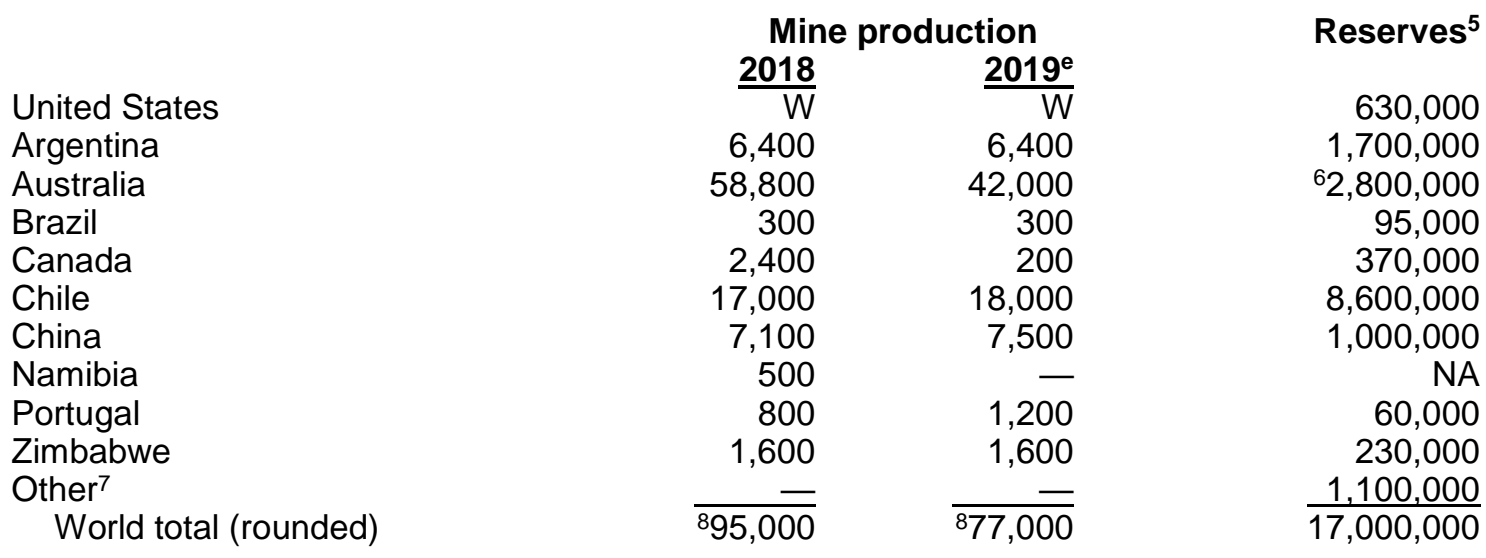

World Resources: Owing to continuing exploration, identified lithium resources have increased substantially worldwide and total about 80 million tons. Lithium resources in the United States-from continental brines, geothermal brines, hectorite, oilfield brines, and pegmatites-are 6.8 million tons. Lithium resources in other countries have been revised to 73 million tons. Lithium resources, in descending order, are: Bolivia, 21 million tons; Argentina, 17 million tons; Chile, 9 million tons; Australia, 6.3 million tons; China, 4.5 million tons; Congo (Kinshasa), 3 million tons; Germany, 2.5 million tons; Canada and Mexico, 1.7 million tons each; Czechia, 1.3 million tons; Mali, Russia, and Serbia, 1 million tons each; Zimbabwe, 540,000 tons; Brazil, 400,000 tons; Spain, 300,000 tons; Portugal, 250,000 tons; Peru, 130,000 tons; Austria, Finland and Kazakhstan, 50,000 tons each; and Namibia, 9,000 tons.

Substitutes: Substitution for lithium compounds is possible in batteries, ceramics, greases, and manufactured glass. Examples are calcium, magnesium, mercury, and zinc as anode material in primary batteries; calcium and aluminum soaps as substitutes for stearates in greases; and sodic and potassic fluxes in ceramics and glass manufacture.

\footnotetext{
eEstimated. W Withheld to avoid disclosing company proprietary data. NA Not available. - Zero.

${ }^{1}$ Defined as production + imports - exports. Rounded to one significant digit to avoid disclosing company proprietary data.

${ }^{2}$ Source: Industrial Minerals, IM prices: Lithium carbonate, large contracts, delivered continental United States.

${ }^{3}$ Defined as imports - exports + adjustments for Government and industry stock changes.

${ }^{4}$ See Appendix B for definitions.

${ }^{5}$ See Appendix $C$ for resource and reserve definitions and information concerning data sources.

${ }^{6}$ For Australia, Joint Ore Reserves Committee-compliant reserves were 1.7 million tons.

${ }^{7}$ Other countries with reported reserves include Finland, Mali, and Mexico.

${ }^{8}$ Excludes U.S. production.
} 


\section{MAGNESIUM COMPOUNDS ${ }^{1}$}

[Data in thousand metric tons of magnesium oxide $(\mathrm{MgO})$ content unless otherwise noted] ${ }^{2}$

Domestic Production and Use: Seawater and natural brines accounted for about $73 \%$ of U.S. magnesium compound production in 2019. The value of production of all types of magnesium compounds was estimated to be $\$ 276$ million. Magnesium oxide and other compounds were recovered from seawater by one company in California and another company in Delaware, from well brines by one company in Michigan, and from lake brines by two companies in Utah. Magnesite was mined by one company in Nevada. One company in Washington processed olivine that was mined previously for use as foundry sand. About $72 \%$ of the magnesium compounds consumed in the United States were used in agricultural, chemical, construction, deicing, environmental, and industrial applications in the form of caustic-calcined magnesia, magnesium chloride, magnesium hydroxide, and magnesium sulfates. The remaining $28 \%$ was used for refractories in the form of dead-burned magnesia, fused magnesia, and olivine.

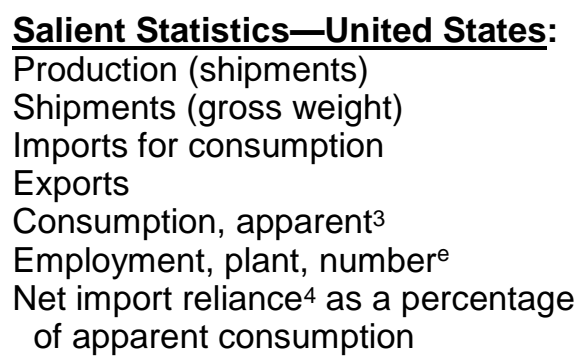

$\begin{array}{rrrrr}\frac{\mathbf{2 0 1 5}}{394} & \frac{\mathbf{2 0 1 6}}{408} & \frac{\mathbf{2 0 1 7}}{438} & \frac{\mathbf{2 0 1 8}}{405} & \frac{\mathbf{2 0 1 9}}{410} \\ 561 & 579 & 616 & 610 & 620 \\ 602 & 370 & 436 & 551 & 570 \\ 71 & 88 & 103 & 116 & 120 \\ 925 & 690 & 771 & 840 & 860 \\ 260 & 260 & 260 & 270 & 270 \\ 57 & 41 & 43 & 52 & 52\end{array}$

Recycling: Some magnesia-based refractories are recycled, either for reuse as refractory material or for use as construction aggregate.

Import Sources (2015-18): Caustic-calcined magnesia: China, 60\%; Canada, 20\%; Australia, 8\%; Hong Kong, 4\%; and other, 8\%. Dead-burned and fused magnesia: China, 60\%; Brazil, 15\%; Turkey, 6\%; Ukraine, 6\%; and other, 13\%. Magnesium chloride: Israel, 60\%; Netherlands, 28\%; China, 4\%; India, 4\%; and other, 4\%. Magnesium hydroxide: Mexico, 50\%; Netherlands, 15\%; Israel, 14\%; Austria, 10\%; and other, 11\%. Magnesium sulfates: China, 53\%; Germany, 27\%; Canada, 6\%; Mexico, 4\%; and other, 10\%.

\section{Tariff: Item}

Crude magnesite

Dead-burned and fused magnesia

Caustic-calcined magnesia

Kieserite

Epsom salts

Magnesium hydroxide and peroxide

Magnesium chloride

Magnesium sulfate (synthetic)
Number

2519.10.0000

2519.90.1000

2519.90.2000

2530.20.1000

2530.20.2000

2816.10.0000

2827.31.0000

2833.21.0000
Normal Trade Relations 12-31-19

Free.

Free.

Free.

Free.

Free.

$3.1 \%$ ad val.

$1.5 \%$ ad val.

$3.7 \%$ ad val.

Depletion Allowance: Brucite, 10\% (Domestic and foreign); dolomite, magnesite, and magnesium carbonate, 14\% (Domestic and foreign); magnesium chloride (from brine wells), 5\% (Domestic and foreign); and olivine, 22\% (Domestic) and 14\% (Foreign).

\section{Government Stockpile: None.}

Events, Trends, and Issues: Consumption of dead-burned and fused magnesia in the United States increased slightly in 2019 compared with that in 2018. Global consumption of dead-burned and fused magnesia increased by about $4 \%$ during the first 8 months of 2019 compared with that in the same period of 2018, as world steel production increased in 2019. However, sales of magnesia-based refractory products by major producers lagged as many consumers in the steel industry started the year with high stock levels and destocked during the first half of the year, especially in Europe. Consumption by nonferrous metal producers and other consumers of magnesia refractory products offset some of the decreased consumption by the steel industry. Although world prices for dead-burned and fused magnesia started the year high, by March import prices were declining and by August, prices were about 50\% lower than at the start of the year as producers in China sought to sell surplus supplies. Import prices for causticcalcined magnesia were more stable during the year and the average price of imports through August was $14 \%$ higher than that for the same period in 2018. 


\section{MAGNESIUM COMPOUNDS}

Consumption of caustic-calcined magnesia continued to increase for animal feed supplements and fertilizer as the importance of magnesium as a nutrient gained recognition. Environmental applications, such as wastewater treatment, also accounted for increasing consumption of magnesium compounds, including caustic-calcined magnesia and magnesium hydroxide.

Because China was the leading producing country for magnesia and magnesite, policy changes in China affected prices and availability of all grades of magnesia in the world market. Stricter enforcement of environmental regulations in Henan and Shandong Provinces that forced some refractory producers to decrease production was cited for decreased consumption of fused magnesia. Decreased demand in China resulted in lower prices as producers in China increased exports. Lower prices for fused magnesia caused prices for dead-burned magnesia to also decrease; the export price range for dead-burned magnesia from China decreased by about 33\% from the start of the year to the end of June. Magnesite mines in Liaoning Province were shut down from August 1 to October 31 owing to high stocks, low prices, and environmental regulations. The temporary closure of mines in China did not cause magnesia prices to increase significantly as stocks were high before the announcement. The Government of China announced mandatory shutdowns of capacity in several industries, including steelmaking, in certain areas during the winter months, which would likely decrease demand for fused and dead-burned magnesia.

World Magnesite Mine Production and Reserves: ${ }^{5}$ In addition to magnesite, vast reserves exist in well and lake brines and seawater from which magnesium compounds can be recovered.

\begin{tabular}{lrrr} 
& \multicolumn{2}{c}{ Mine production } & Reserves $^{\mathbf{6}}$ \\
United States & $\underline{\mathbf{2 0 1 8}}$ & $\underline{\mathbf{2 0 1 9}}$ & \\
Australia & 265 & 35,000 \\
Austria & 750 & 740 & 7320,000 \\
Brazil & 1,700 & 1,700 & 50,000 \\
China & 18,500 & 19,000 & 390,000 \\
Greece & 450 & 470 & $1,000,000$ \\
India & 175 & 140 & 280,000 \\
Korea, North & 70 & 50 & 82,000 \\
Russia & 1,500 & 1,500 & $2,300,000$ \\
Slovakia & 475 & 500 & $2,300,000$ \\
Spain & 550 & 580 & 120,000 \\
Turkey & 1,800 & 2,000 & 35,000 \\
Other countries & 865 & 600 & 230,000 \\
$\quad$ World total (rounded) & 827,100 & 828,000 & $1,400,000$ \\
\hline
\end{tabular}

World Resources: Resources from which magnesium compounds can be recovered range from large to virtually unlimited and are globally widespread. Identified world magnesite and brucite resources total 12 billion tons and several million tons, respectively. Resources of dolomite, forsterite, magnesium-bearing evaporite minerals, and magnesia-bearing brines are estimated to constitute a resource of billions of tons. Magnesium hydroxide can be recovered from seawater. Serpentine could be used as a source of magnesia but global resources, including in tailings of asbestos mines, have not been quantified but are thought to be very large.

Substitutes: Alumina, chromite, and silica substitute for magnesia in some refractory applications.

\footnotetext{
eEstimated. W Withheld to avoid disclosing company proprietary data.

${ }^{1}$ See also Magnesium Metal.

${ }^{2}$ Previously reported as magnesium content. Based on input from consumers, producers, and others involved in the industry, it was determined that reporting magnesium compound data in terms of contained magnesia was more useful than reporting in terms of magnesium content. Conversion factors used: magnesite, 47.8\% MgO; magnesium chloride, 42.3\% MgO; magnesium hydroxide, 69.1\% MgO; and magnesium sulfate, $33.5 \%$ MgO. ${ }^{3}$ Defined as shipments + imports - exports.

${ }^{4}$ Defined as imports - exports.

${ }^{5}$ Gross weight of magnesite (magnesium carbonate) in thousand tons.

${ }^{6}$ See Appendix $C$ for resource and reserve definitions and information concerning data sources.

${ }^{7}$ For Australia, Joint Ore Reserves Committee-compliant reserves were 37 million tons.

${ }^{8}$ Excludes U.S. production.
} 


\section{MAGNESIUM METAL ${ }^{1}$}

(Data in thousand metric tons unless otherwise noted)

Domestic Production and Use: In 2019, primary magnesium was produced by one company in Utah at an electrolytic process plant that recovered magnesium from brines from the Great Salt Lake. Secondary magnesium was recovered from scrap at plants that produced magnesium ingot and castings, and from aluminum alloy scrap at secondary aluminum smelters. Primary magnesium production in 2019 was estimated to have decreased from that of 2018. Information regarding U.S. primary magnesium production was withheld to avoid disclosing company proprietary data. The leading use for primary magnesium metal, which accounted for $55 \%$ of reported consumption, was in castings, principally used for the automotive industry. Aluminum-base alloys that were used for packaging, transportation, and other applications accounted for $28 \%$ of primary magnesium metal consumption; desulfurization of iron and steel, $13 \%$; and other uses, $4 \%$. About $33 \%$ of the secondary magnesium was consumed for structural uses and about $67 \%$ was used in aluminum alloys.

\begin{tabular}{|c|c|c|c|c|c|}
\hline Salient Statistics-United States: & $\underline{2015}$ & $\underline{2016}$ & $\underline{2017}$ & $\underline{2018}$ & $\underline{2019^{\mathrm{e}}}$ \\
\hline \multicolumn{6}{|l|}{ Production: } \\
\hline Primary & W & W & W & W & W \\
\hline Secondary (new and old scrap) & 88 & 102 & 114 & 109 & 110 \\
\hline Imports for consumption & 49 & 46 & 42 & 47 & 55 \\
\hline Exports & 15 & 19 & 14 & 11 & 10 \\
\hline \multicolumn{6}{|l|}{ Consumption: } \\
\hline Reported, primary & 64 & 69 & 65 & 46 & 55 \\
\hline Apparent ${ }^{2}$ & W & W & W & W & W \\
\hline \multicolumn{6}{|l|}{ Price, annual average: ${ }^{3}$} \\
\hline U.S. spot Western, dollars per pound & 2.15 & 2.15 & 2.15 & 2.17 & 2.35 \\
\hline China, free on board, dollars per metric ton & 2,131 & 2,195 & 2,262 & 2,530 & 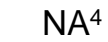 \\
\hline Stocks, producer, yearend & W & W & W & W & W \\
\hline Employment, numbere & 420 & 420 & 400 & 400 & 400 \\
\hline $\begin{array}{l}\text { Net import reliance } 5 \text { as a percentage of } \\
\text { apparent consumption }\end{array}$ & $<50$ & $<25$ & $<25$ & $<50$ & $<50$ \\
\hline
\end{tabular}

Recycling: In 2019 , about 25,000 tons of secondary magnesium was recovered from old scrap and 85,000 tons were recovered from new scrap. Aluminum-base alloys accounted for $67 \%$ of the secondary magnesium recovered, and magnesium-based castings, ingot, and other materials accounted for about 33\%.

Import Sources (2015-18): Israel, 25\%; Canada, 24\%; Mexico, 10\%; United Kingdom, 10\%; and other, 31\%.

Tariff: Item

Unwrought metal

Unwrought alloys

Scrap

Powders and granules

Wrought metal
Number

8104.11.0000

8104.19.0000

8104.20 .0000

8104.30 .0000

8104.90 .0000
Normal Trade Relations

12-31-19

$8.0 \%$ ad val.

$6.5 \%$ ad val.

Free.

$4.4 \%$ ad val.

$14.8 \$ / \mathrm{kg}$ on $\mathrm{Mg}$ content $+3.5 \%$ ad val.

Depletion Allowance: Dolomite, 14\% (Domestic and foreign); magnesium chloride (from brine wells), 5\% (Domestic and foreign).

\section{Government Stockpile: None.}

Events, Trends, and Issues: The sole U.S. producer of primary magnesium temporarily shut down some capacity at the end of 2016 citing the shutdown of a titanium sponge plant that had been a major customer, and this capacity was not expected to restart in the foreseeable future. In May, the U.S. Department of Commerce assigned a preliminary countervailing duty rate of $7.48 \%$ on magnesium produced by one company in Israel. In July, the U.S. International Trade Commission issued a preliminary determination that magnesium produced by the same company in Israel would be subject to an antidumping duty rate of $193.24 \%$. In November, an affirmative final determination was announced that found magnesium from Israel was sold at less than fair value in the United States. The final determinations on the antidumping and countervailing duty rates were expected in January 2020. The investigations into magnesium imports from Israel were initiated in November 2018 after a complaint was filed by the sole domestic primary magnesium producer. The investigations and preliminary determinations were cited for price increases and tight supplies of magnesium throughout the year. 


\section{MAGNESIUM METAL}

Producers in China dominate global magnesium metal production, but several projects were under development to increase primary magnesium metal capacity elsewhere and in China. In the United States, one company was evaluating a location in Washington for a facility to produce magnesium from a dolomite deposit in Nevada. A company in Quebec, Canada, produced a limited amount of magnesium from serpentine contained in asbestos tailings at its 25-kilogram-per-day pilot plant and planned to start construction of a 16,700-ton-per-year plant in 2020, with completion in about 1 year. Another company was testing its process for producing magnesium from serpentinebearing asbestos tailings in the same region of Quebec. In August, a company in Australia completed a feasibility study for a 3,000-ton-per-year plant to recover magnesium from coal fly ash and planned to complete construction by yearend 2020. A magnesium smelter in Turkey restarted production in May under new ownership after being closed for 1 year. In China, a 100,000-ton-per-year plant to produce magnesium from lake brines in Qinghai Province continued ramping up to commercial production in 2019. Construction of the facility was completed in 2017.

The use of magnesium in automobile parts continued to increase as automobile manufacturers sought to decrease vehicle weight in response to consumer desires for increased fuel efficiency. Magnesium castings have substituted for aluminum, iron, and steel in some automobiles. The substitution of aluminum for steel in automobile sheet was expected to increase consumption of magnesium in aluminum alloy sheet. Although some magnesium sheet applications have been developed for automobiles, these were generally limited to expensive sports cars and luxury vehicles, automobiles where the higher price of magnesium is not a deterrent to its use.

\section{World Primary Production and Reserves:}

\begin{tabular}{lrr} 
& \multicolumn{2}{c}{$\begin{array}{c}\text { Primary } \\
\text { Uroduction }\end{array}$} \\
United States & $\underline{\mathbf{2 0 1 8}}$ & $\underline{\mathbf{2 0 1 9}}$ \\
Brazil & 15 & $\mathrm{~W}$ \\
Canada & $(7)$ & $(7)$ \\
China & 860 & 900 \\
Iran & 1 & - \\
Israel & 21 & 20 \\
Kazakhstan & 17 & 25 \\
Russia & 70 & 80 \\
Turkey & 4 & 5 \\
Ukraine & 8 & 10 \\
$\quad$ World total (rounded) & 8996 & \\
$\quad$
\end{tabular}

\section{Reserves $^{6}$}

Magnesium metal is derived from seawater, natural brines, dolomite, serpentine, and other minerals. The reserves for this metal are sufficient to supply current and future requirements.

World Resources: Resources from which magnesium may be recovered range from large to virtually unlimited and are globally widespread. Resources of dolomite, serpentine, and magnesium-bearing evaporite minerals are enormous. Magnesium-bearing brines are estimated to constitute a resource in the billions of tons, and magnesium could be recovered from seawater along world coastlines.

Substitutes: Aluminum and zinc may substitute for magnesium in castings and wrought products. The relatively light weight of magnesium is an advantage over aluminum and zinc in castings and wrought products in most applications; however, its high cost is a disadvantage relative to these substitutes. For iron and steel desulfurization, calcium carbide may be used instead of magnesium. Magnesium is preferred to calcium carbide for desulfurization of iron and steel because calcium carbide produces acetylene in the presence of water.

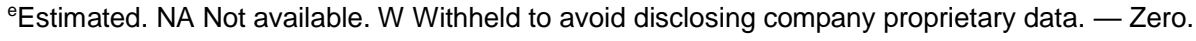

${ }^{1}$ See also Magnesium Compounds.

${ }^{2}$ Defined as primary production + secondary production from old scrap + imports - exports + adjustments for industry stock changes.

${ }^{3}$ Source: Platts Metals Week.

${ }^{4}$ Discontinued.

${ }^{5}$ Defined as imports - exports + adjustments for industry stock changes.

${ }^{6}$ See Appendix $\mathrm{C}$ for resource and reserve definitions and information concerning data sources.

${ }^{7}$ Less than $1 / 2$ unit.

${ }^{8}$ Excludes U.S. production.
} 


\section{MANGANESE}

(Data in thousand metric tons gross weight unless otherwise noted)

Domestic Production and Use: Manganese ore containing 20\% or more manganese has not been produced domestically since 1970. Manganese ore was consumed mainly by eight firms with plants principally in the East and Midwest. Most ore consumption was related to steel production, either directly in pig iron manufacture or indirectly through upgrading the ore to ferroalloys. Additional quantities of ore were used for such nonmetallurgical purposes as production of dry cell batteries, in fertilizers and animal feed, and as a brick colorant. Manganese ferroalloys were produced at two plants. Construction, transportation, and machinery end uses accounted for about $43 \%, 13 \%$, and $11 \%$, respectively, of manganese consumption on a manganese-content basis. Most of the rest went to a variety of other iron and steel applications. In 2019 , the value of domestic consumption, estimated from foreign trade data on a manganese-content basis, was about $\$ 1.2$ billion.

\begin{tabular}{|c|c|c|c|c|c|}
\hline Salient Statistics-United States: ${ }^{1}$ & $\underline{2015}$ & $\underline{2016}$ & $\underline{2017}$ & $\underline{2018}$ & $\underline{2019^{\mathrm{e}}}$ \\
\hline Production, mine & - & - & - & - & \\
\hline \multicolumn{6}{|l|}{ Imports for consumption: } \\
\hline Manganese ore & 441 & 282 & 297 & 440 & 340 \\
\hline Ferromanganese & 292 & 229 & 331 & 427 & 370 \\
\hline Silicomanganese ${ }^{2}$ & 301 & 264 & 351 & 412 & 370 \\
\hline \multicolumn{6}{|l|}{ Exports: } \\
\hline Manganese ore & 1 & 1 & 1 & 3 & \\
\hline Ferromanganese & 5 & 7 & 9 & 10 & 7 \\
\hline Silicomanganese & 1 & 2 & 8 & 4 & \\
\hline \multicolumn{6}{|l|}{ Shipments from Government stockpile: ${ }^{3}$} \\
\hline Manganese ore & - & - & - & - & \\
\hline Ferromanganese & 32 & 42 & 9 & 10 & \\
\hline \multicolumn{6}{|l|}{ Consumption, reported: } \\
\hline Manganese ore ${ }^{4}$ & 451 & 410 & 378 & 370 & 380 \\
\hline Ferromanganese & 344 & 342 & 345 & 348 & 360 \\
\hline Silicomanganese & 138 & 139 & 141 & 139 & 140 \\
\hline Consumption, apparent, manganese ${ }^{5}$ & 693 & 545 & 714 & 793 & 740 \\
\hline \multicolumn{6}{|l|}{$\begin{array}{l}\text { Price, average, } 46 \% \text { to } 48 \% \mathrm{Mn} \text { metallurgical ore, } \\
\text { dollars per metric ton unit, contained } \mathrm{Mn} \text { : }\end{array}$} \\
\hline Cost, insurance, and freight (c.i.f.), U.S. ports ${ }^{\mathrm{e}}$ & 3.53 & 3.41 & 6.43 & 7.17 & 6.60 \\
\hline China spot market (c.i.f.) & 3.22 & 4.48 & 65.62 & 66.91 & ${ }^{7} 6.16$ \\
\hline \multicolumn{6}{|l|}{ Stocks, producer and consumer, yearend: 4} \\
\hline Manganese ore & 187 & 207 & 148 & 185 & 150 \\
\hline Ferromanganese & 21 & 21 & 17 & 27 & 28 \\
\hline Silicomanganese & 21 & 10 & 11 & 21 & 22 \\
\hline $\begin{array}{l}\text { Net import reliance } 8 \text { as a percentage of } \\
\text { apparent consumption }\end{array}$ & 100 & 100 & 100 & 100 & \\
\hline
\end{tabular}

Recycling: Manganese was recycled incidentally as a constituent of ferrous and nonferrous scrap; however, scrap recovery specifically for manganese was negligible. Manganese is recovered along with iron from steel slag.

Import Sources (2015-18): Manganese ore: Gabon, 70\%; South Africa, 17\%; Australia, 6\%; Mexico, 5\%; and other, 2\%. Ferromanganese: South Africa, 27\%; Australia, 19\%; Norway, 16\%; Republic of Korea, 13\%; and other, $25 \%$. Silicomanganese: Georgia, 27\%; South Africa, 24\%; Australia, 20\%; Mexico, 8\%; and other, 21\%. Manganese contained in principal manganese imports: ${ }^{9}$ South Africa, 22\%; Gabon, 21\%; Australia, 15\%; Georgia, 10\%; and other, $32 \%$.

Tariff: Item

Ores and concentrates

Manganese dioxide

High-carbon ferromanganese

Ferrosilicon manganese (silicomanganese)

Metal, unwrought
Number

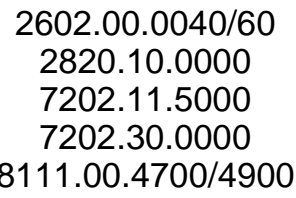

Normal Trade Relations $\underline{12-31-19}$ Free.

$4.7 \%$ ad val. $1.5 \%$ ad val. $3.9 \%$ ad val. $14 \%$ ad val.

Depletion Allowance: 22\% (Domestic), 14\% (Foreign). 


\section{MANGANESE}

\section{Government Stockpile: ${ }^{10}$}

\section{Material}

Manganese ore, metallurgical grade

Ferromanganese, high-carbon

Manganese metal, electrolytic

Inventory
As of 9-30-19
292
193
0.432

FY 2019

$\begin{array}{cc}\begin{array}{c}\text { Potential } \\ \text { Acquisitions }\end{array} & \begin{array}{c}\text { Potential } \\ \text { Disposals }\end{array} \\ - & 292 \\ - & 45 \\ 3 & -\end{array}$

FY 2020

$\begin{array}{cc}\begin{array}{c}\text { Potential } \\ \text { Acquisitions }\end{array} & \begin{array}{c}\text { Potential } \\ \text { Disposals }\end{array} \\ - & 292 \\ - & 45 \\ 5 & -\end{array}$

Events, Trends, and Issues: U.S. manganese apparent consumption was estimated to have decreased by $7 \%$ to 740,000 tons in 2019 compared with that in 2018 as a result of decreases in U.S. ferromanganese and silicomanganese imports. Electrolytic manganese metal was newly added to the National Defense Stockpile in 2019 as a critical material for defense purposes; the last time electrolytic manganese metal was held in the Government stockpile was in 2004.

World Mine Production and Reserves (manganese content): Reserves for Australia, Brazil, Gabon, India, and South Africa were revised based on Government and industry sources.

\begin{tabular}{lrrr} 
& \multicolumn{2}{c}{ Mine production } & Reserves $^{\mathbf{1 1}}$ \\
United States & $\underline{\mathbf{2 0 1 8}}$ & $\underline{\mathbf{2 0 1 9}}$ & \\
Australia & 3,480 & 3,200 & 12100,000 \\
Brazil & 1,310 & 1,200 & 140,000 \\
Burma & 207 & 210 & $\mathrm{NA}$ \\
China & 1,200 & 1,300 & 54,000 \\
Cote d'Ivoire & 395 & 400 & $\mathrm{NA}$ \\
Gabon & 2,330 & 2,400 & 61,000 \\
Georgia & 200 & 200 & $\mathrm{NA}$ \\
Ghana & 1,360 & 1,400 & 13,000 \\
India & 961 & 1,000 & 34,000 \\
Kazakhstan, concentrate & 140 & 130 & 5,000 \\
Malaysia & 390 & 420 & $\mathrm{NA}$ \\
Mexico & 210 & 190 & 5,000 \\
South Africa & 5,800 & 5,500 & 260,000 \\
Ukraine, concentrate & 517 & 540 & 140,000 \\
Other countries & 397 & 910 & Small \\
$\quad$ World total (rounded) & 18,900 & 19,000 & 810,000
\end{tabular}

World Resources: Land-based manganese resources are large but irregularly distributed; those in the United States are very low grade and have potentially high extraction costs. South Africa accounts for about $74 \%$ of the world's identified manganese resources, and Ukraine accounts for about $10 \%$.

Substitutes: Manganese has no satisfactory substitute in its major applications.

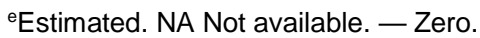

${ }^{1}$ Manganese content typically ranges from $35 \%$ to $54 \%$ for manganese ore and from $74 \%$ to $95 \%$ for ferromanganese.

${ }^{2}$ Imports more nearly represent amount consumed than does reported consumption.

${ }^{3}$ Defined as stockpile shipments - receipts, thousand tons, manganese content. If receipts, a negative quantity is shown.

${ }^{4}$ Exclusive of ore consumed directly at iron and steel plants and associated yearend stocks.

${ }^{5}$ Defined as imports - exports + adjustments for Government and industry stock changes, thousand tons, manganese content. Based on estimates of average content for all significant components—including ore, manganese dioxide, ferromanganese, silicomanganese, and manganese metal— except imports, for which content is reported.

${ }^{6}$ For average metallurgical-grade ore containing $44 \%$ manganese, as reported by CRU Group.

${ }^{7}$ Average weekly price through September 2019 for average metallurgical-grade ore containing $44 \%$ manganese, as reported by CRU Group.

${ }^{8}$ Defined as imports - exports + adjustments for Government and industry stock changes, thousand tons, manganese content.

${ }^{9}$ Includes imports of ferromanganese, manganese ore, silicomanganese, synthetic manganese dioxide, and unwrought manganese metal.

${ }^{10}$ See Appendix B for definitions.

${ }^{11}$ See Appendix $C$ for resource and reserve definitions and information concerning data sources.

${ }^{12}$ For Australia, Joint Ore Reserves Committee-compliant reserves were 45 million tons of manganese content.
} 


\section{MERCURY}

(Data in metric tons of mercury content unless otherwise noted)

Domestic Production and Use: Mercury has not been produced as a principal mineral commodity in the United States since 1992. In 2019, mercury was recovered as a byproduct from processing gold-silver ore at several mines in Nevada; however, production data were not reported. Secondary, or recycled, mercury was recovered from batteries, compact and traditional fluorescent lamps, dental amalgam, medical devices, and thermostats, as well as mercury-contaminated soils. It was estimated that less than 40 tons per year of mercury was consumed domestically. The leading domestic end users of mercury were the chlorine-caustic soda (chloralkali), dental, electronics, and fluorescent-lighting manufacturing industries. Only two mercury cell chloralkali plants operated in the United States in 2019. Until December 31, 2012, domestic- and foreign-sourced mercury was refined and then exported for global use, primarily for small-scale gold mining in many parts of the world. Beginning January 1, 2013, export of elemental mercury from the United States was banned, with some exceptions, under the Mercury Export Ban Act of 2008. Effective January 1, 2020, exports of five additional mercury compounds will be banned. The U.S. Environmental Protection Agency issued the final rule for mercury reporting requirements for the Toxic Substances Control Act. The requirements applied to anyone who manufactured (including imports) mercury or mercury-added products, or otherwise intentionally used mercury in a manufacturing process.

\begin{tabular}{|c|c|c|c|c|c|}
\hline $\begin{array}{l}\text { Salient Statistics-United States: } \\
\text { Production: }\end{array}$ & $\underline{2015}$ & $\underline{2016}$ & $\underline{2017}$ & $\underline{2018}$ & $\underline{2019}^{\mathrm{e}}$ \\
\hline Mine (byproduct) & NA & NA & NA & NA & NA \\
\hline Secondary & NA & NA & NA & NA & NA \\
\hline Imports for consumption (gross weight), metal & 26 & 24 & 20 & 6 & 10 \\
\hline Exports (gross weight), metal & $\left({ }^{1}\right)$ & - & - & - & - \\
\hline Price, average value, dollars per flask $99.99 \%$ : & & & & & \\
\hline European Union ${ }^{2,3}$ & 1,954 & 1,402 & 1,041 & 1,100 & NA \\
\hline Global locations 2, 4 & 2,465 & 1,275 & 1,273 & 2,709 & 2,550 \\
\hline $\begin{array}{l}\text { Net import reliance }{ }^{5} \text { as a percentage of } \\
\text { apparent consumption }\end{array}$ & NA & NA & NA & NA & NA \\
\hline
\end{tabular}

Recycling: In 2019, eight facilities operated by six companies in the United States accounted for the majority of secondary mercury produced and were authorized by the U.S. Department of Energy to temporarily store mercury. Mercury-containing automobile convenience switches, barometers, compact and traditional fluorescent bulbs, computers, dental amalgam, medical devices, and thermostats were collected by smaller companies and shipped to the refining companies for retorting to reclaim the mercury. In addition, many collection companies recovered mercury when retorting was not required. With the rapid phasing out of compact and traditional fluorescent lighting for lightemitting-diode (LED) lighting, there has been an increased amount of mercury being recycled.

Import Sources (2015-18): Canada, 39\%; France, 32\%; Switzerland, 13\%; China, 8\%; and other, 8\%.

Tariff: Item

Mercury

Amalgams
Number

2805.40 .0000

2843.90.0000
Normal Trade Relations

12-31-19

$1.7 \%$ ad val.

$3.7 \%$ ad val.

Depletion Allowance: 22\% (Domestic), 14\% (Foreign).

Government Stockpile: ${ }^{6}$ An inventory of 4,437 tons of mercury was held in storage at the Hawthorne Army Depot in Hawthorne, NV. The Mercury Export Ban Act of 2008 required the U.S. Department of Energy to establish long-term management and storage capabilities for domestically produced elemental mercury. Sales of mercury from the stockpiles remained suspended.

\begin{tabular}{cccc} 
& Inventory & \multicolumn{2}{c}{ FY 2019 } \\
Material & Potential & Potential \\
Mercury & 4,437 & Acquisitions & Disposals
\end{tabular}

FY 2020 $\begin{array}{cc}\text { Potential } & \text { Potential } \\ \text { Acquisitions } & \text { Disposals }\end{array}$ 


\section{MERCURY}

Events, Trends, and Issues: Owing to mercury toxicity and concerns for the environment and human health, overall mercury use has declined in the United States. Mercury continues to be released to the environment from numerous sources, including mercury-containing car switches when automobiles (those produced prior to 2003) are scrapped without recovering them for recycling, coal-fired powerplant emissions, incineration of mercury-containing medical devices, and from naturally occurring sources. Mercury is no longer used in most batteries and paints manufactured in the United States. Some button-type batteries, cleansers, fireworks, folk medicines, grandfather clocks, pesticides, and skin-lightening creams and soaps may still contain mercury. Mercury compounds were used as catalysts in the coal-based manufacture of vinyl chloride monomer in China. In some parts of the world, mercury was used in the recovery of gold in small-scale mining operations. Conversion to nonmercury technology for chloralkali production and the ultimate closure of the world's mercury-cell chloralkali plants may release a large quantity of mercury to the global market for recycling, sale, or, owing to export bans in Europe and the United States, storage.

Byproduct mercury production is expected to continue from large-scale domestic and foreign gold-silver mining and processing, as is secondary production of mercury from an ever-diminishing supply of mercury-containing products. Domestic mercury consumption will continue to decline owing to increased use of LED lighting and consequent reduced use of conventional fluorescent tubes and compact fluorescent bulbs, and continued substitution of nonmercury-containing products in control, dental, and measuring applications.

\section{World Mine Production and Reserves:}

United States
Argentina
China
Kyrgyzstan
Mexico (net exports)
Norway
Peru (exports)
Tajikistan
Other countries
$\quad$ World total (rounded)

\begin{tabular}{|c|c|}
\hline \multicolumn{2}{|c|}{ duction } \\
\hline $2018^{\mathrm{e}}$ & 2019 \\
\hline $\mathrm{NA}$ & $\mathrm{NA}$ \\
\hline 25 & 30 \\
\hline 3,600 & 3,500 \\
\hline 20 & 20 \\
\hline 234 & 240 \\
\hline 20 & 20 \\
\hline 40 & 40 \\
\hline 100 & 100 \\
\hline 20 & 20 \\
\hline 4,060 & $\overline{4,000}$ \\
\hline
\end{tabular}

\section{Reserves $^{7}$}

Quantitative estimates of reserves are not available. China, Kyrgyzstan, and Peru are thought to have the largest reserves.

World Resources: China, Kyrgyzstan, Mexico, Peru, Russia, Slovenia, Spain, and Ukraine have most of the world's estimated 600,000 tons of mercury resources. Mexico reclaims mercury from Spanish colonial silver-mining waste. In Spain, once a leading producer of mercury, mining at its centuries-old Almaden Mine stopped in 2003. In the United States, there are mercury occurrences in Alaska, Arkansas, California, Nevada, and Texas; however, mercury has not been mined as a principal mineral commodity since 1992. The declining consumption of mercury, except for small-scale gold mining, indicates that these resources are sufficient for centuries of use.

Substitutes: Ceramic composites substitute for the dark-gray mercury-containing dental amalgam. "Galistan," an alloy of gallium, indium, and tin, replaces the mercury used in traditional mercury thermometers, and digital thermometers have replaced traditional thermometers. At chloralkali plants around the world, mercury-cell technology is being replaced by newer diaphragm and membrane cell technology. LEDs that contain indium substitute for mercury-containing fluorescent lamps. Lithium, nickel-cadmium, and zinc-air batteries replace mercury-zinc batteries in the United States; indium compounds substitute for mercury in alkaline batteries; and organic compounds have been substituted for mercury fungicides in latex paint.

\footnotetext{
${ }^{e}$ Estimated. NA Not available. - Zero.

${ }^{1}$ Less than $1 / 2$ unit.

${ }^{2}$ Some international data and dealer prices are reported in flasks. One metric ton $(1,000$ kilograms $)=29.0082$ flasks, and 1 flask $=76$ pounds, or 34.47 kilograms, or 0.03447 ton.

${ }^{3}$ Average annual price of minimum 99.99\% mercury published by Argus Media group-Argus Metals International. Price discontinued on May 1 , 2018.

${ }^{4}$ Average midpoint of free market $99.99 \%$ mercury in warehouse, global locations, price published by Metal Bulletin.

${ }^{5}$ Defined as imports - exports + adjustments for Government stock changes.

${ }^{6}$ See Appendix $B$ for definitions.

${ }^{7}$ See Appendix $\mathrm{C}$ for resource and reserve definitions and information concerning data sources.
} 


\section{MICA (NATURAL)}

(Data in metric tons unless otherwise noted)

Domestic Production and Use: Scrap and flake mica production, excluding low-quality sericite, was estimated to be 38,000 tons valued at \$4.6 million. Mica was mined in Georgia, North Carolina, and South Dakota. Scrap mica was recovered principally from mica and sericite schist and as a byproduct from feldspar, industrial sand beneficiation, and kaolin. Eight companies produced an estimated 63,000 tons of ground mica valued at about \$22 million from domestic and imported scrap and flake mica. The majority of domestic production was processed into small-particlesize mica by either wet or dry grinding. Primary uses were joint compound, oil-well-drilling additives, paint, roofing, and rubber products.

A minor amount of sheet mica was produced as incidental production from feldspar mining in North Carolina. Data was withheld to avoid disclosing company proprietary data. The domestic consuming industry was dependent on imports to meet demand for sheet mica. Most sheet mica was fabricated into parts for electrical and electronic equipment.

\section{Salient Statistics-United States:}

Scrap and flake:

Production: 1

Sold and used

Ground

Imports $^{2}$

Exports $^{3}$

Consumption, apparent ${ }^{4}$

Price, average, dollars per metric ton, reported:

Scrap and flake

Ground:

Dry

Wet

Employment, mine, number

Net import reliance 5 as a percentage of apparent consumption

\section{Sheet:}

Sold and used

Imports $^{6}$

Exports $^{7}$

Consumption, apparent ${ }^{5}$

Price, average value, dollars per kilogram,

muscovite and phlogopite mica, reported:

Block

Splittings

Net import reliance 5 as a percentage of apparent consumption

$\begin{array}{rrrrr}\underline{\mathbf{2 0 1 5}} & \underline{\mathbf{2 0 1 6}} & \underline{\mathbf{2 0 1 7}} & \underline{\mathbf{2 0 1 8}} & \underline{\mathbf{2 0 1 9}} \\ & & & & \\ 32,600 & 28,000 & 40,000 & 44,000 & 38,000 \\ 65,800 & 59,500 & 69,700 & 65,300 & 63,000 \\ 33,200 & 31,500 & 29,700 & 28,100 & 29,000 \\ 7,440 & 6,340 & 6,790 & 6,000 & 5,900 \\ 58,400 & 53,200 & 62,900 & 66,100 & 61,000 \\ 142 & 152 & 165 & 122 & 120 \\ 305 & 320 & 292 & 308 & 310 \\ 423 & 435 & 424 & 454 & 480 \\ \text { NA } & \mathrm{NA} & \mathrm{NA} & \mathrm{NA} & \mathrm{NA} \\ 44 & 47 & 36 & 33 & 37 \\ & & & & \\ \text { W } & \mathrm{W} & \mathrm{W} & \mathrm{W} & \mathrm{W} \\ 2,390 & 2,120 & 1,850 & 1,860 & 2,500 \\ 911 & 689 & 704 & 686 & 950 \\ 1,480 & 1,430 & 1,150 & 1,170 & 1,600 \\ & & & & \\ \text { W } & \mathrm{W} & \mathrm{W} & \mathrm{W} & \mathrm{W} \\ 1.61 & 1.61 & 1.66 & 1.65 & 1.65 \\ 100 & 100 & 100 & 100 & 100\end{array}$

Recycling: None.

Import Sources (2015-18): Scrap and flake: Canada, 45\%; China, 31\%; India, 10\%; Finland, 4\%; and other, 10\%. Sheet: China, 48\%; Brazil, 22\%; Belgium, 8\%; Austria, 5\%; and other, 17\%.

\section{Tariff: Item}

Split block mica

Mica splittings

Unworked, other

Mica powder

Mica waste

Plates, sheets, and strips of agglomerated or reconstructed mica

Worked mica and articles of mica, other

\section{Number}

2525.10.0010

2525.10.0020

2525.10.0050

2525.20.0000

2525.30.0000

6814.10 .0000

6814.90 .0000
Normal Trade Relations

12-31-19

Free.

Free.

Free.

Free.

Free.

$2.7 \%$ ad val. $2.6 \%$ ad val. 


\section{MICA (NATURAL)}

Depletion Allowance: 22\% (Domestic), 14\% (Foreign).

Government Stockpile: None.

Events, Trends, and Issues: Domestic production of scrap and flake mica was estimated to have decreased by $14 \%$ in 2019. Apparent consumption of scrap and flake mica decreased by $8 \%$. Apparent consumption of sheet mica was estimated to have increased by $32 \%$ in 2019 as a result of increased imports of sheet mica from China. No environmental concerns are associated with the manufacture and use of mica products. Future supplies of sheet mica for United States consumption were expected to come increasingly from imports, primarily from Brazil, China, and India.

World Mine Production and Reserves: World production of sheet mica is shown to have remained steady; however, reliable production numbers for some countries that may influence that world total were unavailable.

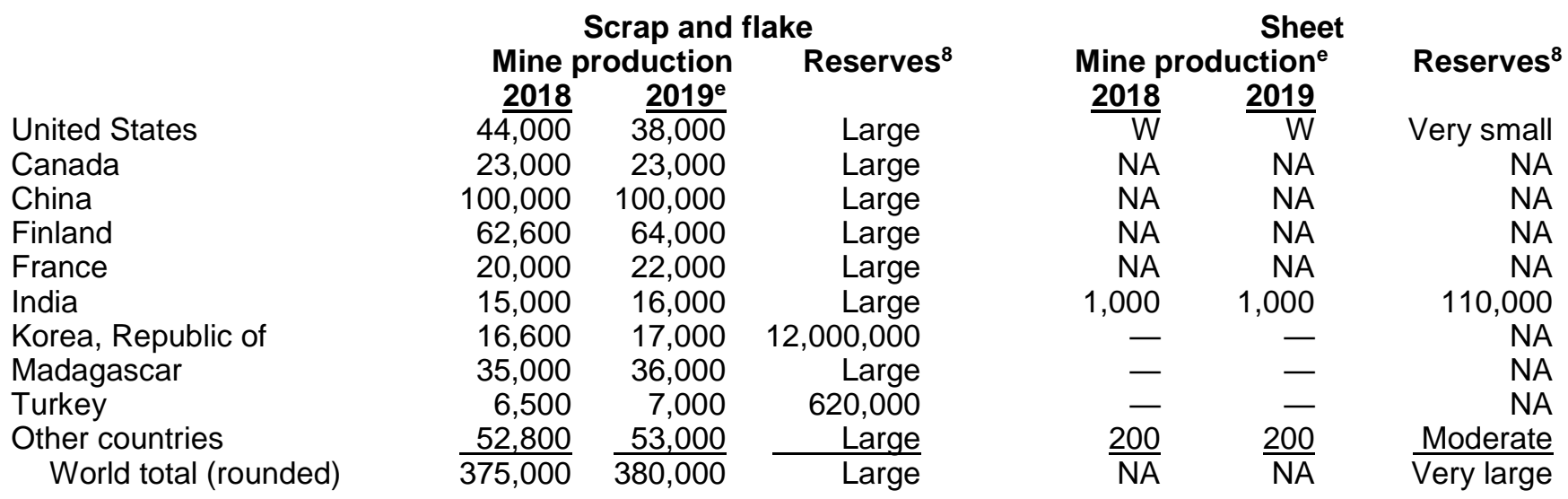

World Resources: Resources of scrap and flake mica are available in clay deposits, granite, pegmatite, and schist, and are considered more than adequate to meet anticipated world demand in the foreseeable future. World resources of sheet mica have not been formally evaluated because of the sporadic occurrence of this material. Large deposits of mica-bearing rock are known to exist in countries such as Brazil, India, and Madagascar. Limited resources of sheet mica are available in the United States. Domestic resources are uneconomic because of the high cost of the hand labor required to mine and process sheet mica from pegmatites.

Substitutes: Some lightweight aggregates, such as diatomite, perlite, and vermiculite, may be substituted for ground mica when used as filler. Ground synthetic fluorophlogopite, a fluorine-rich mica, may replace natural ground mica for uses that require thermal and electrical properties of mica. Many materials can be substituted for mica in numerous electrical, electronic, and insulation uses. Substitutes include acrylic, cellulose acetate, fiberglass, fishpaper, nylatron, nylon, phenolics, polycarbonate, polyester, styrene, polyvinyl chloride, and vulcanized fiber. Mica paper made from scrap mica can be substituted for sheet mica in electrical and insulation applications.

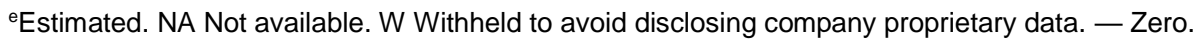

${ }^{1}$ Excludes low-quality sericite used primarily for brick manufacturing.

${ }^{2}$ Includes Harmonized Tariff Schedule of the United States codes: 2525.10.0050, <\$6.00/kg; 2525.20.0000; and 2525.30.0000.

${ }^{3}$ Includes Schedule B numbers: 2525.10.0000, <\$6.00/kg; 2525.20.0000; and 2525.30.0000.

${ }^{4}$ Defined as sold or used by producing companies + imports - exports.

${ }^{5}$ Defined as imports - exports.

${ }^{6}$ Includes Harmonized Tariff Schedule of the United States codes: 2525.10.0010; 2525.10.0020; 2525.10.0050, >\$6.00/kg; 6814.10.0000; and 6814.90 .0000 .

${ }^{7}$ Includes Schedule B numbers: 2525.10.0000, >\$6.00/kg; 6814.10.0000; and 6814.90.0000.

${ }^{8}$ See Appendix $\mathrm{C}$ for resource and reserve definitions and information concerning data sources.
} 


\section{MOLYBDENUM}

(Data in metric tons of molybdenum content unless otherwise noted)

Domestic Production and Use: U.S. mine production of molybdenum in 2019 increased by $7 \%$ to 44,000 tons compared with the previous year. Molybdenum ore was produced as a primary product at two mines - both in Colorado-whereas seven copper mines (four in Arizona and one each in Montana, Nevada, and Utah) recovered molybdenite concentrate as a byproduct. Three roasting plants converted molybdenite concentrate to molybdic oxide, from which intermediate products, such as ferromolybdenum, metal powder, and various chemicals, were produced. Metallurgical applications accounted for about $88 \%$ of the total molybdenum consumed.

\begin{tabular}{|c|c|c|c|c|c|}
\hline Salient Statistics-United States: & $\underline{2015}$ & $\underline{2016}$ & 2017 & $\underline{2018}$ & $\underline{2019^{e}}$ \\
\hline$\overline{\text { Production, mine }}$ & $4 \overline{4,400}$ & $36 \overline{200}$ & $40 \overline{700}$ & $4 \overline{1,400}$ & $4 \overline{4,000}$ \\
\hline Imports for consumption & 17,500 & 22,800 & 36,000 & 37,600 & 37,000 \\
\hline Exports & 41,500 & 31,200 & 43,200 & 48,400 & 57,00 \\
\hline \multicolumn{6}{|l|}{ Consumption: } \\
\hline Reported ${ }^{1}$ & 17,600 & 15,800 & 17,200 & 16,900 & 17,00 \\
\hline Apparent $^{2}$ & 23,800 & 27,900 & 34,100 & 31,400 & 24,0 \\
\hline Price, average value, dollars per kilogram ${ }^{3}$ & 15.10 & 14.40 & 18.06 & 27.04 & \\
\hline Stocks, consumer materials & 1,880 & 1,910 & 2,010 & 1,940 & 1,70 \\
\hline Employment, mine and plant, number & 950 & 920 & 940 & 940 & 95 \\
\hline $\begin{array}{l}\text { Net import reliance } 4 \text { as a percentage of } \\
\text { apparent consumption }\end{array}$ & $E$ & $\mathrm{E}$ & $E$ & $E$ & \\
\hline
\end{tabular}

Recycling: Molybdenum is recycled as a component of catalysts, ferrous scrap, and superalloy scrap. Ferrous scrap comprises revert scrap, and new and old scrap. Revert scrap refers to remnants manufactured in the steelmaking process. New scrap is generated by steel mill customers and recycled by scrap collectors and processors. Old scrap is largely molybdenum-bearing alloys recycled after serving their useful life. The amount of molybdenum recycled as part of new and old steel and other scrap may be as much as $30 \%$ of the apparent supply of molybdenum. There are no processes for the separate recovery and refining of secondary molybdenum from its alloys. Molybdenum is not recovered separately from recycled steel and superalloys, but the molybdenum content of the recycled alloys is significant, and the molybdenum content is reused. Recycling of molybdenum-bearing scrap will continue to be dependent on the markets for the principal alloy metals in which molybdenum is contained, such as iron, nickel, and chromium.

Import Sources (2015-18): Ferromolybdenum: Chile, 54\%; Republic of Korea, 33\%; Canada, 8\%; and other, 5\%. Molybdenum ores and concentrates: Peru, 53\%; Chile, 27\%; Canada, 11\%; Mexico, 8\%; and other, $1 \%$.

Tariff: Item

Molybdenum ore and concentrates, roasted

Molybdenum ore and concentrates, other

Molybdenum chemicals:

Molybdenum oxides and hydroxides

Molybdates of ammonium

Molybdates, all others

Molybdenum pigments, molybdenum orange

Ferroalloys, ferromolybdenum

Molybdenum metals:

Powders

Unwrought

Wrought bars and rods

Wrought plates, sheets, strips, etc.

Wire

Waste and scrap

Other
Number

2613.10.0000

2613.90.0000

2825.70.0000

2841.70 .1000

2841.70 .5000

3206.20 .0020

7202.70 .0000

8102.10 .0000

8102.94 .0000

8102.95 .3000

8102.95 .6000

8102.96 .0000

8102.97 .0000

8102.99 .0000
Normal Trade Relations 12-31-19

$12.8 \$ / \mathrm{kg}+1.8 \%$ ad val. $17.8 \$ / \mathrm{kg}$.

$3.2 \%$ ad val.

$4.3 \%$ ad val.

$3.7 \%$ ad val.

$3.7 \%$ ad val.

$4.5 \%$ ad val.

$9.1 \$ / \mathrm{kg}+1.2 \%$ ad val.

$13.9 \$ / \mathrm{kg}+1.9 \%$ ad val.

$6.6 \%$ ad val.

$6.6 \%$ ad val.

$4.4 \%$ ad val.

Free.

$3.7 \%$ ad val.

Depletion Allowance: 22\% (Domestic), 14\% (Foreign).

Government Stockpile: None. 


\section{MOLYBDENUM}

Events, Trends, and Issues: In 2019, the estimated average molybdic oxide price decreased by $4 \%$ compared with that of 2018, and U.S. estimated mine output of molybdenum increased by $7 \%$ from that of 2018 . The increase in production was seen mainly at byproduct mines. Byproduct molybdenum production continued at the Bagdad, Morenci, Pinto Valley, and Sierrita Mines in Arizona; the Continental Pit Mine in Montana; the Robinson Mine in Nevada; and the Bingham Canyon Mine in Utah. Primary molybdenum production continued at the Climax and Henderson Mines in Colorado. The Thompson Creek Mine in Idaho continued to be on care-and-maintenance status in 2019.

Estimated U.S. imports for consumption decreased slightly from those of 2018 . U.S. exports increased by $17 \%$ from those of 2018. Roasted and unroasted concentrate exports increased by $26 \%$ and $13 \%$, respectively, compared with those during the same period in 2018. Apparent consumption decreased by $22 \%$ compared with that of 2018.

Global molybdenum production in 2019 decreased slightly compared with 2018. In descending order of production, China, Chile, the United States, Peru, and Mexico provided more than $90 \%$ of total global production.

World Mine Production and Reserves: The reserves estimate for Peru was revised based on new information from Government reports.

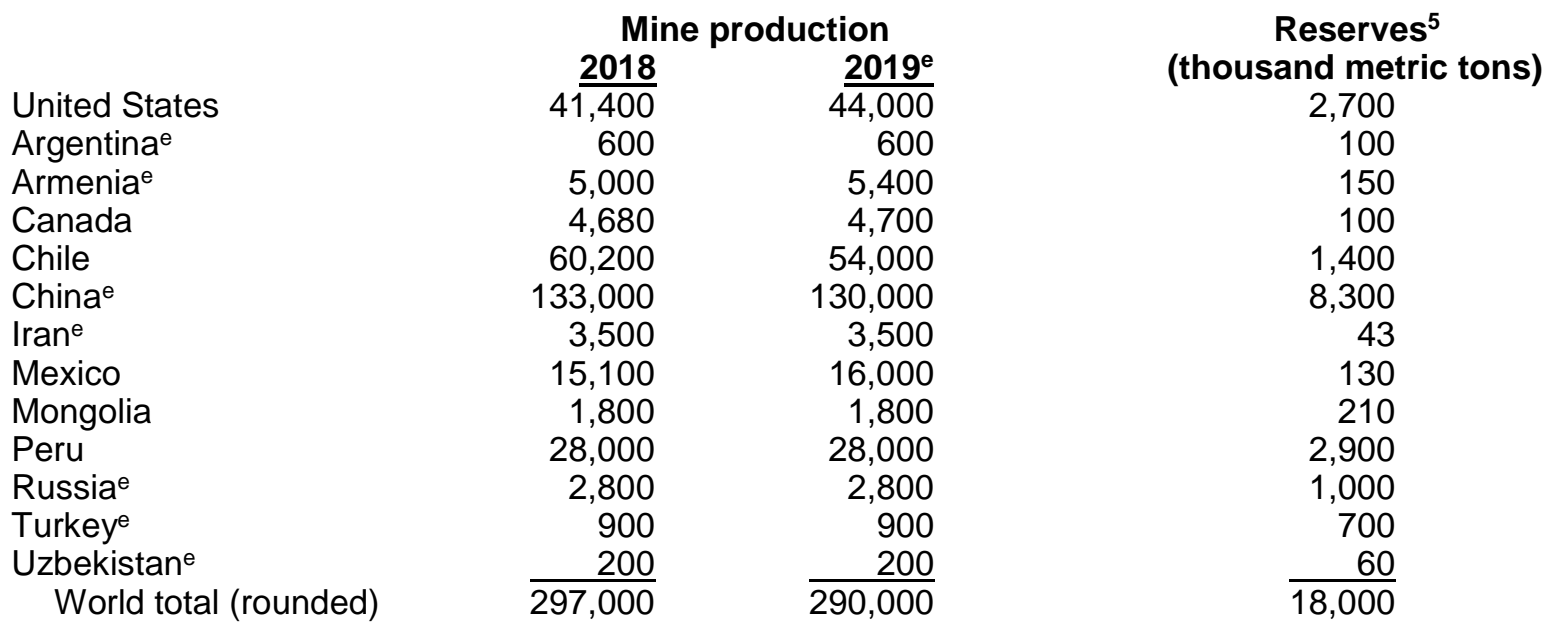

World Resources: Identified resources of molybdenum in the United States are about 5.4 million tons, and in the rest of the world, about 20 million tons. Molybdenum occurs as the principal metal sulfide in large low-grade porphyry molybdenum deposits and as an associated metal sulfide in low-grade porphyry copper deposits. Resources of molybdenum are adequate to supply world needs for the foreseeable future.

Substitutes: There is little substitution for molybdenum in its major application in steels and cast irons. In fact, because of the availability and versatility of molybdenum, industry has sought to develop new materials that benefit from its alloying properties. Potential substitutes include boron, chromium, niobium (columbium), and vanadium in alloy steels; tungsten in tool steels; graphite, tantalum, and tungsten for refractory materials in high-temperature electric furnaces; and cadmium-red, chrome-orange, and organic-orange pigments for molybdenum orange.

\footnotetext{
${ }^{e}$ Estimated. E Net exporter.

${ }^{1}$ Reported consumption of primary molybdenum products.

${ }^{2}$ Defined as production + imports - exports + adjustments for concentrate, consumer, and product producer stock changes.

${ }^{3}$ Time-weighted average price per kilogram of molybdenum contained in technical-grade molybdic oxide, as reported by CRU Group.

${ }^{4}$ Defined as imports - exports + adjustments for industry stock changes.

${ }^{5}$ See Appendix $\mathrm{C}$ for resource and reserve definitions and information concerning data sources.
} 


\section{NICKEL}

(Data in metric tons of nickel content unless otherwise noted)

Domestic Production and Use: In 2019, the underground Eagle Mine in Michigan produced approximately 14,000 tons of nickel in concentrate, which was exported to smelters in Canada and overseas. In October, the mine processed the first ore from the newly developed Eagle East extension. As part of the Superfund Redevelopment Initiative, a company in Missouri constructed a facility to recover metals, including nickel, from mine tailings. Nickel in crystalline sulfate was produced as a byproduct of smelting and refining platinum-group-metal ores mined in Montana.

In the United States, the leading uses for primary nickel are stainless and alloy steels, nonferrous alloys and superalloys, electroplating, and other uses including catalysts and chemicals. Domestic production of stainless steel was estimated to have decreased by approximately $10 \%$ in 2019. Consumption of nickel used in alloys for jet turbine engines continued to increase.

\begin{tabular}{|c|c|c|c|c|c|}
\hline \multicolumn{5}{|l|}{ Production: } & $\underline{2019^{e}}$ \\
\hline Mine & 27,200 & 24,100 & 22,100 & 17,600 & 14,000 \\
\hline Refinery, byproduct & W & W & W & W & W \\
\hline \multicolumn{6}{|l|}{ Imports: } \\
\hline Ores and concentrates & 24 & $\left({ }^{1}\right)$ & 64 & 3 & \\
\hline Primary & 130,000 & 111,000 & 150,000 & 144,000 & 120,000 \\
\hline Secondary & 27,100 & 32,300 & 38,100 & 45,100 & 38,000 \\
\hline \multicolumn{6}{|l|}{ Exports: } \\
\hline Ores and concentrates & 25,400 & 22,400 & 20,000 & 219,000 & 19,000 \\
\hline Primary & 9,610 & 10,300 & 11,000 & 9,780 & 13,000 \\
\hline Secondary & 51,900 & 63,700 & 51,500 & 67,200 & 49,000 \\
\hline \multicolumn{6}{|l|}{ Consumption: } \\
\hline Estimated, primary metal & 110,000 & 98,000 & 100,000 & 110,000 & 110,000 \\
\hline Estimated, secondary & 120,000 & 130,000 & 130,000 & 120,000 & 120,000 \\
\hline Apparent, primary metal ${ }^{3}$ & 118,000 & 104,000 & 140,000 & 136,000 & 110,000 \\
\hline Apparent, total 4 & 234,000 & 235,000 & 273,000 & 259,000 & 230,000 \\
\hline \multicolumn{6}{|l|}{$\begin{array}{l}\text { Price, average annual, London Metal } \\
\text { Exchange (LME): }\end{array}$} \\
\hline Cash, dollars per metric ton & 11,831 & 9,594 & 10,403 & 13,114 & 14,000 \\
\hline Cash, dollars per pound & 5.367 & 4.352 & 4.719 & 5.977 & 6.3 \\
\hline \multicolumn{6}{|l|}{ Stocks, yearend: } \\
\hline Consumer & 19,200 & 15,100 & 14,600 & 16,300 & 16,000 \\
\hline LME U.S. warehouses & 4,212 & 5,232 & 3,780 & 2,268 & 2,000 \\
\hline $\begin{array}{l}\text { Net import reliance } 5 \text { as a percentag } \\
\text { apparent consumption }\end{array}$ & 50 & 44 & 51 & 52 & 47 \\
\hline
\end{tabular}

Recycling: Nickel in alloyed form was recovered from the processing of nickel-containing waste, including flue dust, grinding swarf, mill scale, and shot blast generated during the manufacturing of stainless steel; filter cakes, plating solutions, spent catalysts, spent pickle liquor, sludges, and all types of spent nickel-containing batteries. Nickelcontaining alloys and stainless steel scrap were also melted and used to produce new alloys and stainless steel. In 2019, recycled nickel in all forms accounted for approximately $47 \%$ of apparent consumption.

Import Sources (2015-18): Nickel contained in ferronickel, metal, oxides, and salt: Canada, 41\%; Norway, 11\%; Australia, 8\%; Finland, 8\%; and other, 32\%. Nickel-containing scrap, including nickel content of stainless-steel scrap: Canada, 38\%; Mexico, 28\%; United Kingdom, 9\%; and other, 25\%.

Tariff: Item

Nickel ores and concentrates, nickel content

Ferronickel

Unwrought nickel, not alloyed

Nickel waste and scrap

Nickel powders

Nickel flakes
Number

2604.00.0040

7202.60 .0000

7502.10 .0000

7503.00 .0000

7504.00 .0010

7504.00 .0050
Normal Trade Relations 12-31-19

Free.

Free.

Free.

Free.

Free.

Free.

Depletion Allowance: 22\% (Domestic), 14\% (Foreign). 


\section{NICKEL}

Government Stockpile: ${ }^{6}$ The U.S. Department of Energy is holding nickel ingot contaminated by low-level radioactivity at Paducah, KY, and shredded nickel scrap at Oak Ridge, TN. Ongoing decommissioning activities at former nuclear defense sites were expected to generate additional nickel in scrap. See the Lithium chapter for statistics on lithium-nickel-cobalt-aluminum oxide.

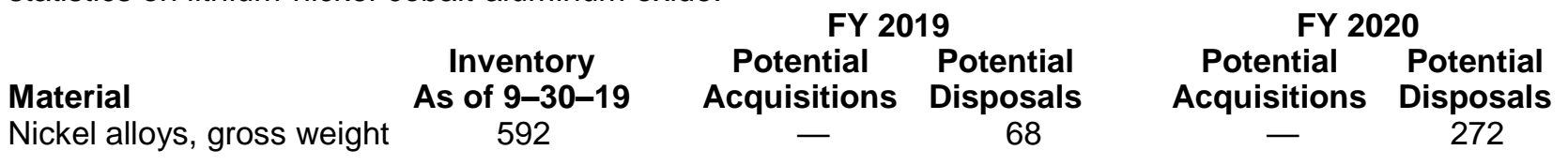

Events, Trends, and Issues: The Government of Indonesia decided to reinstate its ban on direct-shipping nickel ore beginning in January 2020, 2 years earlier than previously announced. The Government had relaxed enforcement of the ban in 2017 following rapid development of the country's nickel-processing capacity, primarily smelters producing nickel pig iron. The return to the regulation was reportedly in order to conserve ore for the domestic processing industry.

In January 2019, a company in Indonesia's Central Sulawesi Province broke ground on a project to produce nickel and cobalt for use in batteries. Globally, numerous idled facilities and delayed development projects resumed activity in anticipation of growing demand for nickel in electric vehicle batteries.

World Mine Production and Reserves: Reserves for Australia, Canada, and Russia were revised based on new information from company or Government reports.

\begin{tabular}{lrrr} 
& \multicolumn{2}{c}{ Mine production } & Reserves $^{\mathbf{7}}$ \\
United States & $\mathbf{2 0 1 8}$ & $\mathbf{2 0 1 9}$ & 110,000 \\
Australia & 17,600 & 14,000 & $820,000,000$ \\
Brazil & 170,000 & 180,000 & $11,000,000$ \\
Canada & 74,400 & 67,000 & $2,600,000$ \\
China & 176,000 & 180,000 & $2,800,000$ \\
Cuba & 110,000 & 110,000 & $5,500,000$ \\
Indonesia & 51,000 & 51,000 & $21,000,000$ \\
New Caledonia & 606,000 & 800,000 & $\mathrm{NA}$ \\
Philippines & 216,000 & 220,000 & $4,800,000$ \\
Russia & 345,000 & 420,000 & $6,900,000$ \\
Other countries & 272,000 & 270,000 & $14,000,000$ \\
$\quad$ World total (rounded) & 366,000 & 370,000 & $89,000,000$
\end{tabular}

World Resources: Identified land-based resources averaging 1\% nickel or greater contain at least 130 million tons of nickel, with about $60 \%$ in laterites and $40 \%$ in sulfide deposits. Extensive nickel resources also are found in manganese crusts and nodules on the ocean floor. The decline in discovery of new sulfide deposits in traditional mining districts has led to exploration in more challenging locations such as east-central Africa and the subarctic.

Substitutes: Low-nickel, duplex, or ultrahigh-chromium stainless steels are being substituted for austenitic grades in construction. Nickel-free specialty steels are sometimes used in place of stainless steel in the power-generating and petrochemical industries. Titanium alloys can substitute for nickel metal or nickel-base alloys in corrosive chemical environments. Lithium-ion batteries may be used instead of nickel metal hydride batteries in certain applications.

\footnotetext{
${ }^{e}$ Estimated. NA Not available. W Withheld to avoid disclosing company proprietary data. — Zero.

${ }^{1}$ Less than $1 / 2$ unit.

${ }^{2}$ Estimated. The U.S. Census Bureau reported that exports of nickel in ores and concentrates were 54,600 tons in 2018; all or part of these data have been referred to the U.S. Census Bureau for verification.

${ }^{3}$ Defined as primary imports - primary exports + adjustments for industry stock changes, excluding secondary consumer stocks.

${ }^{4}$ Defined as apparent primary metal consumption + estimated secondary consumption.

${ }^{5}$ Defined as imports - exports + adjustments for consumer stock changes.

${ }^{6}$ See Appendix B for definitions.

${ }^{7}$ See Appendix $C$ for resource and reserve definitions and information concerning data sources.

${ }^{8}$ For Australia, Joint Ore Reserves Committee-compliant reserves were 5.4 million tons.

${ }^{9}$ Overseas territory of France.
} 


\section{NIOBIUM (COLUMBIUM)}

(Data in metric tons of niobium content unless otherwise noted)

Domestic Production and Use: Significant U.S. niobium mine production has not been reported since 1959. Companies in the United States produced niobium-containing materials from imported niobium concentrates, oxides, and ferroniobium. Niobium was consumed mostly in the form of ferroniobium by the steel industry and as niobium alloys and metal by the aerospace industry. In 2019, there was a decrease in reported consumption of niobium for high-strength low alloy steel and superalloy applications. Major end-use distribution of reported niobium consumption was as follows: steels, about $78 \%$, and superalloys, about $22 \%$. The estimated value of niobium consumption was $\$ 460$ million, as measured by the value of imports.

\begin{tabular}{|c|c|c|c|c|c|}
\hline Salient Statistics_-United States: & 2015 & 2016 & 2017 & 2018 & $\underline{2019^{\mathrm{e}}}$ \\
\hline$\overline{\text { Production, mine }}$ & & $=$ & - & - & \\
\hline Imports for consumption ${ }^{1}$ & 8,520 & 8,250 & 9,330 & 11,200 & 11,000 \\
\hline Exports ${ }^{1}$ & 1,430 & 1,480 & 1,490 & 955 & 570 \\
\hline Shipments from Government stockpile & - & - & - & - & \\
\hline \multicolumn{6}{|l|}{ Consumption:e } \\
\hline Apparent ${ }^{2}$ & 7,080 & 6,730 & 7,780 & 10,100 & 9,90 \\
\hline Reported 3 & 7,510 & 7,370 & 7,640 & 7,130 & 6,000 \\
\hline Unit value, ferroniobium, dollars per kilogram 4 & 24 & 21 & 20 & 21 & 23 \\
\hline $\begin{array}{l}\text { Net import reliance }{ }^{2} \text { as a percentage of } \\
\text { apparent consumption }\end{array}$ & 100 & 100 & 100 & 100 & \\
\hline
\end{tabular}

Recycling: Niobium was recycled when niobium-bearing steels and superalloys were recycled; scrap recovery, specifically for niobium content, was negligible. The amount of niobium recycled is not available, but it may be as much as $20 \%$ of apparent consumption.

Import Sources (2015-18): Niobium ore and concentrate: Rwanda, 39\%; Brazil, 19\%; Australia, 16\%; Congo (Kinshasa), 10\%; and other, 16\%. Niobium oxide: Brazil, 48\%; Russia, 25\%; Thailand, 10\%; Estonia, 9\%; and other, 8\%. Ferroniobium and niobium metal: Brazil, 70\%; Canada, 26\%; Germany, 2\%; and other, 2\%. Total imports: Brazil, 67\%; Canada, 23\%; Russia, 3\%; Germany, 2\%; and other, 5\%. Of the U.S. niobium material imports (by contained weight), $75 \%$ was ferroniobium, $14 \%$ was niobium metal, $10 \%$ was niobium oxide, and $1 \%$ was niobium ores and concentrates.

Tariff: Item

Synthetic tantalum-niobium concentrates Niobium ores and concentrates

Niobium oxide

Ferroniobium:

Less than $0.02 \% \mathrm{P}$ or $\mathrm{S}$, or less than $0.4 \% \mathrm{Si}$

Other

Niobium:

Waste and scrap 5

Powders and unwrought metal

Niobium, other ${ }^{5}$
Number

2615.90.3000

2615.90 .6030

2825.90.1500

7202.93 .4000

7202.93 .8000

8112.92 .0600

8112.92 .4000

8112.99 .9000

\author{
Normal Trade Relations \\ 12-31-19 \\ Free. \\ Free. \\ $3.7 \%$ ad val.
}

$5 \%$ ad val.

$5 \%$ ad val.

Free.

$4.9 \%$ ad val. $4 \%$ ad val.

Depletion Allowance: 22\% (Domestic), 14\% (Foreign).

\section{Government Stockpile: ${ }^{6}$}

\section{Material}

Ferroniobium (gross weight)

Niobium metal (gross weight)
Inventory

As of 9-30-19

407

10
FY 2019

$\begin{array}{cc}\begin{array}{c}\text { Potential } \\ \text { Acquisitions }\end{array} & \begin{array}{c}\text { Potential } \\ \text { Disposals }\end{array} \\ 209 & -\end{array}$

FY 2020

Potential Potential

Acquisitions Disposals

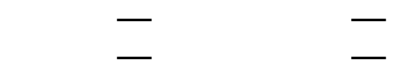

Prepared by Abraham J. Padilla [(703) 648-4965, apadilla@usgs.gov] 


\section{NIOBIUM (COLUMBIUM)}

Events, Trends, and Issues: Niobium principally was imported in the form of ferroniobium. Based on data through August 2019, U.S. niobium apparent consumption (measured in contained niobium) for 2019 was estimated to be 9,900 tons, slightly less than that of 2018 . Brazil continued to be the world's leading niobium producer with $88 \%$ of global production, followed by Canada with 10\%. Global niobium production is thought to have increased in 2019 owing to anticipated growing demand for ferroniobium from steel manufacturers in China following the country's implementation of higher rebar strength standards beginning in November 2018. Niobium was increasingly substituted for vanadium as a microalloying additive in high-strength rebar owing to the supply deficit and high price volatility of ferrovanadium. Based on data through August 2019, ferroniobium imports into China were estimated to have increased by $50 \%$ in 2019 compared with the previous year.

One domestic company developing its Elk Creek project in Nebraska announced a new mine design that was expected to increase the mine life by 4 years and reduce the environmental impacts of its operation. The new design included an onsite water treatment system that would eliminate the need to discharge excess process water into the nearby Missouri River, more efficient recycling of mineral-processing reagents, and the use of advanced emission control technologies that would result in reduced air emissions. The company submitted its construction air permit to the State of Nebraska in July. The project would be the only niobium mine and primary niobium processing facility in the United States. It was expected to begin production after 2020.

In January, a leading niobium producer in Brazil announced plans to increase its annual ferroniobium production capacity by $50 \%$ to 150,000 tons (approximately 98,000 tons of contained niobium). The company expected to invest $\$ 200$ million in the expansion which would be completed before the end of 2020.

World Mine Production and Reserves: The reserves data for the United States and Brazil were revised based on information reported by niobium-producing companies and the Governments of those countries.

\begin{tabular}{|c|c|c|c|}
\hline & \multicolumn{2}{|c|}{ Mine production } & \multirow{2}{*}{ Reserves $^{7}$} \\
\hline & 2018 & $2019^{\mathrm{e}}$ & \\
\hline United States & - & 二 & 210,000 \\
\hline Brazil & 59,000 & 65,000 & $11,000,000$ \\
\hline Canada & 7,700 & 7,600 & $1,600,000$ \\
\hline Other countries & 1,460 & 1,500 & NA \\
\hline World total (rounded) & 68,200 & $\overline{74,000}$ & $>13,000,000$ \\
\hline
\end{tabular}

World Resources: World resources of niobium are more than adequate to supply projected needs. Most of the world's identified resources of niobium occur as pyrochlore in carbonatite (igneous rocks that contain more than 50\%by-volume carbonate minerals) deposits and are outside the United States. The United States has approximately $1,400,000$ tons of niobium in identified resources, most of which were considered subeconomic at 2019 prices for niobium.

Substitutes: The following materials can be substituted for niobium, but a performance loss or higher cost may ensue: ceramic matrix composites, molybdenum, tantalum, and tungsten in high-temperature (superalloy) applications; molybdenum, tantalum, and titanium as alloying elements in stainless and high-strength steels; and molybdenum and vanadium as alloying elements in high-strength low-alloy steels.

\footnotetext{
'Estimated. NA Not available. - Zero.

${ }^{1}$ Imports and exports include the estimated niobium content of ferroniobium, niobium and tantalum ores and concentrates, niobium oxide, and niobium powders and unwrought metal.

${ }^{2}$ Defined as imports - exports + adjustments for Government stock changes.

${ }^{3}$ Only includes ferroniobium and nickel niobium.

${ }^{4}$ Unit value is weighted average unit value of gross weight of U.S. ferroniobium trade. (Trade is imports plus exports.)

${ }^{5}$ This category includes niobium-containing material and other material.

${ }^{6}$ See Appendix B for definitions.

${ }^{7}$ See Appendix $\mathrm{C}$ for resource and reserve definitions and information concerning data sources.
} 


\section{NITROGEN (FIXED)-AMMONIA}

(Data in thousand metric tons of contained nitrogen unless otherwise noted)

Domestic Production and Use: Ammonia was produced by 16 companies at 35 plants in 16 States in the United States during 2019; 2 additional plants were idle for the entire year. About $60 \%$ of total U.S. ammonia production capacity was in Louisiana, Oklahoma, and Texas because of their large reserves of natural gas, the dominant domestic feedstock for ammonia. In 2019, U.S. producers operated at about $90 \%$ of rated capacity. The United States was one of the world's leading producers and consumers of ammonia. Urea, ammonium nitrate, nitric acid, ammonium phosphates, and ammonium sulfate were, in descending order of importance, the major derivatives of ammonia produced in the United States.

Approximately $88 \%$ of apparent domestic ammonia consumption was for fertilizer use, including anhydrous ammonia for direct application, urea, ammonium nitrates, ammonium phosphates, and other nitrogen compounds. Ammonia also was used to produce explosives, plastics, synthetic fibers and resins, and numerous other chemical compounds.

\begin{tabular}{|c|c|c|c|c|c|}
\hline Salient Statistics_United States: & $\underline{2015}$ & $\underline{2016}$ & $\underline{2017}$ & $\underline{2018}$ & $\frac{2019^{\mathrm{e}}}{10000}$ \\
\hline$\overline{\text { Production }}$ & 19,590 & $110 \overline{200}$ & $11 \overline{1,600}$ & 113,100 & $1 \overline{4,000}$ \\
\hline Imports for consumption & 4,320 & 3,840 & 3,090 & 2,530 & 2,000 \\
\hline Exports & 93 & 183 & 612 & 281 & 240 \\
\hline Consumption, apparent ${ }^{2}$ & 13,700 & 13,800 & 14,100 & 15,200 & 16,000 \\
\hline Stocks, producer, yearend & 420 & 400 & 320 & 490 & 400 \\
\hline Price, dollars per short ton, average, f.o.b. Gulf Coast ${ }^{3}$ & 481 & 267 & 247 & 281 & 23 \\
\hline Employment, plant, numbere & 1,200 & 1,300 & 1,500 & 1,600 & 1,600 \\
\hline $\begin{array}{l}\text { Net import reliance } 4 \text { as a percentage } \\
\text { of apparent consumption }\end{array}$ & 30 & 26 & 18 & 14 & 1 \\
\hline
\end{tabular}

Recycling: None.

Import Sources (2015-18): Trinidad and Tobago, 65\%; Canada, 26\%; Russia, 3\%; Venezuela, 3\%; and other, 3\%.

Tariff: Item

Ammonia, anhydrous

Urea

Ammonium sulfate

Ammonium nitrate
Number

2814.10.0000

3102.10 .0000

3102.21 .0000

3102.30 .0000
Normal Trade Relations

12-31-19

Free.

Free.

Free.

Depletion Allowance: Not applicable.

Government Stockpile: None.

Events, Trends, and Issues: The Henry Hub spot natural gas price ranged between $\$ 2.03$ and $\$ 4.12$ per million British thermal units for most of the year, with an average of about $\$ 2.60$ per million British thermal units. Natural gas prices in 2019 were lower than those in 2018; a result of strong supply growth and warmer winter weather compared with that in 2018. The U.S. Department of Energy, Energy Information Administration, projected that Henry Hub natural gas spot prices would average \$2.52 per million British thermal units in 2020 .

The weekly average Gulf Coast ammonia price was $\$ 259$ per short ton at the beginning of 2019 , decreased to $\$ 200$ per short ton in mid-April, and then increased to $\$ 235$ per short ton in mid-August. The average ammonia price for 2019 was estimated to be $\$ 230$ per short ton. In 2019 , low natural gas prices resulted in lower ammonia prices. 


\section{NITROGEN (FIXED)—AMMONIA}

A long period of stable and low natural gas prices in the United States has made it economical for companies to upgrade existing ammonia plants and construct new nitrogen facilities. The additional capacity has reduced ammonia imports. Expansion in the ammonia industry took place throughout the past 5 years; however, no additional ammonia plants are expected to be commissioned before 2022. The newest U.S. ammonia plant located in Freeport, TX, became operational in 2018.

Global ammonia capacity is expected to increase by a total of $4 \%$ during the next 4 years. Capacity additions are expected in Africa, Eastern Europe, and south Asia; however, ongoing plant closures will decrease capacity in east Asia. Demand for ammonia is expected to increase in all regions with the largest increases expected in Africa and Eastern Europe.

Large corn plantings maintain the continued demand for nitrogen fertilizers. According to the U.S. Department of Agriculture, U.S. corn growers planted 37.1 million hectares of corn in the 2019 crop-year (July 1, 2018, through June $30,2019)$, which was $3 \%$ greater than the area planted in 2018. Corn acreage in the 2020 crop-year is expected to increase because of anticipated higher returns for corn compared with those of other crops.

\section{World Ammonia Production and Reserves:}

\begin{tabular}{lrr} 
& \multicolumn{2}{c}{ Plant production } \\
United States & $\underline{\mathbf{2 0 1 8}}$ & $\underline{\mathbf{2 0 1 9}}$ \\
Algeria & 1,100 & 14,000 \\
Australia & 1,600 & 2,300 \\
Belarus & 1,300 & 1,300 \\
Brazil & 1,050 & 1,100 \\
Canada & 1,000 & 1,000 \\
China & 3,830 & 3,800 \\
Egypt & 41,000 & 40,000 \\
Germany & 3,700 & 4,100 \\
India & 2,600 & 2,600 \\
Indonesia & 11,400 & 12,000 \\
Iran & 5,000 & 5,000 \\
Netherlands & 3,400 & 3,400 \\
Oman & 2,400 & 2,400 \\
Pakistan & 1,700 & 1,700 \\
Poland & 3,100 & 3,100 \\
Qatar & 2,170 & 2,200 \\
Russia & 3,100 & 3,100 \\
Saudi Arabia & 14,900 & 15,000 \\
Trinidad and Tobago & 4,000 & 4,300 \\
Ukraine & 4,000 & 4,000 \\
Uzbekistan & 1,620 & 1,600 \\
Vietnam & 1,200 & 1,200 \\
Other countries & 1,100 & 1,100 \\
World total (rounded) & 15,800 & 15,000 \\
& 144,000 & 150,000
\end{tabular}

World Resources: The availability of nitrogen from the atmosphere for fixed nitrogen production is unlimited. Mineralized occurrences of sodium and potassium nitrates, such as those found in the Atacama Desert of Chile, contribute minimally to the global nitrogen supply.

Substitutes: Nitrogen is an essential plant nutrient that has no substitute. No practical substitutes for nitrogen explosives and blasting agents are known.

\footnotetext{
${ }^{\text {eEstimated. }}$

${ }^{1}$ Source: The Fertilizer Institute; data adjusted by the U.S. Geological Survey.

${ }^{2}$ Defined as production + imports - exports + adjustments for industry stock changes.

${ }^{3}$ Source: Green Markets.

${ }^{4}$ Defined as imports - exports + adjustments for industry stock changes.

${ }^{5}$ See Appendix $\mathrm{C}$ for resource and reserve definitions and information concerning data sources.
} 


\section{PEAT}

(Data in thousand metric tons unless otherwise noted)

Domestic Production and Use: The estimated free on board (f.o.b.) mine value of marketable peat production in the conterminous United States was \$14 million in 2019. Peat was harvested and processed by about 28 companies in 12 conterminous States. Florida, Michigan, and Minnesota were the leading producing States, in order of quantity harvested. Reed-sedge peat accounted for approximately $87 \%$ of the total volume produced, followed by sphagnum moss with $10 \%$. Domestic peat applications included earthworm culture medium, golf course construction, mixed fertilizers, mushroom culture, nurseries, packing for flowers and plants, seed inoculants, and vegetable cultivation. In the industrial sector, peat was used as an oil absorbent and as an efficient filtration medium for the removal of waterborne contaminants in mine waste streams, municipal storm drainage, and septic systems.

\begin{tabular}{|c|c|c|c|c|c|}
\hline Salient Statistics-United States: & $\underline{2015}$ & $\underline{2016}$ & $\underline{2017}$ & $\underline{2018}$ & $\frac{2019^{\mathrm{e}}}{470}$ \\
\hline$\overline{\text { Production }}$ & 455 & $\overline{441}$ & $\overline{498}$ & $\overline{479}$ & 470 \\
\hline Sales by producers & 460 & 443 & 515 & 545 & 540 \\
\hline Imports for consumption & 1,150 & 1,130 & 1,150 & 1,200 & 1,10 \\
\hline Exports & 28 & 30 & 30 & 37 & 40 \\
\hline Consumption, apparent ${ }^{1}$ & 1,620 & 1,590 & 1,520 & 1,670 & 1,60 \\
\hline Price, average value, f.o.b. mine, dollars per ton & 28.39 & 31.97 & 27.55 & 25.88 & 28.5 \\
\hline Stocks, producer, yearend & 179 & 125 & 222 & 196 & 18 \\
\hline Employment, mine and plant, numbere & 550 & 550 & 540 & 540 & 50 \\
\hline $\begin{array}{l}\text { Net import reliance } 2 \text { as a percentage of } \\
\text { apparent consumption }\end{array}$ & 72 & 72 & 67 & 71 & \\
\hline
\end{tabular}

Recycling: None.

Import Sources (2015-18): Canada, 95\%; and other, 5\%.

Tariff: Item

Peat

Depletion Allowance: 5\% (Domestic and foreign).

Government Stockpile: None.

Events, Trends, and Issues: Peat is an important component of plant-growing media, and the demand for peat generally follows that of horticultural applications. In the United States, the short-term outlook is for production to average about 470,000 tons per year and imported peat from Canada is expected to continue to account for more than 70\% of domestic consumption. Imports for 2019 were estimated to have decreased to 1.1 million tons from 1.2 million tons in 2018, and exports were estimated to have increased to about 40,000 tons from 37,000 tons in 2018.

Peat stocks were estimated to have decreased in 2019 owing to a wet peat harvesting season causing a decrease in peat production in some parts of the country. Based on estimated world production for 2019, the world's leading peat producers were, in descending order of production, Finland, Germany, Ireland, Belarus, and Sweden.

Africa's first peat-fired powerplant in Gishoma, Rwanda, produced energy at its 15-megawatt-capacity facility, which added to the national power grid in 2019. Another peat-fired powerplant was under construction in Gisagara, Rwanda, and was expected to be operational in 2020. The peat-fired powerplants are anticipated to increase the national power capacity by about $40 \%$ when fully operational, bringing Rwanda closer to its goal of energy independence. 


\section{PEAT}

In other parts of the world, concerns about climate change prompted several countries to plan to decrease or eliminate the use of peat, owing to peatland's ability to act as a carbon sink. Ireland's peat production was expected to decrease over the coming years owing to its transition to alternative fuel sources. The country was aiming to have at least $80 \%$ of its fossil fuel sector employment transitioned to the renewable energy sector by 2025 . Ireland announced in 2019 that it planned to stop all peat harvesting by 2028, 2 years ahead of the previously announced schedule. In 2019, Finland announced its goal of becoming carbon neutral by 2035. To achieve this, peat production will be phased out in favor for other forms of noncarbon energy. Presently, about $40 \%$ of Finland's energy consumption is supplied by peat and other fossil fuels. Several European countries, including Belarus, Ireland, and Sweden, were planning or implementing peatland restoration projects to help combat greenhouse gas emissions and restore wildlife habitats. These initiatives were expected to decrease peat production across Europe in the future.

World Mine Production and Reserves: Reserves for countries that reported by volume only and had insufficient data for conversion to tons were combined and included with "Other countries." Reserves for Latvia were updated with information from company reports.

\begin{tabular}{lrrr} 
& \multicolumn{2}{c}{ Mine production } & Reserves $^{\mathbf{3}}$ \\
United States & $\mathbf{2 0 1 8}$ & $\mathbf{2 0 1 \mathbf { 9 } ^ { \mathbf { e } }}$ & \\
Belarus & 479 & 470 & 150,000 \\
Canada & 2,620 & 2,600 & $2,600,000$ \\
Estonia & 1,240 & 1,300 & 720,000 \\
Finland & 1,030 & 1,000 & 60,000 \\
Germany & 9,970 & 10,000 & $6,000,000$ \\
Ireland & 3,800 & 4,000 & $(4)$ \\
Latvia & 3,000 & 3,000 & $(4)$ \\
Lithuania & 1,900 & 1,900 & 230,000 \\
Poland & 510 & 500 & 210,000 \\
Russia & 700 & 700 & $(4)$ \\
Sweden & 800 & 800 & $1,000,000$ \\
Ukraine & 2,450 & 2,500 & $(4)$ \\
United Kingdom & 590 & 600 & $(4)$ \\
Other countriese & 700 & - & $(4)$ \\
$\quad$ World total (rounded) & 610 & 600 & $1,400,000$ \\
\hline
\end{tabular}

World Resources: Peat is a renewable resource, continuing to accumulate on $60 \%$ of global peatlands. However, the volume of global peatlands has been decreasing at a rate of $0.05 \%$ annually owing to harvesting and land development. Many countries evaluate peat resources based on volume or area because the variations in densities and thickness of peat deposits make it difficult to estimate tonnage. Volume data have been converted using the average bulk density of peat produced in that country. Reserves data were estimated based on data from International Peat Society publications and the percentage of peat resources available for peat extraction. More than $50 \%$ of the U.S. peat resources are located in undisturbed areas of Alaska.

Substitutes: Natural organic materials, such as composted yard waste and coir (coconut fiber), compete with peat in horticultural applications. Shredded paper and straw are used to hold moisture for some grass-seeding applications. The superior water-holding capacity and physiochemical properties of peat limit substitution alternatives in most applications.

\footnotetext{
eEstimated. - Zero.

${ }^{1}$ Defined as production + imports - exports + adjustments for industry stock changes.

${ }^{2}$ Defined as imports - exports + adjustments for industry stock changes.

${ }^{3}$ See Appendix $\mathrm{C}$ for resource and reserve definitions and information concerning data sources.

${ }^{4}$ Included with "Other countries."
} 


\section{PERLITE}

(Data in thousand metric tons unless otherwise noted)

Domestic Production and Use: In 2019, the quantity of domestic processed crude perlite sold and used was estimated to be 480,000 tons with a value of $\$ 35$ million. Crude ore production was from eight mines operated by six companies in five Western States. New Mexico and Oregon continued to be the leading producing States. Processed crude perlite was expanded at 56 plants in 27 States. Domestic apparent consumption was 670,000 tons. The applications for expanded perlite were building construction products, 58\%; fillers, 18\%; horticultural aggregate, 16\%; filter aid, 4\%; and other, 4\%. Other applications included specialty insulation and miscellaneous uses.

\begin{tabular}{|c|c|c|c|c|c|}
\hline Salient Statistics-United States: & 2015 & 2016 & 2017 & 2018 & $\underline{2019^{\mathrm{e}}}$ \\
\hline Mine production, crude ore & $\overline{501}$ & $\overline{521}$ & $\overline{570}$ & $\overline{\mathrm{e} 510}$ & 520 \\
\hline Sold and used, processed crude perlite & 444 & 437 & 479 & e 460 & 48 \\
\hline Imports for consumption ${ }^{1}$ & 154 & 199 & 171 & 204 & 26 \\
\hline Exports $^{1}$ & 18 & 16 & 18 & 16 & \\
\hline Consumption, apparent ${ }^{2}$ & 580 & 620 & 632 & e620 & 67 \\
\hline Price, average value, dollars per ton, f.o.b. mine & 61 & 65 & 73 & 72 & \\
\hline Employment, mine and mill, number & 142 & 135 & 139 & 130 & 14 \\
\hline $\begin{array}{l}\text { Net import reliance }{ }^{3} \text { as a percentage of } \\
\text { apparent consumption }\end{array}$ & 23 & 30 & 24 & 30 & $2 \varepsilon$ \\
\hline
\end{tabular}

Recycling: Not available.

Import Sources (2015-18): Greece, 89\%; China, 8\%; Mexico, 2\%; and other, 1\%.

\section{Tariff: Item}

Vermiculite, perlite and chlorites, unexpanded
Number

2530.10 .0000

\section{Normal Trade Relations $\underline{12-31-19}$}

Free.

Depletion Allowance: 10\% (Domestic and foreign).

\section{Government Stockpile: None.}

Events, Trends, and Issues: Perlite is a siliceous volcanic glass that expands up to 20 times its original volume when rapidly heated. In horticultural uses, expanded perlite is used to provide moisture retention and aeration without compaction when added to soil. Owing primarily to cost, some commercial greenhouse growers in the United States have recently switched to a wood fiber material over perlite. Perlite, however, remained a preferred soil amendment for segments of greenhouse growers because it does not degrade or compact over lengthy growing times and is inert. Construction applications for expanded perlite are numerous because it is lightweight, fire resistant, and an excellent insulator. Novel and small markets for perlite have increased during the past 10 years; cosmetics, environmental remediation, personal care products, and marijuana growing have become increasing markets for perlite. Exploration continued at a perlite deposit in Nevada that could be developed as a potential supplier of crude perlite ore for industrial and household applications. 


\section{PERLITE}

Domestic perlite mining generally takes place in remote areas, and its environmental impact is not severe. The mineral fines, overburden, and reject ore produced during ore mining and processing are used to reclaim the minedout areas, and, therefore, little waste remains. Airborne dust is captured by baghouses, and virtually no runoff contributes to water pollution.

Based on estimated world production for 2019, the world's leading producers were, in descending order of production, China, Greece, Turkey, and the United States, with about 47\%, 20\%, 16\%, and 13\%, respectively, of world production. Although China was the leading producer, most of its perlite production was thought to be consumed internally. Greece and Turkey remained the leading exporters of perlite.

\section{World Perlite Production and Reserves:}

\begin{tabular}{|c|c|c|c|}
\hline & & & Reserves $^{4}$ \\
\hline & $\underline{2018}$ & $\underline{2019^{e}}$ & \\
\hline United States & e, 5510 & 5520 & 50,000 \\
\hline Argentina & 20 & 20 & NA \\
\hline Armenia & 45 & 45 & NA \\
\hline China & 1,900 & 1,900 & NA \\
\hline Greece & 750 & 800 & 120,000 \\
\hline Hungary & 39 & 40 & 49,000 \\
\hline Iran & 20 & 20 & NA \\
\hline Mexico & 20 & 20 & NA \\
\hline New Zealand & 20 & 20 & NA \\
\hline Turkey & 650 & 650 & 57,000 \\
\hline Other countries & 50 & 50 & NA \\
\hline World total (rounded) & $\overline{4,020}$ & $\overline{4,100}$ & NA \\
\hline
\end{tabular}

World Resources: Perlite occurrences in Arizona, Idaho, Nevada, New Mexico, and Oregon are thought to contain large resources. Significant deposits have been reported in China, Greece, Hungary, and Turkey, and a few other countries. Insufficient information is available to make reliable estimates of resources in many perlite-producing countries.

Substitutes: In construction applications, diatomite, expanded clay and shale, pumice, and slag can be substituted for perlite. For horticultural uses, vermiculite, coco coir, wood pulp, and pumice are alternative soil additives and are sometimes used in conjunction with perlite.

\footnotetext{
eEstimated. NA Not available.

${ }^{1}$ Exports and imports were estimated by the U.S. Geological Survey from U.S. Census Bureau combined data for vermiculite, perlite, and chlorites, unexpanded.

${ }^{2}$ Defined as sold or used processed perlite + imports - exports.

${ }^{3}$ Defined as imports - exports.

${ }^{4}$ See Appendix $\mathrm{C}$ for resource and reserve definitions and information concerning data sources.

${ }^{5}$ Mine production of crude ore.
} 


\section{PHOSPHATE ROCK}

(Data in thousand metric tons unless otherwise noted)

Domestic Production and Use: In 2019, phosphate rock ore was mined by five firms at 10 mines in four States and processed into an estimated 23 million tons of marketable product, valued at $\$ 1.6$ billion, free on board (f.o.b.) mine. Florida and North Carolina accounted for more than $75 \%$ of total domestic output; the remainder was produced in Idaho and Utah. Marketable product refers to beneficiated phosphate rock with phosphorus pentoxide $\left(\mathrm{P}_{2} \mathrm{O}_{5}\right)$ content suitable for phosphoric acid or elemental phosphorus production. More than $95 \%$ of the phosphate rock mined in the United States was used to manufacture wet-process phosphoric acid and superphosphoric acid, which were used as intermediate feedstocks in the manufacture of granular and liquid ammonium phosphate fertilizers and animal feed supplements. Approximately $50 \%$ of the wet-process phosphoric acid produced was exported in the form of upgraded granular diammonium (DAP) and monoammonium phosphate (MAP) fertilizer, and merchant-grade phosphoric acid. The balance of the phosphate rock mined was for the manufacture of elemental phosphorus, which was used to produce phosphorus compounds for industrial applications, primarily glyphosate herbicide.

\section{Salient Statistics-United States:}

Production, marketable

Sold or used by producers

Imports for consumption

Consumption, apparent ${ }^{1}$

Price, average value, dollars per ton, f.o.b. mine ${ }^{2}$

Stocks, producer, yearend

Employment, mine and beneficiation plant, number ${ }^{\mathrm{e}}$

Net import reliance ${ }^{3}$ as a percentage of

apparent consumption

$\begin{array}{rr}\underline{\mathbf{2 0 1 5}} & \underline{\mathbf{2 0 1 6}} \\ 27,400 & 27,100 \\ 26,200 & 26,700 \\ 1,960 & 1,590 \\ 28,100 & 28,200 \\ 72.41 & 76.90 \\ 6,730 & 7,450 \\ 2,000 & 2,000\end{array}$

4

$\mathbf{2 0 1 7}$
27,900
26,300
2,470
28,800
73.67
8,440
2,000

5

$\mathbf{2 0 1 8}$
25,800
23,300
2,770
26,000
70.77
10,600
2,000
2

2

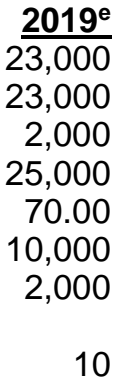

3,000

2,000

25,000

70.00

10,000

2,000

10

Recycling: None.

Import Sources (2015-18): Peru, 79\%; Morocco, 20\%; and other, 1\%.

Tariff: Item

Number

Natural calcium phosphates:

Unground

Ground
2510.10.0000

2510.20.0000
Normal Trade Relations 12-31-19

Free.

Free.

Depletion Allowance: 14\% (Domestic and foreign).

\section{Government Stockpile: None.}

Events, Trends, and Issues: Domestic phosphate rock production was lower in 2019 owing to the temporary closure of one mine in Florida and companies reducing stocks of phosphate rock. Domestic consumption was $4 \%$ lower because of lower production of phosphoric acid and fertilizers. Imports were lower as the result of the permanent closure at the end of 2018 of a phosphoric acid plant in Louisiana that used imported phosphate rock and the temporary closure of another plant in Louisiana in the fourth quarter of 2019.

The leading phosphate rock producer in the United States permanently closed a phosphoric acid and fertilizer plant in June 2019 as part of corporate restructuring. The facility had been idled since 2017 and the phosphate rock mine that supplied the plant closed in late 2018. Another company planned to use the facility to manufacture organic fertilizers.

The only U.S. producer of elemental phosphorus received approval for a new phosphate rock mine in Idaho. The new mine would replace the current mine when the ore is depleted in about 10 years. U.S. phosphate rock annual mine production capacity was expected to remain at 31.1 million tons in 2020.

According to industry analysts, the rated capacity of global phosphate rock mines was projected to increase to 177 million tons in 2023 from 157 million tons in 2019, not including official capacity data for China. Production of marketable phosphate rock in China was thought to be between 80 and 85 million tons per year, compared with official production statistics of 110 million tons per year that included some crude ore production. Most of the increases in production capacity were planned for Africa and the Middle East, where major expansion projects were in progress in Jordan, Morocco, Saudi Arabia, Senegal, and Togo. 


\section{PHOSPHATE ROCK}

A Russian company restarted production of phosphate rock in Syria in 2018 . The mine had been closed since late 2015 because of the conflicts in the region. The Russian company signed a 50-year operating agreement with the Government of Syria to operate the mine. The company planned to produce about 2.2 million tons per year. Production data for Syria have not been verified.

World consumption of $\mathrm{P}_{2} \mathrm{O}_{5}$, contained in phosphoric acid, fertilizers, and other products, was projected to increase to 50 million tons in 2023 from 47 million tons in 2019. Africa, India, and South America accounted for about $75 \%$ of the projected growth. U.S. consumption of $\mathrm{P}_{2} \mathrm{O}_{5}$ was expected to remain between 4.0 and 4.5 million tons per year.

World Mine Production and Reserves: Reserves for Israel, Peru, and South Africa were revised based on industry reports. Reserves for Australia were revised based on Government information.

\begin{tabular}{lrrr} 
& \multicolumn{2}{c}{ Mine production } & Reserves \\
United States & $\mathbf{2 0 1 8}$ & $\mathbf{2 0 1 \mathbf { 9 } ^ { \mathbf { e } }}$ & \\
Algeria & 25,800 & 23,000 & $1,000,000$ \\
Australia & 1,200 & 1,200 & $2,200,000$ \\
Brazil & 2,800 & 2,700 & $51,200,000$ \\
China & 5,740 & 5,300 & $1,700,000$ \\
Egypt & 120,000 & 110,000 & $3,200,000$ \\
Finland & 5,000 & 5,000 & $1,300,000$ \\
India & 989 & 1,000 & $1,000,000$ \\
Israel & 1,600 & 1,600 & 46,000 \\
Jordan & 3,550 & 3,500 & 62,000 \\
Kazakhstan & 8,020 & 8,000 & $1,000,000$ \\
Mexico & 1,300 & 1,300 & 260,000 \\
Morocco and Western Sahara & 1,540 & 1,500 & 30,000 \\
Peru & 34,800 & 36,000 & $50,000,000$ \\
Russia & 3,900 & 3,700 & 210,000 \\
Saudi Arabia & 14,000 & 14,000 & 600,000 \\
Senegal & 6,090 & 6,200 & $1,400,000$ \\
South Africa & 1,650 & 1,600 & 50,000 \\
Syria & 2,100 & 1,900 & $1,400,000$ \\
Togo & 100 & 2,000 & $1,800,000$ \\
Tunisia & 800 & 800 & 30,000 \\
Uzbekistan & 3,340 & 3,000 & 100,000 \\
Vietnam & 900 & 900 & 100,000 \\
Other countries & 3,300 & 5,500 & 30,000 \\
$\quad$ World total (rounded) & 970 & 1,000 & 770,000 \\
\hline
\end{tabular}

World Resources: Some world reserves were reported only in terms of ore tonnage and grade. Phosphate rock resources occur principally as sedimentary marine phosphorites. The largest sedimentary deposits are found in northern Africa, China, the Middle East, and the United States. Significant igneous occurrences are found in Brazil, Canada, Finland, Russia, and South Africa. Large phosphate resources have been identified on the continental shelves and on seamounts in the Atlantic Ocean and the Pacific Ocean. World resources of phosphate rock are more than 300 billion tons. There are no imminent shortages of phosphate rock.

Substitutes: There are no substitutes for phosphorus in agriculture.

\footnotetext{
eEstimated.

${ }^{1}$ Defined as phosphate rock sold or used by producers + imports. U.S. producers stopped exporting phosphate rock in 2003.

${ }^{2}$ Marketable phosphate rock, weighted value, all grades.

${ }^{3}$ Defined as imports + adjustments for industry stock changes.

${ }^{4}$ See Appendix $C$ for resource and reserve definitions and information concerning data sources.

${ }^{5}$ For Australia, Joint Ore Reserves Committee-compliant reserves were 81 million tons.

${ }^{6}$ Production data for large mines only, as reported by the National Bureau of Statistics of China.
} 


\section{PLATINUM-GROUP METALS}

(Palladium, platinum, iridium, osmium, rhodium, and ruthenium)

(Data in kilograms of platinum-group-metal content unless otherwise noted)

Domestic Production and Use: One company in Montana produced over 15,000 kilograms of platinum-group metals (PGMs) with an estimated value of about $\$ 680$ million. Small quantities of primary PGMs also were recovered as byproducts of copper-nickel mining in Michigan; however, this material was sold to foreign companies for refining. The leading domestic use for PGMs was in catalytic converters to decrease harmful emissions from automobiles. Platinum-group metals are also used in catalysts for bulk-chemical production and petroleum refining; dental and medical devices; electronic applications, such as in computer hard disks, hybridized integrated circuits, and multilayer ceramic capacitors; glass manufacturing; investment; jewelry; and laboratory equipment.

\begin{tabular}{|c|c|c|c|c|c|}
\hline$\frac{\text { Salient Statistics-United States: }}{\text { Mine production: }{ }^{1}}$ & \multicolumn{4}{|c|}{ Mine production: ${ }^{1}$} & $\underline{2019^{e}}$ \\
\hline Palladium & 12,500 & 13,100 & 13,600 & 14.300 & 12,000 \\
\hline Platinum & 3,670 & 3,890 & 3,980 & 4,160 & 3,600 \\
\hline \multicolumn{6}{|l|}{ Imports for consumption: ${ }^{2}$} \\
\hline Palladium & 85,300 & 80,400 & 86,000 & 92,900 & 76,000 \\
\hline Platinum & 42,700 & 42,300 & 53,200 & 58,500 & 38,000 \\
\hline PGM waste and scrap & 123,000 & 154,000 & 354,000 & 40,700 & 38,000 \\
\hline Iridium & 1,010 & 1,300 & 1,420 & 1,020 & 910 \\
\hline Osmium & 8 & 27 & 856 & 25 & - \\
\hline Rhodium & 10,600 & 10,700 & 11,600 & 14,500 & 14,000 \\
\hline Ruthenium & 8,230 & 8,410 & 14,600 & 17,900 & 9,900 \\
\hline \multicolumn{6}{|l|}{ Exports: $^{3}$} \\
\hline Palladium & 23,000 & 17,500 & 52,300 & 53,300 & 50,000 \\
\hline Platinum & 14,400 & 14,000 & 16,700 & 18,900 & 17,000 \\
\hline PGM waste and scrap & 246,000 & 48,100 & 55,500 & 31,800 & 19,000 \\
\hline Rhodium & 759 & 794 & 844 & 2,010 & 1,600 \\
\hline Other PGMs & 781 & 736 & 939 & 2,600 & 1,300 \\
\hline \multicolumn{6}{|l|}{ Consumption, apparent ${ }^{4,5}$} \\
\hline Palladium & 117,000 & 118,000 & 89,300 & 95,900 & 80,000 \\
\hline Platinum & 40,800 & 43,200 & 51,500 & 53,800 & 33,000 \\
\hline \multicolumn{6}{|l|}{ Price, dollars per troy ounce: ${ }^{6}$} \\
\hline Palladium & 694.99 & 617.39 & 874.30 & $1,036.43$ & $1,500.00$ \\
\hline Platinum & $1,056.09$ & 989.52 & 951.23 & 882.66 & 850.00 \\
\hline Iridium & 544.19 & 586.90 & 908.35 & $1,293.27$ & $1,500.00$ \\
\hline Rhodium & 954.90 & 696.84 & $1,112.59$ & $2,225.30$ & $3,300.00$ \\
\hline Ruthenium & 47.63 & 42.00 & 76.86 & 244.41 & 270.00 \\
\hline Employment, mine, number ${ }^{1}$ & 1,439 & 1,432 & 1,432 & 1,628 & 1,400 \\
\hline \multicolumn{6}{|c|}{$\begin{array}{l}\text { Net import reliance } 5,7 \text { as a percentage of } \\
\text { apparent consumption: }\end{array}$} \\
\hline Palladium & 53 & 53 & 38 & 41 & 32 \\
\hline Platinum & 66 & 66 & 71 & 74 & 64 \\
\hline
\end{tabular}

Recycling: About 116,000 kilograms of palladium and platinum was recovered globally from new and old scrap in 2018, including about 49,000 kilograms recovered from automobile catalytic converters in the United States.

Import Sources (2015-18): Palladium: South Africa, 33\%; Russia, 33\%; Germany, 7\%; Italy, 7\%; and other, $20 \%$. Platinum: South Africa, 46\%; Germany, 16\%; Italy, 7\%; Russia, 6\%; and other, 25\%.

Tariff: All unwrought and semimanufactured forms of PGMs are imported duty free. See footnotes for specific Harmonized Tariff Schedule of the United States codes.

Depletion Allowance: 22\% (Domestic), 14\% (Foreign). 


\section{PLATINUM-GROUP METALS}

\section{Government Stockpile: ${ }^{8}$}

$\begin{array}{lc}\text { Material } & \begin{array}{c}\text { Inventory } \\ \text { As of 9-30-19 }\end{array} \\ \text { Iridium } & 15 \\ \text { Platinum } & 261\end{array}$

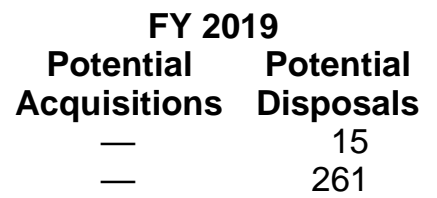

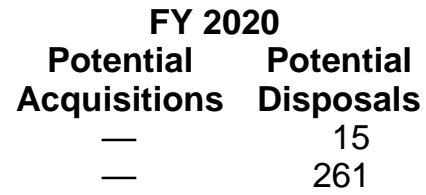

Events, Trends, and Issues: Progress continued at a domestic mine expansion project; full production from the project was expected by late 2021. Based on platinum content, imports of PGM waste and scrap decreased by $89 \%$ in 2018 compared with imports in 2017 and remained at similarly low levels in 2019; however, imports of PGM waste and scrap based on gross weight only decreased by $12 \%$ during the same time period. This indicates that imported PGM waste and scrap has increased in content of PGMs other than platinum.

Production of PGMs in South Africa, the world's leading supplier of mined material, decreased by $4 \%$ compared with that of 2018 owing to increased labor costs, increased costs for electricity, an unreliable supply of electricity, and challenges related to deep-level mining.

The estimated annual average prices of iridium, palladium, rhodium, and ruthenium increased by $15 \%, 41 \%, 50 \%$, and $8 \%$, respectively, compared with those of 2018 . The estimated average annual price of platinum was $3 \%$ lower than that of 2018, continuing a 5-year trend of declining prices. The price of palladium remained higher than that of platinum in 2019, with palladium prices exceeding a previous high of \$1,036.82 in January 2013 and platinum prices decreasing to their lowest level in a decade.

\section{World Mine Production and Reserves:}

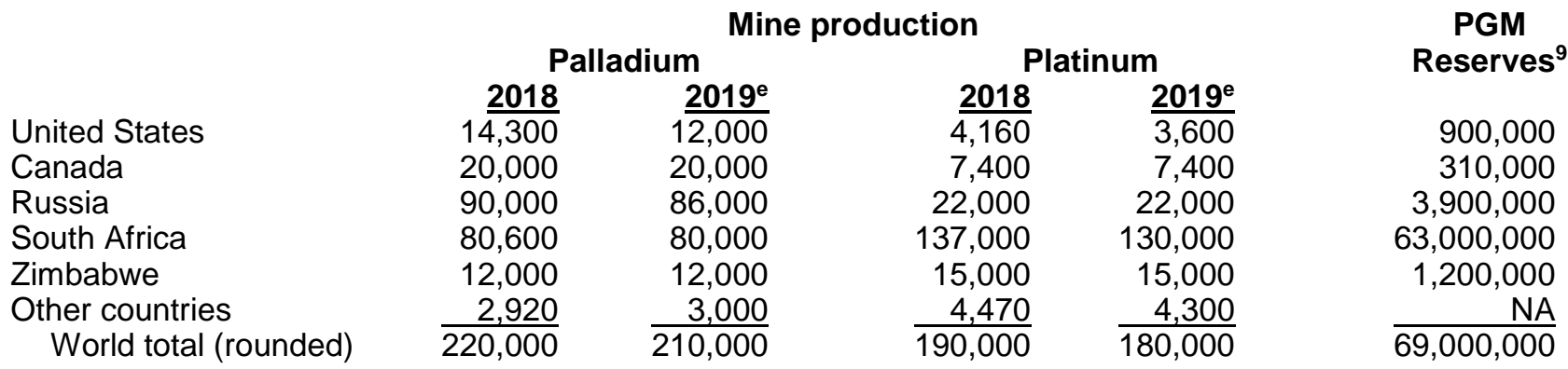

World Resources: World resources of PGMs are estimated to total more than 100 million kilograms. The largest reserves are in the Bushveld Complex in South Africa.

Substitutes: Palladium has been substituted for platinum in most gasoline-engine catalytic converters because of the historically lower price for palladium relative to that of platinum. About $25 \%$ of palladium can routinely be substituted for platinum in diesel catalytic converters; the proportion can be as much as $50 \%$ in some applications. For some industrial end uses, one PGM can substitute for another, but with losses in efficiency.

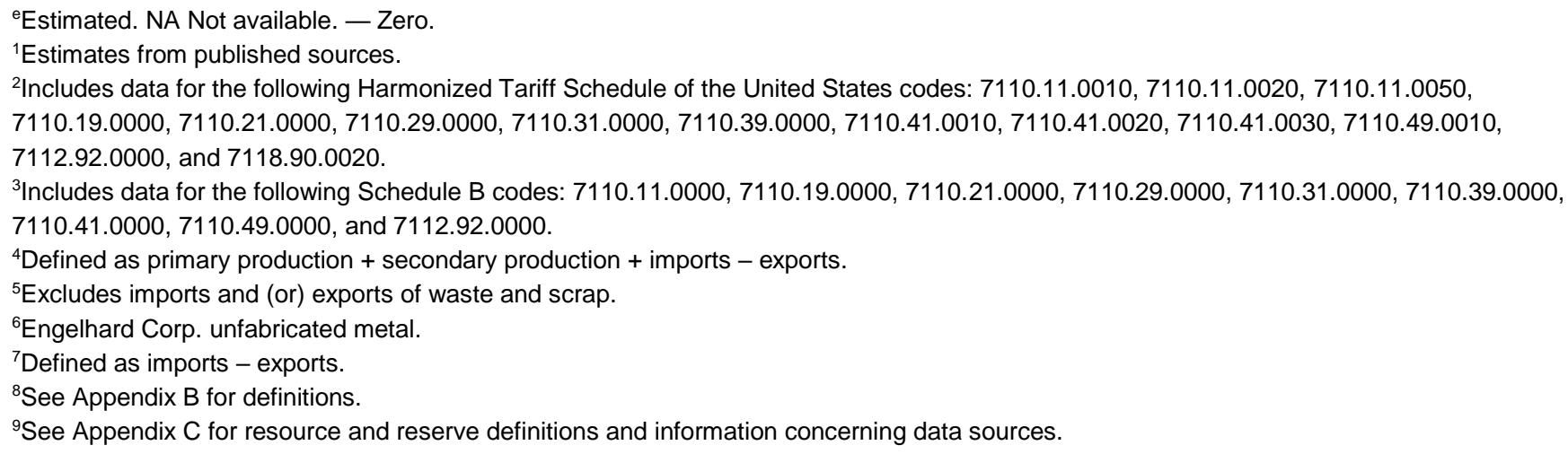




\section{POTASH}

(Data in thousand metric tons of $\mathrm{K}_{2} \mathrm{O}$ equivalent unless otherwise noted)

Domestic Production and Use: In 2019, the estimated sales value of marketable potash, f.o.b. mine, was $\$ 400$ million, which was about the same as that in 2018. Potash denotes a variety of mined and manufactured salts, which contain the element potassium in water-soluble form. In agriculture, the term potash refers to potassic fertilizers, which are potassium chloride (KCl), potassium sulfate or sulfate of potash (SOP), and potassium magnesium sulfate (SOPM) or langbeinite. Muriate of potash (MOP) is an agriculturally acceptable mix of $\mathrm{KCl}(95 \%$ pure or greater) and sodium chloride for fertilizer use. The majority of U.S. production was from southeastern New Mexico, where two companies operated two underground mines and one deep-well solution mine. Sylvinite and langbeinite ores in New Mexico were beneficiated by flotation, dissolution-recrystallization, heavy-media separation, solar evaporation, and (or) combinations of these processes, and accounted for about $50 \%$ of total U.S. producer sales. In Utah, two companies operated three facilities. One company extracted underground sylvinite ore by deep-well solution mining. Solar evaporation crystallized the sylvinite ore from the brine solution, and a flotation process separated the MOP from byproduct sodium chloride. The firm also processed subsurface brines by solar evaporation and flotation to produce MOP at its other facility. Another company processed brine from the Great Salt Lake by solar evaporation to produce SOP and other byproducts.

The fertilizer industry used about $85 \%$ of U.S. potash sales, and the remainder was used for chemical and industrial applications. About $80 \%$ of the potash produced was SOPM and SOP, which are required to fertilize certain chloridesensitive crops. Muriate of potash accounted for the remaining $20 \%$ of production and was used for agricultural and chemical applications.

\begin{tabular}{|c|c|c|c|c|c|}
\hline Salient Statistics-United States: & $\underline{2015}$ & $\underline{2016}$ & $\underline{2017}$ & $\underline{2018}$ & $\underline{2019^{e}}$ \\
\hline Production, marketable ${ }^{1}$ & 740 & 510 & 480 & 520 & 510 \\
\hline Sales by producers, marketable ${ }^{1}$ & 620 & 600 & 490 & 520 & 510 \\
\hline Imports for consumption & 5,190 & 4,550 & 5,870 & 5,710 & 5,000 \\
\hline Exports & 106 & 96 & 128 & 105 & 90 \\
\hline Consumption, apparent ${ }^{1,2}$ & 5,700 & 5,100 & 6,200 & 6,100 & 5,400 \\
\hline $\begin{array}{l}\text { Price, dollars per ton of } \mathrm{K}_{2} \mathrm{O} \text {, } \\
\text { average, all products, f.o.b. mine }{ }^{3}\end{array}$ & 880 & 680 & 770 & 750 & 800 \\
\hline $\begin{array}{l}\text { Price, dollars per ton of } \mathrm{K}_{2} \mathrm{O} \\
\text { average, muriate, f.o.b. mine }\end{array}$ & 580 & 350 & 410 & 440 & 480 \\
\hline Employment, number, mine and mill & 1,300 & 1,150 & 900 & 900 & 900 \\
\hline $\begin{array}{l}\text { Net import reliance } 4 \text { as a percentage of } \\
\text { apparent consumption }\end{array}$ & 89 & 88 & 92 & 92 & 91 \\
\hline
\end{tabular}

Recycling: None.

Import Sources (2015-18): Canada, 81\%; Russia, 8\%; Belarus, 5\%; Israel, 2\%; and other, 4\%.

Tariff: Item

Potassium nitrate

Potassium chloride

Potassium sulfate

Potassic fertilizers, other
Number

2834.21.0000

3104.20 .0000

3104.30 .0000

3104.90 .0100
Normal Trade Relations

$\underline{\text { 12-31-19 }}$

Free.

Free.

Free.

Free.

Depletion Allowance: 14\% (Domestic and foreign).

Government Stockpile: None.

Events, Trends, and Issues: Domestic and world consumption of potash fertilizers was affected by wet conditions during the planting seasons in many countries during the first half of 2019. This resulted in lower potash sales and higher inventories worldwide. In the United States, production and sales of all forms of potash decreased slightly as sales of SOP, SOPM, and MOP for nonfertilizer uses offset some of the lower MOP fertilizer sales. Domestic imports and consumption fell by more than $12 \%$ owing to the poor weather conditions during the spring planting season.

High inventories caused the major world producers to reduce production during the second half of the year. Belarus, Canada, Chile, Germany, and Israel all had temporary mine and plant closures. 


\section{POTASH}

World consumption of potash was estimated to have remained about the same as in 2018 at 43 million tons, owing to increased nonagricultural uses and regional seasonal consumption during the second half of 2019 . World production was estimated to have fallen by $5 \%$ compared with 2018 , owing to high inventories.

Development of a SOP facility in Utah continued in 2019. The Sevier Playa project, which is about 225 kilometers southwest of Salt Lake City, would produce SOP from solar evaporation of surface brines. The operating company received final permits in 2019 and was expected to begin construction in 2020 . Production was scheduled to begin in 2022 at 30,000 tons of SOP and ramp up to full capacity of 372,000 tons per year of SOP in 2025.

Global annual potash production capacity was estimated to be 61 million tons in 2019. New mines in Belarus and Russia, and expansions to existing facilities in Canada and Israel were expected to be completed in 2020. Other projects in Belarus, Canada, China, Jordan, and the United Kingdom could increase capacity to about 68 million tons in 2023; however, these projects were dependent on potash market conditions or securing financing for the projects.

World Mine Production and Reserves: Reserves for Canada, Spain, and the United Kingdom were revised based on official Government information. Reserves for Russia were revised based on information reported by the producers. The previously reported reserve information was based on official Government data, which included some deposits that are considered resources by USGS reserve definition.

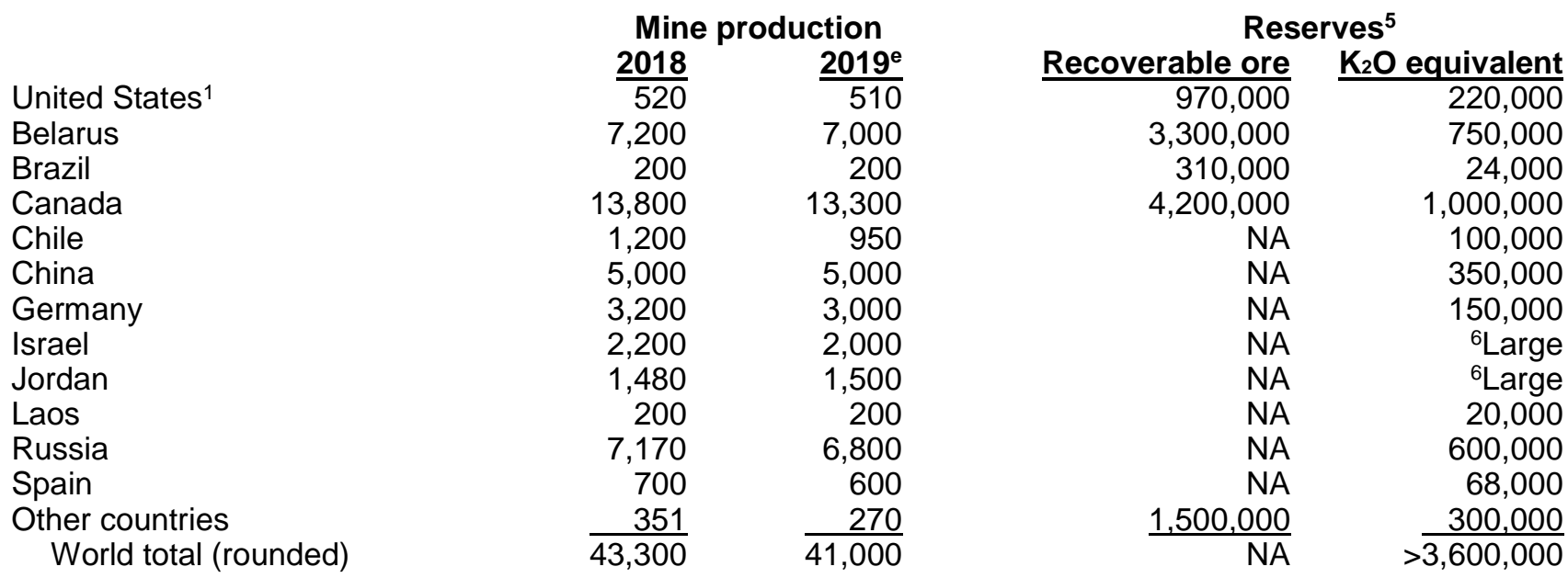

World Resources: Estimated domestic potash resources total about 7 billion tons. Most of these lie at depths between 1,800 and 3,100 meters in a 3,110-square-kilometer area of Montana and North Dakota as an extension of the Williston Basin deposits in Manitoba and Saskatchewan, Canada. The Paradox Basin in Utah contains resources of about 2 billion tons, mostly at depths of more than 1,200 meters. The Holbrook Basin of Arizona contains resources of about 0.7 to 2.5 billion tons. A large potash resource lies about 2,100 meters under central Michigan and contains more than 75 million tons. Estimated world resources total about 250 billion tons.

Substitutes: No substitutes exist for potassium as an essential plant nutrient and as an essential nutritional requirement for animals and humans. Manure and glauconite (greensand) are low-potassium-content sources that can be profitably transported only short distances to crop fields.

\footnotetext{
eEstimated. NA Not available.

${ }^{1}$ Data are rounded to no more than two significant digits to avoid disclosing company proprietary data.

${ }^{2}$ Defined as sales + imports - exports.

${ }^{3}$ Includes MOP, SOP, and SOPM. Does not include other chemical compounds that contain potassium.

${ }^{4}$ Defined as imports - exports.

${ }^{5}$ See Appendix $\mathrm{C}$ for resource and reserve definitions and information concerning data sources.

${ }^{6}$ Israel and Jordan recover potash from the Dead Sea, which contains nearly 2 billion tons of potassium chloride.
} 


\section{PUMICE AND PUMICITE}

(Data in thousand metric tons unless otherwise noted)

Domestic Production and Use: In 2019, 10 operations in five States produced pumice and pumicite. Estimated production ${ }^{1}$ was 510,000 tons with an estimated processed value of about $\$ 17$ million, free on board (f.o.b.) plant. Pumice and pumicite were mined in California, Oregon, Idaho, New Mexico, and Kansas, in descending order of production. The porous, lightweight properties of pumice are well suited for its main uses. Mined pumice was used in the production of abrasives, concrete admixtures and aggregates, lightweight building blocks, horticultural purposes, and other uses, including absorbent, filtration, laundry stone washing, and road use.

\begin{tabular}{|c|c|c|c|c|c|}
\hline Salient Statistics_United States: & $\underline{2015}$ & $\underline{2016}$ & $\underline{2017}$ & $\underline{2018}$ & $\underline{2019^{\mathrm{e}}}$ \\
\hline Production, mine ${ }^{1}$ & $\overline{310}$ & $\overline{374}$ & 383 & 496 & 510 \\
\hline Imports for consumption & 64 & 170 & 166 & 159 & 110 \\
\hline Exports & 11 & 9 & 11 & 11 & 1 \\
\hline Consumption, apparent ${ }^{2}$ & 363 & 535 & 538 & 644 & 610 \\
\hline $\begin{array}{l}\text { Price, average value, dollars per ton, f.o.b. } \\
\text { mine or mill }\end{array}$ & 33 & 38 & 39 & 32 & \\
\hline Employment, mine and mill, number & 140 & 140 & 140 & 140 & 140 \\
\hline $\begin{array}{l}\text { Net import reliance }{ }^{3} \text { as a percentage of } \\
\text { apparent consumption }\end{array}$ & 15 & 30 & 29 & 23 & 17 \\
\hline
\end{tabular}

Recycling: Little to no known recycling.

Import Sources (2015-18): Greece, 93\%; Iceland, 5\%; and Mexico, 2\%.

\section{Tariff: Item}

Pumice, crude or in irregular pieces, including crushed

Pumice, other
Number

2513.10.0010

2513.10.0080
Normal Trade Relations
$\underline{12-31-19}$

Free.

Free.

Depletion Allowance: 5\% (Domestic and foreign).

Government Stockpile: None.

Events, Trends, and Issues: The amount of domestically produced pumice and pumicite sold or used in 2019 was estimated to be $3 \%$ more than that in 2018. Imports were estimated to have decreased, and exports increased compared with those of 2018. Since 2015, apparent consumption and quantity of pumice that was sold or used had followed an upward trend until 2019. Almost all imported pumice originated from Greece in 2019, and primarily supplied markets in the eastern and Gulf Coast regions of the United States. Turkey, followed by Greece, was the leading global producer of pumice and pumicite. Although the domestic mill price for pumice was approximately $\$ 33$ per ton, the average imported value of pumice was approximately $\$ 44$ per ton.

Pumice and pumicite are plentiful in the Western United States, but legal challenges and public land designations could limit access to known deposits. Pumice and pumicite production is sensitive to mining and transportation costs. Although unlikely in the short term, an increase in fuel prices would likely lead to increases in production costs, making imports and competing materials attractive substitutes for domestic products. 


\section{PUMICE AND PUMICITE}

All known domestic pumice and pumicite mining in 2019 was accomplished through open pit methods, generally in remote areas, away from major population centers. Although the generation and disposal of reject fines in mining and milling may result in local dust issues at some operations, such environmental impacts are thought to be restricted to relatively small geographic areas.

World production of pumice and related material was estimated to be 18 million tons in 2019 , which was essentially unchanged from that of 2018. Pumice is used more extensively as a building material outside the United States, which explained the large global production of pumice relative to that of the United States. In Europe, basic home construction uses stone and concrete as the preferred building materials. Prefabricated lightweight concrete walls, which may contain pumice as lightweight aggregate, are often produced and shipped to construction locations. Because of their cementitious properties, light weight, and strength, pumice and pumicite perform well in Europeanstyle construction.

\section{World Mine Production and Reserves:}

\begin{tabular}{|c|c|c|}
\hline & Mine & uction \\
\hline & 2018 & $\underline{2019^{e}}$ \\
\hline United States ${ }^{1}$ & 496 & 510 \\
\hline Algeria $^{5}$ & 900 & 900 \\
\hline Cameroon $^{5}$ & 300 & 300 \\
\hline Chile $^{5}$ & 840 & 800 \\
\hline Ecuador $^{5}$ & 630 & 600 \\
\hline Ethiopia & 800 & 800 \\
\hline France $^{5}$ & 280 & 300 \\
\hline Greece $^{5}$ & 1,130 & 1,100 \\
\hline Guadeloupe & 200 & 200 \\
\hline Guatemala & 570 & 600 \\
\hline Indonesia & 770 & 770 \\
\hline Jordan & 900 & 900 \\
\hline Saudi Arabia ${ }^{5}$ & 530 & 550 \\
\hline Spain & 200 & 200 \\
\hline Syria $^{5}$ & 200 & 200 \\
\hline Turkey ${ }^{6}$ & 7,800 & 7,800 \\
\hline Uganda & 790 & 800 \\
\hline Other countries ${ }^{5}$ & 760 & 670 \\
\hline World total (rounded) & $\overline{18,100}$ & $\overline{18,000}$ \\
\hline
\end{tabular}

World Resources: The identified U.S. resources of pumice and pumicite are concentrated in the Western States and estimated to be more than 25 million tons. The estimated total resources (identified and undiscovered) in the Western and Great Plains States are at least 250 million tons and may total more than 1 billion tons. Large resources of pumice and pumicite have been identified on all continents.

Substitutes: The costs of transportation determine the maximum economic distance pumice and pumicite can be shipped and still remain competitive with alternative materials. Competitive materials that may be substituted for pumice and pumicite include crushed aggregates, diatomite, expanded shale and clay, and vermiculite.

\footnotetext{
eEstimated.

${ }^{1}$ Quantity sold and used by producers.

${ }^{2}$ Defined as production + imports - exports.

${ }^{3}$ Defined as imports - exports.

${ }^{4}$ See Appendix $\mathrm{C}$ for resource and reserve definitions and information concerning data sources.

5 Includes pozzolan and (or) volcanic tuff.

${ }^{6}$ Data reported from a separate official Turkish source indicated a production of 3,430,000 tons in 2018.
} 


\section{QUARTZ CRYSTAL (INDUSTRIAL)}

(Data in kilograms unless otherwise noted)

Domestic Production and Use: Industrial cultured quartz crystal is electronic-grade quartz crystal that is manufactured, not mined. In the past, cultured quartz crystal was primarily produced using lascas ${ }^{1}$ as raw quartz feed material. Lascas mining and processing in Arkansas ended in 1997. Anectodal evidence indicated that two companies produced cultured quartz crystal in the United States, but production statistics were not available. In addition to lascas, these companies may use cultured quartz crystal that has been rejected during the manufacturing process, owing to crystallographic imperfections, as feed material. The companies may use a mix of cultured quartz and imported lascas as feed material. In the past several years, cultured quartz crystal has been increasingly produced overseas, primarily in Asia. Electronic applications accounted for most industrial uses of quartz crystal; other uses included special optical applications.

Virtually all quartz crystal used for electronics was cultured, rather than natural, crystal. Electronic-grade quartz crystal is used to make frequency filters, frequency controls, and timers in electronic circuits employed for a wide range of products, such as communications equipment, computers, and many consumer goods, such as electronic games and television receivers.

\begin{tabular}{|c|c|c|c|c|c|}
\hline Salient Statistics-United States: & $\underline{2015}$ & 2016 & 2017 & 2018 & $\underline{2019^{e}}$ \\
\hline \multicolumn{6}{|l|}{ Production: } \\
\hline Mine (lascas) & - & - & - & - & - \\
\hline Cultured quartz crystal & NA & NA & NA & NA & NA \\
\hline \multicolumn{6}{|l|}{ Imports for consumption: } \\
\hline Quartz (lascas) & NA & NA & NA & NA & NA \\
\hline Piezoelectric quartz, unmounted & 3,400 & 6,280 & 7,210 & 16,100 & 59,000 \\
\hline \multicolumn{6}{|l|}{ Exports: } \\
\hline Quartz (lascas) & NA & NA & NA & NA & NA \\
\hline Piezoelectric quartz, unmounted & 43,600 & 60,500 & 57,900 & 47,500 & 43,000 \\
\hline \multicolumn{6}{|l|}{ Price, dollars per kilogram: } \\
\hline As-grown cultured quartz & 280 & 280 & 280 & 280 & 300 \\
\hline Lumbered quartz ${ }^{2}$ & 160 & 890 & 300 & 300 & 500 \\
\hline \multicolumn{6}{|l|}{ Net import reliance ${ }^{3}$ as a percentage } \\
\hline of apparent consumption & NA & NA & NA & NA & NA \\
\hline
\end{tabular}

Recycling: An unspecified amount of rejected cultured quartz crystal was used as feed material for the production of cultured quartz crystal.

Import Sources (2015-18): Import statistics specific to lascas are not available because they are combined with other types of quartz. Cultured quartz crystal (piezoelectric quartz, unmounted): China, 46\%; Japan, 24\%; Switzerland and Taiwan, 5\% each; and other, 20\%.

\section{Tariff: Item}

Quartz (including lascas)

Piezoelectric quartz, unmounted

\section{Number}

2506.10.0050

7104.10.0000
Normal Trade Relations

12-31-19

Free.

$3 \%$ ad val.

Depletion Allowance: 22\% (Domestic), 14\% (Foreign). 


\section{QUARTZ CRYSTAL (INDUSTRIAL)}

Government Stockpile: ${ }^{4}$ As of September 30, 2019, the National Defense Stockpile (NDS) contained 7,148 kilograms of natural quartz crystal. The stockpile has 11 weight classes for natural quartz crystal that range from 0.2 kilogram to more than 10 kilograms. The stockpiled crystals, however, are primarily in the larger weight classes. The larger pieces are suitable as seed crystals, which are very thin crystals cut to exact dimensions, to produce cultured quartz crystal. In addition, many of the stockpiled crystals could be of interest to the specimen and gemstone industry. Little, if any, of the stockpiled material is likely to be used in the same applications as cultured quartz crystal. No natural quartz crystal was sold from the NDS in 2019. Previously, the only individual crystals from the stockpile that were sold were those that weighed 10 kilograms or more and that could be used as seed material.

\begin{tabular}{|c|c|c|c|c|c|}
\hline \multirow[b]{2}{*}{ Material } & \multirow[b]{2}{*}{$\begin{array}{c}\text { Inventory } \\
\text { As of } 9-30-19\end{array}$} & \multicolumn{2}{|c|}{ FY 2019} & \multicolumn{2}{|c|}{ FY 2020} \\
\hline & & $\begin{array}{c}\text { Potential } \\
\text { Acquisitions }\end{array}$ & $\begin{array}{l}\text { Potential } \\
\text { Disposals }\end{array}$ & $\begin{array}{c}\text { Potential } \\
\text { Acquisitions }\end{array}$ & $\begin{array}{l}\text { Potential } \\
\text { Disposals }\end{array}$ \\
\hline Quartz crystal & 7,148 & - & - & - & - \\
\hline
\end{tabular}

Events, Trends, and Issues: Demand for cultured quartz crystal for frequency-control oscillators and frequency filters in a variety of electronic devices is expected to remain stable. However, silicon has replaced quartz crystal in two very important markets-cellular telephones and other mobile devices and automotive stability control applications. Growth of the consumer electronics market, for products such as personal computers, electronic games, and tablet computers, is likely to continue to sustain global production of cultured quartz crystal.

World Mine Production and Reserves: ${ }^{5}$ This information is unavailable, but the global reserves for lascas are thought to be large.

World Resources: Limited resources of natural quartz crystal suitable for direct electronic or optical use are available throughout the world. World dependence on these resources will continue to decline because of the increased acceptance of cultured quartz crystal as an alternative material. Additionally, techniques using rejected cultured quartz crystal as feed material could mean a decreased dependence on lascas for growing cultured quartz.

Substitutes: Silicon is increasingly being used as a substitute for quartz crystal for frequency-control oscillators in electronic circuits. Other materials, such as aluminum orthophosphate (the very rare mineral berlinite), langasite, lithium niobate, and lithium tantalate, which have larger piezoelectric coupling constants, have been studied and used. The cost competitiveness of these materials, as opposed to cultured quartz crystal, is dependent on the type of application that the material is used for and the processing required.

\footnotetext{
eEstimated. NA Not available. — Zero.

${ }^{1}$ Lascas is a nonelectronic-grade quartz used as a feedstock for growing cultured quartz crystal and for production of fused quartz.

${ }^{2}$ As-grown cultured quartz that has been processed by sawing and grinding.

${ }^{3}$ Defined as imports - exports.

${ }^{4}$ See Appendix $B$ for definitions.

${ }^{5}$ See Appendix $\mathrm{C}$ for resource and reserve definitions and information concerning data sources.
} 


\section{RARE EARTHS ${ }^{1}$}

[Data in metric tons of rare-earth-oxide (REO) equivalent content unless otherwise noted]

Domestic Production and Use: Rare earths were mined domestically in 2019. Bastnaesite (or bastnäsite), a rareearth fluorocarbonate mineral, was mined as a primary product at a mine in Mountain Pass, CA, which was restarted in the first quarter of 2018 after being put on care-and-maintenance status in the fourth quarter of 2015. Monazite, a phosphate mineral, was produced as a separated concentrate or included as an accessory mineral in heavy-mineral concentrates. The estimated value of rare-earth compounds and metals imported by the United States in 2019 was $\$ 170$ million, an increase from $\$ 160$ million in 2018. The estimated distribution of rare earths by end use was as follows: catalysts, 75\%; metallurgical applications and alloys, 5\%; ceramics and glass, 5\%; polishing, 5\%; and other, $10 \%$.

\begin{tabular}{|c|c|c|c|c|c|}
\hline Salient Statistics-United States: & $\underline{2015}$ & $\underline{2016}$ & $\underline{2017}$ & $\underline{2018}$ & $\underline{2019^{e}}$ \\
\hline \multicolumn{6}{|l|}{ Imports: ${ }^{2}$} \\
\hline Compounds & 9,160 & 11,500 & 11,000 & 10,800 & 14,000 \\
\hline \multicolumn{6}{|l|}{ Metals: } \\
\hline Ferrocerium, alloys & 356 & 268 & 309 & 301 & 310 \\
\hline Rare-earth metals, scandium, and yttrium & 385 & 404 & 524 & 527 & 590 \\
\hline \multicolumn{6}{|l|}{ Exports: $^{2}$} \\
\hline Ores and compounds & 4,980 & 590 & 1,740 & 16,800 & 26,000 \\
\hline \multicolumn{6}{|l|}{ Metals: } \\
\hline Ferrocerium, alloys & 1,220 & 943 & 982 & 1,210 & 1,400 \\
\hline Rare-earth metals, scandium, and yttrium & 60 & 103 & 55 & 28 & 100 \\
\hline Consumption, apparent ${ }^{3}$ & 9,550 & 10,500 & 9,060 & 11,600 & 13,000 \\
\hline \multicolumn{6}{|l|}{ Price, dollars per kilogram, average: ${ }^{4}$} \\
\hline Cerium oxide, $99.5 \%$ minimum & 3 & 2 & 2 & 2 & 2 \\
\hline Dysprosium oxide, $99.5 \%$ minimum & 279 & 198 & 187 & 179 & 240 \\
\hline Europium oxide, 99.99\% minimum & 344 & 74 & 77 & 53 & 35 \\
\hline Lanthanum oxide, 99.5\% minimum & 3 & 2 & 2 & 2 & 2 \\
\hline Mischmetal, $65 \%$ cerium, $35 \%$ lanthanum & 7 & 5 & 6 & 6 & 6 \\
\hline Neodymium oxide, 99.5\% minimum & 48 & 40 & 50 & 50 & 45 \\
\hline Terbium oxide, 99.99\% minimum & 564 & 415 & 501 & 455 & 510 \\
\hline Employment, mine and mill, annual average & 351 & - & 24 & 190 & 220 \\
\hline \multicolumn{6}{|l|}{$\begin{array}{l}\text { Net import reliance } 5 \text { as a percentage of } \\
\text { apparent consumption: } 6\end{array}$} \\
\hline Compounds and metals & 38 & 100 & 100 & 100 & 100 \\
\hline Mineral concentrates & $X X$ & $X X$ & $X X$ & E & $\mathrm{E}$ \\
\hline
\end{tabular}

Recycling: Limited quantities of rare earths from batteries, permanent magnets, and fluorescent lamps are recycled.

Import Sources (2015-18): Rare-earth compounds and metals: China, 80\%; Estonia, 6\%; Japan and Malaysia, 3\% each; and other, 8\%. Compounds and metals imported from Estonia, Japan, and Malaysia were derived from mineral concentrates and chemical intermediates produced in Australia, China, and elsewhere.

Tariff: Item

Rare-earth metals, scandium, and yttrium, whether or not intermixed or interalloyed

Cerium compounds:

Oxides

Other

Other rare-earth compounds:

Lanthanum oxides

Other oxides

Lanthanum carbonates

Other carbonates

Other rare-earth compounds

Ferrocerium and other pyrophoric alloys
Number

2805.30.0000

2846.10.0010

2846.10.0050

2846.90.2005

2846.90.2040

2846.90 .8070

2846.90 .8075

2846.90 .8090

3606.90 .3000
Normal Trade Relations 12-31-19

$5.0 \%$ ad val.

$5.5 \%$ ad val.

$5.5 \%$ ad val.

Free.

Free.

$3.7 \%$ ad val.

$3.7 \%$ ad val.

$3.7 \%$ ad val.

$5.9 \%$ ad val.

Depletion Allowance: Monazite, 22\% on thorium content and 14\% on rare-earth content (Domestic), 14\% (Foreign); bastnäsite and xenotime, 14\% (Domestic and foreign). 


\section{RARE EARTHS}

\section{Government Stockpile: ${ }^{7}$}

Material

Cerium

Dysprosium

Europium

Ferrodysprosium, gross weight

Lanthanum, gross weight

Rare earths

Rare-earth-magnet feedstock

Yttrium oxide

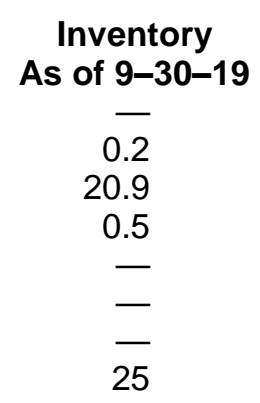

FY 2019

$\begin{array}{cc}\text { Potential } & \text { Potential } \\ \text { Acquisitions } & \text { Disposals }\end{array}$

0.5
35
-
-
416
100
10
-
-
$=$
$=$
-
FY 2020

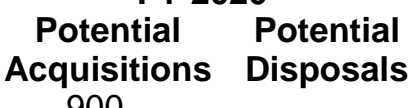
Acquisitions Disposals

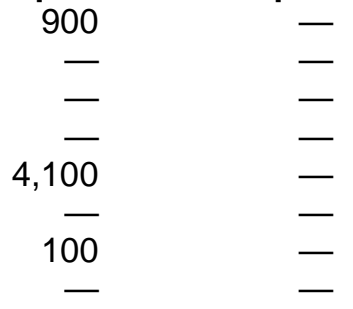

Events, Trends, and Issues: Global mine production was estimated to have increased to 210,000 tons of rare-earthoxide equivalent, an $11 \%$ increase compared with that of 2018. In the United States, domestic production of mineral concentrates, all of which were exported, increased to 26,000 tons, a 44\% increase compared with that of 2018. China continued to dominate the global supply of rare earths. According to China's Ministry of Industry and Information Technology, the mine and separation production quotas for 2019 were 132,000 tons and 127,000 tons, respectively.

World Mine Production and Reserves: Reserves for Canada, Greenland, Tanzania, and South Africa were previously included with "Other countries."

\begin{tabular}{|c|c|c|c|}
\hline & Mine & duction ${ }^{\mathrm{e}}$ & Reserves $^{8}$ \\
\hline & 2018 & $\underline{2019}$ & \\
\hline United States & 18,000 & 26,000 & $1,400,000$ \\
\hline Australia & 21,000 & 21,000 & ${ }^{93}, 300,000$ \\
\hline Brazil & 1,100 & 1,000 & $22,000,000$ \\
\hline Burma (Myanmar) & 19,000 & 22,000 & NA \\
\hline Burundi & 630 & 600 & NA \\
\hline Canada & - & - & 830,000 \\
\hline China & 10120,000 & 10132,000 & $44,000,000$ \\
\hline Greenland & - & - & $1,500,000$ \\
\hline India & 2,900 & 3,000 & $6,900,000$ \\
\hline Madagascar & 2,000 & 2,000 & NA \\
\hline Russia & 2,700 & 2,700 & $12,000,000$ \\
\hline South Africa & - & - & 790,000 \\
\hline Tanzania & - & - & 890,000 \\
\hline Thailand & 1,000 & 1,800 & NA \\
\hline Vietnam & 920 & 900 & $22,000,000$ \\
\hline Other countries & 60 & - & 310,000 \\
\hline World total (rounded) & $\overline{190,000}$ & $\overline{210,000}$ & $120,000,000$ \\
\hline
\end{tabular}

World Resources: Rare earths are relatively abundant in the Earth's crust, but minable concentrations are less common than for most other ores. In North America, measured and indicated resources of rare earths were estimated to include 2.7 million tons in the United States and more than 15 million tons in Canada.

Substitutes: Substitutes are available for many applications but generally are less effective.

\footnotetext{
eEstimated. E Net exporter. NA Not available. XX Not applicable. - Zero.

${ }^{1}$ Data include lanthanides and yttrium but exclude most scandium. See also Scandium and Yttrium.

${ }^{2} \mathrm{REO}$ equivalent or content of various materials were estimated. Source: U.S. Census Bureau.

${ }^{3}$ Defined as production + imports - exports.

${ }^{4}$ Price range from Argus Media group - Argus Metals International.

${ }^{5}$ Defined as imports - exports.

${ }^{6}$ In 2015, domestic production of mineral concentrates was included with apparent consumption of compounds and metals. In 2018 and 2019 , all domestic production of mineral concentrates was exported, and all compounds and metals consumed were assumed to be imported material.

${ }^{7}$ See Appendix B for definitions.

${ }^{8}$ See Appendix $C$ for resource and reserve definitions and information concerning data sources.

${ }^{9}$ For Australia, Joint Ore Reserves Committee-compliant reserves were 1.9 million tons.

${ }^{10}$ Production quota; does not include undocumented production.
} 


\section{RHENIUM}

(Data in kilograms of rhenium content unless otherwise noted)

Domestic Production and Use: During 2019, ores containing 8,400 kilograms of rhenium were mined at six operations (four in Arizona and one each in Montana and Utah). Rhenium compounds are included in molybdenum concentrates derived from porphyry copper deposits, and rhenium is recovered as a byproduct from roasting such molybdenum concentrates. Rhenium recovery occurred in Arizona, Utah, and Pennsylvania. Rhenium-containing products included ammonium perrhenate (APR), metal powder, and perrhenic acid. The major uses of rhenium were in superalloys used in high-temperature turbine engine components and in petroleum-reforming catalysts, representing an estimated $80 \%$ and $15 \%$, respectively, of end uses. Bimetallic platinum-rhenium catalysts were used in petroleum reforming for the production of high-octane hydrocarbons, which are used in the production of lead-free gasoline. Rhenium improves the high-temperature $\left(1,000^{\circ} \mathrm{C}\right)$ strength properties of some nickel-base superalloys. Rhenium alloys were used in crucibles, electrical contacts, electromagnets, electron tubes and targets, heating elements, ionization gauges, mass spectrographs, metallic coatings, semiconductors, temperature controls, thermocouples, vacuum tubes, and other applications. The value of rhenium consumed in 2019 was about $\$ 65$ million as measured by the value of imports of rhenium metal and APR.

\section{Salient Statistics_United States:}

Production $^{1}$

Imports for consumption ${ }^{2}$

Exports

Consumption, apparent ${ }^{3}$

Price, average value, dollars per kilogram, gross weight: 4

Metal pellets, $99.99 \%$ pure

Ammonium perrhenate

Employment, number

Net import reliance 5 as a percentage of apparent consumption

$\begin{array}{rr}\frac{\mathbf{2 0 1 5}}{7,900} & \frac{\mathbf{2 0 1 6}}{8,440} \\ 31,800 & 31,900 \\ \mathrm{NA} & \mathrm{NA} \\ 39,700 & 40,300 \\ & \\ 2,670 & 2,030 \\ 2,820 & 2,510 \\ \text { Small } & \text { Small } \\ & \\ 80 & 79\end{array}$

80

$\underline{2017}$
8,200
34,500
NA
42,700

1,550
1,530
Small

81

2018
8,220
39,400
$N A$
47,600

$2019^{\mathrm{e}}$

8,400

39,000

NA

47,000

$\begin{array}{ll}1,470 & 1,300 \\ 1,410 & 1,300 \\ \text { Small } & \text { Small }\end{array}$

83

82

Recycling: Nickel-base superalloy scrap and scrapped turbine blades and vanes continued to be recycled hydrometallurgically to produce rhenium metal for use in new superalloy melts. The scrapped parts were also processed to generate engine revert-a high-quality, lower cost superalloy meltstock—by an increasing number of companies, mainly in the United States, Canada, Estonia, France, Germany, Japan, Poland, and Russia. Rheniumcontaining catalysts were also recycled.

Import Sources (2015-18): Ammonium perrhenate: Kazakhstan, 29\%; Canada, 20\%; Germany, 14\%; China, 8\%; and other, 29\%. Rhenium metal powder: Chile, 83\%; Germany, 7\%; Belgium, 3\%; Poland, 3\%; and other, 4\%. Total: Chile, 62\%; Germany, 8\%; Kazakhstan, 8\%; Canada, 7\%; and other, 15\%.

\section{Tariff: Item}

Salts of peroxometallic acids, other, ammonium perrhenate Rhenium (and other metals), waste and scrap Rhenium, unwrought and powders Rhenium (and other metals), wrought
Number

2841.90 .2000

8112.92 .0600

8112.92 .5000

8112.99 .9000
Normal Trade Relations 12-31-19

$3.1 \%$ ad val. Free. $3 \%$ ad val. $4 \%$ ad val.

Depletion Allowance: 14\% (Domestic and foreign).

Government Stockpile: None. 


\section{RHENIUM}

Events, Trends, and Issues: During 2019, the United States continued to rely on imports for much of its supply of rhenium. Canada, Chile, Germany, and Kazakhstan supplied most of the imported rhenium. Rhenium imports for consumption remained essentially unchanged from those in 2018. Primary rhenium production in the United States increased slightly compared with that in 2018. Germany and the United States continued to be the leading secondary rhenium producers. Secondary rhenium production also took place in Canada, Estonia, France, Japan, Poland, and Russia. According to industry sources, approximately 20 to 25 tons of rhenium was recycled worldwide in 2019. For the eighth year in a row, rhenium metal and catalytic-grade APR prices decreased. In 2019, catalytic-grade APR prices averaged $\$ 1,300$ per kilogram, an $8 \%$ decrease from the annual average price in 2018 . Rhenium metal pellet prices averaged $\$ 1,300$ per kilogram in 2019 , a $12 \%$ decrease from the annual average price in 2018.

Consumption of catalyst-grade APR by the petroleum industry was expected to remain at high levels. Demand for rhenium in the aerospace industry, although more unpredictable, was also expected to remain at high levels. The major aerospace companies, however, were expected to continue testing superalloys that contain one-half the quantity of rhenium used in engine blades as currently designed, as well as testing rhenium-free alloys for other engine components.

\section{World Mine Production and Reserves:}

\begin{tabular}{|c|c|c|c|}
\hline & Min & ection 6 & Reserves $^{7}$ \\
\hline & 2018 & $\underline{2019^{\mathrm{e}}}$ & \\
\hline United States & $\overline{8,220}$ & $\overline{8,400}$ & 400,000 \\
\hline Armenia & 281 & 280 & 95,000 \\
\hline Canada & - & - & 32,000 \\
\hline Chile $^{8}$ & 27,000 & 27,000 & $1,300,000$ \\
\hline China & 2,500 & 2,500 & NA \\
\hline Kazakhstan & 1,000 & 1,000 & 190,000 \\
\hline Peru & - & - & 45,000 \\
\hline Poland & 9,090 & 9,300 & NA \\
\hline Russia & NA & NA & 310,000 \\
\hline Uzbekistan & 460 & 400 & NA \\
\hline World total (rounded) & $\overline{48,600}$ & $\overline{49,000}$ & $\overline{2,400,000}$ \\
\hline
\end{tabular}

World Resources: Most rhenium occurs with molybdenum in porphyry copper deposits. Identified U.S. resources are estimated to be about 5 million kilograms, and the identified resources of the rest of the world are approximately 6 million kilograms. Rhenium also is associated with copper minerals in sedimentary deposits in Armenia,

Kazakhstan, Poland, Russia, and Uzbekistan, where ore is processed for copper recovery and the rhenium-bearing residues are recovered at copper smelters.

Substitutes: Substitutes for rhenium in platinum-rhenium catalysts are being evaluated continually. Iridium and tin have achieved commercial success in one such application. Other metals being evaluated for catalytic use include gallium, germanium, indium, selenium, silicon, tungsten, and vanadium. The use of these and other metals in bimetallic catalysts might decrease rhenium's share of the existing catalyst market; however, this would likely be offset by rhenium-bearing catalysts being considered for use in several proposed gas-to-liquid projects. Materials that can substitute for rhenium in various end uses are as follows: cobalt and tungsten for coatings on copper x-ray targets, rhodium and rhodium-iridium for high-temperature thermocouples, tungsten and platinum-ruthenium for coatings on electrical contacts, and tungsten and tantalum for electron emitters.

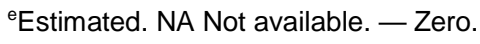

${ }^{1}$ Based on $80 \%$ recovery of estimated rhenium contained in molybdenum disulfide concentrates. Secondary rhenium production is not included.

${ }^{2}$ Does not include wrought forms or waste and scrap. The rhenium content of ammonium perrhenate is $69.42 \%$.

${ }^{3}$ Defined as production + imports - exports.

${ }^{4}$ Average price per kilogram of rhenium in pellets or catalytic-grade ammonium perrhenate. Source: Argus Media group-Argus Metals International. ${ }^{5}$ Defined as imports - exports.

${ }^{6}$ Estimated amount of rhenium recovered in association with copper and molybdenum production. Secondary rhenium production not included.

${ }^{7}$ See Appendix $\mathrm{C}$ for resource and reserve definitions and information concerning data sources.

${ }^{8}$ Estimated rhenium recovered from roaster residues from Belgium, Chile, Mexico, and Peru.
} 


\section{RUBIDIUM}

(Data in metric tons of rubidium oxide unless otherwise noted)

Domestic Production and Use: In 2019, no rubidium was mined in the United States; however, occurrences are known in Alaska, Arizona, Idaho, Maine, South Dakota, and Utah. Rubidium is also associated with some evaporate mineral occurrences in other States. Rubidium is not a major constituent of any mineral. Rubidium concentrate is produced as a byproduct of pollucite (cesium) and lepidolite (lithium) mining and is imported from other countries for processing in the United States.

Applications for rubidium and its compounds include biomedical research, electronics, specialty glass, and pyrotechnics. Specialty glasses are the leading market for rubidium; rubidium carbonate is used to reduce electrical conductivity, which improves stability and durability in fiber optic telecommunications networks. Biomedical applications include rubidium salts used in antishock agents and the treatment of epilepsy and thyroid disorder; rubidium-82, a radioactive isotope used as a blood-flow tracer in positron emission tomographic imaging; and rubidium chloride, used as an antidepressant. Rubidium atoms are used in academic research, including the development of quantum-mechanics-based computing devices, a future application with potential for relatively high consumption of rubidium. Quantum computing research uses ultracold rubidium atoms in a variety of applications. Quantum computers, which have the ability to perform more complex computational tasks than traditional computers by calculating in two quantum states simultaneously, were expected to be in prototype phase by 2025 .

Rubidium's photoemissive properties make it useful for electrical-signal generators in motion-sensor devices, nightvision devices, photoelectric cells (solar panels), and photomultiplier tubes. Rubidium is used as an atomic resonance-frequency-reference oscillator for telecommunications network synchronization, playing a vital role in global positioning systems. Rubidium-rich feldspars are used in ceramic applications for spark plugs and electrical insulators because of their high dielectric constant. Rubidium hydroxide is used in fireworks to oxidize mixtures of other elements and produce violet hues. The U.S. military frequency standard, the United States Naval Observatory (USNO) timescale, is based on 48 weighted atomic clocks, including 4 USNO rubidium fountain clocks.

Salient Statistics_United States: U.S. salient statistics, such as consumption, exports, and imports, are not available. Some concentrate was imported to the United States for further processing. Industry information during the past decade suggests a domestic consumption rate of approximately 2,000 kilograms per year. The United States was $100 \%$ import reliant for rubidium minerals.

In 2019 , one company offered 1-gram ampoules of $99.75 \%$-grade rubidium (metal basis) for $\$ 87.80$, a $4 \%$ increase from $\$ 84.40$ in 2018, and 100-gram ampoules of the same material for $\$ 1,592.00$, a $3 \%$ increase from $\$ 1,546.00$ in 2018. The price for 1-gram ampoules of $99.8 \%$ rubidium formate hydrate (metal basis) was $\$ 34.70$.

In 2019, the prices for 10 grams of $99.8 \%$ (metal basis) rubidium acetate, rubidium bromide, rubidium carbonate, rubidium chloride, and rubidium nitrate were $\$ 49.80, \$ 65.80, \$ 56.80, \$ 59.80$, and $\$ 46.40$, respectively. The price for a rubidium-plasma standard solution (10,000 micrograms per milliliter) was $\$ 52.10$ for 50 milliliters and $\$ 85.00$ for 100 milliliters, a 4\% decrease and 5\% increase, respectively, from those of 2018.

Recycling: None.

Import Sources (2015-18): No reliable data have been available to determine the source of rubidium ore imported by the United States since 1988. Previously, Canada was thought to be the primary supplier of rubidium ore. 


\section{RUBIDIUM}

Tariff: Item

Alkali metals, other

Chlorides, other

Bromides, other

Nitrates, other

Sulfates, other

Carbonates, other
Number

2805.19.9000

2827.39.9000

2827.59.5100

2834.29.5100

2833.29.5100

2836.99 .5000
Normal Trade Relations

12-31-19

$5.5 \%$ ad val.

$3.7 \%$ ad val.

$3.6 \%$ ad val.

$3.5 \%$ ad val.

$3.7 \%$ ad val.

$3.7 \%$ ad val.

Depletion Allowance: 14\% (Domestic and foreign).

Government Stockpile: None.

Events, Trends, and Issues: Domestic rubidium occurrences will remain uneconomic unless market conditions change, such as the development of new end uses or increased consumption for existing end uses, which in turn could lead to increased prices. No known human health issues are associated with exposure to naturally occurring rubidium, and its use has minimal environmental impact.

During 2019, projects that were primarily aimed at developing lithium resources were at various stages of development, including eight subprojects at the King Col project in Australia, the Jubilee Lake lithium prospect in Canada, the Soris lithium project in Namibia, and the Winnipeg River pegmatite field in Canada. The status of these projects ranged from early feasibility studies to active exploration and drilling. No production has been reported at any sites. The projects focused on pegmatites containing pollucite and spodumene, which primarily contain lithium, tantalum, or both, but may also contain minor quantities of cesium and rubidium.

World Mine Production and Reserves: There were no official sources for rubidium production data. Production is known to take place periodically in Namibia and Zimbabwe, but production data are not available. Production of pollucite ceased at the Bernic Lake operation in Manitoba, Canada, at the end of 2015. Rubidium is thought to be mined in China, but information regarding reserves and production is unavailable. Lepidolite and pollucite, the principal rubidium-containing minerals in global rubidium reserves, can contain up to $3.5 \%$ and $1.5 \%$ rubidium oxide, respectively. Rubidium-bearing mineral resources are found in zoned pegmatites. Mineral resources exist globally, but extraction and concentration are cost prohibitive. Reserves data for Canada were added based on industry information.

Canada
Namibia
Zimbabwe
Other countries
$\quad$ World total

$\begin{array}{r}\text { Reserves }^{1} \\ 12,000 \\ 50,000 \\ 30,000 \\ 10,000 \\ \hline 100,000\end{array}$

World Resources: Significant rubidium-bearing pegmatite occurrences have been identified in the United States, Afghanistan, Australia, Canada, China, Denmark, Germany, Japan, Kazakhstan, Namibia, Peru, Russia, the United Kingdom, and Zambia. Minor quantities of rubidium are reported in brines in northern Chile and China and in evaporites in the United States (New Mexico and Utah), France, and Germany.

Substitutes: Rubidium and cesium can be used interchangeably in many applications because they have similar physical properties and atomic radii. Cesium, however, is more electropositive than rubidium, making it a preferred material for some applications.

\footnotetext{
${ }^{1}$ See Appendix $\mathrm{C}$ for resource and reserve definitions and information concerning data sources.
} 


\section{SALT}

(Data in thousand metric tons unless otherwise noted)

Domestic Production and Use: Domestic production of salt was estimated to have increased slightly in 2019 to 42 million tons. The total value of salt sold or used was estimated to be about $\$ 2.3$ billion. Twenty-six companies operated 63 plants in 16 States. The top producing States were, in alphabetical order, Kansas, Louisiana, Michigan, New York, Ohio, Texas, and Utah. These seven States produced about 92\% of the salt in the United States in 2019. The estimated percentage of salt sold or used was, by type, rock salt, 41\%; salt in brine, $41 \%$; vacuum pan salt, 10\%; and solar salt, $8 \%$.

Highway deicing accounted for about $43 \%$ of total salt consumed. The chemical industry accounted for about $37 \%$ of total salt sales, with salt in brine accounting for $89 \%$ of the salt used for chemical feedstock. Chlorine and caustic soda manufacturers were the main consumers within the chemical industry. The remaining markets for salt were, in declining order of use, distributors, $9 \%$; food processing, 4\%; agricultural, 3\%, general industrial, 2\%; and primary water treatment, $1 \%$. The remaining $1 \%$ was other uses combined with exports.

\begin{tabular}{|c|c|c|c|c|c|}
\hline Salient Statistics-United States: ${ }^{1}$ & 2015 & 2016 & 2017 & $\underline{2018}$ & $\underline{2019^{e}}$ \\
\hline Production & 45,100 & $4 \overline{1,700}$ & 39,600 & $\mathrm{e} 4 \overline{1,000}$ & $4 \overline{2,000}$ \\
\hline Sold or used by producers & 42,800 & 39,900 & 38,200 & $\mathrm{e} 40,000$ & 41,000 \\
\hline Imports for consumption & 21,600 & 12,100 & 12,600 & 17,900 & 17,000 \\
\hline Exports & 830 & 729 & 1,120 & 986 & 730 \\
\hline \multicolumn{6}{|l|}{ Consumption: } \\
\hline Apparent $^{2}$ & 63,600 & 51,300 & 49,700 & e57,000 & 57,00 \\
\hline Reported & 52,300 & 47,800 & 45,500 & e 48,000 & 49,00 \\
\hline \multicolumn{6}{|c|}{$\begin{array}{l}\text { Price, average value of bulk, pellets and packaged } \\
\text { salt, dollars per ton, f.o.b. mine and plant: }\end{array}$} \\
\hline Vacuum and open pan salt & 188.87 & 197.78 & 211.71 & e 220.00 & 220.0 \\
\hline Solar salt & 102.04 & 99.69 & 115.88 & e120.00 & 120.0 \\
\hline Rock salt & 56.32 & 56.75 & 60.41 & e 62.00 & 62. \\
\hline Salt in brine & 10.27 & 8.68 & 9.49 & e10.00 & 10. \\
\hline Employment, mine and plant, numbere & 4,200 & 4,000 & 4,100 & 4,100 & 4,10 \\
\hline $\begin{array}{l}\text { Net import reliance }{ }^{3} \text { as a percentage of } \\
\text { apparent consumption }\end{array}$ & 33 & 22 & 23 & 30 & \\
\hline
\end{tabular}

Recycling: None.

Import Sources (2015-18): Chile, 36\%; Canada, 25\%; Mexico, 12\%; Egypt, 6\%; and other, 21\%.

Tariff: Item

Salt (sodium chloride)
Number

2501.00.0000
Normal Trade Relations $\underline{12-31-19}$

Depletion Allowance: 10\% (Domestic and foreign).

Government Stockpile: None.

Events, Trends, and Issues: The winter was slightly colder than average in 2018-19 for the second consecutive year. The number of winter weather events was greater than the last few years in many parts of the United States, including an increase in episodes of freeing rain and sleet, requiring more salt for highway deicing. Rock salt production and imports in 2019 remained at about the same level as that of 2018 because demand from many local and State transportation departments remained relatively high. Most local and State governments in regions that experience cold winters reportedly had depleted stockpiles and needed to replenish supplies of rock salt for the winter of 2019-20. 


\section{SALT}

For the winter of 2019-20, the National Oceanic and Atmospheric Administration predicted a neutral weather pattern without EI Niño or La Niña affects: other weather patterns were expected to have a greater influence. Forecasts include warmer than average temperatures for the northeastern, northwestern, and southern areas of the United States, and the northern plains and Midwest are expected to have average temperatures. Areas from the mid-Atlantic to the northern Rocky Mountains are predicted to have a wetter than average winter, but much of New England and most of the South are forecast to have average precipitation. The early part of the season was noticeably cooler and wetter than normal, and consumers of rock salt had already begun to use stockpiles of salt and considered increasing salt purchases for the remainder of the winter season.

Demand for salt brine used in the chloralkali industry was expected to increase as demand for caustic soda increased globally, especially in Asia. Exports from Australia and especially India increased to meet the increasing demand for caustic soda in China.

\section{World Production and Reserves:}

\begin{tabular}{|c|c|c|}
\hline & Mine & luction ${ }^{\mathrm{e}}$ \\
\hline & 2018 & 2019 \\
\hline United States ${ }^{1}$ & $4 \overline{1,000}$ & $4 \overline{2,000}$ \\
\hline Australia & 12,000 & 13,000 \\
\hline Austria & 4,900 & 4,900 \\
\hline Brazil & 7,500 & 7,600 \\
\hline Canada & 12,000 & 12,000 \\
\hline Chile & 8,000 & 9,000 \\
\hline China & 58,000 & 60,000 \\
\hline France & 5,700 & 5,700 \\
\hline Germany & 14,000 & 14,000 \\
\hline India & 29,000 & 30,000 \\
\hline Italy & 4,100 & 4,100 \\
\hline Mexico & 9,000 & 9,000 \\
\hline Netherlands & 7,000 & 7,000 \\
\hline Pakistan & 4,400 & 4,500 \\
\hline Poland & 4,400 & 4,500 \\
\hline Russia & 7,000 & 7,000 \\
\hline Spain & 4,200 & 4,300 \\
\hline Turkey & 6,500 & 6,600 \\
\hline United Kingdom & 4,100 & 4,100 \\
\hline Other countries & 43,000 & 44,000 \\
\hline World total (rounded) & $\overline{286,000}$ & $\overline{293,000}$ \\
\hline
\end{tabular}

World Resources: World continental resources of salt are vast, and the salt content in the oceans is nearly unlimited. Domestic resources of rock salt and salt from brine are primarily in Kansas, Louisiana, Michigan, New York, Ohio, and Texas. Saline lakes and solar evaporation salt facilities are in Arizona, California, Nevada, New Mexico, Oklahoma, and Utah. Almost every country in the world has salt deposits or solar evaporation operations of various sizes.

Substitutes: No economic substitutes or alternatives for salt exist in most applications. Calcium chloride and calcium magnesium acetate, hydrochloric acid, and potassium chloride can be substituted for salt in deicing, certain chemical processes, and food flavoring, but at a higher cost.

\footnotetext{
eEstimated.

${ }^{1}$ Excludes production from Puerto Rico.

${ }^{2}$ Defined as sold or used by producers + imports - exports.

${ }^{3}$ Defined as imports - exports.

${ }^{4}$ See Appendix $\mathrm{C}$ for resource and reserve definitions and information concerning data sources.
} 


\section{SAND AND GRAVEL (CONSTRUCTION) ${ }^{1}$}

(Data in million metric tons unless otherwise noted)

Domestic Production and Use: In 2019, 970 million tons of construction sand and gravel valued at $\$ 9.0$ billion was produced by an estimated 3,870 companies operating 6,830 pits and 342 sales and distribution yards in 50 States. Leading producing States were Texas, California, Arizona, Minnesota, Michigan, Washington, Ohio, New York, Utah, and Colorado, in order of decreasing tonnage, which together accounted for about $55 \%$ of total output. It is estimated that about $46 \%$ of construction sand and gravel was used as concrete aggregates; $21 \%$, for road base and coverings and road stabilization; $13 \%$, as construction fill; $12 \%$, as asphaltic concrete aggregates and other bituminous mixtures; $13 \%$, as construction fill; and $4 \%$, for other miscellaneous uses. The remaining $4 \%$ was used for concrete products, filtration, golf course maintenance, plaster and gunite sands, railroad ballast, road stabilization, roofing granules, and snow and ice control.

The estimated output of construction sand and gravel in the United States shipped for consumption in the first 9 months of 2019 was 727 million tons, an increase of $3 \%$ compared with that of the same period of 2018. Third quarter shipments for consumption increased by $5 \%$ compared with those of the same period of 2018. Additional production information by quarter for each State, geographic region, and the United States is published by the U.S. Geological Survey (USGS) in its quarterly Mineral Industry Surveys for Crushed Stone and Sand and Gravel.

\section{Salient Statistics-United States:}

Production

Imports for consumption

Exports

Consumption, apparent ${ }^{3}$

Price, average value, dollars per metric ton

Employment, mine and mill, number ${ }^{4}$

Net import reliance ${ }^{5}$ as a percentage of

apparent consumption

$\begin{array}{rr}\frac{2015}{880} & \frac{201}{887} \\ 4 & \\ \left({ }^{2}\right) & ( \\ 884 & 89 \\ 8.28 & 8.41 \\ 34,800 & 35,300\end{array}$

$\left.{ }^{2}\right)$

2017
880
7
$(2)$
886
8.83
36,500

$\left({ }^{2}\right)$

2018
937
6
$\left({ }^{2}\right)$
943
9.14
38,600

1 $\frac{2019^{\mathrm{e}}}{970}$

970

5

$\left({ }^{2}\right)$

980

9.29

37,800

1

Import Sources (2015-18): Canada, 94\%; Mexico, 4\%; China, 1\%; and Norway, 1\%.

Tariff: Item

Sand, other

Pebbles and gravel
Number

2505.90.0000

2517.10.0015
Normal Trade Relations

12-31-19

Free.

Free.

Depletion Allowance: Common varieties, 5\% (Domestic and foreign).

Government Stockpile: None. 


\section{SAND AND GRAVEL (CONSTRUCTION)}

Events, Trends, and Issues: Construction sand and gravel production was about 970 million tons in 2019, an increase of $4 \%$ compared with that of 2018. Apparent consumption also increased by $4 \%$ to 980 million tons. Demand for construction sand and gravel increased in 2019 because of continued growth in the private and public construction markets. Commercial and heavy-industrial construction activity, infrastructure funding, new single-family housing unit starts, and weather affect growth in sand and gravel production and consumption. Long-term increases in construction aggregates demand will be influenced by activity in the public and private construction sectors, as well as by construction work related to security measures being implemented around the Nation. The underlying factors that would support a rise in prices of construction sand and gravel are expected to be present in 2020, especially in and near metropolitan areas.

The construction sand and gravel industry remained concerned with environmental, health, permitting, safety, and zoning regulations. Movement of sand and gravel operations away from densely populated regions was expected to continue where regulations and local sentiment discouraged them. Resultant regional shortages of construction sand and gravel would likely result in higher-than-average price increases in industrialized and urban areas.

\section{World Mine Production and Reserves:}

\begin{tabular}{|c|c|c|c|}
\hline \multirow[b]{3}{*}{ United States } & \multicolumn{2}{|c|}{ Mine production ${ }^{\mathrm{e}}$} & \multirow[t]{2}{*}{ Reserves $^{6}$} \\
\hline & 2018 & $\underline{2019}$ & \\
\hline & 937 & $\overline{970}$ & Reserves are controlled largely by land \\
\hline Other countries ${ }^{7}$ & NA & NA & use and (or) environmental concerns. \\
\hline World total & $\overline{\mathrm{NA}}$ & $\overline{\mathrm{NA}}$ & \\
\hline
\end{tabular}

World Resources: Sand and gravel resources are plentiful throughout the world. However, because of environmental regulations, geographic distribution, and quality requirements for some uses, sand and gravel extraction is uneconomic in some cases. The most important commercial sources of sand and gravel have been glacial deposits, river channels, and river flood plains. Use of offshore deposits in the United States is mostly restricted to beach erosion control and replenishment. Other countries routinely mine offshore deposits of aggregates for onshore construction projects.

Substitutes: Crushed stone, the other major construction aggregate, is often substituted for natural sand and gravel, especially in more densely populated areas of the Eastern United States. Crushed stone remains the dominant choice for construction aggregate use. Increasingly, recycled asphalt and portland cement concretes are being substituted for virgin aggregate, although the percentage of total aggregate supplied by recycled materials remained very small in 2019.

\footnotetext{
eEstimated. NA Not available.

${ }^{1}$ See also Sand and Gravel (Industrial) and Stone (Crushed).

${ }^{2}$ Less than $1 / 2$ unit.

${ }^{3}$ Defined as production + imports - exports.

${ }^{4}$ Including office staff. Source: Mine Safety and Health Administration.

${ }^{5}$ Defined as imports - exports.

${ }^{6}$ See Appendix $C$ for resource and reserve definitions and information concerning data sources.

${ }^{7}$ No reliable production information is available for most countries owing to the wide variety of ways in which countries report their sand and gravel production. Some countries do not report production for this mineral commodity. Production information for some countries is available in the USGS Minerals Yearbook, Volume III, Area Reports: International.
} 


\section{SAND AND GRAVEL (INDUSTRIAL)1}

(Data in thousand metric tons unless otherwise noted)

Domestic Production and Use: In 2019, industrial sand and gravel valued at about $\$ 5.7$ billion was produced by about 191 companies from 308 operations in 35 States. The value of production of industrial sand and gravel in 2019 decreased by $17 \%$ compared with that of the previous year, owing primarily to reduced demand for hydraulicfracturing sand. The likely cause was decreased activity in the oil and gas sector during the year. Leading producing States were Wisconsin, Texas, Illinois, Missouri, Minnesota, Oklahoma, Mississippi, North Carolina, lowa, and Louisiana, in descending order of tonnage produced. Combined production from these States accounted for $85 \%$ of the domestic total. About $73 \%$ of the U.S. tonnage was used as hydraulic-fracturing sand and well-packing and cementing sand; as glassmaking sand and other whole-grain silica, 7\% each; as foundry sand, 3\%; as ceramics, other ground silica, and whole-grain fillers for building products, 2\% each; and recreational sand, 1\%. Abrasives, chemicals, fillers, filtration sand, metallurgical flux, roofing granules, silica gravel, and traction sand, combined, accounted for the remaining $3 \%$ of industrial sand and gravel end uses.

Salient Statistics-United States:
Sold or used
Imports for consumption
Exports
Consumption, apparent ${ }^{2}$
Price, average value, dollars per ton
Employment, quarry and mill, number
Net import reliance ${ }^{3}$ as a percentage
of apparent consumption

$\begin{array}{rrrrr}\mathbf{2 0 1 5} & \mathbf{2 0 1 6} & \mathbf{2 0 1 7} & \mathbf{2 0 1 8} & \underline{\mathbf{2 0 1 9}} \\ 102,000 & 79,400 & 103,000 & 121,000 & 110,000 \\ 289 & 281 & 366 & 392 & 390 \\ 3,910 & 2,780 & 4,680 & 6,560 & 5,900 \\ 98,400 & 76,900 & 98,700 & 115,000 & 100,000 \\ 47.30 & 35.40 & 52.00 & 56.40 & 50.40 \\ 3,500 & 3,500 & 4,000 & 4,000 & 4,000 \\ & & & & \text { E }\end{array}$

Recycling: Some foundry sand is recycled, and recycled cullet (pieces of glass) represents a significant proportion of reused silica. About $34 \%$ of glass containers are recycled.

Import Sources (2015-18): Canada, 86\%; Taiwan, 4\%; Vietnam, 4\%; and other, 6\%.

Tariff: Item

Sand containing $95 \%$ or more silica

and not more than $0.6 \%$ iron oxide
Number

2505.10.1000
Normal Trade Relations $\underline{12-31-19}$

Free.

Depletion Allowance: Industrial sand or pebbles, 14\% (Domestic and foreign).

Government Stockpile: None.

Events, Trends, and Issues: U.S. apparent consumption of industrial sand and gravel was estimated to be 100 million tons in 2019, a 13\% decrease from that of the previous year. Decreased oil and gas drilling in North America and oil well completion activity triggered a corresponding decrease in the production of hydraulic-fracturing sand in 2019 compared with that of the previous year. However, in any given year, more efficient hydraulic-fracturing techniques, which require more silica sand use per well (mostly for secondary recovery at mature wells) along with lower unit cost compared with other proppants, tends to maintain demand for hydraulic-fracturing sand. Imports of industrial sand and gravel in 2019 were about 390,000 tons-nearly the same as those of 2018. Imports of silica are generally of two types-small shipments of very high-purity silica or a few large shipments of lower grade silica shipped only under special circumstances (for example, very low freight rates). The United States remains a net exporter of industrial sand and gravel; U.S. exports of industrial sand and gravel decreased by about $10 \%$ in 2019 compared with those of 2018.

The United States was the world's leading producer and consumer of industrial sand and gravel based on estimated world production figures. It is difficult to collect definitive data on silica sand and gravel production in most nations because of the wide range of terminology and specifications found among different countries. The United States remained a major exporter of silica sand and gravel, shipping it to almost every region of the world. The high level of exports was attributed to the high quality and advanced processing techniques used in the United States for many grades of silica sand and gravel, meeting virtually every specification. 


\section{SAND AND GRAVEL (INDUSTRIAL)}

The industrial sand and gravel industry continued to be concerned with safety and health regulations and environmental restrictions in 2019, especially those concerning crystalline silica exposure. Beginning in 2016, the Occupational Safety and Health Administration (OSHA) finalized new regulations to further restrict exposure to crystalline silica at quarry sites and in other industries that use materials containing it. Phased implementation of the new regulations was scheduled to take effect through 2021, affecting various industries that use materials containing silica. Most provisions of the new regulations became enforceable on June 23, 2018, for general industry and maritime operations. On August 14, 2019, OSHA requested comment and information to enable the agency to consider new developments and enhanced control methods for equipment that generates exposures to silica. Local shortages of industrial sand and gravel were expected to continue to increase owing to land development priorities, local zoning regulations, and logistical issues, including ongoing development and permitting of operations producing hydraulic-fracturing sand. Natural gas and petroleum operations that use hydraulic fracturing may also undergo increased scrutiny. These factors may result in future sand and gravel operations being located farther from high-population centers.

\section{World Mine Production and Reserves:}

\begin{tabular}{|c|c|c|}
\hline & Mine & uctione $^{e}$ \\
\hline & $\underline{2018}$ & 2019 \\
\hline United States & $12 \overline{1,000}$ & $11 \overline{0,000}$ \\
\hline Australia & 3,000 & 3,000 \\
\hline Bulgaria & 7,250 & 7,300 \\
\hline Canada & 2,500 & 2,500 \\
\hline France & 9,310 & 9,300 \\
\hline Germany & 7,500 & 7,500 \\
\hline India & 11,900 & 12,000 \\
\hline Indonesia & 5,540 & 5,500 \\
\hline Italy & 14,000 & 14,000 \\
\hline Japan & 2,520 & 2,500 \\
\hline Korea, Republic of & 4,300 & 4,500 \\
\hline Malaysia & 10,000 & 10,000 \\
\hline Mexico & 2,360 & 2,400 \\
\hline Netherlands & 54,000 & 54,000 \\
\hline New Zealand & 2,320 & 2,300 \\
\hline Poland & 5,120 & 5,000 \\
\hline South Africa & 2,400 & 2,400 \\
\hline Spain & 35,500 & 36,000 \\
\hline Turkey & 13,500 & 14,000 \\
\hline United Kingdom & 4,000 & 4,000 \\
\hline Other countries & 17,200 & 21,300 \\
\hline World total (rounded) & 335,000 & 330,000 \\
\hline
\end{tabular}

\section{Reserves $^{4}$}

Large. Industrial sand and gravel deposits are widespread.

World Resources: Sand and gravel resources of the world are large. However, because of their geographic distribution, environmental restrictions, and quality requirements for some uses, extraction of these resources is sometimes uneconomic. Quartz-rich sand and sandstone, the main sources of industrial silica sand, occur throughout the world.

Substitutes: Alternative materials that can be used for glassmaking and for foundry and molding sands are chromite, olivine, staurolite, and zircon sands. Although costlier and mostly used in deeper wells, alternative materials that can be used as proppants are sintered bauxite and kaolin-based ceramic proppants.

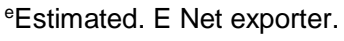

${ }^{1}$ See also Sand and Gravel (Construction).

${ }^{2}$ Defined as production (sold or used) + imports - exports.

${ }^{3}$ Defined as imports - exports.

${ }^{4}$ See Appendix $\mathrm{C}$ for resource and reserve definitions and information concerning data sources.
} 


\section{SCANDIUM $^{1}$}

(Data in metric tons of scandium oxide equivalent unless otherwise noted)

Domestic Production and Use: Domestically, scandium was neither mined nor recovered from process streams or mine tailings in 2019. Previously, scandium was produced domestically primarily from the scandium-yttrium silicate mineral thortveitite and from byproduct leach solutions from uranium operations. Limited capacity to produce ingot and distilled scandium metal existed at facilities in Ames, IA; Tolleson, AZ; and Urbana, IL. The principal source for scandium metal and scandium compounds was imports from China. The principal uses for scandium in 2019 were in aluminum-scandium alloys and solid oxide fuel cells (SOFCs). Other uses for scandium included ceramics, electronics, lasers, lighting, and radioactive isotopes.

\begin{tabular}{|c|c|c|c|c|c|}
\hline \multicolumn{5}{|l|}{ Price, yearend, dollars: } & $\underline{2019^{e}}$ \\
\hline \multicolumn{6}{|l|}{ Compounds, per gram: } \\
\hline Acetate, $99.9 \%$ purity, 5 -gram sample size 2 & 43.00 & 44.00 & 44.00 & 44.00 & 45.00 \\
\hline Chloride, $99.9 \%$ purity, 5 -gram sample size ${ }^{2}$ & 123.00 & 126.00 & 124.00 & 125.00 & 129.00 \\
\hline Fluoride, $99.9 \%$ purity, 1-to-5-gram sample size & 2263.00 & ${ }^{3} 270.00$ & 3277.00 & ${ }^{3} 206.00$ & ${ }^{3} 209.00$ \\
\hline lodide, $99.999 \%$ purity, 5 -gram sample size ${ }^{2}$ & 187.00 & 149.00 & 183.00 & 165.00 & 157.00 \\
\hline Oxide, $99.99 \%$ purity, 5 -kilogram lot size ${ }^{4}$ & 5.10 & 4.60 & 4.60 & 4.60 & 3.90 \\
\hline \multicolumn{6}{|l|}{ Metal: } \\
\hline $\begin{array}{l}\text { Scandium, distilled dendritic, per gram, } \\
\text { 2-gram sample size }{ }^{2}\end{array}$ & 221.00 & 228.00 & 226.00 & 226.00 & 233.00 \\
\hline $\begin{array}{l}\text { Scandium, ingot, per gram, } \\
\text { 5-aram sample size² }\end{array}$ & 13400 & 10700 & 13200 & 13200 & 13400 \\
\hline $\begin{array}{l}\text { Scandium-aluminum alloy, per kilogram, } \\
\text { metric-ton lot size }\end{array}$ & 220.00 & 340.00 & 350.00 & 360.00 & 300.00 \\
\hline $\begin{array}{l}\text { Net import reliance }{ }^{5} \text { as a percentage of } \\
\text { apparent consumption }\end{array}$ & 100 & 100 & 100 & 100 & \\
\hline
\end{tabular}

Recycling: None.

Import Sources (2015-18): Although no definitive data exist listing import sources, imported material is mostly from Europe, China, Japan, and Russia.

\section{Tariff: Item}

Rare-earth metals, unspecified,

not intermixed or interalloyed

Compounds of rare-earth metals:

Mixtures of oxides of yttrium or scandium as the predominant metal

Mixtures of chlorides of yttrium or scandium as the predominant metal

Mixtures of other rare-earth carbonates, including scandium

Mixtures of other rare-earth compounds, including scandium
Number

2805.30.0050

2846.90.2015

2846.90 .2082

2846.90 .8075

2846.90 .8090
Normal Trade Relations 12-31-19

$5.0 \%$ ad val.

Free.

Free.

$3.7 \%$ ad val.

$3.7 \%$ ad val.

Depletion Allowance: 14\% (Domestic and foreign).

\section{Government Stockpile: None.}

Events, Trends, and Issues: The global supply and consumption of scandium was estimated to be about 15 tons to 20 tons per year. Scandium was recovered from titanium, zirconium, cobalt, and nickel process streams. China, the Philippines, and Russia were the leading producers. Prices quoted for scandium oxide in the United States decreased compared with those in 2018. Owing in part to low capacity utilization, China's ex-works prices for scandium oxide were significantly less than United States quoted prices. Although global exploration and development projects continued in anticipation of increased demand, the global scandium market remained small relative to most other metals. 


\section{SCANDIUM}

In the United States, a feasibility study was completed on the polymetallic Elk Creek project in Nebraska. Probable reserves were estimated to be 36 million tons containing 65.7 parts per million (2,400 tons) of scandium. Plans for the project included downstream production of ferroniobium, titanium dioxide, and scandium oxide. The Bokan project in Alaska and the Round Top project in Texas also included scandium recovery in their process plans. In addition, Federal and State agencies were funding the development of methods to separate scandium from coal and coal byproducts.

Globally, several projects were under development while seeking permitting, project financing, and offtake agreements. Reserves at the Nyngan project in New South Wales, Australia, were estimated to be 1.4 million tons containing about 590 tons of scandium. The developer expected to begin commissioning 38.5 tons per year of scandium oxide production capacity in 2021. A definitive feasibility study on the polymetallic Owendale Project in New South Wales was completed in 2018 with the potential to produce 20 tons per year of scandium oxide from reserves of 4.0 million tons containing 570 parts per million scandium (3,500 tons of scandium oxide equivalent). Engineering and design plans for the polymetallic Sunrise Project in New South Wales, continued to advance following an offtake agreement for nickel and cobalt in 2019 and the completion of a definitive feasibility study in 2018. Proven and probable reserves for the Sunrise Project were 147 million tons containing 53 parts per million (7,800 t) scandium. In Queensland, following the completion of a bankable feasibility study on the polymetallic SCONI project in 2018 , reserves were updated to 57 million tons containing 35 parts per million (2,000 tons) scandium.

In the Philippines, a plant designed to recover 7.5 tons per year of scandium oxide equivalent began commercial production at the Taganito high-pressure acid-leach nickel operation. An intermediate scandium concentrate was exported to Japan.

In Russia, feasibility studies for making scandium oxide as a byproduct of alumina refining in the Ural Mountains were ongoing. The pilot plant was reported to have produced scandium oxide with purity greater than $99 \%$. Based on pilot test results, plans were in place for a 3-ton-per-year scandium oxide plant. In Dalur, Kurgan region, development of scandium recovery as a byproduct of uranium production continued, and production capacity included scandium oxide (570 kilograms per year) and aluminum-scandium alloy (24.5 tons per year).

In the European Union, recovery methods were being developed to produce scandium compounds and aluminumscandium alloys from byproducts of aluminum and titanium mining and processing. Globally, several projects were underway to commercialize new aluminum-scandium alloys for casting and additive manufacturing.

World Mine Production and Reserves: ${ }^{6}$ No scandium was recovered from mining operations in the United States. As a result of its low concentration, scandium is produced exclusively as a byproduct during processing of various ores or recovered from previously processed tailings or residues. In recent years, scandium was produced as byproduct material in China (iron ore, rare earths, titanium, and zirconium), Kazakhstan (uranium), Philippines (nickel), Russia (apatite and uranium), and Ukraine (uranium). Foreign mine production data for 2019 were not available.

World Resources: Resources of scandium are abundant. Scandium's crustal abundance is greater than that of lead. Scandium lacks affinity for the common ore-forming anions; therefore, it is widely dispersed in the lithosphere and forms solid solutions with low concentrations in more than 100 minerals. Scandium resources have been identified in Australia, Canada, China, Kazakhstan, Madagascar, Norway, the Philippines, Russia, Ukraine, and the United States.

Substitutes: Titanium and aluminum high-strength alloys, as well as carbon-fiber materials, may substitute in highperformance scandium-alloy applications. Light-emitting diodes displace mercury-vapor high-intensity lights in some industrial and residential applications. In some applications that rely on scandium's unique properties, substitution is not possible.

\footnotetext{
eEstimated.

${ }^{1}$ See also Rare Earths. Scandium is one of the 17 rare-earth elements.

${ }^{2}$ Prices from Alfa Aesar, a Johnson Matthey company.

${ }^{3}$ Prices from Sigma-Aldrich, a part of Millipore Sigma.

${ }^{4}$ Prices from Stanford Materials Corp.

${ }^{5}$ Defined as imports - exports. Quantitative data are not available.

${ }^{6}$ See Appendix C for resource and reserve definitions and information concerning data sources.
} 


\section{SELENIUM}

(Data in metric tons of selenium content unless otherwise noted)

Domestic Production and Use: In 2019, primary selenium was refined from anode slimes recovered from the electrolytic refining of copper at one facility in Texas. Two other electrolytic copper refineries, operating in Arizona and Utah, did not recover selenium domestically. U.S. selenium production and consumption data were withheld to avoid disclosing company proprietary data.

Estimates for world consumption are as follows: metallurgy (including manganese production), 40\%; glass manufacturing, 25\%; agriculture, 10\%; chemicals and pigments, 10\%; electronics, 10\%; and other uses, 5\%.

Selenium is used in blasting caps to control delays; in catalysts to enhance selective oxidation; in copper, lead, and steel alloys to improve machinability; in the electrolytic production of manganese to increase yields; in glass manufacturing to decolorize the green tint caused by iron impurities in container glass and other soda-lime silica glass; in gun bluing to improve cosmetic appearance and provide corrosion resistance; in plating solutions to improve appearance and durability; in rubber compounding chemicals to act as a vulcanizing agent; and in thin-film photovoltaic copper-indium-gallium-diselenide (CIGS) solar cells.

Selenium is an essential micronutrient and is used as a human dietary supplement, a dietary supplement for livestock, and as a fertilizer additive to enrich selenium-poor soils. Selenium is also used as an active ingredient in antidandruff shampoos.

\begin{tabular}{|c|c|c|c|c|c|}
\hline Salient Statistics_-United States: & $\underline{2015}$ & $\underline{2016}$ & $\underline{2017}$ & $\underline{2018}$ & $\frac{2019 \mathrm{e}}{W}$ \\
\hline & W & W & W & $\mathrm{W}$ & \\
\hline \multicolumn{6}{|l|}{ Imports for consumption: } \\
\hline $\begin{array}{l}\text { Selenium metal } \\
\text { Selenium dioxide }\end{array}$ & $\begin{array}{r}444 \\
14\end{array}$ & $\begin{array}{r}411 \\
21\end{array}$ & $\begin{array}{r}450 \\
19\end{array}$ & $\begin{array}{r}445 \\
12\end{array}$ & $\begin{array}{r}500 \\
1\end{array}$ \\
\hline Exports,${ }^{1}$ metal & 468 & 150 & 242 & 158 & 260 \\
\hline Consumption, apparent, ${ }^{2}$ metal & W & W & W & W & W \\
\hline Price, average, dollars per pound ${ }^{3}$ & 22.09 & 23.69 & 10.78 & 18.97 & 20.00 \\
\hline Stocks, producer, refined, yearend & W & W & W & W & W \\
\hline $\begin{array}{l}\text { Net import reliance } 4 \text { as a percentage of } \\
\text { apparent consumption, metal }\end{array}$ & $\mathrm{E}$ & $\mathrm{E}$ & $\mathrm{E}$ & $<25$ & $<25$ \\
\hline
\end{tabular}

Recycling: Domestic production of secondary selenium was estimated to be very small because most scrap from older plain paper photocopiers and electronic materials was exported for recovery of the contained selenium.

Import Sources (2015-18): China, 22\%; the Philippines, 17\%; Mexico, 13\%; Germany, 11\%; and other, 37\%.

\section{Tariff: Item}

Selenium metal

Selenium dioxide

\section{Number}

2804.90.0000

2811.29.2000
Normal Trade Relations 12-31-19

Free.

Free.

Depletion Allowance: 14\% (Domestic and foreign).

Government Stockpile: None.

Events, Trends, and Issues: The supply of selenium is directly affected by the supply of the materials from which it is a byproduct-copper and, to a lesser extent, nickel—and it is directly affected by the number of facilities that recover selenium. The estimated annual average price for selenium was $\$ 20.00$ per pound in 2019 , about $5 \%$ more than the annual average price in 2018. Average monthly prices have remained steady since November 2018. 


\section{SELENIUM}

Electrolytic manganese production was the main metallurgical end use for selenium in China, where selenium dioxide was used in the electrolytic process to increase current efficiency and the metal deposition rate. Selenium consumption in China was thought to have increased in recent years; 49 electrolytic manganese producers were reported to have been operating and consuming selenium in 2018 (latest information available), down from 51 reported in 2017.

\section{World Refinery Production and Reserves:}

\begin{tabular}{|c|c|c|c|}
\hline & Refir & Iction 5 & Reserves $^{6}$ \\
\hline & 2018 & $\underline{2019^{e}}$ & \\
\hline United States & $\mathrm{W}$ & $\mathrm{W}$ & 10,000 \\
\hline Belgium & 200 & 200 & - \\
\hline Canada & 61 & 60 & 6,000 \\
\hline China & 930 & 930 & 26,000 \\
\hline Finland & 100 & 100 & - \\
\hline Germany & 300 & 300 & - \\
\hline Japan & 768 & 770 & - \\
\hline Peru & 45 & 45 & 13,000 \\
\hline Poland & 76 & 70 & 3,000 \\
\hline Russia & 150 & 150 & 20,000 \\
\hline Sweden & 90 & 50 & - \\
\hline Turkey & 50 & 50 & - \\
\hline Other countries ${ }^{7}$ & 44 & 40 & $\underline{21,000}$ \\
\hline World total (rounded) & 72,810 & $\overline{72,800}$ & $\overline{99,000}$ \\
\hline
\end{tabular}

World Resources: Reserves for selenium are based on identified copper deposits and average selenium content. Coal generally contains between 0.5 and 12 parts per million of selenium, or about 80 to 90 times the average for copper deposits. The recovery of selenium from coal fly ash, although technically feasible, does not appear likely to be economical in the foreseeable future.

Substitutes: Silicon is the major substitute for selenium in low- and medium-voltage rectifiers. Organic pigments have been developed as substitutes for cadmium sulfoselenide pigments. Other substitutes include cerium oxide as either a colorant or decolorant in glass; tellurium in pigments and rubber; bismuth, lead, and tellurium in freemachining alloys; and bismuth and tellurium in lead-free brasses. Sulfur dioxide can be used as a replacement for selenium dioxide in the production of electrolytic manganese metal, but it is not as energy efficient.

The selenium-tellurium photoreceptors used in some plain paper copiers and laser printers have been replaced by organic photoreceptors in newer machines. Amorphous silicon and cadmium telluride are the two principal competitors with CIGS in thin-film photovoltaic solar cells.

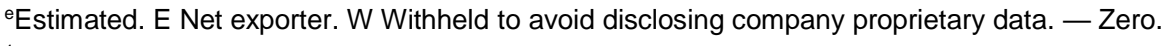

${ }^{1}$ There was no exclusive Schedule B number for selenium dioxide exports.

${ }^{2}$ Defined as production + imports - exports + adjustments for industry stock changes.

${ }^{3}$ U.S. spot market price for selenium metal powder, minimum 99.5\% purity, in 5-ton lots. Source: Platts Metals Week.

${ }^{4}$ Defined as imports - exports + adjustments for industry stock changes; export data incomplete for common forms of selenium, and may be exported under unexpected or misidentified forms, such as copper slimes, copper selenide, or zinc selenide.

${ }^{5}$ Insofar as possible, data relate to refinery output only; thus, countries that produced selenium contained in blister copper, copper concentrates, copper ores, and (or) refinery residues, but did not recover refined selenium from these materials indigenously, were excluded to avoid double counting.

${ }^{6}$ See Appendix $C$ for resource and reserve definitions and information concerning data sources.

${ }^{7}$ Excludes U.S. production. Australia, Iran, Kazakhstan, Mexico, the Philippines, and Uzbekistan are known to produce refined selenium, but output was not reported, and information was inadequate to make reliable production estimates.
} 


\section{SILICON}

(Data in thousand metric tons of silicon content unless otherwise noted)

Domestic Production and Use: Six companies produced silicon materials at seven plants, all east of the Mississippi River. Most ferrosilicon was consumed in the ferrous foundry and steel industries, predominantly in the Eastern United States, and was sourced primarily from domestic quartzite (silica). The main consumers of silicon metal were producers of aluminum alloys and the chemical industry. The semiconductor and solar energy industries, which manufacture chips for computers and photovoltaic cells from high-purity silicon, respectively, also consumed silicon metal.

\begin{tabular}{|c|c|c|c|c|c|}
\hline $\begin{array}{l}\text { Salient Statistics-United States: } \\
\text { Production: }\end{array}$ & $\underline{2015}$ & $\underline{2016}$ & $\underline{2017}$ & $\underline{2018}$ & $\underline{2019^{e}}$ \\
\hline Ferrosilicon and silicon metal 1,2 & 411 & 384 & 415 & 430 & 320 \\
\hline \multicolumn{6}{|l|}{ Imports for consumption: } \\
\hline Ferrosilicon, all grades ${ }^{1}$ & 162 & 155 & 147 & 140 & 140 \\
\hline Silicon metal & 140 & 122 & 136 & 116 & 130 \\
\hline \multicolumn{6}{|l|}{ Exports: } \\
\hline Ferrosilicon, all grades ${ }^{1}$ & 9 & 7 & 11 & 12 & 10 \\
\hline Silicon metal & 37 & 60 & 71 & 45 & 40 \\
\hline \multicolumn{6}{|l|}{ Consumption, apparent: ${ }^{3}$} \\
\hline Ferrosilicon, all grades ${ }^{1}$ & W & W & W & W & W \\
\hline Silicon metal ${ }^{2}$ & W & W & $\mathrm{W}$ & W & W \\
\hline Total & $\overline{661}$ & $\overline{601}$ & 616 & 637 & 560 \\
\hline \multicolumn{6}{|c|}{ Price, average, cents per pound of silicon: } \\
\hline Ferrosilicon, 50\% Si ${ }^{4}$ & 101 & 83 & 94 & 104 & 100 \\
\hline Ferrosilicon, $75 \% \mathrm{Si}^{5}$ & 88 & 71 & 87 & 108 & 93 \\
\hline Silicon metal $\left.\right|^{2,5}$ & 127 & 91 & 117 & 134 & 110 \\
\hline \multicolumn{6}{|l|}{ Stocks, producer, yearend: } \\
\hline Ferrosilicon and metal ${ }^{1,2}$ & 33 & 26 & 26 & 19 & 20 \\
\hline \multicolumn{6}{|l|}{$\begin{array}{l}\text { Net import reliance } 6 \text { as a percentage } \\
\text { of apparent consumption: }\end{array}$} \\
\hline Ferrosilicon, all grades ${ }^{1}$ & $>50$ & $>50$ & $<50$ & $<50$ & $<5$ \\
\hline Silicon metal ${ }^{2}$ & $<50$ & $<50$ & $<50$ & $<50$ & $<50$ \\
\hline Total & 38 & 36 & 33 & 32 & 41 \\
\hline
\end{tabular}

Recycling: Insignificant.

Import Sources (2015-18): Ferrosilicon: Russia, 38\%; Canada, 13\%; China, 13\%; Brazil, 8\%; and other, $28 \%$. Silicon metal: Brazil, 28\%; Canada, 18\%; and other, 54\%. Total: Russia, 20\%; Brazil, 17\%; Canada, 15\%; and other, $48 \%$.

\section{Tariff: Item}

Silicon, more than $99.99 \% \mathrm{Si}$

Silicon, $99.00 \%-99.99 \% \mathrm{Si}$

Silicon, other

Ferrosilicon, 55\%-80\% Si: More than $3 \% \mathrm{Ca}$

Other

Ferrosilicon, 80\%-90\% Si

Ferrosilicon, more than $90 \% \mathrm{Si}$

Ferrosilicon, other:

More than $2 \% \mathrm{Mg}$

Other

\section{Number}

2804.61.0000

2804.69.1000

2804.69.5000

7202.21 .1000

7202.21 .5000

7202.21 .7500

7202.21 .9000

7202.29 .0010

7202.29 .0050
Normal Trade Relations 12-31-19

Free.

$5.3 \%$ ad val.

$5.5 \%$ ad val.

$1.1 \%$ ad val. $1.5 \%$ ad val. $1.9 \%$ ad val. $5.8 \%$ ad val.

Free.

Free. 


\section{SILICON}

Depletion Allowance: Quartzite, 14\% (Domestic and foreign); gravel, 5\% (Domestic and foreign).

Government Stockpile: None.

Events, Trends, and Issues: Combined domestic ferrosilicon and silicon metal production in 2019, expressed in terms of contained silicon, decreased from that of 2018. One producer idled a silicon metal production facility at the end of 2018 to consolidate operations and respond to reduced demand. Domestic production during the first 9 months of 2019 was about $19 \%$ less, on a gross-weight basis, than that during the same period in 2018. By September 2019, average U.S. ferrosilicon spot market prices had decreased slightly for 50\%-grade ferrosilicon and by $14 \%$ for $75 \%$ grade ferrosilicon compared with the annual average spot price in 2018. The average silicon metal spot market price had decreased by $18 \%$ compared with the annual average spot price in 2018 . Oversupply in the market combined with decreased demand from ferrosilicon and silicon metal consumers contributed to declining prices in 2019.

Excluding the United States, ferrosilicon accounted for about 55\% of world silicon production on a silicon-content basis in 2019. Global production for 2018 was revised from the previous year's publication owing to increases in the estimates for production from China. The leading countries for ferrosilicon production were, in descending order and on a contained-weight basis, China, Russia, and Norway. For silicon metal, the leading producers were China, Norway, and Brazil. China accounted for approximately $64 \%$ of total global estimated production of silicon materials in 2019.

\section{World Production and Reserves:}

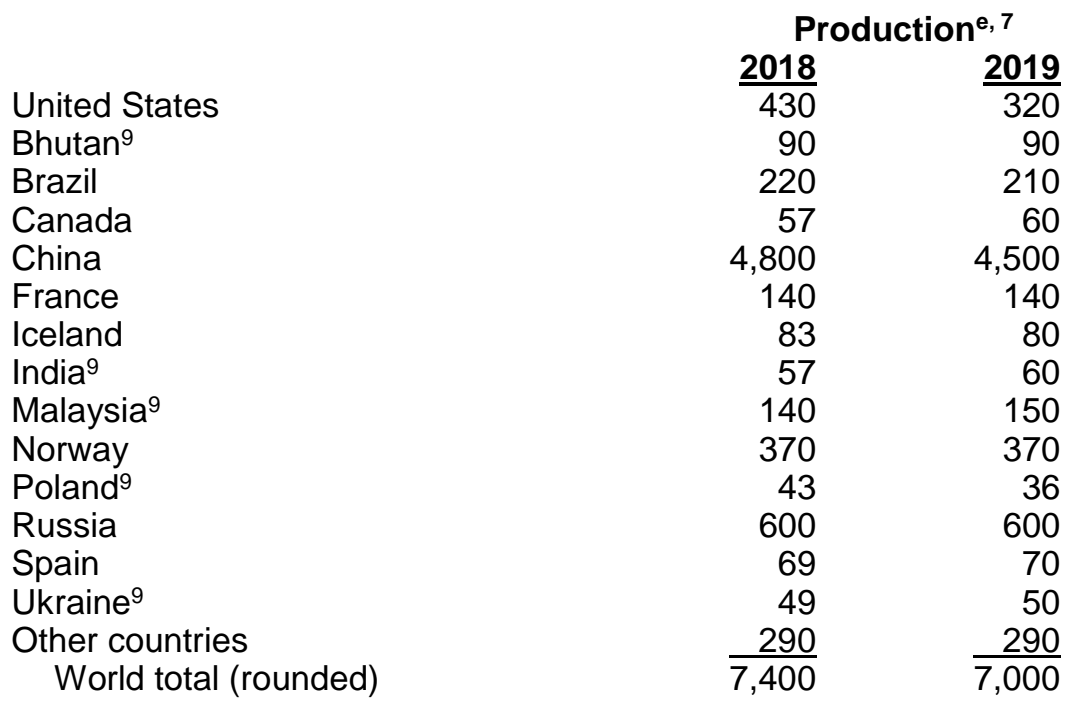

World Resources: World and domestic resources for making silicon metal and alloys are abundant and, in most producing countries, adequate to supply world requirements for many decades. The source of the silicon is silica in various natural forms, such as quartzite.

Substitutes: Aluminum, silicon carbide, and silicomanganese can be substituted for ferrosilicon in some applications. Gallium arsenide and germanium are the principal substitutes for silicon in semiconductor and infrared applications.

\footnotetext{
eEstimated. W Withheld to avoid disclosing company proprietary data.

${ }^{1}$ Ferrosilicon grades include the two standard grades of ferrosilicon $-50 \%$ and $75 \%$ silicon—plus miscellaneous silicon alloys.

${ }^{2}$ Metallurgical-grade silicon metal.

${ }^{3}$ Defined as production + imports - exports + adjustments for industry stock changes.

${ }^{4} \mathrm{CRU}$ Group transaction prices based on weekly averages.

${ }^{5}$ S\&P Global Platts mean import prices based on monthly averages.

${ }^{6}$ Defined as imports - exports + adjustments for industry stock changes.

${ }^{7}$ Production quantities are the silicon content of combined totals for ferrosilicon and silicon metal, except as noted.

${ }^{8}$ See Appendix $\mathrm{C}$ for resource and reserve definitions and information concerning data sources.

${ }^{9}$ Silicon content of ferrosilicon only.
} 


\section{SILVER}

(Data in metric tons ${ }^{1}$ of silver content unless otherwise noted)

Domestic Production and Use: In 2019, U.S. mines produced approximately 980 tons of silver with an estimated value of $\$ 510$ million. Silver was produced at 4 silver mines and as a byproduct or coproduct from 33 domestic baseand precious-metal operations. Alaska continued as the country's leading silver-producing State, followed by Nevada. There were 24 U.S. refiners that reported production of commercial-grade silver with an estimated total output of 2,500 tons from domestic and foreign ores and concentrates and from new and old scrap. The physical properties of silver include high ductility, electrical conductivity, malleability, and reflectivity. In 2019, the estimated domestic uses for silver were electrical and electronics, 30\%; jewelry and silverware, 26\%; coins and medals, 12\%; photography, $3 \%$; and other, $29 \%$. Other applications for silver include use in antimicrobial bandages, clothing, pharmaceuticals, and plastics; batteries; bearings; brazing and soldering; catalytic converters in automobiles; electroplating; inks; mirrors; photovoltaic solar cells; water purification; and wood treatment. Mercury and silver, the main components of dental amalgam, are biocides, and their use in amalgam inhibits recurrent decay.

\begin{tabular}{|c|c|c|c|c|c|}
\hline $\begin{array}{l}\text { Salient Statistics_-United States: } \\
\text { Production: }\end{array}$ & $\underline{2015}$ & $\underline{2016}$ & $\underline{2017}$ & $\underline{2018}$ & $\underline{2019^{e}}$ \\
\hline Mine & 1,090 & 1,150 & 1,030 & 934 & 980 \\
\hline \multicolumn{6}{|l|}{ Refinery: } \\
\hline Primary & 1,530 & 1,530 & 1,420 & 1,420 & 1,400 \\
\hline Secondary (new and old scrap) & 1,100 & 1,010 & 1,030 & 1,050 & 1,100 \\
\hline Imports for consumption ${ }^{2}$ & 5,930 & 6,160 & 5,040 & 4,840 & 4,700 \\
\hline Exports ${ }^{2}$ & 818 & 289 & 157 & 602 & 300 \\
\hline Consumption, apparent ${ }^{3}$ & 6,590 & 8,040 & 7,320 & 6,090 & 6,500 \\
\hline Price, average, dollars per troy ounce 4 & 15.72 & 17.20 & 17.07 & 15.75 & 16.20 \\
\hline \multicolumn{6}{|l|}{ Stocks, yearend: } \\
\hline Industry & 869 & 866 & 490 & 632 & 630 \\
\hline Treasury 5 & 498 & 498 & 498 & 498 & 498 \\
\hline New York Commodities Exchange-COMEX & 5,000 & 5,710 & 7,570 & 9,140 & 9,800 \\
\hline Employment, mine and mill, number6 & 1,210 & 1,190 & 1,010 & 961 & 970 \\
\hline \multicolumn{6}{|l|}{ Net import reliance ${ }^{7}$ as a percentage } \\
\hline of apparent consumption & 67 & 73 & 72 & 67 & \\
\hline
\end{tabular}

Recycling: In 2019, approximately 1,100 tons of silver was recovered from new and old scrap, about $17 \%$ of apparent consumption.

Import Sources (2015-18): ${ }^{2}$ Mexico, 48\%; Canada, 29\%; Peru, 5\%; Poland, 4\%; and other, 14\%.

Tariff: Item

Silver ores and concentrates, silver content Bullion, silver content

Dore, silver content
Number

2616.10.0040

7106.91.1010

7106.91 .1020
Normal Trade Relations 12-31-19

$0.8 \$ / \mathrm{kg}$ on lead content. Free. Free.

Depletion Allowance: 15\% (Domestic), 14\% (Foreign).

Government Stockpile: The U.S. Department of the Treasury maintains stocks of silver (see salient statistics above).

Events, Trends, and Issues: The estimated average silver price in 2019 was $\$ 16.20$ per troy ounce, 3\% higher than the average price in 2018 . The price began the year at $\$ 15.46$ per troy ounce, then decreased to a low of $\$ 14.37$ per troy ounce on May 28 . The price increased to a high of $\$ 19.40$ per troy ounce on September 4 before trending downward through November. 


\section{SILVER}

In 2019, global consumption of silver was estimated to have increased slightly from that of 2018. Coin and bar consumption increased for the third year in a row. Consumption for jewelry and silverware was also estimated to have increased in 2019. Photography and other industrial uses decreased in 2019. Overall, production in the global silver market was estimated to have been greater than consumption in 2019 resulting in an excess supply of silver; however, investor purchases were expected to more than offset the surplus and support the higher silver price. ${ }^{8}$

World silver mine production increased slightly in 2019 to an estimated 27,000 tons, principally as a result of increased production from mines in Argentina, Australia, Mexico, and Poland. Some silver-producing mines in Chile and Peru experienced reductions in production owing to protester blockades and worker strikes. Domestic silver mine production increased by $5 \%$ in 2019 compared with that in 2018 principally from increased production at mining operations in Alaska.

World Mine Production and Reserves: Reserves for Australia, Peru, and Poland were revised based on new information from official Government sources.

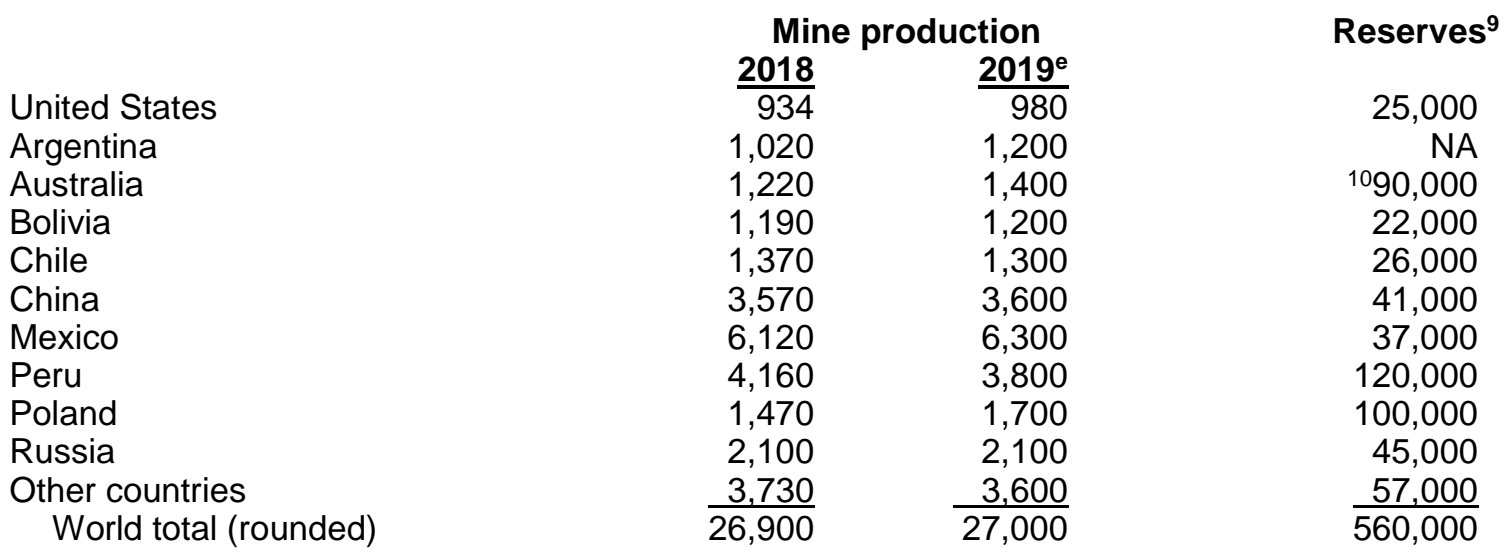

World Resources: Although silver was a principal product at several mines, silver was primarily obtained as a byproduct from lead-zinc mines, copper mines, and gold mines, in descending order of production. The polymetallic ore deposits from which silver was recovered account for more than two-thirds of U.S. and world resources of silver. Most recent silver discoveries have been associated with gold occurrences; however, copper and lead-zinc occurrences that contain byproduct silver will continue to account for a significant share of reserves and resources in the future.

Substitutes: Digital imaging, film with reduced silver content, silverless black-and-white film, and xerography substitute for traditional photographic applications for silver. Surgical pins and plates may be made with stainless steel, tantalum, and titanium in place of silver. Stainless steel may be substituted for silver flatware. Nonsilver batteries may replace silver batteries in some applications. Aluminum and rhodium may be used to replace silver that was traditionally used in mirrors and other reflecting surfaces. Silver may be used to replace more costly metals in catalytic converters for off-road vehicles.

\footnotetext{
eEstimated. NA Not available.

${ }^{1}$ One metric ton $(1,000$ kilograms $)=32,150.7$ troy ounces.

${ }^{2}$ Silver content of base metal ores and concentrates, refined bullion, and dore; excludes coinage, and waste and scrap material.

${ }^{3}$ Defined as mine production + secondary production + imports - exports + adjustments for Government and industry stock changes.

${ }^{4}$ Engelhard's industrial bullion quotations. Source: Platts Metals Week.

${ }^{5}$ Balance in U.S. Mint only; includes deep storage and working stocks.

${ }^{6}$ Source: U.S. Department of Labor, Mine Safety and Health Administration. Only includes mines where silver is the primary product.

${ }^{7}$ Defined as imports - exports + adjustments for Government and industry stock changes.

${ }^{8}$ DiRienzo, Michael, and Newman, Philip, 2019, Release of Metal Focus interim silver market review—Silver to remain in a small surplus in 2019,

but improving investor sentiment will help drive the price higher: Silver Institute and Metal Focus, November 19, 2 p.

${ }^{9}$ See Appendix $C$ for resource and reserve definitions and information concerning data sources.

${ }^{10}$ For Australia, Joint Ore Reserves Committee-compliant reserves were 25,000 tons.
} 


\section{SODA ASH}

(Data in thousand metric tons unless otherwise noted)

Domestic Production and Use: The total value of domestic natural soda ash (sodium carbonate) produced in 2019 was estimated to be about $\$ 1.8$ billion $^{1}$ and U.S. production of 12 million tons was about the same as that of the previous year. The U.S. soda ash industry comprised four companies in Wyoming operating five plants and one company in California with one plant. The five producing companies have a combined annual nameplate capacity of 13.9 million tons (15.3 million short tons). Borax, salt, and sodium sulfate were produced as coproducts of sodium carbonate production in California. Chemical caustic soda, sodium bicarbonate, and sodium sulfite were manufactured as coproducts at several of the Wyoming soda ash plants. Sodium bicarbonate was produced at an operation in Colorado using soda ash feedstock shipped from the company's Wyoming facility.

Based on 2019 quarterly reports, the estimated distribution of soda ash by end use was glass, 47\%; chemicals, 30\%; distributors, 6\%; soap and detergents, 6\%; miscellaneous uses, 5\%; flue gas desulfurization, 4\%; pulp and paper, $1 \%$; and water treatment, $1 \%$.

\begin{tabular}{|c|c|c|c|c|c|}
\hline Salient Statistics-United States: & $\underline{2015}$ & $\underline{2016}$ & $\underline{2017}$ & $\underline{2018}$ & $\frac{2019^{e}}{12000}$ \\
\hline$\overline{\text { Production } 2}$ & $1 \overline{1,600}$ & $1 \overline{1,800}$ & $12 \overline{12,000}$ & $1 \overline{11,900}$ & $1 \overline{2,000}$ \\
\hline Imports for consumption & 40 & 35 & 19 & 51 & 100 \\
\hline Exports & 6,400 & 6,760 & 6,990 & 6,960 & 6,900 \\
\hline \multicolumn{6}{|l|}{ Consumption: } \\
\hline Apparent $^{3}$ & 5,200 & 5,030 & 5,040 & 4,980 & 5,200 \\
\hline Reported & 4,990 & 5,120 & 4,910 & 4,850 & 4,800 \\
\hline \multicolumn{6}{|l|}{$\begin{array}{l}\text { Price: } \\
\text { Average sales value (natural source): }\end{array}$} \\
\hline Average sales value (natural source): & & & & & \\
\hline f.o.b. mine or plant, dollars per metric ton & 155.30 & 149.83 & 146.26 & 148.69 & 150.00 \\
\hline f.o.b. mine or plant, dollars per short ton & 140.88 & 135.92 & 132.68 & 134.89 & 136.00 \\
\hline Stocks, producer, yearend & 285 & 336 & 293 & 297 & 300 \\
\hline Employment, mine and plant, numbere & 2,500 & 2,500 & 2,600 & 2,600 & 2,600 \\
\hline $\begin{array}{l}\text { Net import reliance } 4 \text { as a percentage } \\
\text { of apparent consumption }\end{array}$ & $\mathrm{E}$ & $\mathrm{E}$ & $E$ & E & 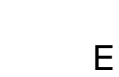 \\
\hline
\end{tabular}

Recycling: No soda ash was recycled by producers; however, glass container producers use cullet glass, thereby reducing soda ash consumption.

Import Sources (2015-18): Germany, 28\%; Turkey, 25\%; Italy, 14\%; United Kingdom, 11\%; and other, $22 \%$.

Tariff: Item

Disodium carbonate

2836.20 .0000
Normal Trade Relations

12-31-19

$1.2 \%$ ad val.

Depletion Allowance: Natural, 14\% (Domestic and foreign).

Government Stockpile: None. 


\section{SODA ASH}

Events, Trends, and Issues: Relatively low production costs and lower environmental impacts provide natural soda ash producers some advantage over producers of synthetic soda ash. The production of synthetic soda ash normally consumes more energy and releases more carbon dioxide than that of natural soda ash. In recent years, U.S. producers of natural soda ash were able to expand their markets when several synthetic soda ash plants were closed or idled around the world.

Soda ash exports from Turkey increased in 2018 when a 2.5-million-ton-per-year plant opened all of its production lines after several months of operational delays. Some of the exports came to the United States starting in September 2018 and several more relatively large shipments were reported in 2019. Total production capacity in Turkey is estimated to be between 4 million and 5 million tons per year and soda ash shipments, especially for export, are expected to increase significantly during the next few years.

Three groups dominate production and have become the world's leading suppliers of soda ash-American National Soda Ash Corp., which represented three of the five domestic producers in 2019; multiple producers in China; and Solvay S.A. of Belgium. Increasing soda ash exports from Turkey may affect sales from these three groups. The United States likely will remain competitive with producers in China and Turkey for markets elsewhere in Asia. Asia and South America remain the most likely areas for increased soda ash consumption in the near future. U.S. producers expect modest growth in production and exports through 2020.

World Production and Reserves: Reserves for Ethiopia and Turkey were revised based on Government and industry reports.

Natural:

United States

Botswana

Ethiopia

Kenya

Turkey

Other countries

World total, natural (rounded)

World total, synthetic (rounded)

World total (rounded)

\begin{tabular}{rr}
\multicolumn{2}{r}{ Mine production } \\
$\underline{\mathbf{2 0 1 8}}$ & $\underline{\mathbf{2 0 1 9}}$ \\
11,900 & 12,000 \\
240 & 250 \\
8 & 8 \\
300 & 300 \\
3,400 & 3,500 \\
NA & NA \\
\hline 16,000 & 16,000 \\
41,000 & 42,000 \\
57,000 & 58,000
\end{tabular}

\begin{tabular}{r} 
Reserves $^{5,6}$ \\
$723,000,000$ \\
400,000 \\
400,000 \\
7,000 \\
900,000 \\
280,000 \\
\hline $25,000,000$ \\
$X X$ \\
$X X$
\end{tabular}

World Resources: Natural soda ash is obtained from trona and sodium carbonate-rich brines. The world's largest deposit of trona is in the Green River Basin of Wyoming. About 47 billion tons of identified soda ash resources could be recovered from the 56 billion tons of bedded trona and the 47 billion tons of interbedded or intermixed trona and halite, which are in beds more than 1.2 meters thick. Underground room-and-pillar mining, using conventional and continuous mining, is the primary method of mining Wyoming trona ore. This method has an average $45 \%$ mining recovery, whereas average recovery from solution mining is $30 \%$. Improved solution-mining techniques, such as horizontal drilling to establish communication between well pairs, could increase this extraction rate and enable companies to develop some of the deeper trona beds. Wyoming trona resources are being depleted at the rate of about 15 million tons per year (8.3 million tons of soda ash). Searles Lake and Owens Lake in California contain an estimated 815 million tons of soda ash reserves. At least 95 natural sodium carbonate deposits have been identified in the world, only some of which have been quantified. Although soda ash can be manufactured from salt and limestone, both of which are practically inexhaustible, synthetic soda ash is costlier to produce and generates environmental wastes.

Substitutes: Caustic soda can be substituted for soda ash in certain uses, particularly in the pulp and paper, water treatment, and certain chemical sectors. Soda ash, soda liquors, or trona can be used as feedstock to manufacture chemical caustic soda, which is an alternative to electrolytic caustic soda.

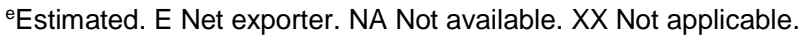

${ }^{1}$ Does not include values for soda liquors and mine waters.

${ }^{2}$ Natural only.

${ }^{3}$ Defined as production + imports - exports + adjustments for industry stock changes.

${ }^{4}$ Defined as imports - exports + adjustments for industry stock changes.

${ }^{5}$ The reported quantities are sodium carbonate only. About 1.8 tons of trona yields 1 ton of sodium carbonate.

${ }^{6}$ See Appendix $\mathrm{C}$ for resource and reserve definitions and information concerning data sources.

${ }^{7}$ From trona, nahcolite, and dawsonite deposits.
} 


\section{STONE (CRUSHED) ${ }^{1}$}

(Data in million metric tons unless otherwise noted)

Domestic Production and Use: In 2019, 1.53 billion tons of crushed stone valued at more than $\$ 18.7$ billion was produced by an estimated 1,430 companies operating 3,440 quarries and 176 sales and (or) distribution yards in 50 States. Leading States were, in descending order of production, Texas, Pennsylvania, Florida, Missouri, North Carolina, Ohio, Georgia, Virginia, Illinois, and Kentucky, which combined accounted for more than one-half of the total crushed stone output. Of the total domestic crushed stone produced in 2018 , about $69 \%$ was limestone and dolomite; $15 \%$, granite; $6 \%$, traprock; $5 \%$, miscellaneous stone; $3 \%$, sandstone and quartzite; and the remaining $2 \%$ was divided, in descending order of tonnage, among marble, volcanic cinder and scoria, calcareous marl, slate, and shell. It is estimated that of the 1.6 billion tons of crushed stone consumed in the United States in $2019,72 \%$ was used as construction aggregate, mostly for road construction and maintenance; $16 \%$ for cement manufacturing; $8 \%$ for lime manufacturing; $3 \%$ for other chemical, special, and miscellaneous uses and products; and $2 \%$ for agricultural uses.

The estimated output of crushed stone in the United States shipped for consumption in the first 9 months of 2019 was 1.14 billion tons, an increase of $8 \%$ compared with that of the same period of 2018 . Third quarter shipments for consumption increased by $9 \%$ compared with those of the same period of 2018 . Additional production information, by quarter for each State, geographic division, and the United States, is reported in the U.S. Geological Survey quarterly Mineral Industry Surveys for Crushed Stone and Sand and Gravel.

\begin{tabular}{|c|c|c|c|c|c|}
\hline Salient Statistics-United States: & $\underline{2015}$ & $\underline{2016}$ & $\underline{2017}$ & $\underline{2018^{e}}$ & $\frac{2019^{\mathrm{e}}}{1520}$ \\
\hline Production & $\overline{1,340}$ & $\overline{1,360}$ & $\overline{1,370}$ & $\overline{1,420}$ & 1,530 \\
\hline Recycled material & 48 & 49 & 42 & 48 & 48 \\
\hline Imports for consumption & 20 & 20 & 19 & 21 & \\
\hline Exports & $(2)$ & 1 & 1 & $(2)$ & \\
\hline Consumption, apparent ${ }^{3}$ & 1,410 & 1,430 & 1,430 & 1,480 & 1,60 \\
\hline Price, average value, dollars per metric ton & 10.49 & 11.07 & 11.45 & 11.86 & 12.26 \\
\hline Employment, quarry and mill, number ${ }^{4}$ & 67,100 & 68,100 & 68,600 & 68,500 & 67,900 \\
\hline $\begin{array}{l}\text { Net import reliance } 5 \text { as a percentage of } \\
\text { apparent consumption }\end{array}$ & 1 & 1 & 1 & 1 & \\
\hline
\end{tabular}

Recycling: Road surfaces made of asphalt concrete and portland cement concrete surface layers, which contain crushed stone aggregate, were recycled on a limited but increasing basis in most States. In 2019, asphalt and portland cement concrete road surfaces were recycled in all 50 States.

Import Sources (2015-18): Mexico, 56\%; Canada, 27\%; The Bahamas, 11\%; Honduras, 5\%; and Jamaica, 1\%.

\section{Tariff: Item}

Chalk:

Crude

Other

Limestone, except pebbles and gravel

Crushed or broken stone

Marble granules, chippings and powder

Stone granules, chippings and powders

Limestone flux; limestone and other calcareous stone
Number

2509.00.1000

2509.00 .2000

2517.10.0020

2517.10.0055

2517.41.0000

2517.49.0000

2521.00.0000
Normal Trade Relations $\underline{12-31-19}$

Free.

Free.

Free.

Free.

Free.

Free.

Free. 


\section{STONE (CRUSHED)}

Depletion Allowance: (Domestic) 14\% for some special uses; $5 \%$, if used as ballast, concrete aggregate, riprap, road material, and similar purposes.

Government Stockpile: None.

Events, Trends, and Issues: Crushed stone production was about 1.53 billion tons in 2019, an increase of 8\% compared with that of 2018. Apparent consumption also increased to about 1.60 billion tons. Consumption of crushed stone increased in 2019 because of continued growth in the private and public construction markets. Commercial and heavy industrial construction activity, infrastructure funding, new single-family housing unit starts, and weather, affect growth in crushed stone production and consumption. Long-term increases in construction aggregates demand are influenced by activity in the public and private construction sectors, as well as by construction work related to security measures being implemented around the Nation. The underlying factors that would support a rise in prices of crushed stone are expected to be present in 2020 , especially in and near metropolitan areas.

The crushed stone industry continued to be concerned with environmental, health, and safety regulations. Shortages in some urban and industrialized areas are expected to continue to increase owing to local zoning regulations and land-development alternatives. These issues are expected to continue and to cause new crushed stone quarries to locate away from large population centers.

\section{World Mine Production and Reserves:}

\begin{tabular}{|c|c|c|c|}
\hline \multirow[b]{3}{*}{ United States } & \multicolumn{2}{|c|}{ Mine production ${ }^{\mathrm{e}}$} & \multirow[t]{2}{*}{ Reserves $^{6}$} \\
\hline & $\underline{2018}$ & $\underline{2019}$ & \\
\hline & $\overline{1,420}$ & $\overline{1,530}$ & Adequate, except where specia \\
\hline Other countries ${ }^{7}$ & NA & NA & types are needed or where \\
\hline World total & NA & NA & local shortages exist. \\
\hline
\end{tabular}

World Resources: Stone resources are plentiful throughout the world. Supply of high-purity limestone and dolomite suitable for specialty uses is limited in many geographic areas. The largest resources of high-purity limestone and dolomite in the United States are in the central and eastern parts of the country.

Substitutes: Crushed stone substitutes for roadbuilding include sand and gravel, and iron and steel slag. Substitutes for crushed stone used as construction aggregates include construction sand and gravel, iron and steel slag, sintered or expanded clay or shale, perlite, or vermiculite. Increasingly, recycled asphalt and portland cement concretes are being substituted for virgin aggregate, although the percentage of total aggregate supplied by recycled materials remained very small in 2019.

\footnotetext{
eEstimated. NA Not available.

${ }^{1}$ See also Sand and Gravel (Construction) and Stone (Dimension).

${ }^{2}$ Less than $1 / 2$ unit.

${ }^{3}$ Defined as production + recycled material + imports - exports.

${ }^{4}$ Including office staff. Source: Mine Safety and Health Administration.

${ }^{5}$ Defined as imports - exports.

${ }^{6}$ See Appendix $C$ for resource and reserve definitions and information concerning data sources.

${ }^{7}$ Consistent production information is not available for other countries owing to a wide variety of ways in which countries report their crushed stone production. Some countries do not report production for this mineral commodity. Production information for some countries is available in the U.S. Geological Survey Minerals Yearbook, Volume III, Area Reports: International.
} 


\section{STONE (DIMENSION) ${ }^{1}$}

(Data in thousand metric tons unless otherwise noted)

Domestic Production and Use: Approximately 2.7 million tons of dimension stone, valued at $\$ 440$ million, was sold or used by U.S. producers in 2019. Dimension stone was produced by 197 companies operating 250 quarries in 33 States. Leading producer States were, in descending order by tonnage, Texas, Wisconsin, Indiana, Georgia, and Vermont. These five States accounted for about $68 \%$ of the production quantity and contributed about $56 \%$ of the value of domestic production. Approximately $50 \%$, by tonnage, of dimension stone sold or used was limestone, followed by sandstone (20\%), granite (18\%), miscellaneous stone (8\%), and marble and slate (2\% each). By value, the leading sales or uses were for limestone (45\%), followed by granite $(25 \%)$, sandstone $(11 \%)$, miscellaneous stone $(9 \%)$, slate $(6 \%)$, and marble (4\%). Rough stone represented $54 \%$ of the tonnage and $47 \%$ of the value of all the dimension stone sold or used by domestic producers, including exports. The leading uses and distribution of rough stone, by tonnage, were in building and construction (53\%) and in irregular-shaped stone (35\%). The leading uses and distribution of dressed stone, by tonnage, were in ashlars and partially squared pieces (41\%), slabs and blocks for building and construction (12\%), and curbing (11\%).

\begin{tabular}{|c|c|c|c|c|c|}
\hline$\frac{\text { Salient Statistics_-United States: }}{\text { Sold or used by producers: }{ }^{2}}$ & $\underline{2015}$ & $\underline{2016}$ & $\underline{2017}$ & $\underline{2018}$ & $\underline{2019^{e}}$ \\
\hline Tonnage & 2,700 & 2,960 & 2,860 & 2,650 & 2,700 \\
\hline Value, million dollars & 469 & 448 & 450 & 435 & 440 \\
\hline Imports for consumption, value, million dollars & 2,350 & 2,180 & 2,120 & 2,090 & 1,900 \\
\hline Exports, value, million dollars & 75 & 65 & 69 & 70 & 60 \\
\hline Consumption, apparent, value, million dollars ${ }^{3}$ & 2,740 & 2,560 & 2,500 & 2,460 & 2,300 \\
\hline Price & \multicolumn{5}{|c|}{ Variable, depending on type of product } \\
\hline Employment, quarry and mill, number ${ }^{4}$ & 4,000 & 4,000 & 3,900 & 3,900 & 3,900 \\
\hline $\begin{array}{l}\text { Net import reliance } 5 \text { as a percentage of } \\
\text { apparent consumption (based on value) }\end{array}$ & 83 & 83 & 82 & 82 & 81 \\
\hline \multicolumn{6}{|l|}{ Granite only, sold or used by producers: } \\
\hline Tonnage & 585 & 593 & 510 & 483 & 480 \\
\hline Value, million dollars & 130 & 130 & 113 & 108 & 110 \\
\hline Imports, value, million dollars & 1,330 & 1,100 & 1,010 & 915 & 880 \\
\hline Exports, value, million dollars & 27 & 21 & 22 & 19 & 18 \\
\hline Consumption, apparent, value, million dollars 3 & 1,430 & 1,210 & 1,100 & 1,000 & 970 \\
\hline Price & \multicolumn{5}{|c|}{ Variable, depending on type of product } \\
\hline Employment, quarry and mill, number ${ }^{4}$ & 880 & 880 & 800 & 800 & 800 \\
\hline $\begin{array}{l}\text { Net import reliance } 5 \text { as a percentage of } \\
\text { apparent consumption (based on value) }\end{array}$ & 91 & 89 & 90 & 89 & 89 \\
\hline
\end{tabular}

Recycling: Small amounts of dimension stone were recycled, principally by restorers of old stone work.

Import Sources (2015-18 by value): All dimension stone: China, 25\%; Brazil, 24\%; Italy, 21\%; Turkey, 16\%; and other, 14\%. Granite only: Brazil, 45\%; China, 24\%; India, 16\%; Italy, 8\%; and other, 7\%.

Tariff: Dimension stone tariffs ranged from free to $6.5 \%$ ad valorem, according to type, degree of preparation, shape, and size, for countries with normal trade relations in 2019. Most crude or roughly trimmed stone was imported at $3.7 \%$ ad valorem or less. 


\section{STONE (DIMENSION)}

Depletion Allowance: 14\% (Domestic and foreign); slate used or sold as sintered or burned lightweight aggregate, 7.5\% (Domestic and foreign); dimension stone used for rubble and other nonbuilding purposes, 5\% (Domestic and foreign).

Government Stockpile: None.

Events, Trends, and Issues: The United States remained one of the world's leading markets for dimension stone. In 2019, total imports of dimension stone decreased in value by about $9 \%$ compared with the value in 2018. In 2019, steady activity in new residential construction resulted in a slight increase in domestic production of dimension stone compared with that of the previous year. Dimension stone for construction and refurbishment was used in commercial and residential markets; in 2019, the renovation market for existing homes remained steady and unchanged compared with that in the previous year. Dimension stone exports decreased to about $\$ 60$ million. Apparent consumption, by value, was estimated to be $\$ 2.3$ billion in 2019 -a 7\% decrease compared with that of 2018 .

The dimension stone industry continued to be concerned with safety and health regulations and environmental restrictions in 2019, especially those concerning crystalline silica exposure. Beginning in 2016, the Occupational Safety and Health Administration (OSHA) finalized new regulations to further restrict exposure to crystalline silica at quarry sites and other industries that use materials containing it. Phased implementation of the new regulations was scheduled to take effect through 2021, affecting various industries that use materials containing silica. Most provisions of the new regulations became enforceable on June 23, 2018, for general industry and maritime operations. On August 14, 2019, OSHA requested comment and information to enable the agency to consider new developments and enhanced control methods for equipment that generates exposures to silica.

\section{World Mine Production and Reserves:}

United States

Other countries

World total

\begin{tabular}{lr}
\multicolumn{2}{c}{ Mine production } \\
$\frac{\mathbf{2 0 1 8}}{2,650}$ & $\frac{2019}{2,700}$ \\
NA & NA \\
\hline NA & NA
\end{tabular}

\section{Reserves $^{6}$}

Adequate, except for certain special types and local shortages.

World Resources: Dimension stone resources of the world are sufficient. Resources can be limited on a local level or occasionally on a regional level by the lack of a particular kind of stone that is suitable for dimension purposes.

Substitutes: Substitutes for dimension stone include aluminum, brick, ceramic tile, concrete, glass, plastics, resinagglomerated stone, and steel.

\footnotetext{
eEstimated. NA Not available.

${ }^{1}$ See also Stone (Crushed).

${ }^{2}$ Includes granite, limestone, and other types of dimension stone.

${ }^{3}$ Defined as sold or used (value) + imports (value) - exports (value).

${ }^{4}$ Excludes office staff.

${ }^{5}$ Defined as imports - exports.

${ }^{6}$ See Appendix C for resource and reserve definitions and information concerning data sources.
} 


\section{STRONTIUM}

(Data in metric tons of strontium content unless otherwise noted)

Domestic Production and Use: Although deposits of strontium minerals occur widely throughout the United States, none have been mined in the United States since 1959. Domestic production of strontium carbonate, the principal strontium compound, ceased in 2006. Virtually all of the strontium mineral celestite consumed in the United States since 2006 is thought to have been used as an additive in drilling fluids for oil and natural gas wells. A few domestic companies produced small quantities of downstream strontium chemicals from imported strontium carbonate.

Based on import data, the estimated end-use distribution in the United States for strontium, including celestite and strontium compounds, was, in descending order, drilling fluids, $64 \%$; ceramic ferrite magnets and pyrotechnics and signals, $12 \%$ each; and electrolytic production of zinc, master alloys, pigments and fillers, and other applications, including glass, $3 \%$ each.

\begin{tabular}{|c|c|c|c|c|c|}
\hline Salient Statistics-United States: & $\underline{2015}$ & $\underline{2016}$ & $\underline{2017}$ & $\underline{2018}$ & $\underline{2019^{e}}$ \\
\hline Production & 二 & 二 & - & 二 & - \\
\hline \multicolumn{6}{|l|}{ Imports for consumption: } \\
\hline Celestite $^{1}$ & 24,500 & 4,420 & 11,300 & 16,900 & 11,000 \\
\hline Strontium compounds ${ }^{2}$ & 7,100 & 6,420 & 6,660 & 6,350 & 6,300 \\
\hline Exports, strontium compounds & 86 & 91 & 36 & 32 & 24 \\
\hline \multicolumn{6}{|l|}{ Consumption, apparent: ${ }^{3}$} \\
\hline Celestite & 24,500 & 4,420 & 11,300 & 16,900 & 11,000 \\
\hline Strontium compounds & 7,020 & 6,330 & 6,620 & 6,320 & 6,300 \\
\hline Total & 31,500 & 10,700 & 17,900 & 23,200 & 17,000 \\
\hline \multirow{2}{*}{\multicolumn{6}{|c|}{$\begin{array}{l}\text { Price, average value of celestite imports } \\
\text { at port of exportation, dollars per ton } \\
\text { Net import reliance }{ }^{3} \text { as a percentage of }\end{array}$}} \\
\hline & & & & & \\
\hline apparent consumption & 100 & 100 & 100 & 100 & 100 \\
\hline
\end{tabular}

Recycling: None.

Import Sources (2015-18): Celestite: Mexico, 100\%. Strontium compounds: Mexico, 53\%; Germany, 37\%; China, 7\%; and other, 3\%. Total imports: Mexico, 87\%; Germany, 10\%; China, 2\%; and other, 1\%.

Tariff: Item

Celestite

Strontium compounds:

Strontium metal

Strontium oxide, hydroxide, peroxide

Strontium nitrate

Strontium carbonate
Number

2530.90 .8010

2805.19.1000

2816.40 .1000

2834.29.2000

2836.92.0000
Normal Trade Relations

12-31-19

Free.

$3.7 \%$ ad val.

$4.2 \%$ ad val.

$4.2 \%$ ad val.

$4.2 \%$ ad val. 


\section{STRONTIUM}

Depletion Allowance: 22\% (Domestic), 14\% (Foreign).

Government Stockpile: None.

Events, Trends, and Issues: Imports of celestite, the most commonly used strontium mineral, decreased by $35 \%$ following 2 years of increases. The decrease was likely the result of decreased natural gas- and oil-drilling activity. Nearly all celestite imports were from Mexico and were thought to be used as additives in drilling fluids for oil and natural gas exploration and production. For these applications, celestite is ground but undergoes no chemical processing. A small quantity of high-value celestite imports were reported; these were most likely mineral specimens. Outside the United States, celestite is the raw material from which strontium carbonate and other strontium compounds are produced.

Strontium carbonate is the most commonly traded strontium compound and is used as the raw material from which other strontium compounds are derived. Strontium carbonate is sintered with iron oxide to produce permanent ceramic ferrite magnets, and strontium nitrate contributes a brilliant red color to fireworks and signal flares. Smaller quantities of these and other strontium compounds were consumed in several other applications, including electrolytic production of zinc, glass production, master alloys, and pigments and fillers.

\section{World Mine Production and Reserves: ${ }^{4}$}

United States
Argentina
China
Iran
Mexico
Spain
Turkey
$\quad$ World total (rounded)

\begin{tabular}{|c|c|c|}
\hline \multicolumn{2}{|c|}{ Mine production } & \multirow{2}{*}{ Reserves $^{5}$} \\
\hline $2018^{e}$ & $2019^{e}$ & \\
\hline & 700 & \\
\hline 700 & 700 & All other: \\
\hline 50,000 & 50,000 & $6,800,000$ \\
\hline 37,000 & 37,000 & \\
\hline 40,000 & 40,000 & \\
\hline 90,000 & 90,000 & \\
\hline 1,000 & 1,000 & \\
\hline$\overline{220,000}$ & $\overline{220,000}$ & $\overline{6,800,000}$ \\
\hline
\end{tabular}

World Resources: World resources of strontium are thought to exceed 1 billion tons.

Substitutes: Barium can be substituted for strontium in ferrite ceramic magnets; however, the resulting barium composite will have reduced maximum operating temperature when compared with that of strontium composites. Substituting for strontium in pyrotechnics is hindered by difficulty in obtaining the desired brilliance and visibility imparted by strontium and its compounds. In drilling mud, barite is the preferred material, but celestite may substitute for some barite, especially when barite prices are high.

\footnotetext{
eEstimated. - Zero.

${ }^{1}$ The strontium content of celestite is $43.88 \%$, assuming an ore grade of $92 \%$, which was used to convert units of celestite to strontium content. ${ }^{2}$ Strontium compounds, with their respective strontium contents, in descending order, include metal (100.00\%); oxide, hydroxide, and peroxide (70.00\%); carbonate (59.35\%); and nitrate (41.40\%). These factors were used to convert gross weight of strontium compounds to strontium content.

${ }^{3}$ Defined as imports - exports.

${ }^{4}$ Gross weight of celestite in tons.

${ }^{5}$ See Appendix $\mathrm{C}$ for resource and reserve definitions and information concerning data sources.
} 


\section{SULFUR}

(Data in thousand metric tons of sulfur content unless otherwise noted)

Domestic Production and Use: In 2019, recovered elemental sulfur and byproduct sulfuric acid were produced at 95 operations in 27 States. Total shipments were valued at about $\$ 440$ million. Elemental sulfur production was estimated to be 8.2 million tons; Louisiana and Texas accounted for about $55 \%$ of domestic production. Elemental sulfur was recovered, in descending order of tonnage, at petroleum refineries, natural-gas-processing plants, and coking plants by 35 companies at 90 plants in 26 States. Byproduct sulfuric acid, representing about $7 \%$ of production of sulfur in all forms, was recovered at five nonferrous-metal smelters in four States by four companies. Domestic elemental sulfur provided $62 \%$ of domestic consumption, and byproduct acid accounted for about $6 \%$. The remaining $32 \%$ of sulfur consumed was provided by imported sulfur and sulfuric acid. About $90 \%$ of sulfur consumed was in the form of sulfuric acid.

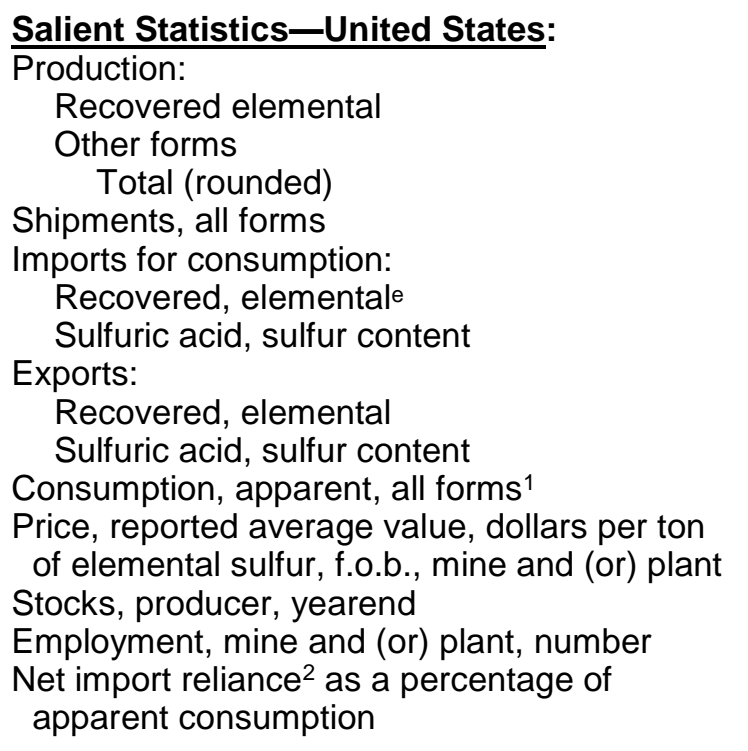

\begin{tabular}{rrrrr}
$\underline{\mathbf{2 0 1 5}}$ & $\underline{\mathbf{2 0 1 6}}$ & $\underline{\mathbf{2 0 1 7}}$ & $\underline{\mathbf{2 0 1 8}}$ & $\underline{\underline{\mathbf{2 0 1 9}}}$ \\
8,890 & 9,070 & 9,070 & 9,010 & 8,200 \\
646 & $\frac{673}{9,740}$ & $\frac{575}{9,640}$ & $\frac{670}{9,680}$ & $\frac{620}{8,800}$ \\
\hline 9,540 & 9,690 & 8,800 \\
9,560 & 9,750 & 9,700 & 9,690 & \\
2,240 & 1,820 & 1,850 & 2,230 & 2,000 \\
1,160 & 1,050 & 954 & 997 & 980 \\
1,850 & 2,060 & 2,340 & 2,390 & 2,300 \\
58 & 59 & 80 & 112 & 70 \\
11,000 & 10,500 & 10,000 & 10,400 & 9,400 \\
87.62 & 37.88 & 46.40 & 70.00 & 50.00 \\
138 & 144 & 124 & 122 & 110 \\
2,600 & 2,500 & 2,400 & 2,400 & 2,400 \\
14 & 7 & & & 7
\end{tabular}

Recycling: Typically, between 2.5 million and 5 million tons of spent sulfuric acid is reclaimed from petroleum refining and chemical processes during any given year.

Import Sources (2015-18): Elemental: Canada, 77\%; Russia, 10\%; Kazakhstan, 5\%; Mexico, 3\%; and other, 5\%. Sulfuric acid: Canada, 63\%; Mexico, 19\%; and other, 18\%. Total sulfur imports: Canada, 72\%; Mexico 9\%; Russia, 7\%; Kazakhstan, 3\%; and other, 9\%.

\section{Tariff: Item}

Sulfur, crude or unrefined

Sulfur, all kinds, other

Sulfur, sublimed or precipitated

Sulfuric acid
Number

2503.00.0010

2503.00.0090

2802.00.0000

2807.00.0000
Normal Trade Relations 12-31-19

Free.

Free.

Free.

Free.

Depletion Allowance: 22\% (Domestic and foreign).

\section{Government Stockpile: None.}

Events, Trends, and Issues: Total U.S. sulfur production in 2019 was estimated to have decreased by $9 \%$ from that of 2018 and shipments also decreased by $9 \%$ from those of 2018. Domestic production of elemental sulfur from petroleum refineries and recovery from natural gas operations decreased by $9 \%$. A decline in refinery operating utilization and processing of more sweet crude oil likely lead to decreased production. Domestically, refinery sulfur production is expected to remain relatively constant as well as byproduct sulfuric acid, unless one or more of the remaining nonferrous-metal smelters close. 


\section{SULFUR}

Domestic phosphate rock consumption in 2019 was estimated to be slightly lower than that in 2018, which resulted in decreased consumption of sulfur to process the phosphate rock into phosphate fertilizers.

World sulfur production was about the same as it was in 2018 but is likely to steadily increase for the foreseeable future. New sulfur demand associated with phosphate fertilizer projects is expected in west Asia and Africa. A major change for 2020 will be the implementation of new international standards limiting sulfur oxide emissions from ships on January 1,2020 . The global sulfur content of marine fuels would be limited to $0.5 \%$ sulfur content from $3.5 \%$ sulfur content, likely leading to increased sulfur production in North America, Asia, and Europe.

Contract sulfur prices in Tampa, FL, began 2019 at around $\$ 140$ per ton. The sulfur price continued to decrease throughout the year and reached about $\$ 46$ per ton in early October, the lowest price since 2009. The price decrease was a result of a weak phosphate fertilizer market. Prices for exported sulfur were higher than domestic prices. In the past few years, sulfur prices have been variable, a result of the volatility in the demand for sulfur.

\section{World Production and Reserves:}

\begin{tabular}{|c|c|c|}
\hline & Produ & All forms \\
\hline & 2018 & $2019^{e}$ \\
\hline United States & $\overline{9,680}$ & $\overline{8,800}$ \\
\hline Australia & 900 & 900 \\
\hline Brazil & 500 & 500 \\
\hline Canada & 5,320 & 5,300 \\
\hline Chile & 1,500 & 1,500 \\
\hline China $^{4}$ & 17,400 & 17,400 \\
\hline Finland & 940 & 940 \\
\hline Germany & 868 & 870 \\
\hline India & 3,430 & 3,400 \\
\hline Iran & 2,200 & 2,200 \\
\hline Italy & 550 & 550 \\
\hline Japan & 3,400 & 3,400 \\
\hline Kazakhstan & 3,510 & 3,600 \\
\hline Korea, Republic of & 3,080 & 3,100 \\
\hline Kuwait & 850 & 900 \\
\hline Netherlands & 520 & 520 \\
\hline Poland & 1,230 & 1,230 \\
\hline Qatar & 2,000 & 2,100 \\
\hline Russia & 7,080 & 7,100 \\
\hline Saudi Arabia & 6,500 & 6,600 \\
\hline United Arab Emirates & 3,300 & 3,400 \\
\hline Venezuela & 700 & 700 \\
\hline Other countries & 3,930 & 3,900 \\
\hline World total (rounded) & $\overline{79,400}$ & $\overline{79,000}$ \\
\hline
\end{tabular}

\section{Reserves $^{3}$}

Reserves of sulfur in crude oil, natural gas, and sulfide ores are large. Because most sulfur production is a result of the processing of fossil fuels, supplies should be adequate for the foreseeable future. Because petroleum and sulfide ores can be processed long distances from where they are produced, sulfur production may not be in the country to which the reserves were attributed. For instance, sulfur from Saudi Arabian oil may be recovered at refineries in the United States.

World Resources: Resources of elemental sulfur in evaporite and volcanic deposits, and sulfur associated with natural gas, petroleum, tar sands, and metal sulfides, total about 5 billion tons. The sulfur in gypsum and anhydrite is almost limitless, and 600 billion tons of sulfur is contained in coal, oil shale, and shale rich in organic matter. Production from these sources would require development of low-cost methods of extraction. The domestic sulfur resource is about one-fifth of the world total.

Substitutes: Substitutes for sulfur at present or anticipated price levels are not satisfactory; some acids, in certain applications, may be substituted for sulfuric acid, but usually at a higher cost.

\footnotetext{
${ }^{\text {eEstimated. }}$

${ }^{1}$ Defined as production + imports - exports + adjustments for industry stock changes.

${ }^{2}$ Defined as imports - exports + adjustments for industry stock changes.

${ }^{3}$ See Appendix $\mathrm{C}$ for resource and reserve definitions and information concerning data sources.

${ }^{4}$ China sulfur production includes byproduct elemental sulfur recovered from natural gas and petroleum, the estimated sulfur content of byproduct

sulfuric acid from metallurgy, and the sulfur content of sulfuric acid from pyrite.
} 


\section{TALC AND PYROPHYLLITE ${ }^{1}$}

(Data in thousand metric tons unless otherwise noted)

Domestic Production and Use: Three companies operated five talc-producing mines in three States during 2019, and domestic production of crude talc was estimated to have decreased by $3 \%$ to 630,000 tons valued at almost $\$ 24$ million. Montana was the leading producer State, followed by Texas and Vermont. Total sales (domestic and export) of talc by U.S. producers were estimated to be 570,000 tons valued at $\$ 120$ million, a slight increase from those in 2018. Talc produced and sold in the United States was used in paint (23\%), ceramics (including automotive catalytic converters) $(20 \%)$, paper (15\%), plastics (12\%), rubber (4\%), roofing (3\%), and cosmetics $(2 \%)$. The remaining $21 \%$ was for export, insecticides, refractories, and other miscellaneous uses.

One company in North Carolina mined and processed pyrophyllite in 2019. Domestic production was withheld in order to avoid disclosing company proprietary data and was estimated to have decreased from that in 2018 . Pyrophyllite was sold for refractory, paint, and ceramic products.

\begin{tabular}{|c|c|c|c|c|c|}
\hline Salient Statistics-United States: & $\underline{2015}$ & $\underline{2016}$ & $\underline{2017}$ & $\underline{2018}$ & $\underline{2019^{e}}$ \\
\hline Production, mine & 615 & 578 & $\overline{610}$ & $\overline{\mathrm{e}} 650$ & 630 \\
\hline Sold by producers & 535 & 528 & 528 & e550 & 570 \\
\hline Imports for consumption & 322 & 378 & 354 & 313 & 310 \\
\hline Exports & 206 & 239 & 220 & 273 & 240 \\
\hline Consumption, apparent ${ }^{2}$ & 651 & 668 & 662 & e590 & 640 \\
\hline Price, average, milled, dollars per metric ton ${ }^{3}$ & 186 & 197 & 214 & 226 & 230 \\
\hline Employment, mine and mill, talc ${ }^{4}$ & 239 & 223 & 206 & 208 & 206 \\
\hline Employment, mine and mill, pyrophyllite ${ }^{4}$ & 29 & 30 & 31 & 30 & 31 \\
\hline $\begin{array}{l}\text { Net import reliance } 5 \text { as a percentage of } \\
\text { apparent consumption }\end{array}$ & 22 & 27 & 20 & 7 & 11 \\
\hline
\end{tabular}

Recycling: Insignificant.

Import Sources (2015-18): Pakistan, 41\%; Canada, 27\%; China, 21\%; and other, 11\%. Large quantities of crude talc are thought to have been mined in Afghanistan before being milled in and exported from Pakistan.

Tariff: Item

Natural steatite and talc:

Not crushed, not powdered

Crushed or powdered

Talc, steatite, and soapstone; cut or sawed
Number

2526.10.0000

2526.20.0000

6815.99 .2000
Normal Trade Relations $\underline{12-31-19}$

Free.

Free.

Free.

Depletion Allowance: Block steatite talc: 22\% (Domestic), 14\% (Foreign). Other talc and pyrophyllite: 14\% (Domestic and foreign).

Government Stockpile: None. 


\section{TALC AND PYROPHYLLITE}

Events, Trends, and Issues: Canada, China, and Pakistan were the principal sources for United States talc imports in recent years. Imports from Pakistan increased significantly in recent years and imports from China dropped to about one-third of previous levels. In 2019, imports from China stayed near 2018 levels and imports from Pakistan increased by about $16 \%$ compared to those of the previous year. Canada and Mexico continued to be the primary destinations for United States talc exports, collectively receiving about one-half of exports. U.S. talc production decreased in 2019 from that of 2018 but was still the second-highest level of production during the past 5 years. Apparent consumption was relatively flat for 4 consecutive years through 2017 but decreased in 2018 before increasing in 2019.

Ceramic tile and sanitaryware formulations and the technology for firing ceramic tile changed over recent decades, reducing the amount of talc required for the manufacture of some ceramic products. For paint, the industry shifted its focus to production of water-based paint (a product for which talc is not well suited because it is hydrophobic) from oilbased paint, in order to reduce volatile emissions. Paper manufacturing began to decrease beginning in the 1990s, and some talc used for pitch control was replaced by chemical agents. For cosmetics, manufacturers of body dusting powders shifted some of their production from talc-based to corn-starch-based products. The paper industry has traditionally been the largest consumer of talc worldwide; however, plastics are expected to overtake paper as the predominant end use within the next several years, as papermakers in Asia make greater use of talc substitutes and as the use of talc in automobile plastics increases.

World Mine Production and Reserves: Reserves for Brazil, India, and the Republic of Korea were revised based on Government and industry sources.

United States (crude)

Brazil (crude and beneficiated) ${ }^{7}$

Canada (unspecified minerals)

China (unspecified minerals)

Finland

France (crude)

India ${ }^{7}$

Italy (includes steatite)

Japan $^{7}$

Korea, Republic of ${ }^{7}$

Other countries (includes crude) ${ }^{7}$

World total (rounded) ${ }^{7}$

\begin{tabular}{|c|c|}
\hline \multicolumn{2}{|c|}{ Mine production } \\
\hline 2018 & 2019 \\
\hline 650 & $\overline{630}$ \\
\hline 660 & 650 \\
\hline 210 & 210 \\
\hline 1,800 & 1,800 \\
\hline 380 & 370 \\
\hline 450 & 450 \\
\hline 920 & 950 \\
\hline 170 & 170 \\
\hline 160 & 160 \\
\hline 350 & 350 \\
\hline 815 & 820 \\
\hline$\overline{6,600}$ & $\overline{6,600}$ \\
\hline
\end{tabular}

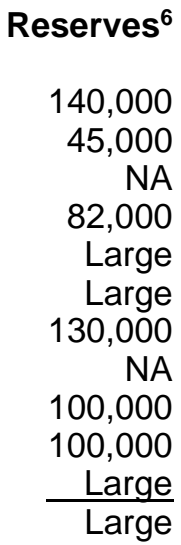

World Resources: The United States is self-sufficient in most grades of talc and related minerals, but lower priced imports have replaced domestic minerals for some uses. Talc occurs in the United States from New England to Alabama in the Appalachian Mountains and the Piedmont region, as well as in California, Montana, Nevada, Texas, and Washington. Domestic and world identified resources are estimated to be approximately five times the quantity of reserves.

Substitutes: Substitutes for talc include bentonite, chlorite, feldspar, kaolin, and pyrophyllite in ceramics; chlorite, kaolin, and mica in paint; calcium carbonate and kaolin in paper; bentonite, kaolin, mica, and wollastonite in plastics; and kaolin and mica in rubber.

\footnotetext{
${ }^{e}$ Estimated. NA Not available.

${ }^{1}$ All statistics exclude pyrophyllite unless otherwise noted.

${ }^{2}$ Defined as sold by producers + imports - exports.

${ }^{3}$ Average ex-works unit value of milled talc sold by U.S. producers, based on data reported by companies.

${ }^{4}$ Includes only companies that mine talc or pyrophyllite. Excludes office workers and mills that process imported or domestically purchased material.

${ }^{5}$ Defined as imports - exports.

${ }^{6}$ See Appendix $C$ for resource and reserve definitions and information concerning data sources.

${ }^{7}$ Includes pyrophyllite.
} 


\section{TANTALUM}

(Data in metric tons of tantalum content unless otherwise noted)

Domestic Production and Use: Significant U.S. tantalum mine production has not been reported since 1959. Domestic tantalum resources are of low grade, some are mineralogically complex, and most are not commercially recoverable. Companies in the United States produced tantalum alloys, capacitors, carbides, compounds, and tantalum metal from imported tantalum ores and concentrates and tantalum-containing materials. Tantalum metal and alloys were recovered from foreign and domestic scrap. Domestic tantalum consumption was not reported by consumers. Major end uses for tantalum included alloys for gas turbines used in the aerospace and oil and gas industries; tantalum capacitors for automotive electronics, mobile phones, and personal computers; tantalum carbides for cutting and boring tools; and tantalum oxide $\left(\mathrm{Ta}_{2} \mathrm{O}_{5}\right)$ was used in glass lenses to make lighter weight camera lenses that produce a brighter image. The value of tantalum consumed in 2019 was estimated to exceed $\$ 270$ million as measured by the value of imports.

\begin{tabular}{|c|c|c|c|c|c|}
\hline$\frac{\text { Salient Statistics_-United States: }}{\text { Production: }}$ & 2015 & $\underline{2016}$ & $\underline{2017}$ & 2018 & $\underline{2019^{\mathrm{e}}}$ \\
\hline Mine & - & - & - & - & \\
\hline Secondary & NA & NA & NA & NA & \\
\hline Imports for consumption ${ }^{1}$ & 1,240 & 1,060 & 1,460 & 1,660 & 1,300 \\
\hline Exports $^{1}$ & 657 & 604 & 549 & 681 & 440 \\
\hline Shipments from Government stockpile & - & - & - & - & - \\
\hline Consumption, apparent ${ }^{2}$ & 587 & 460 & 907 & 978 & 870 \\
\hline Price, tantalite, dollars per kilogram of $\mathrm{Ta}_{2} \mathrm{O}_{5}$ content $^{3}$ & 193 & 193 & 193 & 214 & 162 \\
\hline $\begin{array}{l}\text { Net import reliance } 4 \text { as a percentage } \\
\text { of apparent consumption }\end{array}$ & 100 & 100 & 100 & 100 & 100 \\
\hline
\end{tabular}

Recycling: Tantalum was recycled mostly from new scrap that was generated during the manufacture of tantalumcontaining electronic components, and from tantalum-containing cemented carbide and superalloy scrap. The amount of tantalum recycled was not available, but it may be as much as $30 \%$ of apparent consumption.

Import Sources (2015-18): Tantalum ores and concentrates: Rwanda, 39\%; Brazil, 20\%; Australia, 17\%; Congo (Kinshasa), 10\%; and other, 14\%. Tantalum metal and powder: China, 39\%; Germany, 19\%; Kazakhstan, 14\%; Thailand, 12\%; and other, 16\%. Tantalum waste and scrap: Mexico, 14\%; Austria, 11\%; Japan, 10\%; Germany, 9\%; and other, $56 \%$.

Tariff: Item

Synthetic tantalum-niobium concentrates

Tantalum ores and concentrates

Tantalum oxide 5

Potassium fluorotantalate ${ }^{5}$

Tantalum, unwrought:

Powders

Alloys and metal

Tantalum, waste and scrap

Tantalum, other
Number

2615.90.3000

2615.90 .6060

2825.90.9000

2826.90.9000

8103.20.0030

8103.20 .0090

8103.30.0000

8103.90 .0000
Normal Trade Relations 12-31-19

Free.

Free.

$3.7 \%$ ad val. $3.1 \%$ ad val.

$2.5 \%$ ad val.

$2.5 \%$ ad val.

Free.

$4.4 \%$ ad val.

Depletion Allowance: 22\% (Domestic), 14\% (Foreign).

\section{Government Stockpile: 6}

\section{Material}

Tantalum carbide powder

Tantalum metal ${ }^{7}$ (gross weight)

Tantalum alloy (gross weight)
Inventory
As of $9-30-19$

1.71

0.084

0.0015
FY 2019

Potential Potential Acquisitions Disposals

$\begin{array}{rr}- & 1.71 \\ 15.4 & 0.09 \\ - & -\end{array}$

FY 2020

Potential Potential Acquisitions Disposals

$\begin{array}{rr}- & 1.71 \\ 15.4 & 0.09 \\ - & -\end{array}$




\section{TANTALUM}

Events, Trends, and Issues: U.S. tantalum apparent consumption (measured in contained tantalum) was estimated to have decreased by $11 \%$ from that of 2018. U.S. imports for consumption decreased by $21 \%$ from those of 2018. U.S. domestic exports decreased by $35 \%$ from those of 2018. The overall decrease in tantalum trade in 2019 was attributed to decreases in the trade of tantalum ores and concentrates (43\% decrease in exports; $26 \%$ decrease in imports) and tantalum scrap (60\% decrease in exports; $28 \%$ decrease in imports). Congo (Kinshasa) and Rwanda accounted for $60 \%$ of estimated global tantalum production in 2019.

In 2019, the average monthly price of tantalum ore decreased to about $\$ 158$ per kilogram of $\mathrm{Ta}_{2} \mathrm{O}_{5}$ content in October from about $\$ 173$ per kilogram of $\mathrm{Ta}_{2} \mathrm{O}_{5}$ content in January. This average monthly price in 2019 represented a decrease of about $26 \%$ from the average monthly price in 2018. The decrease in tantalum ore prices in 2019 was largely driven by an increasing supply of low-cost byproduct tantalum concentrates from two lithium operations in Western Australia. However, in August one of the two producing companies began scaling back operations and planned to place its Bald Hill Mine on care-and-maintenance status owing to slower than expected demand growth for lithium and a sharp decline in lithium prices between 2018 and 2019. The second company, which operated the Pilgangoora project, postponed a planned yearend 2019 expansion that would have more than doubled its lithium and tantalum production capacities.

In July, a specialty metals processor in Estonia suspended its niobium and tantalum recovery operations. The company reached its limit for onsite storage of the radioactive tailings that were produced during recovery of niobium and tantalum. The Ministry of Environment of Estonia required the company to have an agreement for offsite storage or disposal of the radioactive tailings before it could resume recovery operations.

World Mine Production and Reserves: Reserves for Australia were revised based on Government and industry information.

\begin{tabular}{|c|c|c|c|}
\hline & \multicolumn{2}{|c|}{ Mine production } & \multirow[t]{2}{*}{ Reserves $^{8}$} \\
\hline & 2018 & $\underline{2019^{e}}$ & \\
\hline United States & - & - & - \\
\hline Australia & 23 & 20 & 955,000 \\
\hline Brazil & 250 & 250 & 34,000 \\
\hline Burundi & 23 & 32 & NA \\
\hline China & 90 & 100 & NA \\
\hline Congo (Kinshasa) & 740 & 740 & NA \\
\hline Ethiopia & 70 & 40 & NA \\
\hline Nigeria & 200 & 210 & NA \\
\hline Russia & 38 & 38 & NA \\
\hline Rwanda & 421 & 370 & NA \\
\hline Other countries & 40 & 39 & NA \\
\hline World total (rounded) & $\overline{1,890}$ & $\overline{1,800}$ & $>90,000$ \\
\hline
\end{tabular}

World Resources: Identified world resources of tantalum, most of which are in Australia, Brazil, and Canada, are considered adequate to supply projected needs. The United States has about 55,000 tons of tantalum resources in identified deposits, most of which were considered uneconomic at 2019 prices for tantalum.

Substitutes: The following materials can be substituted for tantalum, but a performance loss or higher costs may ensue: niobium and tungsten in carbides; aluminum, ceramics, and niobium in electronic capacitors; glass, molybdenum, nickel, niobium, platinum, stainless steel, titanium, and zirconium in corrosion-resistant applications; and hafnium, iridium, molybdenum, niobium, rhenium, and tungsten in high-temperature applications.

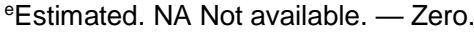

${ }^{1}$ Imports and exports include the estimated tantalum content of niobium and tantalum ores and concentrates, unwrought tantalum alloys and powder, tantalum waste and scrap, and other tantalum articles. Synthetic concentrates and niobium ores and concentrates were assumed to contain $32 \% \mathrm{Ta}_{2} \mathrm{O}_{5}$. Tantalum ores and concentrates were assumed to contain $37 \% \mathrm{Ta}_{2} \mathrm{O}_{5}$. $\mathrm{Ta}_{2} \mathrm{O}_{5}$ is $81.897 \% \mathrm{Ta}$.

${ }^{2}$ Defined as production + imports - exports + adjustments for Government stock changes.

${ }^{3}$ Price is annual average price reported by CRU Group. Estimate for 2019 includes data through October 2019.

${ }^{4}$ Defined as imports - exports + adjustments for Government stock changes.

${ }^{5}$ This category includes tantalum-containing material and other material.

${ }^{6}$ See Appendix B for definitions.

${ }^{7}$ Potential acquisitions are for unspecified tantalum materials; potential disposals are for tantalum scrap in the Government stockpile.

${ }^{8}$ See Appendix $C$ for resource and reserve definitions and information concerning data sources.

${ }^{9}$ For Australia, Joint Ore Reserves Committee-compliant reserves were 14,000 tons.
} 


\section{TELLURIUM}

(Data in metric tons unless otherwise noted)

Domestic Production and Use: In 2019, no tellurium was produced in the United States. One firm in Texas was thought to export copper anode slimes to Mexico for recovery of commercial-grade tellurium. Downstream companies further refined imported commercial-grade metal to produce tellurium dioxide, high-purity tellurium, and tellurium compounds for specialty applications.

Tellurium was predominantly used in the production of cadmium telluride (CdTe) for thin-film solar cells. Another important end use was for the production of bismuth telluride (BiTe), which is used in thermoelectric devices for both cooling and energy generation. Other uses were as an alloying additive in steel to improve machining characteristics, as a minor additive in copper alloys to improve machinability without reducing conductivity, in lead alloys to improve resistance to vibration and fatigue, in cast iron to help control the depth of chill, and in malleable iron as a carbide stabilizer. It was used in the chemical industry as a vulcanizing agent and accelerator in the processing of rubber and as a component of catalysts for synthetic fiber production. Other uses included those in photoreceptor and thermoelectric devices, blasting caps, and as a pigment to produce various colors in glass and ceramics.

Global consumption estimates of tellurium by end use are solar, 40\%; thermoelectric production, 30\%; metallurgy, $15 \%$; rubber applications, 5\%; and other, 10\%.

$\begin{array}{lrrrrr}\text { Salient Statistics-United States: } & \underline{\mathbf{2 0 1 5}} & \underline{\mathbf{2 0 1 6}} & \underline{\mathbf{2 0 1 7}} & \frac{\mathbf{2 0 1 8}}{-} & \frac{\mathbf{2 0 1 9}^{\mathbf{e}}}{\text { Production, refinery }} \\ \text { Imports for consumption } & 76 & 73 & 163 & 192 & 50 \\ \text { Exports } & 41 & 3 & 2 & 4 & 1 \\ \text { Consumption, apparent }^{1} & \mathrm{~W} & \mathrm{~W} & \mathrm{~W} & \mathrm{~W} & \mathrm{~W} \\ \text { Price, dollars per kilogram }^{2} & 79 & 36 & 38 & 80 & 70 \\ \text { Stocks, producer, refined, yearend }^{\text {Net import reliance }}{ }^{3} \text { as a percentage of } & \mathrm{W} & \mathrm{W} & \mathrm{W} & \mathrm{W} & \mathrm{W} \\ \quad \text { apparent consumption } & >95 & >95 & >95 & >95 & >95\end{array}$

Recycling: For traditional metallurgical and chemical uses, there was little or no old scrap from which to extract secondary tellurium because these uses of tellurium are highly dispersive or dissipative. A very small amount of tellurium was recovered from scrapped selenium-tellurium photoreceptors employed in older plain-paper copiers in Europe. A plant in the United States recycled tellurium from CdTe solar cells; however, the amount recycled was limited because most CdTe solar cells were relatively new and had not reached the end of their useful life.

Import Sources (2015-18): Canada, 64\%; China, 25\%; Germany, 7\%; and other, 4\%.

Tariff: Item

Tellurium
Number

2804.50.0020
Normal Trade Relations $\underline{12-31-19}$

Free.

Depletion Allowance: $14 \%$ (Domestic and foreign).

Government Stockpile: None.

Events, Trends, and Issues: Domestic tellurium production was estimated to have remained essentially unchanged from that in 2018. One domestic producer of anode slimes shipped at least a portion of its anode slimes to Mexico for treatment and refining. World production of tellurium in 2019 was estimated to be about 470 tons. In 2019, the domestic average monthly price of tellurium generally decreased in the first 10 months of the year, from around $\$ 80$ per kilogram in January to $\$ 65$ per kilogram in October. 


\section{TELLURIUM}

Domestic imports of tellurium were estimated to have decreased by about $74 \%$ in 2019 from those of 2018 , mostly as a result of a significant decrease in imports from China and Canada. During the first 8 months of 2019, the United States imported 2 tons of tellurium from Canada and 0.3 tons of tellurium from China. During the same period of 2018, the United States imported 99 tons of tellurium from Canada and 7 tons of tellurium from China.

China was the leading producer of refined tellurium, recovering tellurium from copper anode slimes and from residues generated during the lead, nickel, precious metals, and zinc smelting processes.

The Yunnan Provincial government in China announced an auction of 170 tons of tellurium from the defunct Fanya Metal Exchange (FME) with a starting price of $\$ 43$ per kilogram (306 yuan per kilogram), or a total lot bid of $\$ 7.34$ million (51.95 million yuan).

A solar cell manufacturer in Germany announced in April that it would increase production rate of CdTe solar cells to 60 megawatts per year after finding a new investor in July 2018.

World Refinery Production and Reserves: The figures shown for reserves include only tellurium contained in copper reserves. These estimates assume that more than one-half of the tellurium contained in unrefined copper anodes is recoverable.

\begin{tabular}{lrrr} 
& \multicolumn{2}{c}{ Refinery } & production \\
United States & $\mathbf{2 0 1 8}$ & $\mathbf{2 0 1 9}$ & Reserves $^{\mathbf{4}}$ \\
Bulgaria & - & - & 3,500 \\
Canada & 5 & 5 & NA \\
China & 25 & 30 & 800 \\
Japan & 280 & 290 & 6,600 \\
Russia & 58 & 55 & NA \\
South Africa & 42 & 40 & - \\
Sweden & 6 & 5 & 670 \\
Other countries & 45 & 40 & 19,000 \\
$\quad$ World total (rounded) & $\mathrm{NA}$ & $\mathrm{NA}$ & 31,000
\end{tabular}

World Resources: Data on tellurium resources were not available. More than $90 \%$ of tellurium has been produced from anode slimes collected from electrolytic copper refining, and the remainder was derived from skimmings at lead refineries and from flue dusts and gases generated during the smelting of bismuth, copper, and lead-zinc ores. Potential sources of tellurium include bismuth telluride and gold telluride ores.

Substitutes: Several materials can replace tellurium in most of its uses, but usually with losses in efficiency or product characteristics. Bismuth, calcium, lead, phosphorus, selenium, and sulfur can be used in place of tellurium in many free-machining steels. Several of the chemical process reactions catalyzed by tellurium can be carried out with other catalysts or by means of noncatalyzed processes. In rubber compounding, sulfur and (or) selenium can act as vulcanization agents in place of tellurium. The selenides and sulfides of niobium and tantalum can serve as electricalconducting solid lubricants in place of tellurides of those metals.

The selenium-tellurium photoreceptors used in some plain paper photocopiers and laser printers have been replaced by organic photoreceptors in newer devices. Amorphous silicon and copper indium gallium selenide were the two principal competitors of CdTe in thin-film photovoltaic solar cells. Bismuth selenide and organic polymers can be used to substitute for some BiTe thermal devices.

\footnotetext{
eEstimated. NA Not available. W Withheld to avoid disclosing company proprietary data. - Zero.

${ }^{1}$ Defined as production + imports - exports + adjustments for industry stock changes.

${ }^{2}$ Average annual price. Source: Argus Media group-Argus Metals International for $99.95 \%$ tellurium, free on board, U.S. warehouses.

${ }^{3}$ Defined as imports - exports + adjustments for industry stock changes.

${ }^{4}$ See Appendix $\mathrm{C}$ for resource and reserve definitions and information concerning data sources.

In addition to the countries listed, Australia, Belgium, Chile, Colombia, Germany, Kazakhstan, Mexico, the Philippines, and Poland produced

refined tellurium, but output was not reported and available information was inadequate to make reliable production and reserves estimates.
} 


\section{THALLIUM}

(Data in kilograms unless otherwise noted)

Domestic Production and Use: The value of consumption of thallium metal and thallium compounds was estimated to be about $\$ 300,000$. The primary end uses included the following: radioactive thallium-201 used for medical purposes in cardiovascular imaging; thallium as an activator (sodium iodide crystal doped with thallium) in gamma radiation detection equipment (scintillometer); thallium-barium-calcium-copper-oxide high-temperature superconductor used in filters for wireless communications; thallium in lenses, prisms, and windows for infrared detection and transmission equipment; thallium-arsenic-selenium crystal filters for light diffraction in acousto-optical measuring devices; and thallium in mercury alloys for low-temperature measurements. Other uses include: as an additive in glass to increase its refractive index and density, a catalyst for organic compound synthesis, and a component in high-density liquids for gravity separation of minerals.

\begin{tabular}{|c|c|c|c|c|c|}
\hline Salient Statistics-United States: & 2015 & 2016 & 2017 & $\underline{2018}$ & $2019^{e}$ \\
\hline Production, refinery & 二 & 二 & 二 & 二 & 二 \\
\hline \multicolumn{6}{|l|}{ Imports for consumption: } \\
\hline Unwrought metal and metal powders & - & - & - & - & - \\
\hline Waste and scrap & - & - & - & 23 & 30 \\
\hline Other articles & 334 & 193 & - & 41 & 40 \\
\hline \multicolumn{6}{|l|}{ Exports: } \\
\hline Unwrought metal and powders & 104 & 56 & 34 & 100 & 230 \\
\hline Waste and scrap & 1,450 & 286 & 364 & 853 & 110 \\
\hline Other articles & 1,070 & 973 & 1,560 & 131,400 & 179,000 \\
\hline Consumption, estimated ${ }^{2}$ & 334 & 193 & - & 64 & 70 \\
\hline Price, metal, dollars per kilograme, 3 & 7,400 & 7,400 & NA & NA & 7,600 \\
\hline $\begin{array}{l}\text { Net import reliance } 4 \text { as a percentage of } \\
\text { estimated consumption }\end{array}$ & NA & NA & NA & NA & NA \\
\hline
\end{tabular}

Recycling: None.

Import Sources (2015-18): Russia, 53\%; Germany, 33\%; China, 8\%; and the United Kingdom, 6\%.

Tariff: Item

Unwrought and powders

Waste and scrap

Other

Depletion Allowance: 14\% (Domestic and foreign).
Number

8112.51 .0000

8112.52 .0000

8112.59 .0000
Normal Trade Relations

12-31-19

$4.0 \%$ ad val.

Free.

$4.0 \%$ ad val.

Government Stockpile: None. 


\section{THALLIUM}

Events, Trends, and Issues: In 2019, imports of thallium waste and scrap increased by $30 \%$ and imports of other thallium articles were essentially unchanged compared with 2018. Most imports of other thallium articles from 2015 to 2018 came into the Cleveland, OH, customs district. In 2019, imports came into the Dallas-Fort Worth, TX, customs district. Exports of unwrought thallium and powders more than doubled in 2019 compared with 2018. All exports of unwrought thallium and powders left the New Orleans, LA, customs district and 58\% went to Taiwan and $42 \%$ went to Germany. All exports of thallium waste and scrap went to Mexico in 2019. In 2018 and 2019, there was a significant increase in the export quantity of other thallium articles (Schedule B number 8112.59.0000) as reported by the U.S. Census Bureau. In 2018, most of the exports of other thallium articles left from the Charleston, SC, customs district and were shipped to Colombia. In 2019, most of the exports of other thallium articles left from the customs districts of New York, NY, and Norfolk, VA. The exports from both ports were shipped to Egypt and the average unit value was extremely low. It is possible items may have been misclassified.

Demand for thallium for use in cardiovascular-imaging applications has declined owing to superior performance and availability of alternatives, such as the medical isotope technetium-99. A global shortage of technetium-99 from 2009 to 2011 had contributed to an increase in thallium consumption during that time period. Since 2011, consumption of thallium has declined significantly. Small quantities of thallium are used for research.

The leading global uses for thallium were photoelectric cells, infrared optical materials, and low melting glasses. Many producers of these products were in China, Japan, and the Republic of Korea.

Thallium metal and its compounds are highly toxic materials and are strictly controlled to prevent harm to humans and the environment. Thallium and its compounds can be absorbed into the human body by skin contact, ingestion, or inhalation of dust or fumes. Under its national primary drinking water regulations for public water supplies, the U.S. Environmental Protection Agency has set an enforceable Maximum Contaminant Level of 2 parts per billion thallium in drinking water.

World Refinery Production and Reserves: ${ }^{5}$ Thallium is produced commercially in only a few countries as a byproduct in the roasting of copper, lead, and zinc ores and is recovered from flue dust. Because most producers withhold thallium production data, global production data are limited. In 2019, global production of thallium was estimated to be less than 8,000 kilograms. China, Kazakhstan, and Russia were thought to be leading producers of primary thallium. Since 2005, substantial thallium-rich deposits have been identified in Brazil, China, North Macedonia, and Russia.

World Resources: Although thallium is reasonably abundant in the Earth's crust, estimated at about 0.7 part per million, it exists mostly in association with potassium minerals in clays, granites, and soils, and it is not generally considered to be commercially recoverable from those materials. The major source of recoverable thallium is the trace amounts found in copper, lead, zinc, and other sulfide ores. Quantitative estimates of reserves are not available, owing to the difficulty in identifying deposits where thallium can be extracted economically. Previous estimates of reserves were based on the thallium content of zinc ores. World resources of thallium contained in zinc resources could be as much as 17 million kilograms; most are in Canada, Europe, and the United States. Global resources of coal contain an estimated 630 million kilograms of thallium.

Substitutes: Although other materials and formulations can substitute for thallium in gamma radiation detection equipment and optics used for infrared detection and transmission, thallium materials are presently superior and more cost effective for these very specialized uses. The medical isotope technetium-99 can be used in cardiovascularimaging applications instead of thallium.

Nonpoisonous substitutes, such as tungsten compounds, are being marketed as substitutes for thallium in highdensity liquids for gravity separation of minerals.

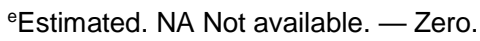

${ }^{1}$ Includes material that may have been misclassified.

${ }^{2}$ Estimated to be equal to imports.

${ }^{3}$ Estimated price of $99.99 \%$-pure granules in 100 gram lots.

${ }^{4}$ Defined as imports - exports. Consumption and exports of unwrought thallium were from imported material or from a drawdown in unreported inventories.

${ }^{5}$ See Appendix C for resource and reserve definitions and information concerning data sources.
} 


\section{THORIUM}

[Data in kilograms gross weight unless otherwise noted]

Domestic Production and Use: The world's primary source of thorium is the rare-earth and thorium phosphate mineral monazite. In 2019, monazite may have been produced as a separated concentrate or included as an accessory mineral in heavy-mineral concentrates. Essentially, all thorium compounds and alloys consumed by the domestic industry were derived from imports. The number of companies that processed or fabricated various forms of thorium for commercial use was not available. Thorium's use in most products was generally limited because of concerns over its naturally occurring radioactivity. Imports of thorium compounds are sporadic owing to changes in consumption and fluctuations in consumer inventory levels. The estimated value of thorium compounds imported for consumption by the domestic industry in 2019 was about $\$ 533,000$, compared with $\$ 567,000$ in 2018 .

\begin{tabular}{|c|c|c|c|c|c|}
\hline$\frac{\text { Salient Statistics_-United States: }}{\text { Production, } \text { mine }^{1}}$ & $\frac{2015}{-}$ & $\frac{2016}{N A}$ & $\frac{2017}{N A}$ & e, $2500, \frac{\mathbf{2 0 1 8}}{000}$ & $21,20 \frac{\mathbf{2 0 1 9}}{0,000}$ \\
\hline \multicolumn{6}{|l|}{ Imports for consumption: } \\
\hline Thorium ore and concentrates (monazite) & - & 16,000 & - & 1,000 & 1,000 \\
\hline Thorium compounds (oxide, nitrate, etc.) & 2,740 & 3,120 & 8,510 & 9,000 & 8,300 \\
\hline \multicolumn{6}{|l|}{ Exports: } \\
\hline Thorium ore and concentrates (monazite) & - & NA & NA & 520,000 & $1,200,000$ \\
\hline Thorium compounds (oxide, nitrate, etc.) & 32,700 & 36,000 & 36,100 & 33,000 & 33,200 \\
\hline \multicolumn{6}{|l|}{ Consumption, apparent: ${ }^{4}$} \\
\hline Thorium ore and concentrates (monazite) & - & 16,000 & - & $\left({ }^{5}\right)$ & 1,000 \\
\hline Thorium compounds (oxide, nitrate, etc.) & 40 & $(5)$ & 2,410 & 6,000 & 5,100 \\
\hline $\begin{array}{l}\text { Value, thorium compounds, gross weight, } \\
\text { dollars per kilogram, India }\end{array}$ & 63 & 65 & 73 & 72 & 72 \\
\hline $\begin{array}{l}\text { Net import reliance }{ }^{7} \text { as a percentage of } \\
\text { apparent consumption }\end{array}$ & NA & NA & NA & NA & NA \\
\hline
\end{tabular}

Recycling: None.

Import Sources (2015-18): Monazite: Canada, 100\%. Thorium compounds: India, 89\%; France 9\%; and the United Kingdom, 2\%.

\section{Tariff: Item}

Thorium ores and concentrates (monazite)

Thorium compounds

\section{Number}

2612.20.0000

2844.30.1000

\author{
Normal Trade Relations \\ 12-31-19 \\ Free. \\ $5.5 \%$ ad val.
}

Depletion Allowance: Monazite, $22 \%$ on thorium content, and $14 \%$ on rare-earth and yttrium content (Domestic); 14\% (Foreign).

Government Stockpile: None. 


\section{THORIUM}

Events, Trends, and Issues: Domestic demand for thorium alloys, compounds, and metals was limited. In addition to research purposes, various commercial uses of thorium included catalysts, high-temperature ceramics, magnetrons in microwave ovens, metal-halide lamps, nuclear medicine, optical coatings, tungsten filaments, and welding electrodes.

India maintained its position as the primary source of imported thorium compounds in 2019. The unit value of imports from India remained unchanged from 2018 at \$72 per kilogram.

Exports of unspecified thorium compounds were 3,200 kilograms in 2019; however, 33\% of the exports were reported to have a unit value of less than $\$ 50$ per kilogram and may have been misclassified. Owing to potentially misclassified material and variations in the type and purity of thorium compound, the unit value of exports varied widely by month and by exporting customs district.

Globally, monazite was produced primarily for its rare-earth-element content, and only a small fraction of the byproduct thorium produced was consumed. India was the leading producer of monazite. Construction began at the Eneabba mineral sands project in Australia with production slated for 2020. Thorium consumption worldwide is relatively small compared with that of most other mineral commodities. In international trade, China was the leading importer of monazite; Brazil, Madagascar, Thailand, and Vietnam were China's leading import sources.

Several companies and countries were active in the pursuit of commercializing thorium as a fuel material for a new generation of nuclear reactors. Thorium-based nuclear research and development programs have been or are underway in Belgium, Brazil, Canada, China, Czechia, France, Germany, India, Israel, Japan, the Netherlands, Norway, Russia, the United Kingdom, and the United States.

World Refinery Production and Reserves: ${ }^{8}$ Production and reserves are associated with the recovery of monazite in heavy-mineral-sand deposits. Without demand for the rare earths, monazite would probably not be recovered for its thorium content under current market conditions.

World Resources: The world's leading thorium resources are found in placer, carbonatite, and vein-type deposits. Thorium is found in several minerals, including monazite, thorite, and thorianite. According to the Organisation for Economic Co-operation and Development's Nuclear Energy Agency, worldwide identified thorium resources were estimated to total 6.4 million tons of thorium. Thorium resources are found throughout the world, most notably in Australia, Brazil, India, and the United States. India has the largest resources ( 850,000 tons), followed by Brazil (630,000 tons), and Australia and the United States (600,000 tons each).

Substitutes: Nonradioactive substitutes have been developed for many applications of thorium. Yttrium compounds have replaced thorium compounds in incandescent lamp mantles. A magnesium alloy containing lanthanides, yttrium, and zirconium can substitute for magnesium-thorium alloys in aerospace applications. Cerium and lanthanum can substitute for thorium in welding electrodes.

\footnotetext{
eEstimated. NA Not Available. - Zero.

${ }^{1}$ Monazite may have been produced as a separate concentrate or included as an accessory mineral in heavy-mineral concentrates.

${ }^{2}$ Estimates based on exports.

${ }^{3}$ Includes material that may have been misclassified.

${ }^{4}$ Defined as production + imports - exports. Shown separately for ores and concentrates and for compounds. Production is only for ores and concentrates.

${ }^{5}$ The apparent consumption calculation yields negative values for thorium compounds in 2016 and for thorium ores and concentrates in 2018.

${ }^{6}$ Based on U.S. Census Bureau customs data.

${ }^{7}$ Defined as imports - exports; however, a meaningful net import reliance could not be calculated owing to uncertainties in the classification of material being imported and exported.

${ }^{8}$ See Appendix C for resource and reserve definitions and information concerning data sources.
} 
Domestic Production and Use: Tin has not been mined or smelted in the United States since 1993 and 1989, respectively. Twenty-five firms accounted for over $90 \%$ of the primary tin consumed domestically in 2019 . The major uses for tin in the United States were tinplate, 21\%; chemicals, 17\%; solder, 14\%; alloys, 10\%; babbitt, brass and bronze, and tinning, 11\%; and other, 27\%. Based on the average Platts Metals Week New York dealer price for tin, the estimated value of imported refined tin in 2019 was $\$ 703$ million, and the estimated value of tin recovered from old scrap domestically in 2019 was $\$ 213$ million.

\begin{tabular}{|c|c|c|c|c|c|}
\hline Salient Statistics-United States: & 2015 & 2016 & $\underline{2017}$ & $\underline{2018}$ & $\underline{2019^{e}}$ \\
\hline $\begin{array}{l}\text { Old scrape } \\
\text { Ollual. }\end{array}$ & 10,100 & 10,300 & 10,300 & 10,300 & 10,000 \\
\hline New scrap & 1,120 & 1,080 & 900 & 900 & 1,000 \\
\hline \multicolumn{6}{|l|}{ Imports for consumption: } \\
\hline Tin, refined & 33,600 & 32,200 & 34,100 & 36,800 & 35,000 \\
\hline Tin, alloys, gross weight & 2,720 & 1,910 & 1,590 & 1,430 & 980 \\
\hline Tin, waste and scrap, gross weight & 32,700 & 27,200 & 52,100 & 47,700 & 35,000 \\
\hline \multicolumn{6}{|l|}{ Exports: } \\
\hline Tin, refined & 807 & 1,150 & 1,560 & 962 & 1,500 \\
\hline Tin, alloys, gross weight & 2,540 & 1,040 & 965 & 885 & 2,900 \\
\hline Tin, waste and scrap, gross weight & 2,530 & 4,570 & 3,360 & 5,970 & 2,100 \\
\hline Shipments from Government stockpile, gross weight & - & - & 2 & 13 & 1 \\
\hline Consumption, apparent, refined ${ }^{1}$ & 42,700 & 42,100 & 42,800 & 47,000 & 44,000 \\
\hline \multicolumn{6}{|l|}{ Price, average, cents per pound: ${ }^{2}$} \\
\hline New York dealer & 756 & 839 & 937 & 936 & 860 \\
\hline London Metal Exchange, cash & 729 & 815 & 911 & 914 & 840 \\
\hline Stocks, consumer and dealer, yearend & 7,090 & 6,370 & 6,390 & 5,570 & 4,900 \\
\hline $\begin{array}{l}\text { Net import reliance }{ }^{3} \text { as a percentage of } \\
\text { apparent consumption, refined }\end{array}$ & 76 & 76 & 76 & 78 & 77 \\
\hline
\end{tabular}

Recycling: About 11,000 tons of tin from old and new scrap was estimated to have been recycled in 2019. Of this, about 10,000 tons was recovered from old scrap at 2 detinning plants and about 75 secondary nonferrous metalprocessing plants, accounting for $24 \%$ of apparent consumption.

Import Sources (2015-18): Refined tin: Indonesia, 25\%; Malaysia, 24\%; Peru, 20\%; Bolivia, 18\%; and other, 13\%. Waste and scrap: Canada, 99\%; and other, $1 \%$.

\section{Tariff: Item}

Unwrought tin:

Tin, not alloyed

Tin alloys, containing, by weight:

$5 \%$ or less lead

More than 5\% but not more than 25\% lead

More than 25\% lead

Tin waste and scrap
Number

8001.10.0000

8001.20 .0010

8001.20 .0050

8001.20 .0090

8002.00 .0000
Normal Trade Relations 12-31-19

Free.

Free.

Free.

Free.

Free.

Depletion Allowance: 22\% (Domestic), 14\% (Foreign). 


\section{TIN}

\section{Government Stockpile: ${ }^{4}$}

\begin{tabular}{|c|c|}
\hline Material & $\begin{array}{c}\text { Inventory } \\
\text { As of 9-30-19 }\end{array}$ \\
\hline Tin (gross weight) & 4,025 \\
\hline
\end{tabular}

\begin{tabular}{cc}
\multicolumn{2}{c}{ FY 2019} \\
$\begin{array}{cc}\text { Potential } & \text { Potential } \\
\text { Acquisitions } & \text { Disposals } \\
40 & -\end{array}$
\end{tabular}
FY 2020
Potential Potential Acquisitions Disposals 40

Events, Trends, and Issues: Apparent consumption of tin in the United States was estimated to have decreased by $6 \%$ in 2019 compared with consumption in 2018. Indonesia was the leading supplier of refined tin and Canada was the leading supplier of tin waste and scrap to the United States in 2019. The estimated amount of tin recycled in 2019 decreased slightly compared with that in 2018. Estimated annual average tin prices based on the first 9 months in 2019 were 860 and 840 cents per pound for the New York dealer price and London Metal Exchange cash price, respectively-an $8 \%$ decrease for both prices from those in 2018. In 2019, the monthly average New York dealer tin price peaked in March at 992 cents per pound, then steadily decreased through August to a monthly average price of 776 cents per pound, where monthly average prices remained essentially unchanged through October.

World Mine Production and Reserves: Reserves for Australia and Burma were revised based on new information from Government sources.

\begin{tabular}{lrrr} 
& \multicolumn{2}{c}{ Mine production } & Reserves $^{\mathbf{5}}$ \\
United States & $\underline{\mathbf{2 0 1 8}}$ & $\underline{\mathbf{2 0 1 9}}$ & - \\
Australia & $6,8 \overline{-}$ & $7,0 \overline{-}$ & 420,000 \\
Bolivia & 16,900 & 17,000 & 400,000 \\
Brazil & 17,100 & 17,000 & 700,000 \\
Burma & 54,600 & 54,000 & 100,000 \\
China & 90,000 & 85,000 & $1,100,000$ \\
Congo (Kinshasa) & 7,400 & 10,000 & 150,000 \\
Indonesia & 85,000 & 80,000 & 800,000 \\
Laose & 1,100 & 1,000 & $\mathrm{NA}$ \\
Malaysia & 4,300 & 4,000 & 250,000 \\
Nigeria & 7,800 & 7,500 & $\mathrm{NA}$ \\
Peru & 18,600 & 18,500 & 110,000 \\
Russia & 1,400 & 1,400 & 350,000 \\
Rwanda & 2,400 & 3,000 & $\mathrm{NA}$ \\
Vietnam & 4,560 & 4,500 & 11,000 \\
Other countries & 310 & 1,400 & 350,000 \\
$\quad$ World total (rounded) & 318,000 & 310,000 & $4,700,000$
\end{tabular}

World Resources: Identified resources of tin in the United States, primarily in Alaska, were insignificant compared with those of the rest of the world. World resources, principally in western Africa, southeastern Asia, Australia, Bolivia, Brazil, Indonesia, and Russia, are extensive and, if developed, could sustain recent annual production rates well into the future.

Substitutes: Aluminum, glass, paper, plastic, or tin-free steel substitute for tin content in cans and containers. Other materials that substitute for tin are epoxy resins for solder; aluminum alloys, alternative copper-base alloys, and plastics for bronze; plastics for bearing metals that contain tin; and compounds of lead and sodium for some tin chemicals.

\footnotetext{
eEstimated. NA Not available. - Zero.

${ }^{1}$ Defined as production (old scrap) + refined tin imports - refined tin exports + adjustments for Government and industry stock changes. Excludes imports and exports of alloys, and waste and scrap.

${ }^{2}$ Source: Platts Metals Week.

${ }^{3}$ Defined as imports - exports + adjustments for Government and industry stock changes, excluding imports and exports of waste and scrap.

${ }^{4}$ See Appendix B for definitions.

${ }^{5}$ See Appendix $C$ for resource and reserve definitions and information concerning data sources.

${ }^{6}$ For Australia, Joint Ore Reserves Committee-compliant reserves were 250,000 tons.
} 


\section{TITANIUM AND TITANIUM DIOXIDE ${ }^{1}$}

(Data in metric tons unless otherwise noted)

Domestic Production and Use: Titanium sponge metal was produced by two operations in Nevada and Utah. Production data were withheld to avoid disclosing company proprietary data. The facility in Salt Lake City, UT, with an estimated capacity of 500 tons per year, used the Armstrong method to produce high-purity titanium for use in electronics. The operations in Nevada, with an estimated capacity of 12,600 tons per year, used the Kroll method, the dominant process of titanium sponge production for use in aerospace, industrial, and all other applications. A third facility, in Rowley, UT, with an estimated capacity of 10,900 tons per year, was using the Kroll method until it was idled and placed on care-and-maintenance status in 2016 owing to market conditions.

In 2019, an estimated $80 \%$ of titanium metal was used in aerospace applications; the remaining $20 \%$ was used in armor, chemical processing, marine hardware, medical implants, power generation, and consumer and other applications. Assuming an average purchase price of $\$ 9.10$ per kilogram, the value of sponge metal consumed was about $\$ 320$ million.

In 2019, titanium dioxide $\left(\mathrm{TiO}_{2}\right)$ pigment production, by four companies operating five facilities in four States, was valued at about $\$ 3.0$ billion. The estimated end-use distribution of $\mathrm{TiO}_{2}$ pigment consumption was paints (including lacquers and varnishes), 59\%; plastics, 20\%; paper, 5\%; and other, 16\%. Other uses of $\mathrm{TiO}_{2}$ included catalysts, ceramics, coated fabrics and textiles, floor coverings, printing ink, and roofing granules.

\begin{tabular}{|c|c|c|c|c|c|}
\hline Salient Statistics-United States: & $\underline{2015}$ & $\underline{2016}$ & $\underline{2017}$ & $\underline{2018}$ & $2019^{e}$ \\
\hline \multicolumn{6}{|l|}{ Titanium sponge metal: } \\
\hline Production & W & W & W & W & W \\
\hline Imports for consumption & 20,700 & 16,200 & 24,100 & 23,700 & 27,000 \\
\hline Exports & 1,700 & 724 & 3,130 & 533 & 1,000 \\
\hline Consumption, reported & 31,200 & 34,100 & 37,400 & 35,200 & 35,000 \\
\hline Price, dollars per kilogram, yearend & 9.40 & 9.50 & 9.10 & 9.20 & 9.20 \\
\hline Stocks, industry, yearende & 25,000 & 25,100 & 13,200 & 10,700 & 11,000 \\
\hline Employment, numbere & 300 & 150 & 150 & 150 & 150 \\
\hline $\begin{array}{l}\text { Net import reliance }{ }^{2} \text { as a percentage of } \\
\text { reported consumption }\end{array}$ & 61 & 45 & 88 & 73 & 86 \\
\hline \multicolumn{6}{|l|}{ Titanium dioxide pigment: } \\
\hline Production & $1,220,000$ & $1,240,000$ & $1,260,000$ & $1,150,000$ & $1,100,000$ \\
\hline Imports for consumption & 221,000 & 247,000 & 239,000 & 269,000 & 240,000 \\
\hline Exports & 649,000 & 651,000 & 634,000 & 529,000 & 400,000 \\
\hline Consumption, apparent ${ }^{3}$ & 792,000 & 840,000 & 870,000 & 893,000 & 900,000 \\
\hline Producer price index $(1982=100)$, yearend 4 & 176 & 175 & 205 & 205 & 207 \\
\hline Employment, numbere & 3,110 & 3,110 & 3,110 & 3,050 & 3,050 \\
\hline $\begin{array}{l}\text { Net import reliance }{ }^{2} \text { as a percentage of } \\
\text { apparent consumption }\end{array}$ & $\mathrm{E}$ & $\mathrm{E}$ & $\mathrm{E}$ & $\mathrm{E}$ & $\mathrm{E}$ \\
\hline
\end{tabular}

Recycling: About 62,000 tons of titanium scrap metal was consumed in $2019-50,000$ tons by the titanium industry, 10,000 tons by the steel industry, 500 tons by the superalloy industry, and the remainder in other industries.

Import Sources (2015-18): Sponge metal: Japan, 86\%; Kazakhstan, 8\%; Ukraine, 4\%; China, 1\%; and Russia, 1\%. Titanium dioxide pigment: Canada, 35\%; China, 25\%; Germany, 9\%; Mexico, 4\%; and other, 27\%.

\section{Tariff: Item}

Titanium oxides (unfinished $\mathrm{TiO}_{2}$ pigments)

$\mathrm{TiO}_{2}$ pigments, $80 \%$ or more $\mathrm{TiO}_{2}$

$\mathrm{TiO}_{2}$ pigments, other

Ferrotitanium and ferrosilicon titanium

Unwrought titanium metal

Titanium waste and scrap metal

Other titanium metal articles

Wrought titanium metal
Number

2823.00.0000

3206.11 .0000

3206.19 .0000

7202.91 .0000

8108.20 .0010

8108.30 .0000

8108.90 .3000

8108.90 .6000
Normal Trade Relations

12-31-19

$5.5 \%$ ad val.

$6.0 \%$ ad val.

$6.0 \%$ ad val.

$3.7 \%$ ad val.

$15.0 \%$ ad val.

Free.

$5.5 \%$ ad val.

$15.0 \%$ ad val. 


\section{TITANIUM AND TITANIUM DIOXIDE}

Depletion Allowance: Not applicable.

Government Stockpile: None.

Events, Trends, and Issues: Domestic consumption of titanium sponge in 2019 was essentially unchanged compared with that of 2018. Increased imports outpaced increased exports of titanium sponge leading to an increase in net import reliance to $86 \%$. Japan and Kazakhstan were the leading import sources for titanium sponge. Domestic production of $\mathrm{TiO}_{2}$ pigment in 2019 was estimated to be about 1.1 million tons, a decrease from that of 2018. Although heavily reliant on imports of titanium mineral concentrates, the United States was a net exporter of $\mathrm{TiO}_{2}$ pigments.

Following a settlement reached with the U.S. Federal Trade Commission, a leading global producer of titanium minerals and pigments based in the United States acquired the second-ranked global producer of titanium pigments headquartered in Saudi Arabia. One key requirement of the approval was the divesture of two titanium pigment plants in Ashtabula, $\mathrm{OH}$.

In Yanbu, Saudi Arabia, a new titanium sponge operation was being commissioned, but was delayed by technical issues. The new facility was jointly owned by companies based in Saudi Arabia and Japan and was expected to produce up to 15,600 tons per year of titanium sponge.

\section{World Sponge Metal Production and Sponge and Pigment Capacity:}

\begin{tabular}{|c|c|c|c|c|}
\hline & \multicolumn{2}{|c|}{ Sponge production } & \multicolumn{2}{|c|}{ Capacity $2019^{5}$} \\
\hline & $\underline{2018}$ & $2019^{\mathrm{e}}$ & Sponge & Pigment \\
\hline United States & $\mathrm{W}$ & $\mathrm{W}$ & 13,100 & $1, \overline{370,000}$ \\
\hline Australia & - & - & - & 260,000 \\
\hline Canada & - & - & - & 104,000 \\
\hline China ${ }^{\mathrm{e}}$ & 75,000 & 84,000 & 117,000 & $3,250,000$ \\
\hline Germany & - & - & - & 472,000 \\
\hline India & 250 & 250 & 500 & 108,000 \\
\hline Japane & 49,000 & 54,000 & 68,800 & 314,000 \\
\hline Kazakhstane & 16,000 & 20,000 & 31,000 & 1,000 \\
\hline Mexico & - & - & - & 300,000 \\
\hline Russiae & 44,000 & 44,000 & 46,500 & 55,000 \\
\hline Saudi Arabia & - & - & 15,600 & 210,000 \\
\hline Ukraine & 8,000 & 9,000 & 12,000 & 120,000 \\
\hline United Kingdom & - & - & - & 315,000 \\
\hline Other countries & $=$ & $=$ & $=$ & 784,000 \\
\hline World total (rounded) & $\overline{6} 192,000$ & 6210,000 & $\overline{305,000}$ & $\overline{7,660,000}$ \\
\hline
\end{tabular}

World Resources: Reserves and resources of titanium minerals are discussed in the Titanium Mineral Concentrates chapter.

Substitutes: Few materials possess titanium metal's strength-to-weight ratio and corrosion resistance. In highstrength applications, titanium competes with aluminum, composites, intermetallics, steel, and superalloys. Aluminum, nickel, specialty steels, and zirconium alloys may be substituted for titanium for applications that require corrosion resistance. Ground calcium carbonate, precipitated calcium carbonate, kaolin, and talc compete with titanium dioxide as a white pigment.

\footnotetext{
eEstimated. E Net exporter. W Withheld to avoid disclosing company proprietary data. — Zero.

${ }^{1}$ See also Titanium Mineral Concentrates.

${ }^{2}$ Defined as imports - exports.

${ }^{3}$ Defined as production + imports - exports.

${ }^{4}$ U.S. Department of Labor, Bureau of Labor Statistics.

${ }^{5}$ Yearend operating capacity.

${ }^{6}$ Excludes U.S. production.
} 


\section{TITANIUM MINERAL CONCENTRATES ${ }^{1}$}

(Data in thousand metric tons of $\mathrm{TiO}_{2}$ content unless otherwise noted)

Domestic Production and Use: At the beginning of 2019, two companies were recovering ilmenite and rutile concentrates from surface-mining operations near Nahunta, GA, and Starke, FL. In August, the owner of the operation in Florida acquired the operations in Georgia. A third (separate) company processed existing mineral sands tailings in Florida. Based on reported data through October 2019, the estimated value of titanium mineral and synthetic concentrates imported into the United States in 2019 was $\$ 840$ million. Zircon was a coproduct of mining from ilmenite and rutile deposits. About $90 \%$ of titanium mineral concentrates were consumed by domestic titanium dioxide $\left(\mathrm{TiO}_{2}\right)$ pigment producers. The remaining $10 \%$ was used in welding-rod coatings and for manufacturing carbides, chemicals, and titanium metal.

\begin{tabular}{|c|c|c|c|c|c|}
\hline Salient Statistics_-United States: & $\underline{2015}$ & $\underline{2016}$ & $\underline{2017}$ & $\underline{2018}$ & $\frac{2019^{\circ}}{100}$ \\
\hline$\overline{\text { Production }^{2}}$ & $\overline{200}$ & $\overline{100}$ & $\overline{100}$ & $\overline{100}$ & 100 \\
\hline Imports for consumption & 1,100 & 1,020 & 1,180 & 1,100 & 1,30 \\
\hline Exports, all forms $\mathrm{e}^{\mathrm{T}}$ & 2 & 5 & 6 & 32 & \\
\hline Consumption, apparent ${ }^{3}$ & 1,300 & 1,120 & 1,270 & 1,170 & $1,4 C$ \\
\hline \multicolumn{6}{|l|}{ Price, dollars per metric ton: } \\
\hline Rutile, bulk, minimum 95\% $\mathrm{TiO}_{2}$, f.o.b. Australia ${ }^{4}$ & 840 & 740 & 740 & 1,025 & 1,10 \\
\hline Ilmenite, bulk, minimum $54 \% \mathrm{TiO}_{2}$, f.o.b. Australia 4 & 110 & 105 & 173 & NA & \\
\hline Ilmenite, import, dollars per ton & 215 & 142 & 172 & 219 & $1 \varepsilon$ \\
\hline Slag, $80 \%-95 \% \mathrm{TiO}_{2}{ }^{5}$ & $687-742$ & $612-682$ & $621-700$ & $699-738$ & $740-90$ \\
\hline Employment, mine and mill, number & 285 & 156 & 264 & 270 & \\
\hline $\begin{array}{l}\text { Net import reliance }{ }^{6} \text { as a percentage of } \\
\text { apparent consumption }\end{array}$ & 85 & 91 & 92 & 91 & \\
\hline
\end{tabular}

Recycling: None.

Import Sources (2015-18): South Africa, 36\%; Australia, 26\%; Canada, 11\%; Mozambique, 10\%; and other, 17\%.

Tariff: Item

Synthetic rutile

Ilmenite and ilmenite sand

Rutile concentrate

Titanium slag
Number

2614.00.3000

2614.00.6020

2614.00 .6040

2620.99 .5000
Normal Trade Relations

$\underline{12-31-19}$

Free.

Free.

Free.

Free.

Depletion Allowance: Ilmenite and rutile; 22\% (Domestic), 14\% (Foreign).

Government Stockpile: None.

Events, Trends, and Issues: Consumption of titanium mineral concentrates is tied to production of $\mathrm{TiO}_{2}$ pigments that are primarily used in paint, paper, and plastics. Domestic apparent consumption of titanium mineral concentrates in 2019 was estimated to have increased by about 16\% from that of 2018. Exports in 2019 decreased substantially from those in the previous year because of a large intracompany transfer of inventory to Australia from Virginia in 2018.

In Australia, mining was restarting at the Jacinth-Ambrosia Mine in South Australia. In Greenland, a prefeasibility study was completed on the Dundas mining project on the northwestern coast of Greenland. Production capacity of up to 440,000 tons per year of ilmenite concentrate was planned to be commissioned by 2021 contingent upon approval of a mining license. China continued to be the leading producer and consumer of titanium mineral concentrates. In Saudi Arabia, a project to produce up to 500,000 tons per year of titanium slag was scheduled to be commissioned in 2020. Other projects were being developed in Australia, Mozambique, and Tanzania. 


\section{TITANIUM MINERAL CONCENTRATES}

World Mine Production and Reserves: Reserves for Kenya, Madagascar, and South Africa were revised based on Government or industry reports.

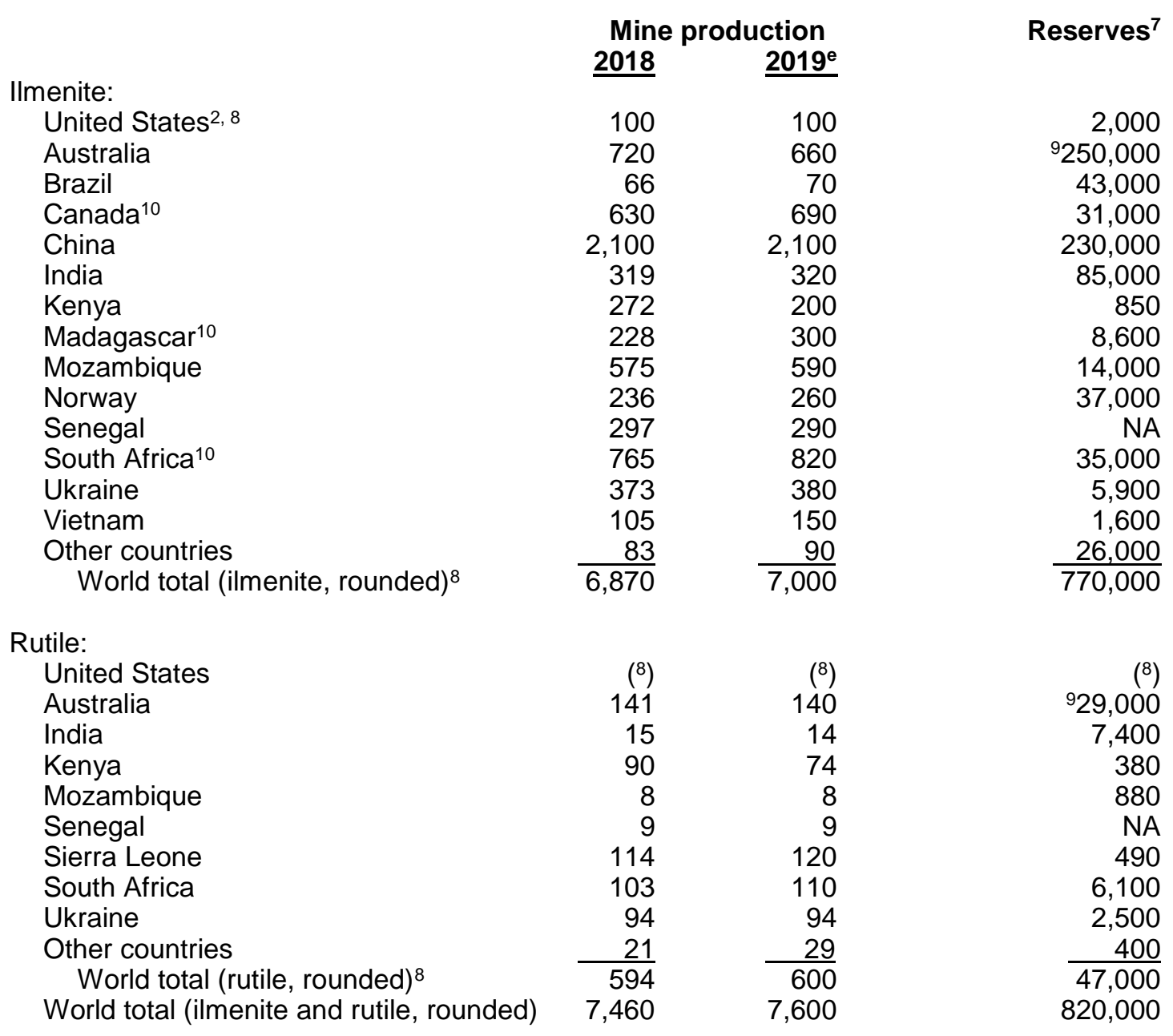

World Resources: IImenite accounts for about $89 \%$ of the world's consumption of titanium minerals. World resources of anatase, ilmenite, and rutile total more than 2 billion tons.

Substitutes: Ilmenite, leucoxene, rutile, slag, and synthetic rutile compete as feedstock sources for producing $\mathrm{TiO}_{2}$ pigment, titanium metal, and welding-rod coatings.

\footnotetext{
EEstimated. NA Not available.

${ }^{1}$ See also Titanium and Titanium Dioxide.

${ }^{2}$ Rounded to the nearest 100,000 tons to avoid disclosing company proprietary data.

${ }^{3}$ Defined as production + imports - exports.

${ }^{4}$ Source: Industrial Minerals; average of yearend price. Prices of ilmenite from Australia were discontinued at yearend 2017.

${ }^{5}$ Landed duty-paid value based on U.S. imports for consumption. Data series revised to reflect annual average unit value range of significant importing countries.

${ }^{6}$ Defined as imports - exports.

${ }^{7}$ See Appendix $\mathrm{C}$ for resource and reserve definitions and information concerning data sources.

${ }^{8} \mathrm{U}$.S. rutile production and reserves data are included with ilmenite.

${ }^{9}$ For Australia, Joint Ore Reserves Committee-compliant reserves for ilmenite and rutile were 57 million and 6.7 million tons, respectively.

${ }^{10}$ Mine production is primarily used to produce titaniferous slag.
} 


\section{TUNGSTEN}

(Data in metric tons of tungsten content unless otherwise noted)

Domestic Production and Use: There has been no known domestic commercial production of tungsten concentrates since 2015. Approximately six companies in the United States used chemical processes to convert tungsten concentrates, ammonium paratungstate (APT), tungsten oxide, and (or) scrap to tungsten metal powder, tungsten carbide powder, and (or) tungsten chemicals. Nearly $60 \%$ of the tungsten used in the United States was used in cemented carbide parts for cutting and wear-resistant applications, primarily in the construction, metalworking, mining, and oil and gas drilling industries. The remaining tungsten was used to make various alloys and specialty steels; electrodes, filaments, wires, and other components for electrical, electronic, heating, lighting, and welding applications; and chemicals for various applications. The estimated value of apparent consumption in 2019 was approximately $\$ 700$ million.

\begin{tabular}{|c|c|c|c|c|c|}
\hline $\begin{array}{l}\text { Salient Statistics_-United States: } \\
\text { Production: }\end{array}$ & $\underline{2015}$ & $\underline{2016}$ & $\underline{2017}$ & $\underline{2018}$ & $\underline{2019^{\mathrm{e}}}$ \\
\hline \multicolumn{6}{|l|}{ Production: } \\
\hline Mine & NA & - & - & - & \\
\hline Secondary & W & W & W & W & W \\
\hline \multicolumn{6}{|l|}{ Imports for consumption: } \\
\hline Concentrate & 3,970 & 3,580 & 3,920 & 4,050 & 2,900 \\
\hline Other forms & 6,270 & 6,300 & 9,780 & 10,400 & 10,900 \\
\hline \multicolumn{6}{|l|}{ Exports: } \\
\hline Concentrate & 398 & 183 & 532 & 284 & 720 \\
\hline Other forms & 3,360 & 3,200 & 3,010 & 3,210 & 2,900 \\
\hline \multicolumn{6}{|l|}{ Shipments from Government stockpile: } \\
\hline Concentrate & - & - & 1,460 & 1,180 & 750 \\
\hline Other forms & - & - & - & - & \\
\hline \multicolumn{6}{|l|}{ Consumption: } \\
\hline Reported, concentrate & W & W & W & W & W \\
\hline Apparent, all forms ${ }^{1}$ & W & W & W & W & \\
\hline \multicolumn{6}{|l|}{ Price, concentrate, dollars per $\mathrm{mtu} \mathrm{WO}_{3},{ }^{2}$ average, } \\
\hline U.S. spot market, Platts Metals Week & 302 & 148 & 245 & 326 & 270 \\
\hline Stocks, industry, yearend, concentrate and other forms & W & W & W & W & W \\
\hline $\begin{array}{l}\text { Net import reliance } 3 \text { as a percentage of } \\
\text { apparent consumption }\end{array}$ & $>25$ & $>25$ & $>50$ & $>50$ & $>50$ \\
\hline
\end{tabular}

Recycling: The estimated quantity of secondary tungsten produced and the amount consumed from secondary sources by processors and end users in 2019 were withheld to avoid disclosing company proprietary data.

Import Sources (2015-18): Tungsten contained in ores and concentrates, intermediate and primary products, wrought and unwrought tungsten, and waste and scrap: China, 31\%; Bolivia, 10\%; Germany, 9\%; Spain, 6\%; and other, $44 \%$.

\section{Tariff: Item}

Ores

Concentrates

Tungsten oxides

Ammonium tungstates

Tungsten carbides

Ferrotungsten

Tungsten powders

Tungsten waste and scrap
Number

2611.00.3000

2611.00.6000

2825.90.3000

2841.80 .0010

2849.90.3000

7202.80 .0000

8101.10 .0000

8101.97 .0000
Normal Trade Relations 12-31-19

Free.

$37.5 \$ / \mathrm{kg}$ tungsten content.

$5.5 \%$ ad val.

$5.5 \%$ ad val.

$5.5 \%$ ad val.

$5.6 \%$ ad val.

$7.0 \%$ ad val.

$2.8 \%$ ad val.

Depletion Allowance: 22\% (Domestic), 14\% (Foreign).

\section{Government Stockpile: ${ }^{4}$}

\section{Material}

Metal powder

Ores and concentrates

Tungsten alloys, gross weight ${ }^{5}$

Prepared by Kim B. Shedd [(703) 648-4974, kshedd@usgs.gov]
FY 2019

$\begin{array}{ccc}\begin{array}{c}\text { Inventory } \\ \text { As of 9-30-19 } \\ 125\end{array} & \begin{array}{c}\text { Potential } \\ \text { Acquisitions }\end{array} & \begin{array}{c}\text { Potential } \\ \text { Disposals }\end{array} \\ 8,370 & - & 125 \\ 6 & - & 1,360 \\ & 5 & -\end{array}$

FY 2020

Potential Potential Acquisitions Disposals 125

$\begin{array}{lr}- & 125 \\ - & 1,360\end{array}$




\section{TUNGSTEN}

Events, Trends, and Issues: World tungsten supply was dominated by production in China and exports from China. China's Government regulated its tungsten industry by limiting the number of mining and export licenses, imposing quotas on concentrate production, and placing constraints on mining and processing. Production of tungsten concentrate outside China in 2019 was expected to be less than that of 2018, owing in part to the closure of the sole tungsten mine in the United Kingdom after the owner entered voluntary administration in late 2018. Scrap continued to be an important source of raw material for the tungsten industry worldwide.

China was the world's leading tungsten consumer. Analysts forecast global tungsten demand in 2019 to be less than that in 2018, as a result of destocking by consumers and reduced consumption owing to reported slowing global economic growth. In September, APT stocks equivalent to 3 months of production in China were sold from the Fanya Metal Exchange to a leading Chinese tungsten mining and processing company. This relieved some of the uncertainty that had been hanging over the global tungsten market since the exchange's collapse in 2015. During most of 2019, Chinese and European prices of tungsten concentrate and downstream tungsten materials trended downward; prices increased following the Fanya sale.

World Mine Production and Reserves: Reserves for the United Kingdom were revised based on a company report. Reserves for North Korea are based on a report from an independent research organization funded by the Government of the Republic of Korea.

\begin{tabular}{|c|c|c|c|}
\hline & Mine & iction & Reserves $^{6}$ \\
\hline & $\underline{2018}$ & $2019^{e}$ & \\
\hline United States & 二 & 二 & NA \\
\hline Austria & 936 & 940 & 10,000 \\
\hline Bolivia & 1,370 & 1,200 & NA \\
\hline China & 65,000 & 70,000 & $1,900,000$ \\
\hline Korea, North & 1,410 & 1,100 & 29,000 \\
\hline Mongolia & 1,940 & 1,900 & NA \\
\hline Portugal & 715 & 700 & 3,100 \\
\hline Russia & 1,500 & 1,500 & 240,000 \\
\hline Rwanda & 920 & 1,100 & NA \\
\hline Spain & 750 & 500 & 54,000 \\
\hline United Kingdom & 900 & - & 44,000 \\
\hline Vietnam & 4,800 & 4,800 & 95,000 \\
\hline Other countries & 900 & 900 & 820,000 \\
\hline World total (rounded) & 81,100 & 85,000 & $3,200,000$ \\
\hline
\end{tabular}

World Resources: World tungsten resources are geographically widespread. China ranks first in the world in terms of tungsten resources and reserves and has some of the largest deposits. Canada, Kazakhstan, Russia, and the United States also have significant tungsten resources.

Substitutes: Potential substitutes for cemented tungsten carbides include cemented carbides based on molybdenum carbide, niobium carbide, or titanium carbide; ceramics; ceramic-metallic composites (cermets); and tool steels. Most of these options reduce, rather than replace, the amount of tungsten used. Potential substitutes for other applications are as follows: molybdenum for certain tungsten mill products; molybdenum steels for tungsten steels, although most molybdenum steels still contain tungsten; lighting based on carbon nanotube filaments, induction technology, and light-emitting diodes for lighting based on tungsten electrodes or filaments; depleted uranium or lead for tungsten or tungsten alloys in applications requiring high-density or the ability to shield radiation; and depleted uranium alloys or hardened steel for cemented tungsten carbides or tungsten alloys in armor-piercing projectiles. In some applications, substitution would result in increased cost or a loss in product performance.

\footnotetext{
eEstimated. NA Not available. W Withheld to avoid disclosing company proprietary data. - Zero.

${ }^{1}$ Defined as mine production + secondary production + imports - exports + adjustments for Government and industry stock changes.

${ }^{2} \mathrm{~A}$ metric ton unit $(\mathrm{mtu})$ of tungsten trioxide $\left(\mathrm{WO}_{3}\right)$ contains 7.93 kilograms of tungsten.

${ }^{3}$ Defined as imports - exports + adjustments for Government and industry stock changes.

${ }^{4}$ See Appendix $B$ for definitions.

${ }^{5}$ Inventory includes tungsten alloys and tungsten-rhenium metal; potential acquisitions are tungsten-rhenium metal only.

${ }^{6}$ See Appendix C for resource and reserve definitions and information concerning data sources.
} 


\section{VANADIUM}

(Data in metric tons of vanadium content unless otherwise noted)

Domestic Production and Use: In January 2019, byproduct vanadium production resumed in Utah and an estimated 470 tons of contained vanadium with an estimated value of $\$ 6.8$ million was produced. In 2009-13, small quantities of vanadium were similarly produced as a byproduct from the mining of uraniferous sandstones on the Colorado Plateau. Secondary vanadium production continued primarily in Arkansas, Delaware, Ohio, Pennsylvania, and Texas, where processed waste materials (petroleum residues, spent catalysts, utility ash, and vanadium-bearing pig iron slag) were used to produce ferrovanadium, vanadium-bearing chemicals or specialty alloys, vanadium metal, and vanadium pentoxide. Metallurgical use, primarily as an alloying agent for iron and steel, accounted for about $94 \%$ of domestic reported vanadium consumption in 2019. Of the other uses for vanadium, the major nonmetallurgical use was in catalysts to produce maleic anhydride and sulfuric acid.

\begin{tabular}{|c|c|c|c|c|c|}
\hline Salient Statistics-United States: & $\underline{2015}$ & $\underline{2016}$ & $\underline{2017}$ & $\underline{2018}$ & $\frac{2019^{\mathrm{e}}}{470}$ \\
\hline$\overline{\text { Production, mine, mill }}$ & - & 二 & 二 & 二 & 470 \\
\hline \multicolumn{6}{|l|}{ Imports for consumption: } \\
\hline Vanadium ores and concentrates & 72 & 18 & 1 & 330 & \\
\hline Ferrovanadium & 1,980 & 1,590 & 2,810 & 3,130 & 2,5 \\
\hline Vanadium pentoxide, anhydride & 2,870 & 2,460 & 3,400 & 4,600 & 4,00 \\
\hline Oxides and hydroxides, other & 94 & 660 & 148 & 98 & 1 \\
\hline Aluminum-vanadium master alloys & 143 & 157 & 288 & 281 & 24 \\
\hline Ash and residues & 4,600 & 2,820 & 2,540 & 2,810 & 2,10 \\
\hline Vanadium chemicals $^{1}$ & 292 & 407 & 526 & 470 & 1 \\
\hline Vanadium metal $^{2}$ & 135 & 33 & 54 & 28 & \\
\hline \multicolumn{6}{|l|}{ Exports: } \\
\hline Vanadium ores and concentrates & 166 & 260 & 37 & 29 & \\
\hline Ferrovanadium & 122 & 394 & 229 & 575 & \\
\hline Vanadium pentoxide, anhydride & 356 & 5 & 126 & 563 & 2. \\
\hline Oxides and hydroxides, other & 100 & 81 & 148 & 53 & \\
\hline Aluminum-vanadium master alloys & 128 & 53 & 132 & 90 & \\
\hline Ash and residues & 43 & 123 & 322 & 289 & 2 \\
\hline Vanadium metal $^{2}$ & 4 & 15 & 45 & 30 & \\
\hline \multicolumn{6}{|l|}{ Consumption: } \\
\hline Apparent ${ }^{3}$ & 9,300 & 7,220 & 8,740 & 10,100 & 8,30 \\
\hline Reported & 4,720 & 4,620 & 4,680 & 5,660 & 4,60 \\
\hline Price, average, dollars per pound vanadium pentoxide ${ }^{4}$ & 4.16 & 3.38 & 7.61 & 16.4 & 11 \\
\hline Stocks, yearend 5 & 136 & 138 & 125 & 185 & \\
\hline $\begin{array}{l}\text { Net import reliance } 6 \text { as a percentage of } \\
\text { apparent consumption }\end{array}$ & 100 & 100 & 100 & 100 & \\
\hline
\end{tabular}

Recycling: The quantity of vanadium recycled from spent chemical process catalysts was significant and may compose as much as $40 \%$ of total vanadium catalysts.

Import Sources (2015-18): Ferrovanadium: Austria, 48\%; Canada, 22\%; Russia, 14\%; Republic of Korea, 11\%; and other, 5\%. Vanadium pentoxide: South Africa, 44\%; Brazil, 29\%; China, 11\%; Taiwan, 6\%; and other, 10\%.

\section{Tariff: Item}

Vanadium ores and concentrates

Vanadium bearing ash and residues

Vanadium bearing ash and residues, other

Chemical compounds:

Vanadium pentoxide, anhydride

Vanadium oxides and hydroxides, other

Vanadium sulfates

Vanadates

Hydrides \& nitrides, of vanadium

Ferrovanadium

Vanadium metal

Vanadium and articles thereof ${ }^{7}$

\section{Number}

2615.90.6090

2620.40 .0030

2620.99.1000

2825.30.0010

2825.30.0050

2833.29.3000

2841.90.1000

2850.00 .2000

7202.92 .0000

8112.92 .7000

8112.99 .2000

\section{Normal Trade Relations \\ 12-31-19 \\ Free. \\ Free. \\ Free.}

$5.5 \%$ ad val.

$5.5 \%$ ad val.

$5.5 \%$ ad val.

$5.5 \%$ ad val.

$5.5 \%$ ad val.

$4.2 \%$ ad val.

$2.0 \%$ ad val.

$2.0 \%$ ad val.

Depletion Allowance: 22\% (Domestic), 14\% (Foreign). 


\section{VANADIUM}

Government Stockpile: None.

Events, Trends, and Issues: U.S. apparent consumption of vanadium in 2019 decreased by $18 \%$ from that of 2018. Among the major uses for vanadium, production of carbon, full-alloy, and high-strength low-alloy steels accounted for $18 \%, 45 \%$, and $31 \%$, respectively, of domestic consumption. Average 2019 vanadium pentoxide prices decreased by $28 \%$ compared with 2018 prices, and ferrovanadium prices decreased by $41 \%$ to $\$ 23$ per pound in 2019 compared with 2018. In January 2019 , ferrovanadium prices averaged $\$ 43.10$ per pound but continued to decrease for the remainder of 2019. Byproduct vanadium production in the United States resumed in early 2019 at the White Mesa mill in Utah. The company expected to continue production, subject to successful recovery and suitable prices. An iron and vanadium mine in South Africa remained closed leaving South Africa with only two major producers of vanadium. A producer in Brazil that started production in 2014 began construction on an expansion project in 2018 that would increase its production capacity by $25 \%$. The expansion was expected to be completed by the end of the third quarter of 2019.

The implementation of the new high-strength rebar standards by the Standardization Administration of China has been enforced more gradually than originally expected. Larger mills began implementation in 2018; however, smaller mills have been slower to implement the new standards. Enforcement of the new standards was also reportedly more difficult to monitor at smaller mills. The increase of vanadium in rebar was originally expected to increase overall consumption of vanadium in China by approximately 10,000 tons per year.

World Mine Production and Reserves: Reserves for Australia and Brazil were revised based on Government reports.

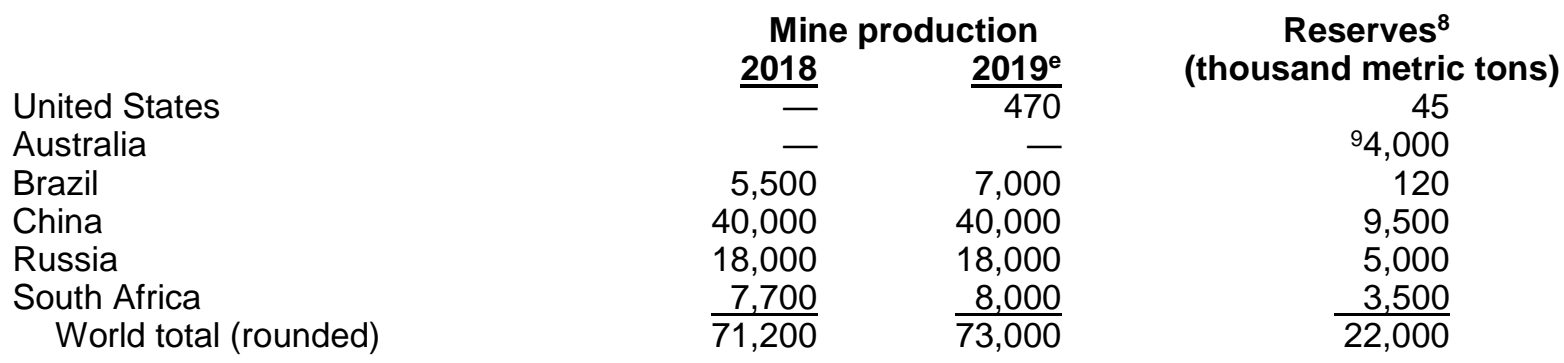

World Resources: World resources of vanadium exceed 63 million tons. Vanadium occurs in deposits of phosphate rock, titaniferous magnetite, and uraniferous sandstone and siltstone, in which it constitutes less than $2 \%$ of the host rock. Significant quantities are also present in bauxite and carboniferous materials, such as coal, crude oil, oil shale, and tar sands. Because vanadium is typically recovered as a byproduct or coproduct, demonstrated world resources of the element are not fully indicative of available supplies. Although domestic resources and secondary recovery are adequate to supply a large portion of domestic needs, all of U.S. demand is currently met by foreign sources.

Substitutes: Steels containing various combinations of other alloying elements can be substituted for steels containing vanadium. Certain metals, such as manganese, molybdenum, niobium (columbium), titanium, and tungsten, are to some degree interchangeable with vanadium as alloying elements in steel. Platinum and nickel can replace vanadium compounds as catalysts in some chemical processes. Currently, no acceptable substitute for vanadium is available for use in aerospace titanium alloys.

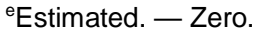

${ }^{1}$ Includes hydrides, nitrides, sulfates, and vanadates of vanadium.

${ }^{2}$ Vanadium metal includes waste and scrap.

${ }^{3}$ Defined as production + net import reliance.

${ }^{4}$ Prices for 2015-2016 are U.S. annual average vanadium pentoxide prices. The 2017 annual average vanadium pentoxide price includes U.S. monthly averages for January 2017-June 2017 and China monthly average prices for July 2017-December 2017. The prices for 2018-2019 are the China annual average vanadium pentoxide prices.

${ }^{5}$ Includes chlorides, ferrovanadium, vanadates, vanadium-aluminum alloy, other vanadium alloys, vanadium metal, vanadium pentoxide, and other specialty chemicals.

${ }^{6}$ Defined as imports - exports + adjustments for industry stock changes.

${ }^{7}$ Aluminum-vanadium master alloy consisting of $35 \%$ aluminum and $64.5 \%$ vanadium.

${ }^{8}$ See Appendix $\mathrm{C}$ for resource and reserve definitions and information concerning data sources.

${ }^{9}$ For Australia, Joint Ore Reserves Committee-compliant reserves were 1.1 million tons.
} 


\section{VERMICULITE}

(Data in thousand metric tons unless otherwise noted)

Domestic Production and Use: Two companies with mining and processing facilities in South Carolina and Virginia produced approximately 200,000 tons of vermiculite concentrate, but actual data have been rounded to one significant digit to avoid disclosing company proprietary data. Flakes of raw vermiculite concentrate are micaceous in appearance and contain interlayer water in their structure. When the flakes are heated rapidly at a temperature above $870{ }^{\circ} \mathrm{C}$, the water flashes into steam, and the flakes expand into accordionlike particles. This process is called exfoliation or expansion, and the resulting lightweight material is chemically inert, fire resistant, and odorless. Most of the vermiculite concentrate produced in the United States was shipped to 17 exfoliating plants in 11 States. The end uses for exfoliated vermiculite were estimated to be agriculture and horticulture, $46 \%$; lightweight concrete aggregates (including cement premixes, concrete, and plaster), 17\%; insulation, 10\%; and other, $27 \%$.

\begin{tabular}{|c|c|c|c|c|c|}
\hline Salient Statistics-United States: & $\underline{2015}$ & $\underline{2016}$ & $\underline{2017}$ & $\underline{2018}$ & $\underline{2019^{\circ}}$ \\
\hline Productione, 1,2 & 100 & 100 & 100 & 100 & 200 \\
\hline Imports for consumptione & 25 & 36 & 28 & 37 & \\
\hline Exports & 19 & 21 & 16 & 14 & \\
\hline Consumption, apparent, concentrate 3 & 110 & 120 & 110 & 120 & 22 \\
\hline Consumption, reported, exfoliated & 65 & 68 & 72 & 76 & \\
\hline $\begin{array}{l}\text { Price, range of value, concentrate, } \\
\text { dollars per ton, ex-plant }\end{array}$ & $140-575$ & $140-575$ & 140-575 & $140-575$ & $140-57$ \\
\hline Employment, number & 63 & 63 & 63 & 65 & \\
\hline $\begin{array}{l}\text { Net import reliance } 4 \text { as a percentage of } \\
\text { apparent consumptione, } 2\end{array}$ & 10 & 10 & 10 & 20 & \\
\hline
\end{tabular}

Recycling: Insignificant.

Import Sources (2015-18): South Africa, 66\%; Brazil, 29\%; Zimbabwe, 4\%; and Kenya, 1\%.

\section{Tariff: Item}

Vermiculite, perlite and chlorites, unexpanded

Exfoliated vermiculite, expanded clays, foamed

slag, and similar expanded materials
Number

2530.10 .0000

6806.20 .0000
Normal Trade Relations

$\frac{12-31-19}{\text { Free }}$

Free.

Free.

Depletion Allowance: 14\% (Domestic and foreign).

Government Stockpile: None.

Events, Trends, and Issues: U.S. exports and imports of vermiculite are not collected as a separate category by the U.S. Census Bureau. However, United States imports were estimated to be about 32,000 tons in 2019, almost $14 \%$ less than those of 2018. Coarse-grade vermiculite remained in short supply; however, prices were unchanged in 2019. Most imports came from South Africa and Brazil in 2019.

Expansion at the 30,000-ton-per-year Namekara Mine in Uganda continued toward its goal of 80,000 tons per year of production. The deposit was considered to be one of the world's largest vermiculite deposits with significant portions of medium- and coarse-grade material. The Namekara deposit has enough resources for more than 50 years of production at previously announced rates. 


\section{VERMICULITE}

A company in Brazil continued to expand production capacity at its vermiculite mine in central Brazil and continued with the development of another deposit near Brasilia to bring the company's total production capacity to 200,000 tons per year. Companies in China with significant vermiculite resources also were ramping up production, although processing operations continued to be somewhat constrained by increased enforcement of environmental regulations. Specific production data were not available for China.

Exploration and development of vermiculite deposits containing medium, large, and premium (coarser) grades (mostly in China and South Africa) are likely to continue because of the higher demand for those grades. Finer grade production has exceeded consumption for several years. However, coarser grade (greater than 5-millimeter particle size) production has not been able to keep up with demand. Producers will continue to investigate ways to increase the use of the finer grades in existing products and in uses that require coarse material. Innovative applications continue to emerge, including the use of vermiculite to combat air pollution and absorb water in mines, replacing zeolites in ion-exchange columns, purifying wastewater, and containing or removing nuclear waste.

\section{World Mine Production and Reserves:}

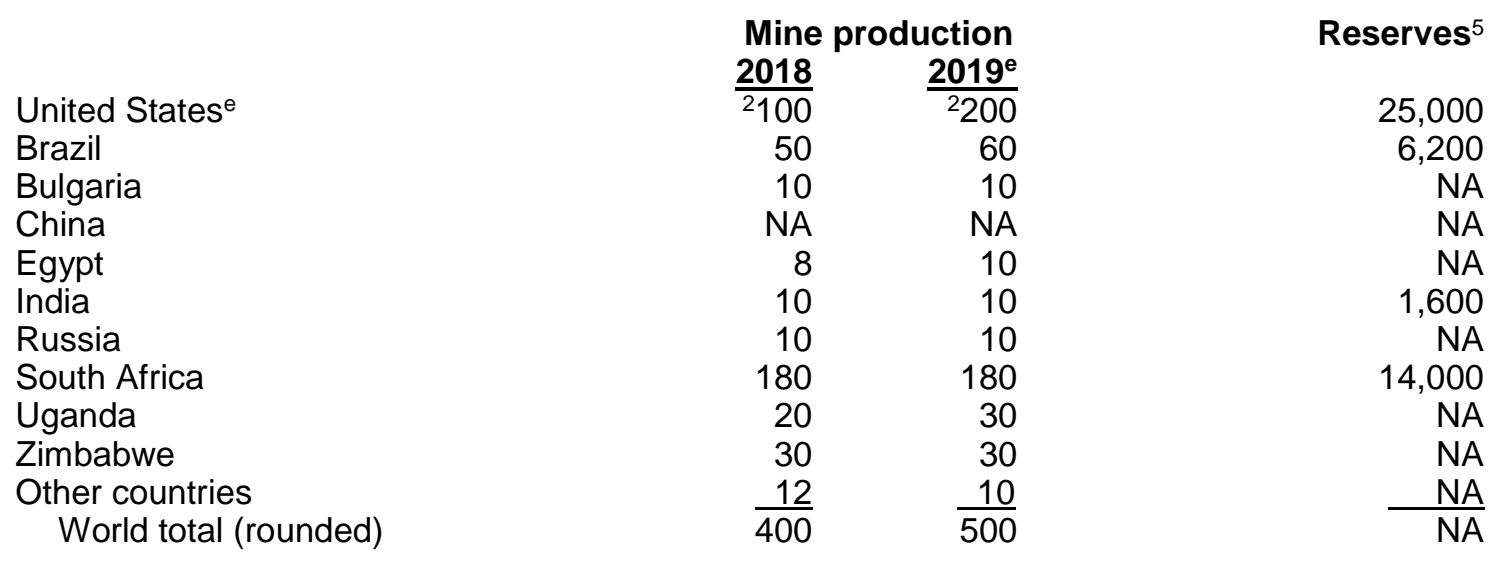

World Resources: In addition to the producing mines in South Carolina and Virginia, there are vermiculite occurrences in Colorado, Nevada, North Carolina, Texas, and Wyoming which contain estimated resources of 2 million to 3 million tons. Significant deposits have been reported in Australia, China, Russia, Uganda, and some other countries, but reserves and resource information comes from many sources and, in most cases, it is not clear whether the numbers refer to vermiculite alone or vermiculite plus other minerals and host rock and overburden.

\section{Substitutes:}

Expanded perlite is a substitute for exfoliated vermiculite in lightweight concrete and plaster. Other denser but less costly alternatives in these applications include expanded clay, shale, slag, and slate. Alternate materials for loose-fill fireproofing insulation include fiberglass, perlite, and slag wool. In agriculture, substitutes include bark and other plant materials, peat, perlite, sawdust, and synthetic soil conditioners.

\footnotetext{
eEstimated. NA Not available.

${ }^{1}$ Concentrate sold or used by producers.

${ }^{2}$ Data are rounded to one significant digit to avoid disclosing company proprietary data.

${ }^{3}$ Defined as concentrate sold or used by producers + imports - exports.

${ }^{4}$ Defined as imports - exports.

${ }^{5}$ See Appendix $\mathrm{C}$ for resource and reserve definitions and information concerning data sources.
} 


\section{WOLLASTONITE}

(Data in metric tons unless otherwise noted)

Domestic Production and Use: Wollastonite was mined by two companies in New York during 2019. U.S. production of wollastonite (sold or used by producers) was withheld to avoid disclosing company proprietary data but was estimated to have decreased from that of 2018. Economic resources of wollastonite typically form as a result of thermal metamorphism of siliceous limestone during regional deformation or chemical alteration of limestone by siliceous hydrothermal fluids along faults or contacts with magmatic intrusions. Deposits of wollastonite have been identified in Arizona, California, Idaho, Nevada, New Mexico, New York, and Utah; however, New York is the only State where long-term continuous mining has taken place.

The U.S. Geological Survey does not collect consumption statistics for wollastonite, but consumption was estimated to have decreased in 2019, compared with that of 2018. Ceramics (frits, sanitaryware, and tile), friction products (primarily brake linings), metallurgical applications (flux and conditioner), paint (architectural and industrial paints), plastics and rubber markets (thermoplastic and thermoset resins and elastomer compounds), and miscellaneous uses (including adhesives, concrete, glass, and sealants) accounted for wollastonite sales in the United States.

In ceramics, wollastonite decreases shrinkage and gas evolution during firing; increases green and fired strength; maintains brightness during firing; permits fast firing; and reduces crazing, cracking, and glaze defects. In metallurgical applications, wollastonite serves as a flux for welding, a source for calcium oxide, a slag conditioner, and protects the surface of molten metal during the continuous casting of steel. As an additive in paint, it improves the durability of the paint film, acts as a pH buffer, improves resistance to weathering, reduces gloss and pigment consumption, and acts as a flatting and suspending agent. In plastics, wollastonite improves tensile and flexural strength, reduces resin consumption, and improves thermal and dimensional stability at elevated temperatures. Surface treatments are used to improve the adhesion between wollastonite and the polymers to which it is added. As a substitute for asbestos in floor tiles, friction products, insulating board and panels, paint, plastics, and roofing products, wollastonite is resistant to chemical attack, stable at high temperatures, and improves flexural and tensile strength.

Salient Statistics_United States: The United States was thought to be a net exporter of wollastonite in 2019. Comprehensive trade data were not available for wollastonite because it is imported and exported under a generic Harmonized Tariff Schedule of the United States code that includes multiple mineral commodities. Prices for domestically produced wollastonite were estimated to be between $\$ 300$ to $\$ 320$ per metric ton. Price data for globally produced wollastonite were unavailable. Products with finer grain sizes and acicular (highly elongated) particles sold for higher prices. Surface treatment, when necessary, also increased the selling price. Approximately 64 people were employed at wollastonite mines and mills in 2019 (excluding office workers).

Recycling: None.

Import Sources (2015-18): Comprehensive trade data were not available, but wollastonite was primarily imported from Canada, Finland, India, and Mexico.

\section{Tariff: Item}

Mineral substances not elsewhere specified or included

Depletion Allowance: $10 \%$ (Domestic and foreign).
Number

2530.90 .8050
Normal Trade Relations 12-31-19

Free.

Government Stockpile: None. 


\section{WOLLASTONITE}

Events, Trends, and Issues: Construction of new housing units through August 2019, decreased slightly compared with those during the same period in 2018 , suggesting that sales of wollastonite to domestic construction-related markets, such as adhesives, caulks, cement board, ceramic tile, paints, stucco, and wallboard, might have decreased. Most major markets, in which wollastonite is used, were estimated to have decreased, except for primary iron and steel. Production of motor vehicles and parts, which contain wollastonite in friction products and plastic and rubber components, decreased; plastics production decreased; rubber production decreased; but primary iron and steel products increased.

Globally, ceramics, polymers (such as plastics and rubber), and paint accounted for most wollastonite sales. Lesser global uses for wollastonite included miscellaneous construction products, friction materials, metallurgical applications, and paper. Global sales of wollastonite were estimated to be in the range of 850,000 to 900,000 tons, similar to those in 2018.

The leading U.S. producer of wollastonite delayed plans to develop a mine within the Adirondack Forest Preserve of New York, and instead continued to use resources from its current mine. The Adirondack Forest Preserve land became available for development as part of a land swap transaction approved by the State of New York in 2013.

World Mine Production and Reserves: The United States is thought to rank among the top producers globally; however, many countries do not publish wollastonite production. Data for China were revised based on a new data source, which significantly increased estimated production compared with the previously published data.

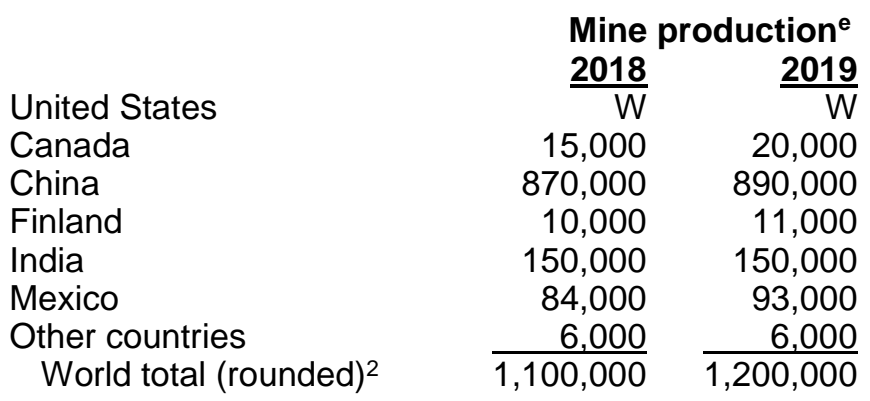

\section{Reserves $^{1}$}

World reserves of wollastonite exceed 100 million tons. Many deposits, however, have not been surveyed, precluding accurate estimates of reserves.

World Resources: Reliable estimates of wollastonite resources do not exist for most countries. Large deposits of wollastonite have been identified in China, Finland, India, Mexico, and the United States. Smaller, but significant, deposits have been identified in Canada, Chile, Kenya, Namibia, South Africa, Spain, Sudan, Tajikistan, Turkey, and Uzbekistan.

Substitutes: The acicular nature of many wollastonite products allows it to compete with other acicular materials, such as ceramic fiber, glass fiber, steel fiber, and several organic fibers, such as aramid, polyethylene, polypropylene, and polytetrafluoroethylene, in products where improvements in dimensional stability, flexural modulus, and heat deflection are sought. Wollastonite also competes with several nonfibrous minerals or rocks, such as kaolin, mica, and talc, which are added to plastics to increase flexural strength, and such minerals as barite, calcium carbonate, gypsum, and talc, which impart dimensional stability to plastics. In ceramics, wollastonite competes with carbonates, feldspar, lime, and silica as a source of calcium and silica. Its use in ceramics depends on the formulation of the ceramic body and the firing method.

\footnotetext{
eEstimated. W Withheld to avoid disclosing company proprietary data.

${ }^{1}$ See Appendix $\mathrm{C}$ for resource and reserve definitions and information concerning data sources.

${ }^{2}$ Excludes U.S. production.
} 


\section{YTTRIUM $^{1}$}

[Data in metric tons of yttrium-oxide $\left(\mathrm{Y}_{2} \mathrm{O}_{3}\right)$ equivalent content unless otherwise noted]

Domestic Production and Use: Yttrium is one of the rare-earth elements. Bastnaesite (or bastnäsite), a rare-earth fluorocarbonate mineral, was mined in 2019 as a primary product at the Mountain Pass Mine in California, which was restarted in the first quarter of 2018 after being put on care-and-maintenance status in the fourth quarter of 2015. Monazite, a rare-earth phosphate mineral, also may have been produced as a separated concentrate or included as an accessory mineral in heavy-mineral concentrates. Yttrium was estimated to represent about $0.12 \%$ of the rareearth elements in the Mountain Pass bastnaesite ore.

The leading end uses of yttrium were in ceramics, metallurgy, and phosphors. In ceramic applications, yttrium compounds were used in abrasives, bearings and seals, high-temperature refractories for continuous-casting nozzles, jet-engine coatings, oxygen sensors in automobile engines, and wear-resistant and corrosion-resistant cutting tools. In metallurgical applications, yttrium was used as a grain-refining additive and as a deoxidizer. Yttrium was used in heating-element alloys, high-temperature superconductors, and superalloys. In electronics, yttrium-iron garnets were components in microwave radar to control high-frequency signals. Yttrium was an important component in yttriumaluminum-garnet laser crystals used in dental and medical surgical procedures, digital communications, distance and temperature sensing, industrial cutting and welding, nonlinear optics, photochemistry, and photoluminescence. Yttrium was used in phosphor compounds for flat-panel displays and various lighting applications.

\begin{tabular}{|c|c|c|c|c|c|}
\hline Salient Statistics-United States: & $\underline{2015}$ & $\underline{2016}$ & $\underline{2017}$ & $\underline{2018}$ & $\underline{2019^{\mathrm{e}}}$ \\
\hline$\overline{\text { Production, mine }}$ & $\mathrm{NA}$ & 二 & 二 & $\mathrm{NA}$ & $\mathrm{NA}$ \\
\hline \multicolumn{6}{|l|}{ Imports for consumption: } \\
\hline Yttrium, alloys, compounds, and metale, 2 & 360 & 340 & 380 & 450 & 570 \\
\hline Exports, compoundse, 3 & 39 & 2 & 2 & 14 & 7 \\
\hline Consumption, apparente, 4 & 300 & 300 & 400 & 500 & 600 \\
\hline \multicolumn{6}{|l|}{ Price, dollars per kilogram, average: } \\
\hline Yttrium oxide, minimum 99.999 purity 5 & 8 & 4 & 3 & 3 & 3 \\
\hline Yttrium metal, minimum 99.9\% purity 5 & 48 & 35 & 35 & 36 & 34 \\
\hline \multirow{2}{*}{\multicolumn{6}{|c|}{ Net import reliance 6,7 as a percentage of }} \\
\hline & 100 & 100 & 100 & 100 & 100 \\
\hline
\end{tabular}

Recycling: Insignificant.

Import Sources (2015-18): ${ }^{8}$ Yttrium compounds: China, 87\%; Estonia, 5\%; Republic of Korea, 2\%; Japan, 2\%; and other, $4 \%$. Nearly all imports of yttrium metal and compounds are derived from mineral concentrates processed in China. Import sources do not include yttrium contained in value-added intermediates and finished products.

\section{Tariff: Item}

Rare-earth metals, unspecified, whether or not intermixed or interalloyed

Mixtures of rare-earth oxides containing yttrium

or scandium as the predominant metal

Mixtures of rare-earth chlorides containing yttrium

or scandium as the predominant metal

Yttrium-bearing materials and compounds

containing by weight $>19 \%$ to $<85 \% \mathrm{Y}_{2} \mathrm{O}_{3}$

Other rare-earth compounds, including yttrium and other compounds
Number

2805.30.0090

2846.90.2015

2846.90 .2082

2846.90 .4000

2846.90.8000
Normal Trade Relations 12-31-19

$5.0 \%$ ad val.

Free.

Free.

Free.

$3.7 \%$ ad val. 


\section{YTTRIUM}

Depletion Allowance: Monazite, thorium content, 22\% (Domestic), 14\% (Foreign); yttrium, rare-earth content, 14\% (Domestic and foreign); and xenotime, 14\% (Domestic and foreign).

\section{Government Stockpile: ${ }^{9}$}

\section{Material}

Yttrium oxide

\author{
Inventory \\ As of 9-30-19 \\ 25
}

\author{
FY 2019 \\ Potential Potential \\ Acquistions Disposals \\ 10
}

\author{
FY 2020 \\ Potential Potential \\ Acquisitions Disposals
}

Events, Trends, and Issues: China produced most of the world's supply of yttrium from its weathered clay ionadsorption ore deposits in the southern Provinces_primarily Fujian, Guangdong, and Jiangxi-and from a lesser number of deposits in Guangxi and Hunan Provinces. Processing was primarily at facilities in Guangdong, Jiangsu, and Jiangxi Provinces. In 2019, yttrium was produced from similar clay deposits in Burma (Myanmar).

Globally, yttrium was mainly consumed in the form of oxide compounds for ceramics and phosphors. Lesser amounts were consumed in electronic devices, lasers, optical glass, and metallurgical applications. The average price for yttrium metal decreased by $5 \%$ compared with that of 2018 . Yttrium oxide prices remained nearly unchanged since 2016. China's Ministry of Industry and Information Technology raised the rare-earth mining and separation quotas to record highs of 132,000 tons and 127,000 tons of rare-earth-oxide equivalent, respectively. The yttrium content of the production quota was not specified. In 2019, China's exports of yttrium compounds and metal were estimated to be 3,000 tons of yttrium-oxide equivalent, and the leading export destinations were, in descending order, Japan, the United States, Italy, and the Republic of Korea.

World Mine Production and Reserves: ${ }^{10}$ World mine production of yttrium contained in rare-earth mineral concentrates was estimated to be 10,000 to 14,000 tons. Most of this production took place in China and Burma. Global reserves of yttrium oxide were estimated to be more than 500,000 tons. The leading countries for these reserves included Australia, Brazil, Canada, China, and India. Although mine production in Burma was significant, information on reserves in Burma was not available. Global reserves may be adequate to satisfy near-term demand at current rates of production; however, changes in economic conditions, environmental issues, or permitting and trade restrictions could affect the availability of many of the rare-earth elements, including yttrium.

World Resources: Large resources of yttrium in monazite and xenotime are available worldwide in placer deposits, carbonatites, uranium ores, and weathered clay deposits (ion-adsorption ore). Additional resources of yttrium occur in apatite-magnetite-bearing rocks, deposits of niobium-tantalum minerals, nonplacer monazite-bearing deposits, sedimentary phosphate deposits, and uranium ores.

Substitutes: Substitutes for yttrium are available for some applications but generally are much less effective. In most uses, especially in electronics, lasers, and phosphors, yttrium is generally not subject to direct substitution by other elements. As a stabilizer in zirconia ceramics, yttrium oxide may be substituted with calcium oxide or magnesium oxide, but the substitutes generally impart lower toughness.

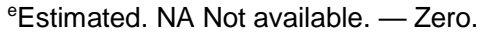

${ }^{1}$ See also Rare Earths; trade data for yttrium are included in the data shown for rare earths.

${ }^{2}$ Estimated from Trade Mining LLC and IHS Markit Ltd. shipping records.

${ }^{3}$ Estimated from Harmonized Tariff System-based Schedule B code: 2846.90.2015.

${ }^{4}$ Defined as imports - exports. Rounded to one significant digit. Yttrium consumed domestically was imported or refined from imported materials.

${ }^{5}$ Free on board China. Source: Argus Media group-Argus Metals International, London, United Kingdom.

${ }^{6}$ Defined as imports - exports.

${ }^{7}$ In 2015, 2018, and 2019, domestic production of mineral concentrates was stockpiled or exported. Consumers of compounds and metals were reliant on imports and stockpiled inventory.

${ }^{8}$ Includes estimated yttrium-oxide equivalent content from the following Harmonized Tariff Schedule codes: 2846.90.2015, 2846.90.2082,

2846.90.4000, 2846.90.8050, and 2846.90.8060.

${ }^{9}$ See Appendix B for definitions.

${ }^{10}$ See Appendix $C$ for resource and reserve definitions and information concerning data sources.
} 


\section{ZEOLITES (NATURAL)}

(Data in metric tons unless otherwise noted)

Domestic Production and Use: In 2019, six companies in the United States operated nine zeolite mines and produced an estimated 98,000 tons of natural zeolites, a 14\% increase from that in 2018 . Two mines owned by an additional company were idle during the year, but zeolites may have been sold from ore stockpiles at one of these operations. Chabazite was mined in Arizona, and clinoptilolite was mined in California, Idaho, New Mexico, Oregon, and Texas. Minor quantities of erionite, ferrierrite, mordenite, and (or) phillipsite were also likely produced. New Mexico was estimated to be the leading natural zeolite-producing State in 2019, followed by, in descending order, California, Idaho, Texas, Oregon, and Arizona. The top three companies accounted for approximately $85 \%$ of total domestic production.

An estimated 92,000 tons of natural zeolites were sold in the United States during 2019 , an increase of $14 \%$ compared with sales in 2018. Domestic uses were, in decreasing order by estimated quantity, animal feed, odor control, unclassified end uses (such as ice melt, soil amendment, synthetic turf, etc.), water purification, pet litter, wastewater treatment, fungicide or pesticide carrier, oil and grease absorbent, gas absorbent (and air filtration), fertilizer carrier, desiccant, and aquaculture. Animal feed, odor control, and water purification applications likely accounted for about $70 \%$ of the domestic sales tonnage.

Salient Statistics_United States:

Production, mine

Sales, mill

Imports for consumptione

Exportse

Consumption, apparent ${ }^{1}$

Price, range of value, dollars per ton ${ }^{2}$

Employment, mine and mille, 3

Net import reliance ${ }^{4}$ as a percentage of

apparent consumption

$\begin{array}{rrrrr}\mathbf{2 0 1 5} & \mathbf{2 0 1 6} & \mathbf{2 0 1 7} & \underline{\mathbf{2 0 1 8}} & \underline{\underline{\mathbf{2 0 1 9}}} \\ 75,100 & 75,200 & 82,400 & 86,100 & 98,000 \\ 73,200 & 71,300 & 81,300 & 80,500 & 92,000 \\ <1,000 & <1,000 & <1,000 & <1,000 & <1,000 \\ <1,000 & <1,000 & <1,000 & <1,000 & <1,000 \\ 73,200 & 71,300 & 81,300 & 80,500 & 92,000 \\ 110-950 & 100-400 & 100-300 & e 50-300 & 50-300 \\ 100 & 115 & 110 & 110 & 120 \\ \text { E } & \text { E } & \text { E } & E & E\end{array}$

Recycling: Zeolites used for desiccation, gas absorbance, wastewater cleanup, and water purification may be reused after reprocessing of the spent zeolites. Information about the quantity of recycled natural zeolites was unavailable.

Import Sources (2015-18): Comprehensive trade data were not available for natural zeolite minerals because they were imported and exported under a generic U.S. Census Bureau Harmonized Tariff Schedule code that includes multiple mineral commodities or under codes for finished products. Nearly all imports and exports consisted of synthetic zeolites.

\section{Tariff: Item}

Mineral substances not elsewhere specified or included

Depletion Allowance: 14\% (Domestic and foreign).
Number

2530.90 .8050
Normal Trade Relations $\underline{12-31-19}$

Free.

Government Stockpile: None. 


\section{ZEOLITES (NATURAL)}

Events, Trends, and Issues: Prior to the 1990s, annual output of natural zeolites in the United States was less than 15,000 tons. Production rose more than sixfold from 1990 through 2019 owing predominantly to increases in sales for animal feed applications, although sales for odor control and water purification also increased significantly. In contrast, sales for pet litter declined substantially during this period as a result of competition from other products.

World Mine Production and Reserves: Many countries either do not report production of natural zeolites or production is reported with a 2- to 3-year lag time. End uses for natural zeolites in countries that mine large tonnages of zeolite minerals typically include low-value, high-volume construction applications, such as dimension stone, lightweight aggregate, and pozzolanic cement. As a result, production data for some countries may not accurately indicate the quantities of natural zeolites used in the high-value applications that are reflected in the domestic data.

World reserves of natural zeolites have not been estimated. Deposits occur in many countries, but companies rarely publish reserves data. Further complicating estimates of reserves is the fact that much of the reported world production includes altered volcanic tuffs with low to moderate concentrations of zeolites that are typically used in high-volume construction applications. Some deposits should, therefore, be excluded from reserves estimates because it is the rock itself and not its zeolite content that makes the deposit valuable.

Production data for multiple countries were revised based on information from Government and industry sources.

\begin{tabular}{lrr} 
& \multicolumn{2}{c}{ Mine production } \\
& $\mathbf{2 0 1 8}$ & $\mathbf{2 0 1 9}$ \\
United States & $\mathbf{8 6 , 1 0 0}$ & 98,000 \\
China & 320,000 & 320,000 \\
Cuba & 652,600 & 55,000 \\
Indonesia & 130,000 & 130,000 \\
Jordan & 10,000 & 10,000 \\
Korea, Republic of & 6144,000 & 150,000 \\
New Zealand & 100,000 & 100,000 \\
Russia & 35,000 & 35,000 \\
Slovakia & 117,000 & 120,000 \\
Turkey & 65,000 & 65,000 \\
Other countries & 75,000 & 75,000 \\
$\quad$ World total (rounded) & $1,100,000$ & $1,200,000$
\end{tabular}

\section{Reserves $^{5}$}

Two of the leading companies in the United States reported combined reserves of 80 million tons in 2019; total U.S. reserves likely are substantially larger. World data are unavailable, but reserves are estimated to be large.

World Resources: Recent estimates for domestic and global resources of natural zeolites are not available. Resources of chabazite and clinoptilolite in the United States are sufficient to satisfy foreseeable domestic demand.

Substitutes: For pet litter, zeolites compete with other mineral-based litters, such as those manufactured using bentonite, diatomite, fuller's earth, and sepiolite; organic litters made from shredded corn stalks and paper, straw, and wood shavings; and litters made using silica gel. Diatomite, perlite, pumice, vermiculite, and volcanic tuff compete with natural zeolite as lightweight aggregate. Zeolite desiccants compete against such products as magnesium perchlorate and silica gel. Zeolites compete with bentonite, gypsum, montmorillonite, peat, perlite, silica sand, and vermiculite in various soil amendment applications. Activated carbon, diatomite, or silica sand may substitute for zeolites in water-purification applications. As an oil absorbent, zeolites compete mainly with bentonite, diatomite, fuller's earth, sepiolite, and a variety of polymer and natural organic products. In animal feed, zeolites compete with bentonite, diatomite, fuller's earth, kaolin, silica, and talc as anticaking and flow-control agents.

\footnotetext{
eEstimated. E Net exporter.

${ }^{1}$ Defined as mill sales + imports - exports. Information about industry stocks was unavailable.

${ }^{2}$ Range of ex-works mine and mill unit values for individual natural zeolite operations, based on data reported by U.S. producers and U.S.

Geological Survey estimates. Average unit values per ton for the past 5 years were $\$ 150$ in $2015, \$ 140$ in 2016 and 2017 , and an estimated $\$ 125$ in 2018 and 2019. Prices vary with the percentage of zeolite present in the product, the chemical and physical properties of the zeolite mineral(s), particle size, surface modification and (or) activation, and end use.

${ }^{3}$ Excludes administration and office staff. Estimates based on data from the Mine Safety and Health Administration.

${ }^{4}$ Defined as imports - exports.

${ }^{5}$ See Appendix $\mathrm{C}$ for resource and reserve definitions and information concerning data sources.

${ }^{6}$ Reported figure.
} 


\section{ZINC}

(Data in thousand metric tons of zinc content unless otherwise noted)

Domestic Production and Use: The value of zinc mined in 2019, based on zinc contained in concentrate, was about $\$ 2.1$ billion. Zinc was mined in six States at 15 mines operated by five companies. Two smelter facilities, one primary and one secondary, operated by two companies, produced commercial-grade zinc metal. Of the total reported zinc consumed, most was used in galvanizing, followed by brass and bronze, zinc-based alloys, and other uses.

\begin{tabular}{|c|c|c|c|c|c|}
\hline $\begin{array}{l}\text { Salient Statistics_-United States: } \\
\text { Production: }\end{array}$ & $\underline{2015}$ & $\underline{2016}$ & $\underline{2017}$ & $\underline{2018}$ & $\underline{2019^{e}}$ \\
\hline Zinc in ore and concentrate & 825 & 805 & 774 & 824 & 78 \\
\hline Refined zinc ${ }^{1}$ & 172 & 126 & 132 & 116 & 120 \\
\hline \multicolumn{6}{|l|}{ Imports for consumption: } \\
\hline Zinc in ore and concentrate & $\left({ }^{2}\right)$ & $\left({ }^{2}\right)$ & 7 & $\left({ }^{2}\right)$ & \\
\hline Refined zinc & 771 & 713 & 729 & 775 & 830 \\
\hline \multicolumn{6}{|l|}{ Exports: } \\
\hline Zinc in ore and concentrate & 708 & 597 & 682 & 806 & \\
\hline Refined zinc & 13 & 47 & 33 & 23 & \\
\hline Shipments from Government stockpile & - & - & - & - & \\
\hline Consumption, apparent, refined zinc ${ }^{3}$ & 931 & 792 & 829 & 868 & 950 \\
\hline \multicolumn{6}{|l|}{ Price, average, cents per pound: } \\
\hline North American ${ }^{4}$ & 95.5 & 101.4 & 139.3 & 141.0 & 125.0 \\
\hline London Metal Exchange (LME), cash & 87.6 & 94.8 & 131.2 & 132.7 & 117.0 \\
\hline $\begin{array}{l}\text { Reported producer and consumer stocks, refined zinc, } \\
\text { yearend }\end{array}$ & 87 & 80 & 112 & 117 & 12 \\
\hline \multicolumn{6}{|l|}{ Employment: } \\
\hline Mine and mill, number ${ }^{5}$ & 2,690 & 2,350 & 2,420 & 2,630 & 2,500 \\
\hline Smelter, primary, number & 250 & 246 & 240 & 250 & 250 \\
\hline \multicolumn{6}{|l|}{$\begin{array}{l}\text { Net import reliance } 6 \text { as a percentage of } \\
\text { apparent consumption: }\end{array}$} \\
\hline Ore and concentrate & $\mathrm{E}$ & $\mathrm{E}$ & $\mathrm{E}$ & $\mathrm{E}$ & \\
\hline Refined zinc & 81 & 84 & 84 & 87 & \\
\hline
\end{tabular}

Recycling: In 2019, about 25\% (30,000 tons) of the refined zinc produced in the United States was recovered from secondary materials at both primary and secondary smelters. Secondary materials included galvanizing residues and crude zinc oxide recovered from electric arc furnace dust.

Import Sources (2015-18): Ore and concentrate: Peru, 98\%; and other, 2\%. Refined metal: Canada, 64\%; Mexico, 13\%; Australia, 7\%; Peru, 7\%; and other, 9\%. Waste and scrap (gross weight): Canada, 72\%; Mexico, 28\%; and other, $<1 \%$. Combined total (includes gross weight of waste and scrap): Canada, 64\%; Mexico, 13\%; Australia, 7\%; Peru, 7\%; and other, $9 \%$.

\section{Tariff: Item}

Zinc ores and concentrates, Zn content

Zinc oxide; zinc peroxide

Unwrought zinc, not alloyed:

Containing $99.99 \%$ or more zinc

Containing less than $99.99 \%$ zinc:

Casting-grade

Other

Zinc alloys

Zinc waste and scrap

\section{Number}

2608.00.0030

2817.00.0000

7901.11 .0000

7901.12 .1000

7901.12 .5000

7901.20 .0000

7902.00 .0000

\author{
Normal Trade Relations \\ 12-31-19 \\ Free. \\ Free.
}

$1.5 \%$ ad val.

$3 \%$ ad val.

$1.5 \%$ ad val.

$3 \%$ ad val.

Free.

Depletion Allowance: 22\% (Domestic), 14\% (Foreign).

\section{Government Stockpile: ${ }^{7}$}

$\begin{array}{lc} & \begin{array}{c}\text { Inventory } \\ \text { Material }\end{array} \\ \text { Zinc of 9-30-19 } & 7.25\end{array}$

FY 2019

$\begin{array}{cc}\begin{array}{c}\text { Potential } \\ \text { Acquisitions }\end{array} & \begin{array}{c}\text { Potential } \\ \text { Disposals }\end{array} \\ - & 7.25\end{array}$

FY 2020

$\begin{array}{cc}\text { Potential } & \text { Potential } \\ \text { Acquisitions } & \begin{array}{c}\text { Disposals } \\ -\end{array} \\ & 7.25\end{array}$

Prepared by Amy C. Tolcin [(703) 648-4940, atolcin@usgs.gov] 
Events, Trends, and Issues: Global zinc mine production in 2019 was estimated to be 13 million tons, a 4\% increase from that of 2018. Notable zinc mine production increases took place in Australia, China, and South Africa. In Australia, the Woodlawn tailings project opened in May and significant increases in production took place at the Dugald River Mine, the Lady Loretta Mine, and two tailings reprocessing projects commissioned in 2018. In South Africa, production increased at the Gamsberg Mine, which was commissioned in late 2018.

According to the International Lead and Zinc Study Group, ${ }^{8}$ global refined zinc production in 2019 was estimated to be 13.49 million tons, and metal consumption was estimated to be 13.67 million tons, resulting in a production-toconsumption deficit of about 180,000 tons of refined zinc.

Domestic zinc mine production decreased in 2019, owing partially to the closure of the Pend Oreille Mine in Washington State in July after current reserves were exhausted. The mine was reopened in December 2014 after being closed since 2009. U.S. apparent consumption of refined zinc increased to a 5-year high of 950,000 tons in 2019. The estimated annual average North American Special High Grade (SHG) zinc price decreased by $11 \%$ in 2019 from that in 2018 to $\$ 1.25$ per pound.

World Mine Production and Reserves: Reserves for Australia, Canada, India, Kazakhstan, Mexico, Peru, Russia, and Sweden were revised based on Government or industry reports.

\begin{tabular}{lrrr} 
& \multicolumn{2}{c}{ Mine } & production \\
& $\mathbf{2 0 1 8}$ & $\underline{\mathbf{2 0 1 9}}$ & Reserves $^{\mathbf{1 0}}$ \\
United States & 824 & 780 & 11,000 \\
Australia & 1,110 & 1,300 & 1168,000 \\
Bolivia & 480 & 460 & 4,800 \\
Canada & 287 & 300 & 2,200 \\
China & 4,170 & 4,300 & 44,000 \\
India & 750 & 800 & 7,500 \\
Kazakhstan & 304 & 290 & 12,000 \\
Mexico & 691 & 690 & 22,000 \\
Peru & 1,470 & 1,400 & 19,000 \\
Russia & 300 & 300 & 22,000 \\
Sweden & 234 & 230 & 3,600 \\
Other countries & 1,840 & 1,900 & 34,000 \\
$\quad$ World total (rounded) & 12,500 & 13,000 & 250,000
\end{tabular}

World Resources: Identified zinc resources of the world are about 1.9 billion tons.

Substitutes: Aluminum and plastics substitute for galvanized sheet in automobiles; aluminum alloys, cadmium, paint, and plastic coatings replace zinc coatings in other applications. Aluminum- and magnesium-base alloys are major competitors for zinc-base diecasting alloys. Many elements are substitutes for zinc in chemical, electronic, and pigment uses.

\footnotetext{
eEstimated. E Net exporter. - Zero.

${ }^{1}$ Includes primary and secondary refined production.

${ }^{2}$ Less than $1 / 2$ unit.

${ }^{3}$ Defined as refined production + refined imports - refined exports + adjustments for Government stock changes.

${ }^{4}$ Platts Metals Week price for North American SHG zinc; based on the LME cash price plus premium.

${ }^{5}$ Includes mine and mill employment at all zinc-producing mines. Source: Mine Safety and Health Administration.

${ }^{6}$ Defined as imports - exports + adjustments for Government stock changes.

${ }^{7}$ See Appendix B for definitions.

${ }^{8}$ International Lead and Zinc Study Group, 2019, ILZSG session/forecasts: Lisbon, Portugal, International Lead and Zinc Study Group press

release, October $28,7 \mathrm{p}$.

${ }^{9}$ Zinc content of concentrate and direct shipping ore.

${ }^{10}$ See Appendix $C$ for resource and reserve definitions and information concerning data sources.

${ }^{11}$ For Australia, Joint Ore Reserves Committee-compliant reserves were 25 million tons.
} 


\section{ZIRCONIUM AND HAFNIUM}

(Data in metric tons unless otherwise noted)

Domestic Production and Use: In 2019, two firms recovered zircon (zirconium silicate) from surface-mining operations in Florida and Georgia as a coproduct from the mining of heavy-mineral sands and the processing of titanium and zirconium mineral concentrates, and a third company processed existing mineral sands tailings in Florida. Zirconium metal and hafnium metal were produced from zirconium chemical intermediates by one producer in Oregon and one in Utah. Zirconium and hafnium are typically contained in zircon at a ratio of about 36 to 1 . Zirconium chemicals were produced by the metal producer in Oregon and by at least 10 other companies. Ceramics, foundry sand, opacifiers, and refractories are the leading end uses for zircon. Other end uses of zircon include abrasives, chemicals (predominantly, zirconium basic sulfate and zirconium oxychloride octohydrate as intermediate chemicals), metal alloys, and welding rod coatings. The leading consumers of zirconium metal are the chemical process and nuclear energy industries. The leading use of hafnium metal is in superalloys.

Salient Statistics-United States:

Production, zirconium ores and concentrates $\left(\mathrm{ZrO}_{2} \text { content }\right)^{1}$ Imports:

Zirconium ores and concentrates ( $\mathrm{ZrO}_{2}$ content)

Zirconium, unwrought, powder, and waste and scrap

Zirconium, wrought

Hafnium, unwrought, powder, and waste and scrap

Exports:

Zirconium ores and concentrates ( $\mathrm{ZrO}_{2}$ content)

Zirconium, unwrought, powder, and waste and scrap

Zirconium, wrought

Consumption, apparent, zirconium ores and concentrates, $\left(\mathrm{ZrO}_{2} \text { content }\right)^{3}$

Prices:

Zircon, dollars per metric ton (gross weight):

Australia, free on board ${ }^{4}$

China, cost insurance and freight ${ }^{5}$ Imported 6

Zirconium, unwrought, import, China, dollars per kilogram ${ }^{7}$

Hafnium, unwrought, dollars per kilogram ${ }^{5}$

Net import reliance ${ }^{8}$ as a percentage of apparent consumption:

Zirconium ores and concentrates

Hafnium

$\begin{array}{rrrrr}\underline{\mathbf{2 0 1 5}} & \underline{\mathbf{2 0 1 6}} & \underline{\mathbf{2 0 1 7}} & \mathbf{2 0 1 8} & \underline{\mathbf{2 0 1 9}} \\ 250,000 & & 250,000 & 2100,000 & 2100,000 \\ 20,800 & 24,900 & 24,300 & 26,400 & 24,000 \\ 1,140 & 1,040 & 899 & 1,880 & 2,200 \\ 188 & 195 & 282 & 284 & 320 \\ 72 & 180 & 113 & 41 & 30 \\ & & & & \\ 3,200 & 3,280 & 31,500 & 77,500 & 52,000 \\ 515 & 363 & 627 & 556 & 730 \\ 1,020 & 788 & 972 & 1,150 & 950 \\ & & & & \\ 270,000 & W & 240,000 & 250,000 & 250,000 \\ & & & & \\ 1,025 & 975 & 975 & \mathrm{NA} & \mathrm{NA} \\ \mathrm{NA} & \mathrm{NA} & 1,295 & 1,625 & 1,630 \\ 1,061 & 877 & 916 & 1,290 & 1,500 \\ 15 & 33 & 12 & 13 & 16 \\ 1,250 & 930 & 900 & 840 & 830 \\ & & & & \\ <25 & <50 & \mathrm{E} & \mathrm{E} & \mathrm{E} \\ \mathrm{NA} & \mathrm{NA} & \mathrm{NA} & \mathrm{NA} & \mathrm{NA}\end{array}$

Recycling: Companies in Oregon and Utah recycled zirconium from new scrap generated during metal production and fabrication and (or) from post-commercial old scrap. Zircon foundry mold cores and spent or rejected zirconia refractories are often recycled. Hafnium metal recycling was insignificant.

Import Sources (2015-18): Zirconium ores and concentrates: South Africa, 53\%; Senegal, 28\%; Australia, 15\%; Russia, 2\%; and other, 2\%. Zirconium, unwrought, including powder: China, 78\%; Germany, 14\%; Japan, 5\%; France, 2\%; and other, 1\%. Hafnium, unwrought: Germany, 45\%; France, 29\%; China, 15\%; United Kingdom, 11\%; and other, $<1 \%$.

Tariff: Item

Zirconium ores and concentrates

Ferrozirconium

Zirconium, unwrought and powder

Zirconium waste and scrap

Other zirconium articles

Hafnium, unwrought, powder, and waste and scrap
Number

2615.10.0000

7202.99 .1000

8109.20 .0000

8109.30 .0000

8109.90 .0000

8112.92 .2000
Normal Trade Relations

12-31-19

Free.

$4.2 \%$ ad val.

$4.2 \%$ ad val.

Free.

$3.7 \%$ ad val.

Free. 


\section{ZIRCONIUM AND HAFNIUM}

Depletion Allowance: 22\% (Domestic), 14\% (Foreign).

Government Stockpile: None.

Events, Trends, and Issues: The average unit value for imports of zircon concentrates increased for the third year in a row. The average unit value for exports of zircon concentrates rose slightly in 2019 compared with 2018.

In China, zircon production was estimated to have decreased significantly. It was reported that China began conducting environmental inspections in July in the Provinces of Chongqing, Fujian, Gansu, Hainan, Qinghai, and Shanghai, which resulted in mine and plant closures, including zircon mines in Hainan Province. It was uncertain how long the mines and plants would be closed.

During 2019, several large mining projects with zirconium were in development but construction had not begun on any them. In Western Australia, the Thunderbird mineral sands project received full permitting, secured a 15-year agreement with a provider of liquified natural gas, and was seeking full funding of the project. In New South Wales, Australia, the Dubbo polymetallic project also received full permitting and was seeking funding. In Siberia, construction was to begin in the second half of 2019 at the Tugan titanium-zirconium deposit but concerns regarding funding delayed the start of work.

World Mine Production and Reserves: World primary hafnium production data are not available and quantitative estimates of hafnium reserves are not available. Zirconium reserves for Kenya and South Africa were revised based on company reporting.

\begin{tabular}{|c|c|c|c|}
\hline & \multicolumn{2}{|c|}{$\begin{array}{l}\text { Zirconium ores and concentrates, mine production } \\
\text { (thousand metric tons, gross weight) }\end{array}$} & \multirow[t]{2}{*}{$\begin{array}{l}\text { Zirconium reserves }^{9} \\
\text { (thousand metric tons, } \mathrm{ZrO}_{2} \text { content) }\end{array}$} \\
\hline & 2018 & $2019^{e}$ & \\
\hline United States & $\frac{5100}{2100}$ & $\frac{2100}{2100}$ & 500 \\
\hline Australia & 560 & 550 & 1042,000 \\
\hline China & 140 & 80 & 500 \\
\hline Kenya & 45 & 50 & 120 \\
\hline Mozambique & 48 & 50 & 1,800 \\
\hline Senegal & 64 & 70 & NA \\
\hline South Africa & 350 & 370 & 6,500 \\
\hline Other countries & 170 & 170 & 11,000 \\
\hline World total (rounded) & $\overline{1.480}$ & $\overline{1.400}$ & 62,000 \\
\hline
\end{tabular}

World Resources: Resources of zircon in the United States included about 14 million tons associated with titanium resources in heavy-mineral-sand deposits. Phosphate rock and sand and gravel deposits could potentially yield substantial amounts of zircon as a byproduct. World resources of hafnium are associated with those of zircon and baddeleyite. Quantitative estimates of hafnium resources are not available.

Substitutes: Chromite and olivine can be used instead of zircon for some foundry applications. Dolomite and spinel refractories can also substitute for zircon in certain high-temperature applications. Niobium (columbium), stainless steel, and tantalum provide limited substitution in nuclear applications, and titanium and synthetic materials may substitute in some chemical processing plant applications. Silver-cadmium-indium control rods are used in lieu of hafnium at numerous nuclear powerplants. Zirconium can be used interchangeably with hafnium in certain superalloys.

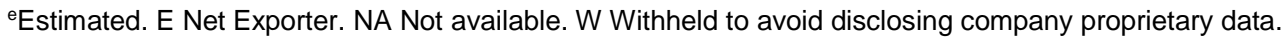

${ }^{1}$ Contained $\mathrm{ZrO}_{2}$ content calculated at $65 \%$ of gross production.

${ }^{2}$ Rounded to one significant digit to avoid disclosing company proprietary data.

${ }^{3}$ Defined as production + imports - exports.

${ }^{4}$ Source: Industrial Minerals, average of yearend price. Prices of zircon from Australia were discontinued at yearend 2017.

${ }^{5}$ Source: Argus Media group-Argus Metals International, average of yearend price.

${ }^{6}$ Unit value based on annual United States imports for consumption from Australia, Senegal, and South Africa.

${ }^{7}$ Unit value based on annual United States imports for consumption from China.

${ }^{8}$ Defined as imports - exports.

${ }^{9}$ See Appendix $\mathrm{C}$ for resource and reserve definitions and information concerning data sources.

${ }^{10}$ For Australia, Joint Ore Reserves Committee-compliant reserves were 13 million tons.
} 


\section{APPENDIX A}

\section{Abbreviations and Units of Measure}

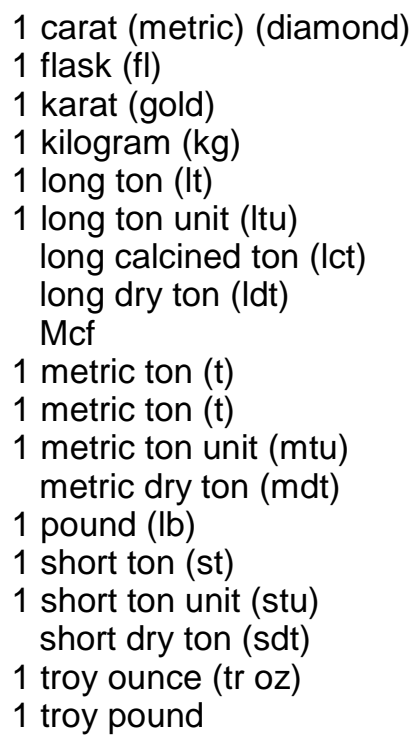

$=200$ milligrams

$=76$ pounds, avoirdupois

$=$ one twenty-fourth part

$=2.2046$ pounds, avoirdupois

$=2,240$ pounds, avoirdupois

$=1 \%$ of 1 long ton or 22.4 pounds, avoirdupois

$=$ excludes water of hydration

$=$ excludes excess free moisture

$=1,000$ cubic feet

$=2,204.6$ pounds, avoirdupois, or 1,000 kilograms

$=1.1023$ short ton

$=1 \%$ of 1 metric ton or 10 kilograms

$=$ excludes excess free moisture

$=453.6$ grams

$=2,000$ pounds, avoirdupois

$=1 \%$ of 1 short ton or 20 pounds, avoirdupois

$=$ excludes excess free moisture

$=1.09714$ avoirdupois ounces or 31.103 grams

$=12$ troy ounces

\section{APPENDIX B}

\section{Definitions of Selected Terms Used in This Report}

\section{Terms Used for Materials in the National Defense Stockpile and Helium Stockpile}

Inventory refers to the quantity of mineral materials held in the National Defense Stockpile or in the Federal Helium Reserve. Nonstockpile-grade materials may be included in the table; where significant, the quantities of these stockpiled materials are specified in the text accompanying the table.

Potential disposals indicate the total amount of a material in the National Defense Stockpile that the U.S. Department of Defense is permitted to dispose of under the Annual Materials Plan approved by Congress for the fiscal year. Congress has authorized disposal over the long term at rates designed to maximize revenue but avoid undue disruption to the usual markets and financial loss to the United States. Fiscal year (FY) 2019 is the period from October 1, 2018, through September 30, 2019. FY 2020 is the period from October 1, 2019, through September 30, 2020. Disposals are defined as any disposal or sale of National Defense Stockpile stock. For mineral commodities that have a disposal plan greater than the inventory, the actual quantity will be limited to the remaining disposal authority or inventory. Unlike sales from the National Defense Stockpile, helium sales by the Bureau of Land Management under the Helium Privatization Act of 1996 are permitted to exceed disposal plans.

Potential acquisitions indicate the maximum amount of a material that may be acquired by the U.S. Department of Defense for the National Defense Stockpile under the Annual Materials Plan approved by Congress for the fiscal year. FY 2019 is the period from October 1, 2018, through September 30, 2019. FY 2020 is the period from October 1, 2019, through September 30, 2020.

\section{Depletion Allowance}

The depletion allowance is a business tax deduction analogous to depreciation, but which applies to an ore reserve rather than equipment or production facilities. Federal tax law allows this deduction from taxable corporate income, recognizing that an ore deposit is a depletable asset that must eventually be replaced. 


\section{APPENDIX C-Reserves and Resources}

Reserves data are dynamic. They may be reduced as ore is mined and (or) the feasibility of extraction diminishes, or more commonly, they may continue to increase as additional deposits (known or recently discovered) are developed, or currently exploited deposits are more thoroughly explored and (or) new technology or economic variables improve their economic feasibility. Reserves may be considered a working inventory of mining companies' supplies of an economically extractable mineral commodity. As such, the magnitude of that inventory is necessarily limited by many considerations, including cost of drilling, taxes, price of the mineral commodity being mined, and the demand for it. Reserves will be developed to the point of business needs and geologic limitations of economic ore grade and tonnage. For example, in 1970, identified and undiscovered world copper resources were estimated to contain 1.6 billion metric tons of copper, with reserves of about 280 million tons of copper. Since then, almost 560 million tons of copper have been produced worldwide, but world copper reserves in 2019 were estimated to be 870 million tons of copper, more than triple those of 1970 , despite the depletion by mining of more than the original estimated reserves.

Future supplies of minerals will come from reserves and other identified resources, currently undiscovered resources in deposits that will be discovered in the future, and material that will be recycled from current inuse stocks of minerals or from minerals in waste disposal sites. Undiscovered deposits of minerals constitute an important consideration in assessing future supplies. Mineral-resource assessments have been carried out for small parcels of land being evaluated for land reclassification, for the Nation, and for the world.

\section{Part A-Resource/Reserve Classification for Minerals ${ }^{1}$}

\section{INTRODUCTION}

Through the years, geologists, mining engineers, and others operating in the minerals field have used various terms to describe and classify mineral resources, which as defined herein include energy materials. Some of these terms have gained wide use and acceptance, although they are not always used with precisely the same meaning.

The USGS collects information about the quantity and quality of all mineral resources. In 1976, the USGS and the U.S. Bureau of Mines developed a common classification and nomenclature, which was published as USGS Bulletin 1450-A-"Principles of the Mineral Resource Classification System of the U.S. Bureau of Mines and U.S. Geological Survey." Experience with this resource classification system showed that some changes were necessary in order to make it more workable in practice and more useful in long-term planning. Therefore, representatives of the USGS and the U.S. Bureau of Mines collaborated to revise Bulletin 1450-A. Their work was published in 1980 as USGS Circular 831- "Principles of a Resource/Reserve Classification for Minerals."

Long-term public and commercial planning must be based on the probability of discovering new deposits, on developing economic extraction processes for currently unworkable deposits, and on knowing which resources are immediately available. Thus, resources must be continuously reassessed in the light of new geologic knowledge, of progress in science and technology, and of shifts in economic and political conditions. To best serve these planning needs, known resources should be classified from two standpoints: (1) purely geologic or physical/chemical characteristics-such as grade, quality, tonnage, thickness, and depth-of the material in place; and (2) profitability analyses based on costs of extracting and marketing the material in a given economy at a given time. The former constitutes important objective scientific information of the resource and a relatively unchanging foundation upon which the latter more valuable economic delineation can be based.

The revised classification system, designed generally for all mineral materials, is shown graphically in figures 1 and 2; its components and their usage are described in the text. The classification of mineral and energy resources is necessarily arbitrary because definitional criteria do not always coincide with natural boundaries. The system can be used to report the status of mineral and energy-fuel resources for the Nation or for specific areas. $^{1}$

\section{RESOURCE/RESERVE DEFINITIONS}

A dictionary definition of resource, "something in reserve or ready if needed," has been adapted for mineral and energy resources to comprise all materials, including those only surmised to exist, that have present or anticipated future value.

Resource.-A concentration of naturally occurring solid, liquid, or gaseous material in or on the Earth's crust in such form and amount that economic extraction of a commodity from the concentration is currently or potentially feasible.

Original Resource.-The amount of a resource before production.

Identified Resources.-Resources whose location, grade, quality, and quantity are known or estimated from specific geologic evidence. Identified resources include economic, marginally economic, and subeconomic components. To reflect varying degrees of geologic certainty, these economic divisions can be subdivided into measured, indicated, and inferred.

${ }^{1}$ Based on U.S. Geological Survey Circular 831, 1980. 
Demonstrated.-A term for the sum of measured plus indicated.

Measured.-Quantity is computed from dimensions revealed in outcrops, trenches, workings, or drill holes; grade and (or) quality are computed from the results of detailed sampling. The sites for inspection, sampling, and measurements are spaced so closely and the geologic character is so well defined that size, shape, depth, and mineral content of the resource are well established.

Indicated.-Quantity and grade and (or) quality are computed from information similar to that used for measured resources, but the sites for inspection, sampling, and measurement are farther apart or are otherwise less adequately spaced. The degree of assurance, although lower than that for measured resources, is high enough to assume continuity between points of observation.

Inferred.-Estimates are based on an assumed continuity beyond measured and (or) indicated resources, for which there is geologic evidence. Inferred resources may or may not be supported by samples or measurements.

Reserve Base.-That part of an identified resource that meets specified minimum physical and chemical criteria related to current mining and production practices, including those for grade, quality, thickness, and depth. The reserve base is the inplace demonstrated (measured plus indicated) resource from which reserves are estimated. It may encompass those parts of the resources that have a reasonable potential for becoming economically available within planning horizons beyond those that assume proven technology and current economics. The reserve base includes those resources that are currently economic (reserves), marginally economic (marginal reserves), and some of those that are currently subeconomic (subeconomic resources). The term "geologic reserve" has been applied by others generally to the reserve-base category, but it also may include the inferred-reserve-base category; it is not a part of this classification system.

Inferred Reserve Base.-The in-place part of an identified resource from which inferred reserves are estimated. Quantitative estimates are based largely on knowledge of the geologic character of a deposit and for which there may be no samples or measurements. The estimates are based on an assumed continuity beyond the reserve base, for which there is geologic evidence.

Reserves.-That part of the reserve base which could be economically extracted or produced at the time of determination. The term reserves need not signify that extraction facilities are in place and operative. Reserves include only recoverable materials; thus, terms such as "extractable reserves" and "recoverable reserves" are redundant and are not a part of this classification system.

Marginal Reserves.-That part of the reserve base which, at the time of determination, borders on being economically producible. Its essential characteristic is economic uncertainty. Included are resources that would be producible, given postulated changes in economic or technological factors.
Economic.-This term implies that profitable extraction or production under defined investment assumptions has been established, analytically demonstrated, or assumed with reasonable certainty.

Subeconomic Resources.-The part of identified resources that does not meet the economic criteria of reserves and marginal reserves.

Undiscovered Resources.-Resources, the existence of which are only postulated, comprising deposits that are separate from identified resources. Undiscovered resources may be postulated in deposits of such grade and physical location as to render them economic, marginally economic, or subeconomic. To reflect varying degrees of geologic certainty, undiscovered resources may be divided into two parts, as follows:

Hypothetical Resources.-Undiscovered resources that are similar to known mineral bodies and that may be reasonably expected to exist in the same producing district or region under analogous geologic conditions. If exploration confirms their existence and reveals enough information about their quality, grade, and quantity, they will be reclassified as identified resources.

Speculative Resources.-Undiscovered resources that may occur either in known types of deposits in favorable geologic settings where mineral discoveries have not been made, or in types of deposits as yet unrecognized for their economic potential. If exploration confirms their existence and reveals enough information about their quantity, grade, and quality, they will be reclassified as identified resources.

Restricted Resources/Reserves.-That part of any resource/reserve category that is restricted from extraction by laws or regulations. For example, restricted reserves meet all the requirements of reserves except that they are restricted from extraction by laws or regulations.

Other Occurrences.-Materials that are too low grade or for other reasons are not considered potentially economic, in the same sense as the defined resource, may be recognized and their magnitude estimated, but they are not classified as resources. A separate category, labeled other occurrences, is included in figures 1 and 2 . In figure 1, the boundary between subeconomic and other occurrences is limited by the concept of current or potential feasibility of economic production, which is required by the definition of a resource. The boundary is obviously uncertain, but limits may be specified in terms of grade, quality, thickness, depth, percent extractable, or other economic-feasibility variables.

Cumulative Production.-The amount of past cumulative production is not, by definition, a part of the resource. Nevertheless, a knowledge of what has been produced is important in order to understand current resources, in terms of both the amount of past production and the amount of residual or remaining in-place resource. A separate space for cumulative production is shown in figures 1 and 2 . Residual material left in the ground during current or future extraction should be recorded in the resource category appropriate to its economic-recovery potential. 
Figure 1.-Major Elements of Mineral-Resource Classification, Excluding Reserve Base and Inferred Reserve Base

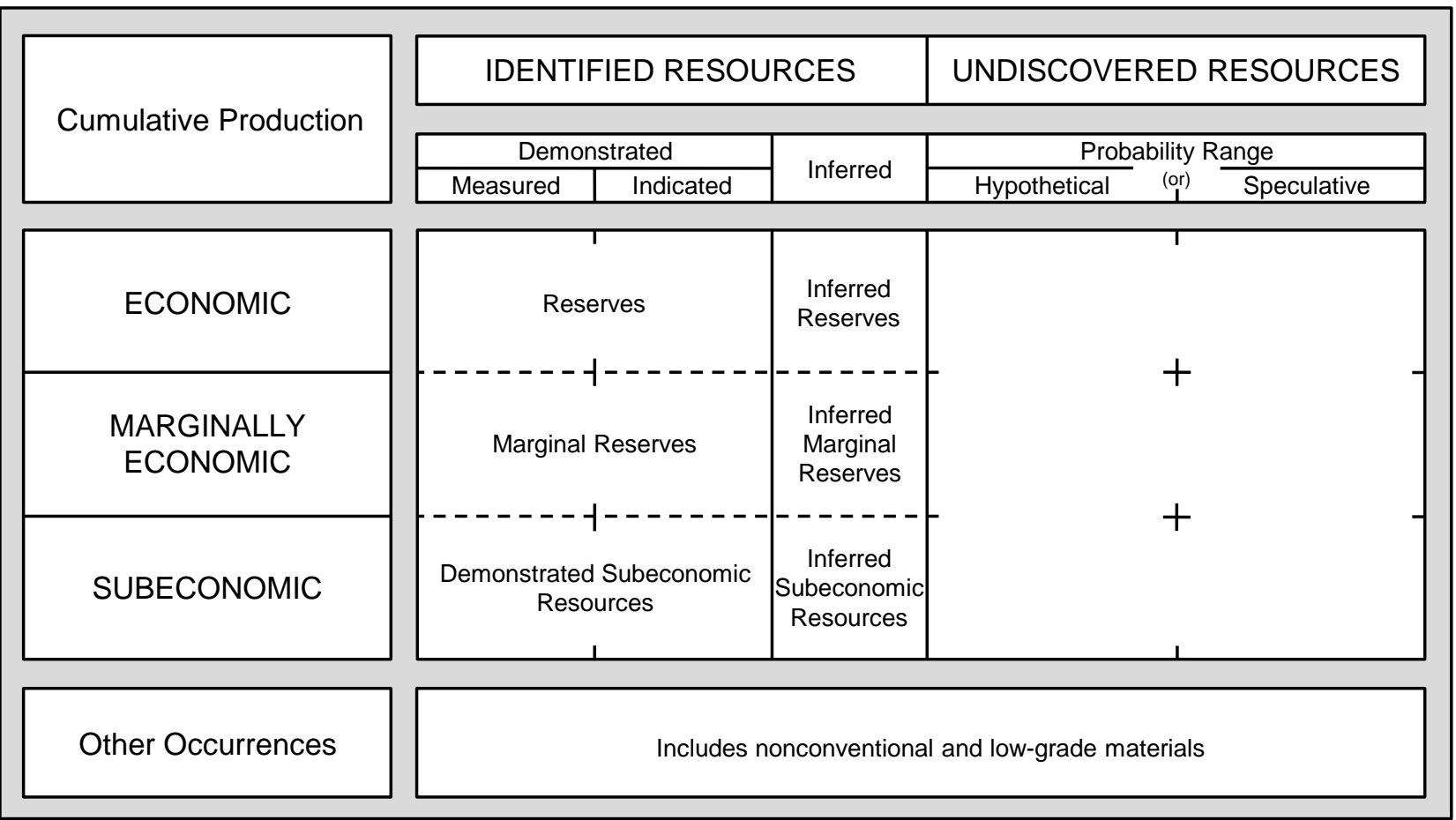

Figure 2.-Reserve Base and Inferred Reserve Base Classification Categories

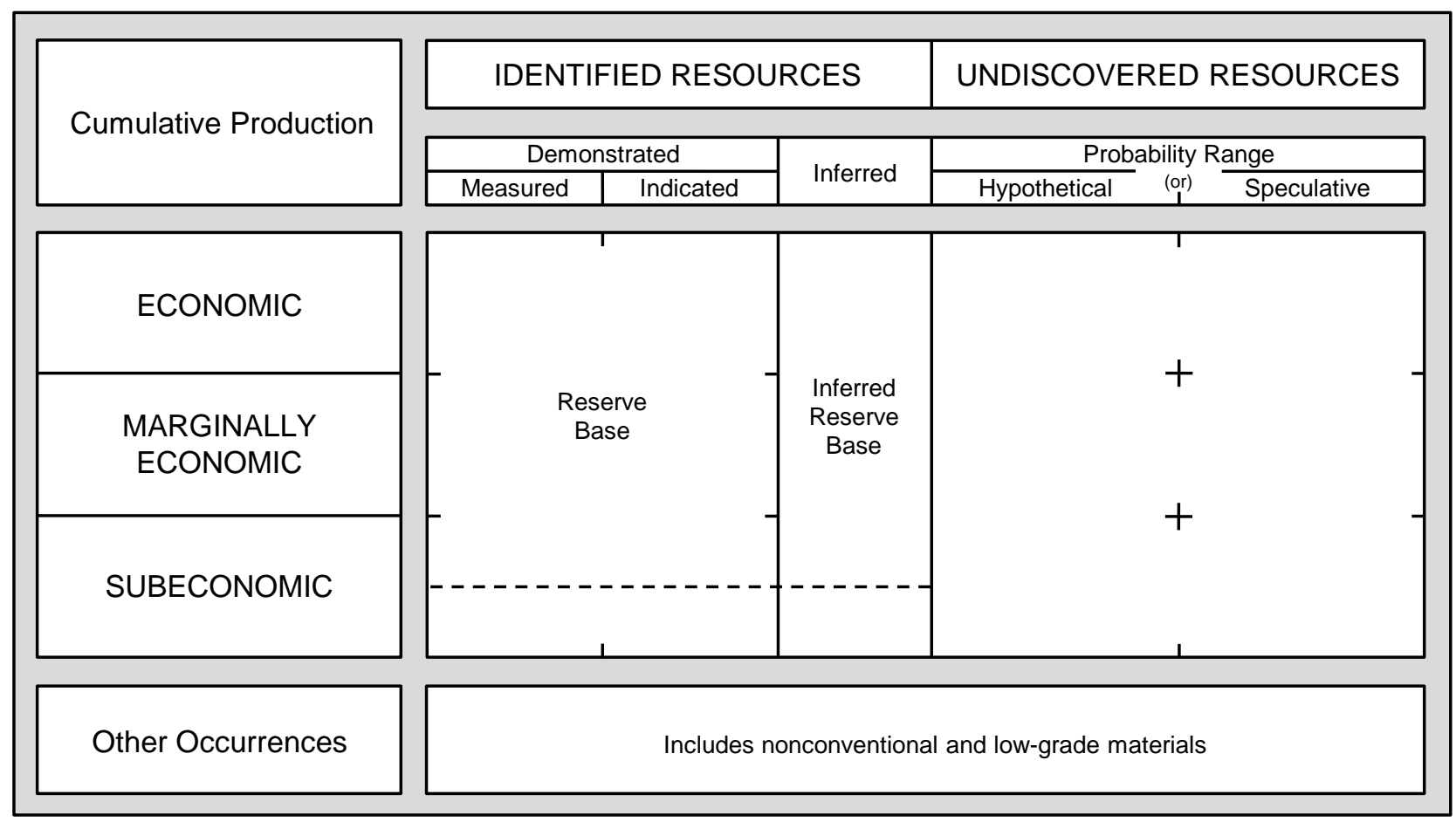




\section{Part B-Sources of Reserves Data}

National information on reserves for most mineral commodities found in this report, including those for the United States, is derived from a variety of sources. The ideal source of such information would be comprehensive evaluations that apply the same criteria to deposits in different geographic areas and report the results by country. In the absence of such evaluations, national reserves estimates compiled by countries for selected mineral commodities are a primary source of national reserves information. Lacking national assessment information by governments, sources such as academic articles, company reports, presentations by company representatives, and trade journal articles, or a combination of these, serve as the basis for national information on reserves reported in the mineral commodity sections of this publication.

A national estimate may be assembled from the following: historically reported reserves information carried for years without alteration because no new information is available, historically reported reserves reduced by the amount of historical production, and company-reported reserves. International minerals availability studies conducted by the U.S. Bureau of Mines before 1996 and estimates of identified resources by an international collaborative effort (the International Strategic Minerals Inventory) are the bases for some reserves estimates. The USGS collects information about the quantity and quality of mineral resources but does not directly measure reserves, and companies or governments do not directly report reserves to the USGS. Reassessment of reserves is a continuing process, and the intensity of this process differs for mineral commodities, countries, and time period.

Some countries have specific definitions for reserves data, and reserves for each country are assessed separately, based on reported data and definitions. An attempt is made to make reserves consistent among countries for a mineral commodity and its byproducts. For example, the Australasian Joint Ore Reserves Committee (JORC) established the Australasian Code for Reporting of Exploration Results, Mineral Resources and Ore Reserves (the JORC Code) that sets out minimum standards, recommendations, and guidelines for public reporting in Australasia of exploration results, mineral resources, and ore reserves. Companies listed on the Australian Securities Exchange and the New Zealand Stock Exchange are required to report publicly on ore reserves and mineral resources under their control, using the JORC Code.

Data reported for individual deposits by mining companies are compiled in Geoscience Australia's national mineral resources database and used in the preparation of the annual national assessments of Australia's mineral resources. Because of its specific use in the JORC Code, the term "reserves" is not used in the national inventory, where the highest category is "Economic Demonstrated Resources" (EDR). In essence, EDR combines the JORC Code categories proved reserves and probable reserves, plus measured resources and indicated resources. This is considered to provide a reasonable and objective estimate of what is likely to be available for mining in the long term. Accessible Economic Demonstrated Resources represent the resources within the EDR category that are accessible for mining. Reserves for Australia in Mineral Commodity Summaries 2020 are Accessible EDR. For more information, see table 3. Australia's Identified Mineral Resources as of December 2017 can be found at https://d28rz98at9flks.cloudfront.net/124309 /124309_AIMR.pdf.

In Canada, the Canadian Institute of Mining, Metallurgy and Petroleum (CIM) provides definition standards for the classification of mineral resources and mineral reserves estimates into various categories. The category to which a resource or reserves estimate is assigned depends on the level of confidence in the geologic information available on the mineral deposit, the quality and quantity of data available on the deposit, the level of detail of the technical and economic information that has been generated about the deposit, and the interpretation of the data and information. For more information on the CIM definition standards, see https://mrmr.cim.org/en/standards/canadian-mineralresource-and-mineral-reserve-definitions/.

In Russia, reserves for most minerals can appear in a number of sources, although no comprehensive list of reserves is published. Reserves data for a limited set of mineral commodities are available in the annual report "Gosudarstvennyi Doklad o Sostoyanii i Ispol'zovanii Mineral'no-Syryevyh Resursov Rossiyskoy Federatsii" (State report on the state and use of mineral and raw materials resources of the Russian Federation), which is published by the Ministry of Natural Resources and Environment of the Russian Federation. Reserves data for various minerals appear at times in journal articles, such as those in the journal "Mineral'nyye Resursy Rossii. Ekonomika i Upravleniye" (Mineral Resources of Russia. Economics and Management), which is published by the "OOO RG-Inform," a subsidiary of Rosgeologiya Holding. It is sometimes not clear if the reserves are being reported in ore or mineral content. It is also in many cases not clear which definition of reserves is being used, because the system inherited from the former Soviet Union has a number of ways in which the term "reserves" is defined, and these definitions qualify the percentage of reources that are included in a specific category. For example, the Soviet reserves classification system, besides the categories $A, B, C 1$, and C2, which represent progressively detailed knowledge of a mineral deposit based on exploration data, has other subcategories cross imposed upon the system. Under the broad category reserves (zapasy), there are subcategories that include balance reserves (economic reserves or balansovyye zapasy) and outside-the-balance reserves (noneconomic reserves or zabalansovye zapasy), as well as categories that include explored, industrial, and proven reserves, and the reserves totals can vary significantly, depending on the specific definition of reserves being reported. 


\section{APPENDIX D}

\section{Country Specialists Directory}

Minerals information country specialists at the U.S. Geological Survey collect and analyze information on the mineral industries of more than 170 nations throughout the world. The specialists are available to answer minerals-related questions concerning individual countries.

\begin{tabular}{|c|c|}
\hline Africa and the Middle East & \\
\hline Algeria & Mowafa Taib \\
\hline Angola & Meralis Plaza-Toledo \\
\hline Bahrain & Philip A. Szczesniak \\
\hline Benin & Meralis Plaza-Toledo \\
\hline Botswana & Thomas R. Yager \\
\hline Burkina Faso & Alberto A. Perez \\
\hline Burundi & Thomas R. Yager \\
\hline Cabo Verde & Meralis Plaza-Toledo \\
\hline Cameroon & Philip A. Szczesniak \\
\hline Central African Republic & James J. Barry \\
\hline Chad & Philip A. Szczesniak \\
\hline Comoros & James J. Barry \\
\hline Congo (Brazzaville) & James J. Barry \\
\hline Congo (Kinshasa) & Thomas R. Yager \\
\hline Côte d'Ivoire & Alberto A. Perez \\
\hline Diibouti & Thomas R. Yager \\
\hline Egypt & Mowafa Taib \\
\hline Equatorial Guinea & Meralis Plaza-Toledo \\
\hline Eritrea & Thomas R. Yager \\
\hline Eswatini & James J. Barry \\
\hline Ethiopia & Meralis Plaza-Toledo \\
\hline Gabon & Alberto A. Perez \\
\hline The Gambia & Meralis Plaza-Toledo \\
\hline Ghana & Meralis Plaza-Toledo \\
\hline Guinea & Alberto A. Perez \\
\hline Guinea-Bissau & Meralis Plaza-Toledo \\
\hline Iran & Philip A. Szczesniak \\
\hline Iraq & Philip A. Szczesniak \\
\hline Israel & Philip A. Szczesniak \\
\hline Jordan & Mowafa Taib \\
\hline Kenya & Thomas R. Yager \\
\hline Kuwait & Philip A. Szczesniak \\
\hline Lebar & Mowafa Taib \\
\hline Lesotho & James J. Barry \\
\hline Liberia & Meralis Plaza-Toledo \\
\hline Libya & Mowafa Taib \\
\hline Madagascar & Thomas R. Yager \\
\hline Malawi & Thomas R. Yager \\
\hline Mali & Alberto A. Perez \\
\hline Mauritania & Mowafa Taib \\
\hline Mauritius & James J. Barry \\
\hline Morocco \& Western Sahara & Mowafa Taib \\
\hline Mozambique & Meralis Plaza-Toledo \\
\hline Namibia & J. Barry \\
\hline Niger & Alberto A. Perez \\
\hline Nigeria & Thomas R. Yager \\
\hline Oman & Philip A. Szczesniak \\
\hline Qatar & Philip A. Szczesniak \\
\hline Reunion & James J. Barry \\
\hline Rwanda & Thomas R. Yager \\
\hline São Tomé \& Principe & Meralis Plaza-Toledo \\
\hline Saudi Arabia & Mowafa Taib \\
\hline Senegal & Alberto A. Perez \\
\hline Seychelles & James J. Barry \\
\hline Sierra Leone & Alberto A. Perez \\
\hline
\end{tabular}

Somalia

South Africa

South Sudan

Sudan

Syria

Tanzania

Togo

Tunisia

Uganda

United Arab Emirates

Yemen

Zambia

Zimbabwe

\section{Asia and the Pacific}

Afghanistan

Australia

Bangladesh

Bhutan

Brunei

Burma (Myanmar)

Cambodia

China

Fiji

India

Indonesia

Japan

Korea, North

Korea, Republic of

Laos

Malaysia

Mongolia

Nauru

Nepal

New Caledonia

New Zealand

Pakistan

Papua New Guinea

Philippines

Singapore

Solomon Islands

Sri Lanka

Taiwan

Thailand

Timor-Leste

Vietnam

\section{Europe and Central Eurasia}

Albania
Armenia
Austria
Azerbaijan
Belarus
Belgium

Jaewon Chung Elena Safirova Keita F. DeCarlo Elena Safirova

Elena Safirova Loyd M. Trimmer III
Philip A. Szczesniak Thomas R. Yager

Alberto A. Perez

Mowafa Taib

Mowafa Taib

Thomas R. Yager

Alberto A. Perez

Mowafa Taib

Thomas R. Yager

Philip A. Szczesniak

Mowafa Taib

James J. Barry

James J. Barry

Karine M. Renaud

Spencer D. Buteyn

Ji Won Moon

Ji Won Moon

Spencer D. Buteyn

Ji Won Moon

Ji Won Moon

Sean Xun

Spencer D. Buteyn

Karine M. Renaud

Jaewon Chung

Keita F. DeCarlo

Jaewon Chung

Jaewon Chung

Ji Won Moon

Spencer D. Buteyn

Jaewon Chung

Spencer D. Buteyn

Ji Won Moon

Spencer D. Buteyn

Spencer D. Buteyn

Ji Won Moon

Spencer D. Buteyn

Ji Won Moon

Spencer D. Buteyn

Jaewon Chung

Ji Won Moon

Jaewon Chung

Ji Won Moon

Jaewon Chung

Ji Won Moon 


\section{Europe and Central Eurasia-Continued}

Bosnia and Herzegovina
Bulgaria
Croatia
Cyprus
Czechia
Denmark, Faroe Islands,
and Greenland
Estonia
Finland
France
Georgia
Germany
Greece
Hungary
Iceland
Ireland
Italy
Kazakhstan
Kosovo
Kyrgyzstan
Latvia
Lithuania
Luxembourg
Malta
Moldova
Montenegro
Netherlands
North Macedonia
Norway
Poland
Portugal
Romania
Russia
Serbia
Slovakia
Slovenia
Spain
Sweden
Switzerland
Tajikistan

Konang

Karine M. Renaud

Karine M. Renaud

Karine M. Renaud

Sinan Hastorun

Loyd M. Trimmer III

Joanna Goclawska

Keita F. DeCarlo

Joanna Goclawska

Keita F. DeCarlo

Elena Safirova

Elena Safirova

Sinan Hastorun

Loyd M. Trimmer III

Joanna Goclawska

Joanna Goclawska

Loyd M. Trimmer III

Elena Safirova

Sinan Hastorun

Karine M. Renaud

Keita F. DeCarlo

Keita F. DeCarlo

Keita F. DeCarlo

Jaewon Chung

Elena Safirova

Jaewon Chung

Loyd M. Trimmer III

Karine M. Renaud

Joanna Goclawska

Joanna Goclawska

Joanna Goclawska

Keita F. DeCarlo

Elena Safirova

Karine M. Renaud

Keita F. DeCarlo

Loyd M. Trimmer III

Loyd M. Trimmer III

Joanna Goclawska

Keita F. DeCarlo

Karine M. Renaud
Turkey

Turkmenistan

Ukraine

United Kingdom

Uzbekistan

Sinan Hastorun

Karine M. Renaud

Elena Safirova

Jaewon Chung

Elena Safirova

North America, Central America, and the Caribbean

Aruba

The Bahamas

Belize

Canada

Costa Rica

Cuba

Dominican Republic

El Salvador

Guatemala

Haiti

Honduras

Jamaica

Mexico

Nicaragua

Panama

Trinidad and Tobago

South America

Argentina

Bolivia

Brazil

Chile

Colombia

Ecuador

French Guiana

Guyana

Paraguay

Peru

Suriname

Uruguay

Venezuela
Yadira Soto-Viruet

Yadira Soto-Viruet

Jesse J. Inestroza

James J. Barry

Jesse J. Inestroza

Yadira Soto-Viruet

Yadira Soto-Viruet

Jesse J. Inestroza

Jesse J. Inestroza

Yadira Soto-Viruet

Jesse J. Inestroza

Yadira Soto-Viruet

Alberto A. Perez

Jesse J. Inestroza

Jesse J. Inestroza

Yadira Soto-Viruet

Jesse J. Inestroza

Yolanda Fong-Sam

Yolanda Fong-Sam

Yadira Soto-Viruet

Jesse J. Inestroza

Jesse J. Inestroza

Yolanda Fong-Sam

Yolanda Fong-Sam

Yadira Soto-Viruet

Yadira Soto-Viruet

Yolanda Fong-Sam

Yadira Soto-Viruet

Yolanda Fong-Sam

\section{Country specialist}

James J. Barry

Spencer D. Buteyn

Jaewon Chung

Keita F. DeCarlo

Yolanda Fong-Sam

Joanna Goclawska

Sinan Hastorun

Jesse J. Inestroza

Ji Won Moon

Alberto A. Perez

Meralis Plaza-Toledo

Karine M. Renaud

Elena Safirova

Yadira Soto-Viruet

Philip A. Szczesniak

Mowafa Taib

Loyd M. Trimmer III

Sean Xun

Thomas R. Yager

\section{Telephone}

(703) 648-7752

(703) 648-7738

(703) 648-4793

(703) 648-7716

(703) 648-7756

(703) 648-7973

(703) 648-7744

(703) 648-7779

(703) 648-7791

(703) 648-7749

(703) 648-7759

(703) 648-7748

(703) 648-7731

(703) 648-4957

(703) 648-7728

(703) 648-4986

(703) 648-4983

(703) 648-7746

(703) 648-7739

\section{E-mail}

jbarry@usgs.gov

sbuteyn@usgs.gov

jchung@usgs.gov

kdecarlo@usgs.gov

yfong-sam@usgs.gov

jgoclawska@usgs.gov

shastorun@usgs.gov

jinestroza@usgs.gov

jmoon@usgs.gov

aperez@usgs.gov

mplaza-toledo@usgs.gov

krenaud@usgs.gov

esafirova@usgs.gov

ysoto-viruet@usgs.gov

pszczesniak@usgs.gov

mtaib@usgs.gov

Itrimmer@usgs.gov

sxun@usgs.gov

tyager@usgs.gov 